\title{
Mineral Resources of the Chichagof and Baranof Islands Area, Southeast Alaska
}

Peter E. Bittenbender

Jan C. Still

Kenneth M. Maas, and

Mitchell E. McDonald, Jr.

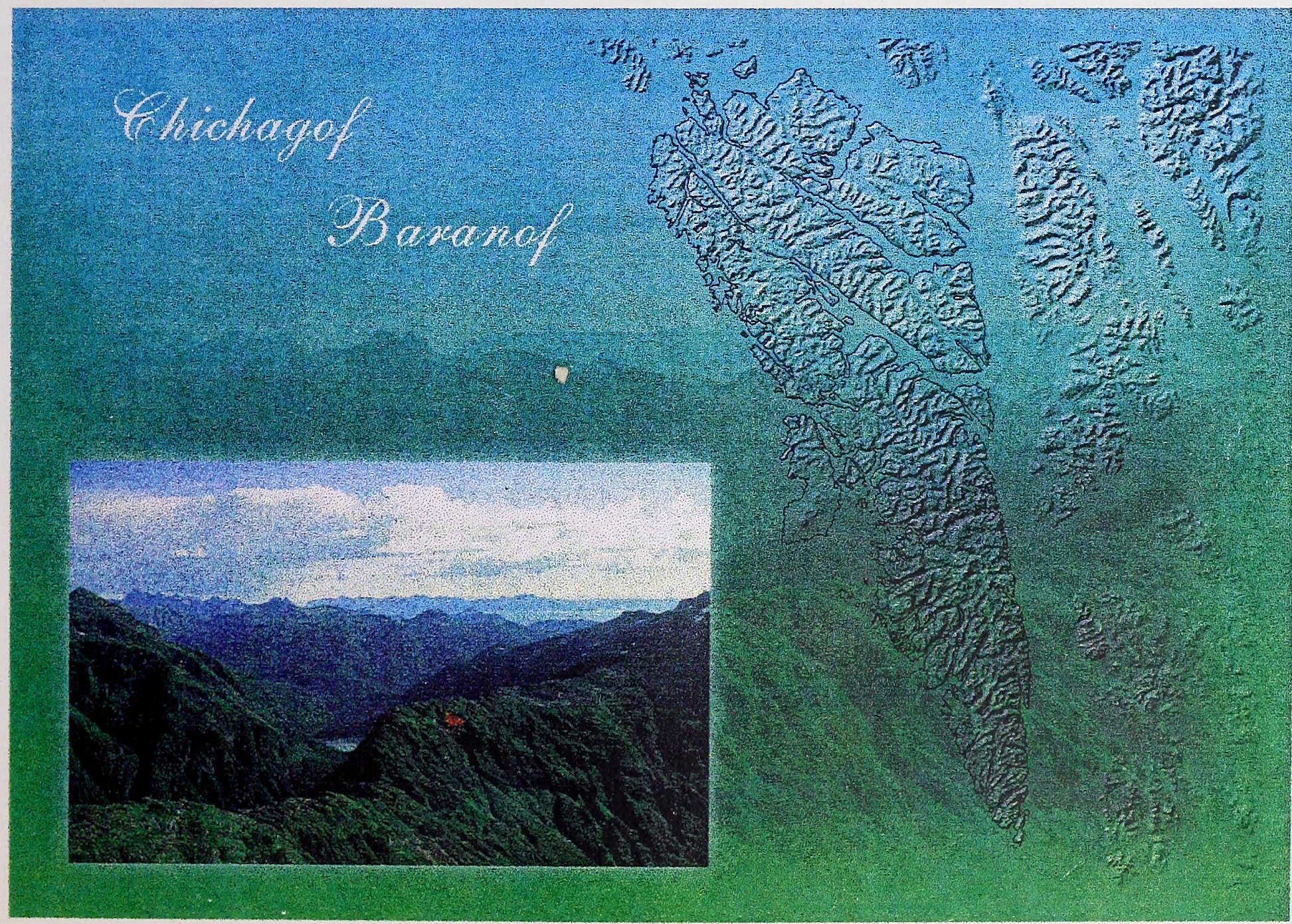


BLM LIBRARY

BLDG 50, ST-150A

DENVER FECERAL CENTEF

P.O. BOX 25047

DENVEA, COLORADO 80225 


\title{
Mineral Resources of the Chichagof and Baranof Islands Area, Southeast Alaska
}

\author{
by \\ Peter E. Bittenbender \\ Jan C. Still \\ Kenneth M. Maas \\ and Mitchell E. McDonald, Jr.
}

BLM-Alaska Technical Report 19

February 1999

U. S. Department of the Interior

Bureau of Land Management

Alaska State Office

222 W. 7th Avenue, \#13

Anchorage, Alaska 99513 


\section{Mission Statement}

The Bureau of Land Management sustains the health, diversity and productivity of the public lands for the use and enjoyment of present and future generations.

\section{Authors}

Peter E. Bittenbender, Kenneth M. Maas and Mitchell E. McDonald, Jr. are geologists in the BLM-Alaska Division of Lands, Minerals and Resources, working for the Juneau Mineral Information Center, Bureau of Land Management, Juneau, Alaska.

Jan C. Still is a mining engineer in the Division of Lands, Minerals and Resources, working for the Juneau Mineral Information Center, Bureau of Land Management, Juneau, Alaska.

\section{Cover}

Digital elevation model of northern Southeast Alaska with the Chichagof and Baranof Islands Study Area outlined. Inset shows the west ridge of Mt. Muravief on southern Baranof Island.

\section{Technical Reports}

Technical Reports issued by the Bureau of Land Management-Alaska present the results of research, studies, investigations, literature searches, testing, or similar endeavors on a variety of scientific and technical subjects. The results presented are final, or are a summation and analysis of data at an intermediate point in a long-term research project, and have received objective review by peers in the author's field.

The reports are available while supplies last from BLM External Affairs, 222 West 7th Avenue \#13, Anchorage, Alaska 99513 and from the Juneau Minerals Information Center, 100 Savikko Road, Mayflower Island, Douglas, AK 99824, (907) 364-1553. Copies are also available for inspection at the Alaska Resource Library and Information Service (Anchorage), the USDI Resources Library in Washington, D. C., various libraries of the University of Alaska, the BLM National Business Center Library (Denver) and other selected locations.

A complete bibliography of all BLM-Alaska scientific reports can be found on the Internet at:

http://www.ak.blm.gov/affairs/sci_rpts.html. Related publications are also listed at http://juneau.ak.blm.gov. 


\section{UNITED STATES \\ DEPARTMENT OF THE INTERIOR \\ BUREAU OF LAND MANAGEMENT}

\section{MINERAL ASSESSMENT REPORT}

\section{Mineral Resources of the Chichagof and Baranof Islands Area, Southeast Alaska}

Prepared By:

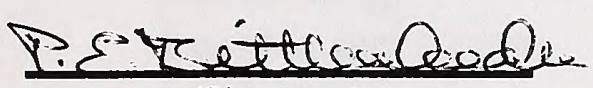
(Signature)

Geologist

(Title)

$\frac{12 / 18 / 98}{\text { (Date) }}$

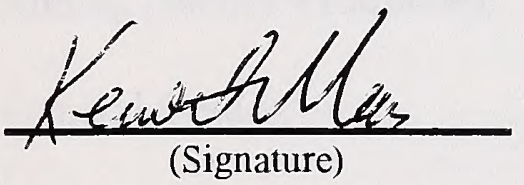

Geologist

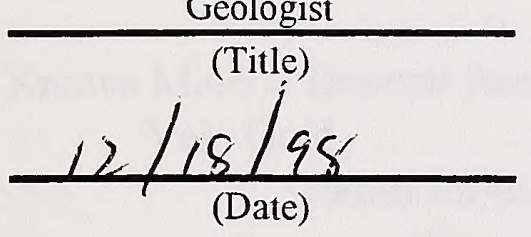

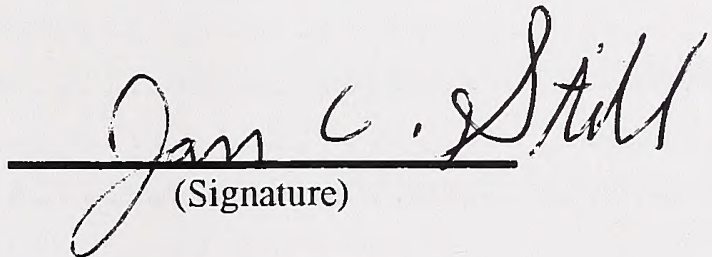

Mining Engineer

(Title)
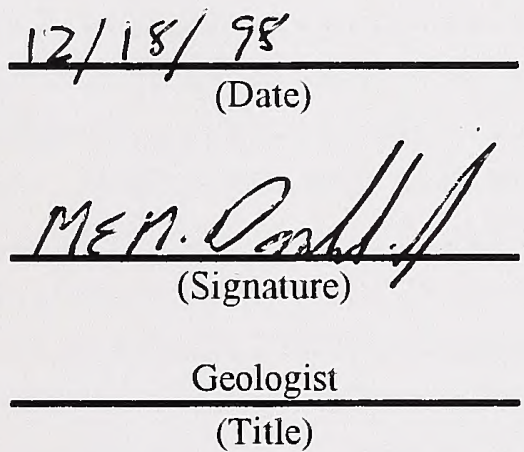

$\frac{i 2 / 18 / 98}{\text { (Date) }}$
Technical Reviewers:

Donald Baggs, BLM, Anchorage, Alaska

John Kato, USDA, FS, Juneau, Alaska

Cliff Taylor, USGS, Denver, Colorado
Management Acknowledgment:

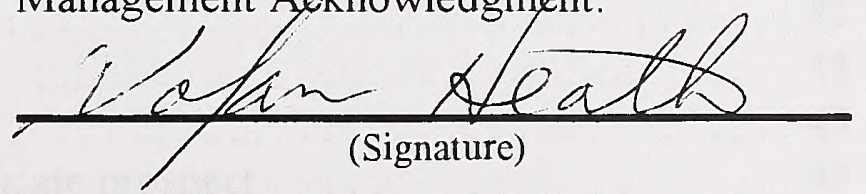

Deputy State Director, Lands, Minerals \& Resources (Title)

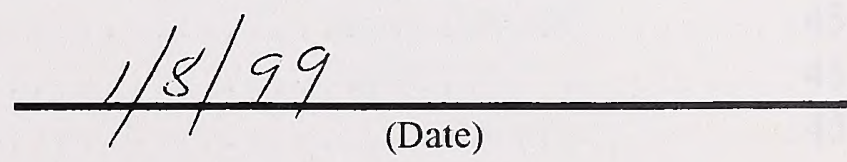


(n)

$$
\begin{aligned}
& \text { - } \\
& \text { - n }
\end{aligned}
$$




\section{TABLE OF CONTENTS}

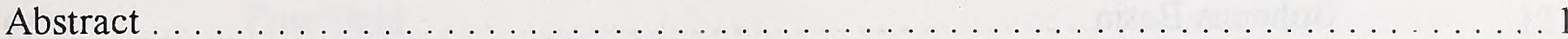

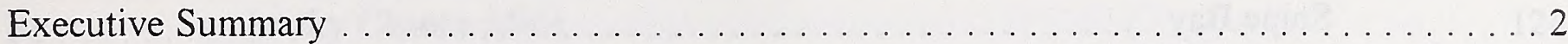

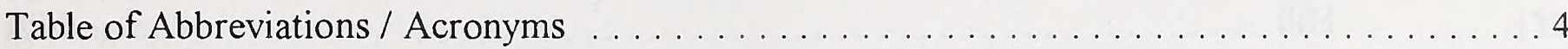

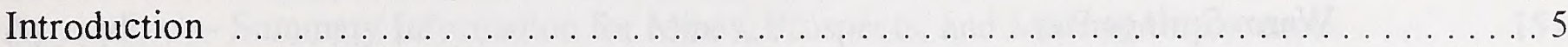

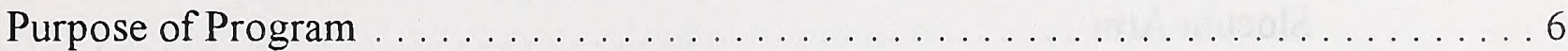

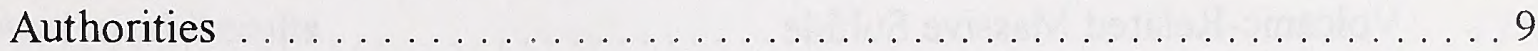

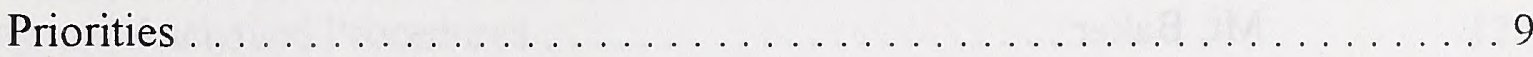

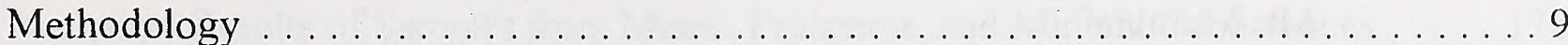

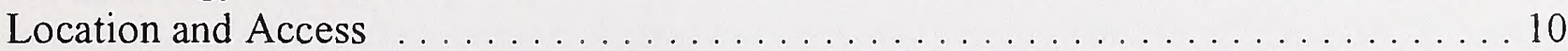

Land Status . . . . . . . . . . . . . . . . . . . . . . . . . 10

Acknowledgments . . . . . . . . . . . . . . . . . . . 14

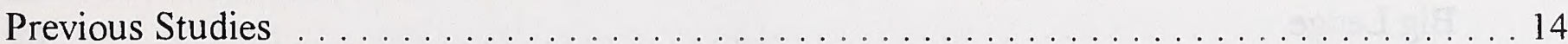

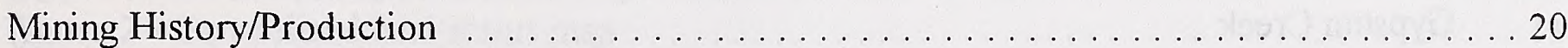

General Geology . . . . . . . . . . . . . . . . . . . . . . . . . . . . . . . . 22

Land Use and Resource Issues . . . . . . . . . . . . . . . . . . . . . . 26

Known Mineral Deposit Areas . . . . . . . . . . . . . . . . . . . . . 31

Vein Gold . . . . . . . . . . . . . . . . . . . . . . . . . . . . . . . . . 31

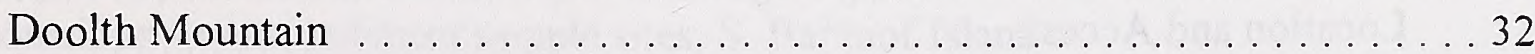

Chichagof Mine .......................... 37

Hirst-Chichagof Mine ... . . . . . . . . . . . . . . . . . . 39

Alaska Chichagof Mine ...................... . 41

Jumbo Mine . . . . . . . . . . . . . . . . . . . . . . . . . . . . . . . 41

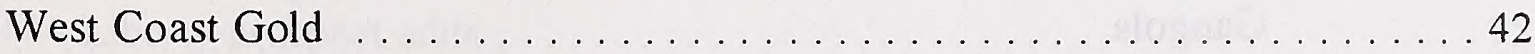

Golden Hand Apex Mine . . . . . . . . . . . . . . . . . . . . . . . 43

Cobol Mine . . . . . . . . . . . . . . . . . . . . . . . . . . . . . . . 43

New Chichagof Mining Syndicate prospect . . . . . . . . . . . . . 43

Falcon Arm prospect . . . . . . . . . . . . . . . . . . . . . . . . . . 43

Lisianski . . . . . . . . . . . . . . . . . . . . . . . . . . . . 44

Apex and El Nido Mines . . . . . . . . . . . . . . . . . . . 45

Bon Tara Mine . . . . . . . . . . . . . . . . . . . . . . . . . 45

Goldwin Mine . . . . . . . . . . . . . . . . . . . . 45 
Mine Mountain Mine ... . . . . . . . . . . . . . . . . . . . . 46

Silver Bay . . . . . . . . . . . . . . . . . . . . . . . . . . 47

Magmatic Segregation ... . . . . . . . . . . . . . . . . . . . . . 48

Bohemia Basin . . . . . . . . . . . . . . . . . . . . . . . . . 49

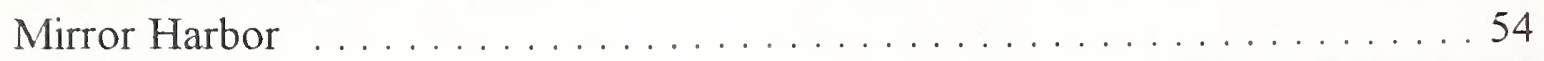

Snipe Bay . . . . . . . . . . . . . . . . . . . . . . . . 56

Red Bluff Bay . . . . . . . . . . . . . . . . . . . . . . 57

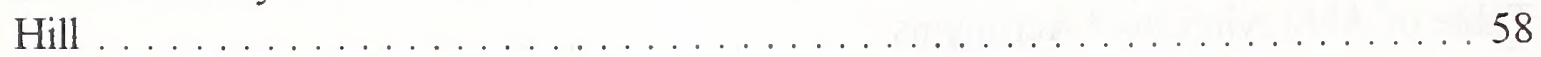

Porphyry . . . . . . . . . . . . . . . . . . . . . . . . . . . . 59

Warm Springs Bay . . . . . . . . . . . . . . . . . . . . 60

Slocum Arm . . . . . . . . . . . . . . . . . . . . . . . . . . . . . . . . 62

Volcanic-Related Massive Sulfide . . . . . . . . . . . . . . . . . . . 63

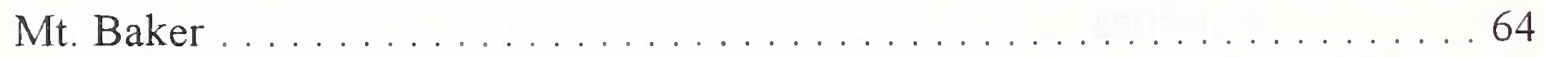

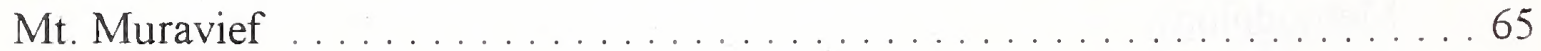

Other Mines, Prospects, or Mineral Occurrences . . . . . . . . . . . . . . . . . . . 67

Kaiser Gypsum Mine . . . . . . . . . . . . . . . . . . . . . . . . . . . . . . 67

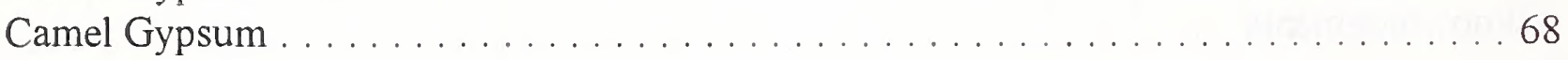

Sealion Cove .................................... 68

Big Ledge . . . . . . . . . . . . . . . . . . . . . . . . . . . . . 69

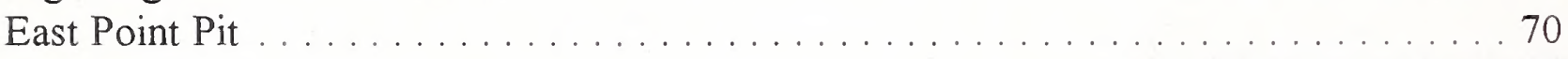

Gypsum Creek . . . . . . . . . . . . . . . . . . . . . . 70

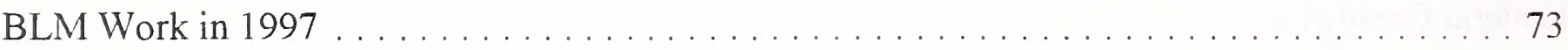

Mt. Muravief . . . . . . . . . . . . . . . . . . . . . . . . . . . 73

Freshwater Bay . . . . . . . . . . . . . . . . . . . . . 79

Special Section: Silver Bay Area . . . . . . . . . . . . . . . . . . . . . 87

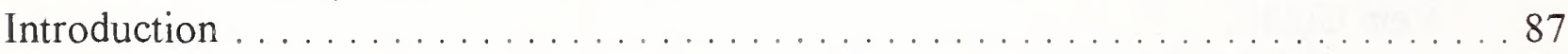

Location and Access . . . . . . . . . . . . . . . . . . . . . . 87

History / Production . . . . . . . . . . . . . . . . . . . . 87

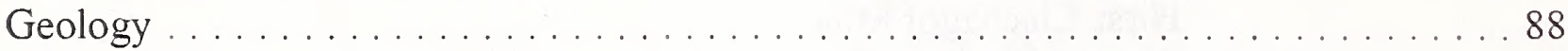

Selected Mines and Prospects $\ldots \ldots \ldots \ldots \ldots \ldots \ldots \ldots \ldots \ldots \ldots$

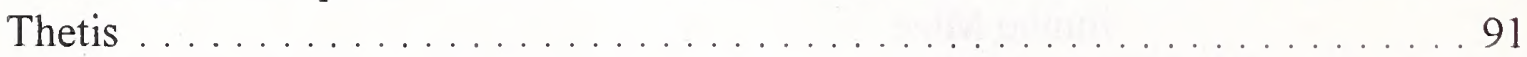

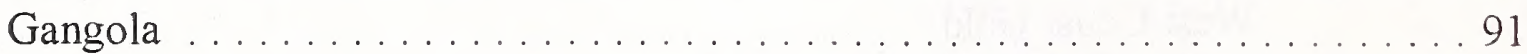

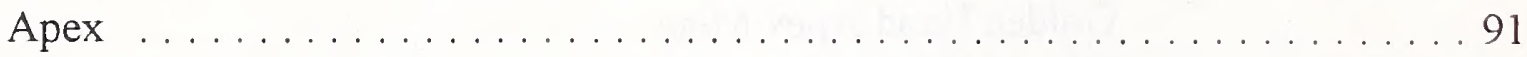

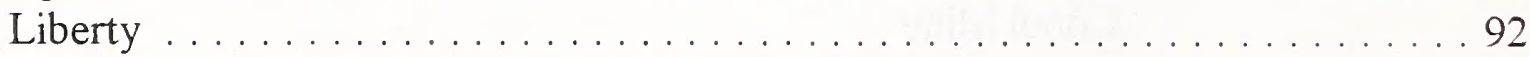

Edgecumbe Exploration . . . . . . . . . . . . . . . . . . . . . 92

Eureka . . . . . . . . . . . . . . . . . . . . . . . . . . . . . . . 99

Bonanza No. 1 . . . . . . . . . . . . . . . . . . . . . . . . . . . 99

Stewart Mine . . . . . . . . . . . . . . . . . . . . . . . . . . . . . . . . . 99

Lower Ledge . . . . . . . . . . . . . . . . . . . . . . . . 100

No name . . . . . . . . . . . . . . . . . . . . . . . . . . 100 
Bauer ....................................... 100

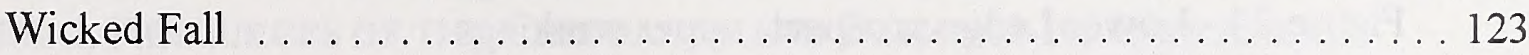

Pinta Lake area . . . . . . . . . . . . . . . . . . . . . . 123

Free Gold . . . . . . . . . . . . . . . . . . . . . . . . . 123

Lucky Chance Mountain . . . . . . . . . . . . . . . . . . . . . . . . . 124

Lucky Chance Mine ............................ 124

Bibliography . . . . . . . . . . . . . . . . . . . . . . . . . . . . . . 133

Appendix A - Summary Information for Mines, Prospects, and Mineral Occurrences . . . . . 151

Appendix B - Analytical Results _. . . . . . . . . . . . . . . . . . . . . . . . 175

Sampling and Analytical Procedures . . . . . . . . . . . . . . . . . . . 175

Analytical Results of Samples from Mines, Prospects, and Mineral Occurrences . . . . 176

Appendix C - Alphabetical list of Mines, Prospects, and Mineral Occurrences . . . . . . . . 221

\section{ILLUSTRATIONS}

Figure 1 - Location map of the Chichagof-Baranof Islands study area $\ldots \ldots \ldots \ldots \ldots \ldots 7$

Figure 2 - Generalized land status map . . . . . . . . . . . . . . . . . 11

Figure 3 - Map showing location and extent of previous studies . . . . . . . . . . 15

Figure 4 - Tectonostratigraphic terranes of the Chichagof-Baranof study area . . . . . . . 23

Figure 5 - Greater Doolth Mountain area showing geology, prospects, and patented claims ... 33

Figure 6 - Doolth Mountain area showing faults, workings, prospects, and patented claims . . 35

Figure 7 - Bohemia Basin area showing general geology and location of deposits . . . . . . . 51

Figure 8 - General geologic map of the Mt. Muravief area . . . . . . . . . . . . . 75

Figure 9 - Geologic map of the Mt. Muravief, West Ridge exposure . . . . . . . . . . . 77

Figure 10 - Anomalous stream sediment sample sites, S. Baranof Island . . . . . . . . . . 81

Figure 11 - Geologic map of rock pit at Freshwater Bay molybdenum occurrence . . . . . . . 8 83

Silver Bay: mine and prospect maps

Figure 12 - Silver Bay area showing general geology and location of prospects . . . 8 89

Figure 13 - Thetis prospect adit . . . . . . . . . . . . . . . . . 93

Figure 14 - Liberty prospect adits . . . . . . . . . . . . . . . . . . . 95

Figure 15 - Workings on Edgecumbe Exploration, Bonanza Nos. 21 \& 22 claims . . . . 97

Figure 16 - Eureka prospect adit . . . . . . . . . . . . . . . . . . . 101

Figure 17 - Bonanza No. 1 adit . . . . . . . . . . . . . . . . . . . . . 103

Figure 18 - Stewart Mine area showing location of workings and land boundaries . . 105

Figure 19 - Stewart Mine, adit no. 1, upper and lower levels, cross section . . . . . . . 107

Figure 20 - Stewart Mine, adits no. 2 and no. 3 . . . . . . . . . . . . . . . . . . 109

Figure 21 - Stewart Mine, mill site . . . . . . . . . . . . . . . . . . . 111

Figure 22 - Lower Ledge prospect, area map . . . . . . . . . . . . . . . . . . 113 
Figure 23 - Lower Ledge prospect, lower workings . . . . . . . . . . . . . . . 115

Figure 24 - Lower Ledge prospect, upper workings . . . . . . . . . . . . . . . 117

Figure 25 - No Name prospect adit . . . . . . . . . . . . . . . . . . 119

Figure 26 - Bauer prospect adit . . . . . . . . . . . . . . . . . 121

Figure 27 - Wicked Fall prospect adit . . . . . . . . . . . . . . . . . 125

Figure 28 - Lucky Chance Mine workings, plan view . . . . . . . . . . . 127

Figure 29 - Lucky Chance Mine workings, cross section and plan view of no. 2 adit . 129

Plate 1 - Mines, prospects, and occurrences in the Chichagof-Baranof Islands area . . . in pocket Plate 2 - Sample location map . . . . . . . . . . . . . . . . . . . in pocket Plate 3 - Edgecumbe Exploration Company claim map ................ in pocket

\section{TABLES}

Table 1 - Alaska Territorial Dept. of Mines and Div. of Mines and Minerals reports . . 18 Table 2 - Summary of mine production . . . . . . . . . . . . . . . . 22

Table 3 - Summary of land use and resource issues for each KMDA . . . . . . . . . . 29

Table 4 - Selected analytical results of samples from Freshwater Bay . . . . . . . . . 86

Table A-1 - Summary information for mines, prospects, and mineral occurrences . . . 154

Table B-1 - Analytical results of samples from mines, prospects, and occurrences . . . 179

Table B-2 - Analytical results of rare earth element samples . . . . . . . . . . . . 218

Table B-3 - Analytical results of carbonate/whole rock samples . . . . . . . . 218

Table B-4 - Detection limits by analytical technique . . . . . . . . . . . . . . . . 219 


\title{
MiNERAL RESOURCES OF THE CHICHAGOF AND BARANOF ISLANDS AREA, SOUTHEAST ALASKA
}

By Peter E. Bittenbender, Jan C. Still, Kenneth M. Maas, and Mitchell E. McDonald, Jr.

\begin{abstract}
The Chichagof and Baranof Islands area constitutes over two and a half million acres along the northwest coast of southeast Alaska. BLM personnel investigated mineral occurrences in the area between 1995 and 1997. This report provides information on those investigations and includes sections on land status, history and production, previous studies, general geology, and potential land use and resource development conflicts.

The historic Chichagof and Hirst-Chichagof Mines account for most of the past production of 791,000 ounces of gold and 228,000 ounces of silver from the Chichagof-Baranof area. These mines also account for most of the area's gold and silver resources of 675,000 ounces of gold and 195,000 ounces of silver. Much of the land with gold and silver potential in the west Chichagof area is covered by a wilderness designation that precludes mineral development.

cobalt-bearing resources are located at Bohemia Basin on Yakobi Island. Similar, but smaller, magmatic segregation deposits occur at Mirror Harbor and Snipe Bay. A wilderness designation covers the Mirror Harbor area.

The Pacific Coast Gypsum Company produced 500,000 tons of gypsum from a mine near Iyoukeen Cove on eastern Chichagof Island between 1906 and 1923. The ChichagofBaranof area also has the potential for porphyry copper and molybdenum, volcanic-related copper, and skarn deposits.

The Chichagof-Baranof study reveals for the first time information on volcanic-related copper on southern Baranof Island, and porphyry molybdenum and skarn, near Freshwater Bay on eastern Chichagof Island. The history of mineral activity in Silver Bay, along with previously unpublished maps and sample results are presented.
\end{abstract}

Twenty-four million tons of nickel-copper- 


\section{EXECUTIVE SUMMARY}

The Chichagof and Baranof Islands area constitutes over two and a half million acres located along the northwest coast of southeast Alaska. The area includes historic producers of gold, silver, and gypsum. The area's main gold producers, the Chichag of and Hirst-Chichagof Mines, produced 791,000 ounces of gold and 228,000 ounces of silver between 1906 and 1943. Approximately 500,000 tons of gypsum was produced by the Pacific Gypsum Company from a mine near Iyoukeen Cove on eastern Chichagof Island between 1906 and 1923.

Bureau of Land Management (BLM) personnel (employees of the Bureau of Mines prior to 1996) investigated mineral occurrences in the Chichagof and Baranof Islands area during 1995, 1996, and 1997. BLM crews examined 46 mines and prospects, and over 50 reconnaissance sites, and collected over 850 samples. A 220 sample stream sediment reconnaissance program was carried out on southern Baranof Island. Detailed work was not performed on western Chichagof Island and Yakobi Island because extensive prior studies were conducted by the Bureau of Mines in 1978 and 1979 (Still and Weir, 1981; Kimball, 1982). Discussion of the western Chichagof and Yakobi Island mineral deposits is included here for completeness and to allow a comparison to be made with other deposits in the study area.

Based on the current mineral assessment, as well as on previous Bureau of Mines and U. S. Geological Survey (USGS) studies, 13 known mineral deposit areas (KMDA's) have been delineated. The boundaries of these areas were determined by geology, and the distribution and type of mineral deposits. Deposit types and commodities include:- vein gold (gold, silver) magmatic segregation (nickel, copper, cobalt, chromium), porphyry (copper, molybdenum), and volcanic-related massive sulfide (copper, zinc). The potential to develop the minerals in each of the KMDA's depends upon the size and grade of the deposits, deposit types, mineralogy, commodities, access, and potential land use conflicts. Mineral development potential is addressed with regard to each of the KMDA's.

There are four KMDA's with vein gold potential, Doolth Mountain, West Coast Gold, Lisianski, and Silver Bay. The one with the highest potential for development is the Doolth Mountain KMDA. With inferred/hypothetical resources of 675,000 ounces of gold and 195,000 ounces of silver, it contains the largest known gold and silver resources in the Chichagof-Baranof study area. Most of these resources are within the 39 patented mining claims that form the Chichagof Mine and the Hirst-Chichagof Mine properties. The remainder of the Doolth Mountain KMDA is within a designated wilderness where mineral development is not allowed, except on claims with valid existing rights. The West Coast Gold KMDA has a significant number of known mineral occurrences, but also has a wilderness designation (except for one unpatented claim) and mining is not allowed without valid existing rights. The Lisianski KMDA also has a significant number of mineral occurrences, with about half of the area open to mining. The open area includes the Apex and El Nido Mines, which are reported to contain an approximately 26,000-ounce unconfirmed gold resource. The land status in most of the Silver Bay KMDA allows for mineral development, but the size, 
grade, and continuity of the deposits makes development unlikely.

Five KMDA's with potential for magmatic segregation deposits are located in the study area. The Bohemia Basin KMDA contains resources of over 24 million tons of nickelcopper-cobalt-bearing rock and is the area most likely to be developed. According to the economic feasibility studies by Coldwell (1998), the deposit at present is subeconomic, and would require approximately a doubling of metal value or size to approach economic viability. The Bohemia Basin resources are covered by nine patented claims. The Mirror Harbor and Snipe Bay KMDA's contain resources of 1 million tons and 94,000 tons of nickel-coppercobalt-bearing rock, respectively. Both of these, however, are less likely to be developed. All of the land within the Mirror Harbor KMDA is designated as wilderness, as is about three quarters of the Snipe Bay KMDA. Two areas of magmatic segregation-type deposit potential least likely to be developed are the Red Bluff Bay and Hill KMDA's. Both are of limited size and grade, and are covered by land status designations restrictive to mineral development.
There are four KMDA's in the study area with potential for porphyry-type deposits and for volcanic-related massive sulfide deposits. The Warm Springs Bay and Slocum Arm KMDA's host porphyry-type mineralization. The mineralized rock in both areas covers a broad extent, however the Warm Springs Bay area is more likely to attract development, given its land status that is less restrictive to mineral development. The likelihood of mineral development in the KMDA's marked by volcanic-related deposits is considered as medium in the Mt. Baker area, and as low in the Mt. Muravief area.

The Chichagof-Baranof study reveals for the first time information on volcanic-related copper on southern Baranof Island. Results of the first examination of a molybdenum occurrence in a road pit south of Freshwater Bay is also discussed. BLM investigators discovered skarn minerals near Gypsum Creek on eastern Chichagof Island and report on recent claims staked for skarn potential near East Point, north of Tenakee Inlet. The history of mineral activity in Silver Bay, along with previously unpublished maps and sample results, is also presented. 


\section{TABLE OF ABBREVIATIONS / ACRONYMS}

ANILCA
BLM
Bureau of Mines
Forest Service
KMDA('s)
LUD
MAS
no.
oz
oz/t
oz/yd ${ }^{3}$
PGM
ppb
ppm
tons
USGS
o

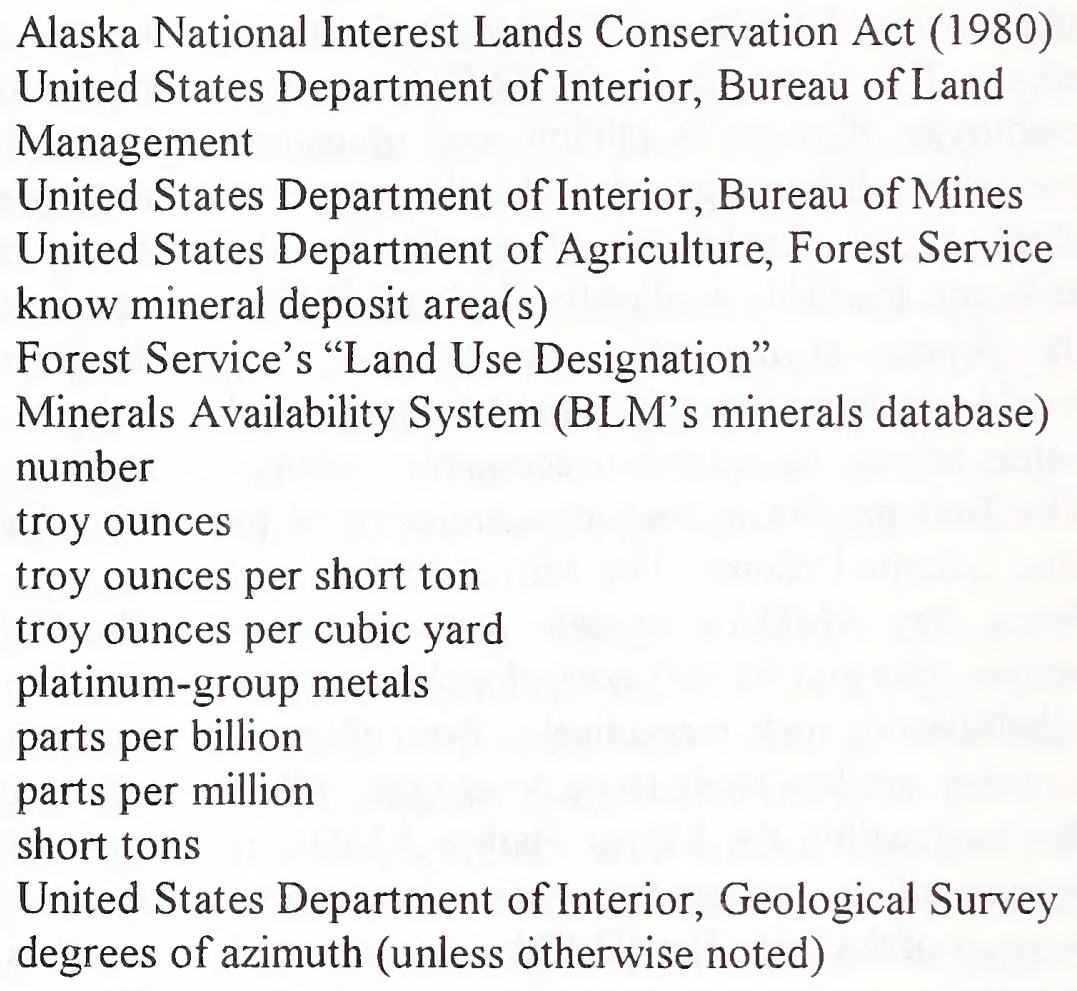




\section{INTRODUCTION}

Mining in the Chichagof-Baranof study area (Fig. 1) dates back to about 1870 and represents some of the earliest mining in Alaska. The area corresponds to the historic Chichagof District, also known as the Sitka Mining District (Knopf, 1912), which is an area that has produced significant quantities of gold, silver, and gypsum. Exploration efforts have also targeted occurrences of nickel, chromium, copper, and molybdenum. Occurrences of tungsten, iron, potassium feldspar, palygorskite, andalusite, and cement-grade limestone have also been noted. Mineral deposit types include vein gold, epithermal vein, magmatic segregation, hydrothermal or sedimentary gypsum, volcanicrelated massive sulfide, porphyry copper and/or molybdenum, pegmatite, and iron-copper skarn.

The Bureau of Land Management (BLM) finished a three-year mineral assessment of the Chichagof and Baranof Islands area in 1997. This report summarizes the mineral endowment of the area from data generated during the current study and also from previous investigations, particularly those of the Bureau of Mines between 1979 and 1980 (Still and Weir, 1981; Kimball, 1982).

The Chichagof-Baranof study was initiated by the Bureau of Mines in 1995. With the closure of the Bureau of Mines in 1996, responsibility for the investigation was taken over by the BLM. Investigation of the area was undertaken at the request of the USDA, Forest Service (Forest Service) whose goal is to encourage and facilitate orderly mineral development, while ensuring operations are conducted in an environmentally sound manner, and that disturbed lands are reclaimed for other productive uses. Each element of this goal requires a thorough understanding of the mineral endowment and development potential of the selected area.

The Chichagof-Baranof mineral assessment included site surveying, geologic mapping, and sampling of historic mines, prospects, and mineral occurrences as well as reconnaissance investigations of prospective mineralized areas. BLM personnel investigated approximately 90 mines, prospects, or mineral occurrences during the course of this study. Reconnaissance-type investigations examined numerous exposures, particularly along the logging road network on the northeast side of Chichagof Island. A 220sample, stream sediment reconnaissance program was carried out on southern Baranof Island in search of mineralized rock similar to that found in the Mt. Muravief area. In total, over 850 rock chip, placer, and stream sediment samples were collected for geochemical analysis. The overall project objectives were to:

- identify the type, amount, and distribution of mineral deposits in the district

- determine mineral resource estimates when possible

- conduct feasibility studies for selected deposit types

- address land use and resource issues related to mining activities

Field investigations during the current study explicitly excluded the historically significant deposits in the west Chichagof-Yakobi Island area. Mineral assessments of this area were previously completed by Bureau of Mines workers Still and Weir (1981) and Kimball (1982). A discussion of the west ChichagofYakobi Island area is included here, however, for completeness and so that a comparison can 
be made with other mineralized areas on Chichagof and Baranof Islands.

Discussion of the mineral endowment of the study area is structured upon 13 known mineral deposit areas (KMDA's) and the deposit type within each area. This approach provides an overview of the most important mineralized areas and allows a comparison to be made between areas with similar deposit types. Each KMDA is evaluated with regard to the size and grade of known resources, the extent and nature of the deposits, results of BLM sampling where applicable, current land status and how it affects mineral development activities, and accessibility of the areas. A brief discussion of additional prospects and mineral occurrences outside the more significant KMDA's is also provided. Detailed work was accomplished in the south Baranof and Freshwater Bay areas by the BLM in 1997, and in the Silver Bay area during the course of the study. The work accomplished in these areas is presented in separate sections, outside the framework of the KMDA comparison.

This report presents an overview of land status, mining history, previous studies, general geology and mineral deposit types, and a bibliography of geological and mining-related reports pertaining to the study area. Plate 1 shows the location of the KMDA's, mines, prospects, and mineral occurrences within the study area as well as many of the geographic locations mentioned in the text. Table A-1 summarizes pertinent information on mines, prospects, and mineral occurrences and is presented in Appendix A. Plate 1 and Table A-1 are cross-referenced using "prospect" numbers or "P" numbers (eg., P63). Plate 2 shows the locality of all samples collected from 1995 to 1997. Table B-1 in Appendix $\mathrm{B}$ is a corresponding table of analytical results. Plate 2 and Table B-1 are cross-referenced using a different set of "map" numbers. An alphabetical listing of mines, prospects, and mineral occurrences with correlated prospect and map numbers is presented in Appendix C.

Several publications have already been released regarding the current mineral assessment of the Chichagof-Baranof area. Bureau of Mines and BLM investigations conducted during 1995 and 1996 were published by Maas and others (1996) and Bittenbender and Still (1997), respectively. A report on the economic feasibility of mining low sulfide, vein gold- and magmatic segregation-type deposits in the ChichagofBaranof area was published by Coldwell (1998).

\section{PURPoSE OF PROgRAM}

Mineral assessment studies in Alaska expand the body of public, minerals-related, knowledge and support Department of the Interior policies that improve Federal stewardship and land-use planning on public lands. They provide important geoscience, mining engineering, and mineral economic information that become part of a comprehensive inventory of resources on Federal land. The total data set allows physical, biological, and economic sciences to be considered in Federal land planning and decision making. The information and the resulting policies are necessary to ensure the sound use of natural resources, while preserving and protecting environmental and cultural values. Information provided by these studies is also useful to legislators, other land-managing agencies, and mineral industry leaders to make informed decisions affecting future mineral resource activities and their associated socioeconomic effects on the State of Alaska.

Mineral assessment studies improve the understanding of the mineral development 


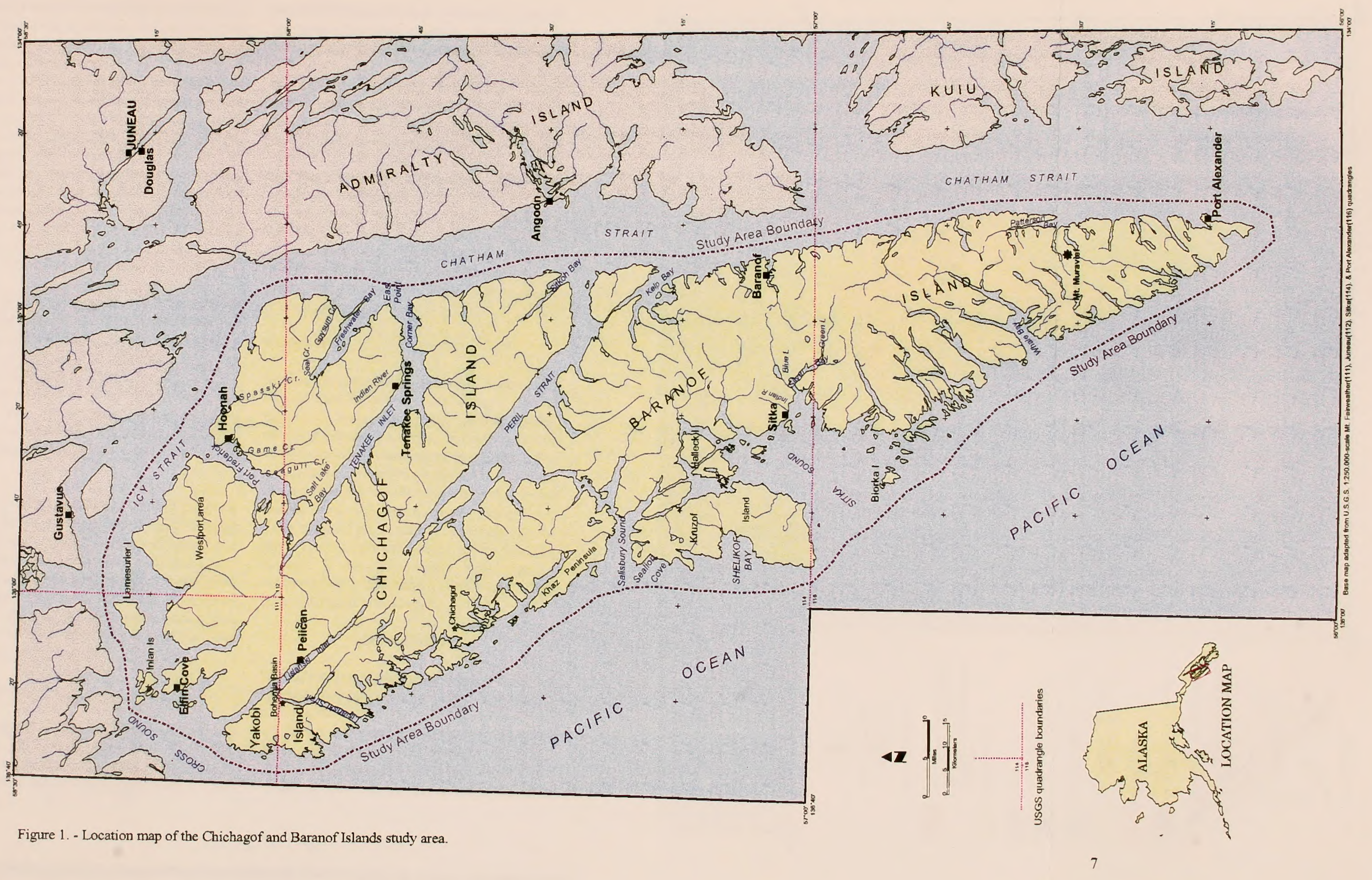


potential of an area by creating an inventory of mineral resources, evaluating the likelihood that more resources may exist, and estimating the technical, environmental, and economic feasibility of mining certain mineral deposits. They also review land-use and environmental issues as they relate to potential mineral development scenarios. The mineral assessments address specific data and analysis requirements mandated by the National Environmental Policy Act (NEPA), the Federal Land Management and Policy Act (FLPMA), the National Forest Management Act, the Alaska National Interest Lands Conservation Act (ANILCA), and other statutes.

Area-wide mineral assessments of Alaska are conducted in coordination with several Federal agencies. Historically, these have included the Bureau of Mines, U.S. Geological Survey (USGS), BLM, and the Forest Service. Early in 1996, the Bureau of Mines was closed as an agency and its functions, personnel, and mandates in Alaska were transferred to the BLM under Secretarial Order 3196, dated January 19, 1996.

Under the BLM mineral assessment program, several mining districts (including Goodnews Bay, Juneau, Valdez Creek, Colville, and Ketchikan), national forests (Chugach), and BLM resource planning areas (Steese-White Mountains, Forty Mile, and Black River) have been investigated. Many of these studies have been conducted in coordination with State and nongovernmental organizations as well.

\section{Authorities}

In accordance with Section 1010 of the ANILCA (PL 96-487; 94 Stat. 2371) the Secretary of the Interior is authorized, "...to the full extent of his authority, assess the oil, gas, and other mineral potential on all public lands in the State of Alaska in order to expand the database with respect to the mineral potential of such lands. The mineral assessment program may include, but shall not be limited to, ... core and test drilling for geologic information.... To the maximum extent practicable, the Secretary shall consult and exchange information with the State of Alaska regarding the responsibilities of the Secretary under this section and similar programs undertaken by the State." The Wilderness Act, National Environmental Policy Act (NEPA), and Federal Land Policy and Management Act (FLPMA) also require interdisciplinary resource assessments before a major Federal land use decision is made on public lands.

\section{Priorities}

Mineral assessment study areas are chosen using a prioritization process that weighs several factors, including land status, mining history, current prospecting activity, geologic potential, accessibility, and conflicting land uses. The extent and age of previous studies is also taken into account. Input from other Federal agencies and the State of Alaska are heavily weighted in the process of prioritization. For instance, the priorities of the Forest Service, the leading land manager in southeast Alaska, were a major consideration in undertaking the Chichagof and Baranof Islands area study.

\section{METHODOLOGY}

Mines, prospects, and mineral occurrences are selected for examination after considering information from several different sources. An initial list is compiled from the Minerals Availability System (MAS) database, which was created and maintained by the Bureau of Mines through 1995. The Alaska portion of the MAS 
database is currently maintained by the BLM and contains information on mines, prospects, and mineral occurrences throughout Alaska. Each site from the MAS list is reviewed and prioritized after completing a thorough literature search. Properties with multiple references and evidence of past production or development are given high priority. Sites where recent work or claim staking has been performed are given moderate priority for field investigation. The literature may reveal that some sites represent claim staking only, consequently, locations and information are scarce. These sites are given a low priority. The literature search may also reveal properties that were not included in the MAS database, but nonetheless merit investigation.

Previous studies by government agencies such as the USGS or Alaska Division of Geological and Geophysical Surveys may contain geophysical or geochemical information on sites that warrant follow-up examination. Other factors that influence site selection include favorable regional geology and newly created access (e.g., logging roads, glacial retreat, etc.). Site examinations may also be recommended by area land managers, prospectors, and geologists.

\section{LOCATION AND ACCESS}

The Chichagof and Baranof Islands study area consists of the islands west of Chatham Strait and south of Cross Sound and Icy Strait. It includes Chichagof, Baranof, Inian, Lemesurier, Yakobi, Kruzof and the smaller islands along the Pacific coast (Fig. 1, Plate 1). The area is depicted on parts of the Mt. Fairweather, Juneau, Sitka, and Port Alexander 1:250,000scale USGS quadrangle maps. Population centers in the district include Sitka, Hoonah, and the smaller communities of Tenakee Springs, Pelican, Elfin Cove, Port Alexander, and
Baranof.

The area is characterized by rugged, glaciated topography with peaks in excess of 4,800 feet. The steep terrain restricts foot access in many places. Numerous inlets and bays cut through the islands providing rock exposure along shorelines that can be accessed by boat. Extensive logging road networks traverse the northeast part of Chichagof Island and can be accessed from Hoonah. Logging roads also provide access to the Sitkoh Bay-Corner Bay area. A short paved-road network surrounds Sitka. The Alaska Marine Highway System (ferry) provides service to Sitka, Hoonah, Tenakee Springs, and Pelican. Fixed-wing and helicopter service can be obtained from Sitka. Sitka is the largest population center in the area and offers some supplies and services. Juneau, approximately 90 miles northeast of Sitka, can also be used for logistical support.

\section{LAND STATUS}

Land management responsibilities in the Chichagof-Baranof area are divided among the Forest Service, regional and village Native corporations, the State of Alaska, and private entities (Fig. 2; see Plate 1 for additional geographic locations). Most of the land on Baranof Island and the adjacent islands is administered by the Forest Service and is open to mineral location and development. There are several exceptions. The major exception is the 319,568-acre South Baranof Wilderness created by ANILCA. It is managed by the Forest Service, but is closed to mineral entry. The St. Lazaria National Wildlife Refuge, located on a small island south of Kruzof Island, is managed by the Fish and Wildlife Service and is also closed to mineral entry. A small parcel of land north of Sitka is included within an enacted Municipal watershed classification (PL 78-262) 


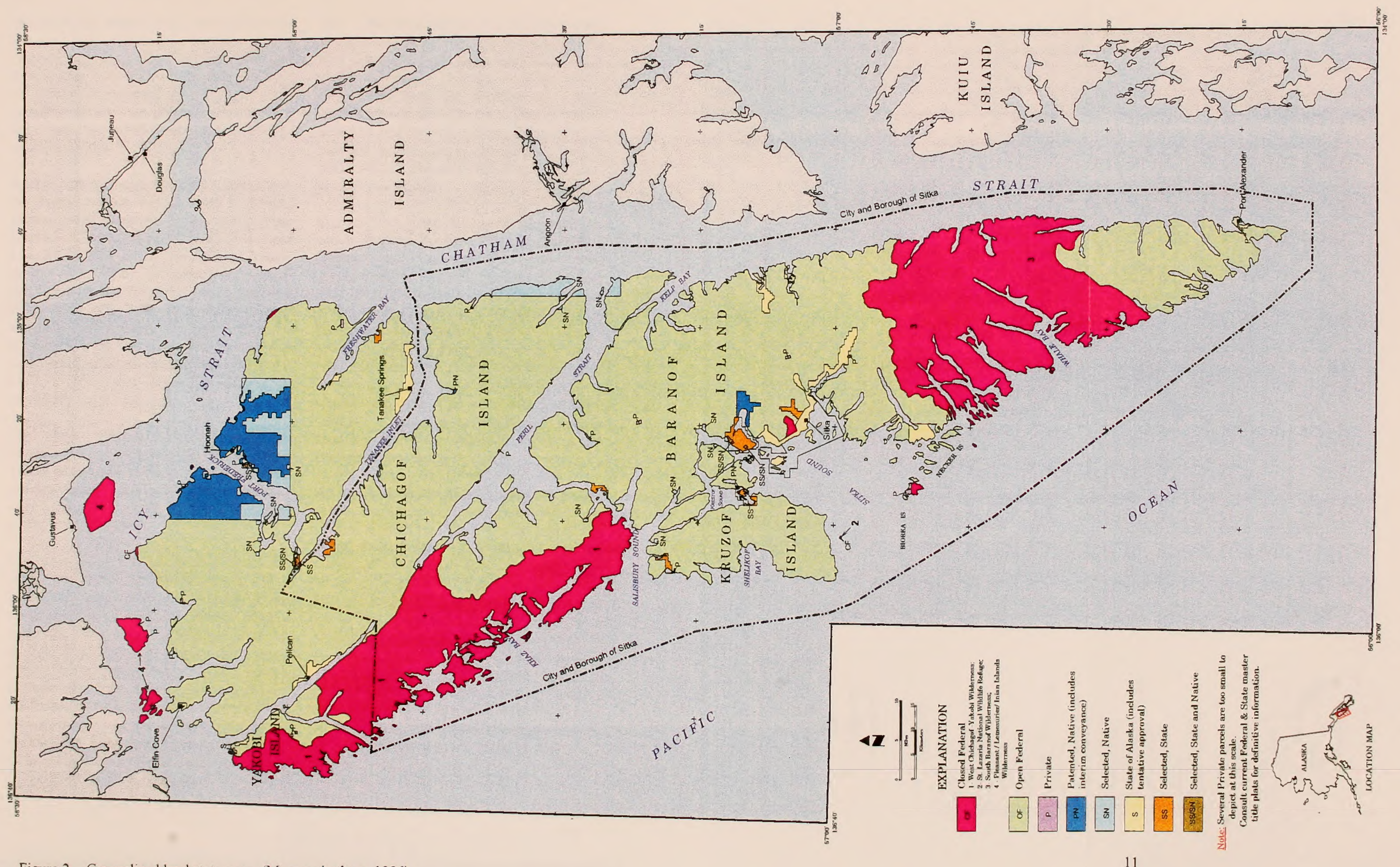


that precludes mineral entry. Several lakes on the east side of Baranof Island, including Baranof, Kasnyku, Carbon, Antipatr, Deer, and Betty Lakes, have been withdrawn by the State of Alaska as potential power sites. This classification does not preclude mineral entry, but it may place specific restrictions on miningrelated activities.

A large part of Chichagof Island is managed by the Forest Service and is open to mineral location and development. However, significant acreage has been designated as LUD II (Land Use Designation II) by the Tongass Timber Reform Act (1990) and subsequent updates resulting from the Tongass Land Management Plan (1996). This designation restricts certain activities and provides for the area to be managed in a roadless state. Roads supporting mineral exploration and development activities in LUD II designated areas are allowed as specifically authorized uses.

The West Chichagof-Yakobi Wilderness occupies 265,529 acres on West Chichagof and Yakobi Islands, and is closed to mineral location and development. The newly created PleasantInian-Lemesurier Islands Wilderness is also closed to mineral entry.

The Huna Totem Village Corporation (Native village corporation for Hoonah) owns a large tract of land on northeastern Chichagof Island, centered around the town of Hoonah. Mineral rights on this native corporation land are managed by Sealaska Corporation, the regional Native corporation for southeast Alaska. Sealaska also holds title to several parcels of subsurface estate in the same vicinity. Several parcels in this area are currently in selection status. The Shee-Atika Corporation (Native village corporation for Sitka) owns land near the Sitka airport as well as a parcel near Katlian
Bay. The Kootznahoo Corporation (Native village corporation for Angoon) has selected land along Chatham Strait from Basket Bay south to Point Thatcher. Most Native corporation lands are available for mineral exploration and development as long as this use does not conflict with traditional, cultural, and subsistence uses. Lease arrangements must be made with the appropriate Native corporations prior to any activity.

State and Municipal land is found adjacent to Sitka, Tenakee Springs, Pelican, Elfin Cove, Baranof, and Port Alexander. Other small conveyances are scattered throughout the study area. The City and Borough of Sitka developed a draft comprehensive plan for lands within its jurisdiction in February, 1995. A general provision affecting the mining industry states, "any uses that can potentially degrade the natural habitat will be reviewed and monitored on a case-by-case basis (City and Borough of Sitka, 1995)." Users are encouraged to provide information to the Borough early in the permitting process.

Active and patented mining claims are present within the study area. Patented claims are present in the following locations: Lemesurier Island, Bohemia Basin, Kimshan Cove (HirstChichagof Mine), Klag Bay (Chichagof Mine), Iyoukeen Cove (Kaiser Gypsum Mine), Rodman Bay and southeast of the head of Rodman Bay, Silver Bay (Stewart Mine), and Pande Basin. Ownership information for the patented claims within the City and Borough of Sitka boundaries can be obtained from the assessors office in Sitka. Records for unpatented, active claims are kept by the BLM and are available from the BLM offices in Anchorage and Juneau as well as from the Forest Service offices in Sitka and Juneau. 
Private parcels are scattered throughout the study area, but most are too small to depict at the scale of Figure 2. Consult the Forest
Service, BLM or State of Alaska to obtain more precise, up-to-date information on these parcels.

\section{ACKNOWLEDGMENTS}

A number of individuals provided assistance in field work and in compiling this report. Their efforts are gratefully acknowledged. The authors were assisted in locating, mapping, and sampling properties by Joseph Kurtak, BLM geologist, stationed in Anchorage, Alaska; Shirley Mercer, office automation specialist with the BLM in Juneau; and Sue Karl, a USGS geologist stationed in Anchorage, Alaska. Edward Gensler, environmental engineer with the BLM in Juneau, provided the analysis of potential conflicts between land use and resource development. Jerry Kouzes, BLM cartographic technician from Anchorage, Alaska, and Shirley Mercer drafted the figures presented in this report. Geographical Information System support was provided by TransPacific Computing, Juneau. John Kato acted as supervisor, overseeing the initiation of the study project in 1994. This role was assumed by Roger Baer in 1995.

The authors extend thanks to the Forest Service for the use of their extensive communications network established in the area. Ron Baer, Forest Service, Sitka, contributed minerals information that was not otherwise available Superior accommodations and logistical support were provided by Jake Yearty, skipper of the $\mathrm{M} / \mathrm{V}$ Ocean Ranger and by Gary McWilliams, skipper of the M/V Hyak. Coastal Helicopters and Ward Air of Juneau and Mountain Aviation of Sitka provided reliable air service. Personnel from the Forest Service's Hoonah Ranger Station provided boat and vehicle transportation to road networks outside of the main Hoonah road system.

Several individuals provided mineral information and access to their claims. Their assistance and cooperation improved the comprehensive nature of this study. Thanks are extended to Neil McKinnon, Bob Craig, Arne Johnson, John and Kay Burgess, and Robert DeArmond.

\section{Previous Studies}

There have been several geologic and mineral resource assessments conducted in the Chichagof and Baranof Islands area since the original discoveries of gold-bearing quartz veins near Sitka in 1871 (Fig. 3). A list of publications is presented in the bibliography of this report ( $\mathrm{p}$. 133). The following is a description of the more significant work completed in the study area.
Wright and Wright $(1905,1906)$ prepared the first summaries of mining developments in the Sitka Mining District in 1904 and 1905. Several other USGS workers compiled annual summaries of mineral activity in Alaska that contain a review of the Sitka Mining District. These include: Wright (1906, 1907a, 1908a, 1909), Knopf (1910, 1911), Brooks (1911a, 1911b, 1912, 1913, 1914, 1915, 1916, 1918, 




Figure 3. - Location and extent of selected geologic maps and previous study areas (Maas and others, 1996). 

1923, 1925), Burchard (1914, 1920), Chapin (1916), Martin (1919, 1920), Brooks and Martin (1921), Brooks and Capps (1924), Buddington $(1925,1926)$, Moffit (1927), and Smith (1926, 1929, 1930a, 1930b, 1932, 1933, 1934a, 1934b, 1936, 1937a, 1937b, 1938, 1941, 1942a, 1942c, 1942e).

Examinations of the geology, mineral deposits, and geochemistry of various parts of the study area have been completed by USGS workers. The first extensive study of the Sitka Mining District was completed by Knopf (1912). Overbeck (1919) produced a compilation of the geology and mineral resources of the west coast of Chichagof Island. Reed and Coats (1941) summarized the geology and ore deposits of the Chichagof Mining District. Pecora (1942) described the nickel-copper deposits on the west coast of Chichagof Island, near Mirror Harbor. Rossman (1959) produced a report detailing the geology and ore deposits of Northwestern Chichagof Island. Loney, Condon, and Dutro produced a geologic map of the Freshwater Bay Area, Chichagof Island (Loney and others, 1962). Loney, Berg, Pomeroy, and Brew compiled a reconnaissance geologic map of Chichagof and Northwestern Baranof Islands (Loney and others, 1963). Berg and Hinckley (1963) produced a reconnaissance geologic map of Northern Baranof Island. Loney, Brew, Muffler, and Pomeroy produced a reconnaissance geologic map of Chichagof, Baranof, and Kruzof islands (Loney and others, 1975). Decker (1980a) produced a geologic map of western Chichagof Island. Johnson and Karl (1982) generated a reconnaissance geologic map of the Western Chichagof and Yakobi Islands Wilderness Area and a final geologic map in 1985 (Johnson and Karl, 1985). The most recent geologic map of Southeastern Alaska is by Gehrels and Berg (1992), and includes the Chichagof and Baranof Islands study area.

Several USGS reports detail the geology and mineral deposits of the West Chichagof/Yakobi Islands Wilderness Area. Analytical results from various types of samples taken in the wilderness area were compiled in 1980 (Hessin and others, 1980). A series of geochemical reports were produced in 1982 showing the distribution of individual elements from stream sediment samples, water samples, and heavy-mineral concentrate samples taken within the wilderness area (Hessin, 1982; Hessin and Crenshaw, 1982; Hessin and others, 1982a-f; Hessin and Day, 1982; Hessin and Hoffman, 1982). Johnson and Elliott (1984a-k) produced geochemical maps of individual elements from bedrock samples taken in the wilderness area in 1984. Johnson, Kimball, and Still compiled a report on the mineral resource potential of the wilderness area in 1982 (Johnson and others, 1982).

More site-specific work by USGS workers in the Chichagof-Baranof study area include reports on: Iyoukeen Cove (Burchard, 1920a; Stewart, 1932b; Twenhofel and others, 1949; Flint and Cobb, 1953); Red Bluff Bay (Guild and Balsley, 1942; Kennedy and Walton, 1946a); Bohemia Basin (Reed and Dorr, 1942; Kennedy and Walton, 1946b); Mirror Harbor (Kennedy and Walton, 1946a); Snipe Bay (Reed and Gates, 1942); Redfish Bay (Sainsbury, 1957); and the Apex El Nido area (Twenhofel, 1949).

E. H. Cobb of the USGS compiled metallic mineral resource maps for the Juneau, Mt. Fairweather, Port Alexander, and Sitka 1:250,000-scale quadrangles (Cobb, 1972a-d). $\mathrm{He}$ also wrote summaries of references to the mineral occurrences in the same quadrangles (Cobb. 1978a-d). H. C. Berg completed a report detailing the regional geology, metallogenesis, and mineral resources of 
Southeastern Alaska, by quadrangle (Berg, 1984). Brew, Drew, Schmidt, Root, and Huber developed a methodology to estimate the undiscovered locatable mineral resources throughout the Tongass National Forest (Brew and others, 1991). The report discusses a number of mineral deposits in the current study area. Goldfarb and Miller (1997) edited a compilation of papers on the mineral deposits of Alaska that also mentions a number deposits in the Chichagof-Baranof study area.

Several reports pertaining to the mineral deposits in the area have been prepared by Bureau of Mines workers. One report describes the status of mining in the Chichagof Mining District (Thorne, 1967). Mineral assessment reports address the west part of Western Chichagof Island (Still and Weir, 1981) as well as adjacent parts of Chichagof Island and Yakobi Island (Kimball, 1982). A geochemical report describes the distribution of gold, platinum, palladium, and silver in parts of Bohemia Basin (Still, 1988).
Site-specific Bureau of Mines publications on mines in the area include reports on the Chichagof Mine (Humphrey, 1936a; Metz, 1978); the Hirst-Chichag of Mine (Humphrey, 1936b, 1938; Metz, 1978); Yakobi Island nickel (or Bohemia Basin; U. S. Bureau of Mines, 1944; Kennedy, 1944; East and others, 1948); Mirror Harbor nickel deposits (U. S. Bureau of Mines, 1944b; Traver, 1948); Snipe Bay nickelcobalt deposits (Foley, 1989); Slocum Arm molybdenum (Thorne, 1952); diamond drilling of the Gypsum-Camel (or Camel Gypsum) prospect at Iyoukeen Cove (Jermain and Rutledge, 1952); and the Lucky Devil claims (or Mt. Baker; Thorne, 1960).

Geologists and mining engineers from the Alaska Territorial Department of Mines and its successor, the Division of Mines and Minerals, reported on specific mineral properties and mineralized areas in the Chichagof-Baranof area between 1918 and 1968. These reports are listed in Table 1, along with other reports published by the two agencies.

Table 1. Alaska Territorial Dept. of Mines and Division of Mines and Minerals reports

\begin{tabular}{|l|l|l|l|}
\hline \multirow{2}{*}{ Author } & \multicolumn{1}{c|}{ Property Name } & \multirow{2}{*}{ Date } \\
\cline { 2 - 4 } & \multicolumn{1}{|c|}{ Author's } & \multicolumn{1}{c|}{ This report } & \multicolumn{1}{c|}{1968} \\
\hline Ballard & Slocum Arm Molybdenite & Slocum Arm (P95) & 1962 \\
\hline Bush and Kenly & Lucky Devil mining claims & Mt. Baker (P44) & 1946 \\
\hline Gustafson & Camel Gypsum & same (P20) & 1962 \\
\hline Herreid & Camel Gypsum/Pacific Gypsum & same (P20) & 1953 \\
\hline Holdsworth and Williams & Red Bluff Bay & same (P138) & 1942 \\
\hline Laney & Alaska Nickel Mines & Mirror Harbor (P45) & 1961 \\
\hline McPhar Geophysics Ltd. & Chichagof area & & 1938 \\
\hline Racey & New Chichagof Mining Syndicate & same (P49) & 19 \\
\hline
\end{tabular}




\begin{tabular}{|c|c|c|c|}
\hline \multirow{2}{*}{ Author } & \multicolumn{2}{|c|}{ Property Name } & \multirow{2}{*}{ Date } \\
\hline & Author's & This report & \\
\hline Roehm & Lucky Strike & Koby (P31) & $1936 f$ \\
\hline Roehm & Alaska Gold Digger group & American Gold Company (P69) & $1936 c$ \\
\hline Roehm & Chichagof Creek group & Helen Chichagof (P76) & $1936 b$ \\
\hline Roehm & Goldwin group & same (P13) & $1936 d$ \\
\hline Roehm & New Chichagof Mining Syndicate & same (P49) & $1936 \mathrm{e}$ \\
\hline Roehm & Mike Wall prospect & Woll (P82) & $1936 \mathrm{~g}$ \\
\hline Roehm & Slocum-Grunter prospect & Cobol Mine (P91) & $1936 \mathrm{~h}$ \\
\hline Roehm & Green Lake Group & same (P128) & $1938 \mathrm{a}$ \\
\hline Roehm & Halleck Island & same (P109) & $1938 b$ \\
\hline Roehm & Krestof Group & same (P107) & $1938 c$ \\
\hline Roehm & Little Blonde \& High Grade Groups & same (106) & $1938 d$ \\
\hline Roehm & Bohemia Tunnel & Bohemia Basin (P11) & $1938 \mathrm{e}$ \\
\hline Roehm & Lucky Chance Mine & same (P135) & 1940 \\
\hline Ryason & Mt. Baker Copper prospect & same $(\mathrm{P} 44)$ & 1961 \\
\hline Smith & Doolth Peninsula & & 1924 \\
\hline Stewart & Mineral Resources - Chichagof Is. & & 1931 \\
\hline Vevelstad & Yakobi Island drill logs & Bohemia Basin (P11) & $\begin{array}{l}\text { unknow } \\
\mathrm{n}\end{array}$ \\
\hline Williams & El Nido Mine & Apex El Nido (P17) & 1955 \\
\hline Winchell & Alaska Nickel Mines & Mirror Harbor (P45) & 1918 \\
\hline
\end{tabular}

Several unpublished reports and theses on mineral locations in the area have been completed and include: an M.S. thesis on wallrock alteration at the Chichagof and HirstChichagof Mines (Dadoly, 1987); reports on the Hirst-Chichagof Mining Company (Fiedler, 1941b; Kazee, 1941); New Chichagof Mining Syndicate (Nelson, 1932); an M.S. thesis on the Takanis copper-nickel-cobalt prospect, Bohemia Basin (Jirik, 1982); Bohemia Basin nickel
(Ricker, 1941); Alaska Nickel Mines/Mirror Harbor (Flemming, 1917; Rogers, 1917; Healy, 1918; Jackson, 1918; Sanford, 1942; Traver, 1944); Apex El Nido Mine (Holmes, 1941); Mt. Baker copper prospect (Moerlein, 1971); report on several Chichagof Island prospects (Nelson, 1931 a); Cobol Mine (Williams, 1928; Ship and Shipman, 1938); molybdenum ore dressing at Cobol (Wells, 1952); E. B. Sparling's Haywire Group (or Apex and El Nido; Decker, 1931); 
Helen (Chichagof) Group (Nelson, 1932); Slim and Jim copper prospect (Storm, 1917); a Ph.D. thesis on the Cretaceous subduction complex on Western Chichagof Island (Decker, 1980b); an
M.S. thesis on the geology of the Goddard Hot Springs area (Riefenstuhl, 1983).

\section{MINING HISTORY/PRODUCTION}

The history of mining activity in the ChichagofBaranof area extends from the early 1870's to the present. Mineral production came predominantly from the Chichagof and HirstChichagof Mines on the west side of Chichagof Island, but other sites recorded production as well. A summary of mine production in the study area is presented in Table 2 .

The earliest mining activity in the study area took place on the Indian River near Sitka in 1871 (DeArmond, 1997a). No significant developments followed in the Indian River area, but additional discoveries were made in 1872 at the Stewart property in Silver Bay, southeast of Sitka. By 1879 , a 10-stamp mill was erected on the Stewart property (Knopf, 1912). About the same time a 5-stamp mill was erected at the Lucky Chance Mine, also in the Silver Bay area, although exact details of this mine's development are unknown (Roehm, 1940). The gold rush to Juneau, which began in 1880-81, prompted an exodus from Silver Bay, and mining activity slowed considerably in the area.

Early prospecting also took place in the vicinity of Yakobi Island. Gold was discovered at the Bon Tara Mine near the eastern tip of the island, in 1887. About $\$ 1,100$ worth of gold $(55 \mathrm{oz})$ was recovered from the property (Overbeck, 1919). Yakobi Island was also the site of the Bohemia Basin nickel-copper-cobalt discovery in 1919 (Reed and Dorr, 1942). The area was drilled extensively during World War II (U.S. Bureau of Mines, 1944a; Kennedy and Walton, 1946b). The International Nickel Company (INCO) continued drilling the deposit in the 1950's (Kimball, 1982). Later, Inspiration Development Company completed 29,000 feet of drilling at Bohemia Basin between 1972 and 1979. They established a resource of about 24 million tons of mineralized rock (Thornsberry and DeWilliam, 1982).

Before the discovery of the larger Bohemia Basin deposit, a copper-nickel-cobalt deposit was found at Mirror Harbor on the northwest side of Chichagof Island in 1911 (Overbeck, 1919). Mirror Harbor was also drilled by the Bureau of Minesas part of its strategic minerals program during World War II (U.S. Bureau of Mines, 1944b).

The discovery of gold at Klag Bay in 1905 (Knopf, 1912) was the first chapter on what would become the principal gold-producing region of the study area. A quartz outcrop found at the Degroff Mine (later known as the Chichagof Mine) was so rich that ore was sacked and shipped directly to the Tacoma Smelter in Washington State (Still and Weir, 1981). The Golden Gate Mine was discovered in 1905 along the same fault that hosted mineralized rock at the Degroff Mine (Knopf, 1912). The Jumbo Mine was discovered in 1909 , and $1,450 \mathrm{oz}$ of gold were produced from a high-grade pocket found near the beach in Klag Bay (Still and Weir, 1981). This property was operated separately from the Degroff and Golden Gate Mines. A power plant was 
installed at Sister Lake in 1909 to provide power for the Degroff and Golden Gate properties. Operations at these two mines were consolidated in 1911 under the control of the Chichagof Mining Company (Reed and Coats, 1941). The consolidated mine operated almost continuously until 1942, and produced over 600,000 tons of ore, containing nearly $660,000 \mathrm{oz}$ of gold and $195,000 \mathrm{oz}$ of silver. Intermittent cleanup operations at the mine and reworking of old tailings continued until 1973 (Still and Weir, 1981).

The Alaska Chichagof Mine, also located in the Klag Bay area, was discovered in 1928, and incorporated into the Alaska Chichagof Mining Company by 1931. A test shipment was made in 1932. The Chichagof Mining Company optioned the property in 1936, and their records indicate that $660 \mathrm{oz}$ of gold had been recovered from the mine (Reed and Coats, 1941; Still and Weir, 1981).

The Hirst-Chichagof Mine was discovered in 1905 at Kimshan Cove, north of Klag Bay. By 1918 the Hirst-Chichag of Mining Company was formed (Reed and Coats, 1941). The company began mining in 1922, and continued until 1943. The mine produced approximately $131,000 \mathrm{oz}$ of gold and $33,000 \mathrm{oz}$ of silver from over 140,000 tons of ore (Still and Weir, 1981).

The gold-bearing quartz veins at the Apex and El Nido properties turned out to be the next most productive after the Chichagof area mines. The veins were discovered west of Pelican by J. Cann in 1919 and 1920. The two mines that were developed produced over $17,000 \mathrm{oz}$ of gold and 2,400 oz of silver during intermittent operation from 1924-1939. The majority of production came from the Apex workings (Holmes, 1941).

Other discoveries on the west side of Chichagof Island were less productive. The Mine Mountain veins were discovered in 1921 (Reed and Coats, 1941). Production between 1933 and 1935 amounted to about $\$ 3,500$ worth of gold (about 100-150 oz; Kimball, 1982). The Koby gold prospect was discovered in 1933 by J. Koby (Roehm, 1936f). Most development work was completed by 1936 , but no production was reported from the prospect (Kimball, 1982).

Gold and base metals were not the only products mined in the Chichagof-Baranof area. The gypsum deposit of the Pacific Coast Gypsum Company was discovered at Iyoukeen Cove in 1902. Active mining commenced in 1906 and continued intermittently until 1923 (Flint and Cobb, 1953). Nearly 500,000 tons of gypsum were removed from the site (Stewart, 1932b).

Several companies have recently explored deposits in the district. Sites receiving attention include the Chichagof, Hirst-Chichagof, Apex El Nido, Warm Springs Bay, and Silver Bay areas. 
Table 2. Summary of mine production

\begin{tabular}{|c|c|c|c|c|}
\hline Mine (Plate 1 \#) & Activity Years & Gold (oz.) & Silver (oz.) & Gypsum, tons \\
\hline Bon Tara (P12) & 1887 & 55 & & \\
\hline $\begin{array}{l}\text { Apex El Nido } \\
\text { (P17) }\end{array}$ & $\begin{array}{c}1924-28,1934-35 \\
1937-39\end{array}$ & 17,000 & 2,400 & \\
\hline $\begin{array}{l}\text { Mine Mountain } \\
\quad \text { (P34) }\end{array}$ & $1933-35$ & $100-150$ & & \\
\hline Jumbo (P70) & 1909 & 1,450 & & \\
\hline Chichagof (P75) & $1912-1942$ & 659,955 & 195,000 & \\
\hline $\begin{array}{l}\text { Hirst-Chichagof } \\
\text { (P60) }\end{array}$ & $1922-1943$ & 131,000 & 33,000 & \\
\hline $\begin{array}{l}\text { Alaska Chichagof } \\
\text { (P71) }\end{array}$ & 1936 & 660 & & \\
\hline Cobol (P91) & $1926-1959$ & 100 & & \\
\hline $\begin{array}{l}\text { Iyoukeen Cove } \\
\text { (P21) }\end{array}$ & $1906-23$ & & & 500,000 \\
\hline \multicolumn{2}{|c|}{ TOTAL PRODUCTION } & 810,370 & 230,400 & 500,000 \\
\hline
\end{tabular}

\section{GENERAL GEOLOGY}

The Chichagof-Baranof study area is underlain by rocks belonging to three tectonostratigraphic terranes (Berg and others, 1978). From west to east these are the 1) Chugach, 2) Wrangellia, and 3) Alexander terranes (Fig. 4).

The Chugach terrane extends from Baranof Island around the Gulf of Alaska to Kodiak Island (Silberling and others, 1992). It lies outboard of the Wrangellia and Alexander terranes and makes up most of Baranof Island and the west side of Chichagof Island. On Chichagof and northern Baranof Island the terrane is separated from the Wrangellia and Alexander terranes to the northeast by the westvergent Border Ranges thrust fault and the Peril
Strait right-lateral, strike-slip fault, respectively. East of Baranof Island the Chatham Strait regional, strike-slip fault separates the Chugach terrane from the Alexander terrane (Gehrels and Berg, 1994).

Chugach terrane rocks in the study area are made up of marine sedimentary and volcanic rocks that have been interpreted as a deformed flysch and melange sequence that forms a continental margin accretionary complex (Decker and others, 1979; Plafker and others, 1976; Plafker and others, 1977). Dominant units are the Cretaceous Kelp Bay Group that forms the melange and the Cretaceous Sitka Graywacke flysch sequence. The Kelp Bay 


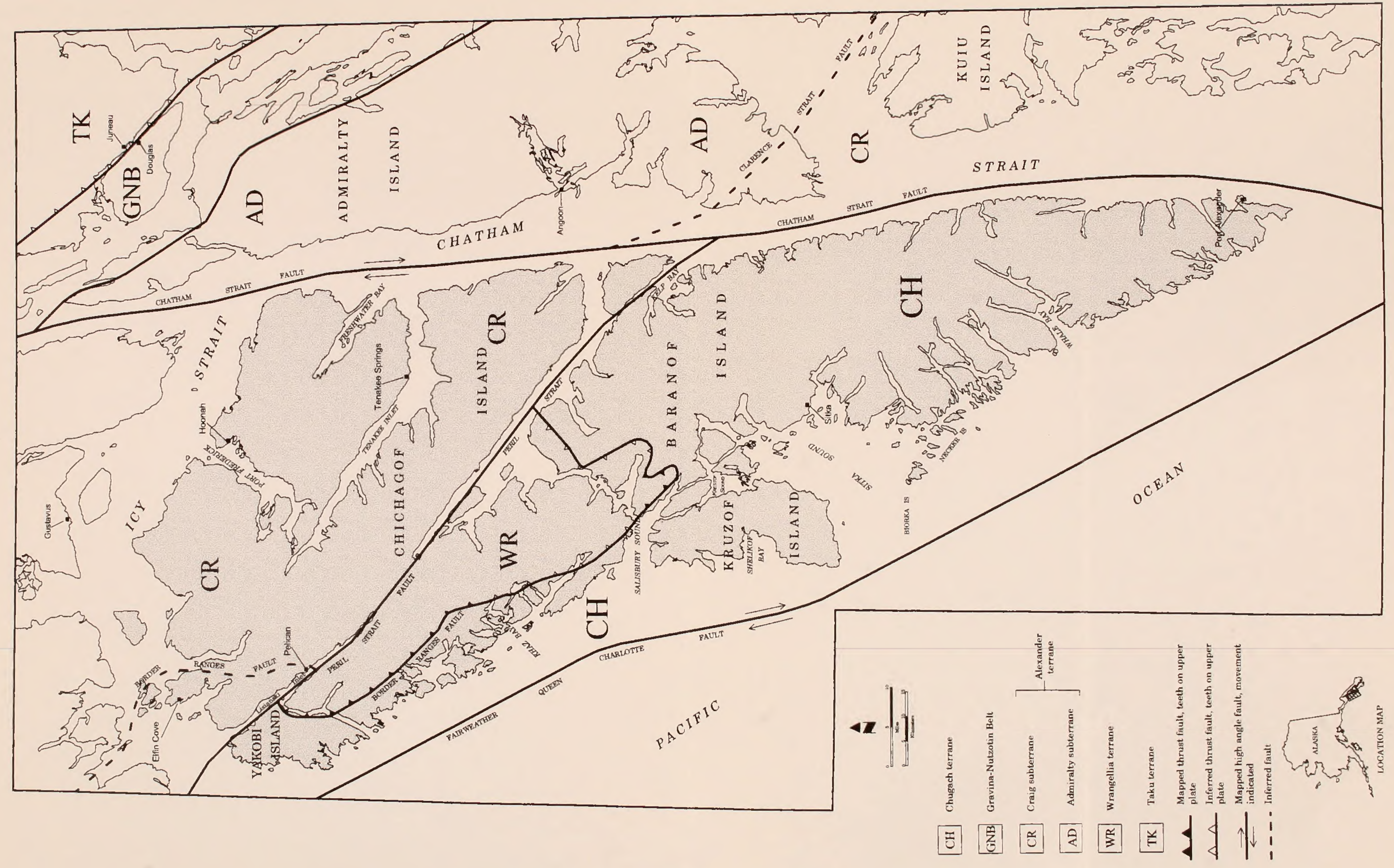



Group west of the Border Ranges Fault includes the Pinnacle Peak Phyllite, the Waterfall Greenstone, and metavolcanic and metasedimentary rocks of the Khaz formation (Johnson and Karl, 1985; Karl and others, 1982). These units have been incised by Tertiary high-angle faults that include the northwest trending Sitka fault zone (Loney and others, 1975, Brew, 1997). These faults have been instrumental in the localization of gold-bearing quartz veins in the Klag Bay and Silver Bay areas.

The Wrangellia terrane extends along the northwest margin of North America from Vancouver Island to south-central Alaska (Jones and others, 1977; Silberling and others, 1992). Within the study area, Wrangellia terrane rocks are located on southwestern Chichagof Island and northwestern Baranof Island. They are separated from the Alexander terrane on the northeast by the Peril Strait fault. The Border Ranges fault separates Wrangellia from the Chugach terrane to the west and south (Gehrels and Berg, 1994).

The oldest Wrangellia terrane rocks found in the study area are late Paleozoic in age (Berg and others, 1978; Johnson and Karl, 1985). These rocks consist of a sequence of marine sedimentary and volcanic rocks. They are overlain by the Triassic Goon Dip Greenstone and Whitestripe Marble (Loney and others, 1975). These two units have been correlated with the Late Triassic Nickolai Greenstone and Chitistone Limestone of the Wrangellia terrane in the Wrangell Mountains (Plafker and others, 1976). Minor Jurassic sedimentary rocks are also included in the Wrangellia terrane as well as a Jurassic tonalite (Berg and others, 1978; Loney and others, 1975). The late Paleozoic Wrangellian depositional environment has been interpreted as an oceanic volcanic arc followed by rifting in Triassic time (Gehrels and Berg, 1988, 1994).

The Alexander terrane hosts the oldest rocks in the study area. The terrane is exposed throughout southeast Alaska and extends northward into southern Alaska (Silberling and others, 1992). The terrane has been divided into two subterranes, of which the Craig subterrane is found within the study area. It is located northeast of Peril Strait and Lisianski Inlet on the northeast side of Chichag of Island. Within the study area, the Alexander terrane is separated on the southwest from the Wrangellia and Chugach terranes by the Peril Strait fault and the Border Ranges fault. East of Chichagof Island, the Chatham Strait fault separates the Craig and Admiralty subterranes of the Alexander terrane (Silberling and others, 1992; Gehrels and Berg, 1994).

The Alexander terrane consists of Paleozoic sedimentary, volcanic, and intrusive rocks. Bedded units of the terrane include clastic sedimentary rocks of the Silurian Point Augusta Formation, the Silurian-Devonian Kennel Creek Limestone, the clastic and overlying limestone members of the Middle and Upper Devonian Cedar Cove Formation, the Upper Devonian Freshwater Bay andesitic and basaltic volcanics, and the Mississippian Iyoukeen Formation limestones (Loney and others, 1975). Intrusive rocks include the Silurian or older Sitkoh Bay alkalic suite (Ford and others, 1990). Alexander terrane rocks have been interpreted as evolving in an oceanic volcanic arc environment followed by a more stable, shallow marine setting (Gehrels and Saleeby, 1987; Gehrels and Berg, 1994).

Several plutonic belts have been distinguished in southeast Alaska, of which two occur in the Chichagof-Baranof study area: the "Fairweather- 
Baranof" belt and the "Muir-Chichagof" belt (Brew and Morrell, 1983; Brew, 1994). The Fairweather-Baranof belt includes early to midTertiary granodiorites, tonalites, trondhjemites, and gabbros on Baranof Island, on the west side of Chichagof Island, and on Yakobi Island. The Tertiary gabbroic rocks at the head of Tenakee Inlet are also included in this belt. Several outcrops of Mesozoic ultramafic rocks, particularly those at Red Bluff Bay and between Red Bluff Bay and Silver Bay have been prospected mainly for chromium and are included in this belt (Brew and Morrell, 1983; Loney and others, 1975).

Brew and Morrell's (1983) Muir-Chichagof belt includes the Cretaceous granodiorites, tonalites, diorites, and gabbros that crop out in an area from southwest of Peril Strait and Lisianski Inlet to northwest of the head of Tenakee Inlet. Scattered outcrops of granodiorite, quartz monzonite, and diorite northeast of this area are also included in the Muir-Chichagof belt (Brew and Morrell, 1983; Loney and others, 1975). The Silurian or older Sitkoh Bay alkalic suite (Ford and others, 1990) defines a third belt on northeast Chichagof Island, which was intruded into the Alexander terrane prior to accretion.

The Quaternary volcanic field at Mount Edgecumbe on Kruzof Island contains basalts, andesites, and dacites and represents the youngest lithified rocks in the study area (Brew and others, 1969; Brew, 1994). Volcanic activity ceased with explosive eruptions dated at about 5,000 years before present (Riehle and Brew, 1984).

Quaternary surficial sedimentary deposits are found along most drainages. These include glacial, glaciofluvial, alluvial, and colluvial deposits.

The structural grain of the Chichagof-Baranof study area is generally oriented northwestsoutheast. This includes terranes and terrane boundaries, regional fault patterns, outcrop patterns of both bedded and intrusive rocks, bedding, and metamorphic foliation. In detail, the structural patterns of the area are complex and include areas disrupted by multiple episodes of folding and faulting. Intense folding ended by early Tertiary, but movement on faults in the area continues to the present (Loney and others, 1975; Gehrels and Berg, 1994).

Metamorphic belts have been defined across southeast Alaska by Brew and others (1992) and by Dusel-Bacon (1994). The metamorphism in the Chichagof-Baranof study area is generally related to accretionary tectonic events as well as to local intrusive activity. The degree of metamorphism in the area ranges from albiteepidote hornfels to possibly pyroxene hornfels facies contact metamorphic grades and from prehnite-pumpellyite to greenschist facies regional metamorphic grades (Brew and others, 1992; Dusel-Bacon, 1994).

\section{LAND USE AND RESOURCE ISSUES}

Land use and resource issues have been examined with respect to the 13 KMDA's in the Chichagof-Baranof area. The land use designations are those employed by the Forest
Service, which is the dominant Federal land management agency in the study area. Various sources were used to determine land use designations including the 1996 Tongass Land 
Management Plan (TLMP), a January 21, 1998 draft copy of a 1997 Forest Plan map, and Alaska Department of Fish and Game information on anadromous fish streams. A discussion of the land use designations within each KMDA and potential conflicts between land use designations and resource development are presented in each of the KMDA descriptions in the "Known Mineral Deposit Areas" section. The location and physical extent of each KMDA was compared to the boundaries of the land use designations listed below (A-O). In many cases a visual estimate was made to determine the amount of land covered by various land use designations in each KMDA.

A rating system is provided to estimate the scope of potential conflict between land use designations and resource development. Information used to determine the ratings includes the type and size of the deposits within the KMDA's and the potential mining method if developed, as well as possible access options for development. Ratings of 'none' through ' 3 ' are described following Table 3 below.

Below is a description of the various land use designations employed by the Forest Service. A table summarizing the land use designations within each KMDA and a rating of potential conflicts is also provided (Table 3 ).

A - The 'Wilderness' assessment was made from information provided on the 1997 Forest Plan map. This designation is characterized by extensive unmodified natural environments, and is withdrawn from all mineral entry. An act of Congress is required to withdraw areas from wilderness status before mineral development would be permitted. An exception to the restriction on mineral development is the existence of claims with valid existing rights that were located prior to the designation of wilderness. In this case access and mineral development would be allowed. Only the Doolth Mountain KMDA has claims with valid existing rights within a wilderness area.

B - The 'Land Use Designation II (LUD II)' assessment was made from information provided on the 1997 Forest Plan map. This designation is managed in a roadless state to preserve wildland character, and is open to locatable mineral entry with potentially significant restrictions.

C - No KMDA's encompassed any 'Special Interest Areas.'

D - No KMDA's encompassed any 'Wild \& Scenic River Candidates.'

E - The 'Enacted Municipal Watershed' assessment was made from information provided on the 1997 Forest Plan map. This designation is mandated for Municipal water supply purposes. Municipal watersheds are closed to all mineral entry. Silver Bay was the only KMDA to encompass enacted Municipal watershed.

F - No KMDA's encompassed any 'Experimental Forest.'

G -The 'Deer Hunting' assessment was made from the 1996 Community Deer Harvest map of TLMP. This resource mapping datum is based on average harvest levels of Sitka black-tail deer for the years of 1987 - 1994. The location and physical extent of the KMDA was compared to known average harvest levels within hunting units or parts of hunting units encompassed by the KMDA. 'Low' deer harvest levels were attributed to areas averaging less than 100 deer per year, 'moderate' as averaging 100 to 500 per 
year, and 'high' harvest levels as averaging over 500 per year.

H - The 'Anadromous Fish Streams' assessment was made from information provided by the Alaska Department of Fish and Game, 1997. This resource mapping datum identifies all streams supporting any anadromous fish. Anadromous streams outside KMDA boundaries that may be affected by mineral development are also considered.

I - The 'Recreation' assessment was made from the 1996 Recreation Places Inventory map from TLMP. This designation includes both primitive and semi-primitive recreation. The areas are managed for a wide variety of recreation activities in a predominantly natural setting. They are considered particularly attractive to users engaged in recreation activities and receive recurring use. They include beaches, streamside or roadside areas, trail corridors or other features. A semi-primitive designation allows road-building. Recreation areas are open to mineral entry.

$\mathrm{J}$ - The 'Recreation Developments' assessment was made from the 1996 Recreation Places Inventory map from TLMP. Recreation developments include shelters, observation sites, campgrounds, cabins, and picnic sites. These developments are withdrawn from all mineral entry.

$\mathrm{K}$ - The 'Tourism Areas' assessment was made from the 1996 Recreation Places Inventory map from TLMP. Tourism areas are recreation areas important for commercial recreation and tourism, which are of value to the local and regional economy. They include areas used by outfitters and guides, resorts, charter boat operations, and bus lines as well as areas identified as attractions in tourism brochures.
L - The 'Timber Harvest' assessment was made from information provided on the 1997 Forest Plan map. This designation marks areas for timber production and is open to mineral development. Only the Slocum Arm KMDA includes any 'Timber Harvest' designated areas.

M - The 'Minerals Prescription Candidate' assessment was made from information provided on the 1997 Forest Plan map. This designation encompasses areas managed to encourage and facilitate locatable mineral exploration and development in an environmentally sound manner. The Lisianski and Bohemia Basin KMDA's were the only ones to include minerals prescription areas.

$\mathrm{N}$ - The 'State Land' assessment was made from information provided on the 1997 Forest Plan map. State land includes all intertidal lands. All the KMDA's encompass intertidal lands except for the Hill and Slocum Arm areas. In the Doolth Mountain area, significant resources are situated on State land in the intertidal zone. Intertidal lands are open to mineral entry. The Silver Bay and Warm Springs Bay KMDA's contain blocks of State land outside the intertidal zone.

O - The 'Private Land' assessment was made from information provided on the 1997 Forest Plan map as well as from master title plats and individual maps of mineral patent lands. Private land locations having the most significance for mineral development are the patented mining claims. The KMDA's with patented mining claims are Doolth Mountain, Bohemia Basin, and Silver Bay. The Silver Bay and Warm Springs Bay KMDA's include private land, other than patented mining claims. Mineral development is allowed on private land. 
Table 3. Summary of land use and resource issues for each KMDA

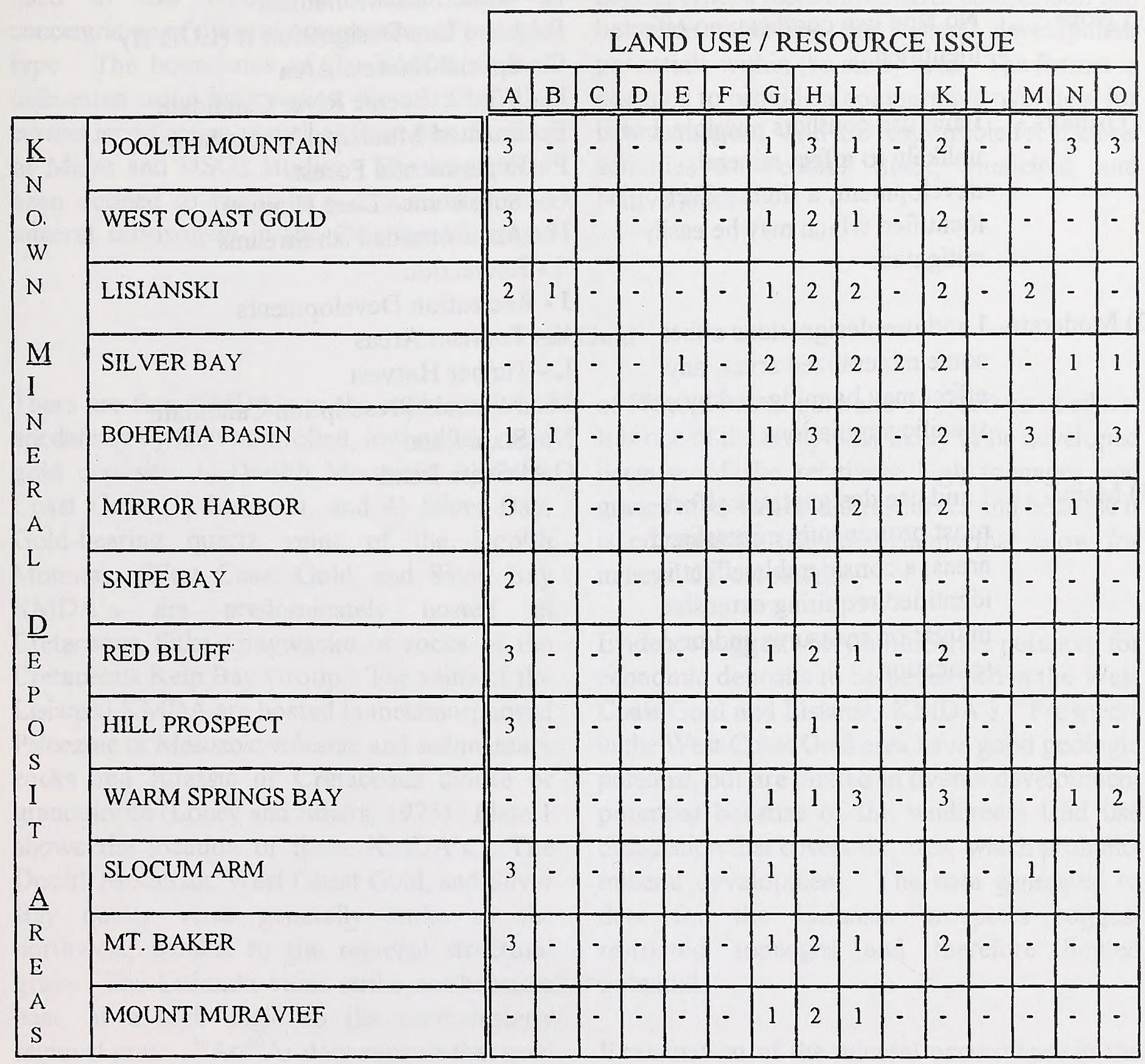


Ratings of potential land use and resource issue conflicts:

(-) None- No land use conflicts; no effect identified.

(1) Minor- Land use conflicts possible, but unlikely to affect mineral development; a slight effect identified which may be easily mitigated.

(2) Moderate- Land use designations affect some mineralized areas; any effect may be mitigated by site specific stipulations.

(3) Major- Land use designations affect most prominently mineralized areas; a considerable effect is identified requiring extensive mitigation measures and/or relocation.
Issues A-O defined as follows:

A - Wilderness/Monument

B - Land Use Designation II (LUD II)

C - Special Interest Area

D - Wild \& Scenic River Candidate

E - Enacted Municipal Watershed

F - Experimental Forest

G - Subsistence Deer Hunting

H - Anadromous Fish Streams

I - Recreation

J - Recreation Developments

$\mathrm{K}$ - Tourism Areas

L - Timber Harvest

M - Minerals Prescription Candidate

N - State Land

O - Private Land 


\section{KNOWN Mineral DePOSIT AREAS}

Known mineral deposit areas (KMDA's), as used in this report, are areas with a concentration of mineral occurrences of a single type. The boundaries of the KMDA's were delineated using information derived from the current investigation as well as from past Bureau of Mines and USGS studies. The areas have been defined to facilitate a discussion of the mineral endowment in the Chichagof-Baranof study area. By limiting the KMDA's to a single deposit type, a more meaningful comparison can be made regarding the mineral development potentials within the study area. The format is designed to provide a comparative overview for land managers, who are responsible for mineral activities on Federal, State, Municipal, and Native lands.

\section{Vein Gold}

There are four KMDA's in the study area that are defined by fault controlled, low sulfide, vein gold deposits: 1) Doolth Mountain, 2) West Coast Gold, 3) Lisianski, and 4) Silver Bay. Gold-bearing quartz veins of the Doolth Mountain, West Coast Gold, and Silver Bay KMDA's are predominately hosted in Cretaceous Sitka Graywacke or rocks of the Cretaceous Kelp Bay Group. The veins of the Lisianski KMDA are hosted in metamorphosed Paleozoic or Mesozoic volcanic and sedimentary rocks and Jurassic or Cretaceous diorite or granodiorite (Loney and others, 1975). Plate 1 shows the location of these KMDA's. The Doolth Mountain, West Coast Gold, and Silver Bay quartz veins generally strike to the northwest, parallel to the regional structural grain. The Lisianski veins strike northeast to east, at a high angle to the northwesterly regional grain. ${ }^{40} \mathrm{Ar} /{ }^{39} \mathrm{Ar}$ data suggest that gold vein formation in all four KMDA's was the product of a short-lived Eocene thermal event (Taylor and others, 1994; Haeussler and others, 1995).

The Doolth Mountain KMDA accounts for almost all of the study area's precious metal production and almost all of the area's resources of $675,000 \mathrm{oz}$ of gold and $195,000 \mathrm{oz}$ of silver. It is one of the areas most likely to be developed because of the relatively high tonnages and grades of its calculated resources and because it is covered by patented claims that allow for mineral development.

Evidence suggests only a moderate potential for economic deposits to be developed in the West Coast Gold and Lisianski KMDA's. Prospects in the West Coast Gold area have good geologic potential, but are limited in overall development potential because of the wilderness land use designation that covers the area, which prohibits mineral development. The data generated to date for the Lisianski prospects suggest restricted tonnages and therefore limited potential.

Examination of the mineral occurrences in the Silver Bay area indicates a small likelihood of locating an economic deposit. Despite the numerous quartz veins in the area, the veins are discontinuous and contain very spotty values.

Wilderness designations have a significant impact on the vein gold development potential in the study area. Outside the private holdings, all 
of the Doolth Mountain and West Coast Gold KMDA's are designated as wilderness where mining is prohibited. About half of the Lisianski KMDA is wilderness. Thirty-nine patented mining claims in the Doolth Mountain area, which contain almost all the resources in the study area, are in-holdings (private property) within the wilderness and could conceivably be developed.

\section{Doolth Mountain KMDA}

\section{Location / Access}

A series of fault-controlled, vein gold deposits define the 5 - by 6-mile Doolth Mountain KMDA, located 50 air miles north-northwest of Sitka on the west coast of Chichagof Island (Plate 1, KMDA no. 5). The area topography rises from sea level to the summit of Doolth Mountain at an elevation of 2,159 feet and ranges from flat lying, brushy, forested lowlands to cliffy, alpine areas. Klag Bay, Kimshan Cove, and Ogden Passage comprise the area waterways. Most of the area prospects are located at, or sufficiently close, to tidewater so that they can be easily accessed by foot. Waterways in the area can be accessed by float plane or boat from Sitka. Figures 5 and 6 show important mines, prospects, patented claims, and the general geology in the Doolth Mountain area.

\section{History / Production}

Gold was discovered at the Chichagof and HirstChichagof deposits in 1905 (Knopf, 1912; Reed and Coats, 1941). The Chichagof Mine, initially financed on high-grade gold ore float, operated from 1906 to 1942. The Hirst-Chichagof Mine operated from 1922 to 1943. They jointly produced $791,000 \mathrm{oz}$ of gold and $228,000 \mathrm{oz}$ of silver from over 740,000 tons of ore (Still and Weir, 1981). The Jumbo Mine was discovered in 1909 and $1,450 \mathrm{oz}$ of gold was reportedly mined from a high-grade pocket at the high tide line. The Alaska Chichagof Mine was discovered in 1928. The Chichagof Mining Company operated this property in 1936 and recovered $660 \mathrm{oz}$ of gold from 600 tons or ore using the Chichagof Mill facilities (Still and Weir, 1981).

Other prospects in the Doolth Mountain area include the McKallick Lode, Basoiniuer, Chichagof Prosperity, Baney, and American Gold Company. These prospects were explored between 1906 and World War II (Still and Weir, 1981). There is no production reported from these prospects, nor are there sufficient data to estimate resources.

\section{Geology}

The Doolth Mountain area is underlain by the Cretaceous Sitka Graywacke, which is a flysch and melange member of the Chugach tectonostratigraphic terrane. The flysch and melange represent an accretionary prism on the outboard margins of the terrane (Plafker and others, 1977). The Sitka Graywacke is composed of weakly metamorphosed sandstone, siltstone, mudstone, and massive graywacke, which generally strikes to the northwest and dips steeply to the southwest (Loney and others, 1975).

The Sitka Graywacke is pervasively fractured by a network of parallel to subparallel, northwest striking, steeply southwest dipping faults (Fig. 


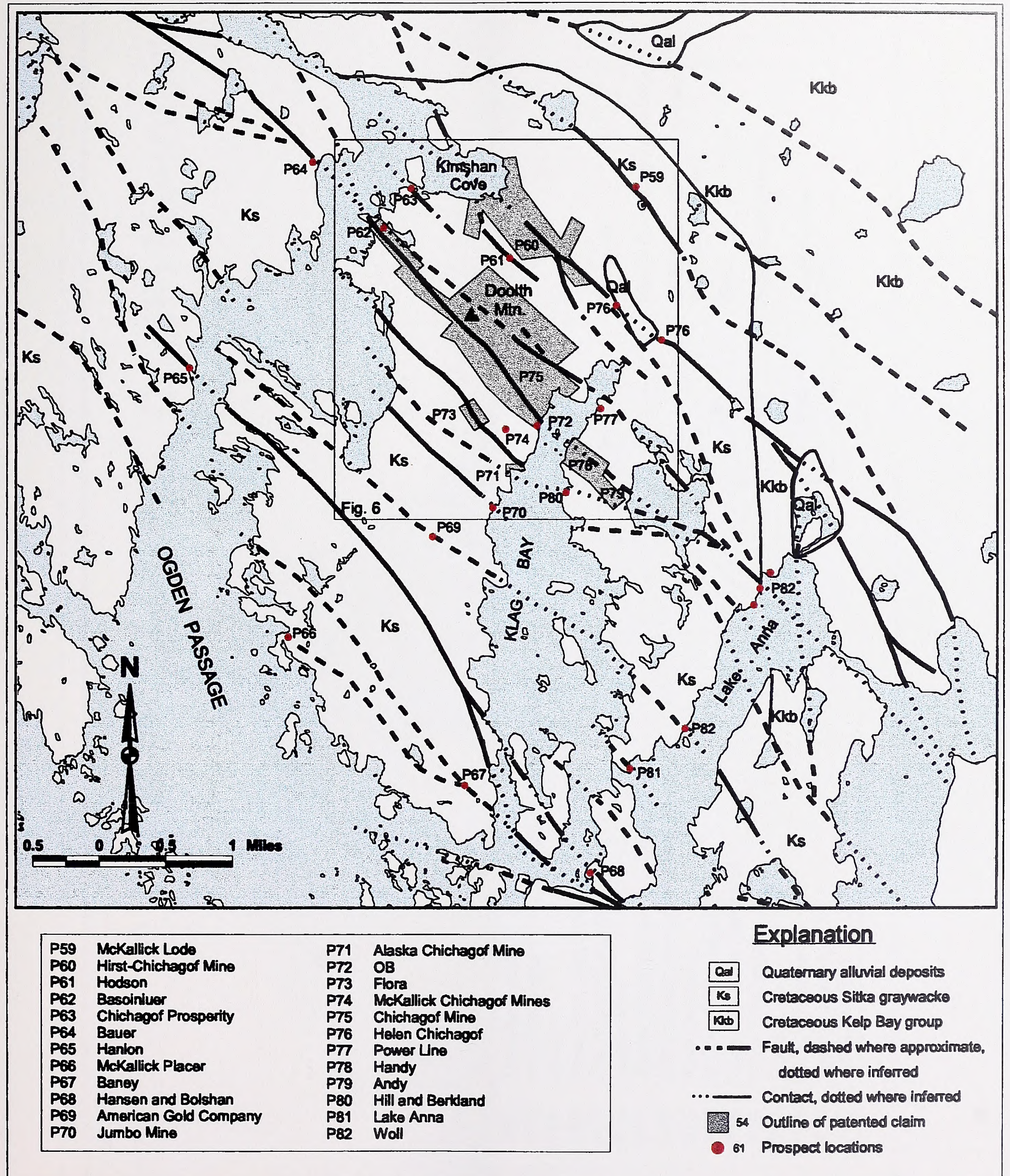

Figure 5 : Greater Doolth Mountain area showing geology, prospects, and patented claims (Still and Weir, 1981; Johnson and Karl, 1985). 





Figure 6: Doolth Mountain area showing faults, mine workings, prospects, and patented claim blocks (Still and Weir, 1981) 

5). All the mines in the Doolth Mountain KMDA and most of the significant prospects are located along these faults. In the vicinity of the mines, the faults generally strike more northerly and dip more steeply than other faults in the area and cut the foliation in the enclosing rocks at a higher angle. This change in orientation created releasing bends that allowed for increased fluid migration and mineral deposition. Felsic dikes were intruded along the faults and are invariably sheared and deformed by later fault movement. Gold-bearing quartz veins were emplaced along sections of the faults. Gold was deposited along ribbons in the quartz, which indicate that deposition coincided with fault movement and that the deposition was probably episodic (Still and Weir, 1981).

Gold mineralization in the area is centered around Doolth Mountain itself, with grades decreasing away from the mountain. The gold occurs as tiny specks in the quartz and also with sulfides. Sulfides make up less than three percent of the veins and consist of pyrite, arsenopyrite, galena, sphalerite, and chalcopyrite. About $70-90 \%$ of the gold was free-milling and the remainder was recovered in the sulfide concentrate (Still and Weir, 1981).

Eocene granitic plutons are located about three miles west of the Doolth Mountain area. ${ }^{40} \mathrm{Ar}{ }^{\beta 9} \mathrm{Ar}$ data suggest that the gold-bearing vein formation and the granitic plutons are products of a short-lived Eocene thermal event. They are thought to be related to the subduction of a spreading center beneath the Chugach accretionary prism (Taylor and others, 1994, Haeussler and others, 1995).

\section{Chichagof Mine (P75)}

The Chichagof Mine is located near the head of Klag Bay on the south side of Doolth Mountain.
It is located along the Chichagof fault, which has an inferred strike length of at least 12 miles (Fig. 6).

The mine opened in 1905, when gold-bearing quartz float was discovered in a creek near the head of Klag Bay. Later that year, ore from a quartz outcrop was shipped to the Tacoma Smelter. The proceeds were used to finance a mill and further mining (Reed and Coats, 1941). From 1906 to 1942, the Chichagof Mine produced $660,000 \mathrm{oz}$ of gold and $195,000 \mathrm{oz}$ of silver from over 600,000 tons of ore (Still and Weir, 1981). Because of shortages of men and equipment created by World War II, the mine closed in 1942. From 1942 to 1973 small amounts of tailings were reworked. The mine and adjacent mineralized area is covered by 29 patented claims and ranks as the third largest lode-gold producer in Alaska (Still and Weir, 1981).

During 1978 and 1979, Bureau of Mines crews examined the Chichagof Mine surface and accessible underground workings and calculated resources. The following mine description and resource estimates are based on that investigation (Still and Weir, 1981). Resource calculations for the Big Croppings veins are from Golden Sitka Resources (1987), who completed additional work in that area.

At the Chichagof Mine tabular but irregular ore zones have a long dimension that plunges to the south and a short dimension parallel to strike. Ore zones have widths to 15 feet, strike lengths to 1,000 feet, and vertical heights to 1,800 feet. One 14-foot-wide stope averaged 6 oz of gold per ton, whereas the average tenor for the life of the mine was $1.10 \mathrm{oz}$ of gold per ton. Mining reached a depth of 2,700 feet below sea 
level. Underground workings explore the fault for 4,800 feet in a horizontal direction and 4,300 feet vertically. Twenty-three percent of the area explored by underground workings was mined. Almost all mine workings are currently inaccessible.

\section{Resources:}

1. Big Croppings area of Chichagof fault: Based on reopening of underground workings, diamond drilling, trenching, and detailed sampling of mine-car loads of ore, Golden Sitka Resources estimated a tonnage and grade for the Big Croppings veins as follows (Grolden Sitka Resources Inc., 1987):

Probable: 17,800 tons at $0.4 \mathrm{oz}$ of gold per ton

Possible: 22,800 tons at $0.4 \mathrm{oz}$ of gold per ton

Inferred: 36,000 tons at $0.4 \mathrm{oz}$ of gold per ton

Total: $\quad 76,600$ tons at $0.4 \mathrm{oz}$ of gold per ton $(30,640 \mathrm{oz}$ of gold)

Inferred resources: (mining width ranging from 3 to 15 feet)

2. Unmined area explored by underground workings--Mine records and geologic inference suggest 155,000 tons at $0.30 \mathrm{oz}$ of gold per ton (46,500 oz of gold) and $0.09 \mathrm{oz}$ of silver per ton $(13,950 \mathrm{oz}$ of silver) above the main haulage level; 308,000 tons at $0.30 \mathrm{oz}$ of gold per ton $(92,400 \mathrm{oz}$ of gold) and $0.09 \mathrm{oz}$ of silver per ton $(27,720 \mathrm{oz}$ of silver) below the main haulage level.

3. Golden Gate \#3--26 Bureau of
Mines underground samples on 11 sample lines, with a 3 -foot mining width, indicate 13,500 tons at 0.11 oz of gold per ton ( $1,485 \mathrm{oz}$ of gold) and $0.04 \mathrm{oz}$ of silver per ton $(540 \mathrm{oz}$ of silver).

4. Chichagof dump--38 Bureau of Mines surface samples on 4 lines (inadequate to estimate grade for whole dump) indicate approximately 200,000 tons having surface value of $0.04 \mathrm{oz}$ of gold per ton and $0.012 \mathrm{oz}$ of silver per ton.

Indicated resources:

Chichag of tailings--36 Bureau of Mines shelby-tube and shovel samples on 4 sample lines, mine records, company drill data, and resource calculations indicate 456,000 tons at $0.11 \mathrm{oz}$ of gold per ton $(50,160 \mathrm{oz}$ of gold) and $0.03 \mathrm{oz}$ of silver per ton $(13,680 \mathrm{oz}$ of silver).

Hypothetical resources:

Unexplored Chichag of claim area or very limited underground exploration--Mine records, geologic inference, and Bureau of Mines sampling of near-surface workings suggest 500,000 tons at $0.60 \mathrm{oz}$ of gold per ton $(300,000$ oz of gold) and $0.18 \mathrm{oz}$ of silver per ton $(90,000$ oz of silver).

In 1981, based on the above Bureau of Mines resource estimates, Exvenco, Inc. initiated environmental studies and conducted a sampling and exploration program at the mine. In 1983, Queenstake Resources, Ltd. and Exvenco, Inc., formed the Chichagof Joint Venture and obtained an option on the property. The joint 
venture began an ambitious program of exploration, rehabilitation, and development at the mine.

In 1985, the joint venture evaluated the reprocessing of mill tailings and explored extensions of five vein structures. About 2,000 feet of underground drifting and 2,500 feet of drilling tested the vein systems. Metallurgical testing began, environmental studies continued, and permit applications were submitted (Golden Sitka Resources Inc., 1987).

In 1986, the joint venture rehabilitated the No. 2 shaft on the main level. The venture also considered new mine designs, including a bargemounted mill and plant that could be inexpensively moved to other properties in the area (Golden Sitka Resources Inc., 1987).

In 1987, only limited fieldwork was done due to ownership and financial restructuring. The two joint venture partners and Vector Mining Company formed Golden Sitka Resources Inc. and raised $\$ 2$ million from an initial public offering on the Vancouver Stock Exchange (Golden Sitka Resources Inc., 1987).

In 1988, planned work, including a 5,250-foot drilling program, was halted after a fire destroyed the project's camp. The company had driven a bypass around an old production stope in the mine to access the face of the Golden Gate adit and planned to explore extensions of the vein systems by extending the adit and driving crosscuts. Golden Sitka Resources announced that operations at the project would be temporarily suspended.

Operations never resumed and the owners of the Chichagof property regained full control after Golden Sitka Resources' lease expired. The owners are considering options for permitting and operating the project (Coldwell, 1998).

\section{Hirst-Chichagof Mine (P60)}

The Hirst-Chichagof Mine is located on the south side of Kimshan Cove on the north side of Doolth Mountain. It is located along the Hirst fault, which is parallel to and approximately 0.8 miles northeast of the Chichagof fault (Fig. 6).

The mine was discovered in 1905. By 1918 the Hirst-Chichagof Mining Company had been formed and by 1920 three drifts had been started and mill equipment had been delivered to the mine (Reed and Coats, 1941). From 1922 to 1943 the mine produced $131,000 \mathrm{oz}$ of gold and $33,000 \mathrm{oz}$ of silver from over 140,000 tons of ore. The mine closed in 1943 because of shortages of men and equipment caused by World War II. An attempt was made to reopen the mine in 1950 but the low price of gold and the deteriorated condition of the mine and mill made the attempt unsuccessful. From 1950 to $1954,124 \mathrm{oz}$ of gold was recovered from a mill clean-up and from mine tailings (Still and Weir, 1981).

During 1978 and 1979 Bureau of Mines crews examined the surface and accessible underground workings and calculated resources (Still and Weir, 1981). The following mine description and resource estimates are based on that report:

The Hirst fault is explored along 5,000 feet of strike, and up to 2,200 feet vertically. Mining reached a depth of 1,800 feet below sea level. Mine records indicate that less than $10 \%$ of the area explored by underground workings was mined. Almost all the of old workings are currently inaccessible. The mine and adjacent mineralized area are partially 
covered by 12 patented claims. The deposit is similar to the Chichagof Mine; the major exception is that a high-grade ore shoot was found 1,600 feet along the Kay split (Fig. 6), a hanging wall split off the Hirst fault. At the Chichagof Mine, all ore shoots are situated along the main Chichagof fault. At least 5,500 feet of strike length on the main Hirst fault, in the vicinity of the underground workings, was not explored.

Inferred resources: (mining width exceeding three feet)

1. Continuation of Kay ore shoot (mining halted in 1943)--Mine records and geologic inference suggest 80,000 tons at $1.00 \mathrm{oz}$ of gold per ton (80,000 oz of gold) and $0.25 \mathrm{oz}$ of silver per ton $(20,000 \mathrm{oz}$ of silver).

2. Unmined area explored by underground workings--Mine records, limited Bureau of Mines underground and surface samples, and geologic inference suggest 70,000 tons at $0.25 \mathrm{oz}$ of gold per ton $(17,500 \mathrm{oz}$ of gold) and $0.06 \mathrm{oz}$ of silver per ton $(4,200 \mathrm{oz}$ of silver).

3. Hirst-Chichagof tailings--11 Bureau of Mines shelby-tube and shovel samples on 3 sample lines, mine records, and an assumption that at least $50 \%$ of original mine tailings are located in or near the tidal zone where potential recovery is possible, suggest 70,000 tons at $0.14 \mathrm{oz}$ of gold per ton $(9,800 \mathrm{oz}$ of gold) and $0.03 \mathrm{oz}$ of silver per ton $(2,100 \mathrm{oz}$ of silver).

4. Hirst-Chichagof dump--13 Bureau of Mines surface samples in 2 lines (inadequate to determine grade for whole dump) suggest approximately 70,000 tons having surface value of $0.04 \mathrm{oz}$ of gold per ton and $0.01 \mathrm{oz}$ of silver per ton.

Hypothetical resources:

Unexplored part of the Hirst fault in the mine area--Mine records and geologic inference suggest the possibility of 100,000 tons at $1.00 \mathrm{oz}$ of gold per ton (100,000 oz of gold) and $0.25 \mathrm{oz}$ of silver per ton $(25,000$ oz of silver).

In 1981, Enserch Inc. started work on the property. They continued exploration and work on reentry to the mine and evaluation of the tailings through 1983 (Coldwell, 1998).

In 1986, the Chichagof Joint Venture (Queenstake Resources, Ltd. and Exvenco, Inc.) started evaluation of the Kay ore shoot by driving a 160-foot crosscut into the main shear zone and establishing a drill station. By 1988, Golden Sitka Resources (Chichagof Joint Venture and Vector Mining Co.) had rehabilitated underground workings and had completed about 3,215 feet of core drilling to assess the possible extension of the Kay ore shoot below previously developed mine levels. Four of the six diamond drill holes intercepted a barren aplite dike with only minor quartz veining at the expected ore zone. The company dropped its option on the Hirst-Chichagof property in late 1988 (Golden Sitka Resources Inc., 1987).

The 1986 work on the Kay ore shoot and subsequent resource estimate by Golden Sitka Resources differs from the 1981 Bureau of Mines resource estimate. Golden Sitka Resources based its revised estimate on only a partial reopening of underground workings, but with detailed sampling. The revised estimated 
tonnage and grade for the Kay ore shoot is (Golden Sitka Resources Inc., 1987):

Probable: 380 tons at $1.5 \mathrm{oz}$ of gold per ton

Possible: $\quad 12,000$ tons at $1.0 \mathrm{oz}$ of gold per ton

Inferred: 18,000 tons at $1.0 \mathrm{oz}$ of gold per ton

Total: $\quad 30,380$ tons at $1.0 \mathrm{oz}$ of gold per ton $(30,380 \mathrm{oz}$ of gold)

\section{Alaska Chichagof Mine (P71)}

The Alaska Chichag of Mine is located near sea level on the west side of Klag Bay about half a mile southwest of the Chichagof fault (Fig. 6). It is located along a fault zone that can be traced for at least one mile. The setting and mineralization are similar to that of the nearby Chichagof Mine. The deposit was discovered in 1928 and by 1931 the Alaska Chichagof Mining Company was incorporated to develop the property. Their holdings consisted of 14 claims that crossed the Doolth Mountain peninsula (Reed and Coats, 1941; Still and Weir, 1981). About 510 feet of underground workings were developed from a portal near the beach (Reed and Coats, 1941), which is covered by a patented claim. In 1936 the property was optioned by the Chichagof Mining Company and 660 tons of ore were mined and processed at the Chichagof mill (Still and Weir, 1981). The next reported activity at the property was a reopening of the underground workings by Enserch Inc. during the early 1980's. There are insufficient data to determine resources for this property.

Jumbo Mine (P70)

The Jumbo Mine is located on the west side of Klag Bay about three quarters of a mile southwest of the Chichagof Mine (Fig. 6). It is located along a fault zone that can be traced for at least one mile. The deposit was discovered in 1909 (Reed and Coats, 1941) when 1,450 oz of gold were reportedly mined from a high grade pocket located in the intertidal zone (Still and Weir, 1981). Overbeck (1919) reported that some of the richest ore and finest gold specimens in the district were from the Jumbo Mine. From 1909 to 1931 a 400-foot shaft, 1,580 feet of drift off the shaft, and numerous pits and trenches were dug to expose mineralized rock in the fault zone (Reed and Coats, 1941).

Bureau of Mines examination during 1978 and 1979 revealed three flooded shafts, a 48 -foot drift, and numerous trenches and pits that expose quartz along a fault zone for 3,000 feet. The highest-grade sample collected was $0.15 \mathrm{oz}$ of gold per ton (Still and Weir, 1981). Maps and samples of the underground workings have never been published, so no resource estimates are available. Given the reports of spectacular gold, but little published information and markedly subeconomic Bureau of Mines surface samples (Still and Weir, 1981), questions remain regarding the resources at this property.

\section{Land Use and Resource Issues}

There are seven land use and resource issues identified in the Doolth Mountain KMDA. They relate to 1) a wilderness designation, 2) private land, 3) State land, 4) recreation areas, 5) recreation areas important to tourism, 6) Sitka black-tail deer hunting, and 7) anadromous fish streams.

All of the Federal land in the Doolth Mountain KMDA is located within the West ChichagofYakobi Wilderness. However, the area includes 39 patented mining claims, and State land in the intertidal zone. Most of the mineral resources are situated on private or State lands. Recreation areas, including areas important to 
tourism, are recognized along much of the shoreline in the area. There is a moderate level of deer hunting in the area. Some of the mineral occurrences are located near anadromous fish streams within the KMDA. Development of the resources at the Chichagof and Hirst-Chichagof Mines would be unlikely to impact the anadromous fish streams.

\section{Mineral Development Potential}

Significant past production, extensive gold quartz vein formation, and inferred/hypothetical resources totaling over $675,000 \mathrm{oz}$ of gold and $195,000 \mathrm{oz}$ of silver establish the Doolth Mountain area as having a high mineral development potential. The Doolth Mountain area is located within the West ChichagofYakobi Wilderness area where mining is prohibited, except on patented mining claims. Almost all the resources in the KMDA are from the Chichagof and Hirst-Chichagof Mines and are covered by patented claims or located within State intertidal lands where mining is allowed. The only exception is the resource at the Kay ore shoot, where the land status has a wilderness designation.

Based on the economic feasibility studies of the Chichagof-Baranof area by Coldwell (1998), the deposits in the Doolth Mountain KMDA are subeconomic. The Chichagof hard rock deposit would require an approximately $150 \%$ increase in the price of gold (1987-1996 average gold price of $\$ 441.98$ used by Coldwell, 1998) to approach economic viability. Coldwell's calculations indicate that the Chichagof tailings are close to economic viability, but that the Hirst-Chichagof hard rock deposit would require an approximately $200 \%$ increase in the price of gold. Given the restrictions caused by land status in the area, the possibility of large increases in deposit size are unlikely.

\section{West Coast Gold KMDA}

\section{Location / Access}

A series of fault-controlled, vein gold deposits define the 8-mile wide by 28-mile long West Coast Gold KMDA, located 50 miles northwest of Sitka on the west coast of Chichagof Island (Plate 1, KMDA no. 6). The smaller, but more highly mineralized, Doolth Mountain KMDA is located at the center of the West Coast Gold area, but is not considered within it. The area topography rises from sea level to over 3,000 feet at the crest of Chichagof Island. Portlock Harbor, Khaz Bay, and Slocum Arm comprise the main waterways in the area. Numerous additional bays and inlets dot the area. Most of the area prospects are located near tidewater and are easily accessible by float plane or boat.

\section{Geology}

The West Coast Gold area is underlain by the Cretaceous Sitka Graywacke, the Cretaceous Kelp Bay Group, and the Triassic Whitestripe Marble. The Sitka Graywacke and the Kelp Bay Group are part of the Chugach tectonostratigraphic terrane and consist of weakly metamorphosed sandstone, siltstone, graywacke, and volcanics that generally strike northwest and dip steeply southwest (Johnson and Karl, 1985). The Whitestripe Marble forms part of the Wrangellia terrane (Plafker and others, 1976). Within the West Coast Gold area the rocks are cut by a series of northwesterly striking, steeply dipping faults. Sheared and deformed felsic dikes are found along these 
faults. Gold-bearing quartz veins were deposited along some of the fault zones. These vein gold deposits are similar in mode of formation and age to those at Doolth Mountain (Still and Weir, 1981, Johnson and others, 1982).

\section{History / Production}

Gold was discovered in the West Coast Gold area during the early part of the 20th century. The most significant mines and prospects are the Golden Hand Apex, New Chichagof Mining Syndicate, Falcon Arm, and Cobol Mine. Production from the area consists of $100 \mathrm{oz}$ of gold from the Cobol Mine and a few oz of gold from the Golden Hand Apex Mine (Still and Weir, 1981).

\section{Golden Hand Apex Mine (P51)}

The Golden Hand Apex Mine was staked in 1921 along a northwest striking, quartz-bearing fault zone (Stewart, 1922). Workings, mostly completed in the 1920 's, consist of a 150 -foot sloughed trench, 140 feet of crosscut, and 85 feet of drift. A small amount of high-grade ore was produced in 1979 by Floyd Branson, the claim holder at the time (Still and Weir, 1981). A quartz vein exposed for 23 feet in two trenches averaged $0.34 \mathrm{oz}$ of gold per ton (six sample lines) across a 3-foot mining width. A representative sample across a 0.2 - by 3 -foot high-grade zone in the footwall of the same vein assayed $187 \mathrm{oz}$ of gold per ton, and a single select sample assayed 489 oz of gold per ton (Still and Weir, 1981). The active Golden Hand Apex claim covers this property and represents an inholding within the West Chichagof-Yakobi Wilderness area.
Cobol Mine (P91)

The Cobol Mine property was staked in 1925 (Stewart, 1932a) along gold-bearing quartz veins hosted in a north striking fault zone. Workings include 2,150 feet of drifts in 2 adits. Production is estimated at over $100 \mathrm{oz}$ of gold. A 57-foot zone, exposed underground, averages $0.28 \mathrm{oz}$ of gold per ton over a 3 -foot mining width. A float sample below a reported 140foot high-grade zone, now covered by a landslide, assayed $8.74 \mathrm{oz}$ of gold per ton (Still and Weir, 1981). Activity on the property continued until 1986. Currently, there are no active mining claims in the area.

New Chichagof Mining Syndicate prospect (P49)

The New Chichagof Mining Syndicate prospect was discovered in 1933 along a northeast striking fault zone (Roehm, 1936e). Gold is found in a quartz-carbonate cemented, limestone breccia. Workings consist of almost 1,000 feet of adits and numerous surface cuts that intermittently expose mineralized rock along a strike length of over 500 feet. A 110-foot section of mineralized quartz vein exposed in the underground workings averages $0.24 \mathrm{oz}$ of gold per ton across a 4-foot mining width (Still and Weir, 1981).

\section{Falcon Arm prospect (P90)}

The Falcon Arm prospect was staked in 1916 (Overbeck, 1919) along a northwest striking fault zone that extends over 5,000 feet. Gold is found in quartz veins that are hosted in mafic dikes and graywacke. Workings consist of 3,130 feet of adits. One adit crosscuts 3,010 feet and fails to intersect mineralized rock. The most significant mineralized rock was found in quartz rubblecrop with blocks up to 1.2 feet 
thick that assayed from 0.5 to $2.15 \mathrm{oz}$ of gold per ton (Still and Weir, 1981).

\section{Land Use and Resource Issues}

There are five land use and resource issues identified in the West Coast Gold KMDA. They relate to 1) a wilderness designation; 2) recreation areas, 3) recreation areas important to tourism, 4) anadromous fish streams, and 5) Sitka black-tail deer hunting.

The West Coast Gold KMDA encompasses the Doolth Mountain KMDA, but does not include it. (See the "Land Use and Resource Issues" section on page 41 for a discussion of issues affecting the Doolth Mountain KMDA.) All of the West Coast Gold area is contained within a designated wilderness, except for a single active claim at the Golden Hand Apex property. There are anadromous fish streams within the KMDA and several mineral occurrences are located near these streams. The active claim is located along an anadromous fish stream as well. There is a moderate level of deer hunting in the area.

\section{Mineral Development Potential}

The four prospects described are the most significant within the West Coast Gold area. Numerous less significant gold prospects are found within the area as well. The extent and persistence of gold values in the four prospects and the proximity and similarity to the highly mineralized Doolth Mountain area suggest a medium mineral development potential for the West Coast Gold area. Except for the active claim at the Golden Hand Apex, all of the West Coast Gold area is located within the West Chichagof-Yakobi Wilderness area where mining is prohibited. This restrictive land status limits the likelihood of mineral development in the area.

\section{Lisianski KMDA}

\section{Location / Access}

Vein gold deposits define the 4-mile wide by 15 mile long Lisianski KMDA located on the northwest side of Chichagof Island and on the southeast end of Yakobi Island (Plate 1, KMDA no. 2). The area is 75 miles northwest of Sitka and 2 miles west of Pelican. Lisianski Inlet, Lisianski Strait, and Stag Bay comprise the area waterways. Steep-walled bays and inlets, and rugged mountains up to 3,613 feet in elevation characterize the area. The waterways can be reached by float plane or boat. The high elevation prospects (e.g., Apex and El Nido) can be reached by a steep, rugged climb from tidewater or by helicopter.

\section{History / Production}

Gold was discovered at the Bon Tara Mine on the east tip of Yakobi Island in 1887 (Overbeck, 1919). Between 1919 and 1923 gold was discovered at the Goldwin, Mine Mountain, and Apex and El Nido Mines. About 17,200 oz of gold and $2,400 \mathrm{oz}$ of silver were produced from the Lisianski area prior to 1940. The Apex and El Nido Mines were the principal producers (Kimball, 1982).

\section{Geology}

Rocks in the Lisianski KMDA consist of late Paleozoic to Mesozoic volcanic and sedimentary rocks that have been metamorphosed to medium 
or high grade (Loney and others, 1975). These rocks are intruded by Jurassic to Cretaceous diorite, quartz diorite, and tonalite (Johnson and Karl, 1985). The structural grain of the area trends northwest-southeast.

Deposits in the area consist of low sulfide, goldbearing, quartz veins that are controlled by northeast to east-west striking, steeply dipping, faults that are oriented at a high angle to the grain of the regional structures. Sulfides in the veins consist mainly of pyrite and arsenopyrite (Kimball, 1982).

\section{Apex and El Nido Mines (P17)}

The Apex and El Nido gold-bearing quartz veins were discovered in 1919 and 1920, respectively. They produced about $17,000 \mathrm{oz}$ of gold and $2,400 \mathrm{oz}$ of silver in the periods $1924-28,1934-$ 35 and 1937-39 (Holmes, 1941).

The deposits consist of one to four feet thick, steeply dipping, gold-bearing quartz veins emplaced in faults in diorite and amphibolite. Scheelite is erratically distributed in the veins. The main Apex vein strikes northeast and dips about $50^{\circ}$ to the northwest; the El Nido vein strikes about $070^{\circ}$ and dips $30^{\circ}$ to $80^{\circ}$ to the southeast. The two vein systems are separated by approximately 2,000 feet of country rock (Kimball, 1982).

Most of the gold production came from the Apex property. The condition of the underground workings during Bureau of Mines examination in 1978-1979 was such that, although both El Nido levels were sampled, only one of four Apex levels was accessible and no stope in either mine was safe to enter. Eightyfive measured surface samples were collected along a complex set of quartz veins over a strike length of 800 feet on the apparent up-dip projections of the Apex veins. The samples did not contain consistent gold values nor reasonable correlation with a 1929 company sampling program (Kimball, 1982). The 1929 company data (Holmes, 1941) indicated high gold values over a long strike length. Holmes (1941) implied that a resource of 26,600 tons having an average grade of nearly 1 ounce of gold per ton was present in 1941. Rossman (1959) stated that the resources at the Apex Mine are not large. Because of the lack of correlation of the surface samples, inaccessibility of underground workings, and the complex character of the vein system, Kimball (1982) was not able to calculate resources for the Apex and El Nido Mines. No additional information regarding resources was available for this report.

\section{Bon Tara Mine (P12)}

The Bon Tara Mine, discovered in 1887 (Overbeck, 1919), consists of gold-bearing quartz veins in shear zones hosted in diorite. The veins have been explored by open cuts and a 35-foot adit. The only reported production is $\$ 1,100$ in gold (55 oz at @ \$20/ounce) at the time of discovery (Overbeck, 1919). Sampling by the Bureau of Mines revealed low grade goldbearing veins (Kimball, 1982).

\section{Goldwin Mine (P13)}

Located in 1920 (Buddington, 1925), the Goldwin Mine consists of quartz veins up to two feet wide hosted in diorite. The veins have been explored by a 240-foot adit (Kimball, 1982). Rossman (1959) reported an assay of $69 \mathrm{oz}$ of gold per ton over a half-foot section of pyriterich vein. Three other representative samples collected nearby assayed from a trace to $0.11 \mathrm{oz}$ of gold per ton (Kimball, 1982). 


\section{Mine Mountain Mine (P34)}

The Mine Mountain Mine (also known as the Cobol or Cobol North Mine) was discovered in 1921 (Reed and Coats, 1941) and has had a reported production of approximately 100 to $150 \mathrm{oz}$ of gold. It consists of gold-bearing quartz veins hosted in diorite and greenstone that were explored by an adit with 250 feet of crosscuts and drifts. Samples across a 0.2- to 1.2-foot-wide vein within a 70 -foot stoped area assayed from nil to $2.45 \mathrm{oz}$ of gold per ton. Other samples from an unstoped area, 120 feet long, across a 0.2 - to 0.7 -foot-wide vein yielded results of nil to $0.15 \mathrm{oz}$ of gold per ton (Kimball, 1982). The Mine Mountain Mine is located in the West Chichagof-Yakobi Wilderness area.

\section{Land Use and Resource Issues}

There are seven land use and resource issues identified in the Lisianski KMDA. They relate to 1) a wilderness designation, 2) recreation areas, 3) recreation areas important to tourism, 4) a LUD II classification, 5) anadromous fish streams, 6) Sitka black-tail deer hunting, and 7) a minerals prescription designation.

The southern part of the Lisianski KMDA is included in the West Chichagof-Yakobi Wilderness. The rest of the area is designated for semi-primitive recreation, with corridors along the coastline recognized as recreation areas important to tourism. In the northern part of the KMDA, an area has been designated as
LUD II. The Apex and El Nido Mines are north of the wilderness boundary and outside the LUD II and important tourism areas. The Mine Mountain Mine, on the other hand, is included within the wilderness area. There are three anadromous fish streams identified in the Lisianski KMDA. All are situated near the head of Stag Bay, where only the Cub Mountain occurrence is located. The areas most likely to be developed in the KMDA would not impact any of the identified streams. A small part of the northwest end of the KMDA (overlapping with the Bohemia Basin KMDA) has a minerals prescription designation, but no known prospects are situated in this area. There is a moderate level of deer hunting in the area.

\section{Mineral Development Potential}

There are insufficient data to determine resources in the Lisianski area. The only published resource calculation is for $26,600 \mathrm{oz}$ of gold at the Apex Mine (Holmes, 1941), but that calculation was not validated by 1978-1979 Bureau of Mines sampling nor with the likely extent of the ore shoot in the underground workings (Kimball, 1982). The amount of historic production suggests the potential for a larger resource. Though the southern half of the Lisianski area is located within the West Chichagof-Yakobi Wilderness area where mining is prohibited, the Lisianski area as a whole has a medium mineral development potential. 


\section{Silver Bay KMDA ${ }^{1}$}

\section{Location / Access}

The Silver Bay KMDA is located east-southeast of Sitka (Plate 1, KMDA no. 9). It includes historic mines, prospects, and mineral occurrences around Silver Bay as well as properties east of Sitka in the Indian River basin. Access to the properties near sea level is possible by small boat from Sitka and by float plane. The higher elevation sites are most easily accessed by helicopter. Access to the area is also possible via private road along the northeast shore of the bay, which serves the Green Lake hydro-power station and reservoir (see Fig. 12). Several trails in the area allow access by foot as well.

\section{History / Production}

The Silver Bay area includes numerous sites that have been prospected for their gold potential from the 1870's to the 1990's (Knopf, 1912, DeArmond, 1997a). The first mining activity in the Chichagof-Baranof area occurred in the Silver Bay area in the 1870's. The Stewart Mine was the first lode gold mine in Alaska (Alaska Yukon Mining Journal, 1901) and the first place a stamp mill was operated in the State (DeArmond, 1997a). The history of individual properties in the area is difficult to ascertain. Complicating the history are the numerous claims, numerous owners, and the very early start of mining activity in the area. DeArmond (1997a) gives a good picture of activity in Silver Bay in a series of articles published in the Daily Sitka Sentinel in 1997.

Despite the long history of mining activity in the
Silver Bay area, little gold was produced. Stamp mills were erected at the Stewart and Lucky Chance Mines as well as at the Edgecumbe Exploration property. Arrastres may have been installed at other properties (DeArmond, 1997a). The Stewart mill, although the first in Alaska, only operated for one or two years (DeArmond, 1997a). Total production from the mill is unknown, but judging from the limited extent of tailings present, it was evidently minor. Production from the Lucky Chance Mine was also small. Roehm (1940) cites an earlier report that about 60 tons of ore had been processed by 1887. Total production from the mine is unknown, but an estimated 1,200 tons of ore were reportedly removed from stopes by 1940 (Roehm, 1940).

\section{Geology / Deposit Type}

Gold in the Silver Bay area is contained in quartz veins hosted in graywacke and argillite of the Cretaceous Sitka Graywacke (Johnson and Karl, 1985). The Sitka Graywacke is part of the Chugach terrane (Monger and Berg, 1987), which represents an accretionary complex of flysch and melange (Plafker and others, 1977; Plafker and Berg, 1994). The discontinuous quartz veins and lenses are up to 16 feet thick (e. g., Stewart), but are generally barren. They commonly include fragments and partings of graywacke and argillite, but very few sulfides. The sulfides present are pyrite, pyrrhotite, arsenopyrite, and rare galena. The veins and lenses are commonly parallel to the structure in the country rock, which is generally northwest trending and steeply dipping. Haeussler and others (1995) suggest the quartz veining and

\footnotetext{
'Additional information on the Silver Bay area, including maps, is provided in a special section of this
} report, p. 87. 
mineralization in the Silver Bay area is related to an Eocene thermal event that is also responsible for the mineralization in the Doolth Mountain, West Coast Gold, and Lisianski KMDA's to the north.

\section{Most Important Prospects}

The BLM's MAS database catalogues 24 mineral locations in the Silver Bay area. The Lucky Chance (P135) and Stewart (P130) Mines are the only ones in the Silver Bay area with any reference to production. A mill was also erected on the Edgecumbe Exploration property (P125), but the BLM found no record of production. Adits, shafts, pits, and trenches mark other prospects in the area. BLM personnel examined many of these prospects including the Liberty (P121), Eureka (P126), Lower Ledge (P129), Bauer (P132), Wicked Fall (P133), and Free Gold (P134) prospects. The more important sites in the Silver Bay area are described in a special section on Silver Bay (p. 87).

\section{Land Use and Resource Issues}

There are eight land use and resource issues identified in the Silver Bay KMDA. They relate to 1) State and Municipal land, 2) enacted Municipal watershed, 3) private land, 4) recreation areas, 5) recreation developments, 6) recreation areas important to tourism, 7) anadromous fish streams, and 8) Sitka black-tail deer hunting.
Land management in the Silver Bay area is divided between Federal, State, and Municipal governments. The non-Federal lands include the power site corridor associated with the Green Lake hydroelectric facility, and a proposed corridor northeast from the head of Bear Cove. The Blue Lake and Indian River drainages are Municipal watershed areas. The most significant mineral occurrences known in the Silver Bay KMDA are on Federal land, with the exception of one patented claim at the Stewart Mine. The Federal land in the area is recognized for its recreation potential and includes recreation developments and recreation areas important to tourism. There are five anadromous fish streams in the area. Two of these streams, near the head of Silver Bay, drain areas with significant mineral occurrences. There is a moderate level of Sitka-black tail deer hunting in the area.

\section{Mineral Development Potential}

The Silver Bay area has a low mineral development potential. Although considerable exploration has been conducted in the area, particularly in the early years of mining in southeast Alaska, no significant discoveries have been made. The main reason for the lack of success is that the quartz veins in the area, though numerous, are discontinuous and contain spotty gold concentrations.

\section{Magmatic Segregation}

Five KMDA's in the study area are defined by magmatic segregation-type deposits that are hosted in mafic or ultramafic intrusives. These are the Bohemia Basin, Mirror Harbor, Snipe Bay, Red Bluff Bay, and Hill KMDA's.
Resources of nickel-copper-cobalt-bearing rock have been determined at three of the KMDA's: Bohemia Basin - 24 million tons; Mirror Harbor - 1 million tons; and Snipe Bay - 94,000 tons. 
No production has occurred from any of the occurrences.

The deposits in the Bohemia Basin KMDA have the highest likelihood of mineral development of any of the magmatic segregation deposits. The tonnages and grades calculated to date are marginally attractive and the land status allows for potential development. A wilderness designation covers about one quarter of the KMDA, but all of the resources defined in the area are located outside the wilderness and are included within nine patented mining claims.

Development of the deposits at the Mirror Harbor and Snipe Bay KMDA's is unlikely. Although Mirror Harbor has higher tonnages and grades than those at Snipe Bay, its inclusion in the West Chichagof-Yakobi Wilderness area reduces the possibility of its development. The
South Baranof Wilderness covers about three quarters of the Snipe Bay KMDA, but excludes the Snipe Bay occurrence.

No economically significant resources have been identified to date at the Red Bluff Bay or Hill KMDA's. Both contain small amounts of chromium. And even though copper-mineralized rock with traces of platinum and palladium have been found in the Hill area, its relatively inaccessible location makes its development unlikely. Land status designations restrictive of mineral development also affect both areas. The South Baranof Wilderness covers all of the Red Bluff Bay $\mathrm{KMDA}$, and about one quarter of the Hill KMDA. Because of the limited resources and restrictive land status, neither area is likely to attract mineral development interest.

\section{Bohemia Basin KMDA}

\section{Location / Access}

The Bohemia Basin nickel-copper-cobalt deposits define a three- by five-mile KMDA located on the southeast side of Yakobi Island (Plate 1, KMDA no. 1). It is located about 75 miles north-northwest of Sitka and about 8 miles west of Pelican. A four wheel drive road and trails extend between the deposits and tidewater at Lisianski Inlet, which is accessible by float plane or boat. Elevations in the area range from sea level to 2,400 feet with rolling hills and some steep cliffs. Resources at Bohemia Basin are contained in three deposits: the Basin, Takanis, and Flapjack deposits. The location of deposits and general geology in the Bohemia Basin area are shown on Figure 7.
History / Production

Exploration activity in the Bohemia Basin area has been extensive and has taken place over a period of 60 years. The first claims were located in 1920, the same year a 156-foot adit was driven on the southeast side of the Basin deposit. By 1940 , there were 15 prospect trenches 15 to 30 feet long (Reed and Dorr, 1942). In 1942 and 1943 the Bureau of Mines and the USGS drilled 15 diamond drill holes, mapped the area, and trenched and sampled along the outcrops. The combined work of both agencies resulted in a Bureau of Mines War Minerals Report (Bureau of Mines, 1944a), which is summarized by Kennedy and Walton (1946b).

In the 1940's the property was obtained by S.H.P. Vevelstad who optioned the claims to 
International Nickel Company (INCO) in the mid 1950's. INCO held the property for three years and completed 28 diamond drill holes on the Basin and Takanis deposits. INCO lost its option to the property after a lawsuit with Vevelstad. Aleco, Inc. acquired the property from Vevelstad in 1971 and optioned it to Inspiration Development Company (Inspiration) in 1972 (Kimball, 1982). Inspiration completed 94 drill holes, conducted extensive geological mapping, geochemical and geophysical surveys, conducted preliminary feasibility studies, including pit designs, did metallurgical testing, and acquired patents for Aleco on nine lode claims covering the Basin and Takanis deposits (Thornsberry and DeWilliam, 1982).

In 1982 Inspiration released the property back to Aleco because of economic factors within the company. The property was purchased by Galactic Resources, Ltd. and Cornucopia Resources, Ltd. of Portland, Oregon in 1983. In 1984 , over 5,000 feet of diamond drilling was completed on the property (Still, 1988). The drilling data remain confidential and were unavailable for this report. No production has occurred from the property.

Between 1979 and 1981 the Bureau of Mines briefly examined the property (Kimball, 1982). A reexamination in 1982 determined that precious metals and PGM concentrations are very low, that they are confined to the nickelcopper occurrences, and that the highest values coincide with the highest nickel-copper values (Still, 1988). A bulk sample (approximately 200 pounds) from the Bohemia Basin adit was supplied to the Bureau of Mines Albany Research Center for metallurgical testing. The results of this testing concluded that gold, platinum, and palladium are concentrated with copper and that they could potentially be low grade metallurgical byproducts (Dahlin and others, 1981).

\section{Geology}

A northwest trending belt of Tertiary gabbroic plutons extends from the Fairweather Stock, located 75 miles northwest of Bohemia Basin in Glacier Bay National Park, to Snipe Bay, located on the southwest side of Baranof Island. Within the Chichagof-Baranof study area, this belt hosts the Bohemia Basin, Mirror Harbor and Snipe Bay deposits. The plutons intrude older metamorphosed alkalic rocks, amphibolites, hornfels, and metagraywackes. Two of these plutons, the Fairweather and the Crillon stocks, exhibit well-defined layering that varyies in composition from diorite to pyroxenite or dunite. The Crillon Stock, located northwest of the Chichagof-Baranof study area, contains the Brady Glacier nickel-copper deposit. That deposit has 180 million tons of indicated and inferred resources averaging $0.53 \%$ nickel, $0.33 \%$ copper, $0.03 \%$ cobalt, and by-product PGM (Brew and others, 1978; Still, 1988). The Brady Glacier resource serves to illustrate the size of potential magmatic segregation deposits in this belt of plutons.

A Tertiary composite stock comprises about one-third of the land area of Yakobi Island. Rock types include tonalite, quartz diorite, diorite, gabbro, gabbronorite, and norite (Himmelberg and others, 1987). These rocks grade into each other and in places can only be identified microscopically. In general, the gabbronorite, which hosts the mineralized rock, occurs as discrete irregular bodies within or bordering the tonalite. The Yakobi Island stock, although much smaller in size, is similar in mode of occurrence to the layered Fairweather and Crillon stocks (Thornsberry and DeWilliam, 1982). 
Tortiary(?) maflc plutonic rocks, mostly gabbronorte

Crotaceous Sitke Graywack

Cretaceous Kalp Bay Group

Crotacoous or Jurassic mafic plutonic rocks, mostly quartz dlorita and diortie

Triassic Whitestripe Marbla

Mesozolc and Paleazolc metamorphic, matavolcanic and metasedimantary rocks, undwided

Anese of norite minarallzation, data from Inspliation Ares of nortita minarealzaton, data from insplration
Developmant Co. (contains nicket-copper-cobalt rasources)

- Contact, dottad where Inferred

Boundary of known mineral dapositt area (KMDA)

$\longrightarrow$ Adt

...... Road

Wilderness boundary
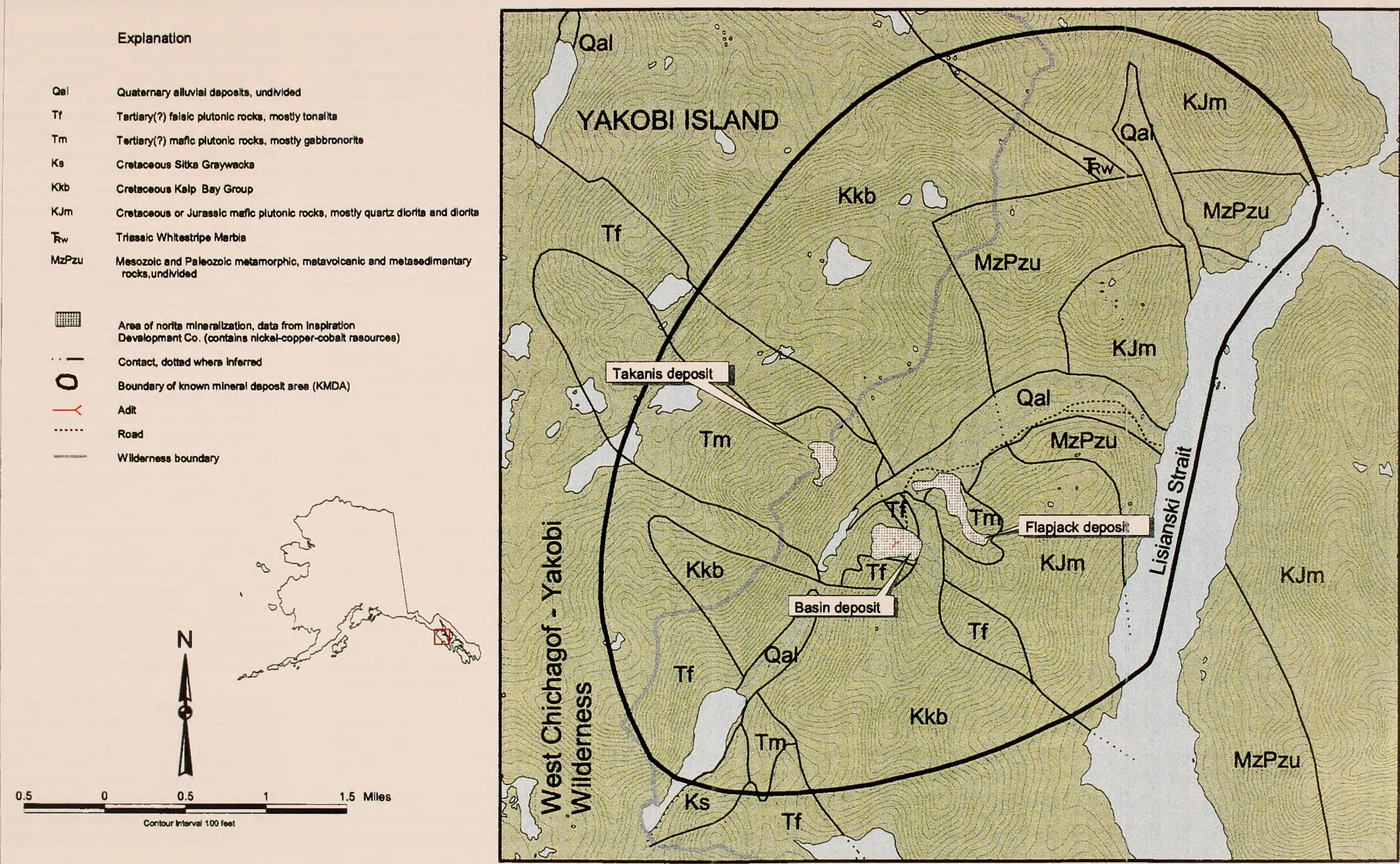

Mineralization at the three Bohemia Basin deposits is similar. Sulfide mineralization includes pentlandite, chalcopyrite, pyrrhotite, and pyrite as disseminated grains, blebs, interstitial networks, and massive aggregates. The nickel-copper-cobalt-bearing mineralized rock is generally restricted to the gabbronorite and all evidence points to concentration of sulfides by segregation within a cooling magma (Himmelberg and others, 1987). Variations within the gabbronorite can be abrupt or gradational with igneous layering a common feature. Generally, the mineralized units are pyroxenite within gabbronorite bodies. At the Basin deposit the mineralized rock occupies the basal zone; however, this is not necessarily the case with the other deposits (Thornsberry and DeWilliam, 1982).

The Basin deposit is contained within an elliptically-shaped gabbronorite plug, 1,200 to 1,400 feet in diameter. The plug is bounded on the east and southwest by barren diorite and pyrrhotite-rich amphibole schist, and on the north and west by the main gabbroic complex. The gabbronorite body is layered, with composition ranging from anorthosite to pyroxenite. The compositional variations are arranged concentrically in a funnel-like shape around the core of the gabbronorite plug. The main mineralized zone is a basal pyroxenite unit, 50 to 150 feet thick, with smaller, usually lowergrade zones, 5 to 20 feet thick, parallel to the main zone (Thornsberry and DeWilliam, 1982).

The Takanis deposit contains at least three separate gabbronorite intrusions with many variations in rock types. It is intruded by a later diorite phase and siliceous to mafic dikes. The mineralized host rock is a dark gray to brown, medium-grained, equigranular gabbronorite, grading to peridotite and pyroxenite. The latter characteristically contains hypersthene and actinolite, and is usually moderately altered. The Takanis ore body dips steeply and is tabular in shape, striking approximately $050^{\circ}$ and dipping $70^{\circ}$ to the southeast. It is approximately 900 feet long by 200 feet wide (Thornsberry and DeWilliam, 1982).

The Flapjack deposit is more poorly delineated than the Basin and Takanis deposits. It is thought to contain a sill-like gabbronorite body within a layered intrusion. The gabbronorite contains tabular-shaped mineralized horizons similar to those in the Takanis deposit (Thornsberry and DeWilliam, 1982).

\section{Resources}

Identified resources for the Bohemia Basin deposits reported by Thornsberry and DeWilliam (1982) are as follows:

Basin deposit: (based on 73 diamond drill holes) $16,186,000$ tons, which average $0.31 \%$ nickel, $0.18 \%$ copper, and $0.02 \%$ cobalt.

Takanis deposit: (based on 47 diamond drill holes) $3,971,500$ tons, which average $0.29 \%$ nickel, $0.18 \%$ copper, and $0.02 \%$ cobalt.

Together, the Basin and Takanis deposits have proven resources accessible by open-pit mining of 15.1 million tons grading $0.37 \%$ nickel, $0.22 \%$ copper, and $0.02 \%$ cobalt at a 2.5:1 stripping ratio.

Flapjack deposit: (based on 4 diamond drill holes) 4,000,000 tons inferred, which average $0.21 \%$ nickel and $0.12 \%$ copper.

Based on Bureau of Mines beneficiation tests, small amounts of gold, platinum, and palladium are recoverable from these deposits (Dahlin and 
others, 1981). However there are insufficient data to estimate specific resources for these commodities (Still, 1988).

\section{Land Use and Resource Issues}

There are eight land use and resource issues identified in the Bohemia Basin KMDA. They relate to 1) private property, 2) a wilderness designation, 3) a LUD II classification, 4), recreation areas, 5) recreation areas important to tourism, 6) minerals prescription designation, 7) anadromous fish streams, and 8) Sitka black-tail deer hunting.

The main mineral deposits at Bohemia Basin are covered by nine patented mining claims. Outside the patented claims, are wilderness, LUD II, and recreation lands. The wilderness boundary abuts the Takanis deposit and may affect its potential development. The LUD II designated area is to the northeast of the known deposits and is therefore a less significant issue. The recreation designation includes areas important for tourism and encompasses the patented claims and the known deposits. Most of the KMDA, outside the wilderness and LUD II areas, falls under a minerals prescription designation. Bohemia Creek is an anadromous fish stream that drains the valley containing the deposits. There is a moderate level of Sitka black-tail deer hunting in the area.

\section{Mineral Development Potential}

Based on economic feasibility studies of the Chichagof-Baranof area by Coldwell (1998), the 24-million ton Bohemia Basin deposit would require twice the current total metal values of nickel, copper, and cobalt to approach economic viability. The deposit would also approach economic viability if about twice the tonnage was developed with the current average grade of $0.29 \%$ nickel, $0.17 \%$ copper, and $0.017 \%$ cobalt. The possibility of open-pit mining and the close proximity to tidewater enhance the development potential of the Bohemia Basin area. So although the deposit is subeconomic at present, the area is likely to continue to attract mineral development interest in the future.

\section{Mirror Harbor KMDA}

\section{Location / Access}

Nickel-copper-cobalt deposits define the 2- by 3mile Mirror Harbor KMDA, located 65 miles north-northwest of Sitka and 14 miles south of the Bohemia Basin deposit. Plate 1 shows the location of the KMDA on the northwest side of Chichagof Island (KMDA no. 3). Elevations in the area extend from sea level to under 300 feet; the area is flat lying, brushy and covered with timber. Many small waterways between Bertha Bay and Little Bay cut the Mirror Harbor area. Access can be made by float plane or boat from
Sitka and by foot to the mineral occurrences.

\section{History / Production}

Nickel-copper-cobalt occurrences were discovered near Mirror Harbor in 1911. In 1915, a 175-foot shaft was sunk with crosscuts at 75 feet and 175 feet below the surface (Pecora, 1942). This shaft is now flooded. During World War II the Bureau of Mines and the USGS mapped, trenched, and drilled the property (U. S. Bureau of Mines, 1944b; Traver, 1948). Inspiration Development Company 
conducted extensive mapping, sampling, and geochemical and geophysical surveys at the property from 1972 to 1982 . In 1982 Inspiration dropped the property (Still 1988). There are no active claims in the Mirror Harbor area, which is now part of the West ChichagofYakobi Wilderness. No production has occurred from the area.

\section{Geology}

The Mirror Harbor area is underlain by Cretaceous Kelp Bay sedimentary and volcanic rocks, and the Cretaceous Sitka Graywacke. These are intruded by Tertiary tonalite and gabbronorite (Johnson and Karl, 1985). The gabbronorite hosts nickel-copper-cobalt magmatic segregation deposits that contain masses and disseminations of pyrrhotite, pentlandite, and chalcopyrite (Still, 1988). The geologic setting and deposit type are similar to those at Bohemia Basin, described above.

\section{Resources}

Three deposits have been delineated within the Mirror Harbor area; two consist of massive sulfides and one of disseminated sulfides. A high-grade massive sulfide body, on which the shaft was driven, contains 7,300 tons averaging $1.60 \%$ nickel and $0.90 \%$ copper. A massive sulfide body on the south side of Davison Bay contains a few tons with a slightly lower grade than that at the shaft. A disseminated deposit located between Mirror Harbor and Davison Bay contains $1,000,000$ tons averaging $0.32 \%$ nickel and $0.12 \%$ copper (Still, 1988).

\section{Land Use and Resource Issues}

There are seven land use and resource issues identified in the Mirror Harbor KMDA. They relate to 1) a wilderness designation, 2) State land, 3) recreation areas, 5) recreation areas important to tourism, 5) a recreation development, 6) anadromous fish streams, and 7) Sitka black-tail deer hunting.

The Mirror Harbor KMDA is located within the West Chichagof-Yakobi Wilderness area. In addition, the area is designated for recreation and as important for tourism. A Forest Service recreation cabin at White Sulphur Springs is located in the area. The known occurrence in the Mirror Harbor area is located in flat-lying terrain, much of it in, or near, State intertidal lands. Although there are at least two anadromous fish streams within the KMDA, they are situated on the north side of the KMDA. Development of the known occurrence would not impact either of the streams. There is a moderate level of deer hunting recognized in the area.

\section{Mineral Development Potential}

The Mirror Harbor deposits are of sufficient size and grade to attract mineral development interests. Though the deposits are relatively small, they are more attractive for development due to the location of similar deposits at Bohemia Basin to the north. A mill facility at Bohemia Basin could potentially process ore extracted from the Mirror Harbor deposits. The land status of the Mirror Harbor KMDA within the West Chichagof-Yakobi Wilderness, detracts from its mineral development potential. 


\section{Snipe Bay KMDA}

\section{Location / Access}

Mineralized rock bearing nickel, copper, and cobalt defines the Snipe Bay KMDA. It is located 45 miles southeast of Sitka on the west side of Baranof Island, on the north side of Snipe Bay (Plate 1, KMDA no. 13). Topography in the area is fairly rugged, with steep cliffs rising from sea level to over 500 feet in elevation. The area is densely forested and brushy. The surge of waves from the open ocean to the west prevents safe access to the area by float plane. Boat access can be made to Snipe Bay, where landing by skiff in relatively calm seas is practical, but more reliable access can be had via helicopter. A steep trail provides access to the deposits from tidewater.

\section{History / Production}

The Snipe Bay deposit was discovered in 1922 (Buddington, 1925). From 1922 to 1942, work on the deposit was limited to trenching. The USGS examined the property in 1929 and 1941 (Reed and Gates, 1942). The Bureau of Mines examined it in 1963 (Pittman, 1963). In 1973 the Inspiration Development Company acquired the property and explored the deposit with 21 diamond drill holes. Claims on the deposit lapsed in 1979 (Roberts, 1983). Bureau of Mines personnel collected metallurgical test samples at the property in 1981 and 1988 (Foley, 1989). There has been no production from the area.

\section{Geology / Resources}

The Snipe Bay area is underlain by Cretaceous Sitka Graywacke, which has been intruded by Tertiary gabbro and norite (Reed and Gates, 1942; Foley, 1989). The magmatic segregation nickel-copper-cobalt deposit occurs in the gabbro. Two mineralized zones are exposed in trenches and have been tested by 21 diamond drill holes. The zones are located in a steep gully at elevations between 480 and 550 feet, and 170 and 320 feet. The ore minerals are nickeliferous pyrrhotite, pentlandite, and chalcopyrite. The zones form a deposit with an indicated resource of 94,000 tons of $0.97 \%$ copper and $0.33 \%$ nickel (Roberts, 1983; Foley, 1989).

The known mineralized zones at Snipe Bay were not re-examined during this study, because of recent work by other Bureau of Mines workers (e.g., Foley, 1989). In 1995 a Bureau of Mines crew collected stream sediment samples in Snipe Bay and examined iron-stained zones in the sea cliffs near the mouth of the bay (Plate 2; Map nos. 338-340, 342-344). Additional mineralized rock was not found and the stream sediment samples had low metal values (Maas and others, 1996).

\section{Land Use and Resource Issues}

There are three land use and resource issues identified in the Snipe Bay area. They relate to 1) a wilderness designation, 2) anadromous fish streams, and 3) Sitka black-tail deer hunting.

The northern part of the Snipe Bay KMDA is located within the South Baranof Wilderness area. However, the occurrence is located just south of the wilderness boundary. Development of the known occurrence may not be affected by this designation, but the potential for future exploration and development in the area is limited by the adjacent wilderness. There is one anadromous fish stream within the KMDA that is located north of the mineralized bodies, in the 
wilderness area. It is unlikely that development would affect the anadromous fish stream. Deer hunting pressure in the south Baranof Island area is listed as moderate, but is likely to be low in the Snipe Bay area itself.

\section{Mineral Development Potential}

Although small, the Snipe Bay deposit is of sufficient size and grade to be given a medium mineral development potential. A medium development designation takes into consideration the presence of similar deposits to the north at Bohemia Basin and Mirror Harbor. Milling requirements could potentially be handled by a facility at Bohemia Basin. The South Baranof Wilderness area borders the Snipe Bay deposit on the north, which limits the possibility of additional exploration in the area.

\section{Red Bluff Bay KMDA}

\section{Location / Access}

The Red Bluff Bay deposit, which defines the $\mathrm{KMDA}$, is located on the northeast side of Red Bluff Bay, about 25 miles southeast of Sitka (Plate 1, KMDA no. 11). The bay takes its name from the bare reddish-brown weathered surface of chromite-bearing ultramafic rocks that underlie 1.25 square miles on a long ridge north and east of the bay. Moderate to steep slopes rise from tidewater to a ridge crest that ranges in elevation from 520 to 1,200 feet. Access is by float plane or boat to Red Bluff Bay and then by foot to the deposit.

\section{History / Production}

Chromite was first recognized in the Red Bluff Bay area in 1933 when 28 claims were staked (Guild and Balsley, 1942). During the 1940's the Alaska Juneau Mining Company held the claims (Carnes, 1980). The USGS mapped and sampled the deposit in 1939 and 1941 (Guild and Balsley, 1942). The Territorial Department of Mines conducted a magnetic survey over the deposit in 1953 (Holdsworth and Williams, 1953). No production has occurred from this property.

\section{Geology}

The Red Bluff Bay ultramafic complex consists of partly serpentinized dunite and pyroxenite. Pyroxenite predominates in the northwestern half of the area where it crops out in large irregular masses. The pyroxenite is commonly altered to amphibolite. The dunite predominates in the eastern and southern parts of the complex. The dunite includes bands of pyroxenite-rich layers that strike north and dip steeply. In places, the pyroxenite and dunite are finely interlayered. Chromite is found disseminated in the dunite, and in richer layers and bands within the dunite that are parallel to the pyroxenite bands. Zones containing disseminations and small lenses of chromite are up to 30 feet wide and several hundred feet long. Chromite lenses up to 3 feet wide and 40 feet long have been found. The chromite lenses probably formed as magmatic segregations during cooling of the intrusive mass (Guild and Balsley, 1942). Greenschist and phyllite surround the Red Bluff Bay intrusive. The complex is bounded by faults, leading to the suggestion that it may have been tectonically emplaced (Loney and others, 1975). 
Two pan concentrate samples were taken during this study to determine the presence of platinumgroup metals (PGM) in the deposit (Plate 2; Map nos. 160, 162; samples 2036, 2037). Although chromium values were high, only trace amounts of PGM were detected.

\section{Resources}

Eight areas of chromium mineralization scattered over a 6,000-foot-long area have been identified by previous workers. These areas contain from $5 \%$ to $50 \% \mathrm{Cr}_{2} \mathrm{O}_{3}$ and a 30,000-ton inferred resource of $12 \% \mathrm{Cr}_{2} \mathrm{O}_{3}$ has been identified. The chromite to iron ratio of the deposit is low, somewhere below the desired threshold of 3:1 (Guild and Balsley, 1942).

\section{Land Use and Resource Issues}

There are five land use and resource issues identified in the Red Bluff KMDA. They relate to 1) a wilderness designation, 2) a recreation area, 3) a recreation area important to tourism 4) an anadromous fish stream, and 5) Sitka blacktail deer hunting.

The entire Red Bluff Bay KMDA is included in the South Baranof Wilderness area. The area is also designated for recreation and is recognized as important for tourism. There is an anadromous fish stream within the KMDA and the known occurrence is located just to the east of it. Mineral development in the area would likely require mitigation for impacts to the stream. There is a moderate level of deer hunting identified in the area.

\section{Mineral Development Potential}

The mineral development potential of the Red Bluff Bay area is low. The chromium deposit is small and low grade, and contains an insufficient chromium to iron ratio to attract serious development interest. In addition, there are no PGM associated with the deposit. The style of mineralization and characteristics of the intrusive body at Red Bluff Bay are similar to those found at the Hill prospect (see below), but not typical of a zoned, Alaska-type ultramafic body (Taylor, 1967; Foley and others, 1997) common in southeast Alaska, which may hold a higher potential for hosting an economic ore body. The area is also within the South Baranof Wilderness where mining is prohibited.

\section{Hill KMDA}

\section{Location / Access}

The Hill KMDA, defined by chromite-bearing ultramafic rocks, is located 15 miles southeast of Sitka along the rugged crest of Baranof Island (Plate 1, KMDA no. 10). The area consists of rugged, glacier-clad mountains that rise to an elevation of over 4,000 feet. Access is by helicopter.
History / Production

Chromite was first discovered in the Hill area about 1935 (Guild and Balsley, 1942). Claims were staked, but were abandoned by 1942 . There are brief references to the prospect in Guild and Balsley (1942), Kennedy and Walton (1946), and Berg and Cobb, (1967). Each report states that the grade and extent of mineralized rock is insufficient to constitute ore. There has been no production from the area. 


\section{Geology}

The chromite-bearing mafic/ultramafic rocks at the Hill prospect are similar to those at Red Bluff Bay, described above. They consist predominately of pyroxenite and dunite. The dunite contains whisps and disseminations of chromite. Disseminated chalcopyrite, pyrite, and pyrrhotite are found within the pyroxenite.

During 1996, the BLM sampled exposures of sulfide-bearing pyroxenite for their copper, nickel, and PGM potential. The samples contained from 12 to $3,050 \mathrm{ppm}$ copper and from 7 to $1,100 \mathrm{ppm}$ nickel (Plate 2, Map nos. 237,238 ; samples $1409,1410,1456,1457$ ). The sample with the highest copper value (sample 1409) also contained the highest PGM value of $55 \mathrm{ppb}$ platinum and $68 \mathrm{ppb}$ palladium. The remaining samples contained up to $5 \mathrm{ppb}$ platinum and $10 \mathrm{ppb}$ palladium. (Bittenbender and Still, 1997).

\section{Land Use and Resource Issues}

There are two land use and resource issues identified in the Hill KMDA. They relate to 1) a wilderness designation, and 2) Sitka black-tail deer hunting.
The southern part of the Hill KMDA, which includes the Hill prospect itself, is included in the South Baranof Wilderness area. The northern part of the KMDA, where there is potential, but no known mineralized rock, is open to mineral entry. Given the remote setting of the Hill $\mathrm{KMDA}$, deer hunting pressure is low, even though the area as a whole is listed with a low to moderate level of deer hunting. There are no anadromous fish streams within the boundaries of the KMDA. However, there are anadromous fish streams, both to the east and west of the area. Mineral development may require some mitigation measures to protect these streams.

\section{Mineral Development Potential}

The mineral development potential of the Hill prospect area is low. The size and extent of chromium mineralization at the occurrence is too low to present a serious exploration target. Concentrations of nickel, copper, and PGM that might make the prospect more attractive were not revealed by this study. In addition, the remoteness of the site and the land use restriction on mineral development lowers the area's development potential.

\section{Porphyry}

Two of the study area's KMDA's are defined by porphyry occurrences. They are the Warm Springs Bay and Slocum Arm KMDA's shown on Plate 1.

Rock mineralized with molybdenum extends across several miles at Warm Springs Bay, but is mainly low grade. It is hosted in Eocene tonalite (Loney and others, 1975). Although surface sampling has revealed a limited occurrence to date, the broad extent of the mineralized rock might attract subsurface exploration. The land status at Warm Springs Bay allows for mineral development.

The molybdenum occurrence at Slocum Arm extends over one square mile and is hosted in Triassic greenstone and Tertiary granodiorite (Loney and others, 1975). Although widespread, the occurrence is low grade. There 
are insufficient data to establish a tonnage and grade at the site. The low grade of the occurrence and the fact that the area is covered by a wilderness designation, lowers the potential of exploration interest in the area.

\section{Warm Springs Bay KMDA}

\section{Location / Access}

Porphyry copper-molybdenum and associated mineralization defines the Warm Springs Bay KMDA. It is located 27 miles due east of Sitka, on the east side of Baranof Island (Plate 1, KMDA no. 8). The Warm Springs Bay KMDA extends for several miles, from the north side of Warm Springs Bay to Chatham Strait. The topography of the area ranges from sea level to over 2,200 feet in elevation. Brush and timber dominate the lower elevations, whereas the upper elevations are alpine and cliffy. Access is possible by float plane, boat, or helicopter.

\section{History / Production}

Mineralized rock at Warm Springs Bay was discovered by El Paso Natural Gas Company in 1973. They staked a block of claims that extended from the north side of Warm Springs Bay to Chatham Strait, a distance of two and a half miles (unpublished BLM records). Results of the company's work have not been released. No production has occurred from this property.

\section{Geology}

The Warm Springs Bay area consists of Eocene hornblende-biotite tonalite and hornblendebiotite granodiorite that contain septa and inclusions of Triassic biotite schist, gneiss, amphibolite, and phyllite (Loney and others, 1975). Examination revealed coppermolybdenum mineralization scattered across a one square-mile area, stretching from the abandoned townsite of Manleyville, east to Chatham Strait, and one mile to the north, along the shoreline. The mineralized rock is found at sea level and extends to over 1,700 feet in elevation. A hornfels zone containing zinc and copper was identified in the contact area adjacent to the intrusion. The contact is exposed at the north edge of the KMDA.

The most extensive zone of copper-molybdenum mineralized rock is exposed along the north shore of Warm Springs Bay. Pyrite, chalcopyrite, and molybdenite are disseminated in silicified tonalite, along the edges of granodiorite inclusions, and in fracturecontrolled quartz stringers. Exposures of tonalite west of Manleyville contain up to five percent pyrite with little chalcopyrite or molybdenite. East of Manleyville, a 300-footlong exposure in the intertidal zone contains more abundant chalcopyrite and molybdenite. Twenty chip samples were taken to evaluate this exposure. Sample results averaged $600 \mathrm{ppm}$ copper and $85 \mathrm{ppm}$ molybdenum. The highest values were found in a 10 -foot chip sample that contained 1,550 ppm copper and $600 \mathrm{ppm}$ molybdenum (Plate 2, Map no. 203, sample 2718). A select sample across a 1.5 -foot-thick quartz lens contained 5,300 ppm copper and 925 ppm molybdenum (Plate 2, Map no. 203, sample 2725). No samples from this mineralized zone had appreciable precious metal values.

Small amounts of molybdenite and sphalerite were found in narrow quartz stringers hosted in granodiorite about three quarters of a mile east 
of Manleyville. Samples of the stringers contained up to $1,650 \mathrm{ppm}$ molybdenum and 1,100 ppm zinc (Plate 2, Map nos.199, 200; samples 2579,2749 ). Samples collected from quartz stringers and tonalite located north of the 300 -foot-long showing contained up to 6,000 ppm copper and $415 \mathrm{ppm}$ molybdenum (Plate 2, Map nos. 201, 203; samples 2577, 2545-47). Seven stream sediment samples collected to the east and west of Manleyville did not contain significant metal values.

Examination along the ridge crest, half to three quarters of a mile north of Manleyville, revealed significantly less silica alteration and pyrite in the tonalite. Samples collected from this area contained variable amounts of chalcopyrite, molybdenite, and sphalerite (Plate 2, Map nos. 193-195). Analyses revealed up to 7,200 ppm zinc (Plate 2, Map no. 193, sample 2753), 1,900 ppm copper (Plate 2, Map no. 194, sample 2587), and $550 \mathrm{ppm}$ molybdenum (Plate 2, Map no. 195, sample 2754). The highest gold value from all samples collected in the Warm Springs Bay area, $170 \mathrm{ppb}$ (Plate 2, Map no. 193, sample 2585), came from this area.

Much of the mineralized rock observed in the Warm Springs Bay area was found along or near a steeply dipping fault zone that extends about one and a half miles from Manleyville northeast to Chatham Strait. This zone contains boulders of quartz and silicified tonalite, and a quartz vein containing pyrite, chalcopyrite, and sphalerite (Plate 2, Map no. 189). Three samples were taken that contained up to $1,750 \mathrm{ppm}$ copper (sample 2751), $544 \mathrm{ppm}$ bismuth, and 2,750 ppm zinc (sample 2584). Zinc values increase and molybdenum values decrease to the northnortheast along the fault zone.
Land Use and Resource Issues

There are six land use and resource issues identified in the Warm Springs Bay KMDA. They relate to 1) private land, 2) a recreation area, 3) a recreation area important to tourism, 4) State land, 5) Sitka black-tail deer hunting, and 6) anadromous fish streams.

The Federal land in the Warm Springs Bay area is open to mineral development. There are, however, several issues that would most likely need to be addressed prior to resource development. The community of Baranof is situated near the center of the KMDA and includes a significant amount of private land. The Warm Springs Bay area is the site of numerous hot mineral springs that attract tourists and other recreational users to the area. The Baranof townsite and hot springs are near the head of Warm Springs Bay, whereas the known occurrence is closer to the mouth of the bay. The valley to the southwest of Warm Springs Bay is the site of a proposed road and power transmission corridor, so the State has some interest in the land management of the area. The deer hunting level in the area is low and is unlikely to be an issue. At least two anadromous fish streams cut through the KMDA, but development in the area of the known occurrence would be unlikely to affect the streams.

\section{Mineral Development Potential}

The discontinuous nature of the mineralized rock and the low metal values in the rocks sampled at Warm Springs Bay discourage additional surface examination of the deposit. A further detraction is the low precious metal values in the samples collected. However, the broad extent of the mineralized rock means the potential for a large, low-grade deposit still exists, and might 
encourage subsurface exploration of the area. Subsurface exploration may include geophysics, detailed soil sampling, or eventually, drilling.
The Warm Springs Bay KMDA is given a medium mineral development potential.

\section{Slocum Arm KMDA}

\section{Location / Access}

The Slocum Arm KMDA is defined by rock mineralized with molybdenum found in dikes, quartz veins, and greenstone. The 2 - by 6-mile area is located on Chichagof Island, 35 miles northwest of Sitka and 1.5 miles east of Hidden Cove, near the head of Slocum Arm (Plate 1, KMDA no. 7). Most of the area is above timberline, except for the southern part, which consists of steep brushy gullies. Access to the area can be obtained by float plane or boat to Hidden Cove. From Hidden Cove, foot access through heavy brush is required to reach the mineralized area. The area can also be accessed by helicopter.

\section{History / Production}

Molybdenum was discovered in the Slocum Arm area in 1943, but there is no evidence of claim staking or development work at that time (unpublished BLM records). By 1952 claims had been staked and the Bureau of Mines examined the property (Thorne, 1952). In 1968 John Ballard, a claim holder, reported on the geology and mineral potential of the area (Ballard, 1968). The prospect was examined again in 1978 by Bureau of Mines personnel (Still and Weir, 1981). No production is known to have occurred from the property.

\section{Geology}

Rocks in the prospect area include Triassic Goondip Greenstone that has been intruded by
Tertiary granodiorite (Johnson and Karl, 1985). Molybdenum is found scattered in quartz stringers and in felsic to intermediate dikes along a 50-foot wide fault zone cutting the greenstone that strikes $020^{\circ}$, and dips up to $55^{\circ}$ to the southeast or northwest. The fault can be traced for 8,500 feet from elevations of 500 to 2,400 feet. A series of north-northwest striking, felsic to intermediate dikes and sills are hosted in greenstone about 1,000 feet east of the fault zone. West striking, steeply dipping quartz veins up to half a foot thick are also hosted in the greenstone at this location (Still and Weir, 1981).

Mineralized rock at the Slocum Arm prospect is hosted in a variety of settings: in quartz veins, in a shear zone with quartz stringers, in fault gouge, in an assortment of dikes, in greenstone, and in the Tertiary granodiorite. The mineralized rock is spread across an area greater than one square mile (Still and Weir, 1981). The following analytical data, taken from the 1981 study, illustrate the grade of the molybdenum mineralization: Samples from the dikes contained up to $190 \mathrm{ppm}$ molybdenum; samples from a diorite sill contained $280 \mathrm{ppm}$ molybdenum; samples from the greenstone contained up to $32 \mathrm{ppm}$ molybdenum; and samples from the quartz veins contained up to $5,400 \mathrm{ppm}$ molybdenum. The quartz sample contained the highest molybdenum value found on the property.

BLM workers attempted to define additional molybdenum occurrences to the east and north 
of the main prospect during this study. A $0.7-$ mile traverse was made along a prominent ridge to the east. Samples were collected of granodiorite, greenstone, and quartz veins hosted in greenstone and granodiorite (Plate 2, Map nos. 146-151). They contained up to 6 ppm molybdenum. A traverse was also made 1,500 feet to the north of the known occurrence. Examination revealed quartz stringers hosted in greenstone and intermediate dikes and sills in greenstone. A sample of quartz in greenstone contained $5 \mathrm{ppm}$ molybdenum and $570 \mathrm{ppm}$ copper (Plate 2, Map no. 147, sample 2772). Analysis of dike samples did not reveal significant metal values. Although similar geology was identified north and east of the Slocum Arm molybdenum deposit, sampling failed to reveal additional mineralized rock.

\section{Land Use and Resource Issues}

There are three land use and resource issues identified in the Slocum Arm KMDA. They relate to 1) a wilderness designation, 2) a timber harvest designation, and 3) Sitka black-tail deer hunting.
Most of the Slocum Arm KMDA is designated as wilderness. The wilderness designation precludes mineral entry and there are no preexisting active mining claims present in the area that might allow for mineral development in a wilderness. The northeast side of the KMDA is designated as a timber harvest area, which would be open for mineral development. This part of the KMDA, however, has no known mineral occurrences. There is a moderate level of deer hunting recognized in the area, but given the remote setting of the occurrence, mineral development would unlikely effect hunting.

\section{Mineral Development Potential}

The Slocum Arm KMDA is assigned a low mineral development potential. Even though the mineralized rock is scattered over a large area, it is relatively low grade. In addition, the mining claims in the area are no longer active, so the area has reverted to a wilderness designation where mining is prohibited.

\section{Volcanic-Related Massive Sulfide}

Two KMDA's located in the study area contain volcanic-related copper occurrences. They are the Mt. Baker and Mt. Muravief KMDA's shown on Plate 1.

The copper occurrence at Mt. Baker is hosted in Triassic Goondip Greenstone (Johnson and Karl, 1985) and extends over an area of about two by three miles. Although some areas of high grade mineralized rock have been found, most of the area contains low grade concentrations. The broad extent of mineralized rock at the site would encourage further evaluation, but the wilderness designation that covers the property makes further exploration unlikely.

At Mt. Muravief, copper-zinc mineralization is hosted in greenstone and in the surrounding schist of the Cretaceous Sitka Graywacke. Investigations to date have established a correlation between the occurrence of greenstone and the copper mineralization. The limited extent of greenstone in the area therefore suggests a limited potential for additional copper mineralization discoveries. Although the land status of the Mt. Muravief KMDA allows for 
mineral development, the potential for further development is low.

\section{Mt. Baker KMDA}

\section{Location / Access}

Rock mineralized with copper defines the 2- by 3-mile Mt. Baker area, located 65 miles northwest of Sitka (Plate 1, KMDA no. 4). The area ranges from sea level, at Goulding Harbor, to the summit of Mt. Baker, at an elevation of over 2,000 feet. Treeline in the area is at about 1,500 feet. Above treeline, the terrain is rugged and has alpine vegetation. Below the treeline, the area is covered with dense brush and timber.

\section{History / Production}

Copper was discovered near the summit of Mt. Baker in 1910. By 1917 over 300 feet of underground workings had been driven and numerous trenches dug. The workings exposed mineralized rock between elevations of 1,300 and 2,000 feet (Overbeck, 1919). The Bureau of Mines examined the property in 1952 and 1953 and conducted detailed rock and soil sampling (Thorne, 1960). Geo-Recon Inc. completed magnetic and self-potential surveys in the area in 1962 (Bush and Kenly, 1962). In 1971, an extensive soil sampling survey was conducted by Moerlein (1971) covering an area 1,000 feet wide and 1,400 feet long. No production has occurred from this property.

\section{Geology}

The Mt. Baker copper occurrence is hosted in greenstone and consists of disseminations and localized masses of chalcopyrite and pyrite. It is classified as a basaltic copper deposit by Berg (1984). Aplite dikes intrude the greenstone, and according to Berg (1984), the adjacent basaltic wallrock is altered and both dikes and wallrock locally contain disseminations and small masses of pyrite and chalcopyrite. The largest concentration of copper is hosted in a northwest striking, vertical, altered zone, 400 feet long. Samples taken from a trench at the southeast end of the zone contained $2.0 \%$ copper across 13 feet. A shallow shaft at the northwest end of the zone exposes $7.5 \%$ copper across 2 feet. Other smaller mineralized sections are exposed within the altered zone as well. Geochemical and geophysical studies indicate a possible three-mile extension of the zone (Kimball, 1982).

\section{Land Use and Resource Issues}

There are five land use and resource issues identified in the Mt. Baker KMDA. They relate to 1) a wilderness designation, 2) a recreation area, 3) a recreation area important to tourism, 4) anadromous fish streams, and 5) Sitka blacktail deer hunting.

The entire Mt. Baker KMDA is included in the West Chichagof-Yakobi Wilderness. Along the southeast edge of the KMDA is an area designated for recreation and is recognized as important for tourism. This area includes the course of a major drainage, which is an anadromous fish stream. There is at least one other anadromous fish stream that drains the area of known mineralization. There is a moderate level of deer hunting recognized in the area. 


\section{Mineral Development Potential}

The possible three-mile extent of mineralized rock, as indicated by geophysics and geochemistry, encourage continued exploration of this deposit. However, the evident lack of continuity of the copper mineralization warrants a medium mineral development potential for the area. The mining claims associated with this property are no longer active, so the area has reverted to a wilderness designation where mineral development is not allowed.

\section{Mt. Muravief KMDA ${ }^{2}$}

\section{Location / Access}

Mt. Muravief is located on the southeast side of Baranof Island, north of Port Herbert and just south of Deep Cove, which is near Patterson Bay (Plate 1, KMDA no. 12). The three mineralized areas on Mt. Muravief are located between 2,400 and 3,000 feet elevation, above the local treeline. The area is marked by rugged topography with Mt. Muravief standing at 3,330 feet. The general area may be accessed by boat. Cliff Lake to the north and Deer Lake to the south are suitable for float plane landing. However the high elevation of the occurrences makes helicopter access preferable (see Fig. 8).

\section{History / Production}

Donald MacDonald, now of Pelican, Alaska, reportedly brought pieces of copper-bearing rock to the Bureau of Mines in Juneau for identification sometime around 1969. Copper had originally been discovered in the area in the 1930's when a 'Vevelstad' held claims there (D. MacDonald, personal communication). A petrographic report, generated by MacDonald's request for sulfide identification (Gnagy., 1969), was discovered by BLM personnel during the current study. Examination of the area in the fall of 1996 resulted in the location of three mineralized occurrences on Mt. Muravief. Only one of the occurrences shows evidence of development, which includes minor stripping and a small opencut. No production has occurred from the property.

\section{Geology}

The copper occurrence at Mt. Muravief is associated with greenstone lenses hosted in Cretaceous Sitka Graywacke. The mineralized rock is commonly concentrated along the greenstone-graywacke contacts and occurs in both lithologies. The association between the copper mineralization and greenstones is unclear, although the secondary nature of mineralization is apparent. A specific deposit type has not been determined for the occurrence.

BLM personnel located copper-mineralized rock in three main areas on the slopes of Mt. Muravief; 1 ) in a cirque on the southwest side of the mountain, 2) on a ridge extending from the peak to the west, and 3 ) on the north face of the mountain (see Fig. 8). In each of these areas the copper minerals are associated with lenses of greenstone within the surrounding

${ }^{2}$ Additional information on the South Baranof area including Mt. Muravief is provided in the "BLM Work in 1997" section of this report (p. 73). 
metasedimentary rocks. The lenses are up to 100 feet wide and extend up to 1,000 feet along strike. Overall, the lenses strike generally to the northwest and dip steeply to the southwest.

Copper minerals in the area occur disseminated in greenstone and graywacke, in massive sulfide lenses, and associated with a volcaniclastic breccia. The sulfides, mainly pyrrhotite and chalcopyrite, occur in seams parallel to the foliation and in patches that cut across the foliation. The greenstone and graywacke hosting the disseminated minerals are commonly ironstained and schistose.

BLM personnel collected 32 samples from the 3 mineralized areas on Mt. Muravief. The samples indicate copper grades up to $6.33 \%$ (Plate 2, Map no. 301, sample 1473), gold to $600 \mathrm{ppb}$ (Plate 2, Map no. 302, sample 1433), silver to 14.5 ppm (Plate 2, Map no. 301, sample 1474), and zinc to 2,200 ppm (Plate 2, Map no. 301, sample 1474). A sample across 18 feet of the mineralized, altered schist on the west ridge returned $1.63 \%$ copper, $3.6 \mathrm{ppm}$ silver, and 560 ppm zinc (Plate 2, Map no. 301, sample 1427).

Two hundred and twenty stream sediment samples were collected from Baranof Island, south of the South Baranof Wilderness area, in an attempt to locate additional copper occurrences. Copper-, zinc-, gold-, and silveranomalous samples were present in the sample set (see Fig. 10) and follow-up traverses were made to locate sources, however, no significant occurrences were discovered.

Copper-mineralized rock was examined in several locations in the Mt. Muravief area. However, the location of the occurrence described by Gnagy (1969) that led the BLM to the area may not have been located. The petrographic report describes stringers of massive chalcocite; no such occurrence was discovered during the field examination.

\section{Land Use and Resource Issues}

There are three land use and resource issues identified in the Mt. Muravief KMDA. They relate to 1) a recreation area, 2) anadromous fish streams, and 3) Sitka black-tail deer hunting.

The primitive recreation designation covering the Mt. Muravief KMDA does not specifically preclude mineral development. Development, however, would have to include mitigation measures to protect the anadromous fish streams in the area. At least one anadromous fish stream drains the area with the known occurrence on the north side of Mt. Muravief itself. There is a moderate level of deer hunting recognized in the area as a whole, but hunting pressure is likely to be low in the immediate Mt. Muravief vicinity.

\section{Mineral Development Potential}

The Mt. Muravief area has a low mineral development potential. The style of mineralization present is not common elsewhere in southeast Alaska, and is not known in deposits with historic development. In addition, the greenstones with which the mineralization is associated are limited in occurrence on southern Baranof Island. The geochemical stream sediment sampling program carried out by the BLM did not locate significant mineralized rock.

The Mt. Muravief area deserves further examination, however. The "massive chalcocite from stringers" mentioned in a petrographic report from the area (Gnagy, 1969) was not located by the BLM during the present study. Although the development potential remains low, the possibility of additional mineral occurrences in the area may be investigated. 


\section{OTHER Mines, Prospects, or Mineral OCCURREnCES}

\section{Kaiser Gypsum Mine}

The Kaiser Gypsum Mine is located on eastern Chichagof Island at Iyoukeen Cove, about 35 miles southwest of Juneau (Plate 1, Prospect no. P21). The deposit and mine workings are located about one mile up Gypsum Creek, north of Iyoukeen Cove.

Gypsum was first discovered at lyoukeen Cove in 1902. Soon after, the Pacific Coast Gypsum Company began developing the deposit. Workings consisted of two shafts, a raise, and up to 3,500 feet of drifts. The deepest workings were 300 feet below the surface. Pacific Coast Gypsum produced 500,000 tons of gypsum from 1906 to 1923 . Flooding by a creek that cuts across the property was an ongoing problem at the mine, and pumps were necessary to keep the underground workings open (Stewart, 1932b; Flint and Cobb, 1953). In 1923 the mine flooded and was closed. The mine's closure may have been due to the flooding or lack of adequate reserves (Flint and Cobb, 1953). The Bureau of Mines drilled the deposit in the early 1960 's, but drilling difficulties prevented the calculation of resources. Six claims covering the deposit were patented in 1915 (MS647). The patented claims apparently became delinquent for tax reasons and were acquired by the Kaiser Gypsum Company in the late 1950's (unpublished BLM records).

The Kaiser Gypsum deposit is hosted in the limestone and shaley limestone of the Mississippian Iyoukeen Formation. It consists of translucent gypsum, mostly pure white in color with irregular narrow gray bands. A limestone breccia that may be a fault breccia or an intraformational breccia at the top of the limestone is in contact with the gypsum. The limestone is cut by irregular lamprophyric dikes. Whether the deposit is sedimentary or hydrothermal in origin has not been established (Flint and Cobb, 1953; Loney and others, 1963).

A petrographic examination of samples from lyoukeen Cove led Gnagy (1962) to suggest the gypsum to be tectonically mobilized and of sedimentary origin.

Resources at the Kaiser Gypsum Mine have not been determined. It is possible that the Pacific Coast Gypsum Company ceased operations in 1923 because of flooding and not because of a lack of adequate reserves. In 1924 the Standard Gypsum Company acquired the property and tried unsuccessfully to resume operations. The fact that this company attempted to reactivate the mine suggests that they may have had some knowledge of additional reserves (Flint and Cobb, 1953). On the other hand, the Standard Gypsum Company also acquired the nearby Camel Gypsum property in 1924, and may have tried to begin commercial operations there (Redman, 1989). They may have had no knowledge of additional reserves at the Kaiser Gypsum Mine. BLM records mention a possible 4.5 million-ton reserve of gypsum remaining in the Kaiser deposit. This figure was apparently derived from descriptions of the underground workings of the mine at the time of closure and was mentioned by J. Cole, of the Kaiser Gypsum Company (unpublished BLM records). 


\section{Camel Gypsum}

The Camel Gypsum deposit is located on the east side of Chichagof Island at Iyoukeen Cove, about 35 miles southwest of Juneau (Plate 1, Prospect no. P20). The gypsum deposit and workings are located near the beach and are accessible by boat or float plane.

Gypsum was discovered at the Kaiser Gypsum property (p. 67) near Iyoukeen Cove in 1902 (Flint and Cobb, 1953). In 1910, a second deposit was discovered at the Camel Gypsum property, about 1.2 miles to the east. By 1942 the Camel Gypsum deposit had been developed by 5 adits, 3 winzes, and a sublevel drift with a total length of 1,060 feet (Jermain and Rutledge, 1952). In 1946, Fir-Tex Insulation Board Company of Oregon optioned the property (Flint and Cobb, 1953). In 1948, Bureau of Mines engineers cleaned and pumped out the winzes and adits, mapped and sampled the property, and drilled two holes (Jermain and Rutledge, 1950, 1952). In 1962 the Bureau of Mines conducted further development work, drilling an additional four holes (U. S. Bureau of Mines, 1962).

The gypsum deposit is hosted in the limestone and shaley limestone of the Mississippian Iyoukeen Formation (Loney and others, 1963). It consists of gypsum, mostly pure white in color, which in places grades to light bluish gray. The gypsum is fine grained and translucent, and approaches alabaster in grade (Jermain and Rutledge, 1952). It is associated with cream or buff limestone breccia and dark-gray cherty limestone. The origin of the deposit has not been determined. Whereas the proximity of a quartz monzonite intrusive supports a hydrothermal origin, the deposit's restriction to the highest part of the Iyoukeen Formation suggests a sedimentary origin (Loney and others, 1963). Gnagy (1962) suggests a tectonically mobilized deposit of sedimentary origin, based on petrographic examination of gypsum samples.

According to unpublished information generated by the 1948 Bureau of Mines examination, "the Camel Gypsum deposit is of small economic importance." Based on sampling and drilling of the deposit, the Bureau of Mines estimated an indicated and inferred resource of 92,500 tons of gypsum (Jermain and Rutledge, 1950).

\section{Sealion Cove}

Narrow quartz veins are exposed in the intertidal zone near Sealion Cove, on the northwest end of Kruzof Island (Plate 2, Map no. 173). BLM personnel examined the area in 1995 and 1996 (Maas and others, 1996; Bittenbender and Still, 1997). Quartz veins in the area were originally reported by Loney and others (1963) as containing molybdenum and minor copper. BLM sampling revealed low copper and molybdenum values, but anomalous gold concentrations.
The Sealion Cove quartz veins are from a quarter to a half foot in width, and are oriented from about $300^{\circ}$ to $070^{\circ}$ and have steep dips. They commonly pinch and swell, and anastomose along strike. The veins are exposed for up to 100 feet along strike, between tidewater and inland vegetation. They crop out for about 200 feet along the shoreline. The veins are hosted by hornfelsed graywacke and generally crosscut felsic dikes that intrude the area. Bedding in the graywacke is oriented 
about $310^{\circ}$. A brecciated zone in the hosting hornfels includes graywacke clasts and quartz stringers. The zone contains minor pyrrhotite that locally comprises up to one to two percent of the rock. There is no obvious structural control to the veining in the area. Small northerly trending faults, with offsets of one to two feet, cut the veins in some places.

The quartz veins contain minor amounts of sulfides including pyrrhotite, arsenopyrite, and chalcopyrite. Vein samples revealed gold values up to 2,450 ppb (Map no. 173, sample 2769). One sample of the graywacke hornfels adjacent to the vein contained $2,360 \mathrm{ppb}$ gold and 6,900 ppm arsenic (Map no. 173, sample 1460). Higher gold values are commonly associated with the higher arsenic values. Samples of the brecciated zone in the hornfels contained very low precious metal values (Map no. 173, samples 1462,1463$)$.

\section{Big Ledge}

The Big Ledge prospect (Plate 2, Map no. 106) is situated at an elevation of 500 feet, on the north side of Tenakee Inlet, about 8 miles east of Tenakee Springs and 1.6 miles west-southwest of East Point. The prospect consists of a nickelcopper bearing dike exposed in a small gully. The site was discovered sometime prior to 1923 , when it was examined by Buddington (1925). Claims covering the prospect were staked and maintained between 1955 and 1957, otherwise no activity or development has been recorded (unpublished BLM records).

BLM personnel examined the Big Ledge occurrence in 1995. The occurrence consists of sulfides hosted in a mafic dike. The dike is oriented north-south and vertical to steeply eastward dipping. It is exposed for about 100 feet on the east bank of a steep gully and is about 40 feet thick at one end and about 10 feet thick at the other. Whether the wedge shape is due to incomplete exposure or a fault that cuts the dike has not been determined. Gouge along the western edge of the dike indicates fault movement, but heavy vegetative cover prevents definitive determination. The dike is cut off along strike by a fault in the creek that forms a gully to the south and is covered by vegetation to the north. About 40 feet north and above the dike is a 25 -foot trench, 2 feet wide that is sloughed and overgrown. Only conglomerate rubble was found in the bottom of the trench. The dike is hosted by a conglomerate member of the Silurian to Devonian Kennel Creek Limestone (Loney and others, 1975). Prominent iron staining marks weathered surfaces of the mafic dike.

Sulfides in the dike at Big Ledge include pyrrhotite, chalcopyrite, pyrite, and pentlandite, and occur as stringers, knots, and disseminations. The stringers are commonly parallel to the margins of the dike and average about one eighth inch thick. One stringer ranged up to half an inch thick and 2.8 feet long. Shearing of the dike is evident parallel to the stringers. The knots of sulfides are up to six inches across.

Samples collected by BLM personnel reveal moderate grades of copper and nickel with some zinc, cobalt, gold, and silver. The weighted average of two samples returned $0.84 \%$ nickel and $0.91 \%$ copper over 40 feet (Map no. 106, sample nos. 2051, 2052). Another measured sample contained $0.96 \%$ nickel, $2.25 \%$ copper, 
$8.8 \mathrm{ppm}$ silver, and $502 \mathrm{ppb}$ gold over 4 feet (Map no. 106, sample no. 2120). A select sample contained $4.4 \%$ nickel, $7.02 \%$ copper,
$1,066 \mathrm{ppm}$ zinc, $910 \mathrm{ppm}$ cobalt, and $22 \mathrm{ppm}$ silver (Map no. 106, sample no. 2121).

\section{East Point Pit}

A rock pit located on the south side of a road above East Point (north of Tenakee Inlet) was examined during this study (Plate 2, Map no. 104). The pit is about nine miles east of Tenakee Springs and eight tenths of a mile due east of East Point. The pit contains float boulders with massive sphalerite and associated galena and chalcopyrite. Limestone of the Silurian to Devonian Kennel Creek Formation (Loney and others, 1975) is the dominant rock type in the pit, although a mafic dike trending $015^{\circ}$ and dipping $60^{\circ}$ northwest cuts through the pit. The dike may be related to the sulfide mineralization. A few of the sulfide-rich boulders contain pieces of dike material. Other dikes found in the pit contain pyrite and/or pyrrhotite, but no other sulfides were found.

The sphalerite is reddish-black and yellow in color and occurs as large clots up to three inches across, and as wisps, tubes, and disseminations. It appears to have selectively replaced parts of the limestone, and does not appear to be structurally controlled. Galena and chalcopyrite are found in lower concentrations within the sphalerite. Much of the limestone outcrop near the dikes contains ankerite or siderite, but no sulfides were found. High-grade samples contained up to $52 \mathrm{ppm}$ silver, $26.4 \%$ zinc, $1.74 \%$ lead, and $460 \mathrm{ppm}$ copper (Map no. 104, samples 2048, 2119).

\section{Gypsum Creek}

BLM geologists examined rock exposures along a logging road on the north side of Gypsum Creek (Plate 2, Map nos. 57-66). Skarn mineralization is exposed in two rock pits and several road cuts, and occurs on both sides of the contact between fossiliferous cherty limestone and granodiorite. The limestone is part of the Mississippian Iyoukeen Formation and the intrusive has been mapped as hornblende-biotite adamellite (Loney and others, 1975).

The easternmost pit is the larger of the two pits and exposes a zone of sheared hornfels and endoskarn up to 60 feet wide. This zone locally contains abundant pyrite, pyrrhotite, and minor chalcopyrite. Garnet, epidote, diopside, and calcite are evident in the endoskarn. A sample of massive pyrrhotite with small stringers of chalcopyrite contained $116 \mathrm{ppm}$ copper and 310 ppm nickel (Map no. 57, sample 2076). No precious metal values were found in the sample. Pyrite seams up to half an inch thick are found in the limestone.

The west pit is located about two and a half miles to the west and exposes similar, but less extensive skarn minerals. A two-foot-wide zone of gossanous, mineralized hornfels containing chalcopyrite and pyrrhotite was sampled and contained 2,210 ppm copper (Map no. 64 , sample 2080). Two samples taken from 
rubble in the pit (Map no. 65, samples 21392140) contained up to $1,950 \mathrm{ppm}$ copper, 28 ppm molybdenum, $300 \mathrm{ppm}$ cobalt, $0.4 \mathrm{ppm}$ silver, and $50 \mathrm{ppb}$ gold. Although the metal values in the skarn are low, the presence of this type of mineralization is noteworthy. These exposures broaden the extent of skarn-type deposit potential on the east side of Chichagof Island. 



\section{BLM WORK IN 1997}

\section{Mt. Muravief}

A copper occurrence in the Mt. Muravief area (Plate 2, Map nos. 301-305) on southern Baranof Island was apparently discovered in the 1930 's. At that time, claims in the area were reportedly held by 'Vevelstad.' Donald MacDonald, a prospector, found additional mineralized rock in the area and brought samples to the Bureau of Mines office in Juneau for sulfide mineral identification (D. MacDonald, personal communication). A subsequent petrographic report indicated the presence of chalcocite and bornite in the samples. The report described "massive chalcocite from stringers" and other outcrops of copper-bearing rocks on the slopes of Mt. Muravief (Gnagy, 1969). Following up on the report, BLM workers located copper minerals in the area in the fall of 1996. During 1997, workers mapped and sampled the occurrence. In an effort to locate additional mineralized rock in the area, a stream sediment geochemical sampling plan was carried out. Anomalous sample results were investigated without finding significant additional occurrences.

The Mt. Muravief area is located within the Chugach terrane (Monger and Berg, 1987). On southern Baranof Island, the terrane is composed of the Sitka Graywacke (Loney and others, 1975), which represents a Cretaceous accretionary wedge complex of flysch and melange (Plafker and Berg, 1994). The area was mapped by Loney and others (1975) as lineated, schistose graywacke and slate, where the Sitka Graywacke has undergone dynamothermal metamorphism.

The country rock in the Mt. Muravief area consists of interlayered graywacke and argillite, with minor greenstone (Fig. 8). In places the layering of the graywacke and argillite is distinct; in others, ductile deformation has transposed bedding such that stretched, rounded clasts and boudins of graywacke are surrounded by argillite. The rock is well foliated with foliation generally striking to the northwest and dipping steeply to the southwest. Tight to open folds, defined by folded foliation surfaces and compositional layering, have axes that plunge about $30^{\circ}$ to the southeast. Iron staining is common on weathered surfaces. The staining is probably derived from oxidation of pyrrhotite that commonly occurs in elongate lenses parallel to the foliation.

Several sets of brittle faults cut the rocks in the Mt. Muravief area and postdate the metamorphic fabric and folding. The faults shown in Figure 8 were determined from air photo lineations and from ground observation. The northwest and east-west trending faults appear to be the youngest and crosscut the more predominant northeast trending faults. Only small offsets were observed on any of the faults in the area. Indicators of sense-of-movement were not definitive.

BLM personnel located copper-mineralized rock in three main areas on the slopes of Mt. Muravief, 1) in a cirque on the southwest side of the mountain, 2) on a ridge extending from the peak to the west, and 3) on the north face of the mountain (Fig. 8). In each of these areas the copper minerals are associated with lenses of greenstone within the surrounding metasedimentary rocks. The lenses are up to 100 feet wide and extend up to 1,000 feet along strike. Overall, the lenses strike generally to the 
northwest and dip steeply to the southwest. They are elongate parallel to the foliation in the metasediments. The contacts between greenstone and metasediments appear to be depositional or intrusive and predate the metamorphic fabric. The lenses are tightly folded, with fold axes plunging $15^{\circ}$ to $40^{\circ}$ to the southeast (Fig. 9). The folds are commonly asymmetric, which in places are consistent with parasitic folds on larger fold structures. The greenstone lenses show some evidence of brittle deformation, whereas the surrounding country rock shows evidence of more ductile deformation. In places, tension gashes filled with quartz are limited to the greenstone.

The greenstone is dark greenish gray, fine- to medium-grained, and commonly well foliated (greenschist). It is made up predominantly of plagioclase, biotite, chlorite, and calcite with minor amphibole and epidote. The amphibole commonly forms porphyroblasts that crosscut the metamorphic foliation. The calcite occurs in lenses and pods that when weathered, causes the greenstone to have a pitted surface.

The copper minerals in the area occur disseminated in greenstone and graywacke, in massive sulfide lenses, and associated with a volcaniclastic breccia. At the West Ridge (Fig. 9), North Face, and SW Cirque occurrences, disseminated copper minerals are associated with an iron-stained, schistose part of the greenstone. This altered zone is commonly concentrated near the greenstone-graywacke contact and occurs on both sides of the contact. The associated schists contain biotite, chlorite, plagioclase, and amphibole, plus sulfides. The sulfides, mainly pyrrhotite and chalcopyrite, occur in seams parallel to the foliation and in patches that cut across the foliation.

Along the west ridge of Mt. Muravief, massive lenses of sulfide occur within the band of altered schists. The lenses are up to 3 feet wide and extend up to 10 feet along strike. The lenses are parallel to the surrounding foliation; they strike about $315^{\circ}$ and dip about $60^{\circ}$ to the southwest. Sulfides include pyrrhotite, chalcopyrite, sphalerite, and bornite. A few small specks of native copper were also found within a massive sulfide lens.

Copper minerals in float were found below the greenstone lens in the southwest cirque of $\mathrm{Mt}$. Muravief. BLM personnel found a 12 -foot by 8 foot by 3-foot boulder composed of metamorphosed volcaniclastic breccia in which coarse-grained chalcopyrite and pyrrhotite is found in the matrix. Chalcopyrite is also disseminated in the fine- to very fine-grained metavolcanic clasts in the breccia. The breccia exhibits evidence of high strain with elongated clasts and a matrix that has flowed around the clasts. Small isoclinal folding of the clasts is also common.

In several locations on the north face of $\mathrm{Mt}$. Muravief malachite stains greenstone surfaces. The source of the copper stain is chalcopyrite that is disseminated in the greenstone, concentrated along fracture surfaces, and forming patches and seams parallel to the foliation. One sample of this copper-bearing greenstone contained up to 3,900 ppm copper and $110 \mathrm{ppb}$ gold (Map no. 303, sample 1444).

BLM personnel collected 32 samples from the 3 mineralized areas on Mt. Muravief. The samples indicate copper grades up to $6.33 \%$ (Map no. 301 , sample 1473), gold to $600 \mathrm{ppb}$ (Map no. 302 , sample 1433), silver to $14.5 \mathrm{ppm}$ (Map no. 301 , sample 1474), and zinc to 2,200 ppm (Map no. 301, sample 1474). A sample across 18 feet of the mineralized altered schist on the West Ridge returned $1.63 \%$ copper, 3.6 ppm silver, 

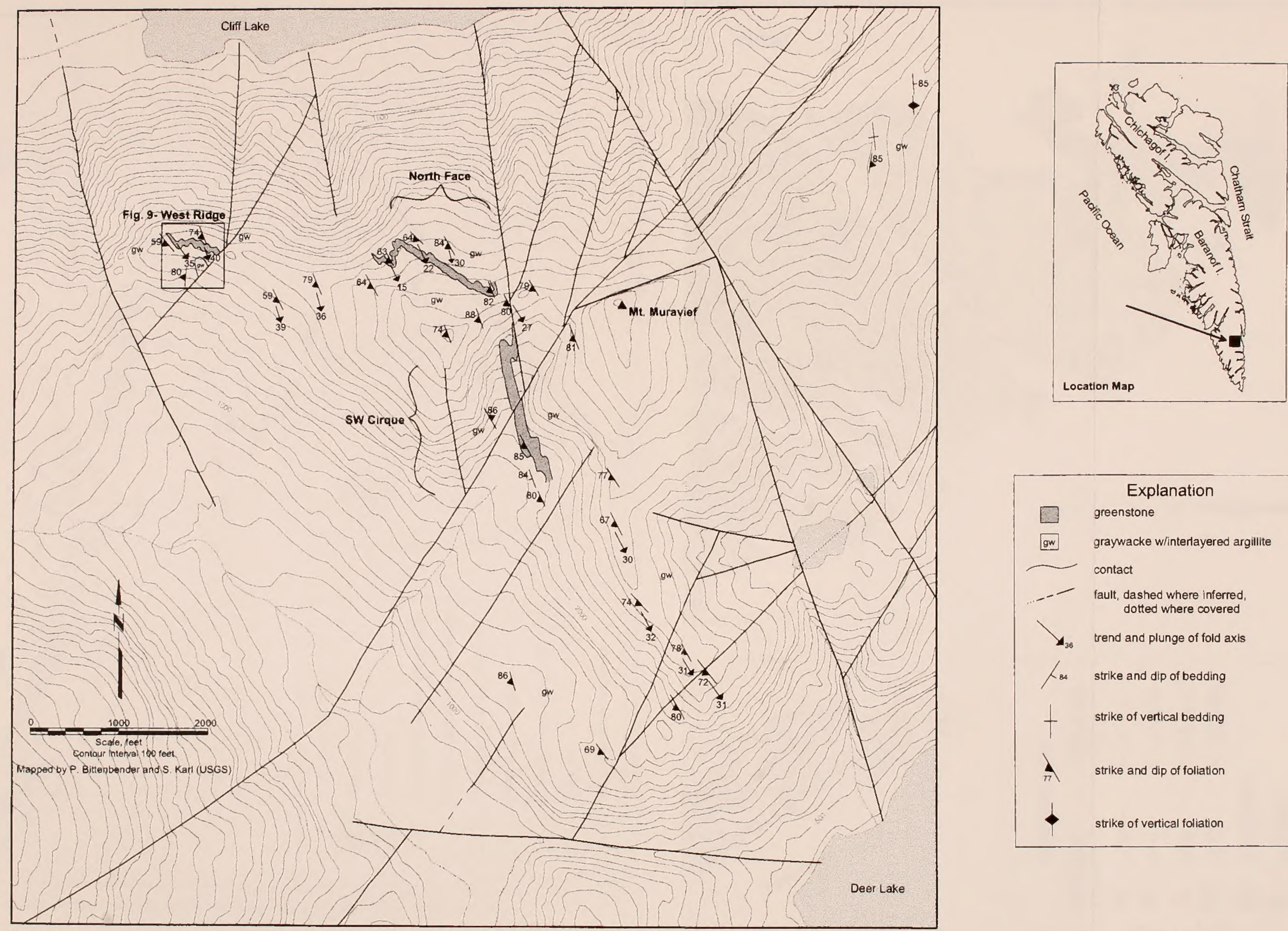

\begin{tabular}{|l} 
Explanation \\
greenstone \\
graywacke w/interlayered argillite \\
contact \\
fault, dashed where inferred, \\
dotted where covered \\
trend and plunge of fold axis \\
strike and dip of bedding \\
strike of vertical bedding \\
strike of vertical foliation dip of foliation
\end{tabular}




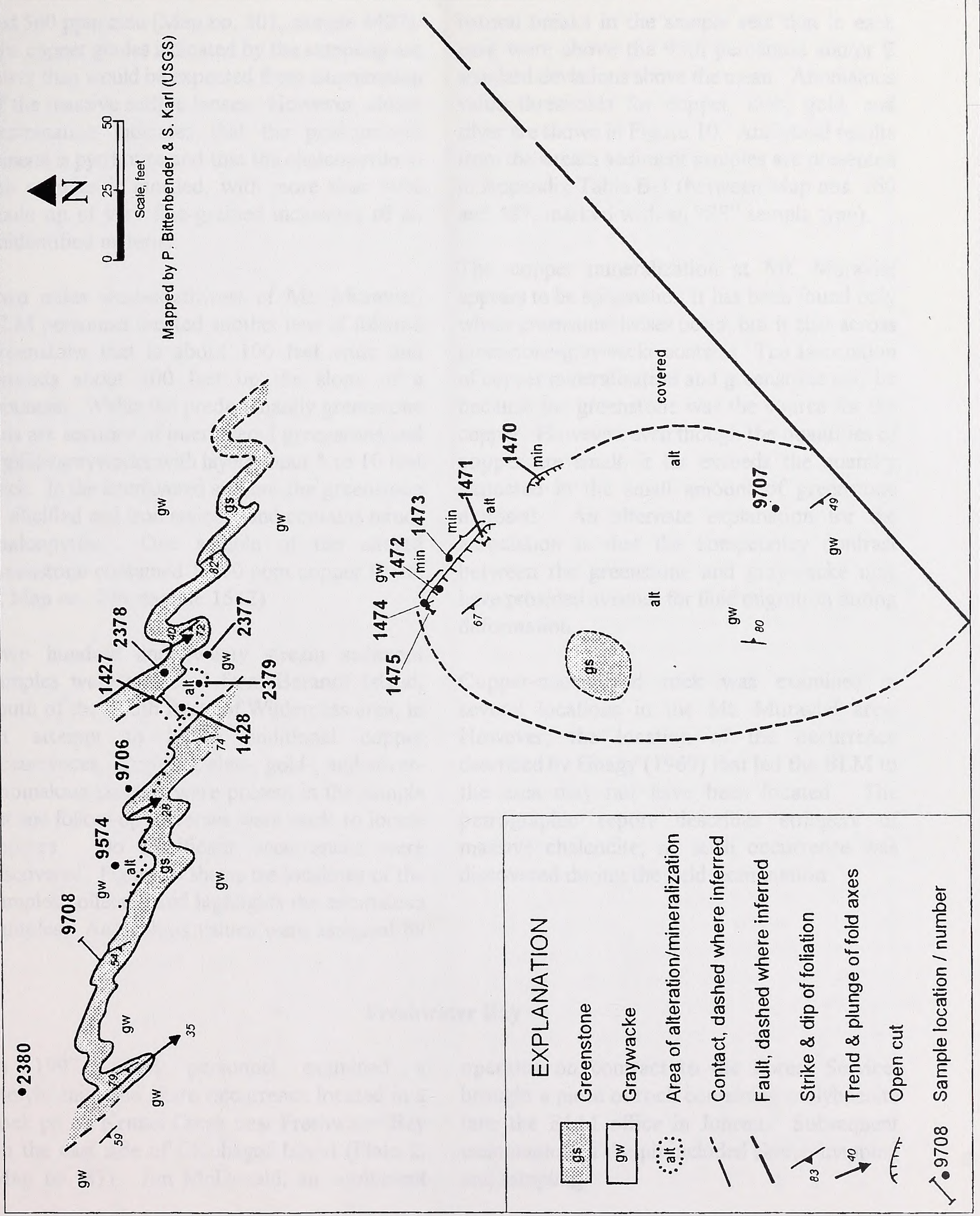

Figure 9. Geologic map of the Mt. Muravief, West Ridge exposure (Plate 2, Map no. 301). 

and 560 ppm zinc (Map no. 301, sample 1427). The copper grades indicated by the sampling are lower than would be expected from examination of the massive sulfide lenses. However, closer examination indicates that the predominant mineral is pyrrhotite and that the chalcopyrite in the samples is mottled, with more than $50 \%$ made up of very fine-grained inclusions of an unidentified material.

Two miles west-southwest of Mt. Muravief, BLM personnel located another lens of foliated greenstone that is about 100 feet wide and extends about 400 feet up the slope of a mountain. Within the predominantly greenstone lens are sections of interlayered greenstone and argillite/graywacke with layers about 5 to 10 feet thick. In the interlayered sections the greenstone is silicified and iron stained, and contains minor chalcopyrite. One sample of the altered greenstone contained 1,300 ppm copper (Plate 2, Map no. 296, sample 1512).

Two hundred and twenty stream sediment samples were collected from Baranof Island, south of the South Baranof Wilderness area, in an attempt to locate additional copper occurrences. Copper-, zinc-, gold-, and silveranomalous samples were present in the sample set and follow-up traverses were made to locate sources. No significant occurrences were discovered. Figure 10 shows the localities of the samples collected and highlights the anomalous samples. Anomalous values were assigned by natural breaks in the sample sets that in each case were above the 95th percentile and/or 2 standard deviations above the mean. Anomalous value thresholds for copper, zinc, gold, and silver are shown in Figure 10. Analytical results from the stream sediment samples are presented in Appendix Table B-1 (between Map nos. 260 and 487 , marked with an "SS" sample type).

The copper mineralization at Mt. Muravief appears to be epigenetic. It has been found only where greenstone lenses occur, but it cuts across greenstone-graywacke contacts. The association of copper mineralization and greenstone may be because the greenstone was the source for the copper. However, even though the quantities of copper are small, it far exceeds the quantity expected in the small amount of greenstone exposed. An alternate explanation for the association is that the competency contrast between the greenstone and graywacke may have provided avenues for fluid migration during deformation.

Copper-mineralized rock was examined in several locations in the Mt. Muravief area. However, the location of the occurrence described by Gnagy (1969) that led the BLM to the area may not have been located. The petrographic report describes stringers of massive chalcocite; no such occurrence was discovered during the field examination.

\section{Freshwater Bay}

In 1997, BLM personnel examined a molybdenite and skarn occurrence located in a rock pit on Kennel Creek near Freshwater Bay on the east side of Chichagof Island (Plate 2, Map no. 87). Jim McDonald, an equipment operator on contract to the Forest Service, brought a piece of rock containing molybdenite into the BLM office in Juneau. Subsequent examination of the pit included sketch mapping and sampling. 
The Freshwater Bay occurrence consists of molybdenite associated with a felsic intrusive that has intruded, migmatized, and hornfelsed the host sedimentary rock. A skarn mineral assemblage with minor sulfides occurs in the country rock and likely accompanied the intrusion (Fig. 11).

The country rock in the rock pit area is a metamorphosed conglomerate and banded hornfels. These rocks are probably part of the Silurian Point Augusta Formation (Loney and others, 1975). The conglomerate commonly contains pebble- to cobble-sized, rounded fragments of felsic and mafic intrusive rocks. Elongated fragments and mineral lineations define a crude foliation in the conglomerate. The conglomerate matrix is a siliceous, dark green-gray, fine-grained hornfels. Intrusive fragments in the conglomerate in places appear to be migmatized and have scalloped to wavy edges. Some originally rounded fragments are not only flattened, but also stretched. Alteration in the conglomerate includes chloritization and the formation of skarn minerals.

Skarn minerals occur in pods and veins that cut across the foliation of the conglomerate. The pods are up to two feet across and three feet long, but, along with the veins, are generally only one to two inches across. Skarn minerals include garnet, epidote, chlorite, and minor wollastonite or tremolite. The pods are commonly zoned with calcite and wollastonite/tremolite in the middle, surrounded by garnet, then epidote, then chlorite. Minor sulfides are found in patches and seams, mainly in the matrix of the conglomerate. Sulfides include pyrrhotite and pyrite, plus a little chalcopyrite.

A leucocratic felsic intrusive crops out in several places in the rock pit. It is very light-colored, fine- to medium-grained, and includes minor mafic enclaves. It is made up predominantly of feldspar and quartz with less than five percent mafic minerals, mainly hornblende. Loney and others $(1963,1975)$ have mapped a Jurassic pluton of varying composition in the area. The intrusive in the pit likely corresponds to their mapped biotite alaskite or hornblende adamellite (Loney and others, 1975).

Molybdenite associated with the intrusive appears to be typical of porphyry-type occurrences. It commonly occurs as thin coatings on planar surfaces, in patches, and finely disseminated. In places the coatings are up to several tenths of an inch thick. Molybdenite is also associated with thin siliceous veinlets that commonly cut the intrusive and extend into the surrounding country rock. Patches and disseminations of pyrrhotite also occur in the intrusive.

Molybdenite is also associated with a mottled, dark grayish-green to dark gray, fine- to medium-grained migmatite. Mafic enclaves appear as breccia fragments in the altered, porphyritic melt fraction of the migmatite. In places the melt portion includes coarse, subhedral, phenocrysts of amphibole. The migmatite is cut by numerous siliceous veinlets and is commonly chloritized. Molybdenite occurs most commonly as surface coatings or seams, but also with the siliceous veinlets, in small patches, and finely disseminated. Pyrrhotite is the only other sulfide seen in the migmatite.

BLM personnel collected 10 samples from the rock pit to assess the molybdenite mineralization (Table 4). No mineralized rock was seen in outcrop; most molybdenite was seen in the pit rubble. Several select samples of migmatized rock from the contact zone were collected from 


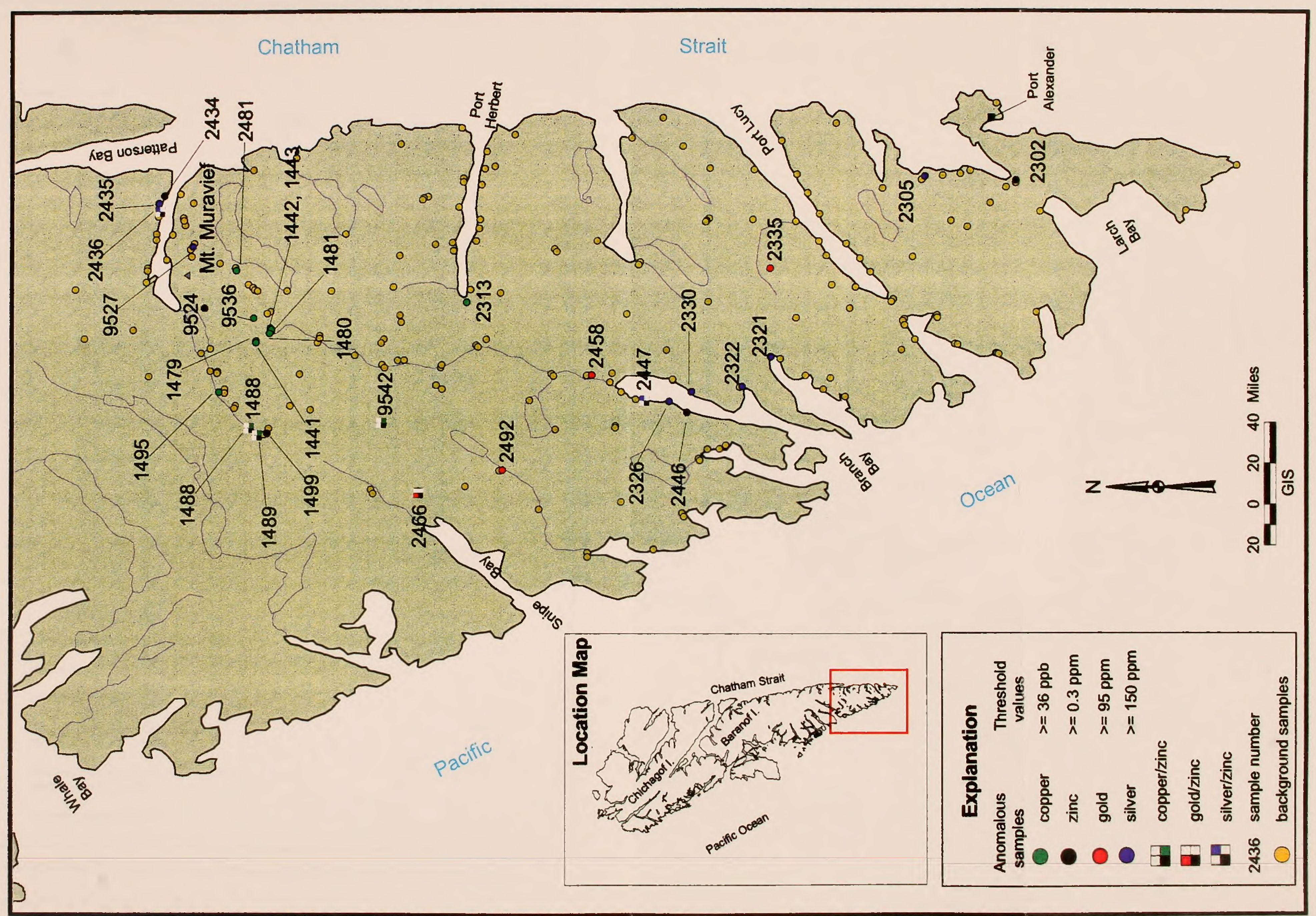

Figure 10. - Anomalous stream-sediment-sample sites, S. Baranof Island. 



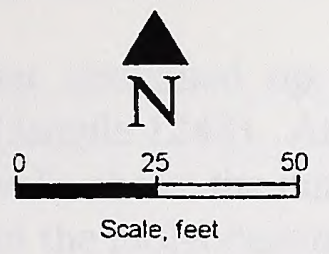

Mapped by P. Bittenbender \& M. McDonald, Jr.

cgl w/skarn

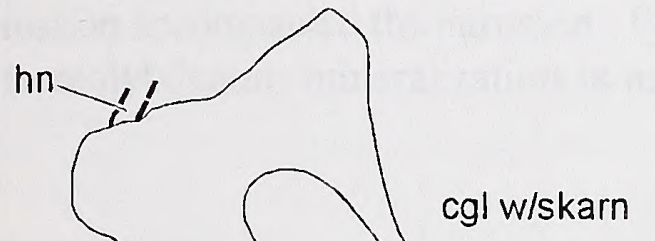

$\mathrm{cgl} \mathrm{w} / \mathrm{hn}$

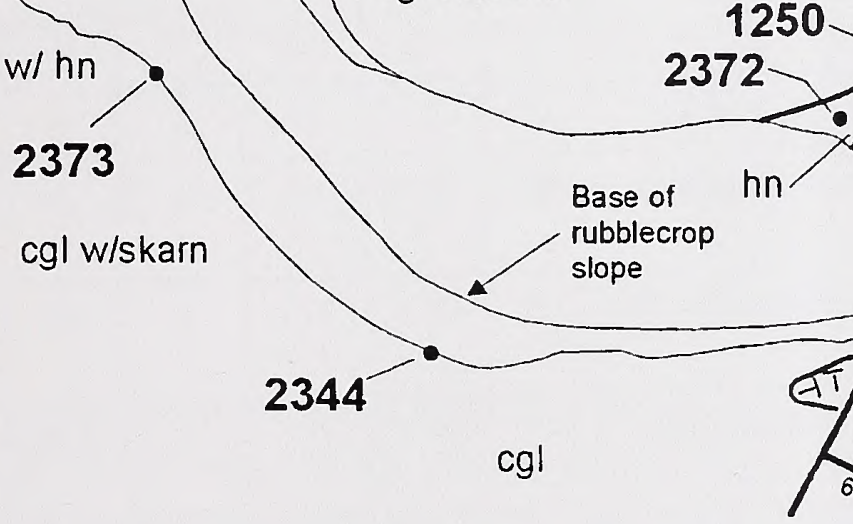

\section{EXPLANATION}

Conglomerate

Hornfels

$\mathrm{hn}$

イ⿺辶イン Intrusive

71 Fault, showing dip, dashed where

inferred

Contact, dashed where approximate, dotted where inferred

2344

- Sample location/ number

Figure 11. Geologic map of rock pit at Freshwater Bay molybdenum occurrence (Map no. 87). 
pit rubble that contained up to $2,030 \mathrm{ppm}$ molybdenum (sample 1248). Analyzed samples from the pit walls above the mineralized rubble failed to detect the molybdenum mineralization (samples 2370-71). No significant amounts of molybdenum were associated with the skarn assemblages.

The Freshwater Bay occurrence represents the intrusion of a molybdenum-bearing, felsic intrusive rock into metasedimentary country rocks. Migmatization and minor skarn mineral formation accompanied the intrusion. Porphyrystyle molybdenum mineralization is associated with the intrusion itself as well as with the migmatized country rock and represents the later stages of intrusion. Additional work in the area should focus on the porphyry potential associated with the intrusion. No economic significance is indicated by the skarn occurrence at this location itself. However, additional small skarn occurrences have been identified in the area, particularly along Gypsum Creek, across Freshwater Bay to the northeast, and at East Point, to the southeast. The East Point Pit skam and Gypsum Creek occurrences are described on page 70 of this report. 
Table 4. Description and selected analytical results of samples collected at the Freshwater Bay rock pit. Sample locations are shown on Fig. 11. Abbreviation descriptions and additional analytical results can be found in Appendix B (p. 175)

\begin{tabular}{|c|c|c|c|l|c|c|c|c|c|c|c|}
\hline $\begin{array}{c}\text { Sam } \\
\text { no. }\end{array}$ & $\begin{array}{c}\text { Sam } \\
\text { type }\end{array}$ & $\begin{array}{c}\text { Sam } \\
\text { size } \\
\text { (ft) }\end{array}$ & $\begin{array}{c}\text { Sam } \\
\text { site }\end{array}$ & \multicolumn{1}{|c|}{ Sample description } & $\begin{array}{c}\mathrm{Au} \\
\mathrm{ppb}\end{array}$ & $\begin{array}{c}\mathrm{Ag} \\
\mathrm{ppm}\end{array}$ & $\begin{array}{c}\mathrm{Cu} \\
\mathrm{ppm}\end{array}$ & $\begin{array}{c}\mathrm{Pb} \\
\mathrm{ppm}\end{array}$ & $\begin{array}{c}\mathrm{Zn} \\
\mathrm{ppm}\end{array}$ & $\begin{array}{c}\mathrm{Mo} \\
\mathrm{ppm}\end{array}$ & $\begin{array}{c}\mathrm{Fe} \\
\%\end{array}$ \\
\hline \hline 1246 & $\mathrm{~S}$ & & $\mathrm{RC}$ & Contact zone & $<5$ & $<0.1$ & 73 & 5 & 12 & 409 & 2.24 \\
\hline 1247 & $\mathrm{~S}$ & & $\mathrm{RC}$ & $\begin{array}{l}\text { Banded hornfels w/ quartz veins \& } \\
\text { blebs }\end{array}$ & $<5$ & $<0.1$ & 134 & 11 & 11 & 611 & 3.03 \\
\hline 1248 & $\mathrm{~S}$ & 1.5 & $\mathrm{RC}$ & $\begin{array}{l}\text { Banded green/black hornfels w/in a } \\
\text { pebble conglomerate }\end{array}$ & $<5$ & $<0.1$ & 57 & 4 & 23 & 2030 & 2.04 \\
\hline 1249 & $\mathrm{~S}$ & & $\mathrm{RC}$ & $\begin{array}{l}\text { Quartz-rich granodiorite at contact, } \\
\text { minor banded hornfels }\end{array}$ & $<5$ & $<0.1$ & 66 & 3 & 9 & 822 & 2.0 \\
\hline 1250 & $\mathrm{~S}$ & & $\mathrm{RC}$ & Dark garnet hornfels & $<5$ & 0.2 & 168 & 5 & 82 & 1566 & 6.66 \\
\hline 2370 & $\mathrm{SC}$ & 15 & $\mathrm{TP}$ & Fault surface in skarnified hornfels & $<5$ & $<0.1$ & 75 & 8 & 30 & 76 & 2.89 \\
\hline 2371 & $\mathrm{SC}$ & 25 & $\mathrm{TP}$ & $\begin{array}{l}\text { Felsic intrusive w/ minor pyrrhotite } \\
\text { \& pyrite }\end{array}$ & $<5$ & $<0.1$ & 50 & 6 & 19 & 70 & 1.6 \\
\hline 2372 & $\mathrm{RC}$ & & $\mathrm{RC}$ & $\begin{array}{l}\text { Heavily iron-stained hornfels w/ } \\
\text { disseminated pyrrhotite }\end{array}$ & $<5$ & $<0.1$ & 116 & 6 & 97 & 54 & 6.28 \\
\hline 2373 & Rep & 3 & TP & $\begin{array}{l}\text { Dark gray hornfels w/ disseminated } \\
\text { pyrrhotite \& trace pyrite }\end{array}$ & $<5$ & $<0.1$ & 68 & 5 & 109 & 49 & 4.98 \\
\hline 2344 & $\mathrm{G}$ & 0.5 & TP & $\begin{array}{l}\text { Iron-stained hornfels w/ fine-grained } \\
\text { disseminated pyrite \& pyrrhotite }\end{array}$ & $<5$ & $<0.1$ & 65 & 5 & 26 & 46 & 2.35 \\
\hline
\end{tabular}




\section{SPECIAL Section: Silver BAy AREA}

\section{Introduction}

Mining activity in the Silver Bay area influenced the history of Sitka and of southeast Alaska. Joe Juneau and Richard Harris, the prospectors credited with the announcement of gold on which Juneau was founded, were grubstaked by George Pilz, who came to Alaska to develop Silver Bay mining properties (DeArmond, 1997a). Though the Silver Bay properties contributed little to Alaska's mining industry, they represent several firsts in the industry. The State's first developed lode gold mine and the first stamp mill were in the Silver Bay area. The gold occurrences in Silver Bay may have more historical than geological significance, however.

This section provides an overview of the Silver
Bay area. It briefly discusses the area's general history and mineral production. The geologic setting and a model for vein formation is provided. More detailed history and site specific maps for selected properties are presented in the individual property summaries (beginning on $\mathrm{p}$. 91). The summaries also discuss the work done by BLM personnel during the present study and the significant results of that work. Figure 12 shows the location of the various prospects in Silver Bay. Complete analytical results are available in Appendix B (p. 175). The "Map nos." listed with each property in the text refer to Figure 12 and Plate 2. The analytical table in Appendix B is ordered by these map numbers.

\section{Location and Access}

The Silver Bay area is located southeast of Sitka (Fig. 12). It includes historic mines, prospects, and mineral occurrences around Silver Bay itself as well as properties east of Sitka in the Indian River basin. Access to the properties near sea level is possible by small boat from Sitka and by floatplane. The higher elevation sites are most easily accessed by helicopter. Access to the area is also possible via private road along the northeast shore of the bay, which serves the Green Lake hydro-power station and reservoir. Several trails in the area allow access by foot as well.

\section{History / Production}

Mining activity in the Silver Bay area represents some of the first of its kind in Alaska. Prospecting for gold in the area began around 1871. The first gold reportedly discovered in the Sitka area was by an ex-soldier, Edward Doyle, who found gold-bearing float in the Indian River east of Sitka. Prospecting at the head of Silver Bay soon followed. Edward Doyle, Frank Mahoney, and William Dunlap are credited as the first gold prospectors in the
Silver Bay area in about 1871 (DeArmond, 1997a). Initial development of the Stewart Mine in 1872 (Knopf, 1912) represents the earliest lode gold mining in Alaska (Alaska Yukon Mining Journal, 1901). The Stewart's stamp mill, which first operated in 1879 , was the first to operate in Alaska. The first claims were recorded in 1874 for the Francis Lode, in the Lucky Chance Mine area (DeArmond, 1997a). The early interest in the Silver Bay area was 
curtailed by the exodus of miners to the new gold discoveries around Juneau in 1880-81. The Klondike Rush of 1897 also drew the interest of miners away from the area. Nonetheless, the Silver Bay area has seen continued prospecting even to the 1990's. From 1981 to 1993, Phillips Petroleum held a block of up to 184 claims in the Silver Bay area. Over 100 years of activity has left behind a complex history of claim names, owners, and prospect development.

Despite the early start of mining in the area, Silver Bay produced only minor amounts of gold. The two most prominent properties, the Stewart and Lucky Chance Mines, boasted 10stamp mills, but officially recorded no production. Newspaper accounts record the activity at the mines (DeArmond, 1997a) and, along with evidence from the properties themselves (e.g., stopes and tailings), indicate that only minor production occurred. The Stewart mill operated for one or two years and some of its production reportedly came from rock hauled in from other Silver Bay prospects (DeArmond, 1997a). Roehm (1940) cites an earlier report that about 60 tons of ore had been processed at the Lucky Chance mill by 1887 . $\mathrm{He}$ also estimated that about 1,200 tons of ore were removed from the stopes at the mine (Roehm, 1940). The only other mill known in the area was at the Edgecumbe Exploration Company's Bonanza Nos. 21 \& 22 claims on the southwest side of Silver Bay. This mill was apparently active in the 1940 's, and may also have milled rock from other prospects in the area (J. Burgess, personal communication). No production figures are available, but evidence suggests that any production that occurred was minor.

\section{Geology}

Gold in the Silver Bay area is hosted in quartz veins in graywacke and argillite of the Cretaceous Sitka Graywacke. The Sitka Graywacke is part of the Chugach terrane (Monger and Berg, 1987) which represents an accretionary complex of flysch and melange (Plafker and Berg, 1994). The discontinuous quartz veins and lenses are up to 16 feet thick (e.g., Stewart), but are generally barren. They commonly include fragments and partings of graywacke and argillite, but very few sulfides. The sulfides present are pyrite, pyrrhotite, arsenopyrite, and rare galena. The veins and lenses are commonly parallel to the structure in the country rock, which is generally northwest trending and steeply dipping.

Recent work by the USGS has correlated Eocene magmatism related to subduction off the coast of Chichagof and Baranof Islands with vein formation in Silver Bay (Haeussler and others, 1995). They relate the thermal event responsible for the magmatism and mineralization to subduction of a slab window beneath the overlying accretionary complex. An age of $49.4 \mathrm{Ma}$, from white mica in quartz veins from the Lucky Chance Mine, correlates to subduction of the Kula-Farallon spreading ridge beneath the North American plate. The quartz veins in Silver Bay were emplaced along fractures that may have propagated during subduction of the topographic high related to the spreading ridge (Haeussler and others, 1995). Alternatively, the veins may have been controlled by preexisting faults such as those of the Sitka fault zone (Loney and others, 1975; Brew, 1997). 


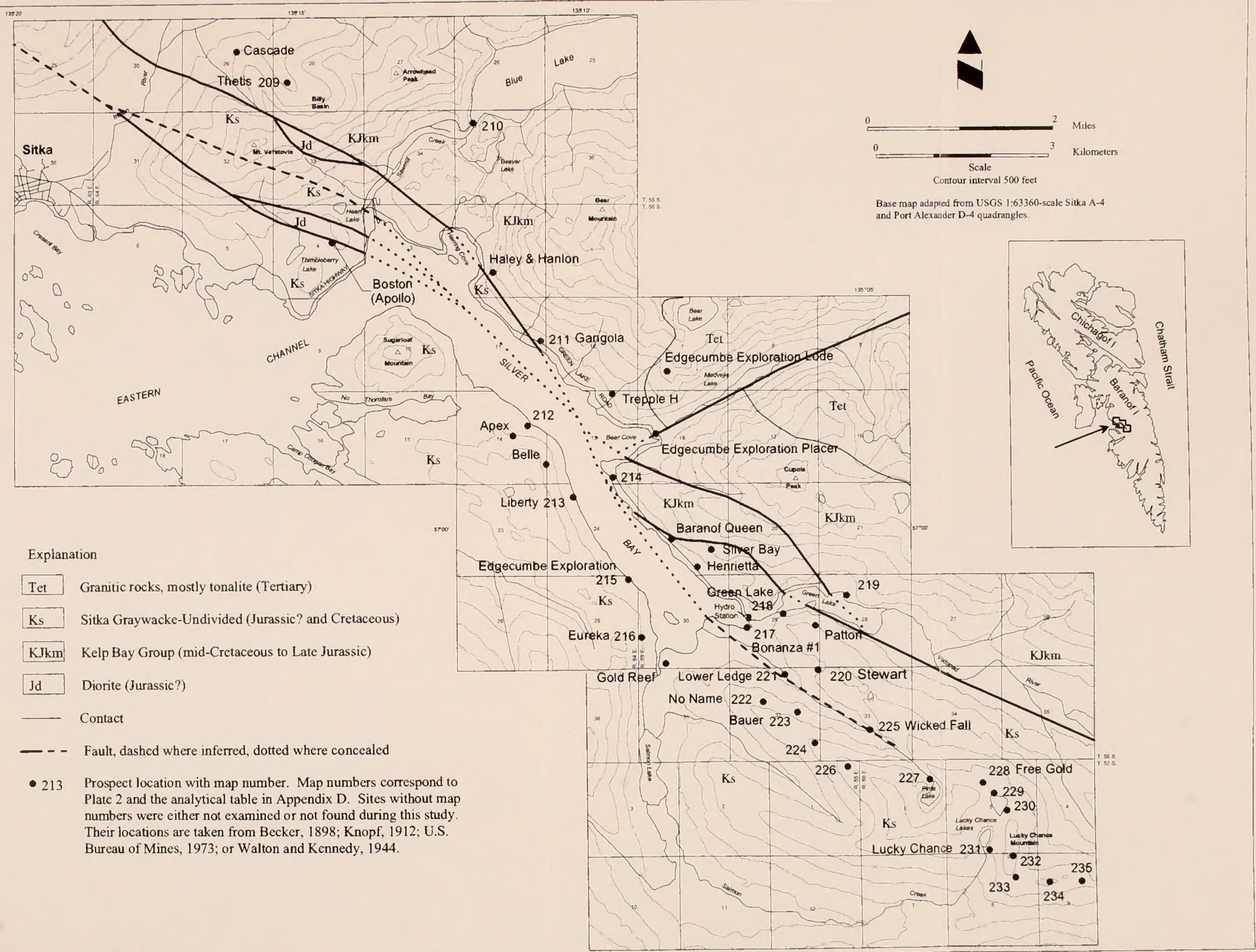




\section{Selected Mines and Prospects}

THETIS (Fig. 12, Map no. 209)

The Thetis prospect is located in an area known as Billy Basin, on the east fork of the Indian River, northeast of Sitka. The Thetis claim was one of four claims staked in the area by William Millmore in 1888 (DeArmond, 1997a). Reference is made to the property in Becker (1898) and Wright and Wright (1905). These publications report two adits in the area as well as a sawmill and two "prospecting mills." Becker describes the occurrence as two and a half feet of quartz with calcite, pyrrhotite, and galena. He reports a mill test as yielding seven dollars worth of gold and one dollar of silver in 1898 (Becker, 1898). Based on a gold price of

GANGOLA (Fig. 12, Map no. 211)

Joseph Gangola, a Sitka prospector, staked a tungsten claim in 1970 on the northeast side of Silver Bay between Herring Cove and Bear Cove. BLM workers examined the area and found a quartz vein exposed in the bed of a small stream and two additional quartz veins located 130 and 145 feet to the southeast. The veins are hosted in Kelp Bay greenstone. They strike $035^{\circ}$ to $070^{\circ}$, dip steeply, and are up to 1.5 feet thick along a 15-foot strike length. Scheelite, chalcopyrite, and pyrrhotite were found in the veins. The southernmost vein is exposed at an elevation of 260 feet by a small open cut measuring 5 feet wide. This vein contained the

APEX (Fig. 12, Map no. 212)

The Apex prospect is located on the west side of Silver Bay, northwest of the Liberty prospect. Historical reference to this property is limited to Knopf (1912). BLM geologists examined the Apex area and found abundant quartz float in a
$\$ 20$ an ounce, this gold grade equals $0.35 \mathrm{oz}$ per ton, a value significantly higher than that found in most places in the Silver Bay area.

BLM personnel located, mapped, and sampled one adit in the Thetis area (Fig. 13). The 28foot adit cuts graywacke with discontinuous quartz stringers. A quartz vein adjacent to a north trending fault in the adit was sampled along with a sample of the quartz stringers. Gold values were below analytical detection limits (sample nos. 1450-53).

most sulfides and highest metal values. A 1.5foot-long chip sample taken across the vein at the cut contained $80 \mathrm{ppb}$ gold, $375 \mathrm{ppm}$ copper, and $380 \mathrm{ppm}$ tungsten (sample 2570). A sample of sulfide-bearing, iron-stained greenstone on either side of the vein contained $570 \mathrm{ppb}$ gold, $960 \mathrm{ppm}$ copper, and 1,100 ppm tungsten (sample 2572). A select dump sample of sulfidebearing quartz contained $85 \mathrm{ppb}$ gold, $260 \mathrm{ppm}$ copper, and $760 \mathrm{ppm}$ tungsten (sample 2573). Samples of the remaining quartz veins contained up to $450 \mathrm{ppb}$ gold, $169 \mathrm{ppm}$ copper, and 180 ppm tungsten (sample 2575).

small creek, a quartz-breccia vein cropping out in a fault zone, and an eight-foot adit. The vein strikes $330^{\circ}$, dips $75^{\circ}$ southwest, and is up to 1.7 feet wide. Arsenopyrite and trace chalcopyrite were found in the vein and associated gouge 
zone. A sample across the vein (sample 2018) contained $270 \mathrm{ppm}$ copper, $44 \mathrm{ppm}$ arsenic, and $0.2 \mathrm{ppm}$ silver. A select sample of quartz float found in a nearby creek contained $920 \mathrm{ppm}$

\section{LIBERTY (Fig. 12, Map no. 213)}

The Liberty property is mentioned in a report on mining in Alaska during 1896 and 1897 (Becker, 1898). Its discovery date is unknown. The property includes 2 adits that are 30 feet and 300 feet in length (Fig. 14). The adits are adjacent to each other and are found within 10 feet of hightide line on the west side of Silver Bay. The adits cut graywacke, graywacke and phyllite, and slate. In the longer adit, a discontinuous quartz vein is exposed for about 100 feet and is up to 5 feet wide. It is a continuation of a vein that is exposed in a creek 80 feet above the adit. The copper and $1.0 \mathrm{ppm}$ silver (sample 2017). The highest gold value from the area was only 40 ppb (sample 2107).

vein is situated along a fault zone between slate on the footwall, and graywacke and phyllite on the hanging wall, and in places forms the matrix of a fault breccia. The quartz contains minor amounts of sulfides, mainly pyrite. Analytical results revealed low precious metal values. The highest gold value was $60 \mathrm{ppb}$ across 3 feet (sample 2236). Most of the samples had elevated arsenic values and two samples contained more than $2 \mathrm{ppm}$ mercury $(2235$, 2236).

\section{Edgecumbe Exploration, Bonanza Nos. 21 \& 22 Claims (Fig. 12, Map no. 215)}

The Bonanza Nos. $21 \& 22$ claims were held by the Edgecumbe Exploration Company that was founded in Sitka in 1930. Charlotte Taylor, President of the company, had control over many of the mining claims in the Silver Bay area in the 1930's and 1940's (Plate 3; DeArmond, 1997a). The history of the Bonanza Nos. $21 \&$ 22 claims themselves is sketchy. A mill was erected on the property, probably in 1941. It was reportedly installed to process ore from the adjacent workings as well as from other claims in Silver Bay (DeArmond, 1997a). Developments include a 120 -foot adit with a winze, and a raise to the surface. Much of the mill itself was recently removed from the property (J. Burgess, personal communication).

BLM personnel mapped and sampled the adit on the Bonanza claims (Fig. 15). The adit was driven in graywacke to undercut a four-foot- wide quartz vein that crops out near the top of the raise. The vein is emplaced along a fault zone. Underground, the quartz reaches a width of five feet, but pinches and swells along strike. The vein is oriented about $320^{\circ}$ and dips $60^{\circ}$ to $85^{\circ}$ to the southwest. It pinches out to the southeast and is cut off by a fault to the northwest. Subhorizontal fault movement after vein emplacement is evident by lineations on the vein's margins. Much of the vein is made up of barren milky quartz, but graphitic ribbon texture is also present. Pyrite and arsenopyrite are present as disseminations as well as localized adjacent to the ribbons in the vein. Analytical results indicate relatively low precious metal values. The highest assays were $1,810 \mathrm{ppb}$ gold in a select sample (sample 2162) and 1,170 ppb gold across 0.7 feet (sample 2161). As commonly found elsewhere in the Silver Bay area, high arsenic and elevated mercury values are associated with the higher gold values. 


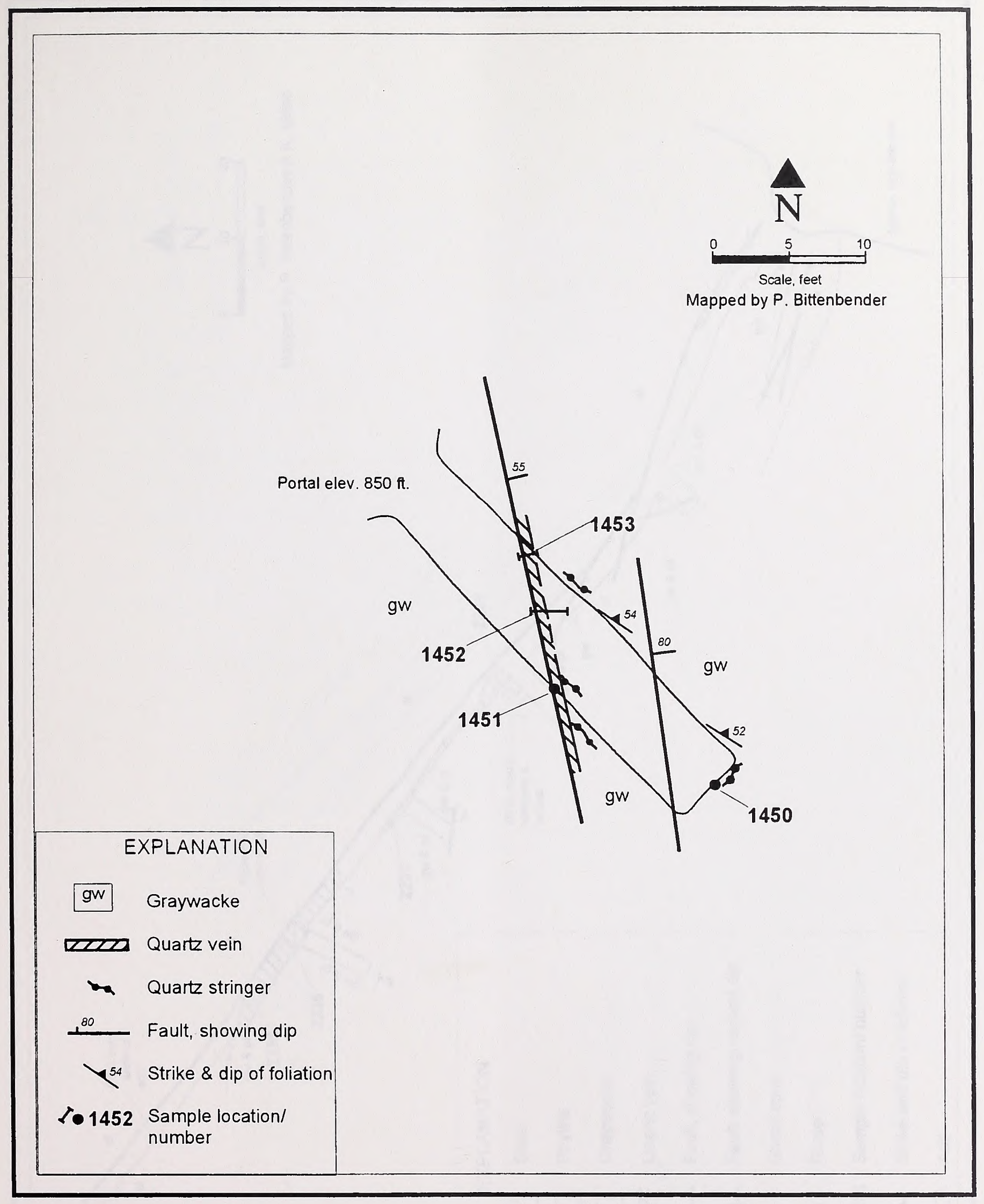

Figure 13.- Thetis prospect adit (Fig. 12, Map no. 209). 


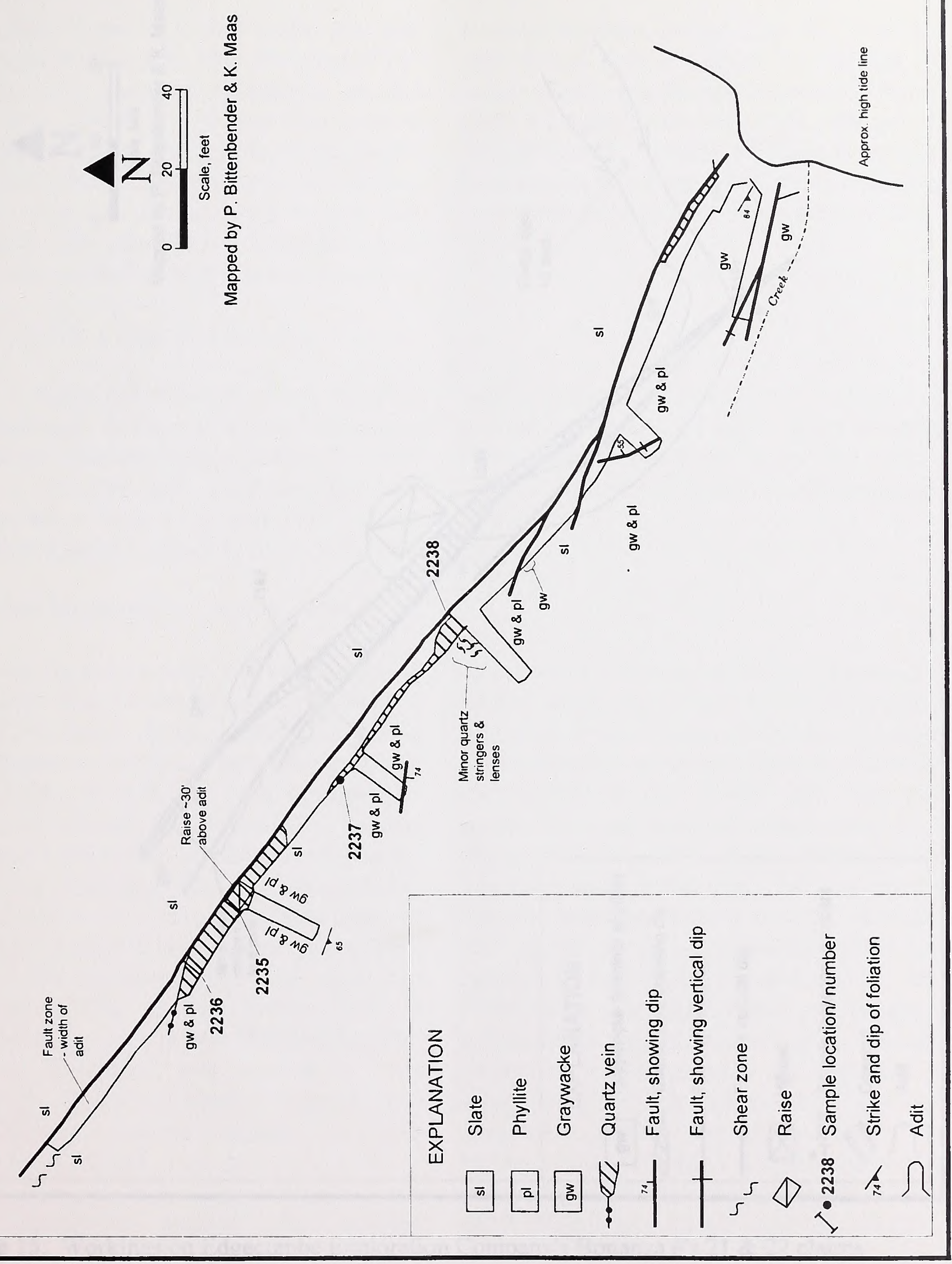

Figure 14. Liberty prospect adits (Fig. 12, Map no. 213). 

Z1
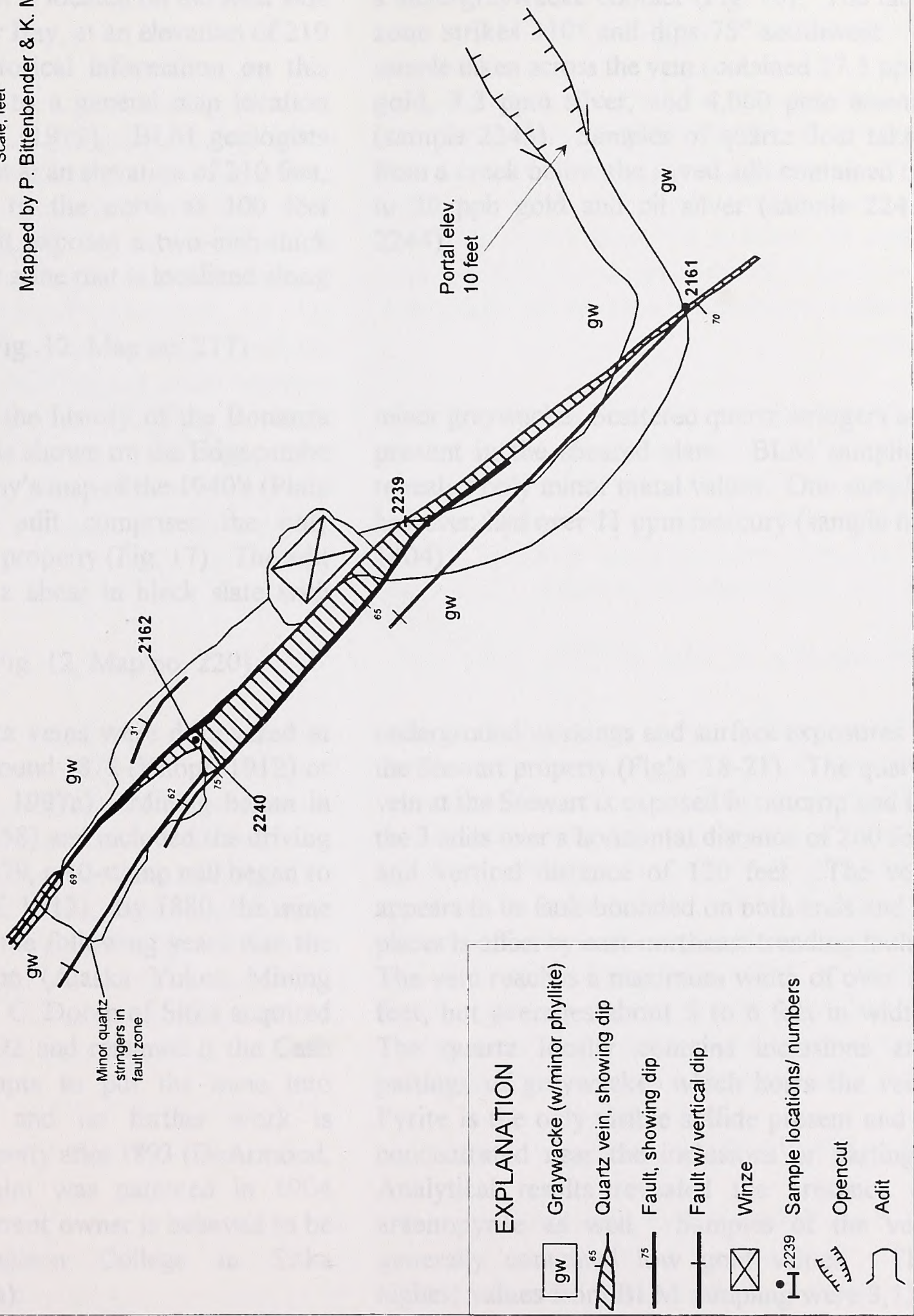

Figure 15. Workings on Edgecumbe Exploration Company's Bonanza \#'s 21 \& 22 claims (Fig. 12, Map no. 215). 
The Eureka prospect is located on the west side of the head of Silver Bay, at an elevation of 210 to 300 feet. Historical information on this prospect is limited to a general map location provided by Knopf (1912). BLM geologists found an 85-foot adit at an elevation of 210 feet, and a caved adit to the north at 300 feet elevation. The adit exposes a two-inch-thick quartz vein in a fault zone that is localized along

\section{BonANZA No. 1 (Fig. 12, Map no. 217)}

Little is known of the history of the Bonanza No. 1 prospect. It is shown on the Edgecumbe Exploration Company's map of the 1940's (Plate 3). A 105-foot adit comprises the only development on the property (Fig. 17). The adit was driven along a shear in black slate with

\section{STEWaRT Mine (Fig. 12, Map no. 220)}

Gold-bearing quartz veins were discovered at the Stewart Mine around 1872 (Knopf, 1912) or 1873 (DeArmond, 1997a). Mining began in 1877 (Kaufman, 1958) and included the driving of three adits. In 1879, a 10-stamp mill began to process ore (Knopf, 1912). By 1880, the mine was closed and in the following years was the subject of litigation (Alaska Yukon Mining Journal, 1901). T. C. Doran of Sitka acquired the property in 1892 and renamed it the Cash Mine. His attempts to put the mine into production failed and no further work is reported on the property after 1893 (DeArmond, 1997a). One claim was patented in 1904 (MS567). The current owner is believed to be the Sheldon Jackson College in Sitka (DeArmond, 1997a).

BLM geologists mapped and sampled a slate-graywacke contact (Fig. 16). The fault zone strikes $310^{\circ}$ and dips $75^{\circ}$ southwest. A sample taken across the vein contained $27.5 \mathrm{ppm}$ gold, $3.2 \mathrm{ppm}$ silver, and 4,060 ppm arsenic (sample 2245). Samples of quartz float taken from a creek below the caved adit contained up to $30 \mathrm{ppb}$ gold and nil silver (sample 2243, 2244).

minor graywacke. Scattered quartz stringers are present in the sheared slate. BLM sampling revealed only minor metal values. One sample, however, had over $11 \mathrm{ppm}$ mercury (sample no. 1404).

underground workings and surface exposures at the Stewart property (Fig's. 18-21). The quartz vein at the Stewart is exposed in outcrop and by the 3 adits over a horizontal distance of 200 feet and vertical distance of 120 feet. The vein appears to be fault-bounded on both ends and in places is offset by east-northeast trending faults. The vein reaches a maximum width of over 16 feet, but averages about 5 to 6 feet in width. The quartz locally contains inclusions and partings of graywacke, which hosts the vein. Pyrite is the only visible sulfide present and is concentrated near the inclusions or partings. Analytical results revealed the presence of arsenopyrite as well. Samples of the vein generally contained low gold values. The highest values from BLM sampling were 3,130 ppb gold over a 3- by 5-foot area (sample 2202) and 2,780 ppb gold across 5 feet (sample 2201; 
Fig. 20). A sample of mill concentrate contained $57.9 \mathrm{ppm}$ gold, $2,000 \mathrm{ppm}$ lead, greater than $1 \%$

LOWER LEDGE (Fig. 12, Map no. 221)

The Lower Ledge prospect was one of the first prospects to be staked and developed in the Silver Bay area (DeArmond, 1997a). Its history however is obscure, mainly due to the numerous names by which it has been recorded. It is mentioned in Becker's report of 1898 , the first published report on the area, as the "Haley and Rogers."

BLM personnel located and mapped a 63-foot adit and flooded shaft near the Silver Bay trail at the head of Silver Bay (Fig's. 22-24). These workings most closely fit the location of the Lower Ledge prospect given by Knopf (1912) and the Edgecumbe Exploration claim map

No NAME (Fig. 12; Map no. 222)

BLM personnel located an adit half a mile northwest of the Bauer prospect whose name and history is unknown. The adit crosscuts graywacke, and graywacke with interbedded phyllite (Fig. 25). Two hundred forty feet from the portal, a 24-foot drift follows a silicified, brecciated zone in graywacke at a contact with greenstone. The brecciated shear zone is oriented $295^{\circ}$ and is steeply dipping. Thin quartz stringers are found at a high angle to the shear. The greenstone southwest of the shear

BAUER (Fig. 12, Map no. 223)

The Bauer property was reportedly staked in 1895. Development of the claim occurred intermittently from 1896 through 1923 (DeArmond, 1997a). By 1904, at least 900 feet of workings had been completed (Wright and arsenic, and greater than $0.1 \%$ mercury (sample 2222; Fig. 21).

(Plate 3). The adit was driven on a one and a half-foot-wide shear zone in Sitka Graywacke and contains quartz stringers up to half an inch wide. The shear is oriented $290^{\circ}$ and is vertical to steeply southwest dipping. Samples taken from the adit contained no visible sulfides and had no detectable precious metal values. Samples of quartz from the dump near the shaft contained minor pyrite, arsenopyrite, and a trace of galena. Most of the dump samples had very low precious metal values. One select sample of float from the creek near the shaft contained 2,350 ppb gold (sample 2518; Fig. 24).

contains minor pyrite on fracture surfaces. Samples from the adit contained very low precious metal values. The highest grade sample contained $60 \mathrm{ppb}$ gold across 3.5 feet (sample 2223). All samples had elevated arsenic values, up to $632 \mathrm{ppm}$ (sample 2223) and two contained 1.6 and $1.9 \mathrm{ppm}$ mercury (samples 2225 and 2223 respectively). The high mercury values correlate with higher gold values here, as they commonly do elsewhere in Silver Bay.

Wright, 1904). By 1912, a 150-foot drift had been added to the workings (Knopf, 1912). BLM personnel mapped and sampled the Bauer adit (Fig. 26). The adit crosscuts graywacke and lesser phyllite, and drifts along a zone of fine- 


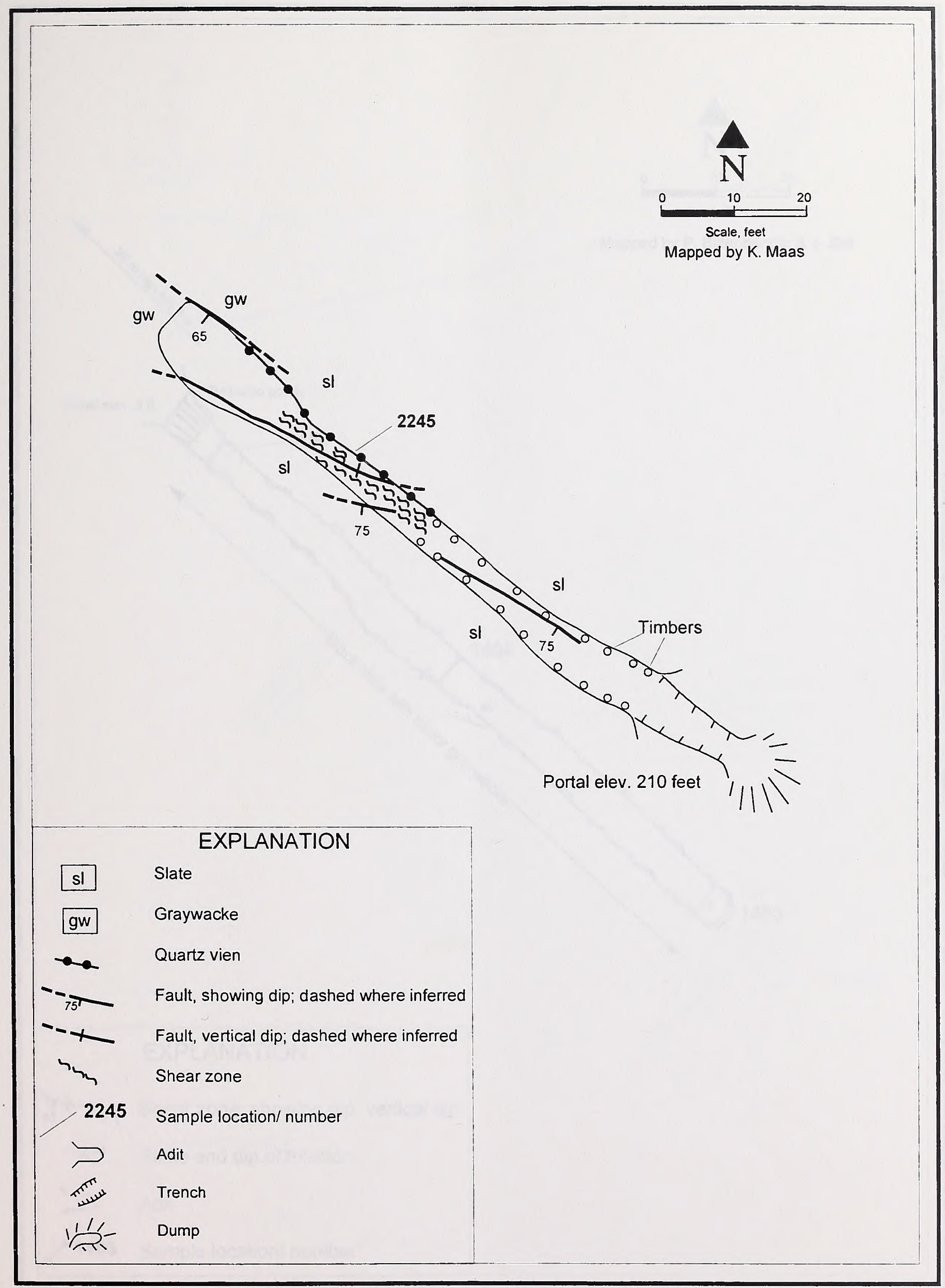

Figure 16. Eureka prospect adit (Fig. 12, Map no. 216). 



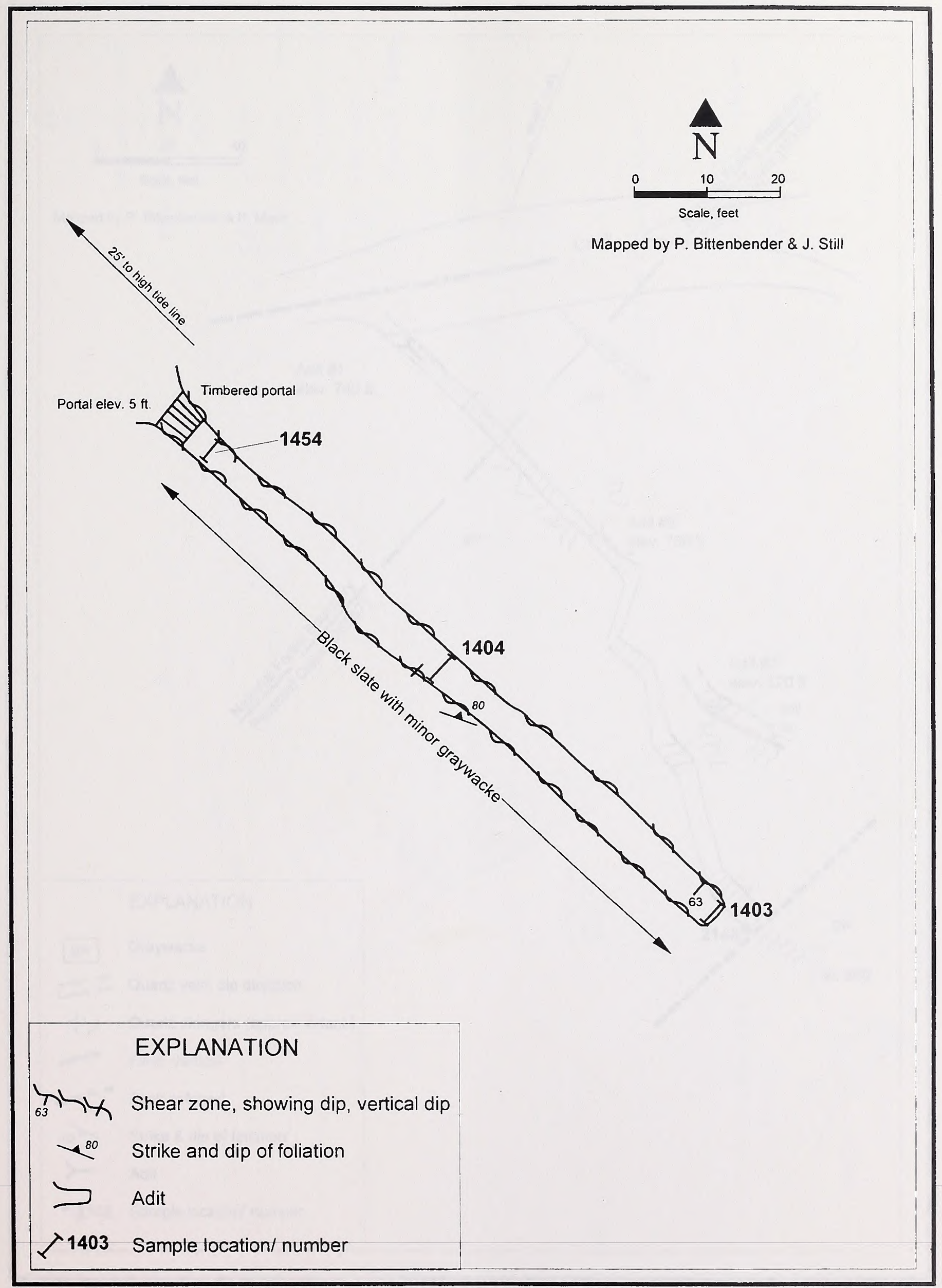

Figure 17. Bonanza No. 1 adit (Fig. 12, Map no. 217). 



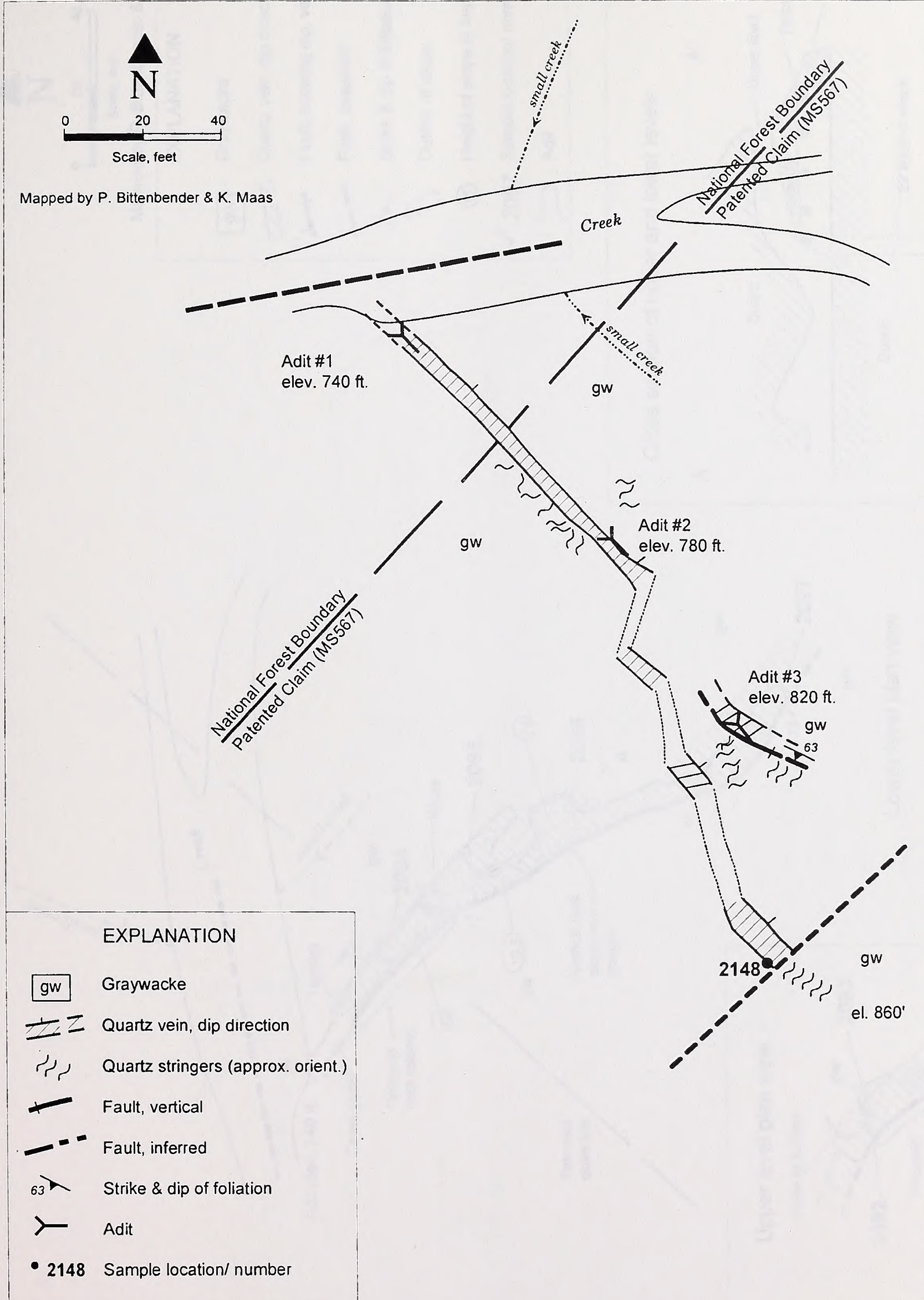

Figure 18. Stewart Mine area showing location of workings and land boundaries (Fig. 12, Map no. 220). 


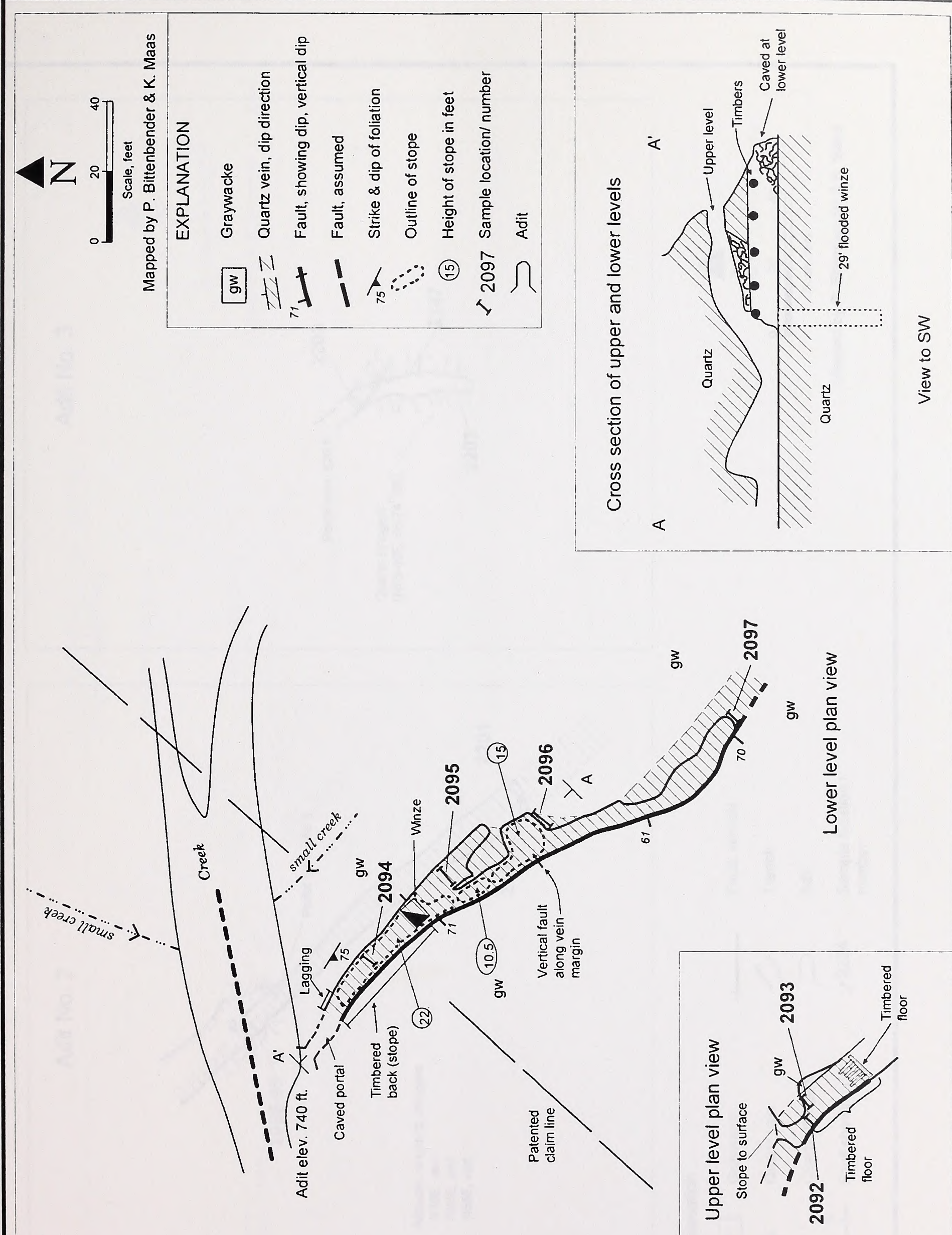

Figure 19. Stewart Mine, adit no. 1, plan views of upper and lower levels, cross section (Fig. 12, Map no. 220). 



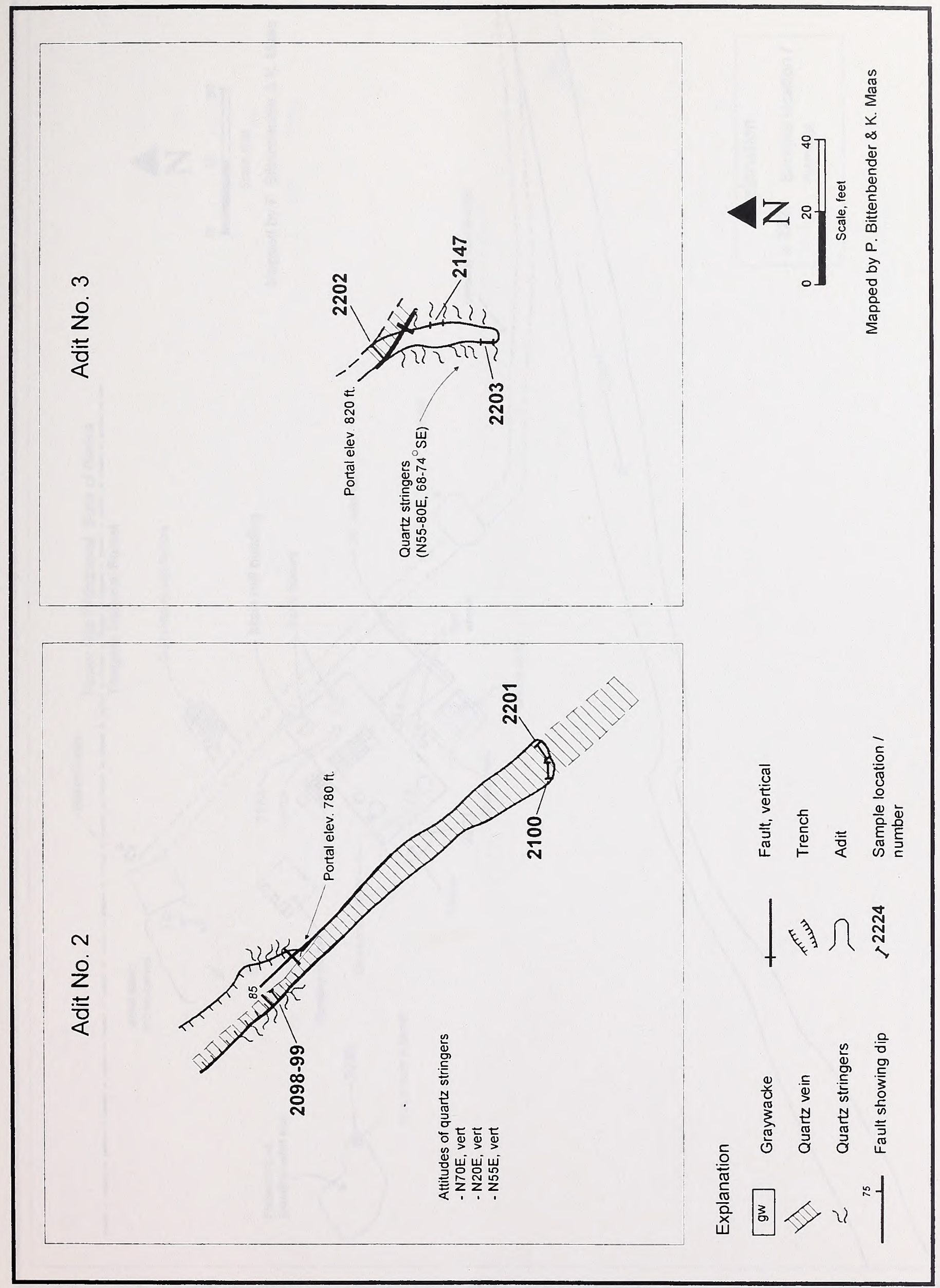

Figure 20. Stewart Mine, adits no.2 and no.3 (Fig. 12, Map no. 220). 



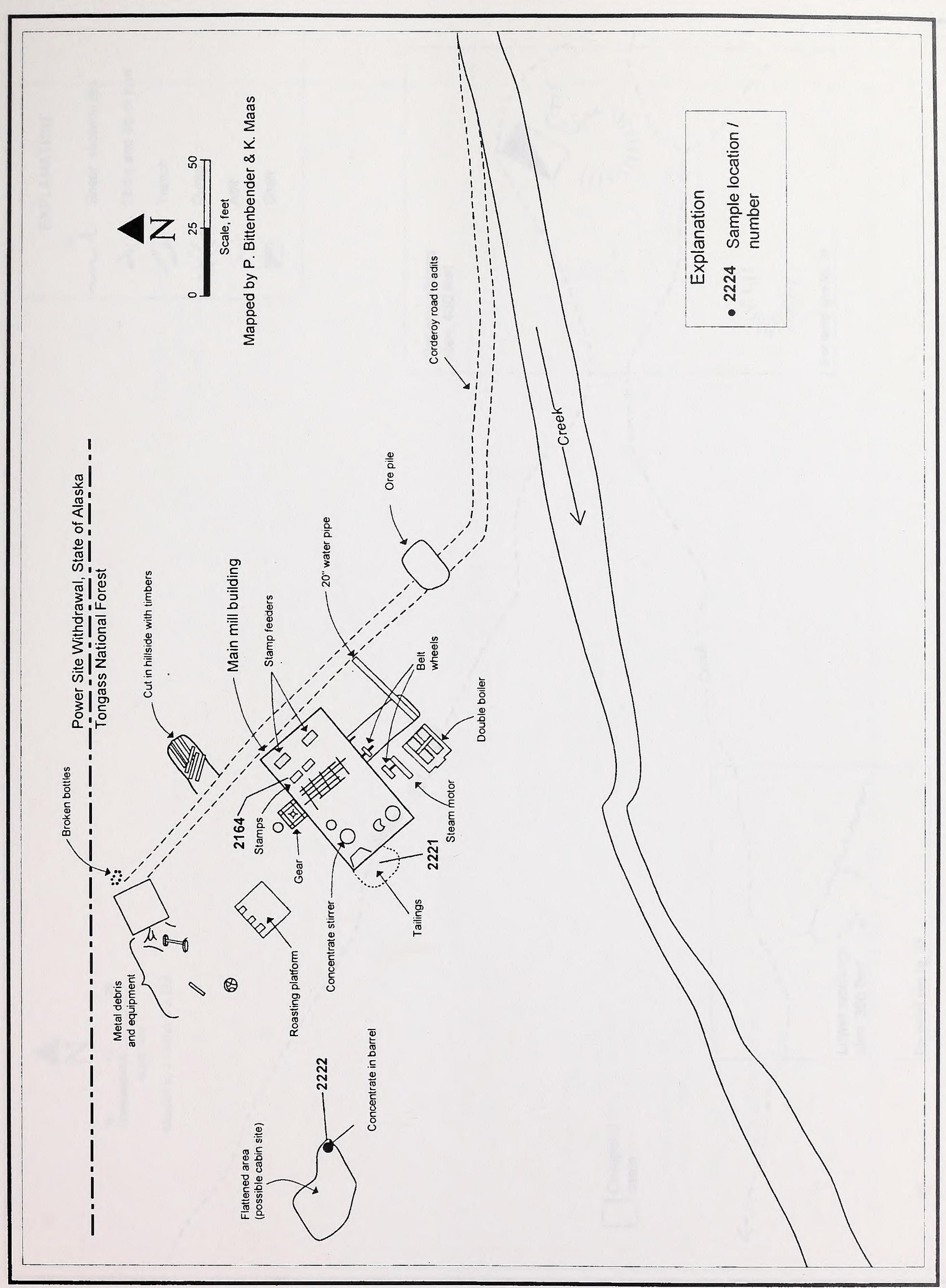

Figure 21. Stewart Mine mill site (Fig. 12, Map no. 220). 

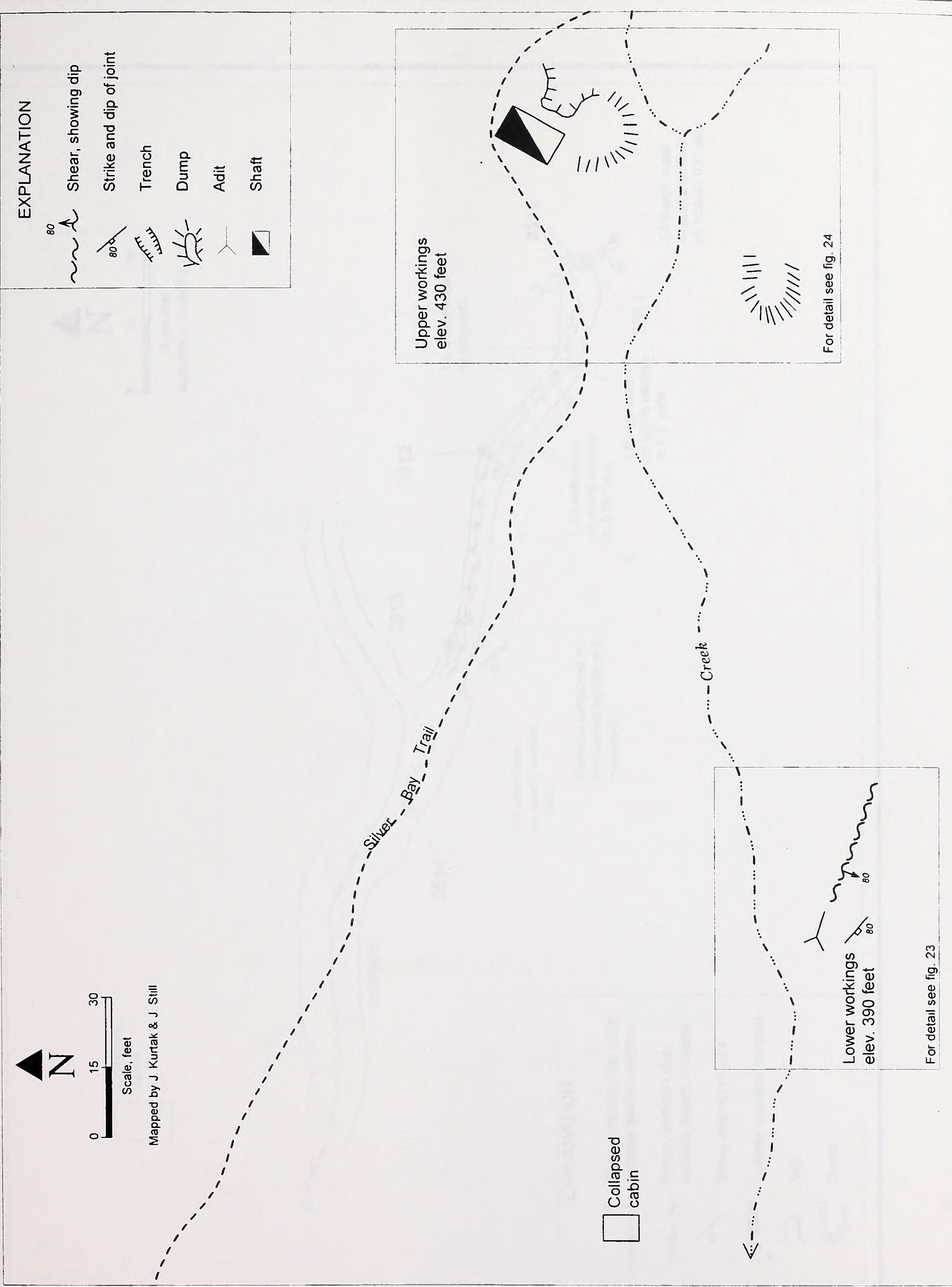

Figure 22. Lower Ledge prospect, area map (Fig. 12, Map no. 221). 


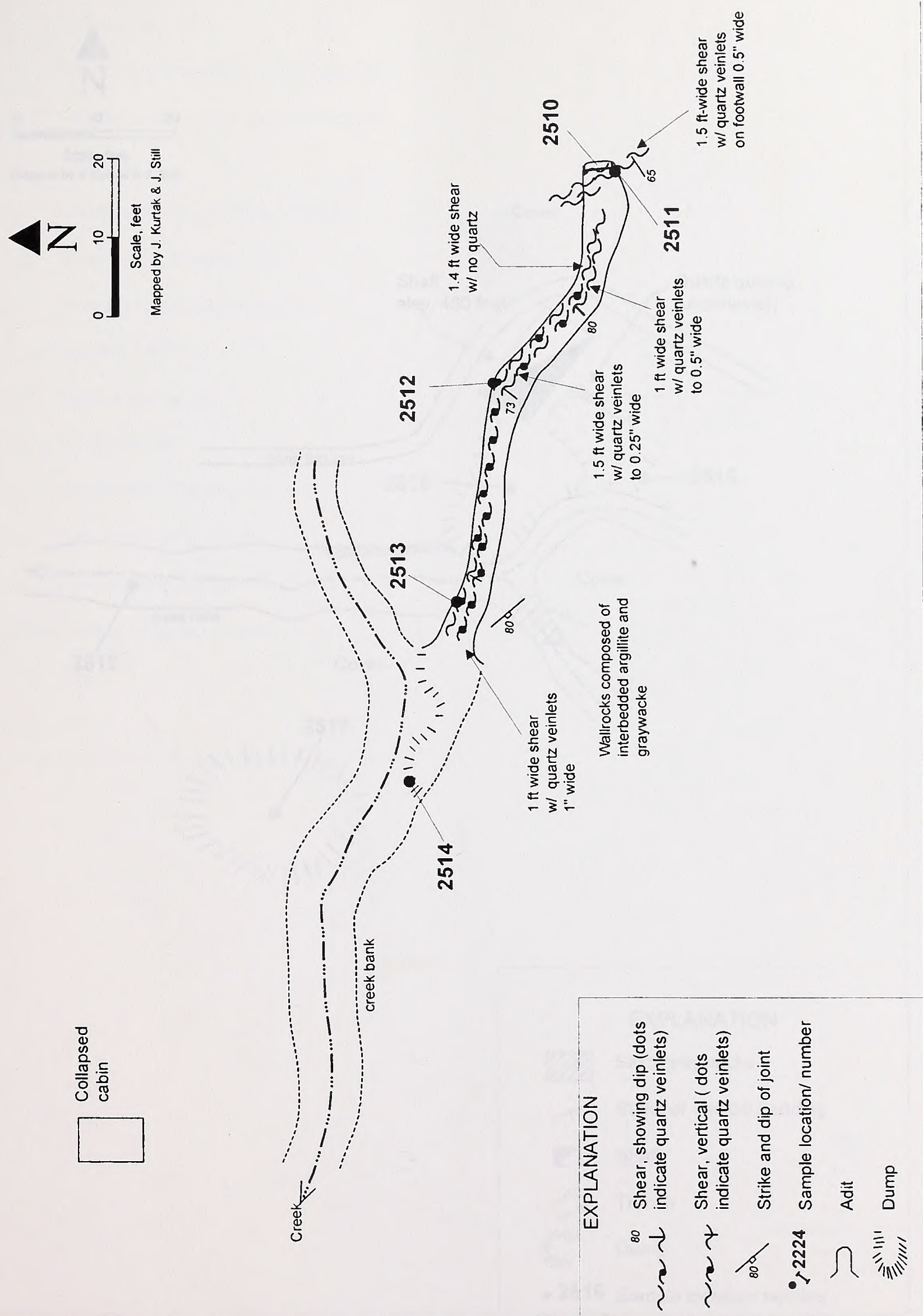

Figure 23. Lower Ledge prospect, lower workings (Fig. 12, Map no. 221). 


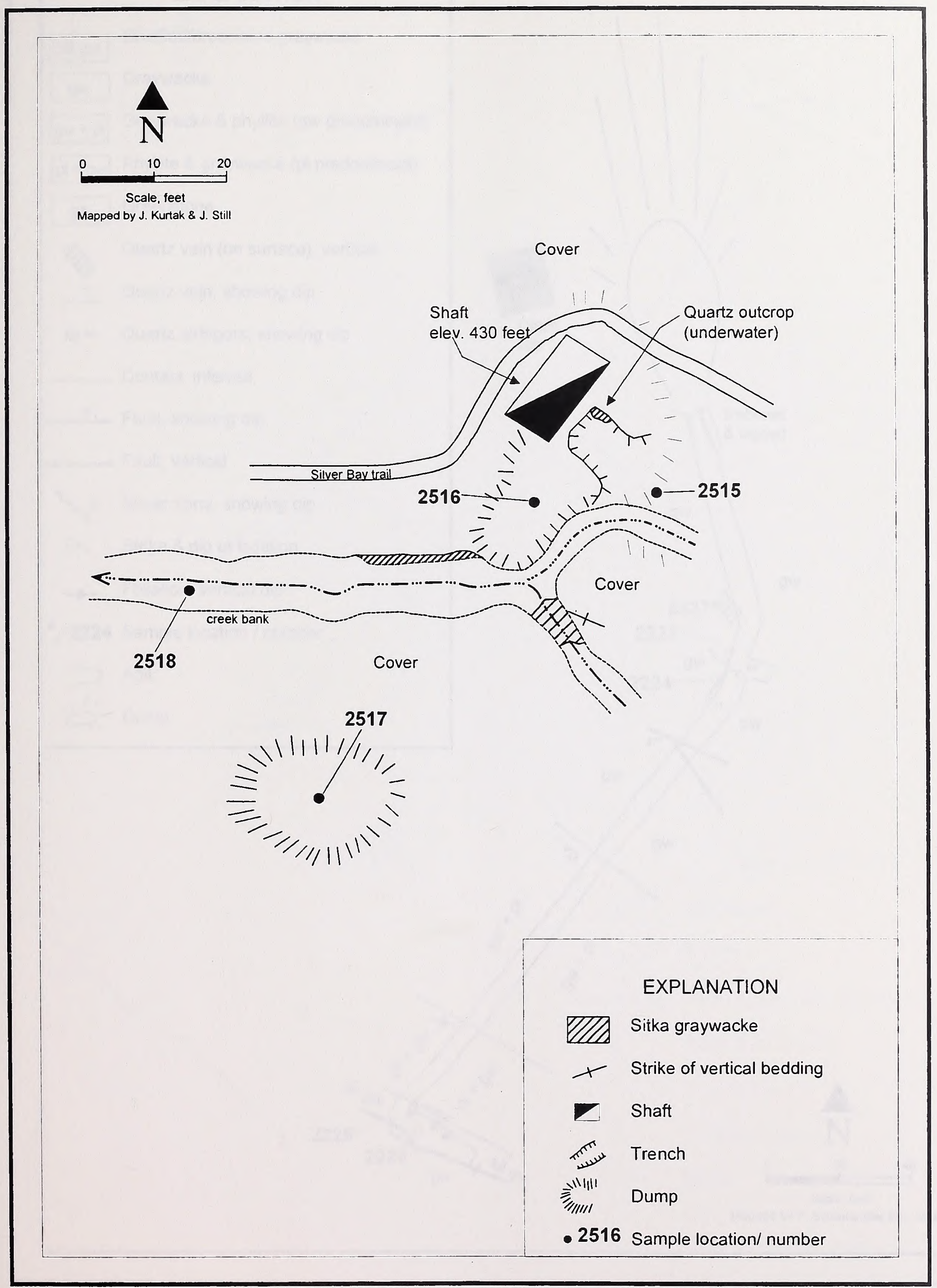

Figure 24. Lower Ledge prospect, upper workings (Fig. 12, Map no. 221). 



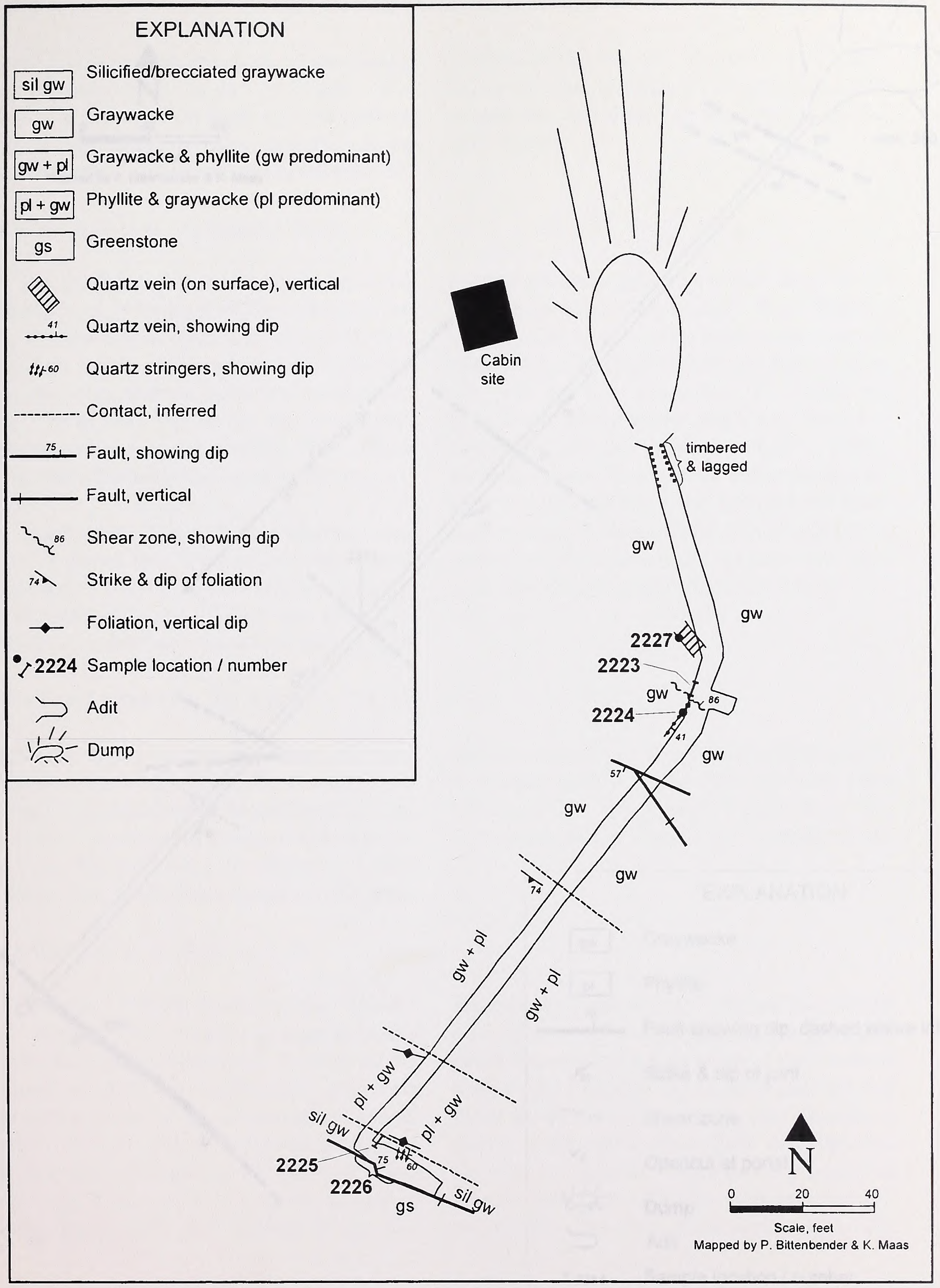

Figure 25. No Name prospect adit (Fig. 12, Map no. 222). 



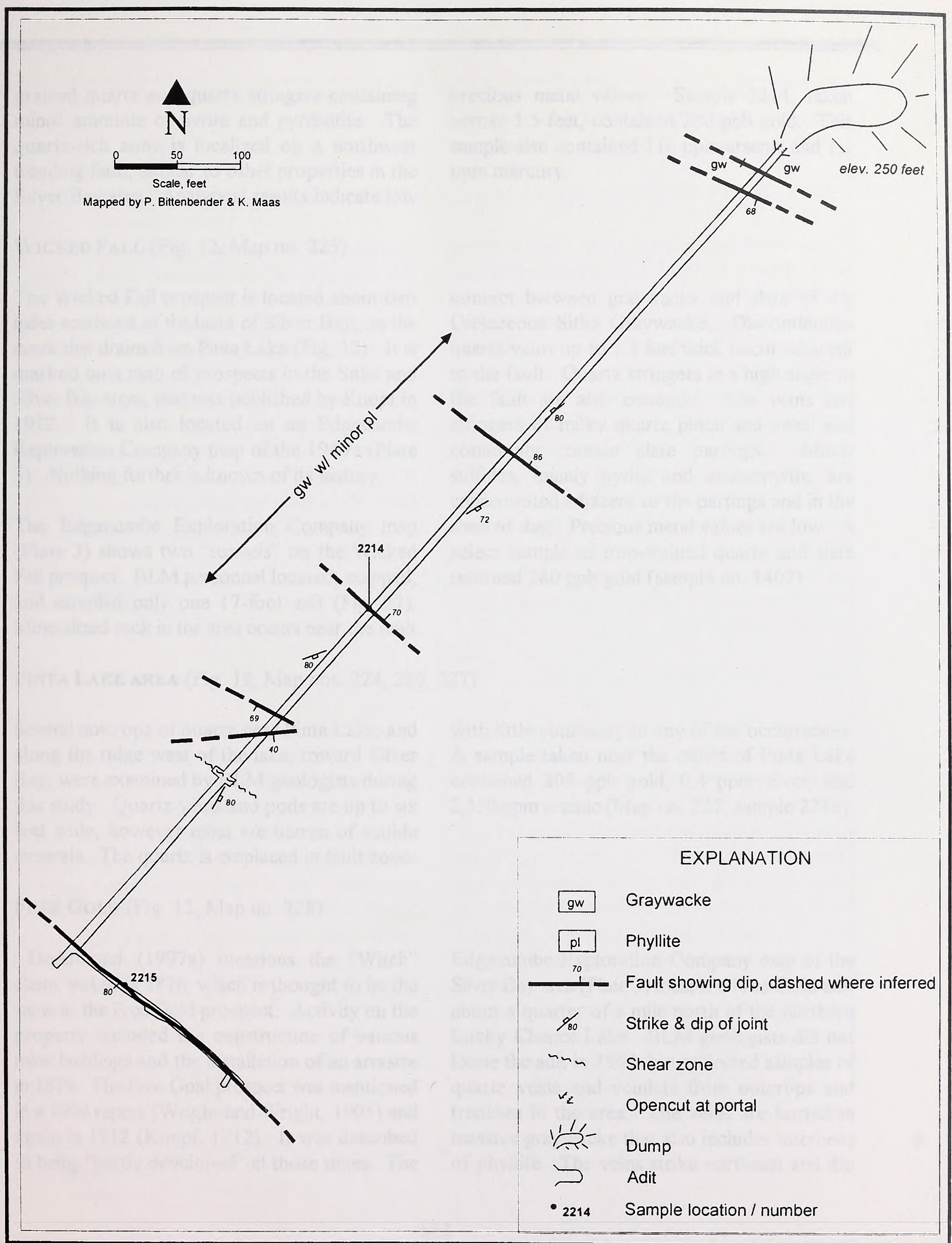

Figure 26. Bauer prospect adit (Fig. 12, Map no. 223). 

grained quartz and quartz stringers containing minor amounts of pyrite and pyrrhotite. The quartz-rich zone is localized on a northwest trending fault, similar to other properties in the Silver Bay area. Analytical results indicate low

WiCKED FALL (Fig. 12, Map no. 225)

The Wicked Fall prospect is located about two miles southeast of the head of Silver Bay, on the creek that drains from Pinta Lake (Fig. 12). It is marked on a map of prospects in the Sitka and Silver Bay areas, that was published by Knopf in 1912. It is also located on an Edgecumbe Exploration Company map of the 1940's (Plate $3)$. Nothing further is known of its history.

The Edgecumbe Exploration Company map (Plate 3) shows two "tunnels" on the Wicked Fall prospect. BLM personnel located, mapped, and sampled only one 17-foot adit (Fig. 27). Mineralized rock in the area occurs near the fault precious metal values. Sample 2214, taken across 1.5 feet, contained $280 \mathrm{ppb}$ gold. This sample also contained $716 \mathrm{ppm}$ arsenic and 1.1 ppm mercury.

contact between graywacke and slate of the Cretaceous Sitka Graywacke. Discontinuous quartz veins up to 1.8 feet thick occur adjacent to the fault. Quartz stringers at a high angle to the fault are also common. The veins and stringers of milky quartz pinch and swell and commonly contain slate partings. Minor sulfides, mainly pyrite and arsenopyrite, are concentrated adjacent to the partings and in the sheared slate. Precious metal values are low. A select sample of iron-stained quartz and slate returned $280 \mathrm{ppb}$ gold (sample no. 1407).

PINTA LAKE AREA (Fig. 12, Map nos. 224, 226, 227)

Several outcrops of quartz near Pinta Lake, and along the ridge west of the lake, toward Silver Bay, were examined by BLM geologists during this study. Quartz veins and pods are up to six feet wide, however most are barren of sulfide minerals. The quartz is emplaced in fault zones

FREE Gold (Fig. 12, Map no. 228)

DeArmond (1997a) mentions the "Witch" claim, staked in 1876, which is thought to be the same as the Free Gold prospect. Activity on the property included the construction of various mine buildings and the installation of an arrastre in 1879. The Free Gold prospect was mentioned in a 1904 report (Wright and Wright, 1905) and again in 1912 (Knopf, 1912). It was described as being "partly developed" at those times. The with little continuity to any of the occurrences. A sample taken near the outlet of Pinta Lake contained $205 \mathrm{ppb}$ gold, $0.4 \mathrm{ppm}$ silver, and 2,550 ppm arsenic (Map no. 227, sample 2218).

Edgecumbe Exploration Company map of the Silver Bay area (Plate 3 ) locates a Free Gold adit about a quarter of a mile north of the northern Lucky Chance Lake. BLM geologists did not locate the adit in 1995, but collected samples of quartz veins and veinlets from outcrops and trenches in the area. The veins are hosted in massive graywacke that also includes interbeds of phyllite. The veins strike northeast and dip 
about $70^{\circ}$ to the northwest. There are no visible sulfides in the quartz veins, but iron staining is present. Analytical results indicated low

\section{LuCKy Chance Mountain (Fig. 12, Map nos.}

While investigating the Lucky Chance Mine, BLM geologists discovered several adits and trenches driven on quartz veins in the Lucky Chance Mountain area. One set of workings lies about half a mile southeast of the Lucky Chance adits (Map nos. 232-235). These workings consist of 4 trenches and a 20-foot adit. The quartz veins generally strike northwest and dip steeply, both to the southwest and northeast. They are typically hosted by graywacke and phyllite. Many of the veins are cut by northnorthwest trending faults. Sulfides are rare. Select samples of iron-stained quartz with pyrite and arsenopyrite contained 4,840 ppb gold (Map no. 235, sample 2229) and 2,230 ppb gold (Map no. 233 , sample 2158 ).

LuCky Chance Mine (Fig. 12, Map no. 231)

The Lucky Chance Mine has an obscure history, complicated mainly by the numerous owners and names associated with the property. The original stakers were the Francis brothers of Sitka who named their claims the Francis Lode. Their 1874 claims were the first recorded in the Silver Bay area. Soon after recording their claims, the Francis brothers sold their interest in them to Nicholas Haley, a mining promoter closely associated with the mining history of Silver Bay. Additional owners included the Lake Mountain Mining Company, and the Providence and Sitka Gold Mining Company (DeArmond, 1997a). These two owners were responsible for most of the developments at the site.

The first reports of development of the Lucky precious metal values (samples 2154-2156).

$229,230,232-235)$

BLM personnel examined an adit and trench on the east side of the northern Lucky Chance Lake, northeast of the Lucky Chance Mine. The workings expose quartz lenses and stringers that are situated along a fault zone oriented $332^{\circ}$ and dipping $67^{\circ}$ northeast. The quartz is hosted by phyllite and graywacke and is exposed for 90 feet along strike and 35 feet vertically. Sulfides include pyrite and arsenopyrite, but are rare. Precious metal values are low. A select sample taken from float on the northwest side of the lake contained 1,180 ppb gold (Map no. 229, sample 2153).

Chance Mine are from a newspaper article in 1885. The article reports a 25 -foot shaft with a 30-foot drift at the mine (DeArmond, 1997a). By 1887 , a 5-stamp mill was in operation and about 60 tons of ore had been processed from 2 adits (Roehm, 1940). By 1904 a 10-stamp mill, a sawmill, and a water-power plant were in operation (Wright and Wright, 1904). Although the total production from the mine is unknown, 1,200 tons of ore were reportedly removed from stopes above the 468-foot, 'No. 2 tunnel' (Fig's. $28,29)$. In addition to this adit, workings included a 45-foot adit ('No. 1 tunnel'), a shaft, an open stope or glory hole, and other small open cuts and trenches (Roehm, 1940). A 3,000 to 4,000-foot aerial tram, erected in 1901, connected the mine site to the mill below. A corduroy road ran from the head of Silver Bay 

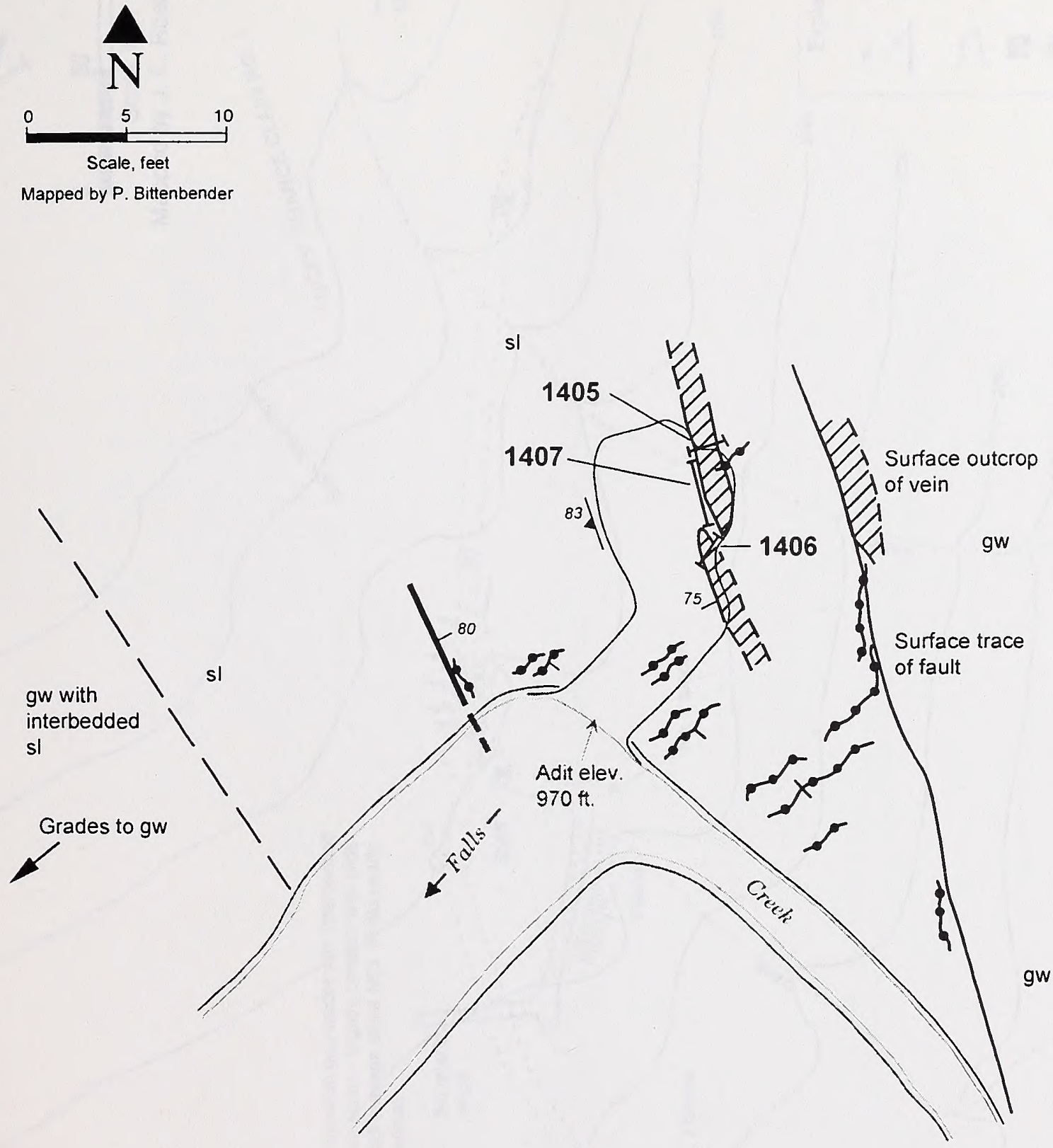

EXPLANATION

sl Slate

$\frac{\mathrm{gw}}{75}$ Graywacke

Zोzz Quartz vein, showing dip direction

Quartz stringers, showing dip; vertical dip

80

Fault, showing dip, dashed

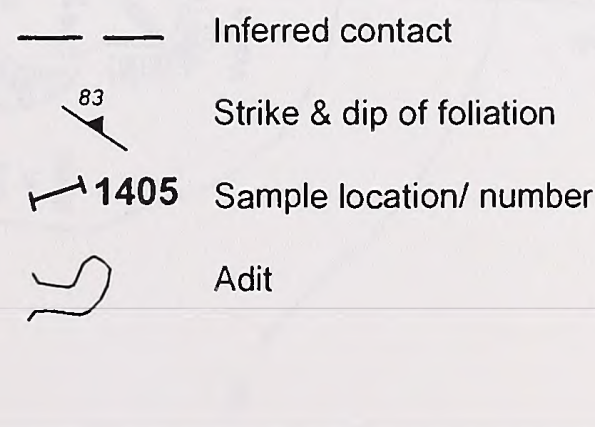
where inferred

Figure 27. Wicked Fall prospect adit (Fig. 12, Map no. 225). 


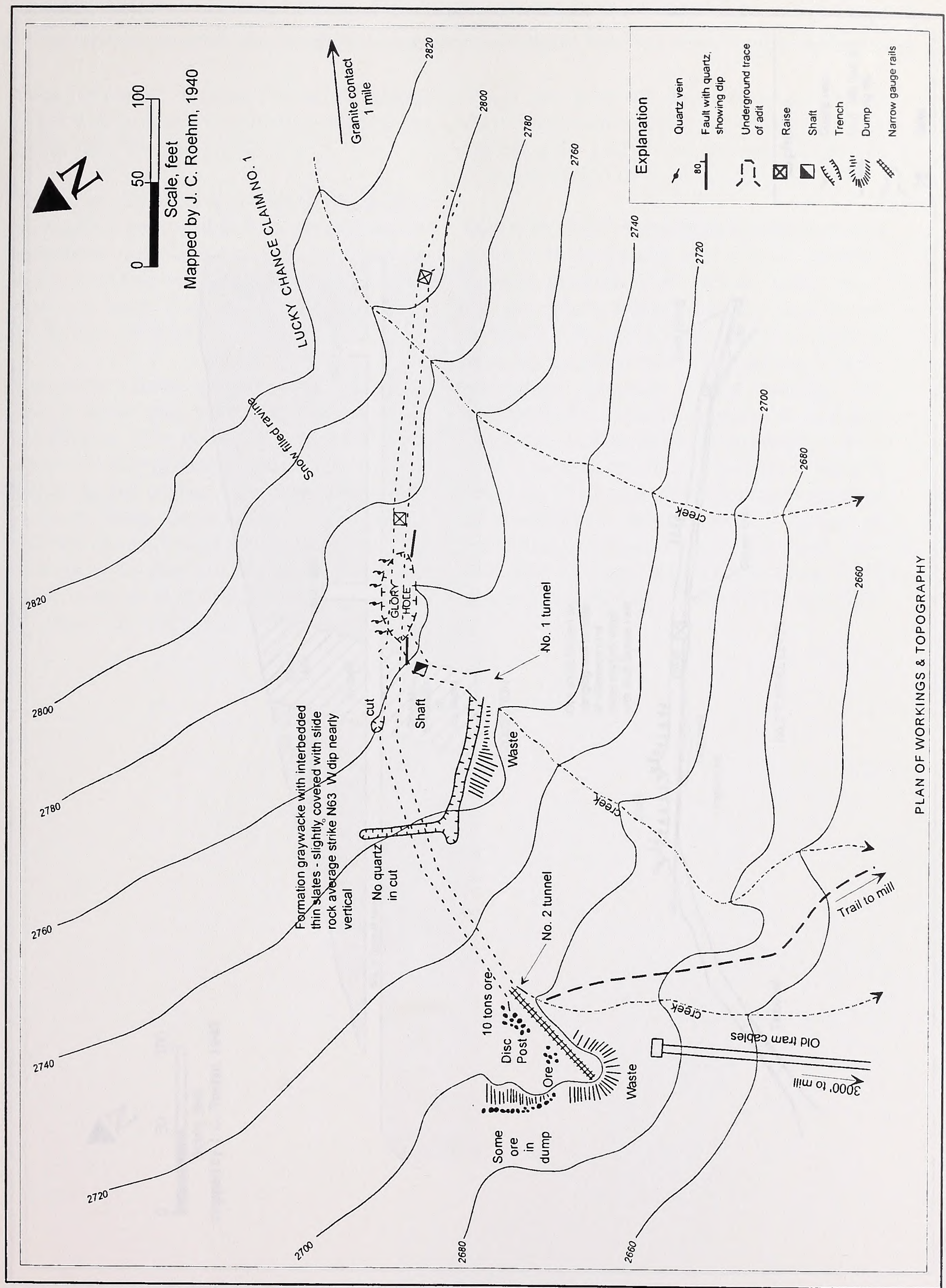

Figure 28. Lucky Chance Mine workings, plan view (Roehm, 1940; Fig. 12, Map no. 231). 



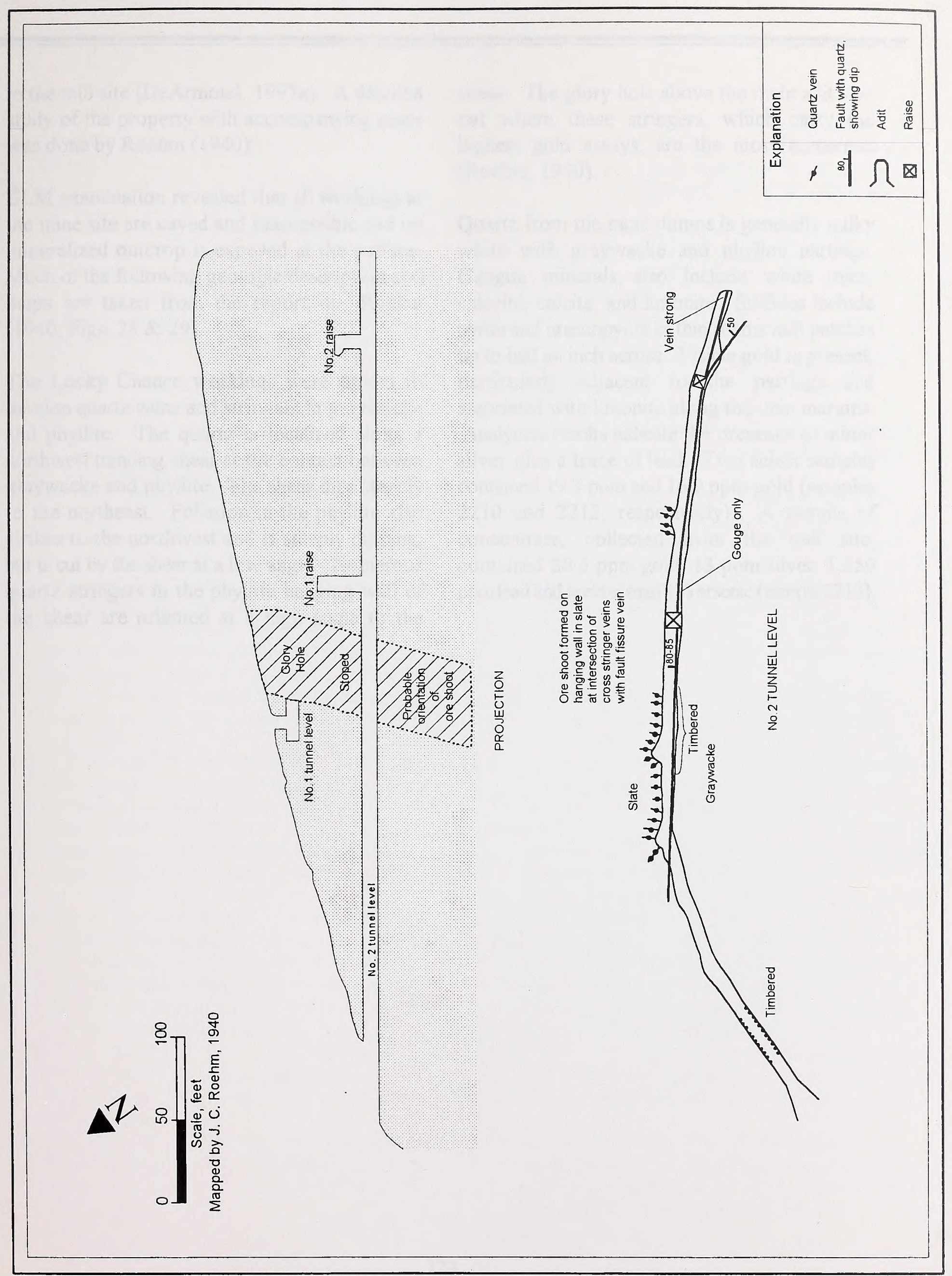

Figure 29. Lucky Chance Mine workings, cross section and plan view of No. 2 adit (Roehm, 1940) (Fig. 12, Map no. 231). 

to the mill site (DeArmond, 1997a). A detailed study of the property with accompanying maps was done by Roehm (1940).

BLM examination revealed that all workings at the mine site are caved and inaccessible and no mineralized outcrop is exposed at the surface. Much of the following geologic description and maps are taken from the report of Roehm (1940; Figs. 28 \& 29).

The Lucky Chance workings were driven to develop quartz veins and stringers in graywacke and phyllite. The quartz is localized along a northwest trending shear at the contact between graywacke and phyllite. The shear dips steeply to the northeast. Foliation in the phyllite also strikes to the northwest and is steeply dipping, but is cut by the shear at a low angle. Numerous quartz stringers in the phyllite hanging wall of the shear are oriented at a high angle to the shear. The glory hole above the main adit was cut where these stringers, which carry the highest gold assays, are the most numerous (Roehm, 1940).

Quartz from the mine dumps is generally milky white with graywacke and phyllite partings. Gangue minerals also include white mica, chlorite, calcite, and limonite. Sulfides include pyrite and arsenopyrite in thin seams and patches up to half an inch across. Visible gold is present, particularly adjacent to the partings and associated with limonite along the vein margins. Analytical results indicate the presence of minor silver plus a trace of lead. Two select samples contained $19.3 \mathrm{ppm}$ and $16.9 \mathrm{ppm}$ gold (samples 2210 and 2212, respectively). A sample of concentrate, collected from the mill site, contained $26.5 \mathrm{ppm}$ gold, $13 \mathrm{ppm}$ silver, 1,250 ppm lead and greater than $1 \%$ arsenic (sample 2213). 



\section{BIBLIOGRAPHY}

Alaska Yukon Mining Journal, April 1901, v.1, no. 1, p. 13 , no. 2, p. 16-17.

Alpha, T. R., and Ford, A. B., 1994, Oblique maps of southeastern Alaska, showing major mineral localities: U. S. Geological Survey Miscellaneous Field Studies Map MF-2271, 2 sheets.

Arth, J. G., 1994, Isotopic composition of the igneous rocks of Alaska, in Plafker, G., and Berg, H. C., eds., The geology of Alaska: Boulder, Colorado, Geological Society of America, The Geology of North America, v. G-1, p. 781-795.

Asbury, D. W., 1964, Report on Vevelstad copper-iron property, Stag Bay, Chichagof Island, Alaska: Alaska Division of Mines and Minerals Miscellaneous Report 114-10, $3 \mathrm{p}$.

Baggs, D. W., Northam, M. J., Meyer, M. P., and Maas, K. M., 1988, Selected significant mineral deposits in Alaska: U. S. Bureau of Mines Information Circular $9177,124 \mathrm{p}$.

Ballard, J. D., 1968, Slocum Arm molybdenite prospect, Chichagof Island, Alaska: Alaska Division of Mines and Minerals Mineral Investigation 114-2, 24 p.

Barker, F., and 14 contributors, 1994, Some accreted volcanic rocks of Alaska and their elemental abundances, in Plafker, G., and Berg, H. C., eds., The geology of Alaska: Boulder, Colorado, Geological Society of America, The Geology of North America, v. G-1, p. 555-587.

Barker, F., Miller, T. P., and Gehrels, G. E., 1994, Map showing major occurrences of accreted volcanic rocks and the pre-Cenozoic and some early Tertiary plutonic rocks of Alaska, in Plafker, G., and Berg, H. C., eds., The geology of Alaska: Boulder, Colorado, Geological Society of America, The Geology of North America, v. G-1, 1 sheet, scale $1: 2,500,000$.

Barnes, D. F., Erwin, M. J., Holden, K. D., and Morin R. L., 1975, U.S. Geological Survey Alaskan gravity data maps of the Port Alexander, Sitka, Juneau, Mt.

Fairweather, and Skagway 1:250,000 quadrangles, Alaska: U.S. Geological Survey Open-File Report 756,45 p., 5 sheets, scale $1: 250,000$.

Bates, R. G., and Wedow, H., Jr., 1953, Preliminary summary review of thorium-bearing mineral occurrences in Alaska: U.S. Geological Survey Circular 202, 12 p.

Baumann, H. N., Jr., 1924, Mining and milling rich gold ore on Chichagof Island: Engineering and Mining Journal-Press, v. 117 , no. 22 , May 31, p. 876-879.
Becker, F. G., 1898, Reconnaissance of the Gulf Fields of southern Alaska, with some notes on the general geology: U.S. Geological Survey 18th Annual Report, pt. 3, p. 1-86.

Beikman, H. M., 1975, Preliminary geologic map of southeastern Alaska: U.S. Geological Survey Miscellaneous Field Studies Map MF-673, 2 sheets, scale $1: 1,000,000$.

Beikman, H. M., Holloway, C. D., and MacKevett, E. M., 1977, Generalized geologic map of the eastern part of southern Alaska: U.S. Geological Survey Open-File Report 77-169-B, 1 sheet, scale 1:1,000,000.

Berg, H. C., 1984, Regional geologic summary, metallogenesis and mineral resources of southeastern Alaska: U.S. Geological Survey Open-File Report 84$572,298 \mathrm{p}$.

Berg, H. C., 1979, Significance of geotectonics in the metallogenesis and resource appraisal of southeastern Alaska: A progress report, in Johnson, K. M., and Williams, J. R., eds., The United States Geological Survey in Alaska: Accomplishments during 1978: U.S. Geological Survey Circular 804-B, p. B115-B1 18.

Berg, H. C., and Cobb, E. H., 1967, Metalliferous lode deposits of Alaska: U.S. Geological Survey Bulletin 1246, p. 138-146.

Berg, H. C., Decker, J. E., and Abramson, B. S., 1981, Metallic mineral deposits of southeastern Alaska: U.S. Geological Survey Open-File Report 81-122, 136 p.

Berg, H. C., and Hinckley, D. W., 1963, Reconnaissance geology of northern Baranof Island, Alaska: U.S. Geological Survey Bulletin 1141-O, 24 p.

Berg, H. C., Jones, D. L., and Coney, P. J., 1978, Map showing Pre-Cenozoic tectonostratigraphic terranes of southeastern Alaska and adjacent areas: U.S.

Geological Survey Open-File Report 78-1085, 2 sheets, scale $1: 1,000,000$.

Berg, H. C., Jones, D. L., and Richter, D. H., 1972, Gravina-Nutzotin Belt - Tectonic significance of an Upper Mesozoic sedimentary and volcanic sequence in southern and southeastern Alaska: U.S. Geological Survey Professional Paper 800-D, p. D1-D24.

Berryhill, R. V., 1963, Examinations of a pegmatite deposit near Redfish Bay, Baranof Island, southeastern Alaska: U. S. Bureau of Mines Examination Report, no. 136, 5 p.

Bittenbender, P. B., and Still, J.C., 1997, Mineral Investigations on Chichagof and Baranof Islands, and vicinity, southeast Alaska, 1996: U.S. Bureau of Land Management - Alaska Open File Report 67, 34 p. 
Brew, D. A., 1988, Latest Mesozoic and Cenozoic magmatism in southeastern Alaska - A synopsis: U.S. Geological Survey Open-File Report 88-405, 29 p.

Brew, D. A., 1994, Latest Mesozoic and Cenozoic magmatism in southeastern Alaska, in Plafker, G. and Berg, H. C., eds., The geology of Alaska: Boulder, Colorado, Geological Society of America, The Geology of North America, v. G-1, p. 621-656.

Brew, D. A., 1997, Description and regional setting of the Silver Bay segment of the Sitka fault zone, southeastern Alaska, and evidence for possible sinistral separation, in Dumoulin, J. A. and Gray, J. E., eds., Geologic studies in Alaska by the U.S. Geological Survey, 1995: U.S. Geological Survey Professional Paper 1574, p. 307-316.

Brew, D. A., Drew, L. J., Schmidt, J. M., Root, J. M., and Huber, D. F., 1991, Undiscovered locatable mineral resources of the Tongass National Forest and adjacent lands, southeastern Alaska: U.S. Geological Survey Open-File Report 91-10, $370 \mathrm{p}$.

Brew, D. A., Hammarstrom, J. M., Himmelberg, G. H., Wooden, J. L., Loney, R. A., and Karl, S. M., 1991, Crawfish Inlet pluton, Baranof Island, southeastern Alaska - A north-tilted Eocene body or an untilted enigma [abs]: Geological Society of America Abstracts with Programs, v. 23, no. 2, p. 8.

Brew, D. A., Himmelberg, G. R., Loney, R. A., and Ford, A. B., 1992, Distribution and characteristics of metamorphic belts in the southeastern Alaska part of the North American Cordillera: Journal of Metamorphic Geology, v. 10, p. 465-482.

Brew, D. A., Johnson, B. R., Grybeck, D., Griscom, A., Barnes, D. F., Kimball, A. L., Still, J. C., and Rataj, J. L., 1978, Mineral resources of the Glacier Bay National Monument wilderness study area, Alaska: U.S. Geological Survey Open-File Report 78-494, 690 p.

Brew, D. A., Karl, S. M., Barnes, D. F., Jachens, R. C., Ford, A. B., and Horner, R., 1991, A northern Cordilleran ocean-continent transect: Sitka Sound, Alaska, to Atlin Lake, British Columbia: Canadian Journal of Earth Science, v. 28, p. 840-853.

Brew, D. A., Karl, S. M., and Miller, J. W., 1988, Megafossils (Buchia) indicate Late Jurassic age for part of Kelp Bay Group on Baranof Island, southeastern Alaska: U.S. Geological Survey Circular 1016, p. 147-149.
Brew, D. A., Loney, R. A., and Muffler, L. J. P., 1966, Tectonic history of southeastern Alaska, in A symposium on tectonic history and mineral deposits of the western cordillera in British Columbia and neighboring parts of the United States: Canadian Institute of Mining and Metallurgy, Special Volume 8, p. 149-170.

Brew, D. A., Loney, R. A., Pomeroy, J. S., and Muffler, L. J. P., 1963, Structural influence on development of linear topographic features, southern Baranof Island, southeastern Alaska, in Short papers in geology and hydrology: U.S. Geological Survey Professional Paper 475-B, p. B110-B113.

Brew, D. A. and Morrell, R. P., 1979a, Correlation of the Sitka Graywacke, unnamed rocks in the Fairweather Range, and Valdez Group, southeastern and southcentral Alaska, in Johnson, K. M., and Williams, J. R., eds., The United States Geological Survey in Alaska: Accomplishments during 1978: U.S. Geological Survey Circular 804-B, p. B123-B125.

Brew, D. A., and Morrell, R. P., 1979b, Intrusive rock belts of southeastern Alaska, in Johnson, K. M., and Williams, J. R., eds., The United States Geological Survey in Alaska: Accomplishments during 1978: U.S. Geological Survey Circular 804-B, p. B116-B121.

Brew, D. A., and Morrell, R. P., 1979c, Preliminary map of intrusive rocks in southeastern Alaska: U.S. Geological Survey Miscellaneous Field Studies Map MF-1048, scale 1:1,000,000.

Brew, D. A., and Morrell, R. P., 1979d, The Wrangell terrane ("Wrangellia") in southeastern Alaska: Tarr Inlet suture zone with its northern and southern extensions, in Johnson, K. M., and Williams, J. R., eds., The United States Geological Survey in Alaska: Accomplishments during 1978: U.S. Geological Survey Circular 804-B, p. B121-B123.

Brew, D. A., and Morrell, R. P., 1983, Intrusive rocks and plutonic belts in southeastern Alaska, in Roddick, J. A., ed., Circum-Pacific plutonic terranes: Geological Society of America Memoir 159, p. 171-193.

Brew, D. A., Muffler, L. J. P., and Loney, R. A., 1966, Eruptive history of the Mount Edgecumbe volcanic field, Kruzof Island, southeastern Alaska (abs.), in Proceedings of 16th Alaskan Science Conference, Juneau, Alaska, p. 115-116.

Brew, D. A., Muffler, L. J. P., and Loney, R. A., 1969, Reconnaissance geology of the Mount Edgecumbe volcanic field, Kruzof Island, southeastern Alaska: U.S. Geological Survey Professional Paper 650-D, p. D1-D18. 
Brooks, A. H., 1911a, Geologic features of Alaskan metalliferous lodes, in Mineral resources of Alaska Report on progress of investigations in 1910: U.S. Geological Survey Bulletin 480-C, p. 43-93.

Brooks, A. H., 1911b, Mining in southeastern Alaska, in Mineral resources of Alaska - Report on progress of investigations in 1911: U.S. Geological Survey Bulletin 480-D, p. 98.

Brooks, A. H., 1912, The Alaskan mining industry in 1911, in Mineral resources of Alaska - Report on progress of investigations in 1911: U.S. Geological Survey Bulletin 520-B, p. 24.

Brooks, A. H., 1913, The Alaskan mining industry in 1912, in Mineral resources of Alaska - Report on progress of investigations in 1912: U.S. Geological Survey Bulletin 542-B, p. 34, 50-51.

Brooks, A. H., 1914, The Alaskan mining industry in 1913, in Mineral resources of Alaska - Report on progress of investigations in 1913: U.S. Geological Survey Bulletin 592-C, p. 60.

Brooks, A. H., 1915, The Alaskan mining industry in 1914, in Mineral resources of Alaska - Report on progress of investigations in 1914: U.S. Geological Survey Bulletin 622-B, p. 43.

Brooks, A. H., 1916, The Alaskan mining industry in 1915, in Mineral resources of Alaska - Report on progress of investigations in 1915: U.S. Geological Survey Bulletin 642-B, p. 53.

Brooks, A. H. ,1918, The Alaskan mining industry in 1916, in Mineral resources of Alaska - Report on progress of investigations in 1916: U.S. Geological Survey Bulletin 662-B, p. 25, 41.

Brooks, A. H., 1919, Alaska's mineral supply: U.S. Geological Survey Bulletin 666-P, p. 97.

Brooks, A. H., 1922, The Alaskan mining industry in 1920 , in Mineral resources of Alaska - Report on progress of investigations in 1920: U.S. Geological Survey Bulletin 722-A, p. 37, 38.

Brooks, A. H., 1923, The Alaskan mining industry in 1921, in Mineral resources of Alaska - Report on progress of investigations in 1921: U.S. Geological Survey Bulletin 739-A, p. 20, 22.

Brooks, A. H., 1925, Alaska's mineral resources and production, 1923, in Mineral resources of Alaska Report on progress of investigations in 1923: U.S. Geological Survey Bulletin 773-A, p. 11, 12, 15, 31, 35,36 .
Brooks, A. H., and Capps, S. R., 1924, The Alaskan mining industry in 1921, in Mineral resources of Alaska - Report on progress of investigations in 1921: U.S. Geological Survey Bulletin 755-A, p. 9, 18, 22 , 25.

Brooks, A. H., and Martin, G. C., 1921, The Alaskan mining industry in 1919, in Mineral resources of Alaska - Report on progress of investigations in 1919: U.S. Geological Survey Bulletin 714-B, p. 75, 76.

Buddington, A. F., 1924, Alaskan nickel minerals: Economic Geology, v. 19, no. 6, p. 521-541.

Buddington, A. F, 1925,. Mineral investigations in southeastern Alaska, in Mineral resources of Alaska Report on progress of investigations in 1923: U.S. Geological Survey Bulletin 773-D, p. 71, 72, 95-125.

Buddington, A. F., 1926, Mineral investigations in southeastern Alaska, in Mineral resources of Alaska Report on progress of investigations in 1924: U.S. Geological Survey Bulletin 783-C, p. 55, 56, 58, 59, 61.

Buddington, A. F., and Chapin, T., 1929, Geology and mineral deposits of southeastern Alaska: U.S. Geological Survey Bulletin 800, 398 p.

Burchard, E. F., 1914, Marble resources of the Juneau, Skagway, and Sitka Districts: U.S. Geological Survey Bulletin 592-D, p. 95-107.

Burchard, E. F., 1920a, Gypsum deposits - Alaska, in Gypsum deposits of the United States: U.S. Geological Survey Bulletin 697, p. 47-48.

Burchard, E. F., 1920b, Marble resources of southeastern Alaska: U.S. Geological Survey Bulletin 682, p. 26, 45-48.

Bush, B. O., and Kenly, R. F., 1962, Report of geophysical investigation, Lucky Devil mining claims, Chichagof Island, Alaska for Geo-Recon, Inc.: Alaska Division of Mines and Geology Miscellaneous Report 114-7, 21 p., 10 sheets.

Carnes, R. D., 1980, Minerals Availability System deposit summary report, Chromium, Red Bluff Bay, Port Alexander, Alaska: Unpublished U. S. Bureau of Mines report, $21 \mathrm{p}$.

Chapin, T., 1916, Mining developments in southeastern Alaska, in Mineral resources of Alaska - Report on progress of investigations in 1915: U.S. Geological Survey Bulletin 642-C, $78 \mathrm{p}$.

Chapman, R. M., and Shacklette, H. T., 1960, Geochemical exploration in Alaska (Yakobi Island): U.S. Geological Survey Professional Paper, 400-B, p. B104B107. 
Churkin, M., Jr., 1973, Paleozoic and Precambrian rocks of Alaska and their role in its structural evolution: U.S. Geological Survey Professional Paper 740, 64 p.

Churkin, M., Jr., and Eberlein, G. D., 1977a, Correlation of the rocks of southeastern Alaska with other parts of the Cordillera, in Blean, K. M., ed., The United States Geological Survey in Alaska: Accomplishments during 1976: U.S. Geological Survey Circular 751-B, p. B69B72.

Churkin, M., Jr., and Eberlein, G. D., 1977b, Ancient borderland terranes of the North American Cordillera: Correlation and microplate tectonics: Geological Society of America Bulletin, v. 88, no. 6, p. 769-786.

City and Borough of Sitka, 1995, February, Draft comprehensive plan, $21 \mathrm{p}$.

Cobb, E. H., 1972a, Metallic mineral resources map of the Juneau quadrangle, Alaska: U.S. Geological Survey Miscellaneous Field Studies Map MF-435, scale $1: 250,000$.

Cobb, E. H., 1972b, Metallic mineral resources map of the Mount Fairweather and Skagway quadrangles, Alaska: U.S. Geological Survey Miscellaneous Field Studies Map MF-436, scale 1:250,000.

Cobb, E. H., 1972c, Metallic mineral resources map of the Port Alexander quadrangle, Alaska: U.S. Geological Survey Miscellaneous Field Studies Map MF-464, scale 1:250,000.

Cobb, E. H., 1972d, Metallic mineral resources map of the Sitka quadrangle, Alaska: U.S. Geological Survey Miscellaneous Field Studies Map MF-467, scale 1:250,000.

Cobb, E. H., 1978a, Summary of references to mineral occurrences (other than mineral fuels and construction materials) in the Juneau quadrangle: U.S. Geological Survey Open-File Report 78-374, 156 p.

Cobb, E. H., 1978b, Summary of references to mineral occurrences (other than mineral fuels and construction materials) in the Mt. Fairweather and Skagway quadrangles: U.S. Geological Survey Open-File Report 78-316, 128 p.

Cobb, E. H., 1978c, Summary of references to mineral occurrences (other than mineral fuels and construction materials) in the Port Alexander quadrangle: U.S. Geological Survey Open-File Report 78-787, 33 p.

Cobb, E. H., 1978d, Summary of references to mineral occurrences (other than mineral fuels and construction materials) in the Sitka quadrangle: U.S. Geological Survey Open-File Report 78-450, 124 p.
Cobb, E. H., Wanek, A. A., Grantz, A., and Carter, C., 1968, Summary report on the geology and mineral resources of the Bering Sea, Bogoslof, Simeonof, Semidi, Tuxedni, St. Lazaria, Hazy Islands, and Forrester Island National Wildlife Refuge, Alaska: U.S. Geological Survey Bulletin 1260-K, p. K19-K21.

Coldwell, J. R., 1998, Economic feasibility of mining in the Chichagof and Baranof Islands area, southeast Alaska: U. S. Bureau of Land Management - Alaska Open File Report 668, $20 \mathrm{p}$.

Cornwall, H. R., 1966, Nickel deposits of North America: U.S. Geological Survey Bulletin 1223, p. 36-39.

Cornwall, H. R., 1973, Nickel, in Brobst, D. A., and Pratt, W. P., eds., United States mineral resources: U.S. Geological Survey Professional Paper 820, 440 p.

Coulter, H. W., Hopkins, D. M., Karlstrom, T. N. V., Pewe, T. L., Wahrhaftig, C., and Williams, J. R., 1965, Map showing extent of glaciations in Alaska: U.S. Geological Survey Miscellaneous Investigation Map I415,1 sheet, scale 1:2,500,000.

Dadoly, J. P., 1987, Gold mineralization in a regional metamorphic terrane: A wall-rock alteration study of the Chichagof and Hirst-Chichagof gold mines, southeast Alaska: Unpublished M. S. thesis, South Dakota School of Mines, Rapid City, SD, 125 p.

Dahlin, D. C., Rule, A. R., and Brown, L. L., 1981, Beneficiation of potential platinum resources from southeastern Alaska: U. S. Bureau of Mines Report of Investigations $8553,14 \mathrm{p}$.

Davis, J. S., 1996, Tectonic significance of constrictional finite strains in the Chugach accretionary complex, Baranof Island, S.E. Alaska [abs.]: Geological Society of America Abstracts with Programs, v. 28, no. 7, p. A-187.

DeArmond, R. N., 1986, From Sitka's Past; Notes and comments by Robert N. DeArmond: Daily Sitka Sentinel, no.'s 33-36, 47-50.

DeArmond, R. N., 1992, The Chichagof discovery, in From Sitka's past; Notes and comments by Robert N. DeArmond: Daily Sitka Sentinel, no.'s 256-260, March-April, 1992.

DeArmond, R. N., 1995, Billy Millmore's Basin, in Around and about Alaska; Notes and comments by Robert N. DeArmond: Daily Sitka Sentinel, 3 articles, January, 1995.

DeArmond, R. N., 1997a, Haleys and Silver Bay, in Around and about Alaska; Notes and comments by Robert N. DeArmond: Daily Sitka Sentinel, series of 29 articles, April to October, 1997. 
DeArmond, R. N., 1997b, Pande Basin, in Around and about Alaska; Notes and comments by Robert $\mathrm{N}$. DeArmond: Daily Sitka Sentinel, 4 articles, March to April, 1997.

Decker, J. E., 1979, Preliminary aeromagnetic map of southeastern Alaska: U.S. Geological Survey OpenFile Report 79-1694, 1 sheet, scale 1:1,000,000.

Decker, J. E., 1980a, Geologic map of western Chichagof Island, southeastern Alaska: U.S. Geological Survey Open-File Report 80-150, 2 sheets, scale 1:63,360.

Decker, J. E., 1980b, Geology of a Cretaceous subduction complex, western Chichag of Island, southeastern Alaska: Unpublished Ph.D. thesis, Stanford Univ., Stanford, CA, $134 \mathrm{p}$.

Decker, J. E., 1982a, Geochemical signature of the Goon Dip Greenstone on Chichagof Island, southeastern Alaska, in Short notes on Alaskan geology, 1981: Alaska Division of Geological and Geophysical Surveys Geology Report 73, p. 29-36.

Decker, J. E., 1982b, Sandstone petrography and subduction zone metamorphism of Upper Cretaceous trench turbidites, Chichagof Island, southeastern Alaska [abs.]: Geological Society of America Abstracts with Programs, v. 14, no. 4, p 159.

Decker, J. E., 1987, Petrogenesis of Upper Cretaceous trench deposits, Chichagof Island, southeast Alaska [abs.]: Society of Economic Paleontologists and Mineralogists, Fourth Annual Midyear Meeting, Austin, TX, p. 19.

Decker, J. E., and Johnson, B. R., 1981, The Nature and position of the Border Ranges Fault on Chichagof Island, in Albert, N. R. D., and Hudson, T., eds., The United States Geological Survey in Alaska: Accomplishments during 1979: U.S. Geological Survey Circular 823-B, p. B102-B104.

Decker, J. E., Mullen, M. W., and Schwab, C. E., 1981, Aeromagnetic profile map of southeastern Alaska: U.S. Geological Survey Open-File Report 81-505, 1 sheet, scale $1: 1,000,000$.

Decker, J. E., Nilsen, T. H., and Karl, S., 1979, Turbidite facies of the Sitka Graywacke, southeastern Alaska, in Johnson, K. M., and Williams, J. R., eds., The United States Geological Survey in Alaska: Accomplishments during 1978: U.S. Geological Survey Circular 804-B, p. B125-B129.

Decker, J. E., and Plafker, G., 1982, Correlation of rocks in the Tarr Inlet Suture Zone with the Kelp Bay Group, in Coonrad, W. L., ed., The United States Geological Survey in Alaska: Accomplishments during 1980: U.S. Geological Survey Circular 844, p. 119-124.
Decker, J. E., Wilson, F. H., and Turner, D. L., 1980, MidCretaceous subduction event in southeastern Alaska [abs.]: Geological Society of America Abstracts with Programs, v. 12, no. 3, p. 103.

Decker, P. A., 1931, E. B. Sparling's Haywire Group, Chichagof Island, Alaska: Unpublished report, 5 p., available from BLM, Juneau, AK.

Dickey, C. F., and Karl, S. M., 1988, Geological bibliography of the Sitka quadrangle, southeastern Alaska: U.S. Geological Survey Open-File Report 88$645,36 \mathrm{p}$.

Dusel-Bacon, C., 1994, Metamorphic history of Alaska, in Plafker, G., and Berg, H. C., eds., The geology of Alaska: Boulder, Colorado, Geological Society of America, The Geology of North America, v. G-1, p. 495-533.

Eakins, G. R., 1968, Uranium in Alaska: Alaska Division of Mines and Geology Geologic Report 38, p. 25.

Eakins, G. R., 1975, Uranium investigations in southeastern Alaska: Alaska Division of Geological and Geophysical Surveys Geologic Report 44, p. 22-28.

East, J. H., Jr., (1940's), High lights of Yakobi Island, Alaska: Unpublished report, 21 p., appendix, diagrams, photographs, available from BLM, Juneau, AK.

East, J. H., Jr., (1940's), Interim report, Bohemia Basin nickel deposit, Yakobi Island, Alaska, Project 504: Unpublished report, 9 p., available from BLM, Juneau, $\mathrm{AK}$.

East, J. H., Traver, W. S., Sanford, R. S., and Wright, W. S., 1948, Yakobi Island nickel deposit, Sitka Mining District, Alaska: U. S. Bureau of Mines Report of Investigations $4182,28 \mathrm{p}$.

Emerson, B. K., Palache, C., Dall, W. H., Ulrich, E. O., and Knowlton, F. H., 1910, Geology and paleontology, Harriman Alaska Expedition, 1899: Harriman Alaska Series, Smithsonian Institute, Washington, D. C., p. 18, 19, 44-48, 92.

Fiedler, H. L., 1941a, Report to the Commissioner of Mines on the inspection of the Chichagof Mining Company, Chichagof, Klag Bay, Alaska: Unpublished report, 6 p., available from BLM, Juneau, AK.

Fiedler, H. L., 1941b, Report to the Commissioner of Mines on the inspection of the Hirst-Chichag of Mining Company, Kimshan Cove, Alaska: Unpublished report, 16 p., available from BLM, Juneau, AK.

Fisher, R. B., Thorne, R. L., and Van Cott, C., 1945, Paligorskite: A possible asbestos substitute: U. S. Bureau of Mines Information Circular 7313, 5 p. 
Fleming, E. E., 1917, Alaska Nickel property, Chichagof: Unpublished report, 9 p., available from BLM, Juneau, AK.

Flint, Jr., G. M., and Cobb, E. H., 1953, Gypsum deposits near Iyoukeen Cove, Chichagof Island, southeastern Alaska, in Mineral resources of Alaska 1951-53: U.S. Geological Survey Bulletin 989-B, p. 27-37.

Foley, J. Y., 1989, Snipe Bay copper-nickel-cobalt deposits: Unpublished U. S. Bureau of Mines Field Report, 19 p., available from BLM, Juneau, AK.

Foley, J. Y., Light, T. D., Nelson, S. W., and Harris, R. A., 1997, Mineral occurrences associated with maficultramafic and related alkaline complexes in Alaska, in Goldfarb, R. J., and Miller, L. D., eds., Mineral deposits of Alaska: Economic Geology Monograph 9, p. 396-449.

Ford, A. B., and Brew, D. A., 1993, Geochemical character of Upper Paleozoic and Triassic greenstone and related metavolcanic rocks of the Wrangellia terrane in northern southeastern Alaska, in Dusel-Bacon, C., and Till, A., eds., Geological studies in Alaska by the U.S. Geological Survey, 1992: U.S. Geological Survey Bulletin 2068, p. 197-217.

Ford, A. B., Brew, D. A., and Koch, R. D., 1989, Alkalic plutonism of the Sitkoh Bay area (Chichagof Island), SE Alaska - Perplexities of age relations [abs.]: EOS (American Geophysical Union Transactions), v. 71, no. 434, p. 1699.

Ford, A. B., Brew, D. A., and Loney, R. A., 1990, The Sitkoh Bay alkalic plutonic suite: Silurian or older alkalic magmatism on eastern Chichagof Island, southeastern Alaska: U.S. Geological Survey OpenFile Report 90-297, 41 p.

Ford, A. B., Karl, S. M., Duttweiler, K. A., Sutphin, D. M., Finn, C. A., and Brew, D. A., 1989, Sitka quadrangle, Alaska - An AMRAP preassessment planning document: U.S. Geological Survey Administrative Report, $92 \mathrm{p}$.

Fowler, H. M., 1950, Report of investigations by Howard M. Fowler, Associate Mining Engineer, Territorial Dept. of Mines in the Hyder, Ketchikan, Wrangell, Petersburg, Juneau, Sitka, and Skagway Precincts, May 24 to November 10, 1950: AK Territorial Dept. of Mines Itinerary Report 195-6, 29 p.

Fukuhara, C. R., 1986, Descriptions of plutons in the western part of the Juneau and parts of the adjacent Skagway 1:250,000 quadrangles, southeastern Alaska: U.S. Geological Survey Open-File Report 86-393, p. 113.

Gates, G. O., (1940's), Notes on certain chromite deposits in Alaska: Unpublished report, 10 p., available from BLM, Juneau, AK.
Gehrels, G. E., and Berg, H. C.,1984, Geologic map of southeastern Alaska: U.S. Geological Survey OpenFile Report 84-886, 28 p., 1 sheet, scale 1:600,000.

Gehrels, G. E., and Berg, H. C.,1988, A review of the regional geology and tectonics of southeastern Alaska: U.S. Geological Survey Open-File Report 88-659, 24 p., 1 sheet.

Gehrels, G. E., and Berg, H. C., 1992, Geologic map of southeastern Alaska: U.S. Geological Survey Miscellaneous Investigation Map I-1867, 24 p., 1 sheet, scale 1:600,000.

Gehrels, G. E., and Berg, H. C., 1994, Geology of southeastern Alaska, in Plafker, G., and Berg, H. C., eds., The geology of Alaska: Boulder, Colorado, Geological Society of America, The Geology of North America, v. G-1, p. 451-467.

Gehrels, G. E., and Saleeby, J. B., 1987, Geologic framework, tectonic evolution, and displacement history of the Alexander terrane: Tectonics, v. 6, no. 2, p. 151-173.

Geist, D. J., Myers, J. D., and Frost, C. D., 1988, Megacryst-bulk rock isotopic disequilibrium as an indicator of contamination process: The Edgecumbe volcanic field, southeastern Alaska: Contributions to Mineralogy and Petrology, v. 99, no. 1, p. 105-112.

Gnagy, W. L., 1962, Some notes on, and a tentative summary of the genesis of the gypsum deposits at the Pacific Coast Mine, Gypsum Creek and Gypsum Camel, Iyoukeen Cove, Chichagof Island, southeast Alaska: Unpublished petrographic report, No. 2-43, U. $\mathrm{S}$. Bureau of Mines, 5 p., available from BLM, Juneau, AK.

Gnagy, W. L., 1969, Petrographic report of the U. S. Bureau of Mines on sample submitted by Donald $E$. MacDonald; Unpublished report, 1 p., available from BLM, Juneau, AK.

Golden Sitka Resources Inc., 1987, Prospectus, 36 p., available from BLM, Juneau, AK.

Goldfarb, R. J., 1997, Metallogenic evolution of Alaska, in Goldfarb, R. J., and Miller, L. D., eds., Mineral deposits of Alaska: Economic Geology Monograph 9, p. 4-34.

Goldfarb, R. J., Leach, D. L., and Pickthorn, 1988, Accretionary tectonics, fluid migration, and gold genesis in the Pacific Border Ranges and Coast Mountains, southern Alaska, in Kisvarsanyi, G., and Grant, S. K., eds., North American conference on tectonic control of ore deposits and the vertical and horizontal extent of ore systems: Proceedings volume, Rolla MO, University of Missouri - Rolla Special Publication, p. 67-79. 
Goldfarb, R. J., Miller, L. D., 1997, eds., Mineral Deposits of Alaska: Economic Geology Monograph 9, 482 p.

Goldfarb, R. J., Miller, L. D., Leach, D. L., and Snee, L. W., 1997, Gold deposits in metamorphic rocks of Alaska, in Goldfarb, R. J., and Miller, L. D., eds., Mineral deposits of Alaska: Economic Geology Monograph 9, p. 151-190.

Goldfarb, R. J., Snee, L. W., and Pickthorn, W. J., 1993, Orogenesis, high- $\mathrm{T}$ thermal events, and gold vein formation within metamorphic rocks of the Alaskan Cordillera: Mineralogical Magazine, v. 57, p. 375394.

Guild, P. W., and Balsley, J. R., 1942, Chromite deposits of Red Bluff Bay and vicinity, Baranof Island, Alaska: U.S. Geological Survey Bulletin 936-G, p. 171-178.

Gustafson, F. D., 1946, Preliminary report on the geology of Camel Gypsum, Alaska: AK Territorial Dept. of Mines Miscellaneous Report 114-6, 5 p.

Haeussler, P. J., Bradley, D., Goldfarb, R., Snee, L., and Taylor, C., 1995, Link between ridge subduction and gold mineralization in southern Alaska: Geology, v. 23, no. 11, p. 995-998.

Haeussler, P. J., Davis, J. S., Roeske, S. M., and Karl, S. M., 1994, Late Mesozoic and Cenozoic faulting at the leading edge of North America, Chichagof and Baranof Islands, southeastern Alaska [abs.]: Geological Society of America Abstracts with Programs, v. 26, no. 7, p. A-317.

Haeussler, P. J., Karl, S. M., and Bradley, D. C., 1996, Oblique accretion of part of the Mesozoic Kelp Bay Group in southeastern Alaska [abs.]: Geological Society of America Abstracts with Programs, v. 28, no. 7, p. A-437.

Healy, R. L., 1918, Report on the Alaska Nickel Mines, Sitka Mining District, southeastern Alaska: Unpublished report, 15 p., available from BLM, Juneau, AK.

Hedderly-Smith, D. A., 1990, Report of the 1989 field season - Sealaska minerals reconnaissance project: Unpublished report, p. 40-44, Sealaska Corporation, Juneau, AK.

Herbert, C. F., and Race, W. H., 1965, Geochemical investigations of selected areas in southeastern Alaska, 1964 and 1965: Alaska Division of Mines and Minerals Geochemical Report no. 6, p. 1-12, 37-46.

Heropoulos, C., and Mays, R. E., 1969, Semiquantitative spectrographic analyses of nine specimens from the Mount Edgecumbe volcanic field, Kruzof Island, southeastern Alaska: U.S. Geological Survey OpenFile Report 69-126, 3 p.
Herreid, G., 1962, Camel Gypsum property and Pacific Gypsum property, Sitka quadrangle: Alaska Division of Mines and Minerals Property Examination 114-14, 5 p., 1 map.

Hessin, T. D., 1982, Geochemical studies in the West Chichagof-Yakobi Wilderness, in Coonrad, W. L., ed., The United States Geological Survey in Alaska: Accomplishments during 1980: U.S. Geological Survey Circular 844, p. 135-136.

Hessin, T. D., and Crenshaw, G. L., 1982, Geochemical map showing the distribution and abundance of sulfate and fluoride in unfiltered water samples in the West Chichagof-Yakobi Wilderness study area, Sitka quadrangle, southeastern Alaska: U.S. Geological Survey Open-File Report 81-27-P, 1 sheet, scale 1:125,000

Hessin, T. D., and Day, G. W., 1982, Geochemical map showing the distribution and abundance of cobalt, chromium, and nickel in the nonmagnetic, heavymineral concentrate samples in the West ChichagofYakobi Wilderness study area, Sitka quadrangle, southeastern Alaska: U.S. Geological Survey OpenFile Report 81-27-T, 1 sheet, scale 1:125,000.

Hessin, T. D., Everman, W. K., and Crenshaw, G. L., 1982a, Geochemical map showing anomalous patterns for the element copper in stream sediments, filtered waters, and non-magnetic heavy-mineral concentrates in the West Chichagof Yakobi wilderness study area, Sitka quadrangle, southeastern Alaska: U.S. Geological Survey Open-File Report 81-27-O, 1 sheet, scale $1: 125,000$.

Hessin, T. D., Everman, W. K., and Crenshaw, G. L., 1982b, Geochemical map showing the distribution and abundance of copper, zinc, molybdenum, arsenic, and uranium in filtered water samples in the West Chichagof-Yakobi Wilderness study area, Sitka quadrangle, southeastern Alaska: U.S. Geological Survey Open-File Report 81-27-N, 1 sheet, scale $1: 125,000$.

Hessin, T. D., Everman, W. K., and Crenshaw, G. L., 1982c, Map showing stream-sediment samples in the West Chichagof-Yakobi Wilderness study area, Sitka quadrangle, southeastern Alaska: U.S. Geological Survey Open-File Report 81-27-M, I sheet, scale $1: 125,000$.

Hessin, T. D., and Hoffman, J. D., 1982, Geochemical map showing the distribution and abundance of cobalt, chromium, and nickel in stream-sediment samples in the West Chichagof-Yakobi Wilderness study area, Sitka quadrangle, southeastern Alaska: U.S. Geological Survey Open-File Report 81-27-R, 1 sheet, scale $1: 125,000$. 
Hessin, T. D., Maslowski, M. G., and Cooley, E. F., 1982d, Geochemical map showing the distribution and abundance of copper, lead, zinc, and barium in the nonmagnetic, heavy-mineral concentrate samples in the West Chichagof-Yakobi Wilderness study area, Sitka quadrangle, southeastern Alaska: U.S. Geological Survey Open-File Report 81-27-S, 1 sheet, scale $1: 125,000$.

Hessin, T. D., Maslowski, M. G., and Day, G. W., 1982e, Geochemical map showing the distribution and abundance of copper, lead, and barium in streamsediment samples in the West Chichagof-Yakobi Wilderness study area, Sitka quadrangle, southeastern Alaska: U.S. Geological Survey Open-File Report 8127-Q, 1 sheet, scale 1:125,000.

Hessin, T. D., Maslowski, M. G., and Day, G. W.,1982f, Geochemical map showing the distribution and abundance of silver, arsenic, gold, tin, and tungsten in the non-magnetic, heavy-mineral concentrate samples in the West Chichagof-Yakobi Wilderness study area, Sitka quadrangle, southeastern Alaska: U.S. Geological Survey Open-File Report 81-27-U, 1 sheet, scale 1:125,000.

Hessin, T. D., Speckman, W. S., Crenshaw, G. L., Hoffman, J. D., and Cooley, E. F., 1980, Analytical results of various types of samples taken in the West Chichagof-Yakobi Wilderness study area, Sitka quadrangle, southeastern Alaska: U.S. Geological Survey Open-File Report 80-905, 72 p.

Hillhouse, J. W., and Coe, R. S., 1994, Paleomagnetic data from Alaska, in Plafker, G., and Berg, H. C., eds., The geology of Alaska: Boulder, Colorado, Geological Society of America, The Geology of North America, v. G-1, p. 797-812.

Himmelberg, G. R., Loney, R. A., and Nabelek, P. I., 1987, Petrogenesis of gabbronorite at Yakobi and northwest Chichagof Islands, Alaska: Geological Society of America Bulletin v. 98, p. 265-270.

Holdsworth, P. R., 1953, Report of the Commissioner of Mines for the biennium ended December 31, 1952: AK Territorial Dept. of Mines, p. 19, 32, 33.

Holdsworth, P. R., 1955, Report of the Commissioner of Mines for the biennium ended December 31, 1954 : AK Territorial Dept. of Mines, p. 32, 33, 48, 49.

Holdsworth, P. R., 1957, Report of the Commissioner of Mines for the biennium ended December 31, 1956: AK Territorial Dept. of Mines, p. 15, 43-44, 47, 52, 68.

Holdsworth, P. R., 1959, Report of the Commissioner of Mines for the biennium ended December 31, 1958: AK Territorial Dept. of Mines, $83 \mathrm{p}$.
Holdsworth, P. R., and Williams, J. A., 1953, Magnetic investigations of chromite deposits at Red Bluff Bay, Baranof Island: AK Territorial Dept. of Mines Mineral Investigation 116-1, 2 p., 2 maps.

Holmes, G. L., 1941, Report on the Apex-El Nido Mine: Unpublished report, 20 p., available from BLM, Juneau, AK.

Hoskin, C. M., 1971, Biogenetic carbonate sediment from an intertidal encrusting community, Sitka Sound, Alaska [abs.]: Geological Society of America Abstracts with Programs, v. 3, no. 7, p. 604-605.

Hudson, T., 1979a, Calc-alkaline plutonism along the Pacific Rim of southern Alaska: U.S. Geological Survey Open-File Report 79-953, 31 p.

Hudson, T., 1979b, Mesozoic plutonic belts of southern Alaska: Geology, v. 7, no. 5, p. 230-234.

Hudson, T. L., 1994, Crustal melting events in Alaska, in Plafker, G., and Berg, H. C., eds., The geology of Alaska: Boulder, Colorado, Geological Society of America, The Geology of North America, v. G-1, p. 657-670.

Hudson, T., Dixon, K., and Plafker, G., 1982, Regional uplift in southeastern Alaska, in Coonrad, W. L., ed., The United States Geological Survey in Alaska: Accomplishments during 1980: U.S. Geological Survey Circular 844, p. 132-135.

Hudson, T., Plafker, G., and Dixon, K., 1982, Horizontal offset history of the Chatham Strait Fault, in Coonrad, W. L., ed., The United States Geological Survey in Alaska: Accomplishments during 1980: U.S. Geological Survey Circular 844, p. 128-132.

Humphrey, H. B., 1936a, Chichagof Mine: Unpublished U. $\mathrm{S}$. Bureau of Mines report, 5 p., available from BLM, Juneau, AK.

Humphrey, H. B., 1936b, Hirst-Chichag of Mine: Unpublished U. S. Bureau of Mines report, 7 p., available from BLM, Juneau, AK.

Humphrey, H. B., 1938, Improvements at Hirst-Chichagof Mine, Kimshan Cove, Alaska: Unpublished U. S. Bureau of Mines report, 3 p., available from BLM, Juneau, AK.

Jackson, G. T., 1918, Alaska Nickel Mines: Unpublished report, 3 p., available from BLM, Juneau, AK.

Jermain, G. D., and Rutledge, F. A., 1950, Diamond drilling the Gypsum-Camel prospect, Iyoukeen Cove, Chichagof Island, southeastern Alaska, confidential section: Unpublished U. S. Bureau of Mines report, 3 p., available from BLM, Juneau, AK.

Jermain, G. D., and Rutledge, F. A., 1952, Diamond drilling the Gypsum-Camel prospect, Iyoukeen Cove, Chichagof Island, southeastern Alaska: U. S. Bureau of Mines Report of Investigations 4852, $6 \mathrm{p}$. 
Jirik, R. S., 1982, Geology of the Takanis copper-nickelcobalt prospect, Yakobi Island, southeastern Alaska: Unpublished M. S. thesis, Washington State Univ., Pullman, WA, $182 \mathrm{p}$.

Johnson, B. R., and Elliott, G. S., 1984a, Map showing bedrock geochemical station locations, West Chichagof-Yakobi Islands Wilderness study area, southeastern Alaska: U.S. Geological Survey OpenFile Report 81-27-A, 1 sheet, scale 1:125,000.

Johnson, B. R., and Elliott, G. S., 1984b, Map showing the distribution and abundance of boron and beryllium in bedrock samples, West Chichagof-Yakobi Islands Wilderness study area, southeastern Alaska: U.S. Geological Survey Open-File Report 81-27-C, 1 sheet, scale $1: 125,000$.

Johnson B. R., and Elliot, G. S., 1984c, Map showing the distribution and abundance of cobalt in bedrock samples, West Chichagof-Yakobi Islands Wilderness study area, southeastern Alaska: U.S. Geological Survey Open-File Report 81-27-E, 1 sheet, scale $1: 125,000$.

Johnson B. R., and Elliot, G. S., 1984d, Map showing the distribution and abundance of copper in bedrock samples, West Chichagof-Yakobi Islands Wilderness study area, southeastern Alaska: U.S. Geological Survey Open-File Report 81-27-D, 1 sheet, scale 1:125,000.

Johnson, B. R., and Elliott, G. S., 1984e, Map showing the distribution and abundance of gold and silver in bedrock samples, West Chichagof-Yakobi Islands Wilderness study area, southeastern Alaska: U.S. Geological Survey Open-File Report 81-27-B, 1 sheet, scale $1: 125,000$.

Johnson B. R., and Elliot, G. S., 1984f, Map showing the distribution and abundance of lead in bedrock samples, West Chichagof-Yakobi Islands Wilderness study area, southeastern Alaska: U.S. Geological Survey OpenFile Report 81-27-H, 1 sheet, scale 1:125,000.

Johnson B. R., and Elliot, G. S., 1984g, Map showing the distribution and abundance of molybdenum, tin, and vanadium in bedrock samples, West Chichagof-Yakobi Islands Wilderness study area, southeastern Alaska: U.S. Geological Survey Open-File Report 81-27-F, 1 sheet, scale $1: 125,000$.

Johnson B. R., and Elliot, G. S., 1984h, Map showing the distribution and abundance of nickel and chromium in bedrock samples, West Chichagof-Yakobi lslands Wilderness study area, southeastern Alaska: U.S. Geological Survey Open-File Report 81-27-G, 1 sheet, scale $1: 125,000$.
Johnson B. R., and Elliot, G. S., 1984i, Map showing the distribution and abundance of scandium and yttrium in bedrock samples, West Chichagof-Yakobi Islands Wilderness study area, southeastern Alaska: U.S. Geological Survey Open-File Report 81-27-I, 1 sheet, scale $1: 125,000$.

Johnson B. R., and Elliot, G. S., 1984j, Map showing the distribution and abundance of strontium and lanthanum in bedrock samples, West ChichagofYakobi Islands Wilderness study area, southeastern Alaska: U.S. Geological Survey Open-File Report 8127-J, 1 sheet, scale 1:125,000.

Johnson B. R., and Elliot, G. S., 1984k, Map showing the distribution and abundance of zinc in bedrock samples, West Chichagof-Yakobi Islands Wilderness study area, Southeastern Alaska: U.S. Geological Survey OpenFile Report 81-27-K, 1 sheet, scale 1:125,000.

Johnson, B. R., and Karl, S. M.,1982, Reconnaissance geologic map of the West Chichagof and Yakobi Islands Wilderness study area, southeastern Alaska: U.S. Geological Survey Miscellaneous Field Studies Map MF- 1476, 1 sheet, scale 1:125,000.

Johnson, B. R., and Karl, S. M., 1985, Geologic map of western Chichagof and Yakobi Islands, southeastern Alaska: U.S. Geological Survey Miscellaneous Investigations Series Map I-1506, 1 sheet, scale $1: 125,000$.

Johnson, B. R., Kimball, A. L., and Still, J. C., 1982, Mineral resource potential of the Western Chichagof and Yakobi Islands Wilderness study area, southeastern Alaska: U.S. Geological Survey Miscellaneous Field Studies Map MF-1476-B, 10 p., 1 sheet, scale 1:125,000

Jones, D. L., Irwin, W. P., and Ovenshine, A. T., 1972, Southeastern Alaska - A displaced continental fragment?: U.S. Geological Survey Professional Paper 800-B, p. B211-B217.

Jones, D. L., Silberling, N. J., Coney, P. J., and Plafker, G., 1987, Lithotectonic terrane map of Alaska (west of 141st meridian): U.S. Geological Survey Miscellaneous Field Studies Map MF-1874-A, 1 sheet, scale $1: 2,500,000$.

Jones, D. L., Silberling, N. J., and Hillhouse, J., 1977, Wrangellia - A displaced terrane in northwestern North America: Canadian Journal of Earth Science, v. 14 , p. 2565-2577.

Karl, S. M., 1991, Regional geology of the Chichagof Mining District, southeastern Alaska [abs.]: Abstracts of Professional Papers, Conference Juneau, Alaska Miners Assoc., p. 12-13. 
Karl, S. M., Brew D. A., and Wardlaw, B. R., 1990, Significance of Triassic marble from Nakwasina Sound, southeastern Alaska, in Dover, J. H., and Galloway, J. B., eds., Geologic studies in Alaska by the U.S. Geological Survey in 1989: U.S. Geological Survey Bulletin 1946, p. 21-28

Karl, S. M., Decker, J. E., and Johnson, B. R., 1982,

Discrimination of Wrangellia and the Chugach terrane in the Kelp Bay Group on Chichagof and Baranof Islands, southeastern Alaska, in Coonrad, W. L., ed., The United States Geological Survey in Alaska: Accomplishments during 1980: U.S. Geological Survey Circular 844, p. 124-128.

Karl, S. M., and Giffen, C. F., 1992, Sedimentology of the Bay of Pillars and Point Augusta Formations, Alexander Archipelago, Alaska: U.S. Geological Survey Bulletin 2041, p. 171-185.

Karl, S. M., Goldfarb, R. J., Kelley, K. C., Sutphin, D. M., Finn, C. A., Ford, A. B., and Brew, D. A., Mineralresource potential of the Sitka $1^{\circ} \times 3^{\circ}$ quadrangle, southeastern Alaska: U.S. Geological Survey Circular 1062, p. 45-46.

Karl, S. M., and Hunt, S. J., 1983, Stratigraphy and turbidite facies associations in the Bay of Pillars Formation, southeastern Alaska, in New developments in the Paleozoic geology of Alaska and the Yukon: Alaska Geological Society Symposium Proceedings, Anchorage, AK, p. 18.

Karl, S. M., Johnson, B. R., and Lanphere, M. A., 1988, New K-Ar ages for plutons on western Chichagof Island and Yakobi Island, in Galloway, J. P., and Hamilton, T. D., eds., Geologic studies in Alaska by the U.S. Geological Survey during 1987: U.S. Geological Survey Circular 1016, p. 164-168.

Kaufman, A., 1958, Southeastern Alaska's mining industry: U. S. Bureau of Mines Information Circular 7844, p. 7 , $12,13$.

Kazee, H. M., 1941, Hirst-Chichagof Mining Company: Unpublished report, 10 p., available from BLM, Juneau, AK.

Kennedy, G. C., 1944, Summary of geological survey results in connection with Bureau of Mines investigation of the nickel-copper deposits of Bohemia Basin, Yakobi Island, southeastern Alaska: Unpublished report, 22 p., available from BLM, Juneau, AK.

Kennedy G. C., and Walton, M. S., 1946a, Geology and associated mineral deposits of some ultrabasic rock bodies in southeastern Alaska: U.S. Geological Survey Bulletin 947-D, p. 65-84.
Kennedy G. C., and Walton, M. S., 1946b, Nickel investigations in southeast Alaska: U.S. Geological Survey Bulletin 947-C, p. 39-64.

Kerr, P. F., 1924, A magmatic sulphide ore from Chichagof Island, Alaska: Economic Geology, v. 19, no. 4, p. 369-376.

Kimball, A. L., 1982, Mineral land assessment of Yakobi Island and adjacent parts of Chichag of Island, southeastern Alaska: U. S. Bureau of Mines Mineral Land Assessment report, MLA 97-82, 199 p.

Knopf, A., 1910, Mining in southeastern Alaska, in Mineral resources of Alaska - Report on progress of investigations in 1909: U.S. Geological Survey Bulletin 442-D, p. 139.

Knopf, A., 1911, Mining in southeastern Alaska, in Mineral resources of Alaska - Report on progress of investigations in 1910: U.S. Geological Survey Bulletin 480-E, p. 98.

Knopf, A., 1912, The Sitka Mining District, Alaska: U.S. Geological Survey Bulletin 504, 32 p.

Kosco, D. G., 1981a, The Mount Edgecumbe volcanic field, Alaska: An example of tholeiitic and calc-alkaline volcanism: Journal of Geology, v. 89, no. 4, p. 459477.

Kosco, D. G., 1981b, The Mount Edgecumbe volcanic field, Alaska: An example of tholeiitic and calcalkaline volcanism (part I); Characteristics of andesitic to dacitic volcanism at Katmai National Park, Alaska (part II): Ph.D. thesis, Univ. of California, Berkeley, CA, $249 \mathrm{p}$.

Kuhn, J. G., 1978, Facts concerning copper-nickel-cobalt deposits on Yakobi Island: Company release, April 3, 3 p., available from BLM, Juneau, AK.

Laney, F. B., 1942, A report of a mineralogical examination of a suite of nickel ores from the Alaska Nickel Mines, near Sitka, Alaska: AK Territorial Dept. of Mines Miscellaneous Report 114-5, 7 p.

Lanphere, M. A., Loney, R. A., and Brew, D. A., 1965, Potassium-argon ages of some plutonic rocks, Tenakee area, Chichagof Island, southeastern Alaska: U.S. Geological Survey Professional Paper 525-B, p. B108B111.

Lathram, E. H., 1964, Apparent right-lateral separation on Chatham Strait Fault, southeastern Alaska: Geological Society of America Bulletin, v. 75, no. 3, p. 249-252.

LKB Resources, Inc., 1979, NURE aerial gamma-ray and magnetic reconnaissance survey, southeastern areaAlaska, Vol. I, II: Work performed under subcontract to Bendix Field Engineering Corp., Grand Junction, CO for the U. S. Dept. of Energy, ca. 280 p., app: Microfilm Record Listings, illus. GJBX-48. 
Loney, R. A., Berg, H. C., Pomeroy, J. S., and Brew, D. A., 1963, Reconnaissance geologic map of Chichagof Island and northwestern Baranof Island, Alaska: U.S. Geological Survey Miscellaneous Geologic

Investigations Map I-388, 1 sheet, scale 1:250,000.

Loney, R. A., and Brew, D. A., 1987, Regional thermal metamorphism and deformation of the Sitka Graywacke, southern Baranof Island, southeastern Alaska: U.S. Geological Survey Bulletin 1779, 17 p.

Loney, R. A., Brew, D. A., and Lanphere, M. A., 1967, Post-Paleozoic radiometric ages and their relevance to fault movements, northern southeastern Alaska: Geological Society of America Bulletin, v. 78, p. 511526.

Loney, R. A., Brew, D. A., Muffler, L. J. P., and Pomeroy, J. S., 1975, Reconnaissance geology of Chichagof, Baranof, and Kruzof Islands, southeastern Alaska: U.S. Geological Survey Professional Paper 792, 105 p.

Loney, R. A., Condon, W. H., and Dutro, J. T., Jr., 1962, Geology of the Freshwater Bay area, Chichagof Island, Alaska: U.S. Geological Survey Bulletin 1108-C, 54 p.

Loney, R. A., Pomeroy, J. S., Brew, D. A., and Muffler, L. J. P., 1964, Reconnaissance geologic map of Baranof and Kruzof Islands, Alaska: Miscellaneous Geologic Investigations Map I-411, 1 sheet, scale 1:250,000.

Maas, K. M., Bittenbender, P. E., and Still, J. C., 1996, Mineral investigations on Baranof and Chichagof Islands, and vicinity, southeast Alaska, 1995: U. S. Bureau of Land Management - Alaska Open File Report 60, $112 \mathrm{p}$.

MacKevett, E. M., Gardner, M. C., Bergman, S. C., Cushing, G., and McClelland, W. D., 1986, Geological evidence for Late Pennsylvanian juxtaposition of Wrangellia and Alexander terrane, Alaska [abs.]: Geological Society of America Abstracts with Programs, v. 18, no. 2, p. 128.

MacKevett, E. M., Jr., and Plafker, G., 1974, The Border Ranges Fault in south-central Alaska: U.S. Geological Survey Journal of Research, v. 2, no. 3, p. 323-329.

Maloney, W., 1916, Report of Territorial Mine Inspector to the Governor of Alaska for the year 1915: AK Territorial Dept. of Mines, p. 5, 8, 29.

Maloney, W., 1918, Report of Territorial Mine Inspector to the Governor of Alaska for the year 1917: AK Territorial Dept. of Mines, p. 17-18.

Martin, G. C., 1919, The Alaska mining industry in 1917 , in Mineral resources in Alaska - Report on progress of investigations in 1917: U.S. Geological Survey Bulletin 692-B, p. 22-23, 30.
Martin, G. C., 1920, The Alaska Mining Industry in 1918, in Mineral resources in Alaska - Report on progress of investigations in 1918: U.S. Geological Survey Bulletin 712-B, p. 27, 30.

Martin, G. C., 1926, Mesozoic stratigraphy of Alaska: U.S Geological Survey Bulletin 776, p. 260, 261.

McClelland, W. C., and Gehrels, G. E., 1987, Evidence of Early-Middle Jurassic deformation and metamorphism along the inboard margin of the Alexander terrane, SE Alaska [abs.]: Geological Society of America Abstracts with Programs, v. 19, no. 7, p. 764.

McPhar Geophysics Limited, 1961, Report on geophysical investigations in the Chichagof area, Alaska, for Baranof Exploration \& Development Co., Inc.: AK Territorial Dept. of Mines Miscellaneous Report 114-8, 9 p., 7 maps.

Metz, P. A., 1978, Chichag of and Hirst-Chichagof Mines, Chichagof Mining District, Alaska: U. S. Bureau of Mines Summary Report, $19 \mathrm{p}$.

Miller, T. P., 1994, Geothermal resources of Alaska, in Plafker, G., and Berg, H. C., eds., The geology of Alaska: Boulder, Colorado, Geological Society of America, The Geology of North America, v. G-1, p. 979-987.

Moerlein, G. A., 1971, Geology, geophysics, and geochemistry, Mt. Baker Copper prospect, Alaska: Unpublished report, 6 p., 4 maps, available from BLM, Juneau, AK.

Moffit, F. H., 1927, Mineral industry in Alaska in 1925, in Mineral resources in Alaska - Report on progress of investigations in 1925: U.S. Geological Survey Bulletin 792-A, p. 10, 38.

Moll-Stalcup, E., Brew, D. A., and Vallier, T. L., 1994, Latest Cretaceous and Cenozoic magmatic rocks of Alaska, in Plafker, G., and Berg, H. C., eds., The geology of Alaska: Boulder, Colorado, Geological Society of America, The Geology of North America, v. G-1, 1 sheet, scale 1:2,500,000.

Monger, J. W. H., and Berg, H. C., 1987, Lithotectonic terrane map of western Canada and southeastern Alaska: U.S. Geological Survey Miscellaneous Field Studies Map MF-1874-B, 12 p., 1 sheet, scale $1: 2,500,000$.

Motyka, R. J., and Moorman, M. A., 1987, Geothermal resources of southeastern Alaska: Alaska Division of Geological and Geophysical Surveys Professional Report 93, 1 sheet, scale 1:1,000,000.

Motyka, R. J., Moorman, M. A., and Reeder, J. W., 1980, Assessment of thermal springs sites in southern southeastern Alaska - Preliminary results and evaluation: Alaska Division of Geological and Geophysical Surveys Open-File Report 127, 72 p. 
Myers, J. D., 1979, Geology and petrology of the

Edgecumbe volcanic field, southeastern Alaska:

Transform fault volcanism and magma mixing: Ph.D. thesis, The Johns Hopkins Univ., Baltimore, MD, 205 p.

Myers, J. D., and Marsh, B. D., 1981, Geology and petrogenesis of the Edgecumbe volcanic field, SE Alaska: The interaction of basalt and sialic crust: Contributions to Mineralogy and Petrology, v. 77, no. 3 , p. 272-287.

Nelson, E. G., 1942(?), Chromite at Red Bluff Bay: Unpublished report, 4 p., available from BLM, Juneau, AK.

Nelson, G. E., 1931 a, Report on McKallick prospect, Smith Group, Anderson-Pearce Group, Ora Group, Basoinieur Group, Radio Group, and notes on Chichagof Gold Mining Company property on Chichagof Island, Alaska: Unpublished report, $6 \mathrm{p}$., available from BLM, Juneau, AK.

Nelson, G. E., 1931b, Report on the Green Lake Group and the Apollo Group: Unpublished report, 3 p., 1 map, available from BLM, Juneau, AK.

Nelson, G. E., 1932, The Helen Group, Chichagof, Alaska: Unpublished report, 3 p., 1 map, available from BLM, Juneau, AK.

Nelson, G. E., 1936, Report on New Chichagof Mining Syndicate, Pinta Bay, west coast of Chichag of Island, southeast Alaska: Unpublished report, 2 p., available from BLM, Juneau, AK.

Noel, G. A., 1967, The productive mineral deposits of southeastern Alaska: Alaska Division of Mines and Minerals, 1966 Annual Report, p. 53, 54, 61, 63, 65.

Nokleberg, W. J., Brew, D. A., Grybeck, D., Yeend, W., Bundtzen, T. K., Robinson, M. S., and Smith, T. E., 1994, Metallogeny and major mineral deposits of Alaska, in Plafker, G., and Berg, H. C., eds., The geology of Alaska: Boulder, Colorado, Geological Society of America, The Geology of North America, v. G-1, p. 855-903.

Nokleberg, W. J., Bundtzen, T. K., Berg, H. C., Brew, D. A., Grybeck, D., Robinson, M. S., Smith, T. E., and Yeend, W., 1994, Metallogenic map of significant metalliferous lode deposits and placer districts in Alaska, in Plafker, G., and Berg, H. C., eds., The geology of Alaska: Boulder, Colorado, Geological Society of America, The Geology of North America, v. G-1, 1 sheet, scale $1: 2,500,000$.

Nokleberg, W. J., Bundtzen, T. K., Berg, H. C., Grybeck, D., Robinson, M. S., Smith, T. E., and Yeend, W., 1987, Significant metalliferous lode deposits and placer districts in Alaska: U.S. Geological Survey Bulletin 1786, 104 p.
Nokleberg, W. J., Bundtzen, T. K., Berg, H. C., Grybeck, D., Robinson, M. S., Smith, T. E., and Yeend, W., 1988, Metallogeny and major mineral deposits of Alaska: U.S. Geological Survey Open-File Report 8873, 97 p., 2 sheets, scale 1:5,000,000.

Nokleberg, W. J., Bundtzen, T. K., Dawson, K. M. Eremin, N. A., Goryachev, N. A., Koch, R. D., Ratkin, V. V., Rozenblum, I. S., Shpikerman, V. I., Frolov, Y. F., Gorodinsky, M. E., Melnikov, V. D., Diggles, M. F., Ognyanov, N. V., Petrachenko, E. D., Petrachenko, R. I., Pozdeev, A. I., Ross, K. V., Wood, D. H., Grybeck, D., Khanchuk, A. I., Kovbas, L. I., Nekrasov, I. Y., and Sidorov, A. A., 1997, Significant metalliferous and selected non-metalliferous lode deposits and placer districts for the Russian Far East, Alaska, and the Canadian Cordillera: U.S. Geological Survey Open-File Report 9-513-A (paper copy), 96513-B (CD-ROM).

Northern Miner, 1988, Golden Sitka busy at Chichagof: Northern Miner, v. 74, no. 24, p. 6.

Ovenshine, A. T., and Brew, D. A., 1972, Separation and history of the Chatham Strait Fault, southeast Alaska, North America: Proceedings of the 24th International Geological Congress, Sec. 3, p. 245-254.

Overbeck, R. M., 1919, Geology and mineral resources of the west coast of Chichag of Island: U.S. Geological Survey Bulletin 692-E, p. 91-136.

Overstreet, W. C., 1967, The geologic occurrence of monazite: U.S. Geological Survey Professional Paper 530, p. $108,109$.

Page, R., 1972, The Sitka, Alaska earthquake of 1972 - An unexpected visitor: Earthquake Information Bulletin v. 5 , no. 5 , p. 4-9.

Panuska, B. C., 1984, Paleomagnetism of the Wrangellia and Alexander terranes and the tectonic history of southern Alaska: Unpublished Ph.D. thesis, Univ. of AK Fairbanks, Fairbanks, AK, 197 p.

Patton, W. W., Box, S. E., and Grybeck, D. J., 1994 , Ophiolites and other mafic-ultramafic complexes in Alaska, in Plafker, G., and Berg, H. C., eds., The geology of Alaska: Boulder, Colorado, Geological Society of America, The Geology of North America, v. G-1, p. 671-686.

Pecora, W. T., 1942, Nickel-copper deposits on the west coast of Chichagof Island, Alaska: U.S. Geological Survey Bulletin 936-I, p. 221-243.

Pittman, T. L., 1963, Data summarizing sample results from the U. S. Bureau of Mines investigation of the Snipe Bay nickel-copper deposit: Unpublished, available from BLM, Juneau, AK. 
Plafker, G., and Berg, H. C., 1994, Overview of the geology and tectonic evolution of Alaska, in Plafker, G., and Berg, H. C., eds., The geology of Alaska: Boulder, Colorado, Geological Society of America, The Geology of North America, v. G-1, p. 989-1021.

Plafker, G., and Berg, H. C., 1994, eds., The Geology of Alaska: Boulder, Colorado, Geological Society of America, The Geology of North America, v. G-1, 1055 p., 13 plates.

Plafker, G., Jones, D. L., Hudson, T., and Berg, H. C., 1976, The Border Ranges fault system in the Saint Elias Mountains and Alexander Archipelago, in Cobb, E. H., ed., The United States Geological Survey: Accomplishments in Alaska in 1975: U.S. Geological Survey Circular 733, p. 14-16.

Plafker, G., Jones, D. L., and Pessagno, E. A., Jr., 1977, A Cretaceous accretionary flysch and melange terrane along the Gulf of Alaska margin, in Blean, K. M., ed., The United States Geological Survey in Alaska: Accomplishments during 1976: U.S. Geological Survey Circular 751-B, p. B41-B43.

Plafker, G., Moore, J. C., and Winkler, G. R., 1994, Geology of the southern Alaska margin, in Plafker, G ., and Berg, H. C., eds., The geology of Alaska: Boulder, Colorado, Geological Society of America, The Geology of North America, v. G-1, p. 389-449.

Pomeroy, J. S., 1964, Recognition criteria of igneous and metamorphic rocks on aerial photographs of Chichagof and Kruzof Islands, southeastern Alaska: U.S. Geological Survey Bulletin 1043-E, p. 87-110.

Racey, P. W., 1938, New Chichagof Mining Syndicate, Pinta Bay, Chichagof Island, Alaska: AK Territorial Dept. of Mines Miscellaneous Report 114-4, 4 p.

Ransome, A. L., and Kerns, W. H., 1954, Names and definitions of regions, districts, and subdistricts in Alaska: U. S. Bureau of Mines Information Circular 7679, $91 \mathrm{p}$.

Redman, E., 1989, Mining gypsum at Iyoukeen Cove: Unpublished report, 5 p., available from BLM, Juneau, AK.

Reed, J. C., 1938, Some mineral deposits of Glacier Bay and vicinity, Alaska: AK Territorial Dept. of Mines Miscellaneous Report 111-1, p. 75, 76, 79.

Reed, J. C., 1939, Preliminary report on the ore deposits of the Chichagof Mining District, Alaska: American Institute of Mining \& Metallurgy, Engineering Technical Publication 1051, $20 \mathrm{p}$.

Reed, J. C., and Coats, R. R., 1941, Geology and ore deposits of the Chichagof Mining District, Alaska: U.S. Geological Survey Bulletin 929, 148 p.
Reed, J. C., and Dorr, J. V. N., 1942, Nickel deposits of Bohemia Basin and vicinity, Yakobi Island, Alaska: U.S. Geological Survey Bulletin 931-F, p. 105-138.

Reed, J. C., and Gates, G. O., 1942, Nickel-copper deposits at Snipe Bay, Baranof Island, Alaska: U.S. Geological Survey Bulletin 936-M, p. 321-330.

Reifenstuhl, R. R., 1983, A geological and geophysical study of the Goddard Hot Springs area, Baranof Island, southeastern Alaska: M. S. thesis, Univ. of Alaska, Fairbanks, AK, 113 p., scale 1:25,000.

Reifenstuhl, R. R., 1984, The Crawfish Inlet Pluton, Baranof Island, southeastern Alaska - Anatexis or magmatic compositional evolution [abs.]: Geological Society of America Abstracts with Programs, v. 16, no. 5, p. 330.

Reifenstuhl, R. R., 1986, Geology of the Goddard Hot Springs Area, Baranof Island, southeastern Alaska: Alaska Division of Geological and Geophysical Surveys Public-Data File 86-2, 82 p., 1 sheet, scale 1:400,000. Ricker, S., 1941, Preliminary report and project set-up, Bohemia Basin Nickel, Yakobi Island, Alaska: Unpublished report, 16 p., available from BLM, Juneau, AK.

Riehle, J. R., and Brew, D. A., 1984, Explosive latest Pleistocene (?) and Holocene activity of the Mount Edgecumbe volcanic field, Alaska, in Reed, K. M., and Bartsch-Winkler, S., eds., The U.S. Geological Survey in Alaska: Accomplishments during 1982: U.S. Geological Survey Circular 939, p. 111-115.

Riehle, J. R., and Brew, D. A., 1987, Pyroclastic deposits of the Edgecumbe volcanic field, Kruzof Island, Alaska, and some speculations about their origin [abs.]: Hawaii Symposium on How Volcanoes Work, (Diamond Jubilee, 1912-1987), U.S. Geological Survey, Hawaii Volcano Observatory, Abstracts Vol., p. 210.

Riehle, J. R., Brew, D. A., and Lanphere, M. A., 1989, Geologic map of the Mount Edgecumbe volcanic field, Kruzof Island, southeastern Alaska: U.S. Geological Survey Miscellaneous Investigation Series Map I-1983, 1 sheet, scale 1:63,360.

Riehle, J. R., Budahn, J. R., Lanphere, M. A., and Brew, D. A., 1994, Rare earth element contents and multiple mantle sources of the transform-related Mount Edgecumbe basalts, southeastern Alaska: Canadian Journal of Earth Sciences, v. 31, p. 852-864.

Riehle, J. R., Champion, D. E., Brew, D. A., and Lanphere, M A., 1992, Pyroclastic deposits of the Mount Edgecumbe volcanic field, Alaska: Evolution of a stratified magma chamber: Journal of Volcanology and Geothermal Research, v. 53, p. 117-143. 
Roberts, W. S., 1983, Minerals Availability System property evaluation file report, Nickel, Snipe Bay, Alaska, Update of property evaluation report by Baggs, D. W.: Unpublished report of the U. S. Bureau of Mines, $13 \mathrm{p}$.

Robinson, M. S., and Decker, J., 1991, Turbidite hosted gold deposits -- An exploration model based on facies relationships [abs.]: Abstracts of Professional Papers, Conference Juneau, Alaska Miners Assoc., p. 5-6.

Roehm, J. C., 1936a, Investigations - Sitka Mining District, vicinities, Lisianski Inlet and west coast of Chichagof Island and itinerary of J. C. Roehm, Associate Engineer, to Commissioner of Mines, Territorial Dept. of Mines, Juneau, Alaska, June 29 to July 8, 1936: AK Territorial Dept. of Mines Itinerary Report 195-30, 11 p.

Roehm, J. C., 1936b, Preliminary report, Chichagof Creek Group, Klag Bay, Chichagof Island, Alaska July 5, 1936: AK Territorial Dept. of Mines Property Examination 114-4, 4 p., 2 maps.

Roehm, J. C., 1936c, Preliminary report of Alaska Gold Digger Group no. 2, Klag Bay, west coast Chichagof Island, July 8, 1936: AK Territorial Dept. of Mines Property Examination 114-6, 5 p., 3 maps.

Roehm, J. C., 1936d, Preliminary report of Goldwin Group, Lisianski Inlet, Chichagof Island, Sitka Mining District: AK Territorial Dept. of Mines Property Examination 114-2, 2 p.

Roehm, J. C., 1936e, Preliminary report of holdings of New Chichagof Mining Syndicate, Pinta Bay, Chichagof Island, July 3, 1936: AK Territorial Dept. of Mines Property Examination 114-3, 3 p., 2 maps.

Roehm, J. C., 1936f, Preliminary report of Lucky Strike prospect, Lisianski Inlet, Chichagof Island, Sitka Mining District, June 30, 1936: AK Territorial Dept. of Mines Property Examination 114-1, 2 p.

Roehm, J. C., 1936g, Preliminary report of Mike Wall prospect, Lake Ann, west coast Chichagof Island, Sitka Mining District, Alaska, July 7, 1936: AK Territorial Dept. of Mines Property Examination 114-5, 1 p.

Roehm, J. C., 1936h, Preliminary report, Slocum-Grunter (Cox-Holyan) prospect, Slocum Arm, Chichagof Island, Alaska, July 7, 1936: AK Territorial Dept. of Mines Property Examination 114-7, 5 p., 1 map.

Roehm,. J. C., 1938a, Preliminary report of Green Lake group of claims, Silver Bay, Sitka Precinct, Alaska, November 10, 1938: AK Territorial Dept. of Mines Property Examination 116-2, 2 p., 1 map.

Roehm, J. C., 1938b, Preliminary report of holdings of the Baranof Mining Company, Halleck Island, Sitka Precinct, Alaska: AK Territorial Dept. of Mines Property Examination 114-10, 2 pp, 1 map.
Roehm, J. C., 1938c, Preliminary report of Krestof group of claims, Krestof Island, Sitka Precinct, Alaska: AK Territorial Dept. of Mines Property Examination 11412, 4 p., 1 map.

Roehm, J. C., 1938d, Preliminary report of Little Blonde and High Grade Groups, Kruzof Island, Alaska: AK Territorial Dept. of Mines Property Examination 114$11,3 \mathrm{p}$.

Roehm, J. C., 1938e, Report of Bohemia Tunnel, Bohemia Basin, Yakobi Island, Alaska, April 23. 1938: AK Territorial Dept. of Mines Property Examination 1149, 2 p., 1 map.

Roehm, J. C., 1938f, Summary report of mining investigations in the Juneau and Sitka Mining Districts to B. D. Stewart, Commissioner of Mines and itinerary of J. C. Roehm, Associate Engineer, Territorial Dept. of Mines, October 26-30 and November 8-12, 1938: AK Territorial Dept. of Mines, Itinerary Report 195$20,3 \mathrm{p}$.

Roehm, J. C., 1938g, Summary report of mining investigations in the Sitka and Juneau Mining Districts, vicinities of Yakobi, Chichagof, Kruzof, Krestof, Halleck and Admiralty Islands and itinerary of J. C. Roehm, Associate Engineer, to Commissioner of Mines, Territorial Dept. of Mines, Juneau, Alaska, April 21 to 30, 1938: AK Territorial Dept. of Mines Itinerary Report 195-21, 12 p.

Roehm, J. C., 1940, Preliminary report of the Lucky Chance Mine, Baranof Island, Sitka Precinct, June 28, 1940: AK Territorial Dept. of Mines Property Examination 116-3, 5 p., 1 map.

Roehm, J. C., 1945, Strategic and critical mineral occurrences in southeastern Alaska: AK Territorial Dept. of Mines Miscellaneous Report 191-5, 118 p.

Roehm, J. C., 1947, Report of investigations by J. C. Roehm, Associate Mining Engineer, Territorial Dept. of Mines, in the Sitka Mining Precinct, Alaska: AK Territorial Dept. of Mines, Itinerary Report 195-42, 17 p., 1 map.

Rogers, J. C., 1917, Alaska Nickel Mines: Unpublished report, 7 p., available from BLM, Juneau, AK

Roppel, P., 1993, The gold at Rodman Bay: Alaska History, v. 8, no. 2, p. 21-35.

Rossman, D. L., 1959, Geology and ore deposits of northwestern Chichagof Island, Alaska: U.S. Geological Survey Bulletin 1058-E, p. 139-216.

Rossman, D. L., 1963, Geology of the eastern part of the Mount Fairweather quadrangle, Glacier Bay, Alaska: U.S. Geological Survey Bulletin 1121-K, 57 p. 
Rowan, E. L., Bailey, E. A., and Goldfarb, R. J., 1989, Geochemical orientation study for identification of metallic mineral resources in the Sitka quadrangle, southeastern Alaska: U.S. Geological Survey Bulletin 1950, p. B1-B12.

Ryason, D. J., 1961, Report on Mt. Baker Copper property: Alaska Division of Mines and Minerals Miscellaneous Report 114-11, 5 p., 1 map.

Saarela, L. H., 1951, Report of the Commissioner of Mines for the biennium ending December 31, 1950: AK Territorial Dept. of Mines, p. 11, 30.

Sainsbury, C. L., 1957, Some pegmatite deposits in southeastern Alaska: U.S. Geological Survey Bulletin 1024-G, p. 141-151.

Sanford, R. S., 1942, Preliminary report and project set-up, Mirror Harbor nickel deposits, Chichagof Island, Territory of Alaska: Unpublished report, 9 p., available from BLM, Juneau, AK.

Ship, C. B. P., and Shipman, E. M., 1938, Cobol prospect: Unpublished report, 14 p., available from BLM, Juneau, AK.

Silberling, N. J., Jones, D. L., Monger, J. W. H., Coney, P. J., 1992, Lithotectonic terrane map of the North American Cordillera: U.S. Geological Survey Miscellaneous Investigations Series Map I-2176, 2 sheets, scale 1:5,000,000.

Silberling, N. J., Jones, D. L., Monger, W. H., Coney, P. J., Berg, H. C., and Plafker, G., 1994, Lithotectonic terrane map of Alaska and adjacent parts of Canada, in Plafker, G., and Berg, H. C., eds., The geology of Alaska: Boulder, Colorado, Geological Society of America, The Geology of North America, v. G-1, 1 sheet, scale $1: 2,500,000$.

Smith, L. H., 1924, A geologic and economic sketch of Doolth Peninsula, west coast of Chichagof Island, Alaska: AK Territorial Dept. of Mines Miscellaneous Report 114-1, 6 p.

Smith, P. S., 1926, Mineral industry of Alaska in 1924, in Mineral resources of Alaska - Report on progress of investigations in 1924: U.S. Geological Survey Bulletin 783-A, p. 7, 26, 30.

Smith, P. S., 1929, Mineral industry of Alaska in 1926, in Mineral resources of Alaska - Report on progress of investigations in 1926: U.S. Geological Survey Bulletin 797-A, p. 10.

Smith, P. S., 1930a, Mineral industry of Alaska in 1927, in Mineral resources of Alaska - Report on progress of investigations in 1927: U.S. Geological Survey Bulletin 810-A, p. 12.
Smith, P. S., 1930b, Mineral industry of Alaska in 1928, in Mineral resources of Alaska - Report on progress of investigations in 1928: U.S. Geological Survey Bulletin 813-A, p. 14, 71, 72.

Smith, P. S., 1932, Mineral industry of Alaska in 1929, in Mineral resources of Alaska - Report on progress of investigations in 1929: U.S. Geological Survey Bulletin 824-A, p. 15, 16, 79-81.

Smith, P. S., 1933, Mineral industry of Alaska in 1930, in Mineral resources of Alaska - Report on progress of investigations in 1930: U.S. Geological Survey Bulletin 836-A, p. 14, 80.

Smith, P. S., 1934a, Mineral industry of Alaska in 1931, in Mineral resources of Alaska - Report on progress of investigations in 1931: U.S. Geological Survey Bulletin 844-A, p. 14, 15

Smith, P. S., 1934b, Mineral industry of Alaska in 1932, in Mineral resources of Alaska - Report on progress of investigations in 1932: U.S. Geological Survey Bulletin 857-A, p. 14, 15, 76.

Smith, P. S., 1936, Mineral industry of Alaska in 1933, in Mineral resources of Alaska - Report on progress of investigations in 1933: U.S. Geological Survey Bulletin 864-A, p. 14, 15, 80.

Smith, P. S., 1937a, Mineral industry of Alaska in 1934, in Mineral resources of Alaska - Report on progress of investigations in 1934: U.S. Geological Survey Bulletin 868-A, p. 15, 16, 82.

Smith, P. S., 1937b, Mineral industry of Alaska in 1935, in Mineral resources of Alaska - Report on progress of investigations in 1935: U.S. Geological Survey Bulletin 880-A, p. 16, 87, 88.

Smith, P. S., 1938, Mineral industry of Alaska in 1936, in Mineral resources of Alaska - Report on progress of investigations in 1936: U.S. Geological Survey Bulletin 897-A, p. 16, 17, 98.

Smith, P. S., 1941, Mineral industry of Alaska in 1937, in Mineral resources of Alaska - Report on progress of investigations in 1937: U.S. Geological Survey Bulletin 910-A, p. 18, 19, 105, 106.

Smith, P. S., 1942a, Mineral industry of Alaska in 1938, in Mineral resources of Alaska - Report on progress of investigations in 1938: U.S. Geological Survey Bulletin 917-A, p. 19-21, 104, 105.

Smith, P. S., 1942b, Past lode-gold production from Alaska, in Mineral resources of Alaska - Report on progress of investigations in 1938: U.S. Geological Survey Bulletin 917-C, p. 195-196.

Smith, P. S., 1942c, Mineral industry of Alaska in 1939, in Mineral resources of Alaska - Report on progress of investigations in 1939: U.S. Geological Survey Bulletin 926-A, p. 18-19, 95-97. 
Smith, P. S., 1942d, Occurrences of molybdenum minerals in Alaska, in Mineral resources of Alaska - Report on progress of investigations in 1939: U.S. Geological Survey Bulletin 926-C, p. 174-176.

Smith, P. S., 1942e, Mineral industry of Alaska in 1940, in Mineral resources of Alaska - Report on progress of investigations in 1940: U.S. Geological Survey Bulletin 933-A, p. 18, 92.

Sonnevil, R. A., 1981, The Chilkat-Prince of Wales plutonic province, southeastern Alaska, in Albert, N. R. D., and Hudson, T., eds., The United States Geological Survey in Alaska: Accomplishments during 1979: U.S. Geological Survey Circular 823-B, p. B112-B115.

Soward, K. S., 1961, Geologic investigations of proposed powersites at Baranof and Carbon Lakes, Baranof Island, Alaska: U.S. Geological Survey Bulletin 1031B, p. 25-46.

Stewart, B. D., 1921, Annual report of the Territorial Mine Inspector to the Governor of Alaska, 1920: AK Territorial Dept. of Mines, p. 21-24.

Stewart, B. D., 1923, Annual report of the Territorial Mine Inspector to the Governor of Alaska, 1922: AK Territorial Dept. of Mines, p. 63-66.

Stewart, B. D., 1924, Annual report of the Territorial Mine Inspector to the Governor of Alaska, 1923: AK Territorial Dept. of Mines, p. 57-60.

Stewart, B. D., 1931, Memorandum on the mineral resources of Chichagof Island: AK Territorial Dept. of Mines Miscellaneous Report 114-3, 5 p.

Stewart, B. D., 1932a, Report on cooperation between the Territory of Alaska and the United States in making mining investigations and in the inspection of mines for the biennium ending March 31, 1931: AK Territorial Dept. of Mines, p. 6, 27-30.

Stewart, B. D., 1932b, The occurrence of gypsum at lyoukeen Cove, Chichagof lsland, in Mineral resources of Alaska - Report on progress of investigations in 1929: U.S. Geological Survey Bulletin 824-F, p. 173177.

Stewart, B. D., 1934, Mining investigations and mine inspections in Alaska, biennium ending March 31, 1933: AK Territorial Dept. of Mines, p. 10-13.

Stewart, B. D., 1937, Report of the Commissioner of Mines to the Governor for the biennium ending December 31, 1936: AK Territorial Dept. of Mines, p. 45-48, 52, 53.

Stewart, B. D., 1939, Report of the Commissioner of Mines to the Governor for the biennium ending December 31, 1938: AK Territorial Dept. of Mines, p. 36-39, 41-45.

Stewart, B. D., 1947, Report of the Commissioner of Mines for the biennium ending December 31, 1946: AK Territorial Dept. of Mines, p. 15.
Stewart, B. D., 1949, Report of the Commissioner of Mines for the biennium ending December 31, 1948: AK Territorial Dept. of Mines, p. 14.

Stewart, B. D., and Dyer, B. W., 1922, Annual report of the Territorial Mine Inspector to the Governor of Alaska, 1921: AK Territorial Dept. of Mines, p. 11, 40-46.

Still, J. C., 1988, Distribution of gold, platinum, palladium, and silver in selected portions of the Bohemia Basin deposits, southeast Alaska (with an appendix on Mirror Harbor): U. S. Bureau of Mines Open File Report 10-88, 42 p., 10 sheets.

Still, J. C., and Weir, K. R., 1981, Mineral land assessment of the west portion of western Chichagof Island, Alaska: U. S. Bureau of Mines Open File Report 89$81,168 \mathrm{p}$.

Storm, L. W., 1917, Report on Slim and Jim Copper prospect, Point Urey, Chichagof Island: Unpublished report, 4 p., available from BLM, Juneau, AK.

Taylor, C. D., Goldfarb, R. J., Snee, L. W., Gent, C. A., Karl, S. M., and Haeussler, P. J., 1994, New age data for gold deposits and granites, Chichagof Mining District, SE Alaska: Evidence for a common origin [abs.]: Geological Society of America Abstracts with Programs, v. 26, no. 7, p. A-140.

Taylor, H. P., Jr., 1967, The zoned ultramafic complexes of southeastern Alaska, in Ultramafic and related rocks, P. J. Wyllie (ed): John Wiley \& Sons, New York, p. 97-121.

The Alaska Geographic Society, 1982, Sitka and its Ocean/Island World: AK Geographic, v. 9, no. 2, 128 p.

Thorne, R. L., 1952, Slocum Arm molybdenum deposit, Southeastern Alaska: Unpublished U. S. Bureau of Mines minerals memorandum, 2 p., available from BLM, Juneau, AK.

Thorne, R. L., 1960, Chichagof-Alaskan Mining Corporation, Lucky Devil claims, Chichagof Island, Alaska: Unpublished U. S. Bureau of Mines Examination Report, 9 p., available from BLM, Juneau, AK.

Thorne, R. L., 1967, Chichagof Mining District, Sitka quadrangle, Southeastern Alaska: Unpublished U. S. Bureau of Mines situation report, $5 \mathrm{p}$.

Thorne, R. L., Muir, N. M., Erickson, A. W., Thomas, B. I., Heide, H. E., and Wright, W. S., 1948, Tungsten deposits in Alaska: U. S. Bureau of Mines Report of lnvestigations 4174 , p. 5, 48-51.

Thornsberry, V. V ., and DeWilliam, P. P., 1982, Prospectus: Aleco Mining Group nickel-copper property (Bohemia Basin and Mirror Harbor) southeast Alaska: Unpublished report, 19 p., available from BLM, Juneau, AK. 
Townsend, H. H., 1924, Mining reports: AK Territorial Dept. of Mines, Itinerary Report 195-47, p. 14.

Traver, W. M., 1942, Bohemia Basin nickel deposits, Yakobi Island, Alaska, Report to Metallurgical Division: Unpublished report, 3 p., available from BLM, Juneau, AK.

Traver, W. M., 1944, Appendix to War Minerals Report, Mirror Harbor nickel deposits, Chichagof Island, Alaska: Unpublished report, 54 p., available from BLM, Juneau, AK.

Traver, W. M., 1948, Mirror Harbor nickel deposits, Chichagof Island, Alaska: U. S. Bureau of Mines Report of Investigations 4168, $13 \mathrm{p}$.

Twenhofel, W. S., 1951, Geology of the proposed Blue Lake dam site and tunnel near Sitka, Alaska: U.S. Geological Survey Circular 147, 4 p.

Twenhofel, W. S., 1953, Potential Alaska mineral resources for proposed electrochemical and electrometallurgical industries in the Upper Lynn Canal area, Alaska: U.S. Geological Survey Circular 252, p. $5,7$.

Twenhofel, W. S., Reed, J. C., and Gates, G. O., 1949, Some mineral investigations in southeastern Alaska: U.S. Geological Survey Bulletin 963-A, p. 20-28. Twenhofel, W. S., and Sainsbury, C. L., 1958, Fault patterns in southeastern Alaska: Geological Society of America Bulletin, v. 69, no. 11, p. 1431-1442.

U.S. Bureau of Mines, Mine production records: Unpublished records, available from BLM, Juneau, AK.

U. S. Bureau of Mines, (undated, 1940's), Red Bluff Bay chromite property, Baranof Island, southeastern Alaska: Unfinished War Minerals Report, 6 p., available from BLM, Juneau, AK.

U. S. Bureau of Mines, 1944a, Yakobi Island, Sitka Mining District, Alaska: War Minerals Report 174, 73 p., available from BLM, Juneau, AK.

U. S. Bureau of Mines, 1944b, Mirror Harbor, Chichagof Island, Alaska: War Minerals Report 333, 9 p., available from BLM, Juneau, AK.

U. S. Bureau of Mines, 1962, Results of diamond drilling at the Camel Gypsum deposit, Iyoukeen Cove, Chichagof Island, southeast Alaska: Unpublished, available from BLM, Juneau, AK.

U. S. Bureau of Mines, 1973, Alaska 1:250,000-scale quadrangle map overlays and paper copy showing mineral deposit locations, principal minerals, number and type of claims, and historical information, includes reference to unpublished MAS file information: U. S. Bureau of Mines Open File Report 20-73, updated in 1986-87, available from BLM, Juneau, AK.
U.S. Geological Survey, 1979, Aeromagnetic map of Yakobi and Chichagof Islands, Alaska: U.S. Geological Survey Open-File Report 79-529, scale $1: 250,000$.

Vevelstad, C., (date unknown), Report on Yakobi Island drill logs: AK Territorial Dept. of Mines Miscellaneous Report 114-9, 58 p.

Walton, M. S., and Kennedy, G. C., 1944, Chromite occurrences and a nickel prospect on Baranof Island, southeastern Alaska: Unpublished report, 4 p., 3 maps, available from BLM, Juneau, AK.

Walton, M. S., and Kennedy, G. C., 1945, Magnetic exploration of the nickel-copper deposits of Bohemia Basin, southeastern Alaska: Economic Geology, v. 40, no. 7 , p. $496-502$.

Wanek, A. A., and Callahan, J. E., 1969, Geology of proposed powersites at Deer Lake and Kasnyku Lake, Baranof Island, southeastern Alaska: U.S. Geological Survey Bulletin 1211-C, 25 p.

Wells, R. R., 1952, Mineral dressing report, Cobolmolybdenum ore: Unpublished report, 3 p., available from BLM, Juneau, AK.

West, W. S., and Benson, P. D., 1955, Investigations for radioactive deposits in southeastern Alaska: U.S. Geological Survey Bulletin 1024-B, p. 45-50.

Wheeler, J. O., Brookfield, A. J., Gabrielse, H., Monger, J. W. H., Tipper, H. W., and Woodsworth, G. J., 1988, Terrane map of the Canadian Cordillera: Geological Survey of Canada Open File 1894, 9 p., 1 sheet, scale $1: 2,000,000$.

Williams, J. A., 1928, Cobol deposit, Slocum Arm, Chichagof Island: Unpublished report, 3 p., available from BLM, Juneau, AK.

Williams, J. A., 1951, Itinerary report of Leo J. Saarela and James A. Williams for the period 15 June to 27 June, 1951 in the Juneau, Sitka, and Petersburg Precincts: AK Territorial Dept. of Mines Itinerary Report 191-1, $5 \mathrm{p}$.

Williams, J. A., 1955, Ariel property, Sitka quadrangle, gold and tungsten, El Nido Mine: AK Territorial Dept. of Mines Property Examination 114-13, 5 p., 2 maps.

Winchell, H. V., 1918, Report on the property of the Alaska Nickel Mines, Mirror Harbor: AK Territorial Dept. of Mines Miscellaneous Report 114-2, 15 p.

Wright, C. W., 1906, Nonmetallic deposits of southeastern Alaska, in Report on progress of investigations of mineral resources of Alaska in 1905: U.S. Geological Survey Bulletin 284-F, p. 58-59. 
Wright, C. W., 1907a, Lode mining in southeastern Alaska, Sitka Mining District, in Report on progress of investigations of mineral resources of Alaska in 1906:

U.S. Geological Survey Bulletin 314-C, p. 59-61.

Wright, C. W., 1907b, Nonmetalliferous mineral resources of southeastern Alaska, gypsum, in Report on progress of investigations of mineral resources of Alaska in 1906: U.S. Geological Survey Bulletin 314-D, p. $79-$ 80.

Wright, C. W., 1908a, Lode mining in southeastern Alaska, 1907, in Mineral resources of Alaska - Report on progress of investigations in 1907: U.S. Geological Survey Bulletin 345-D, p. 78-97.

Wright, C. W., 1908b, The building stones and materials of southeastern Alaska, in Mineral resources of Alaska Report on progress of investigations in 1907: U.S. Geological Survey Bulletin 345-F, p. 124-125.

Wright, C. W., 1909, Mining in southeastern Alaska, in Mineral resources of Alaska - Report on progress of investigations in 1908: U.S. Geological Survey Bulletin 379-D, p. 73, 85.
Wright, F. E., and Wright, C. W., 1905, Economic developments in southeastern Alaska, Sitka Mining District, in Report on progress of investigations of mineral resources of Alaska in 1904: U.S. Geological Survey Bulletin 259-D, p. 57-59.

Wright, F. E., and Wright, C. W., 1906, Lode mining in southeastern Alaska, in Report on progress of investigations of mineral resources of Alaska in 1905: U.S. Geological Survey Bulletin 284-E, p. 45.

Yehle, L. A., 1974a, Reconnaissance engineering geology of Sitka area, Alaska, in Carter, C., ed., U.S. Geological Survey in Alaska program, 1974: U.S. Geological Survey Circular 700, 63 p.

Yehle, L. A., 1974b, Reconnaissance engineering geology of Sitka and vicinity, Alaska, with emphasis on evaluation of earthquake and other geologic hazards: U.S. Geological Survey Open-File Report 74-53, 104 p., 3 sheets, scale 1:9,600.

Zuffa, G. G., Nilsen, T. H., and Winkler, G. R., 1980, Rock-fragment petrography of the upper Chugach terrane, southern Alaska: U.S. Geological Survey Open-File Report 80-713, 28 p. 


\section{APPENDiX A - SUMmary INFORMATION for Mines, PROSPECTS, AND Mineral OCCURRENCES}

Appendix Table A-1 lists summary information for mines, prospects, and mineral occurrences found in the Chichagof-Baranof area. The information provided includes: prospect name and Minerals Availability System (MAS) number, location information, land status, deposit type and major commodities present, workings and current condition, production figures (when available), BLM work during this study, selected references for additional information, and mineral development potential. The last category is a subjective ranking that prioritizes prospects with respect to one another.

\section{Abbreviations and Descriptions}

\section{Prospect Number:}

Refers to mine, prospect, or occurrence numbers used to show locations on Plate 1.

(See Appendix Table C-1 for cross reference between Prospect numbers and Map numbers used in the Analytical Results Table B-1.)

\section{Property Name/MAS no.:}

MAS refers to the Minerals Availability System database devised by the Bureau of Mines and currently supported by the Bureau of Land Management in Alaska.

\section{Location:}

Township, range, section, Bureau of Mines quadrangle number, USGS 1:63,360-scale map number

\section{Land status:}

$\begin{array}{ll}\text { N } & \text { Native } \\ \text { S } & \text { State } \\ \text { OF } & \text { Open Federal (open to mineral entry) } \\ \text { CF } & \text { Closed Federal (closed to mineral entry) } \\ \text { P } & \text { Private (mineral survey number listed) }\end{array}$

Deposit type: (with commodity abbreviations; and other abbreviations as defined on p. 177)

$\begin{array}{ll}\text { V } & \text { Vein } \\ \text { PV } & \text { Polymetallic vein } \\ \text { Mag Seg } & \text { Magmatic segregation } \\ \text { S } & \text { Skarn } \\ \text { P } & \text { Porphyry } \\ \text { Dissem } & \text { Disseminated sulfides }\end{array}$


Deposit type: (continued)

$\begin{array}{ll}\text { VMS } & \text { Volcanogenic massive sulfide } \\ \text { Peg } & \text { Pegmatite } \\ \text { PL } & \text { Placer } \\ \text { O } & \text { Other (or unknown) }\end{array}$

Workings:
$\mathrm{T}(\mathrm{s})$
$\mathrm{P}(\mathrm{s})$
Trench(es)
$\mathrm{C}(\mathrm{s})$
Pit(s)
\# Adit(s):
Cut(s), opencut(s)
\# Shaft(s):
Lengths, in feet; (caved lengths in paren.)
Depths, in feet; (flooded depths in paren.)

\section{Production:}

NA Not Applicable - if no production has occurred from the site

\section{BLM work:}

$\begin{array}{ll}\text { M } & \text { Mapped } \\ \text { S } & \text { Sampled } \\ \text { R } & \text { Reconnaissance, recon sampling } \\ \text { NF } & \text { Not found } \\ \text { NE } & \text { Not examined }\end{array}$

\section{Select references:}

Numbers refer to the references listed on page 173 .

MDP (mineral development potential):

All mines, prospects, and mineral occurrences are assigned high, medium, or low mineral development potential classifications. These rankings reflect the authors' opinions with regard to each property and thereby differ from the mineral development potential ratings given to entire KMDA's in the body of this report. The rankings are based on the following criteria:

$\mathrm{H} \quad$ High grades and probable continuity of mineralized rock exist. The property is likely to have economically mineable resources under current economic conditions. A high potential exists for developing tonnage or volume with reasonable geologic support for continuity of grade. 
M Either a high grade or continuity of mineralized rock exists, but not both. Mineralized rock is confined by geology and/or structures, or grades are overall low. It could serve as a resource if economics were not a factor, but is presently uneconomic under existing conditions.

L The property exhibits uneconomic grades and/or little evidence of continuity of mineralized rock. There is little or no obvious potential for developing ore resources or it is an insignificant source of the material of interest. 


\begin{tabular}{|c|c|c|c|c|c|c|c|c|c|c|}
\hline & $\Sigma= \pm$ & دـ & • & دـ & دـ & 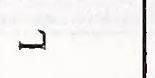 & د & ـ & \lrcorner & ــ \\
\hline & 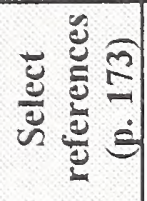 & $\begin{array}{l}n \\
\hat{n} \\
m \\
m\end{array}$ & নे & $\frac{1}{0}$ & $\begin{array}{l}\vec{b} \\
\infty \\
n\end{array}$ & in & $\begin{array}{l}\vec{n} \\
\hat{m}\end{array}$ & in & $\frac{1}{2}$ & $\infty$ \\
\hline & 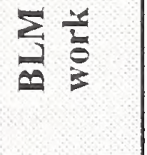 & 岂 & 崩 & 㞱 & 岩 & 㞱 & $\sim$ & 崩 & 步 & 崩 \\
\hline 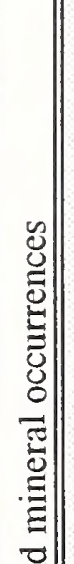 & 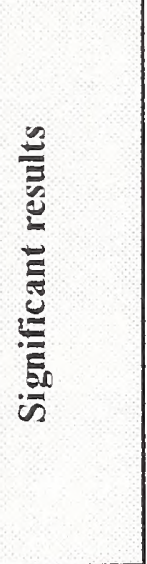 & 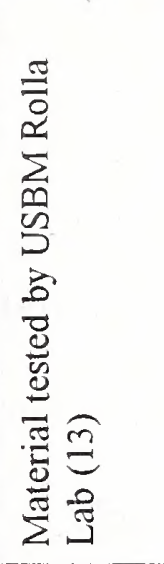 & Z̃ & 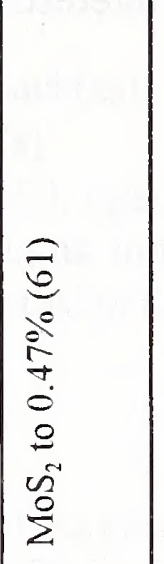 & 芩 & 气ั̆ & 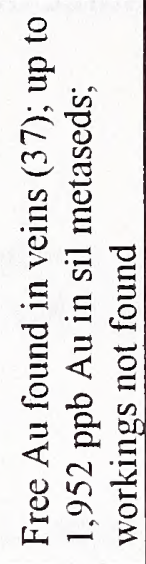 & 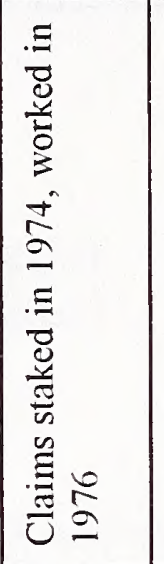 & 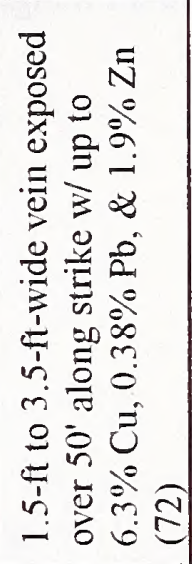 & $\frac{\varrho}{O}$ \\
\hline 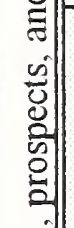 & 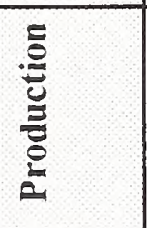 & 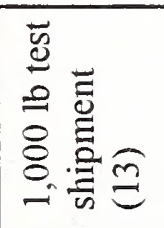 & $\overleftrightarrow{z}$ & $\overleftrightarrow{z}$ & $\overleftrightarrow{z}$ & $\overleftrightarrow{z}$ & $\overleftrightarrow{z}$ & $\overleftrightarrow{z}$ & $\mathbb{z}$ & $\overleftrightarrow{z}$ \\
\hline 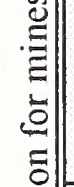 & 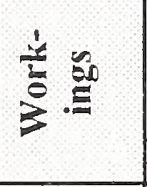 & $\overleftrightarrow{z}$ & $\overleftrightarrow{z}$ & $\mathbb{z}$ & 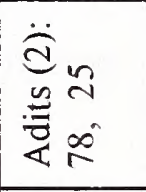 & $\mathbb{z}$ & 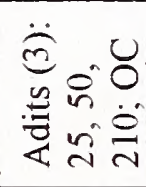 & $\overleftrightarrow{z}$ & $\approx$ & $\overleftrightarrow{z}$ \\
\hline 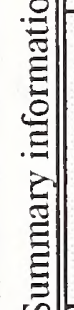 & 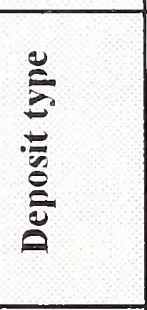 & 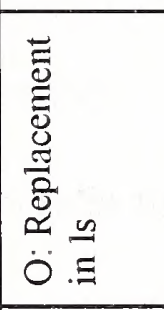 & $\begin{array}{l}\tilde{U} \\
\sum_{i}^{0} \\
\text { in }\end{array}$ & $\begin{array}{l}\tilde{E} \\
\sum_{0}^{0} \\
\ddot{i}\end{array}$ & $\sum_{i=1}^{0}$ & $\begin{array}{l}\tilde{i} \\
\dot{0} \\
\ddot{0}\end{array}$ & 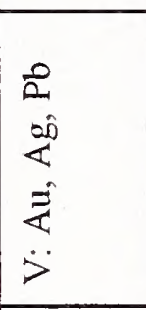 & 2 & $\begin{array}{l}\text { N } \\
0 \\
0 \\
\tilde{3} \\
\ddot{>}\end{array}$ & 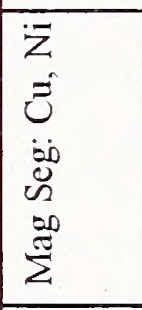 \\
\hline 舟 & 氖 & 先 & 先 & 先 & 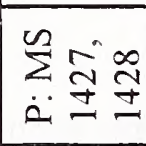 & 든 & 告 & 告 & $z$ & 先 \\
\hline है & 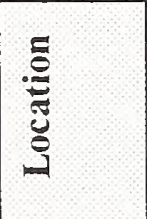 & 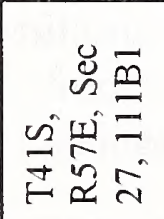 & 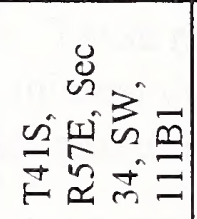 & 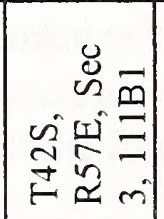 & 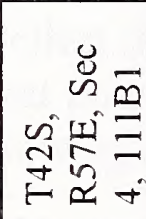 & 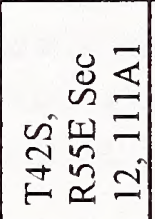 & 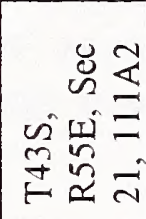 & 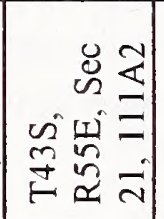 & 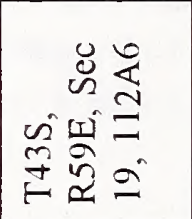 & 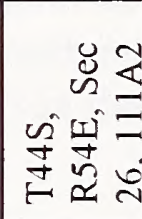 \\
\hline & 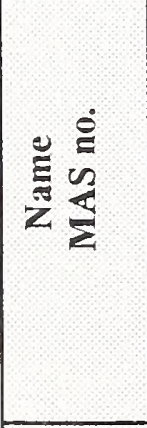 & 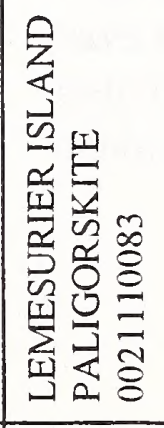 & 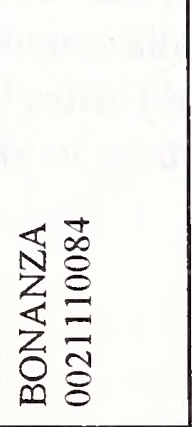 & 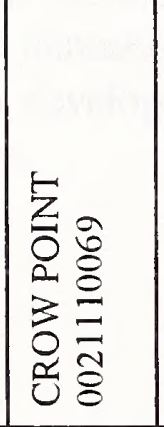 & 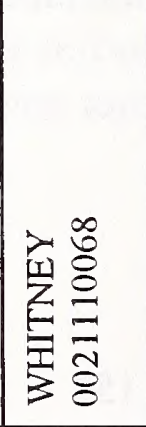 & 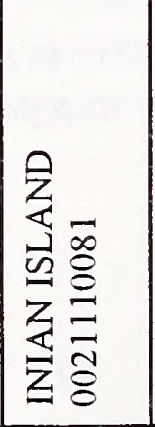 & 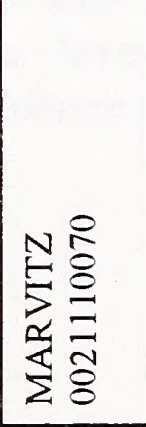 & 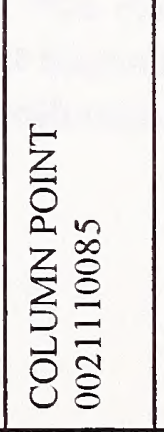 & 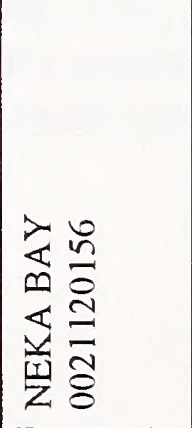 & 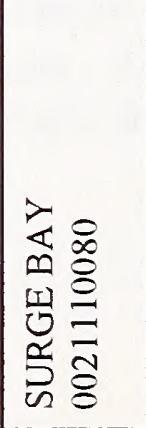 \\
\hline & 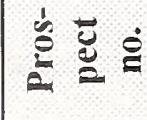 & $\vec{a}$ & $\tilde{\Sigma}$ & $\tilde{a}$ & \pm & $\approx$ & 2 & $\hat{\imath}$ & $\stackrel{\infty}{\alpha}$ & $a$ \\
\hline
\end{tabular}




\begin{tabular}{|c|c|c|c|c|c|c|c|}
\hline 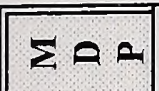 & در & $\dot{\Sigma} I$ & 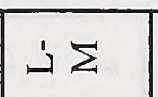 & $\dot{\prime} \Sigma$ & دـ & دـ & H \\
\hline 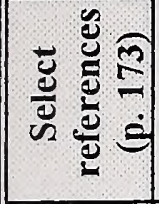 & $\begin{array}{l}\text { ते } \\
\text { ปे }\end{array}$ & 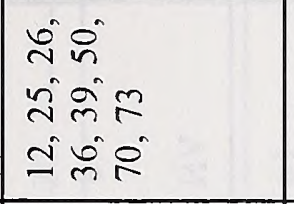 & 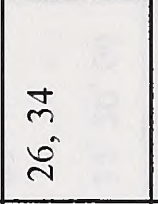 & 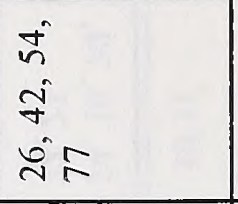 & $\infty$ & 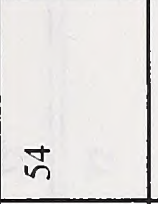 & $\infty$ \\
\hline$\sum_{\dot{\oplus}}$ & 步 & $\approx$ & $\approx$ & $\simeq$ & 㟧 & $\frac{1}{2}$ & $\frac{w}{\mathrm{~L}}$ \\
\hline 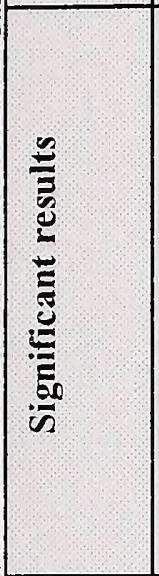 & 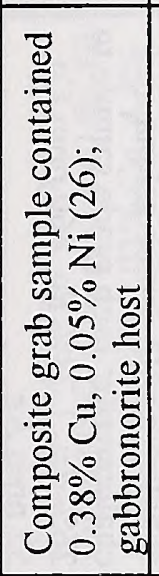 & 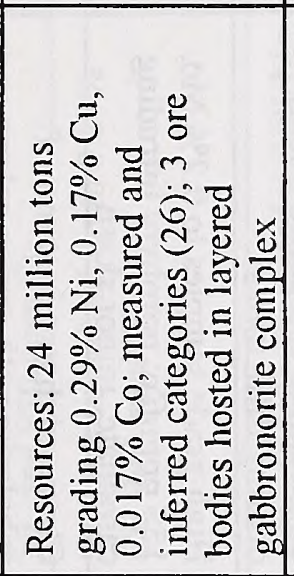 & 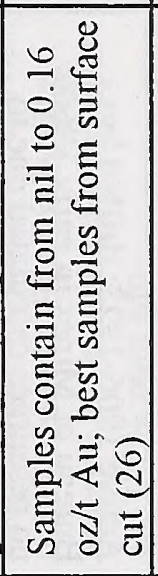 & 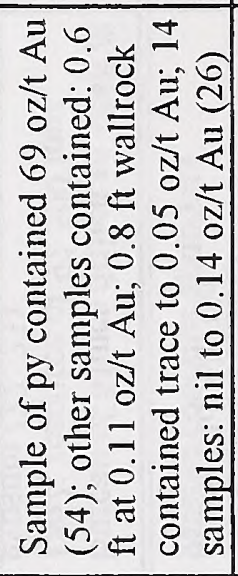 & 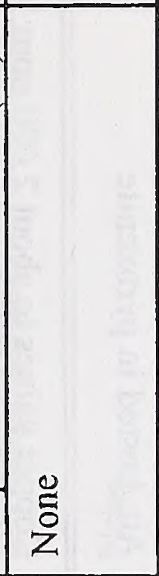 & 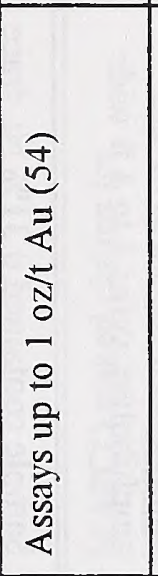 & 竞 \\
\hline$\overline{\frac{g}{2}}$ & $\overleftarrow{z}$ & 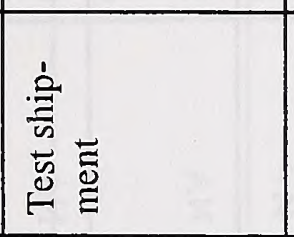 & 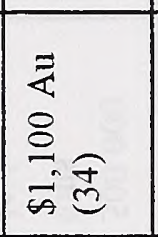 & & $\underline{z}$ & $\frac{\pi}{z}$ & $\frac{\mathbb{z}}{z}$ \\
\hline 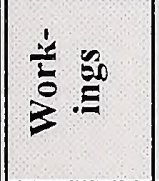 & $\overleftrightarrow{z}$ & 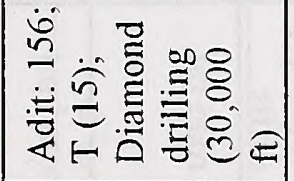 & 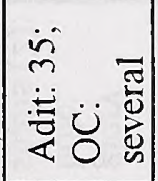 & & $\underset{z}{\mathbb{z}}$ & $\overleftrightarrow{z}$ & $\mathbb{z}$ \\
\hline 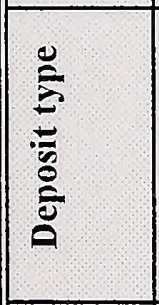 & $\begin{array}{l}z \\
z \\
z \\
b \\
\dot{b} \\
w \\
b \\
\tilde{z} \\
\bar{z}\end{array}$ & 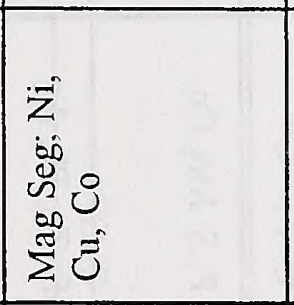 & 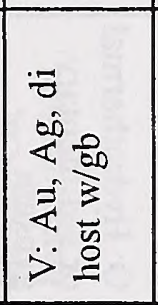 & 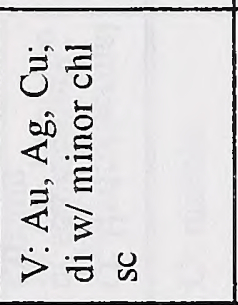 & $\begin{array}{l}z \\
\vdots \\
\end{array}$ & $\begin{array}{l}z \\
\vdots \\
>\end{array}$ & $\begin{array}{l}\bar{z} \\
\dot{z} \\
\dot{\gamma}\end{array}$ \\
\hline 踣 & 先 & 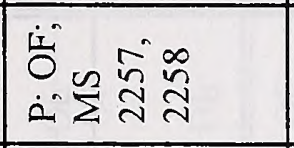 & t艹 & 눙 & 항 & ש & tuㅇㅇ \\
\hline 氙 & 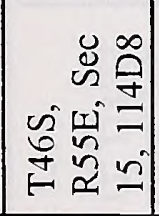 & 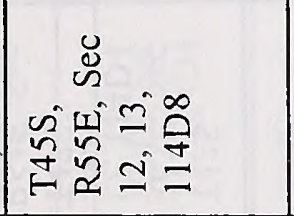 & 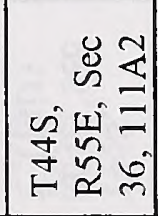 & 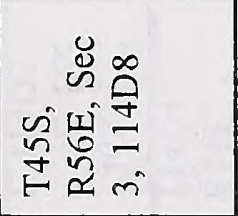 & 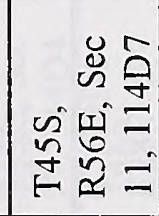 & 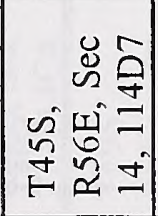 & 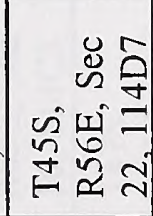 \\
\hline 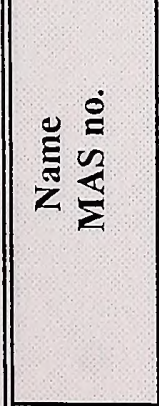 & 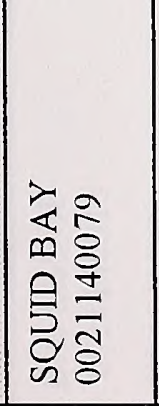 & 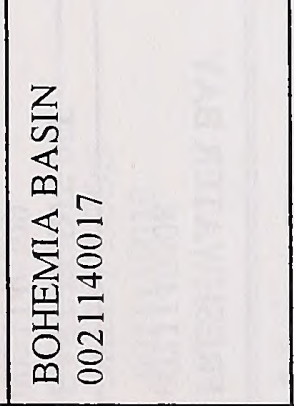 & 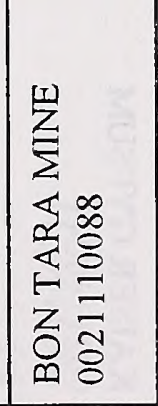 & 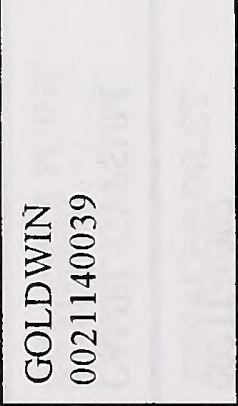 & 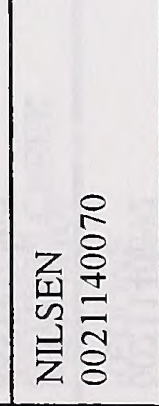 & 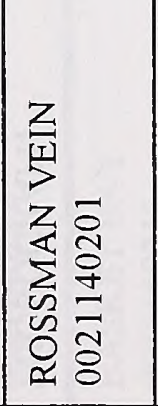 & 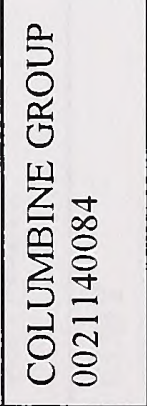 \\
\hline 童总 & $\stackrel{\circ}{2}$ & $\bar{a}$ & $\frac{\simeq}{2}$ & $\frac{m}{2}$ & $\frac{7}{2}$ & $\frac{n}{2}$ & $\frac{\circ}{2}$ \\
\hline
\end{tabular}




\begin{tabular}{|c|c|c|c|c|c|c|c|c|}
\hline & $\sum 00$ & $I$ & 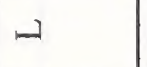 & - & $\omega$ & 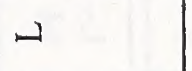 & $\omega$ & $\mapsto$ \\
\hline & 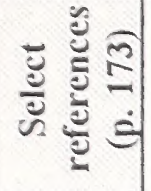 & $\begin{array}{l}\text { in } \\
\stackrel{0}{\sim} \\
\text { ते }\end{array}$ & $N$ & m & 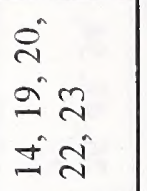 & $\begin{array}{l}\vec{J} \\
\dot{\sim} \\
\dot{\Xi}\end{array}$ & z & 尺े \\
\hline & 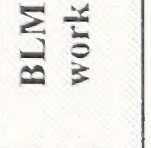 & $\simeq$ & $\frac{n}{z}$ & $\stackrel{\sim}{\Sigma}$ & $\simeq$ & $\simeq$ & $\stackrel{n}{\Sigma}$ & in \\
\hline 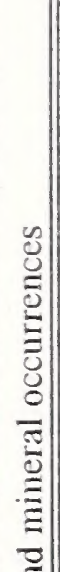 & 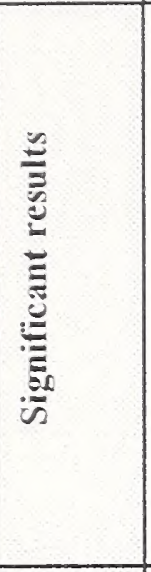 & 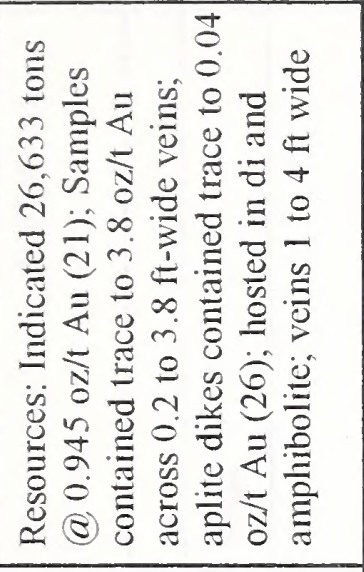 & 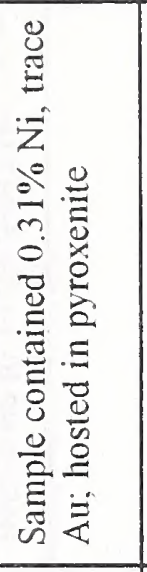 & 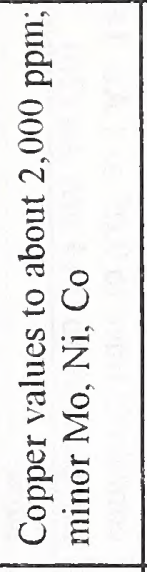 & 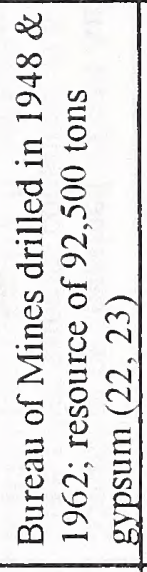 & 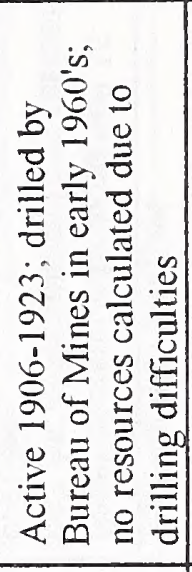 & 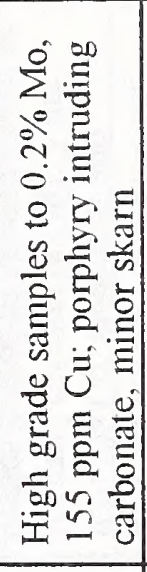 & 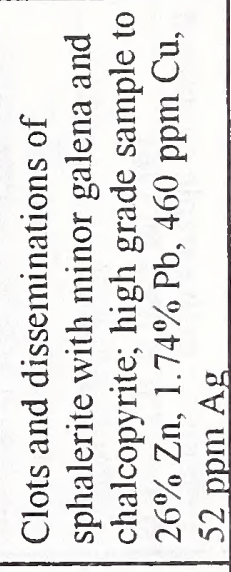 \\
\hline 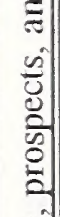 & 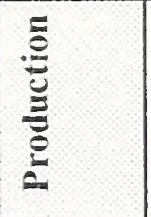 & 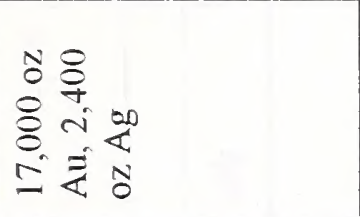 & $\mathbb{z}$ & $\mathbb{Z}$ & $\underset{Z}{\mathbb{Z}}$ & 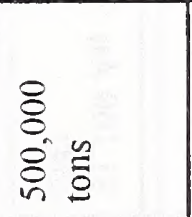 & $\mathbb{z}$ & $\bar{z}$ \\
\hline 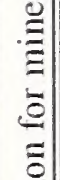 & 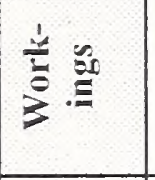 & 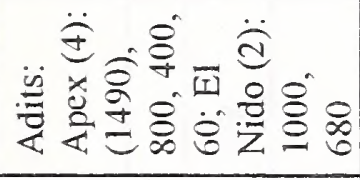 & $\mathbb{z}$ & 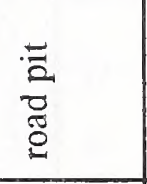 & 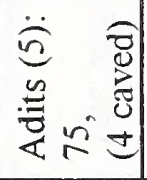 & 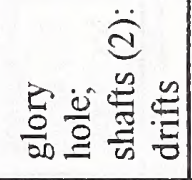 & 苛 & 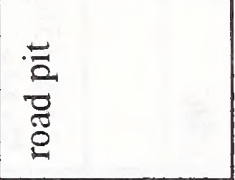 \\
\hline 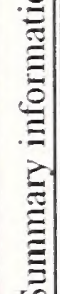 & 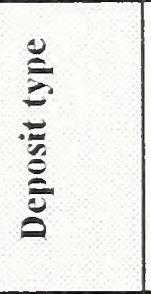 & $\begin{array}{l}3 \\
00 \\
\dot{8} \\
\dot{z} \\
\ddot{j}\end{array}$ & $\begin{array}{l}\bar{z} \\
\dot{0} 0 \\
\dot{\infty} \\
\dot{\infty} \\
\dot{\infty}^{\pi}\end{array}$ & $\begin{array}{l}\vec{U} \\
\dot{i s}\end{array}$ & 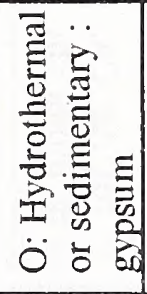 & 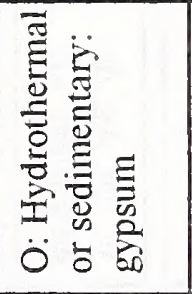 & $\begin{array}{l}\Xi \\
\dot{0} \\
\text { in } \\
0\end{array}$ & $\begin{array}{l}\sum^{0} \\
0 \\
\dot{2} \\
\tilde{N} \\
\ddot{\text { in }}\end{array}$ \\
\hline $\begin{array}{c}-1 \\
\dot{4} \\
0\end{array}$ & Е & 棺 & 告 & 告 & 岁 & $\ddot{\dot{n}} \sum_{\Sigma} \vec{J}$ & 岁 & 告 \\
\hline$\tilde{F}$ & 竞 & 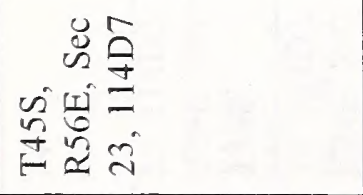 & 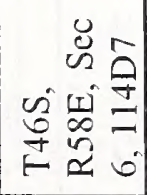 & 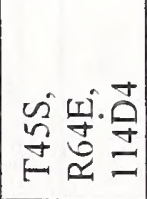 & 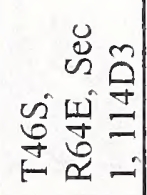 & 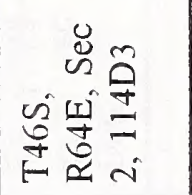 & 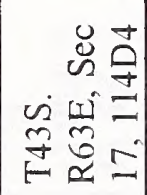 & 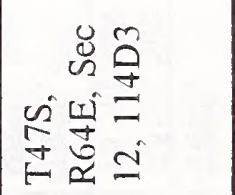 \\
\hline & Ż & 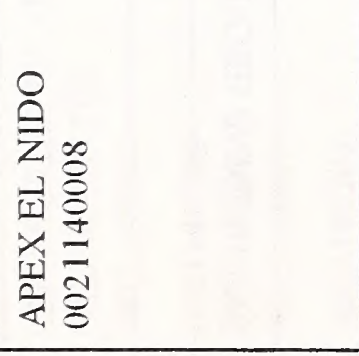 & 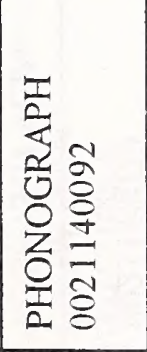 & 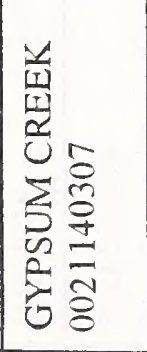 & 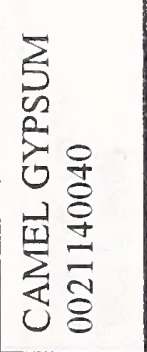 & 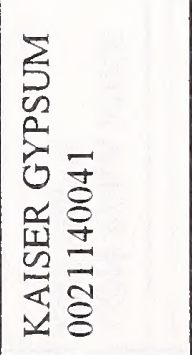 & 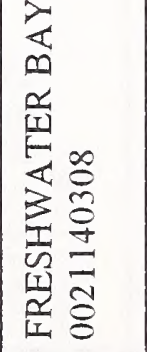 & 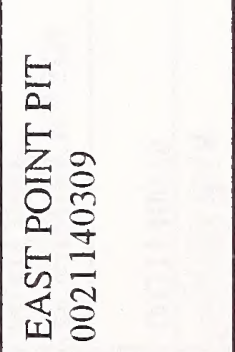 \\
\hline & 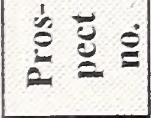 & 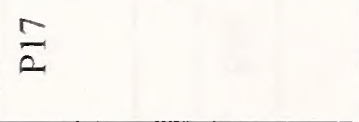 & $\frac{\infty}{2}$ & $\frac{2}{2}$ & 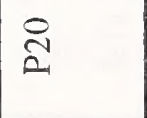 & $\vec{\Lambda}$ & $\stackrel{\widetilde{\Omega}}{\sim}$ & $\tilde{\Lambda}$ \\
\hline
\end{tabular}




\begin{tabular}{|c|c|c|c|c|c|c|c|c|c|}
\hline & 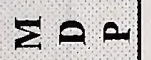 & $\dot{\lrcorner} \Sigma$ & 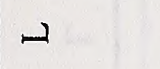 & ـ & $\omega$ & \lrcorner & د & 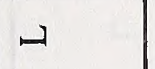 & - \\
\hline & 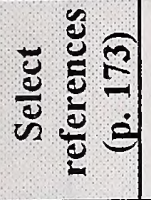 & a & $\infty$ & $\bar{\sigma}$ & $\stackrel{\infty}{\sim}$ & $=$ & $\approx$ & $\approx$ & 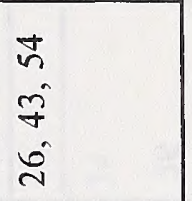 \\
\hline & $\sum_{0=0}$ & $\sum$ & n & os & $\simeq$ & 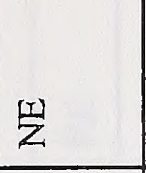 & $\simeq$ & $\simeq$ & $\simeq$ \\
\hline & 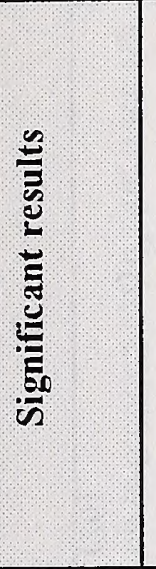 & 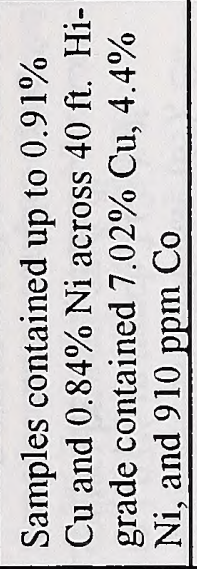 & 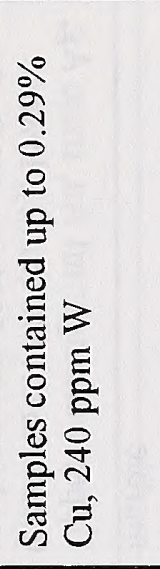 & 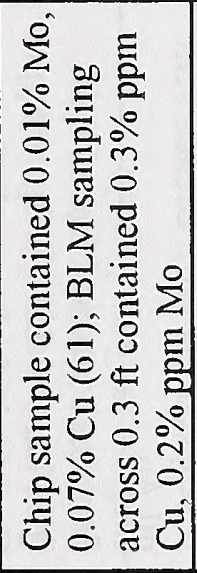 & 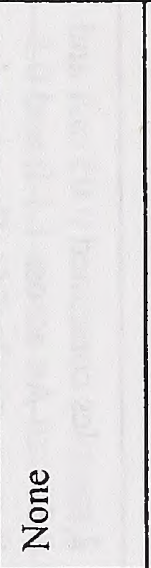 & 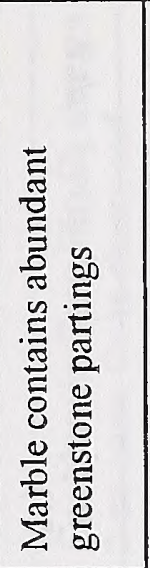 & 芩 & 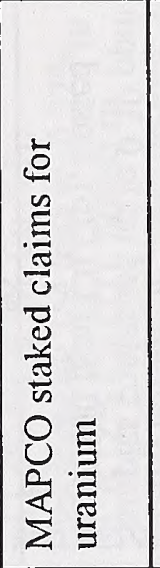 & 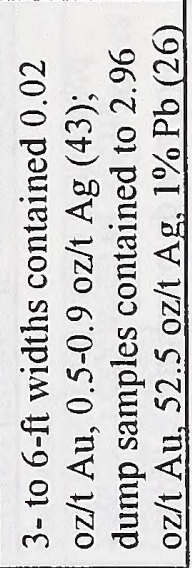 \\
\hline & 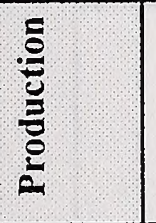 & $\overleftrightarrow{z}$ & $\overleftrightarrow{z}$ & $\overleftrightarrow{z}$ & $\overleftrightarrow{z}$ & $\overleftrightarrow{z}$ & $\overleftrightarrow{z}$ & $\overleftrightarrow{z}$ & $\overleftrightarrow{z}$ \\
\hline & $\stackrel{3}{3}$ & $\ddot{\sim}$ & $\ddot{\leftrightarrow}$ & $\overleftarrow{z}$ & $\overleftrightarrow{z}$ & $\overleftrightarrow{z}$ & $\overleftrightarrow{z}$ & $\overleftrightarrow{z}$ & 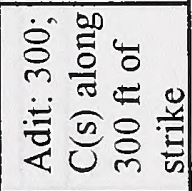 \\
\hline & 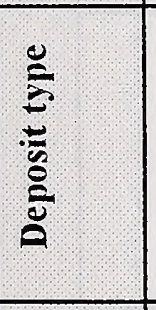 & $\begin{array}{l}\bar{z} \\
\bar{z} \\
\dot{0} \\
\dot{0} \\
\tilde{D} \\
\infty \\
\bar{\Sigma}\end{array}$ & $\begin{array}{l}\vec{U} \\
\ddot{\text { is }}\end{array}$ & 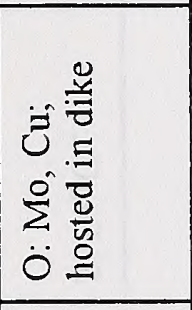 & 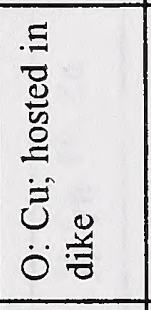 & 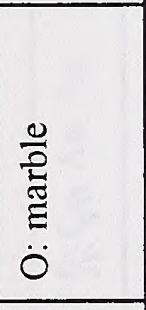 & $\ddot{0}$ & $\ddot{0}$ & 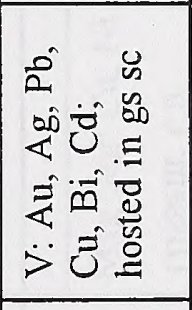 \\
\hline & 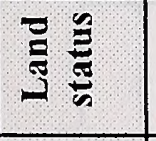 & 능 & $\frac{5}{0}$ & 峞 & $n$ & us & $z$ & $z$ & 岁 \\
\hline & 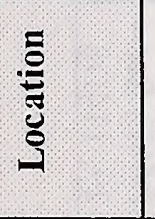 & 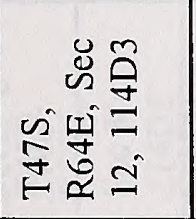 & 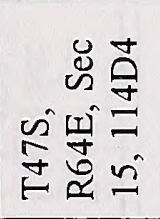 & 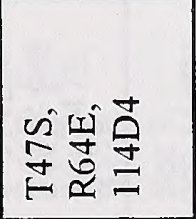 & 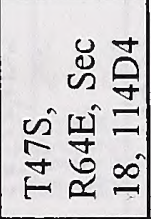 & 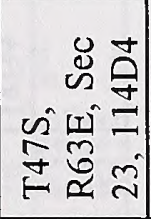 & 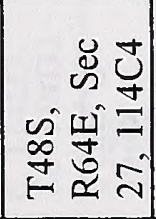 & 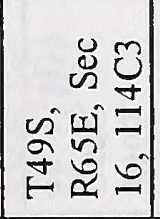 & 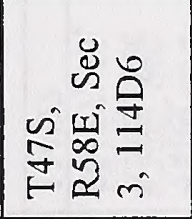 \\
\hline & 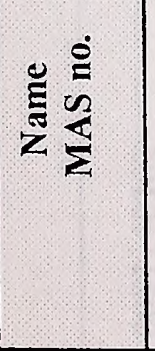 & 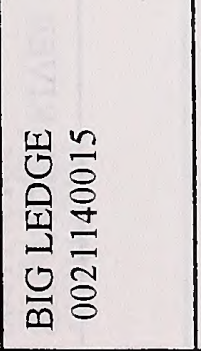 & 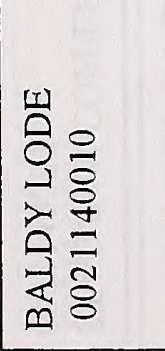 & & 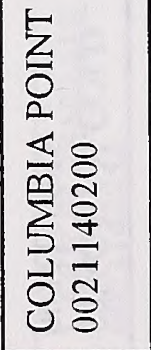 & 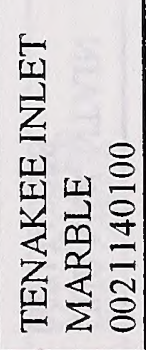 & 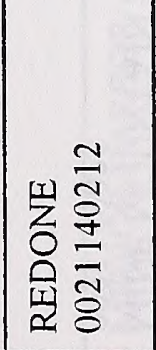 & 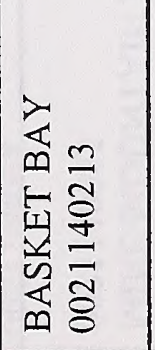 & 离 \\
\hline & 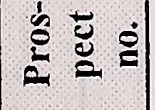 & $\underset{\Omega}{\mathbb{\Omega}}$ & $\cong$ & 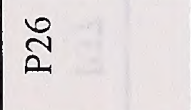 & $\widehat{\Xi}$ & $\stackrel{\infty}{\Omega}$ & ָे & 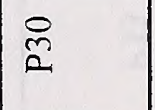 & $\bar{n}$ \\
\hline
\end{tabular}




\begin{tabular}{|c|c|c|c|c|c|c|c|c|c|}
\hline & $\Sigma=\infty$ & - & \lrcorner & \lrcorner$\Sigma$ & د & د. & \lrcorner & دـ & 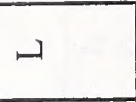 \\
\hline & 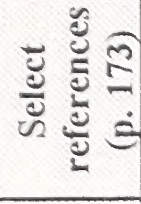 & 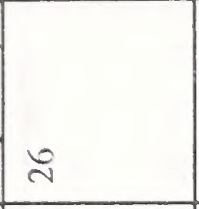 & $\begin{array}{l}\text { in } \\
\text { s. } \\
\text { s. }\end{array}$ & 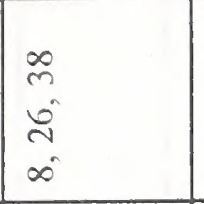 & $\vec{n}$ & $\stackrel{i}{i}$ & 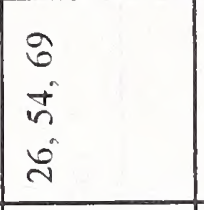 & $\begin{array}{l}\vec{n} \\
\text { sid } \\
i \\
i\end{array}$ & $\stackrel{i}{\pi}$ \\
\hline & $\bar{B}$ & 囩 & 罢 & $\approx$ & 崖 & 崖 & $\frac{112}{2}$ & 罢 & $\frac{1}{2}$ \\
\hline & 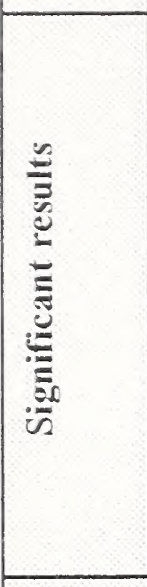 & 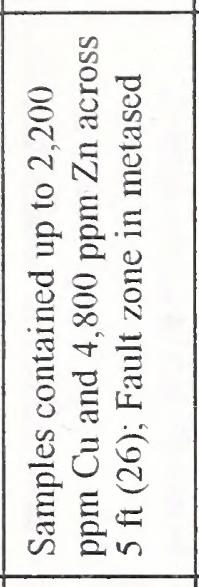 & 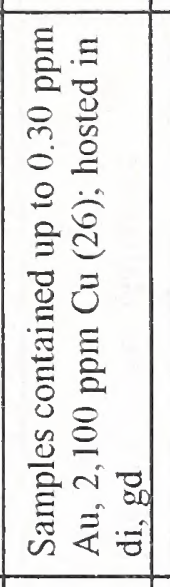 & 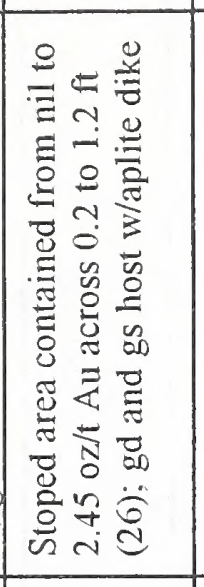 & 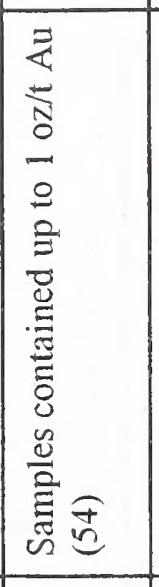 & 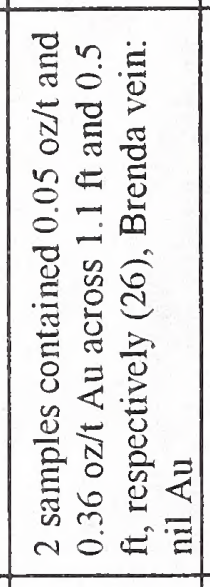 & 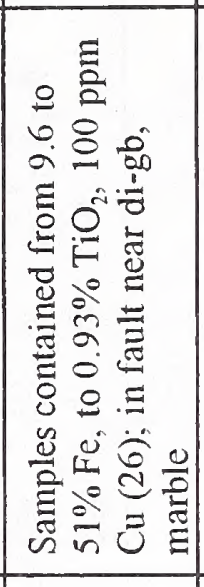 & 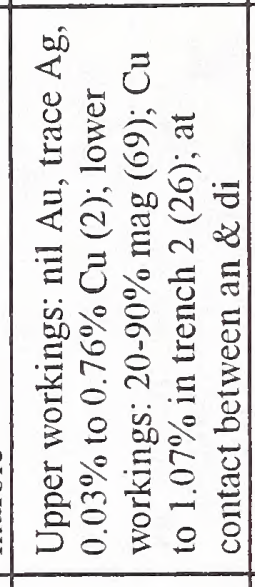 & 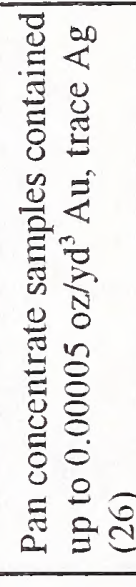 \\
\hline & D. & $\overleftarrow{z}$ & 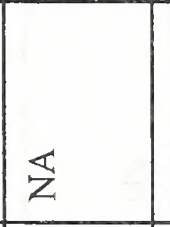 & 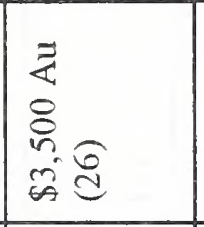 & 昰 & $z$ & $\mathbb{z}$ & $\mathbb{z}$ & $\mathbb{z}$ \\
\hline & 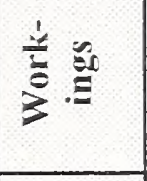 & 昰 & $\underline{z}$ & 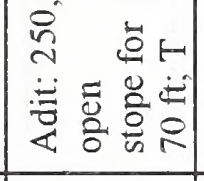 & $\frac{\pi}{2}$ & 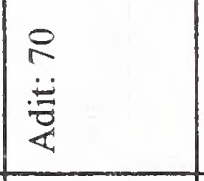 & 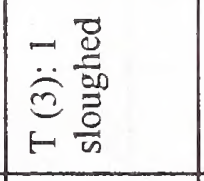 & $\hat{r}$ & $\mathbb{z}$ \\
\hline & 彦 & 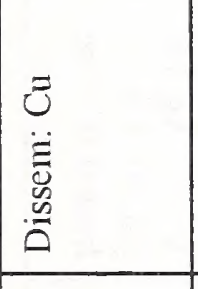 & $\begin{array}{l}z \\
\dot{x} \\
\dot{\nu} \\
\end{array}$ & $\begin{array}{l}\bar{\alpha} \\
\overline{>}\end{array}$ & $\begin{array}{l}\vec{z} \\
>\end{array}$ & \begin{tabular}{|l} 
\\
\\
\end{tabular} & $\begin{array}{l}z \\
j \\
i \\
i \\
\dot{i n} \\
\end{array}$ & $\mid \begin{array}{l}3 \\
0 \\
0 \\
\tilde{0} \\
0 \\
0\end{array}$ & $\begin{array}{l}z \\
\dot{a} \\
\dot{E}\end{array}$ \\
\hline & 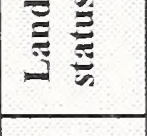 & E & U & 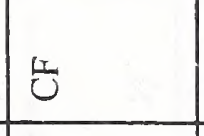 & 告 & 岂 & 先 & 告 & 先 \\
\hline & בֶ๊ & 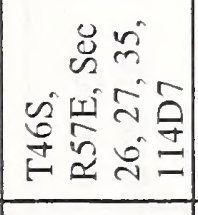 & 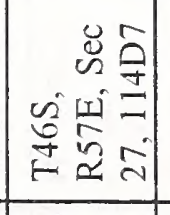 & 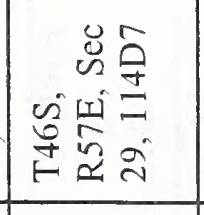 & 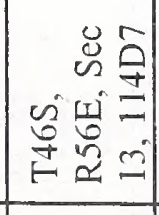 & 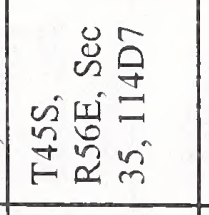 & 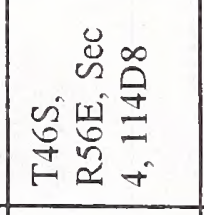 & 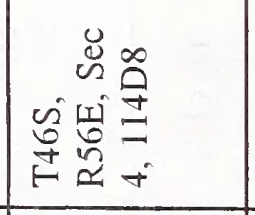 & 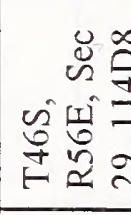 \\
\hline & 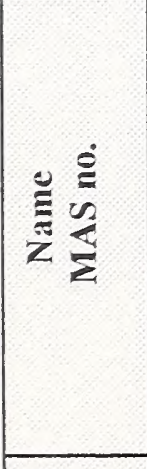 & 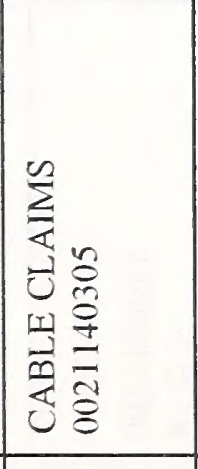 & 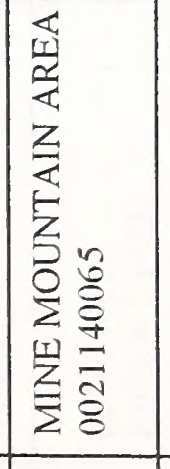 & 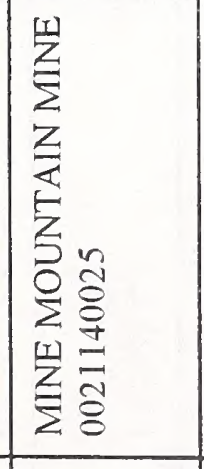 & 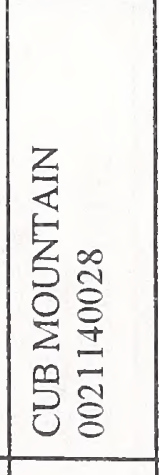 & 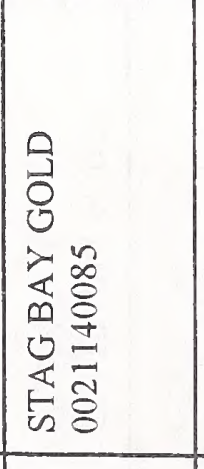 & 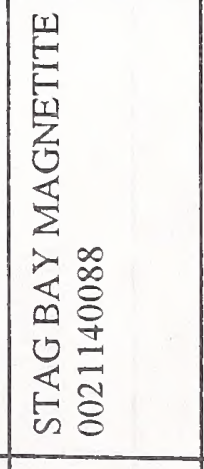 & 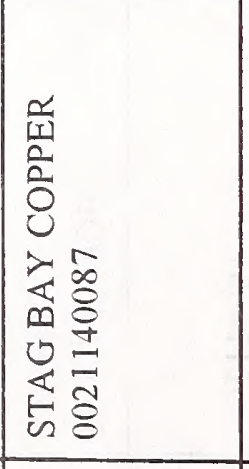 & 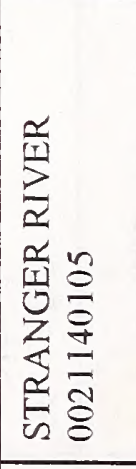 \\
\hline & 竧 & 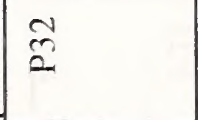 & 2 & {$\left[\begin{array}{c} \pm \\
0\end{array}\right.$} & $\ddot{m}$ & 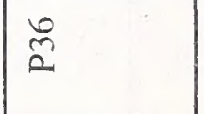 & $\hat{\tilde{\Omega}}$ & $\stackrel{\infty}{2}$ & है \\
\hline
\end{tabular}




\begin{tabular}{|c|c|c|c|c|c|c|c|}
\hline$\Sigma 02$ & ــ & ـ & ـ & دـ & $\dot{\lrcorner} \Sigma$ & $\Sigma$ & ــ \\
\hline 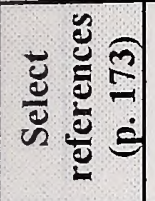 & iి & $\bar{m}$ & $\underset{N}{2}$ & $\vec{n}$ & $\begin{array}{l}\hat{m} \\
\hat{i} \tilde{b} \\
0 i\end{array}$ & 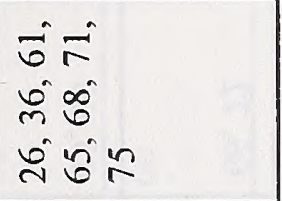 & $\vec{m}$ \\
\hline 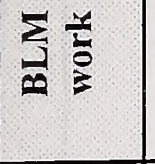 & 㞱 & $\frac{\Gamma}{z}$ & 吕 & 㞱 & $\simeq$ & 岂 & 㞱 \\
\hline 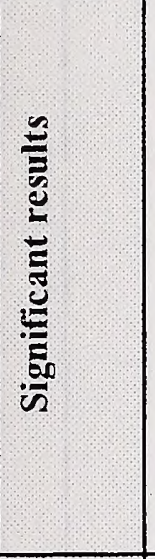 & 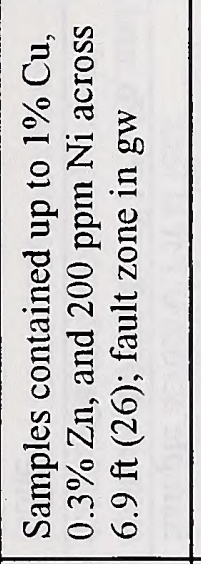 & : & 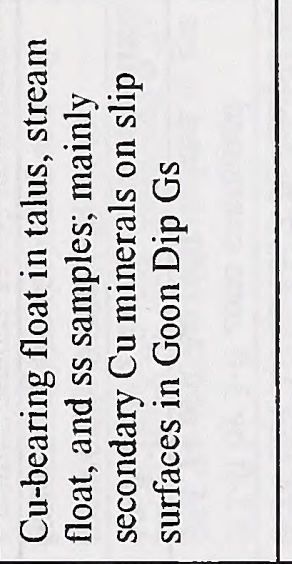 & हू & 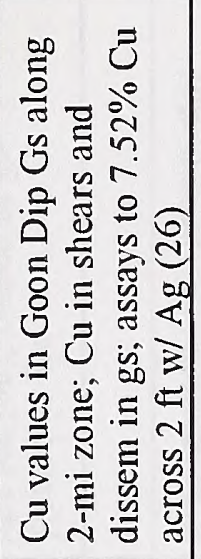 & 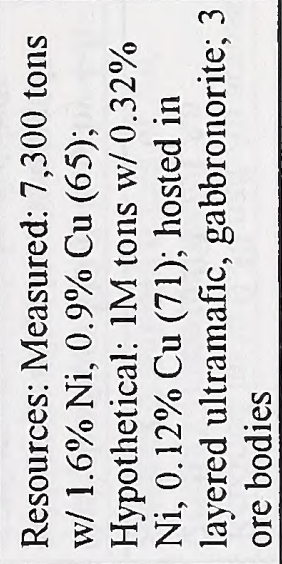 & 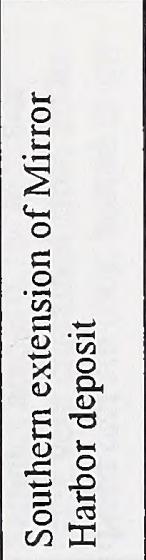 \\
\hline 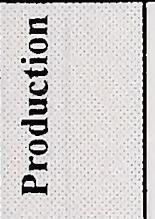 & $\overleftrightarrow{z}$ & 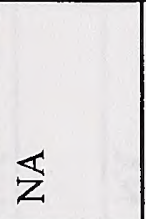 & $\mathbb{z}$ & $\mathbb{z}$ & $\overleftrightarrow{z}$ & 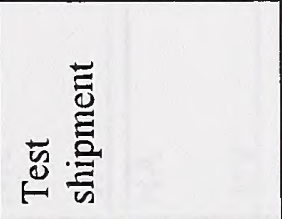 & $\mathbb{z}$ \\
\hline 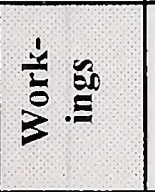 & $\mathbb{z}$ & $\ddot{H}$ & $\overleftrightarrow{z}$ & $\overleftarrow{z}$ & 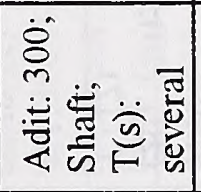 & 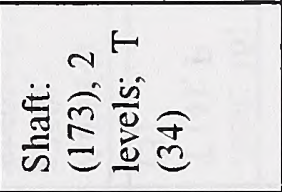 & $\leftarrow$ \\
\hline 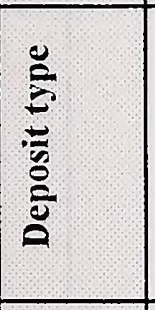 & $\begin{array}{l}\Xi \\
\ddot{>}\end{array}$ & $\begin{array}{l}\exists \\
\dot{3} \\
\dot{\infty} \\
\omega \\
\infty^{\infty} \\
\dot{\Sigma}\end{array}$ & 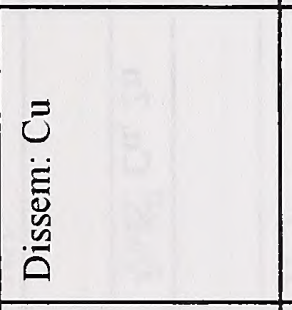 & $\begin{array}{l}\bar{N} \\
0 \\
2 \\
\tilde{B} \\
\ddot{>}\end{array}$ & 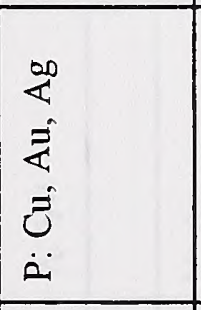 & 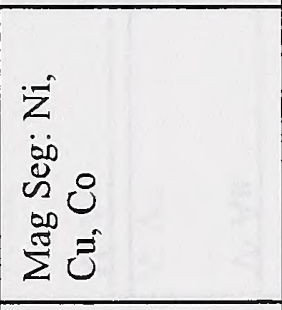 & $\begin{array}{l}\bar{z} \\
\tilde{E} \\
\dot{0} \\
\ddot{\infty} \\
\infty \\
\infty \\
\tilde{z}\end{array}$ \\
\hline 胥 & 岂 & 穵 & 㫕 & 岂 & 岁 & 㫕 & 岂 \\
\hline 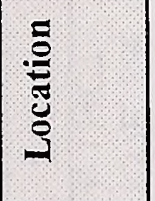 & 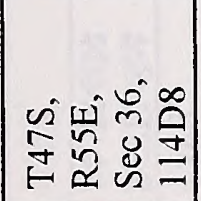 & 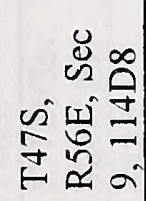 & 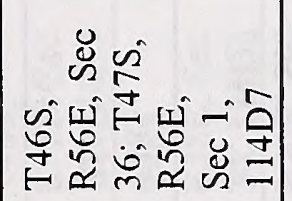 & 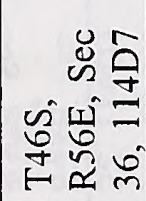 & 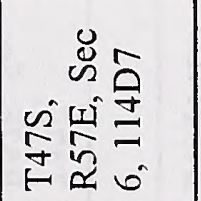 & 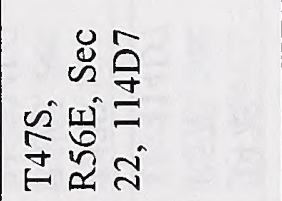 & 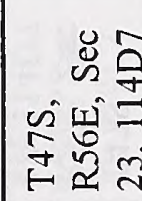 \\
\hline 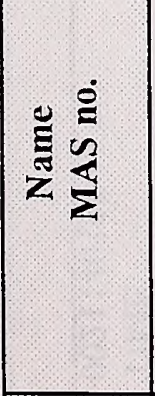 & 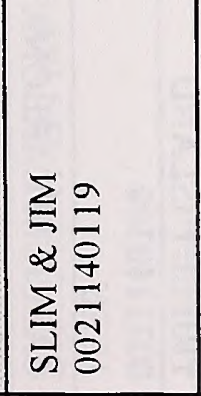 & 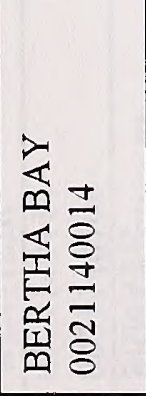 & 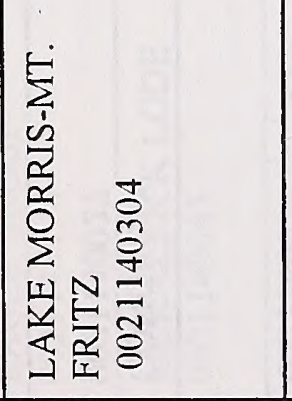 & 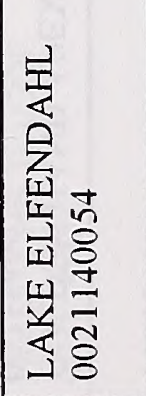 & 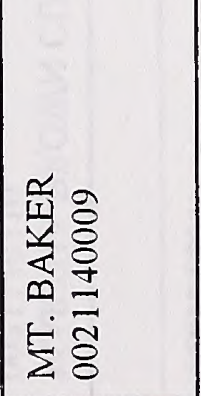 & 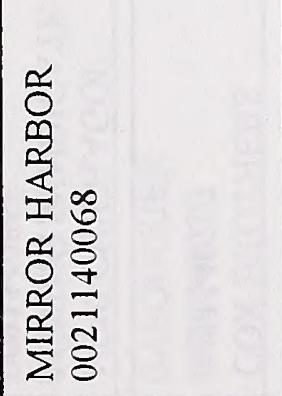 & 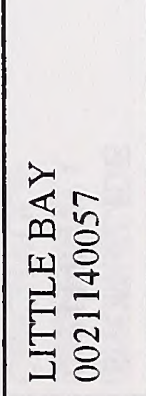 \\
\hline 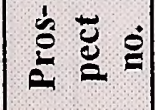 & 早 & $\Xi$ & $\frac{\mathcal{I}}{\mathrm{Q}}$ & $\vec{q}$ & $\underset{\Xi}{ \pm}$ & 管 & $\stackrel{0}{2}$ \\
\hline
\end{tabular}




\begin{tabular}{|c|c|c|c|c|c|c|c|c|c|c|}
\hline & $\Sigma 0=$ & - & 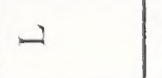 & $\dot{\Sigma} I$ & - & $\sum^{\prime} I$ & 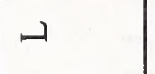 & 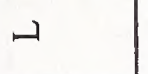 & \lrcorner & 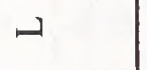 \\
\hline & 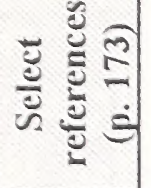 & $\bar{m}$ & वृ & $\begin{array}{l}8 \\
8 \\
\ddots\end{array}$ & 8 & 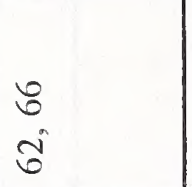 & 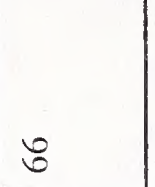 & $\because$ & $\because$ & $\mathscr{0}$ \\
\hline & $\sum_{0} \frac{y}{2}$ & 岂 & 罠 & $\simeq$ & 岂 & $\simeq$ & 㞱 & 兄 & 兄 & 㞱 \\
\hline 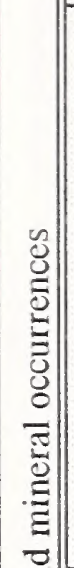 & 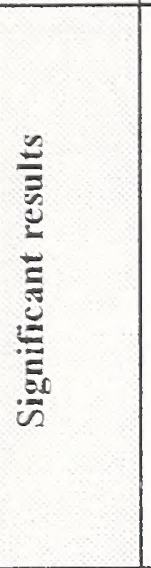 & $\stackrel{0}{\check{Z}}$ & 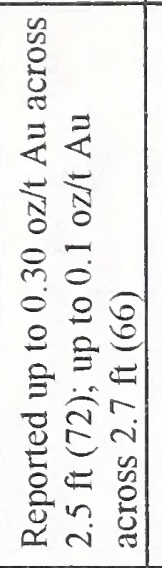 & 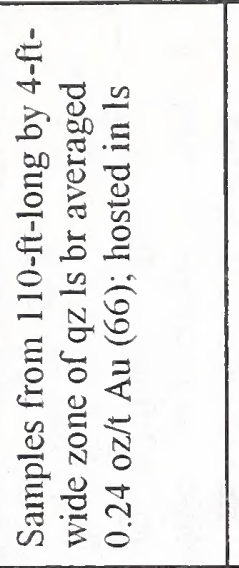 & 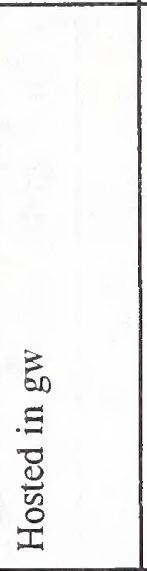 & 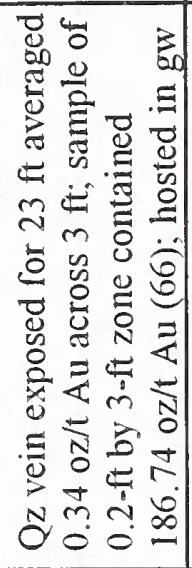 & 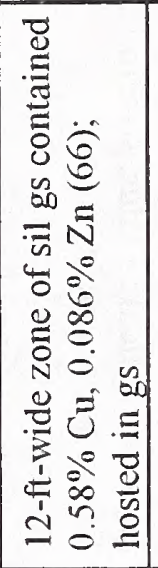 & 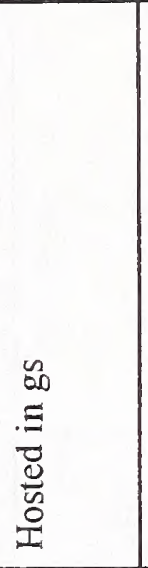 & 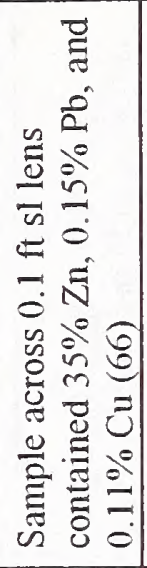 & $\begin{array}{l}Ð \\
\stackrel{2}{z}\end{array}$ \\
\hline \begin{tabular}{l|l}
$\vdots$ \\
0 \\
0 \\
0 \\
0 \\
$\vdots$ \\
$\vdots$
\end{tabular} & : & $\overleftarrow{z}$ & $\overleftrightarrow{z}$ & 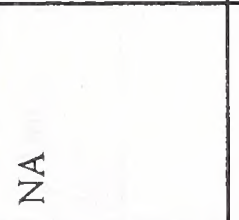 & $\mathbb{Z}$ & \begin{tabular}{l}
3 \\
\multirow{2}{*}{} \\
0 \\
0 \\
+
\end{tabular} & $\mathbb{Z}$ & $\mathbb{Z}$ & $\overleftrightarrow{z}$ & $\mathbb{z}$ \\
\hline 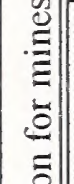 & $\frac{1}{\frac{1}{2}}$ & 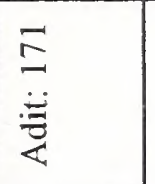 & 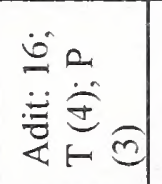 & 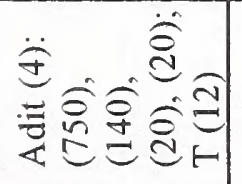 & 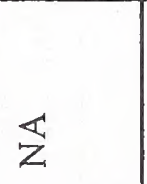 & 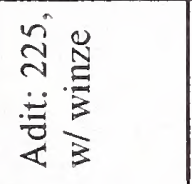 & $\begin{array}{l}\check{2} \\
\stackrel{7}{*}\end{array}$ & 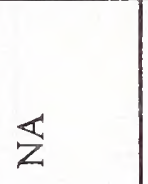 & $\overleftrightarrow{z}$ & $\underset{Z}{\mathbb{Z}}$ \\
\hline 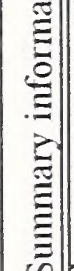 & 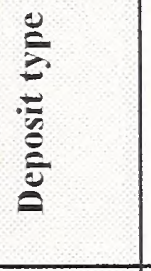 & 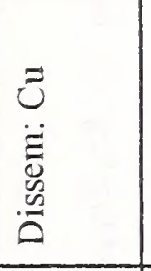 & $\begin{array}{l}\Xi \\
\ddot{\Delta}\end{array}$ & $\begin{array}{l}\Xi \\
\ddot{4}\end{array}$ & $\begin{array}{l}\ddot{z} \\
\ddot{y}\end{array}$ & $\begin{array}{l}\ddot{1} \\
\ddot{7}\end{array}$ & $\begin{array}{l}\text { Nี } \\
\tilde{E} \\
\dot{\infty} \\
\sum\end{array}$ & $\begin{array}{l}\tilde{U} \\
\dot{\ddot{2}} \\
\dot{j}\end{array}$ & $\begin{array}{l}\dot{2} \\
\tilde{N} \\
\dot{j} \\
\dot{j}\end{array}$ & 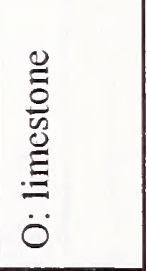 \\
\hline$\frac{1}{4}$ & 氖 & 先 & 至 & I & 岌 & 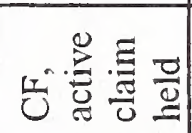 & 甹 & 先 & 岂 & 先 \\
\hline 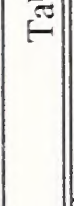 & 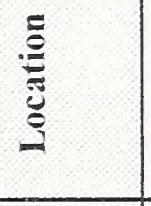 & 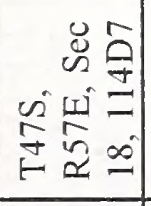 & 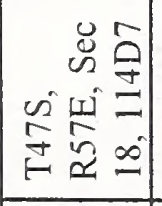 & 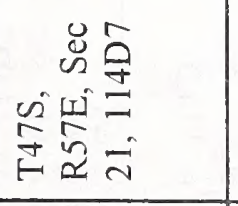 & 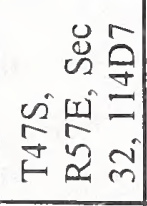 & 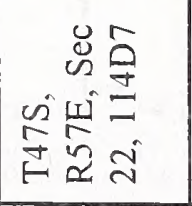 & 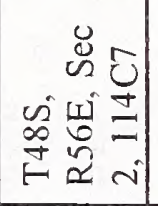 & 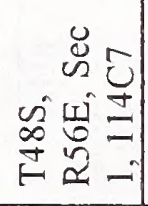 & 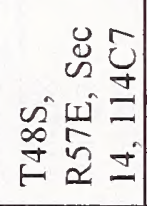 & 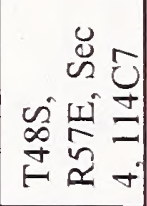 \\
\hline & 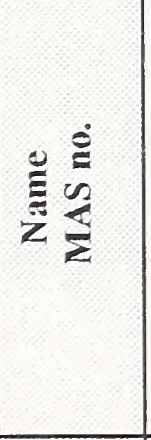 & 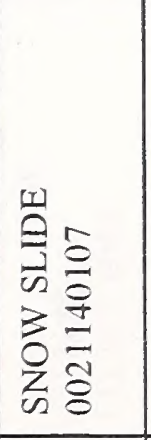 & 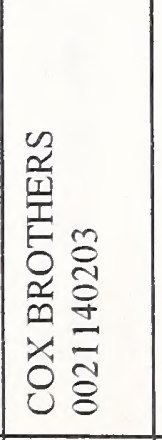 & 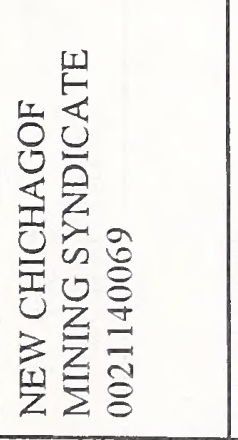 & 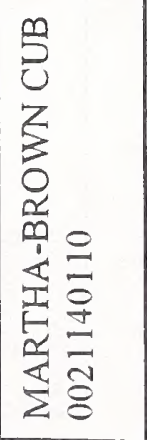 & 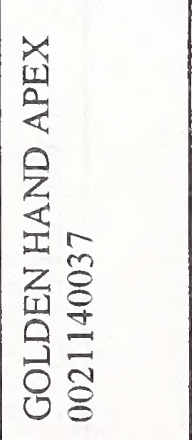 & 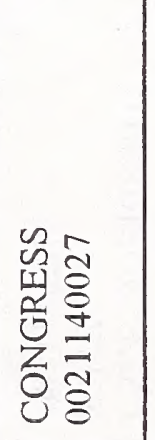 & 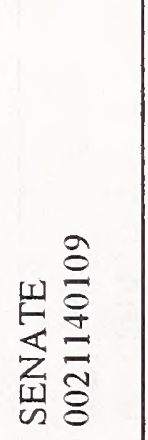 & 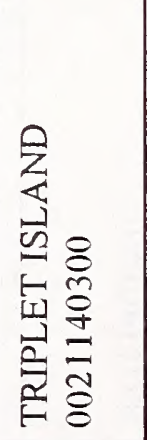 & 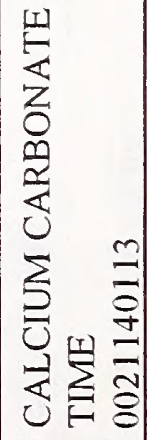 \\
\hline & 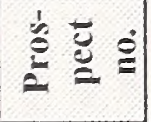 & I & $\stackrel{\infty}{a}$ & $\stackrel{q}{a}$ & ฉ̊ & $\bar{n}$ & $\approx$ & $\tilde{n}$ & $\stackrel{\vec{n}}{2}$ & $\approx$ \\
\hline
\end{tabular}




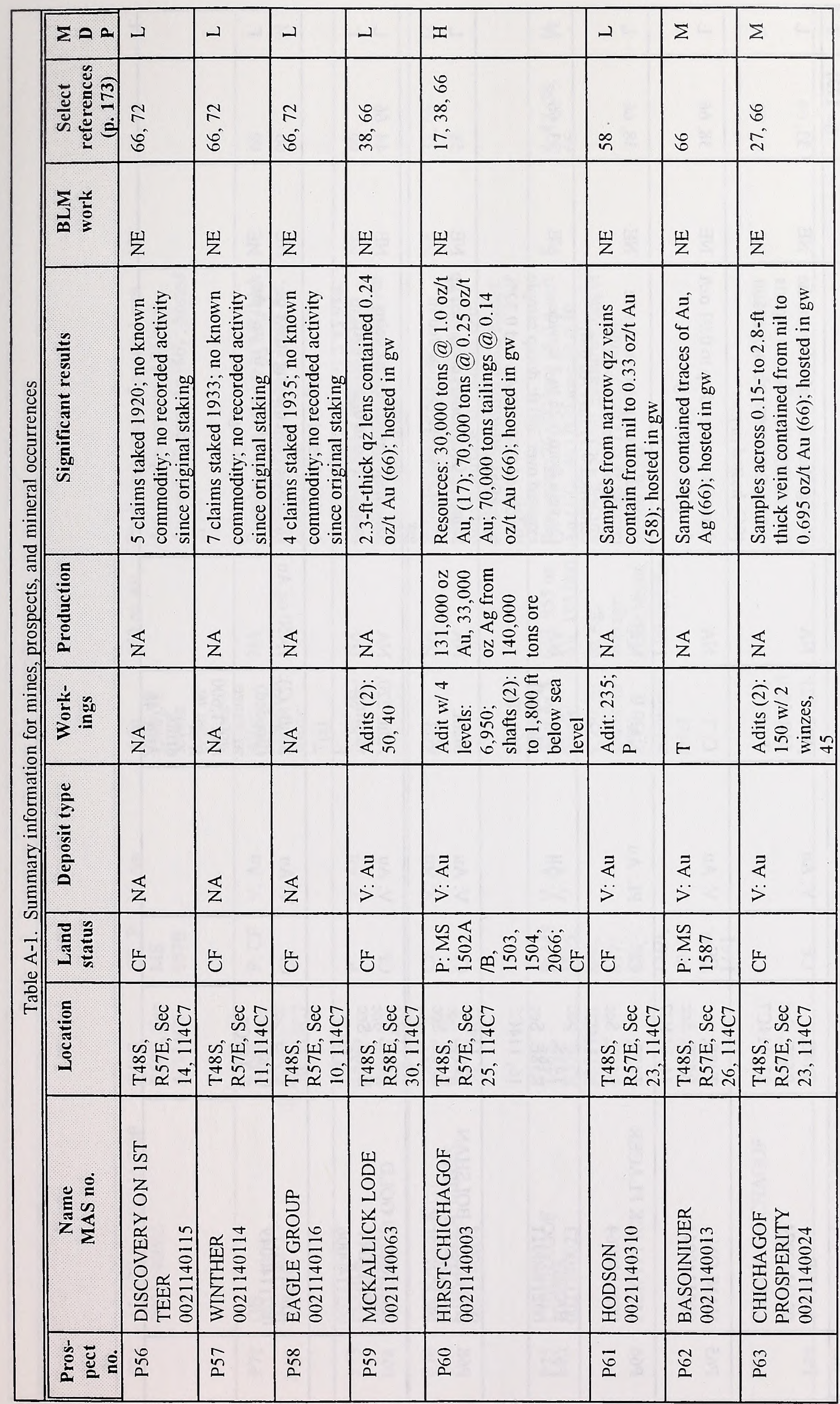




\begin{tabular}{|c|c|c|c|c|c|c|c|c|}
\hline & $\Sigma 0=$ & - & \lrcorner & $\rightarrow$ & $\Sigma$ & - & د & $\Sigma$ \\
\hline & 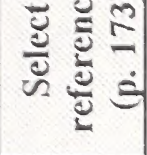 & $\begin{array}{l}8 \\
m \\
m\end{array}$ & $\begin{array}{l}8 \\
\infty \\
\infty \\
m\end{array}$ & $\begin{array}{l}\stackrel{0}{0} \\
\infty \\
m\end{array}$ & $\begin{array}{l}8 \\
\text { m } \\
m\end{array}$ & $\stackrel{\infty}{n}$ & $\begin{array}{l}\stackrel{8}{0} \\
\dot{7}\end{array}$ & 8 \\
\hline & $\bar{a}$ & $\frac{1}{z}$ & 岂 & 崩 & $\frac{\mathrm{II}}{\mathrm{z}}$ & 岂 & 㞱 & 岂 \\
\hline 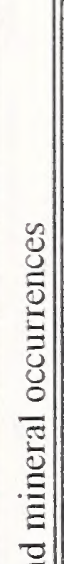 & 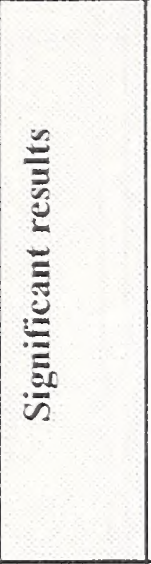 & 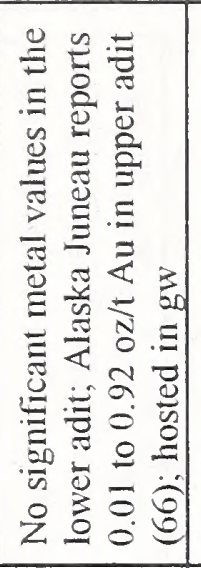 & 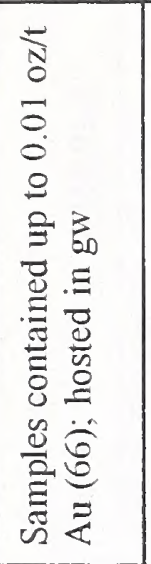 & 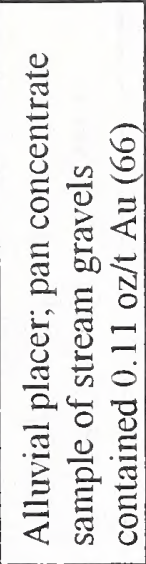 & 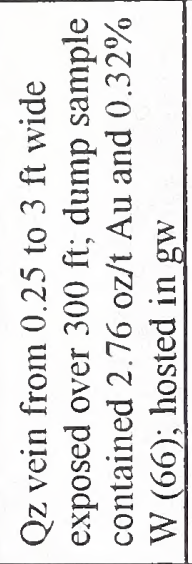 & 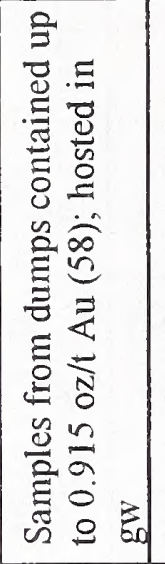 & 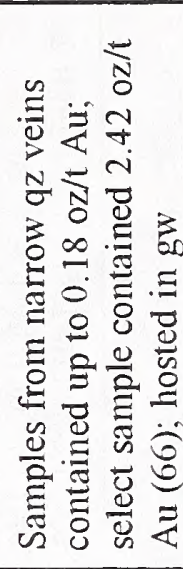 & 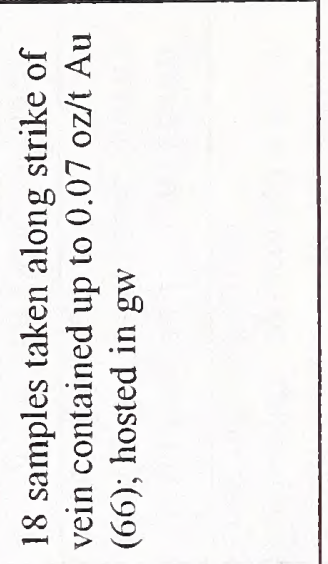 \\
\hline 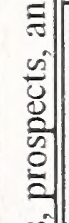 & 氮 & $\overleftarrow{z}$ & $\overleftarrow{z}$ & $\overleftrightarrow{z}$ & $\overleftarrow{z}$ & 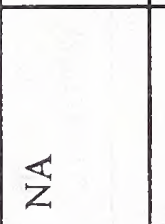 & $\mathbb{z}$ & $\begin{array}{l}Z \\
Z \\
N \\
0 \\
0 \\
0 \\
\vdots \\
-1\end{array}$ \\
\hline 总 & 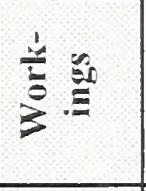 & 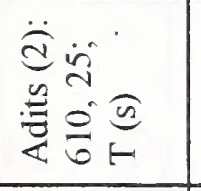 & $\begin{array}{l}E \\
ن\end{array}$ & $\overleftrightarrow{z}$ & 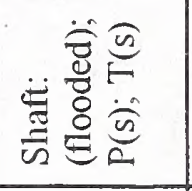 & 氙 & 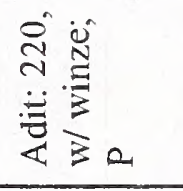 & 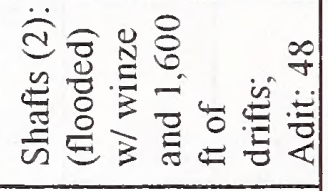 \\
\hline 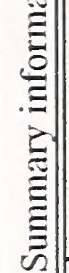 & 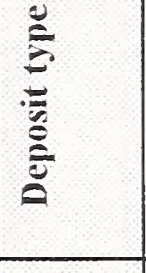 & $\begin{array}{l}z \\
\ddot{\Delta} \\
\ddot{>}\end{array}$ & $\begin{array}{l}\vec{t} \\
\ddot{>}\end{array}$ & $\begin{array}{l}\vec{z} \\
\dot{a}\end{array}$ & $\begin{array}{l}\vec{z} \\
\ddot{>}\end{array}$ & $\begin{array}{l}\vec{\Delta} \\
\ddot{>}\end{array}$ & 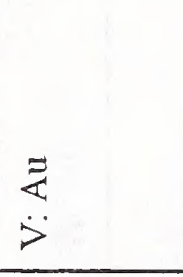 & $\begin{array}{l}\vec{z} \\
\ddot{>}\end{array}$ \\
\hline 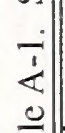 & 吾苛 & 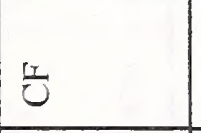 & 至 & 芘 & 先 & U & 先 & 先 \\
\hline f & 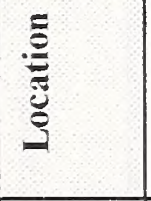 & 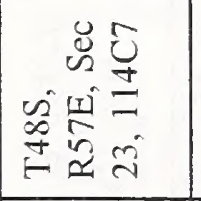 & 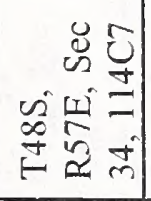 & 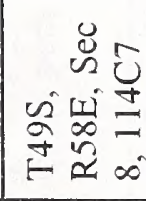 & 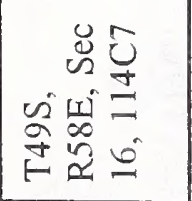 & 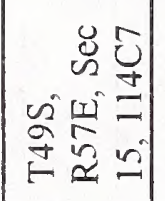 & 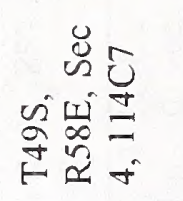 & 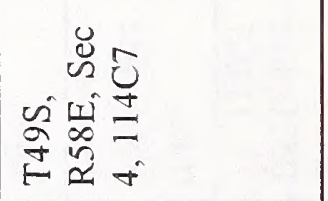 \\
\hline & 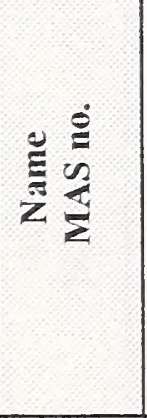 & 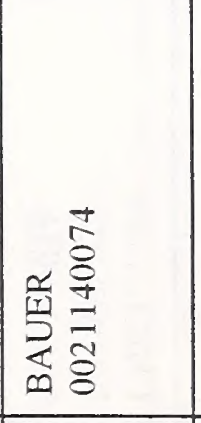 & 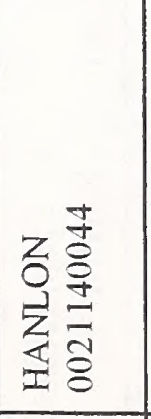 & 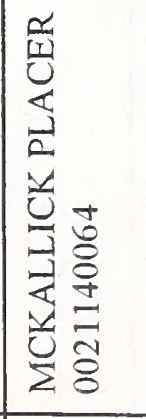 & 酉离 & 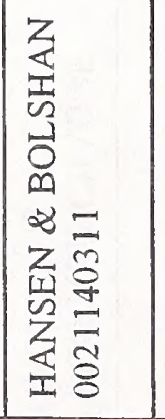 & 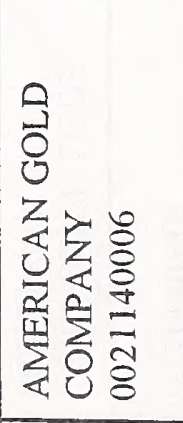 & 兽亭 \\
\hline & $\stackrel{\vec{E}}{\vec{E}}$ & 音 & 8 & ¿ & $\tilde{0}$ & 总 & oे & $\stackrel{R}{2}$ \\
\hline
\end{tabular}




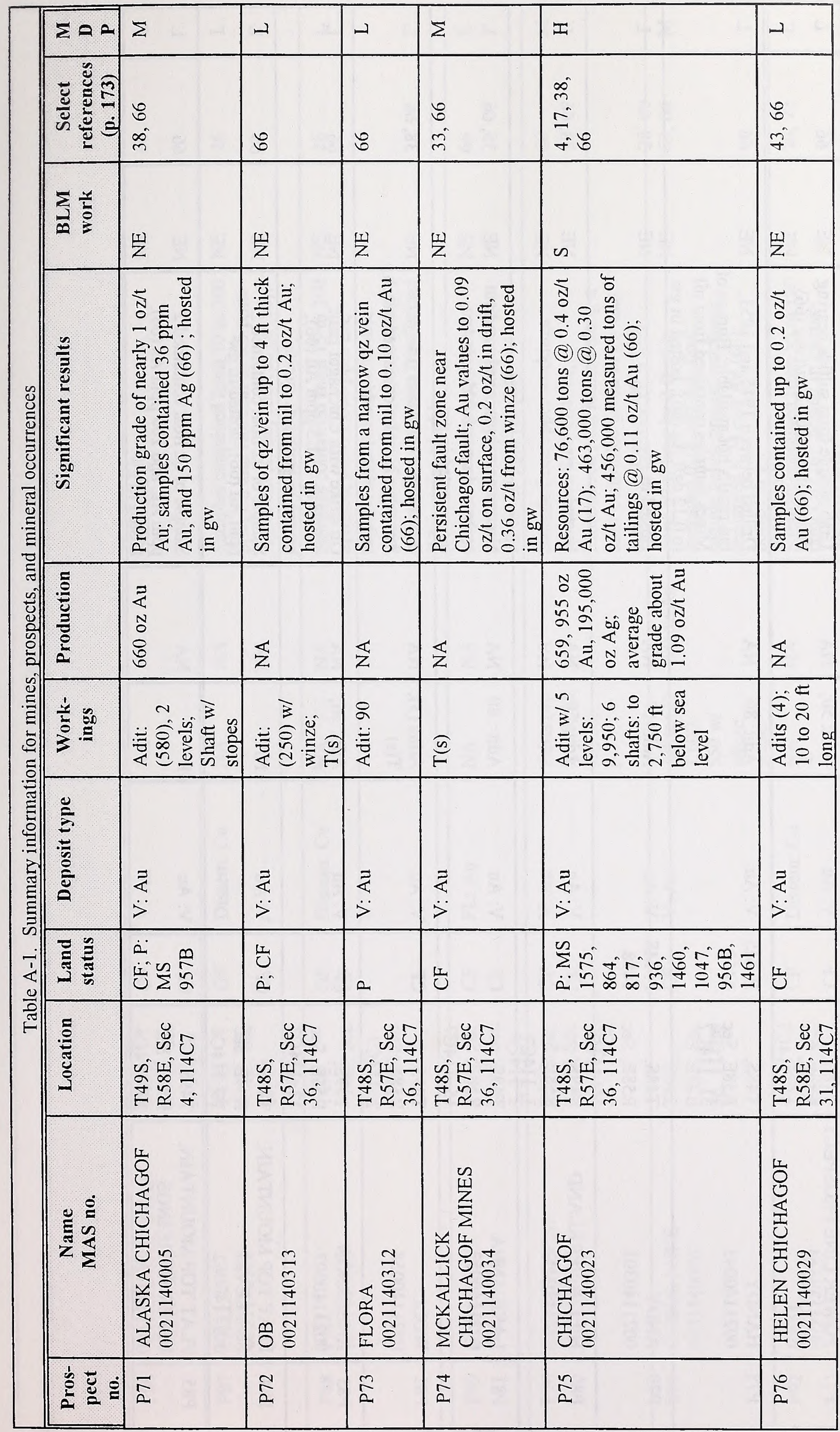




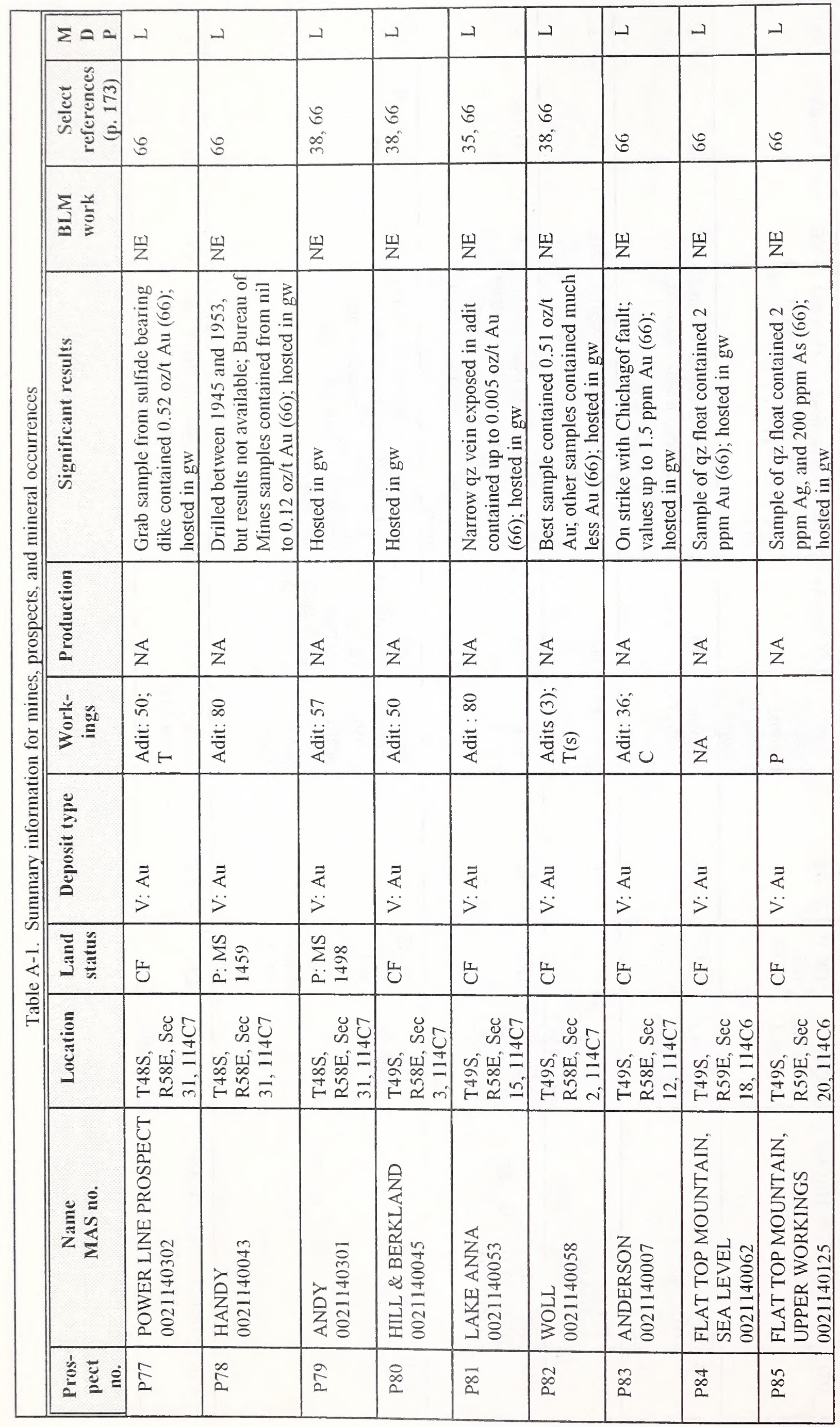




\begin{tabular}{|c|c|c|c|c|c|c|c|}
\hline$\Sigma \theta \alpha$ & - & دـ & دـ & - & $\Sigma$ & $\Sigma$ & $\lambda$ \\
\hline 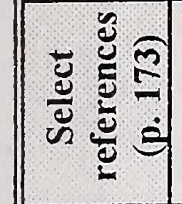 & 8 & $\stackrel{i}{i}$ & $\stackrel{i}{i}$ & 8 & 8 & 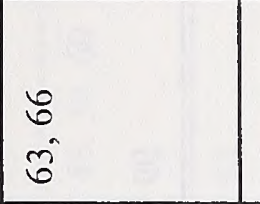 & $\begin{array}{l}\approx \\
\stackrel{\text { s }}{\circ}\end{array}$ \\
\hline$\sum_{10}$ & $\frac{\omega}{z}$ & $\frac{\omega}{z}$ & 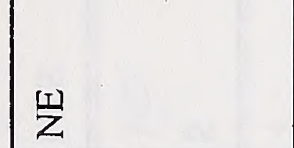 & $\frac{w}{z}$ & $\frac{w}{z}$ & $\frac{1}{z}$ & $\underline{\underline{z}}$ \\
\hline 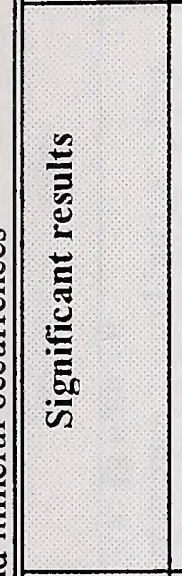 & 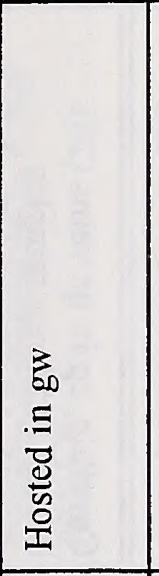 & 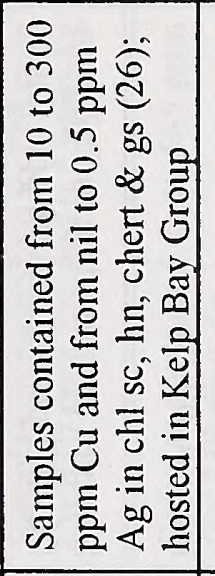 & 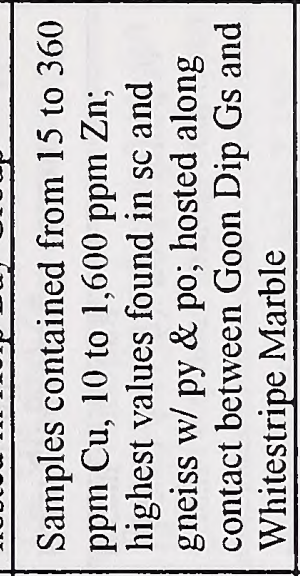 & 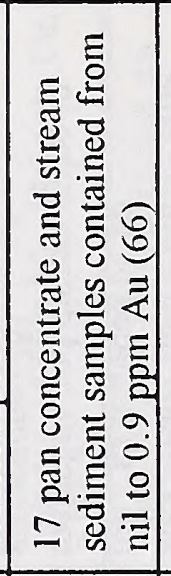 & 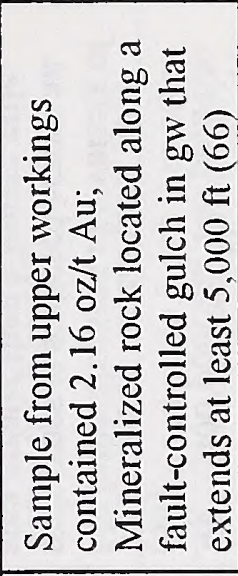 & 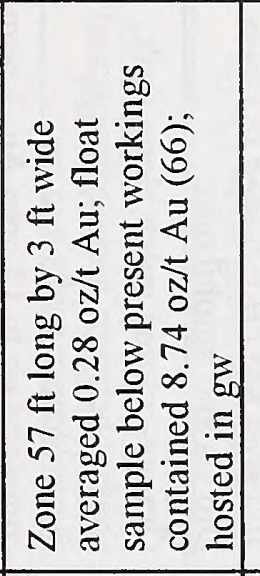 & 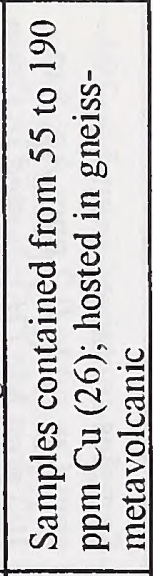 \\
\hline 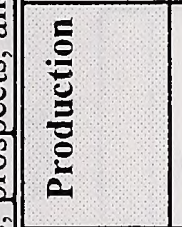 & $\overleftarrow{z}$ & $\mathbb{z}$ & $\overleftrightarrow{z}$ & $\overleftrightarrow{z}$ & $\overleftrightarrow{z}$ & 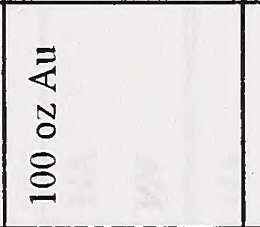 & $\overleftrightarrow{z}$ \\
\hline 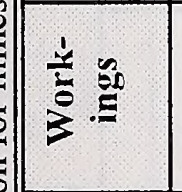 & $\overleftrightarrow{z}$ & $\overleftarrow{z}$ & $\underline{z}$ & $\frac{\pi}{z}$ & 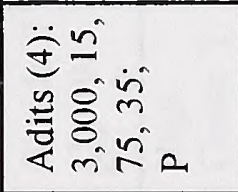 & 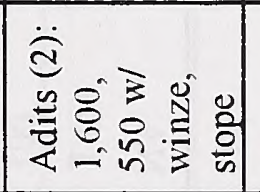 & 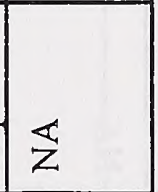 \\
\hline 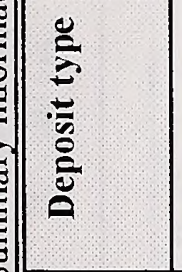 & $\begin{array}{l}\vec{\pi} \\
\dot{>}\end{array}$ & 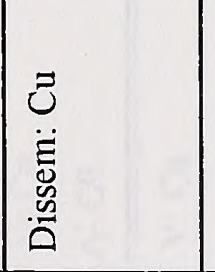 & 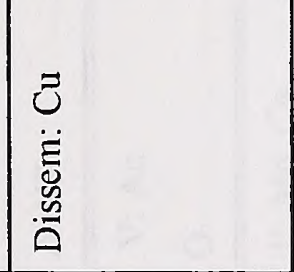 & $\begin{array}{l}\vec{z} \\
\dot{a}\end{array}$ & $\underset{⿱ 亠 ⿻}{\vec{z}}$ & $\frac{\pi}{\square}$ & 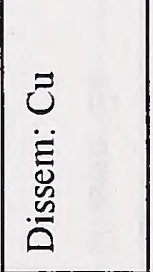 \\
\hline 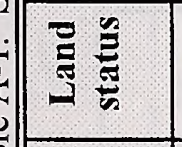 & 岀 & 똥 & 战 & ש & 岂 & 돈 & 岂 \\
\hline 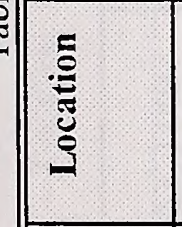 & 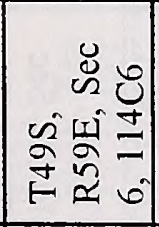 & 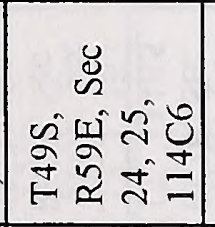 & 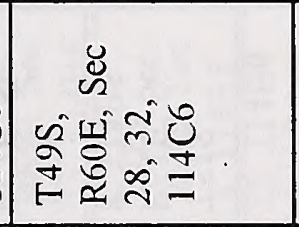 & 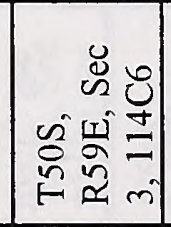 & 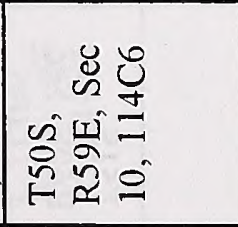 & 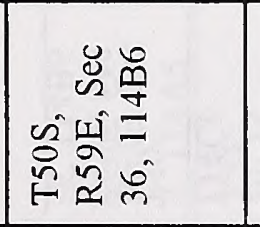 & 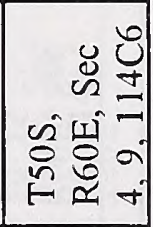 \\
\hline 竞离 & 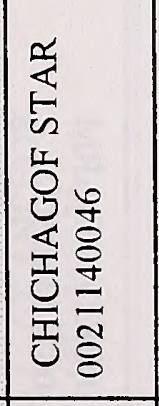 & 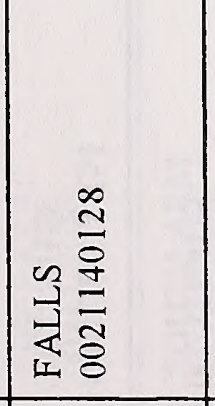 & 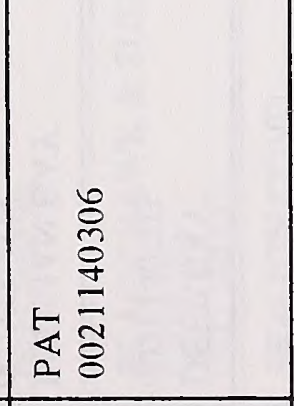 & 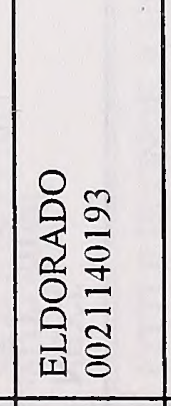 & 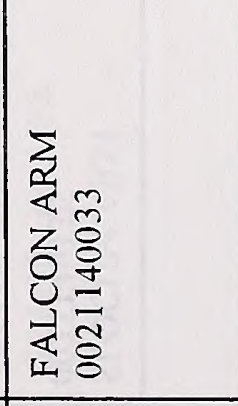 & 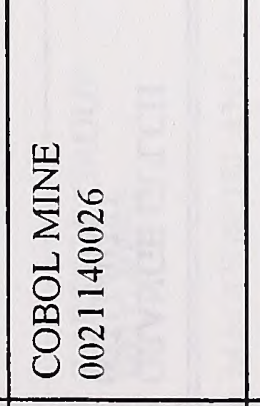 & 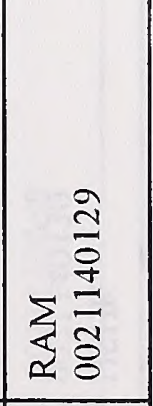 \\
\hline 它导 & $\stackrel{\infty}{\infty}$ & $\stackrel{\infty}{\infty}$ & 咅 & $\stackrel{\circ}{\stackrel{\infty}{\circ}}$ & ฉ & $\bar{\Omega}$ & $\check{\alpha}$ \\
\hline
\end{tabular}




\begin{tabular}{|c|c|c|c|c|c|c|c|c|c|}
\hline & $\Sigma 0=$ & 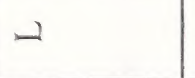 & - & $\Sigma$ & $\omega$ & 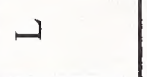 & - & $\omega$ & - \\
\hline & 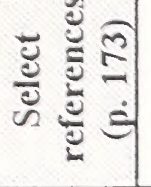 & $\begin{array}{l}\stackrel{N}{\tilde{N}} \\
\stackrel{0}{n}\end{array}$ & $B$ & $\begin{array}{l}B \\
\dot{c} \\
\dot{m}\end{array}$ & $\stackrel{\infty}{\sim}$ & $\stackrel{\sim}{\sim}$ & $\stackrel{2}{i}$ & $\stackrel{\sim}{\sim}$ & $\stackrel{\infty}{\sim}$ \\
\hline & $\sum_{0} \frac{1}{2}$ & 至 & 㟐 & $\Omega$ & 岳 & $\sim \Omega$ & 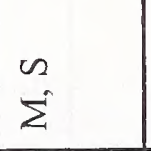 & $\sim$ & $\sim$ \\
\hline 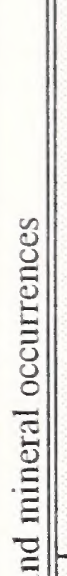 & 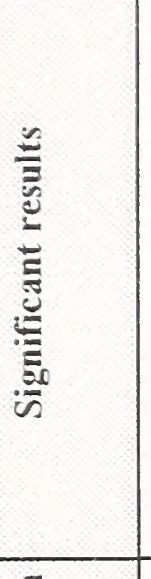 & 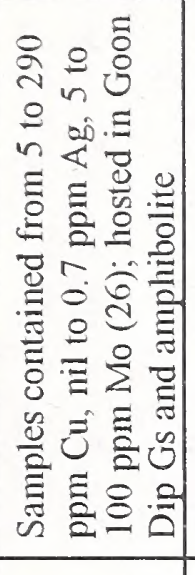 & 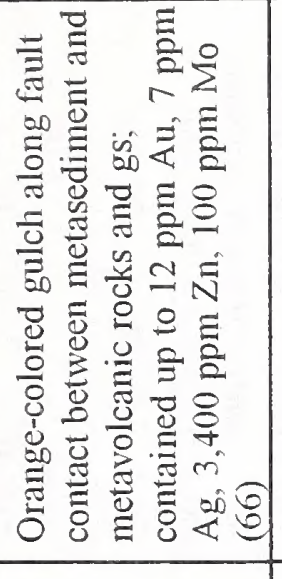 & 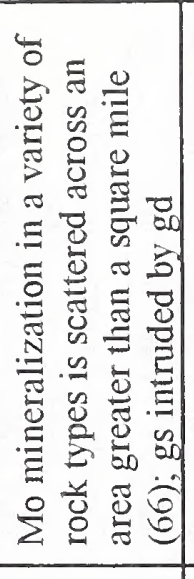 & 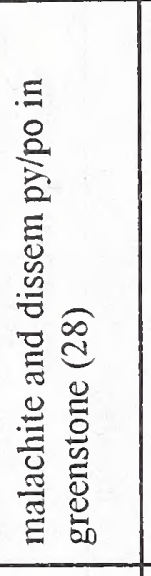 & 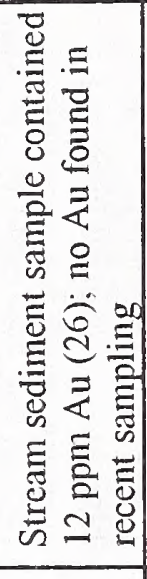 & 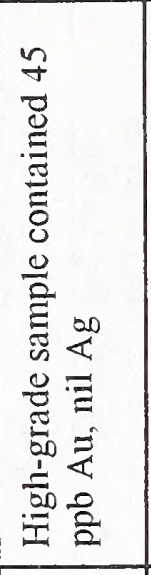 & 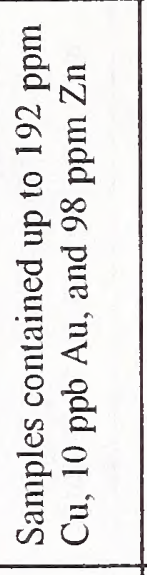 & 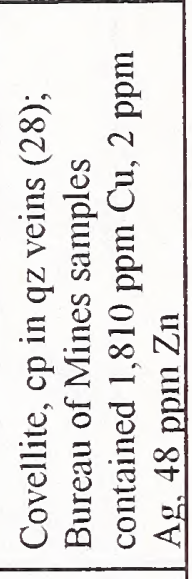 \\
\hline \begin{tabular}{l|l}
$\tilde{3}$ \\
0 \\
0 \\
0 \\
0 \\
0 \\
0
\end{tabular} & 苞 & $\overleftarrow{z}$ & $\mathbb{Z}$ & $\mathbb{Z}$ & $\mathbb{z}$ & $\mathbb{Z}$ & $\mathbb{Z}$ & 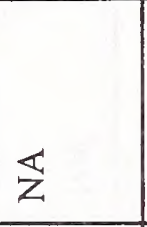 & $\overleftrightarrow{z}$ \\
\hline 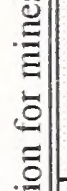 & $\sum^{\frac{1}{E}}$ & 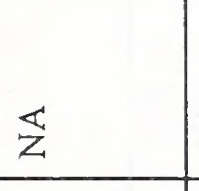 & $\overleftrightarrow{Z}$ & $\mathbb{Z}$ & $\overleftarrow{z}$ & $\mathbb{Z}$ & 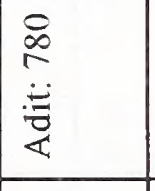 & $\overleftrightarrow{Z}$ & $\mathbb{Z}$ \\
\hline 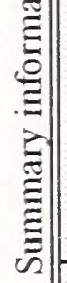 & 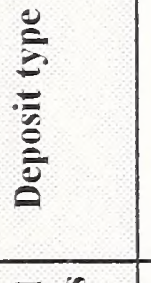 & 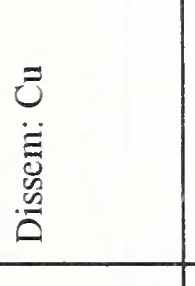 & $\dot{0}$ & $\sum_{i}^{0}$ & 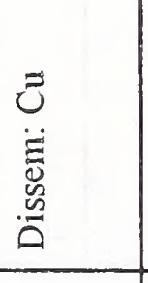 & $\ddot{0}$ & $\begin{array}{l}\Xi \\
\ddot{2} \\
\ddot{>}\end{array}$ & $\begin{array}{l}3 \\
\ddot{\gamma}\end{array}$ & $\begin{array}{l}\tilde{U} \\
\ddot{>}\end{array}$ \\
\hline \begin{tabular}{l||}
- \\
$\vdots$ \\
0 \\
0
\end{tabular} & ב气 & 告 & 岂 & 先 & 先 & 告 & 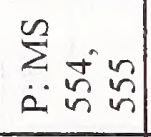 & 告 & 告 \\
\hline$\tilde{ت}$ & 离 & 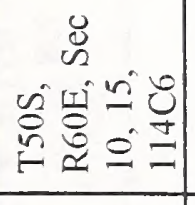 & 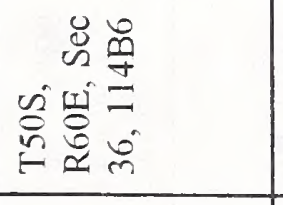 & 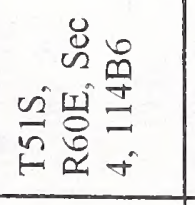 & 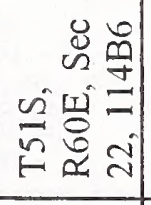 & 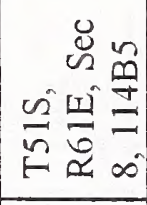 & 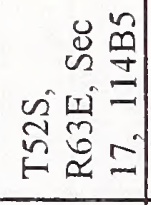 & 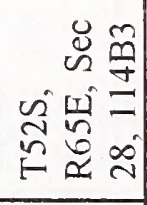 & 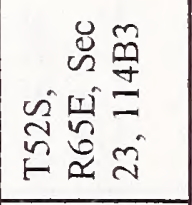 \\
\hline & 总 & 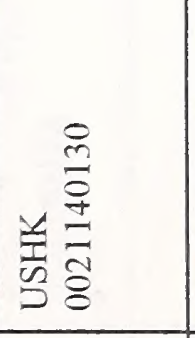 & 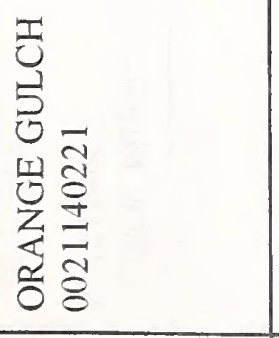 & 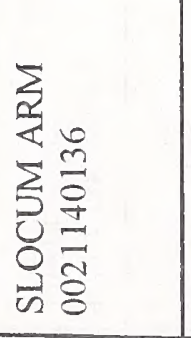 & 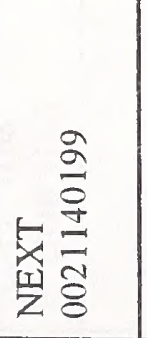 & 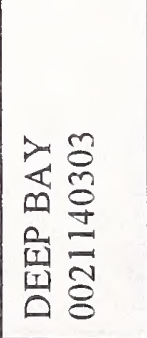 & 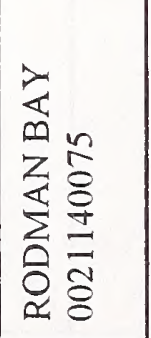 & 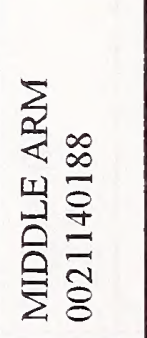 & 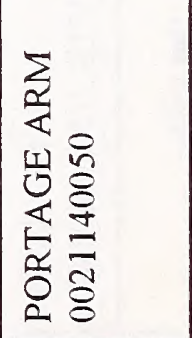 \\
\hline & 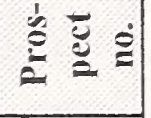 & $\ddot{a}$ & $\vec{a}$ & $\approx$ & ฉ̊ & $\hat{a}$ & $\stackrel{\Omega}{\Omega}$ & ฉิ & $\frac{8}{2}$ \\
\hline
\end{tabular}




\begin{tabular}{|c|c|c|c|c|c|c|c|c|c|}
\hline & $\Sigma a a$ & 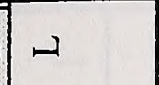 & 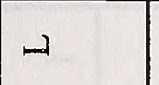 & -1 & 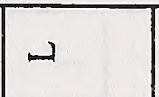 & \lrcorner & د. & 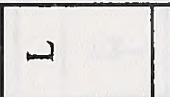 & 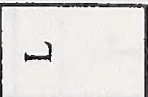 \\
\hline & 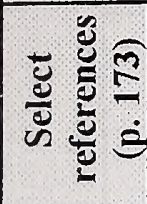 & 4 & $\stackrel{\sim}{\infty}$ & $\stackrel{\infty}{\infty}$ & $\approx$ & $\stackrel{\infty}{\sim}$ & $\begin{array}{l}\bar{n} \\
\dot{q}\end{array}$ & 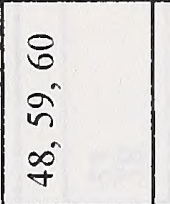 & 5 \\
\hline & 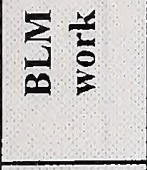 & os & is & n & $\underline{\underline{z}}$ & us & 岂 & $\sum^{2}$ & us \\
\hline & 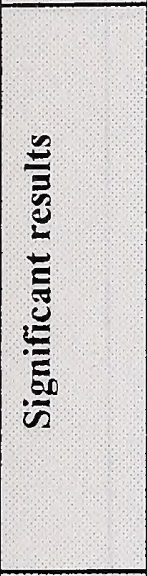 & 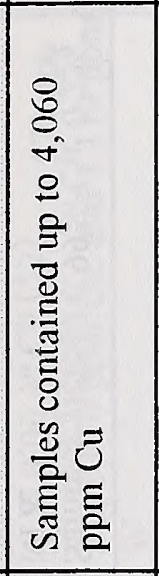 & 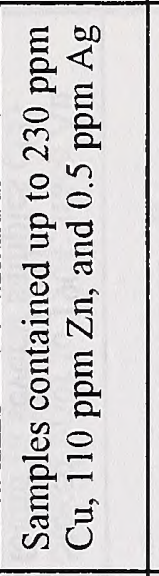 & 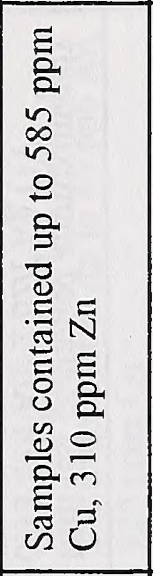 & 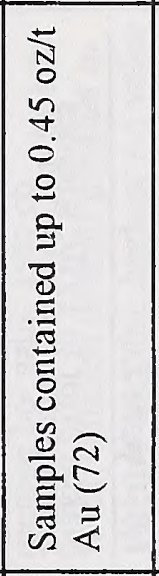 & 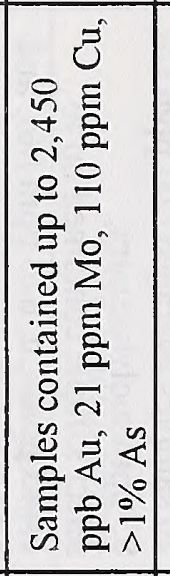 & 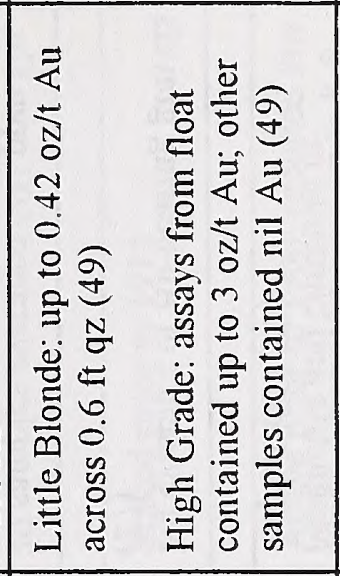 & 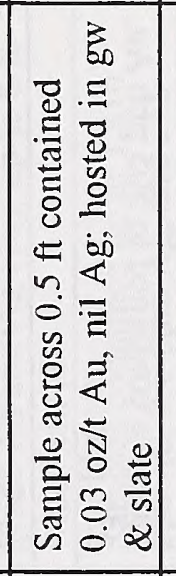 & 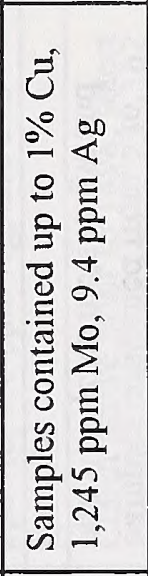 \\
\hline & 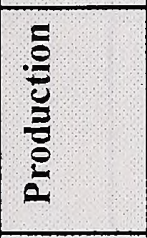 & $\mathbb{z}$ & $\overleftrightarrow{z}$ & $\overleftrightarrow{z}$ & $\overleftrightarrow{z}$ & $\overleftrightarrow{z}$ & $\mathbb{z}$ & $\underline{z}$ & $\mathbb{z}$ \\
\hline & 竎 & $\mathbb{z}$ & $\overleftrightarrow{z}$ & $\overleftrightarrow{z}$ & $\overleftrightarrow{z}$ & $\overleftrightarrow{z}$ & 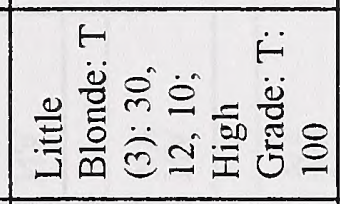 & $\stackrel{a}{a}$ & $\overleftrightarrow{z}$ \\
\hline & לั. & $\begin{array}{l}z \\
\end{array}$ & $\begin{array}{l}z \\
i\end{array}$ & \begin{tabular}{l}
$\tilde{J}$ \\
\hdashline
\end{tabular} & $\stackrel{7}{\square}$ & $\begin{array}{l}z \\
\sum_{0}^{0} \\
0\end{array}$ & 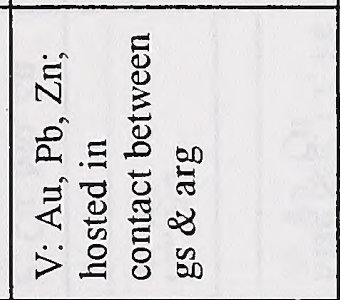 & $\begin{array}{l}\vec{z} \\
\ddot{\nabla}\end{array}$ & $\begin{array}{l}z \\
\sum_{j}^{0} \\
0\end{array}$ \\
\hline & 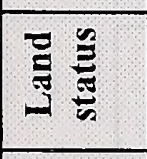 & tin & 똥 & t5 & 눙 & t。 & tᄂ & 感 & 崩 \\
\hline & פ్ & 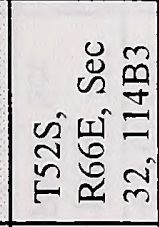 & 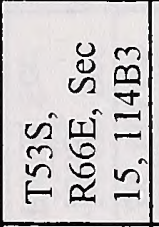 & 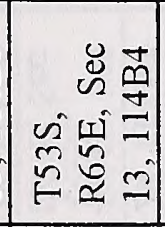 & 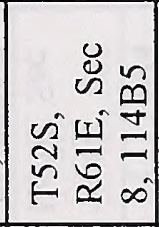 & 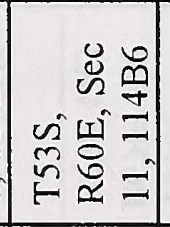 & 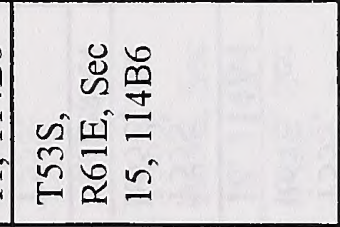 & 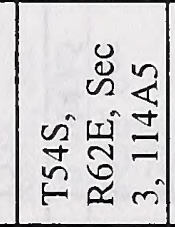 & 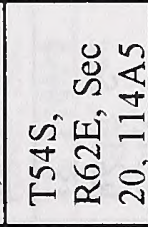 \\
\hline & 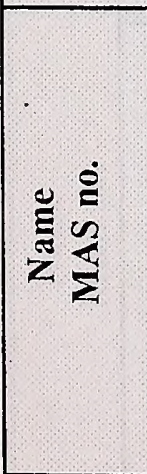 & 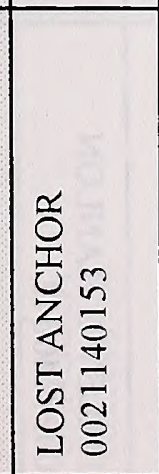 & 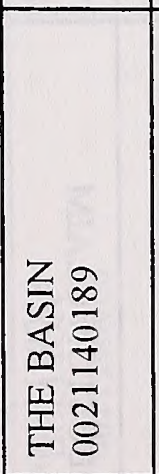 & 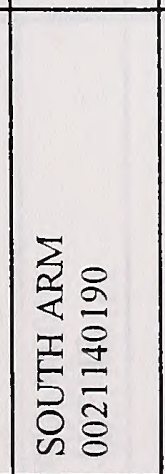 & 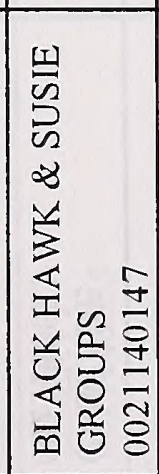 & 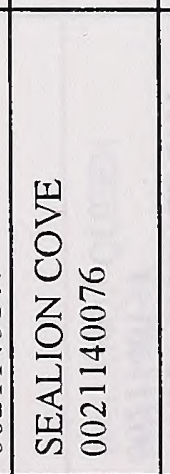 & 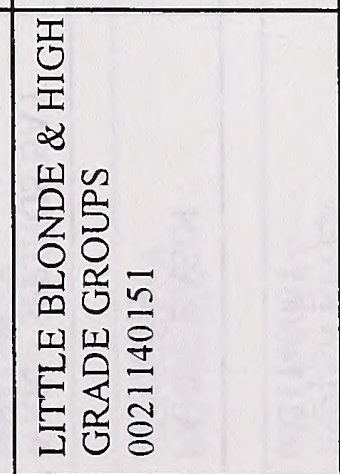 & 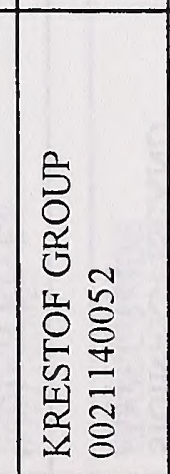 & 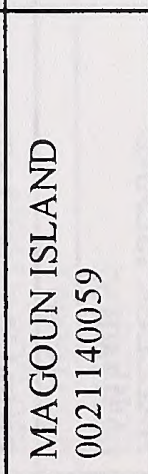 \\
\hline & $\dot{b}$ & $\frac{\bar{a}}{2}$ & $\frac{\tilde{O}}{\underline{\alpha}}$ & $\frac{m}{a}$ & $\frac{\vec{D}}{a}$ & $\frac{n}{2}$ & $\frac{8}{2}$ & $\frac{5}{a}$ & $\frac{\infty}{0}$ \\
\hline
\end{tabular}




\begin{tabular}{|c|c|c|c|c|c|c|c|c|c|c|}
\hline & $\Sigma=a$ & ــ & \lrcorner & $\sim$ & \lrcorner & $\Sigma$ & \lrcorner & \lrcorner & $\mapsto$ & \lrcorner \\
\hline & 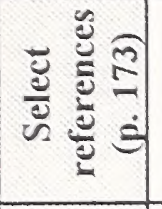 & $\begin{array}{l}\bar{n} \\
5\end{array}$ & $\stackrel{\infty}{\sim}$ & $\stackrel{\infty}{\sim}$ & $\bar{\sim}$ & $\approx$ & $\bar{\sim}$ & $\begin{array}{l}i \\
i \\
i\end{array}$ & $\begin{array}{l}i \\
\dot{n} \\
\ddot{n}\end{array}$ & $\approx$ \\
\hline & $\sum_{\infty} \frac{y}{5}$ & 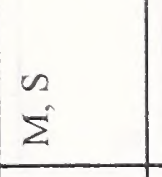 & $\sim$ & $\simeq$ & 崩 & $n$ & 至 & $\sum$ & 㞱 & 㞱 \\
\hline 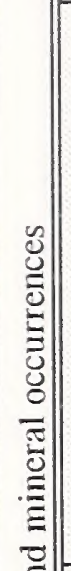 & 总 & 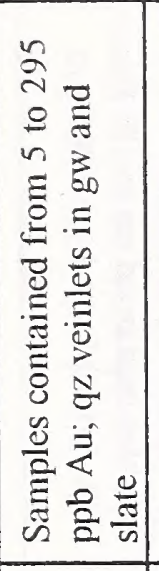 & 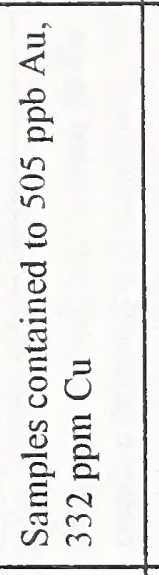 & 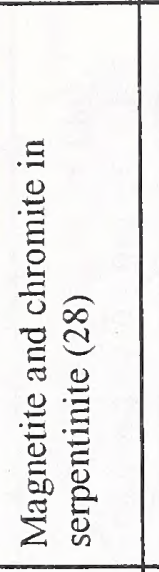 & 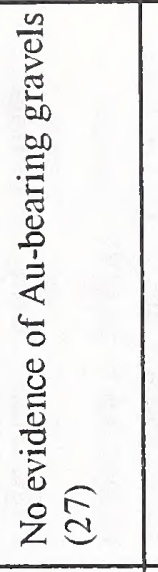 & 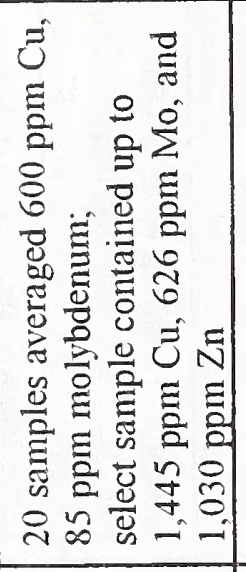 & 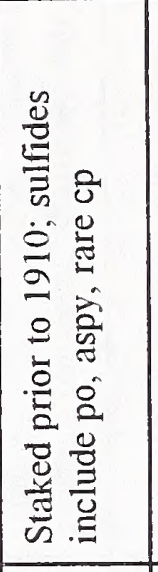 & 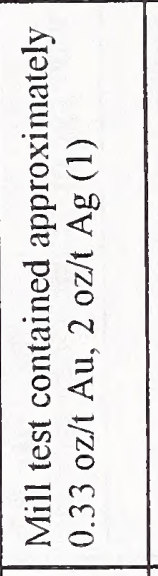 & 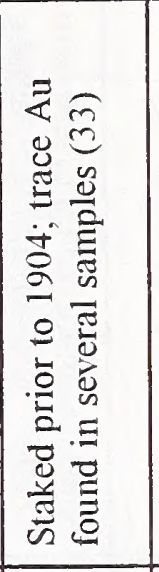 & 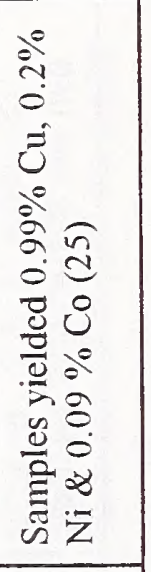 \\
\hline \begin{tabular}{l|l} 
& 0 \\
0 \\
0 \\
0 \\
0 \\
0 \\
0 \\
0
\end{tabular} & $\frac{\tilde{E}}{\stackrel{E}{\mathscr{E}}}$ & $\overleftrightarrow{Z}$ & $\overleftrightarrow{z}$ & $\mathbb{z}$ & $\overleftrightarrow{z}$ & $\mathbb{Z}$ & $\mathbb{Z}$ & 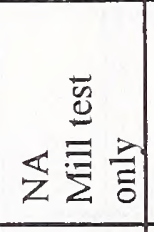 & $\overleftrightarrow{Z}$ & $\overleftrightarrow{Z}$ \\
\hline 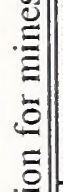 & 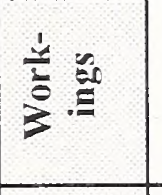 & 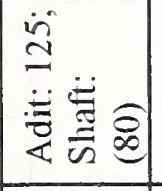 & 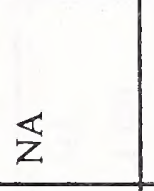 & $\overleftrightarrow{Z}$ & $\overleftrightarrow{z}$ & $\overleftrightarrow{Z}$ & $\widehat{\widetilde{n}}$ & 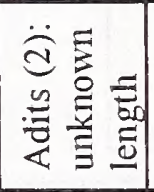 & 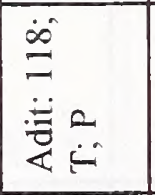 & $\frac{n}{2}$ \\
\hline 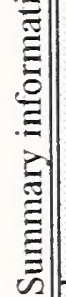 & 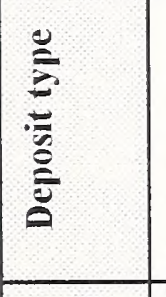 & $\begin{array}{l}\ddot{z} \\
\ddot{>}\end{array}$ & 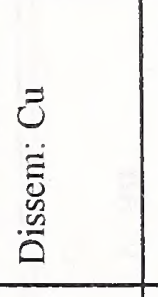 & 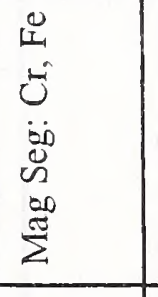 & $\begin{array}{l}\overrightarrow{+} \\
\dot{a}\end{array}$ & $\begin{array}{l}\hat{N} \\
\dot{0} \\
\dot{\Xi} \\
0\end{array}$ & $\begin{array}{l}\vec{z} \\
\ddot{>}\end{array}$ & $\begin{array}{l}\hat{2} \\
00 \\
\dot{3} \\
\dot{3} \\
\ddot{3}\end{array}$ & $\begin{array}{l}\ddot{z} \\
\ddot{>}\end{array}$ & $\begin{array}{l}\dot{U} \\
\tilde{u} \\
\bar{z} \\
\ddot{j}\end{array}$ \\
\hline \begin{tabular}{l|l||} 
\\
$\dot{2}$ \\
0
\end{tabular} & 氞 & 步 & 岁 & 告 & $\begin{array}{l}\sum_{i}^{\infty} \infty \\
i n \\
i n\end{array}$ & 岁 & 岁 & 岁 & us & us \\
\hline 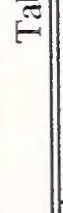 & 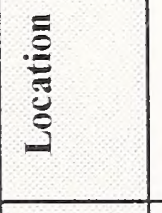 & 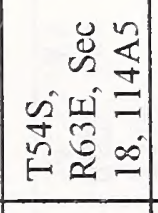 & 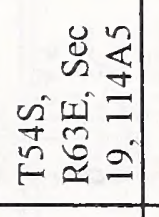 & 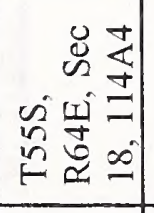 & 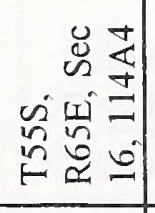 & 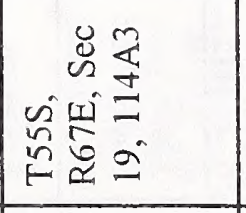 & 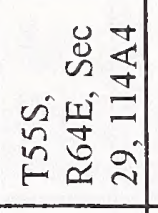 & 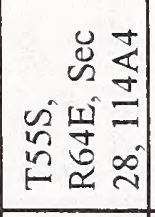 & 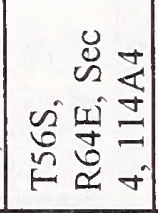 & 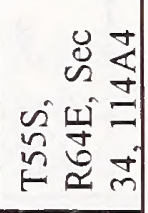 \\
\hline & 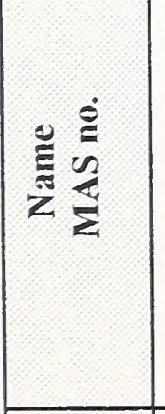 & 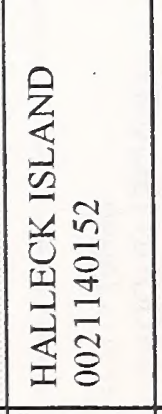 & 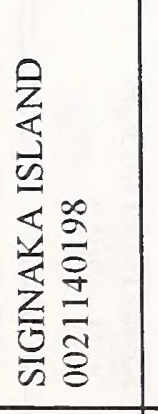 & 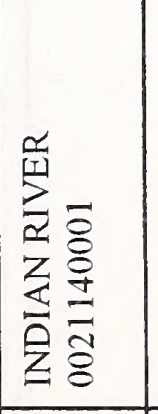 & 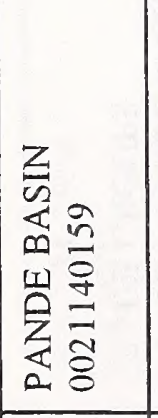 & 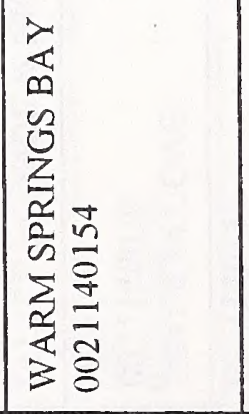 & 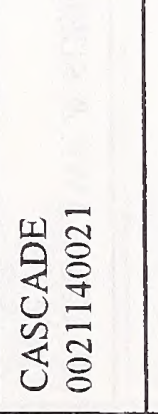 & 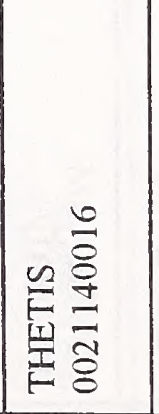 & 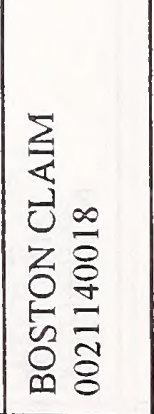 & 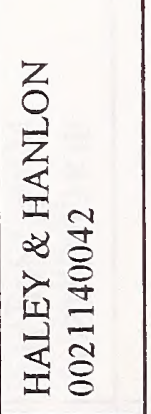 \\
\hline & 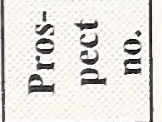 & $\frac{a}{2}$ & $\stackrel{\varrho}{a}$ & $\Xi$ & $\stackrel{I}{\Xi}$ & $\stackrel{m}{a}$ & $\stackrel{\Xi}{\Xi}$ & $\stackrel{n}{a}$ & $\stackrel{0}{=}$ & 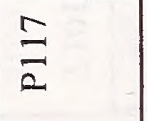 \\
\hline
\end{tabular}




\begin{tabular}{|c|c|c|c|c|c|c|c|c|c|c|}
\hline & $\Sigma=a$ & $\dashv$ & \lrcorner & \lrcorner & \lrcorner & \lrcorner & ـ & ـ & 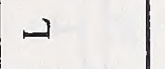 & د \\
\hline & 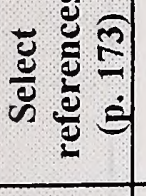 & ת & $\begin{array}{l}\approx \\
\approx\end{array}$ & n & $\begin{array}{l}\tilde{\lambda} \\
i\end{array}$ & $\approx$ & $\approx$ & $\begin{array}{l}\tilde{\lambda} \\
\bar{m}\end{array}$ & $n$ & 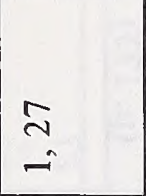 \\
\hline & 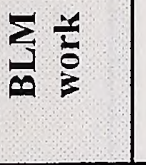 & $\sum^{\infty}$ & 㞱 & $\sum$ & $\stackrel{n}{\Sigma}$ & 㞱 & 坮 & $\frac{\pi}{2}$ & $\sum$ & $\sum$ \\
\hline 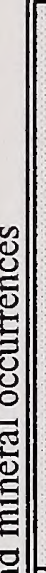 & 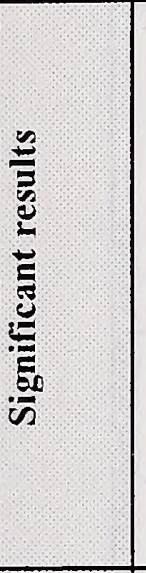 & 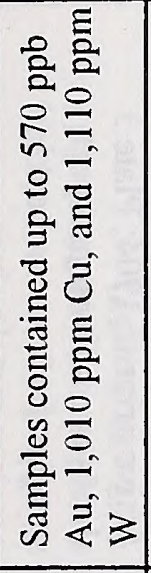 & 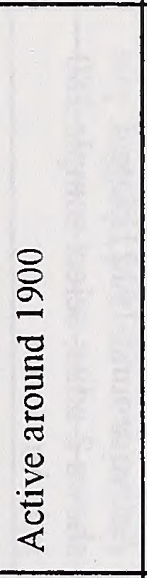 & 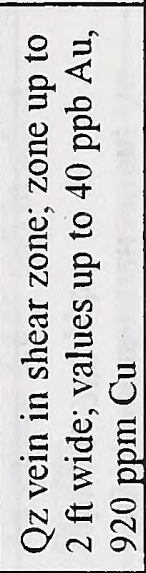 & 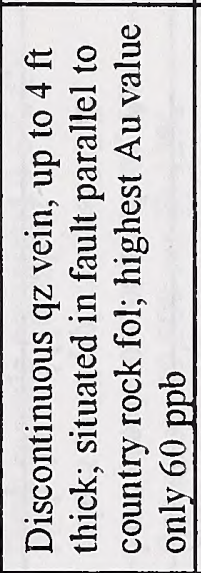 & 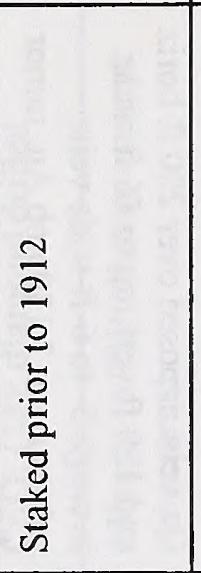 & 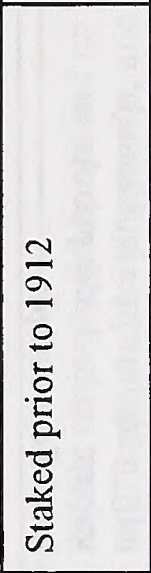 & 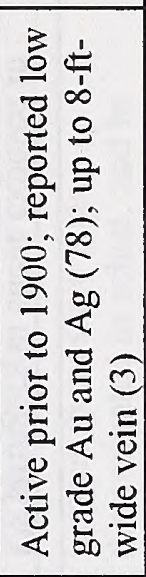 & 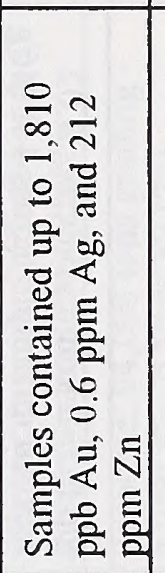 & 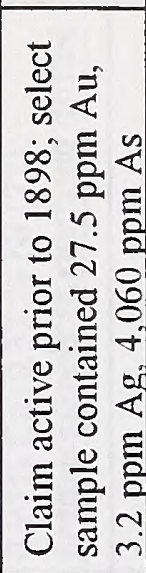 \\
\hline & 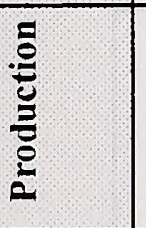 & $\overleftarrow{z}$ & $\overleftrightarrow{z}$ & $\overleftrightarrow{z}$ & $\overleftrightarrow{z}$ & $\overleftrightarrow{z}$ & $\overleftarrow{z}$ & $\overleftrightarrow{z}$ & 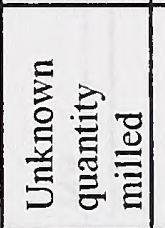 & 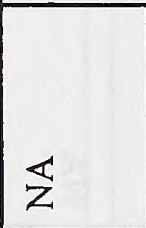 \\
\hline 音 & 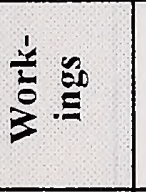 & $\stackrel{2}{\ddot{H}}$ & $\overleftrightarrow{z}$ & 文 & 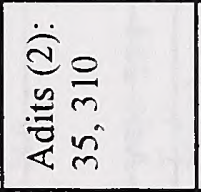 & 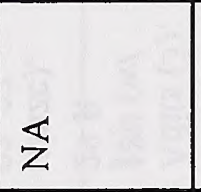 & $\overleftrightarrow{z}$ & $\overleftrightarrow{z}$ & 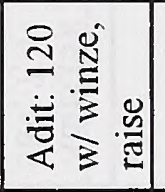 & 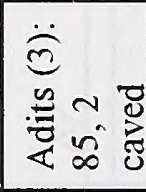 \\
\hline & 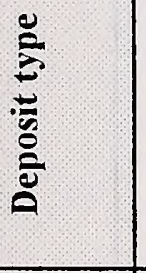 & $\begin{array}{l}z \\
3 \\
\ddot{>}\end{array}$ & $\begin{array}{l}\vec{z} \\
\ddot{>}\end{array}$ & $\begin{array}{l}\nexists \\
\ddot{>}\end{array}$ & $\begin{array}{l}\vec{\Delta} \\
\ddot{>}\end{array}$ & $\begin{array}{l}\vec{\Delta} \\
\ddot{>}\end{array}$ & $\begin{array}{l}\vec{z} \\
\ddot{>}\end{array}$ & $\begin{array}{l}z \\
z \\
\ddot{z} \\
\ddot{7}\end{array}$ & $\begin{array}{l}\vec{z} \\
\ddot{>}\end{array}$ & $\begin{array}{l}\vec{z} \\
\ddot{>}\end{array}$ \\
\hline is & 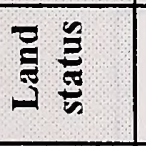 & $\sim 2$ & 岁 & 告 & 峁 & n & $\backsim$ & es & $\frac{1}{0}$ & $\frac{1}{0}$ \\
\hline & 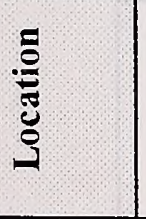 & 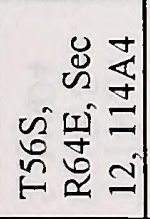 & 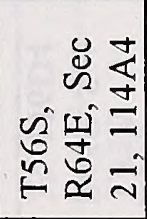 & 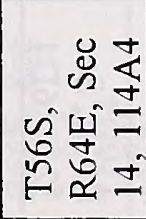 & 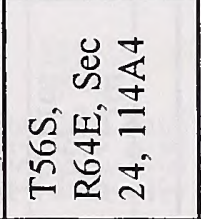 & 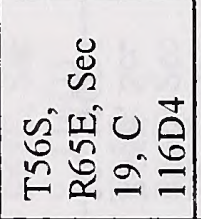 & 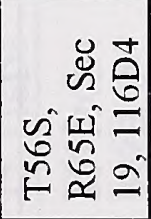 & 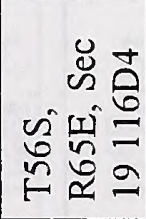 & 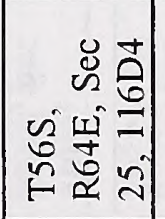 & 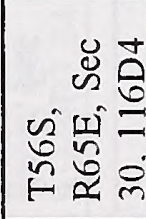 \\
\hline & 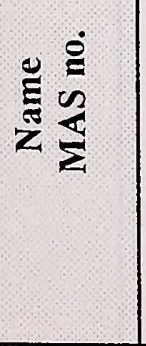 & 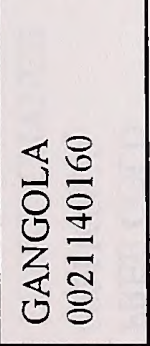 & 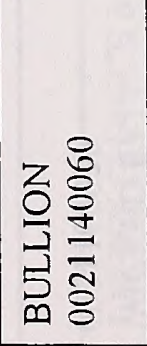 & 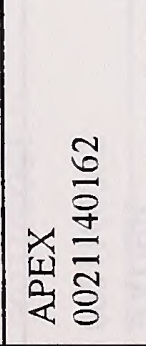 & 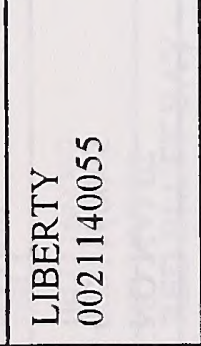 & 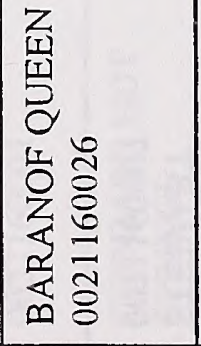 & 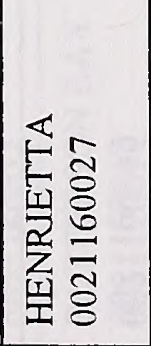 & 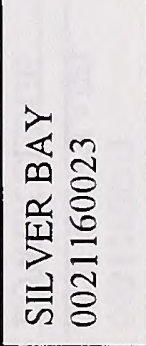 & 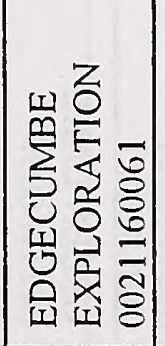 & 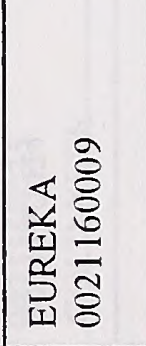 \\
\hline & 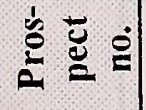 & $\stackrel{\infty}{=}$ & $\frac{2}{2}$ & $\stackrel{\Xi}{2}$ & $\bar{\Xi}$ & $\frac{\pi}{2}$ & $\frac{\pi}{2}$ & $\frac{\pi}{2}$ & $\stackrel{2}{2}$ & $\stackrel{\square}{2}$ \\
\hline
\end{tabular}




\begin{tabular}{|c|c|c|c|c|c|c|c|c|c|}
\hline & $\Sigma=-$ & - & - & - & - & - & $\leadsto$ & \lrcorner & 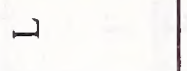 \\
\hline & 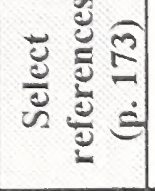 & $\grave{\sim}$ & $\begin{array}{l}q \\
\text { m } \\
m\end{array}$ & $\begin{array}{l}\hat{N} \\
i\end{array}$ & $\begin{array}{l}n \\
\vdots \\
i\end{array}$ & & $\begin{array}{l}\hat{i} \\
\vec{i}\end{array}$ & $\bar{\sim}$ & $\bar{\imath}$ \\
\hline & $\sum_{=0}^{\infty}$ & 之 & $\sim$ & $\stackrel{n}{\Sigma}$ & $\sum$ & $\dot{\Sigma}$ & $\stackrel{\sim}{\Sigma}$ & $\stackrel{\Sigma}{\Sigma}$ & $\infty$ \\
\hline 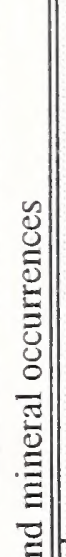 & 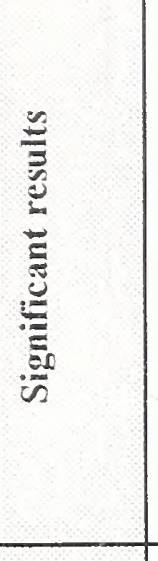 & 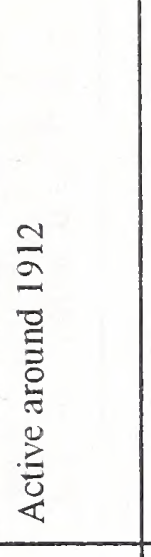 & 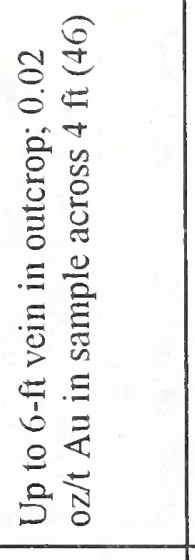 & 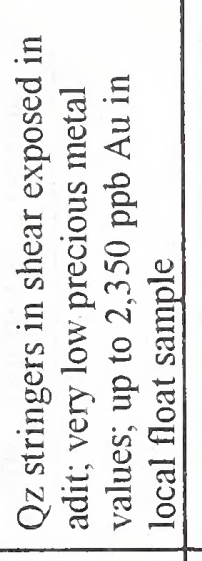 & 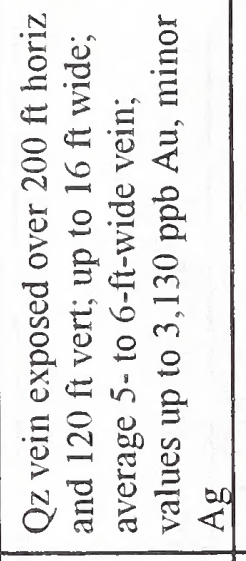 & 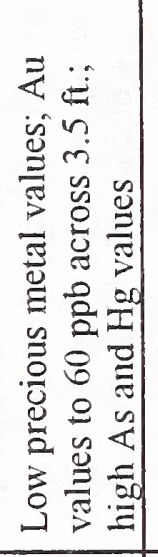 & 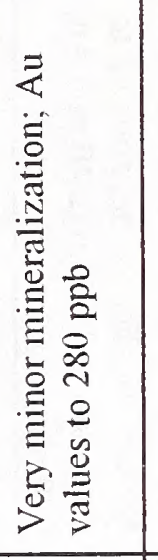 & 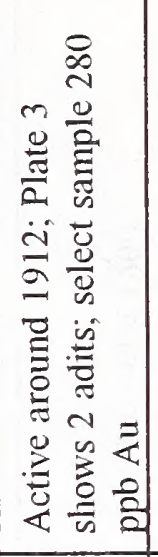 & 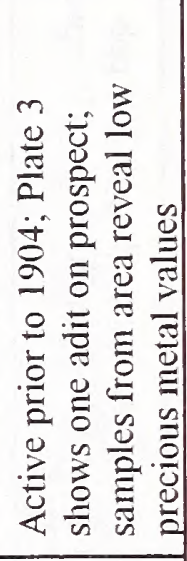 \\
\hline \begin{tabular}{l|l}
$\pi$ \\
0 \\
0 \\
0 \\
0 \\
0 \\
0 \\
0 \\
0
\end{tabular} & & $\overleftrightarrow{z}$ & $\overleftrightarrow{Z}$ & $\overleftrightarrow{Z}$ & 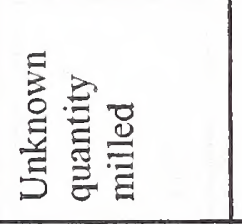 & $\mathbb{Z}$ & $\mathbb{Z}$ & $\overleftrightarrow{Z}$ & $\mathbb{Z}$ \\
\hline 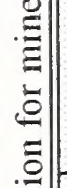 & $\sum_{3}^{\frac{1}{\grave{b}}}$ & $\overleftrightarrow{Z}$ & 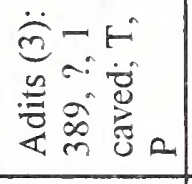 & 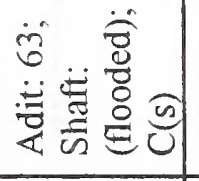 & 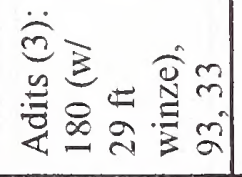 & 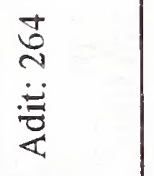 & 泀尽 & 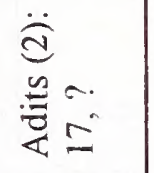 & 昰 \\
\hline 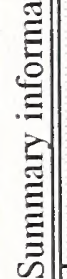 & 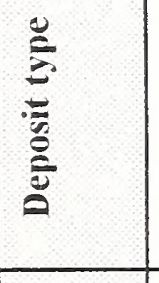 & $\begin{array}{l}\vec{z} \\
\ddot{y}\end{array}$ & $\begin{array}{l}\stackrel{3}{*} \\
\ddot{>}\end{array}$ & $\begin{array}{l}\ddot{z} \\
\ddot{y}\end{array}$ & $\begin{array}{l}\sum_{i}^{\infty} \\
\dot{z} \\
\ddot{j}\end{array}$ & $\begin{array}{l}\vec{z} \\
\ddot{>}\end{array}$ & $\begin{array}{l}\ddot{z} \\
\dot{>}\end{array}$ & $\begin{array}{l}\vec{z} \\
\ddot{>}\end{array}$ & $\begin{array}{l}\ddot{z} \\
\ddot{7}\end{array}$ \\
\hline-1 & 总 & 告 & $\sim$ & 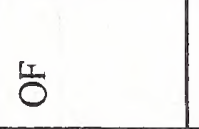 & $\sum_{i}^{\infty} \hat{D}_{0}^{\infty}$ & 5 & 5 & 5 & 5 \\
\hline$\stackrel{\pi}{-\pi}$ & . & 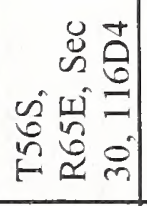 & 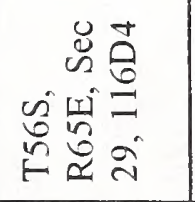 & 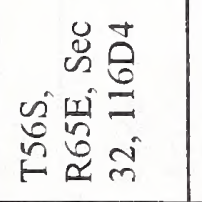 & 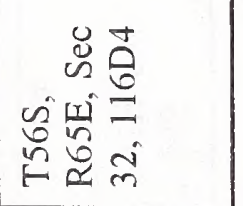 & 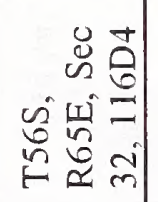 & 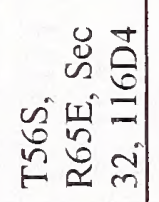 & 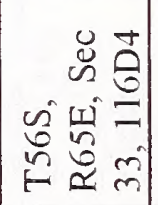 & 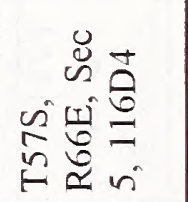 \\
\hline & 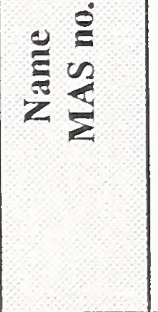 & 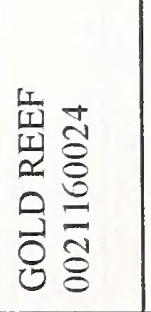 & 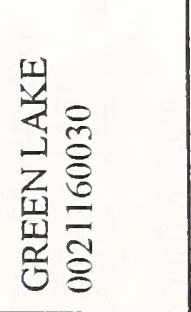 & 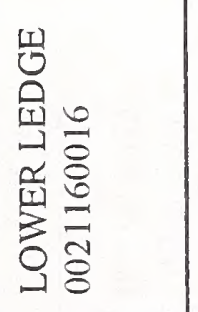 & 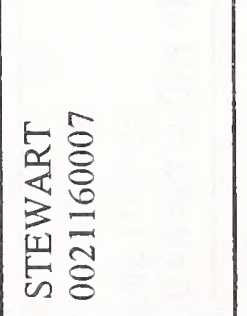 & 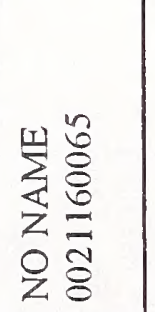 & 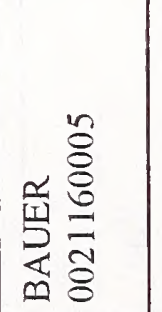 & 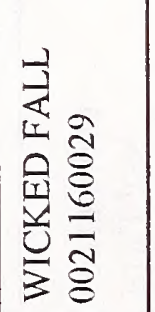 & 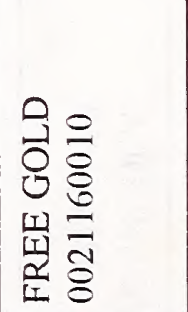 \\
\hline & 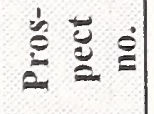 & $\stackrel{\bar{a}}{a}$ & 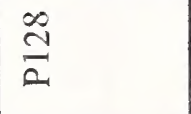 & $\frac{\partial}{a}$ & $\stackrel{i}{a}$ & $\frac{\bar{m}}{a}$ & $\frac{\pi}{2}$ & $\frac{m}{a}$ & $\stackrel{\vec{m}}{a}$ \\
\hline
\end{tabular}




\begin{tabular}{|c|c|c|c|c|c|c|c|c|c|}
\hline & $\Sigma=\alpha$ & A & دـ & ـ & 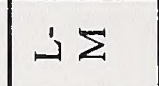 & د & د & دـ & $\Sigma$ \\
\hline & 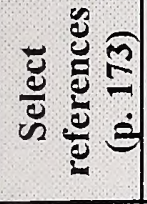 & $\begin{array}{l}n \\
\approx \\
i \\
i\end{array}$ & & $\approx$ & 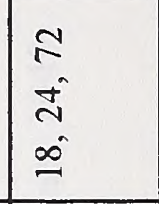 & 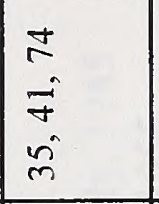 & $r$ & - & $\begin{array}{l}0 \\
0 \\
0 \\
0 \\
0\end{array}$ \\
\hline & 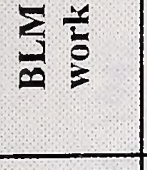 & $n$ & $\sum$ & $n$ & $\infty$ & $n$ & os & $\begin{array}{l}n \\
\Sigma \\
\end{array}$ & is \\
\hline & 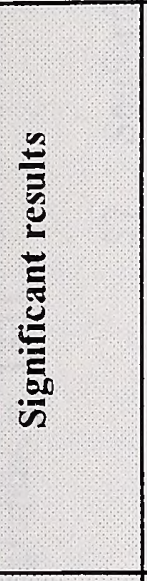 & 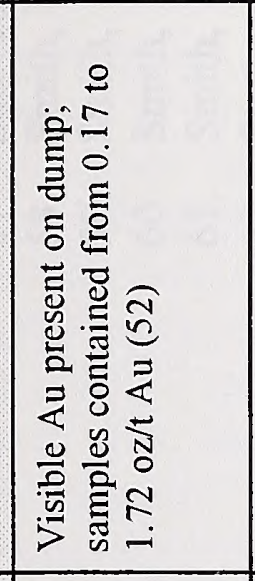 & 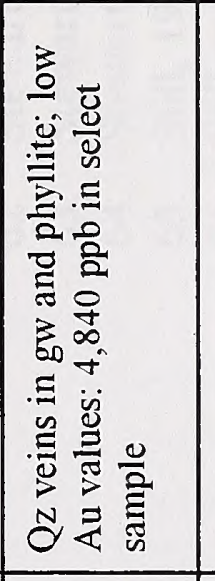 & 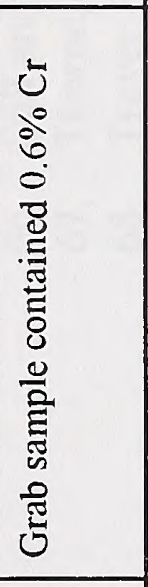 & 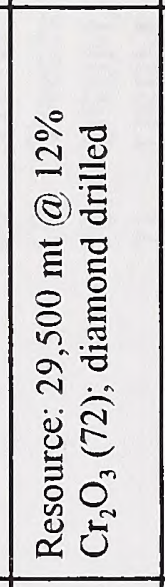 & 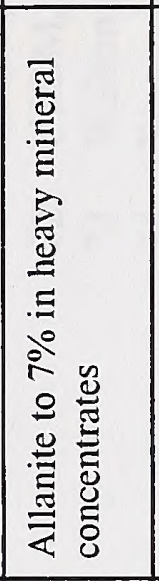 & 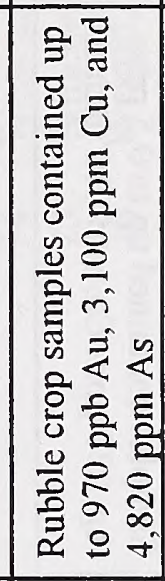 & 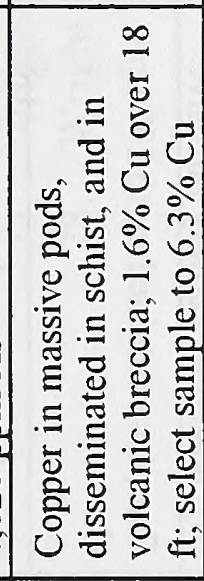 & 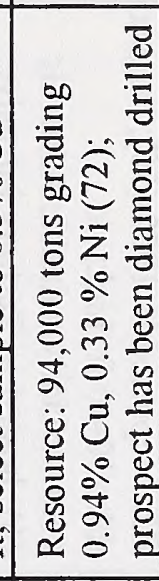 \\
\hline & 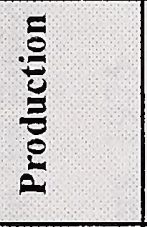 & 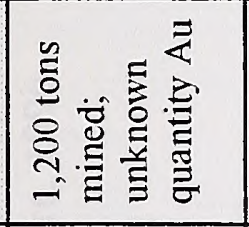 & $\mathbb{z}$ & $\overleftarrow{z}$ & $\underline{z}$ & $\overleftarrow{z}$ & $\overleftarrow{z}$ & $\overleftarrow{z}$ & $\overleftrightarrow{z}$ \\
\hline & 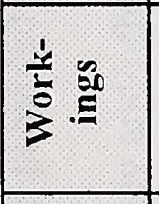 & 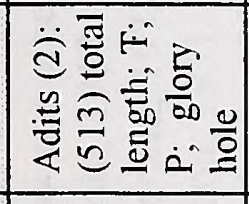 & 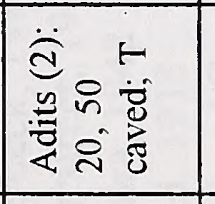 & $\overleftarrow{z}$ & $\stackrel{a}{H}$ & $\overleftarrow{z}$ & $\underline{z}$ & 0 & 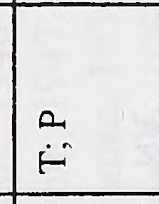 \\
\hline & 总 & $\begin{array}{l}\stackrel{\infty}{x} \\
\dot{x} \\
\dot{>}\end{array}$ & $\begin{array}{l}z \\
>\end{array}$ & 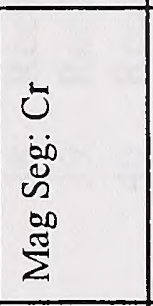 & $\begin{array}{l}\tilde{u} \\
\dot{\omega} \\
\omega \\
\omega \\
00 \\
\Sigma \\
\tilde{z}\end{array}$ & $\begin{array}{l}F \\
5 \\
0 \\
0.0 \\
0 \\
0 \\
\infty \\
\Sigma \\
\end{array}$ & $\begin{array}{l}z \\
0 \\
\end{array}$ & $\begin{array}{l}5 \\
0 \\
0 \\
0\end{array}$ & 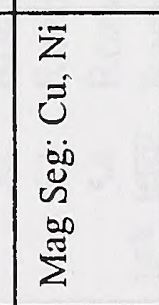 \\
\hline & 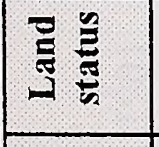 & 考 & 峁 & 㟒山 & 峁 & n & 先 & 峁 & 岁 \\
\hline & 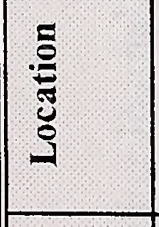 & 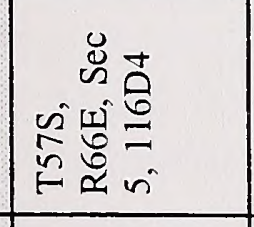 & 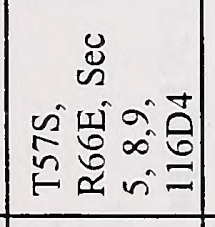 & 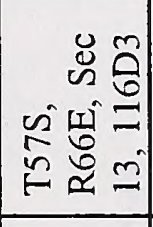 & 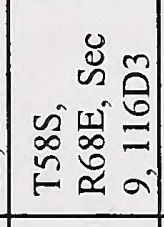 & 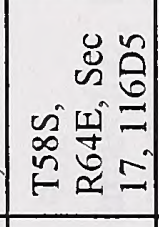 & 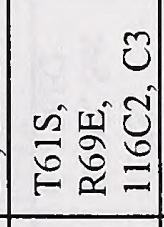 & 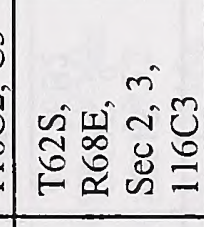 & 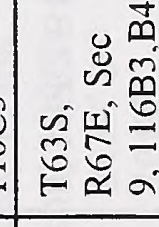 \\
\hline & 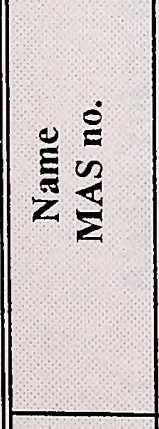 & 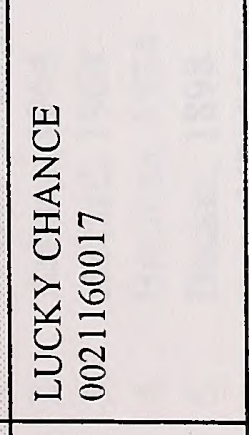 & 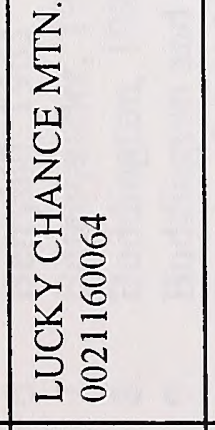 & 狊突 & 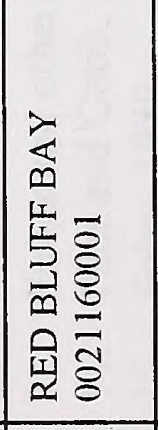 & 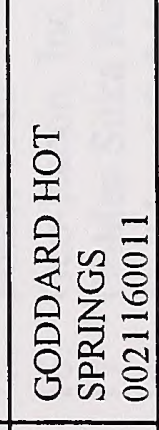 & 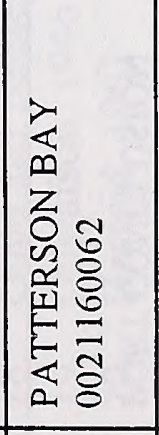 & 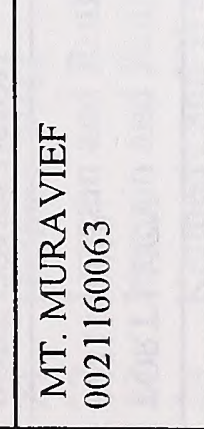 & 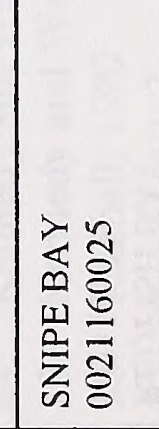 \\
\hline & 总 & $\stackrel{m}{2}$ & \begin{tabular}{|l|l}
$\frac{0}{2}$ \\
$\frac{m}{2}$
\end{tabular} & $\stackrel{\frac{m}{2}}{2}$ & $\begin{array}{l}\infty \\
\frac{\infty}{2} \\
\tilde{m}\end{array}$ & $\frac{\mathscr{m}}{\vec{n}}$ & $\frac{9}{2}$ & $\frac{\Xi}{2}$ & $\frac{7}{2}$ \\
\hline
\end{tabular}




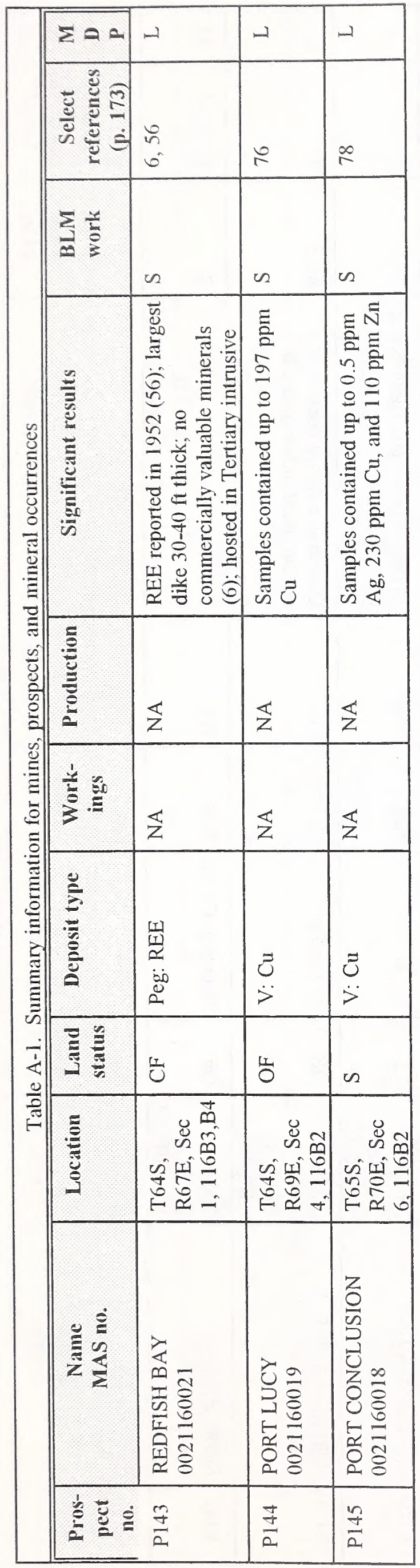




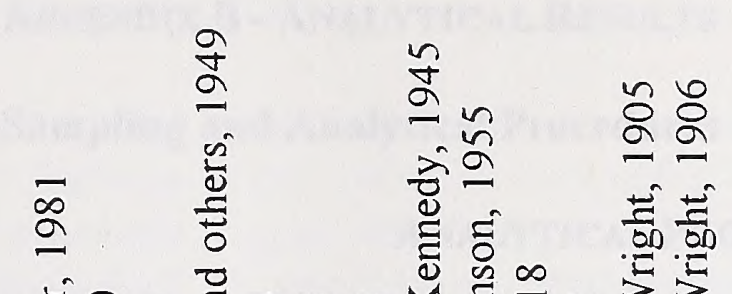

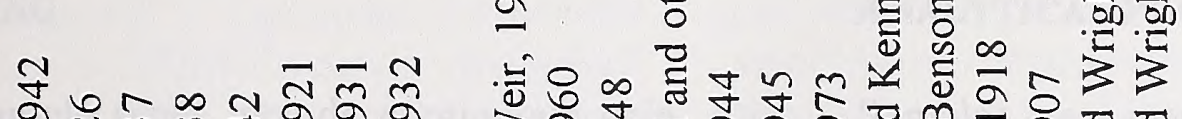
然

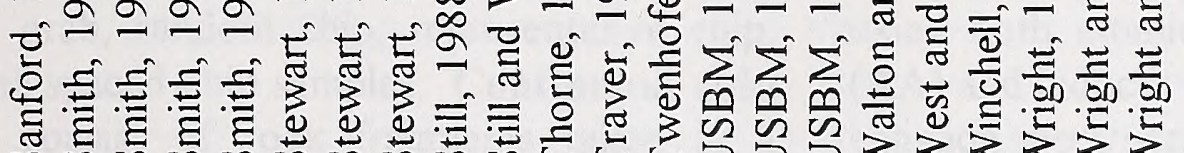

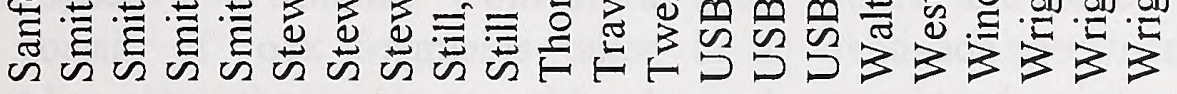

in

퐁

पा

$\sum \geqslant$

$\because$ त्త్

क.

$\sum_{1} \frac{1}{0}$

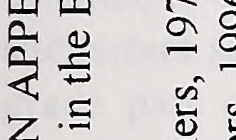

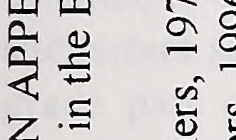

ลूँั

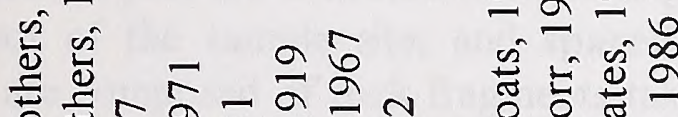

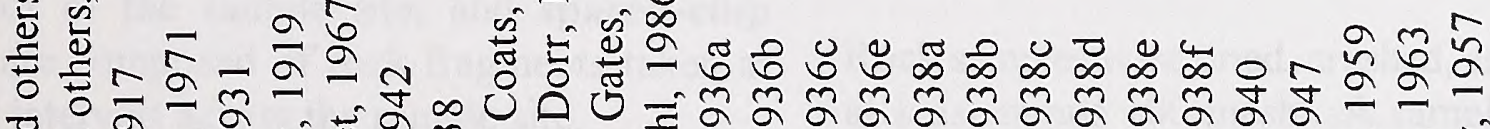

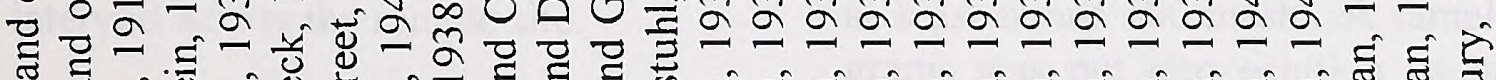
入े

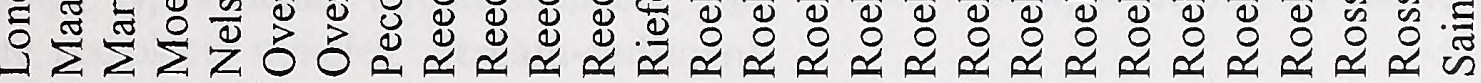

U

出

(돈

兵

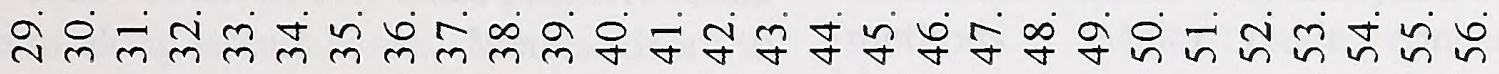

远

㐫

$\hat{\infty}$

๙े

送

ถู

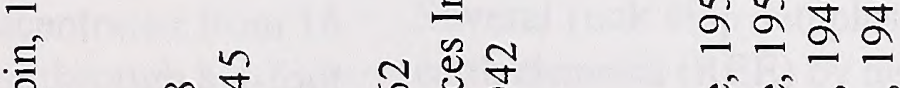

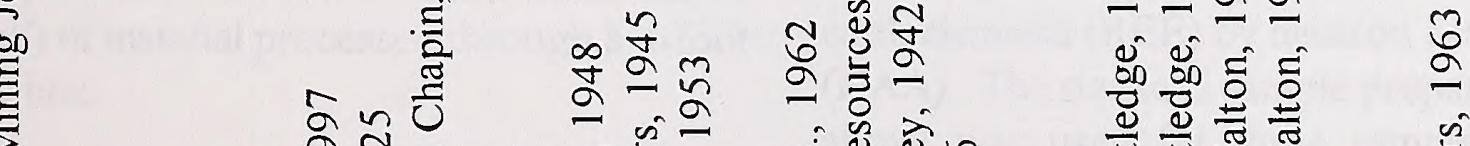

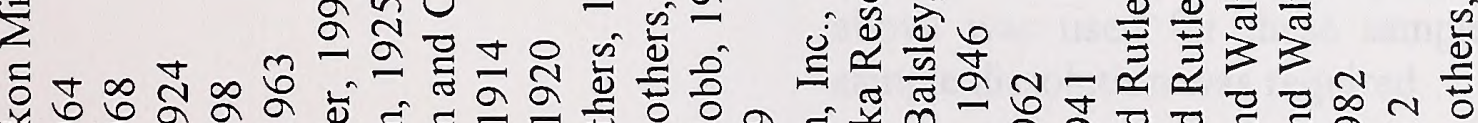
녹 $\alpha$ ᄋ

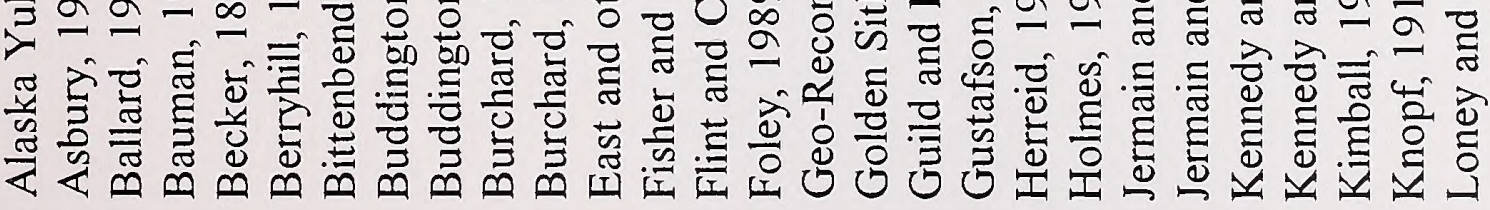

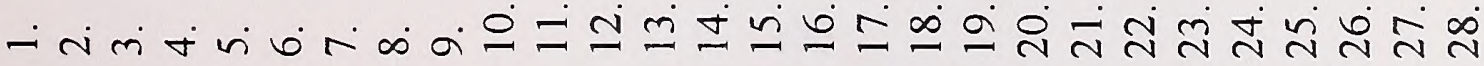





\section{APPENDIX B - ANALYTICAL RESULTS}

\section{Sampling and Analytical Procedures}

\section{SAMPLING}

Rock sample types include continuous chip, chip channel, grab, random chip, representative chip, select, and spaced-chip samples. Continuous chip samples consist of rock fragments taken in a continuous line across the sample site; chip channel samples are rock fragments cut from a sample line of relatively uniform width and depth across the sample site; grab samples are collections of rock fragments taken more or less at random from the sample site; grab samples often include samples of float or rubblecrop; random chip samples are rock fragments collected randomly from the sample site; representative chip samples are rock fragments collected to characterize the rock type at the sample site; select samples are collected from the highestgrade part of the sample site; and spaced-chip samples are composed of rock fragments taken at specified intervals across the sample site.

Stream sample types include stream sediment, pan concentrate, and placer samples. Stream-sediment samples consist of silt to clay-sized particles found in streams or along stream banks. Metals adsorb to these fine particles, so the samples are used to determine the presence of anomalous metal concentrations in the area drained by the stream. Pan concentrate samples are the heavy mineral fraction of a pan full of sand and gravel reduced by normal panning techniques. Placer samples consist of the heavy mineral fraction concentrated from 16 pans $\left(0.1 \mathrm{yd}^{3}\right)$ of material processed through a 4 -foot long sluice box.

\section{ANAlytical Procedures}

Samples were prepared and subsequently analyzed using both atomic absorption spectrophotometry (AA) and inductively coupled argon plasma atomic emission spectroscopy (ICP) techniques. Gold was analyzed using a 30 gram sample by fire assay preconcentration followed by an AA finish. Silver, copper, lead, zinc, nickel, cobalt, and molybdenum were usually analyzed by AA techniques. A few samples were analyzed for platinum-group metals using fire-assay techniques followed by an ICP finish. Several samples were analyzed for the same element using two different techniques. The result from the more accurate method is presented in the tables (see Table B-4, p. 219, for analytical detection limits).

Rock samples were dried, crushed, and pulverized to at least minus 100 mesh. A sample weight of 0.5 grams was put into solution using an aqua-regia leach technique for the AA and ICP analyses.

Limestone samples were analyzed using whole rock methods. Major oxide concentrations were determined by X-ray fluorescence spectroscopy (XRF) and total carbonate by acid/alkali procedures $\left(\mathrm{CaCO}_{3}\right.$ determined by volumetric/titration method ASTM C-25). Each sample was rinsed, dried, and weighed prior to analysis.

Several rock chip samples were analyzed for rareearth elements (REE) by neutron activation analysis (NAA). The standard sample preparation described above was used for these samples, however no sample dissolution was required. 


\section{Analytical Results of Samples from Mines, Prospects, and Mineral Occurrences}

Sample data and analytical results are tabulated in Tables B-1 to B-3. In addition to the analytical results, the following are listed in the tables: map number, field sample number, mineral location name, sample type, sample size, sample site, and sample description. The results are organized by map numbers, which are displayed on the sample locality map (Plate 2, in pocket). The map numbers are arranged generally north to south and west to east on Plate 2. Analytical results from carbonate and whole-rock sampling are presented in Table B-2. Rare-earth element (REE) sample analyses are presented in Table B-3. A list of analytical detection limits is included as Table B-4.

\section{Key TO APPENDIX B TABLES}

All analyses were conducted by a commercial laboratory. Results are presented by chemical element symbol.

Analyses in bold and followed by an asterisk $(*)$ are assay-grade analyses.

\section{ABBREVIATIONS}

Abbreviations for sample types (see page 175 for definitions of sample types):

$\begin{array}{llll} & \text { Rock Chip } & & \text { Stream Sample } \\ \text { C } & \text { continuous chip } & \text { SS } & \text { stream sediment } \\ \text { CC } & \text { chip channel } & \text { PC } & \text { pan concentrate } \\ \text { G } & \text { grab } & \text { PL } & \text { placer } \\ \text { RC } & \text { random chip } & & \\ \text { Rep } & \text { representative chip } & & \\ \text { S } & \text { select } & & \\ \text { SC } & \text { spaced chip } & & \end{array}$

Abbreviations for sample sites:

$\begin{array}{llll}\text { FL } & \text { float } & \text { RC } & \text { rubblecrop } \\ \text { MD } & \text { mine dump } & \text { TP } & \text { trench, pit, or cut } \\ \text { MT } & \text { mill tailings } & \text { UW } & \text { underground workings } \\ \text { OC } & \text { outcrop } & & \end{array}$


Abbreviations used in sample descriptions in Table B-1:

$\begin{array}{llll}\text { @ } & \text { at } & \text { hn } & \text { hornfels/hornfelsed } \\ \text { adj } & \text { adjacent } & \text { hw } & \text { hanging wall } \\ \text { alt } & \text { altered } & \text { int } & \text { intrusive } \\ \text { an } & \text { andesite } & \text { K-spar } & \text { potassium feldspar } \\ \text { ar } & \text { argillite } & \text { ls } & \text { limestone } \\ \text { aspy } & \text { arsenopyrite } & \text { mag } & \text { magnetite } \\ \text { az } & \text { azurite } & \text { meta } & \text { metamorphic } \\ \text { bt } & \text { biotite } & \text { ml } & \text { malachite } \\ \text { br } & \text { breccia/brecciated } & \text { mo } & \text { molybdenite } \\ \text { calc } & \text { calcite/calcareous } & \text { monz } & \text { monzonite } \\ \text { cg } & \text { coarse-grained } & \text { min } & \text { mineralized } \\ \text { cng } & \text { conglomerate } & \text { msv } & \text { massive } \\ \text { chl } & \text { chlorite/chloritic } & \text { oz/t } & \text { troy ounces per short ton } \\ \text { cp } & \text { chalcopyrite } & \text { peg } & \text { pegmatite } \\ \text { di } & \text { diorite } & \text { pl } & \text { phyllite } \\ \text { dissem } & \text { disseminated/disseminations } & \text { po } & \text { pyrrhotite } \\ \text { ep } & \text { epidote } & \text { porph } & \text { porphyry/porphyritic } \\ \text { fel } & \text { felsic } & \text { py } & \text { pyrite/pyritic } \\ \text { fest } & \text { iron stained } & \text { qz } & \text { quartz } \\ \text { fg } & \text { fine-grained } & \text { sed(s) } & \text { sediment(s) } \\ \text { Fm } & \text { Formation } & \text { sc } & \text { schist } \\ \text { fw } & \text { footwall } & \text { sil } & \text { silicified/siliceous } \\ \text { gd } & \text { granodiorite } & \text { sl } & \text { sphalerite } \\ \text { gn } & \text { galena } & \text { sulf } & \text { sulfide } \\ \text { gp } & \text { graphite/graphitic } & \text { vn } & \text { vein } \\ \text { gs } & \text { greenstone } & \text { vnlets } & \text { veinlets } \\ \text { gw } & \text { graywacke } & \text { volc } & \text { volcanic } \\ \text { hem } & \text { hematite } & \text { w/ } & \text { with } \\ \text { hnbd } & \text { hornblende } & \text { xcut } & \text { crosscut/crosscutting } \\ & & & \end{array}$



Table B-1. Analytical results of samples from mines, prospects, and mineral occurrences. 
ณ등 ร $3 \varepsilon^{\infty} \infty \sim \infty$ N 之 ह 등

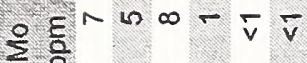

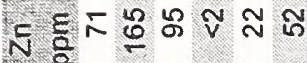

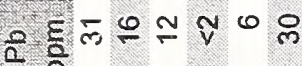
उ हू유유

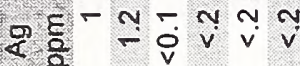
*. $\frac{E}{0}$

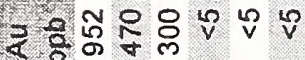

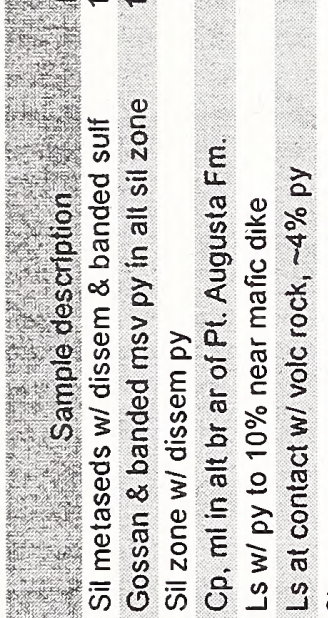

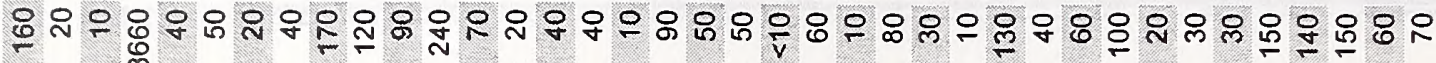

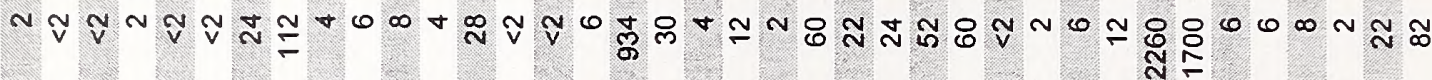

กับ -

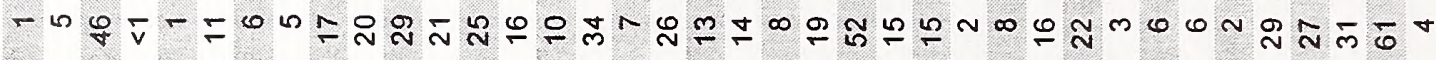

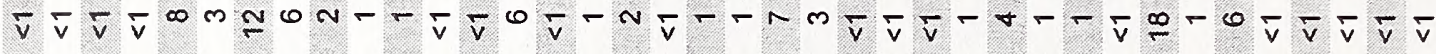
\&กN

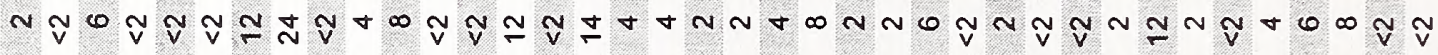
m

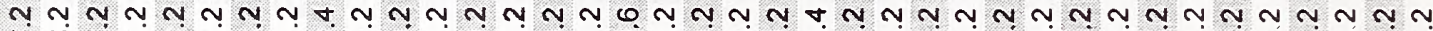

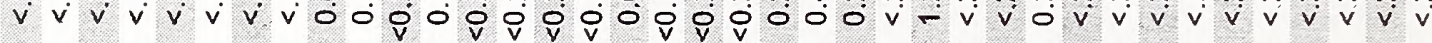

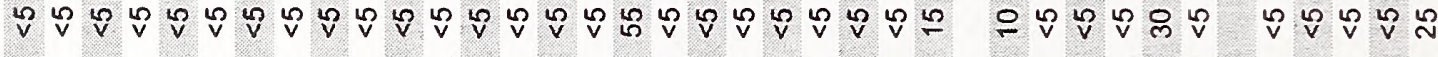

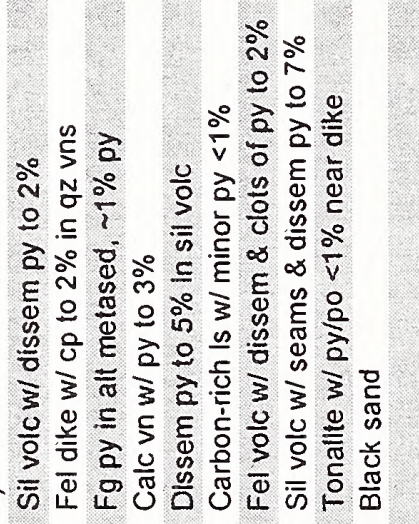

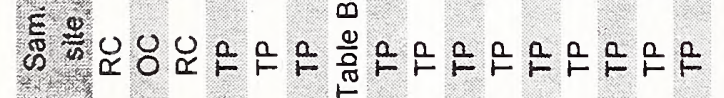

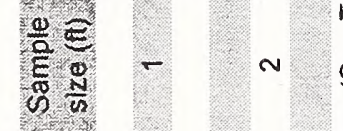

हैं

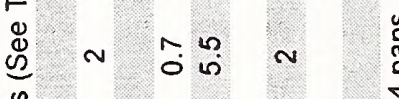

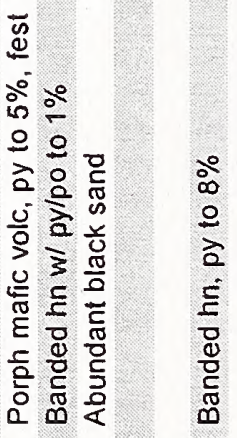

O̊

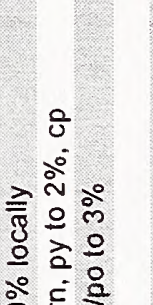

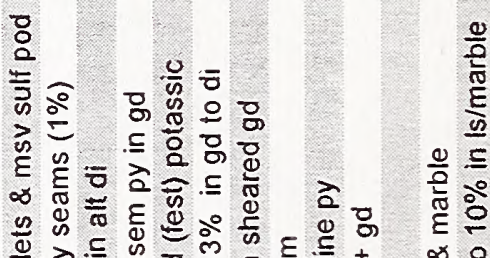
峁

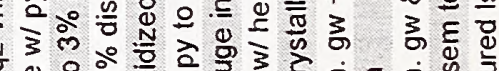

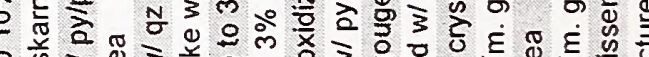

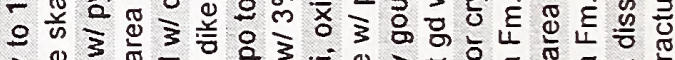

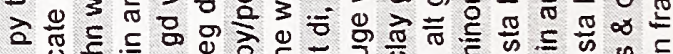

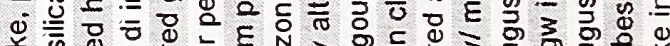

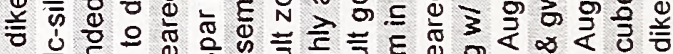

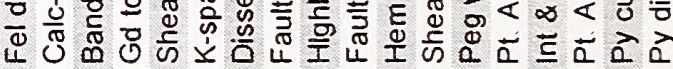
OூO $\tilde{0}$ N

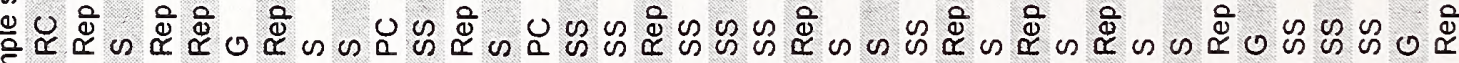

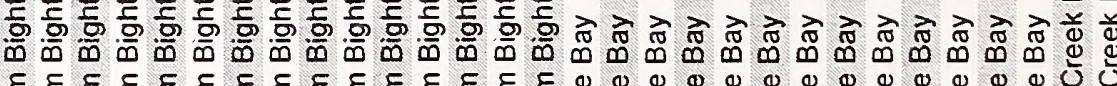

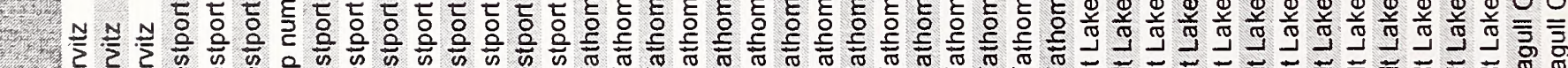

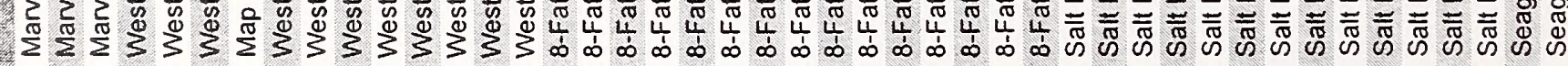

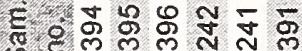
i. $\frac{\pi}{\pi} e^{2}--n m m$

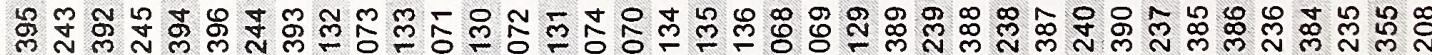

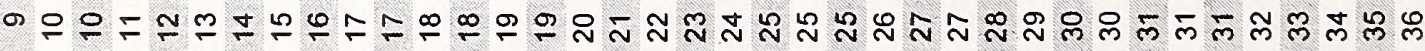




\section{‥ \\ ㅇ. 웅 \\ ฟE $\bar{v} \tau \bar{v}$ \\ กำ}

3 ㅇํำ จิ은은

$>$ > छ

SE

등 웅운

=

- EOㅇㅇㅇ

$2 \approx \bar{v} \bar{v} \bar{v}$

एँ

के

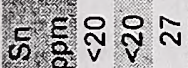

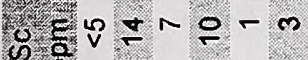

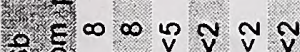

कำ

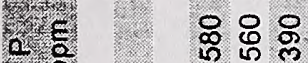

ใ

$z$

$\pi$ da $0.5 \div 2$. . 0 i i 0 o v

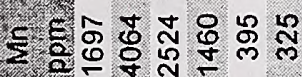

1.

$\sum \pi 0 \div 0 \div-0$

E E

등ㅇㅇㅇㅇㅇㅇㅇㅇㅇ

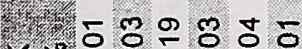

$x .0 .00 \% 00$

$\lim _{0}+\infty 上 2$ 은

1

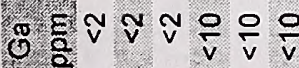

3.

U.

J

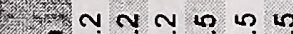

ठE

-

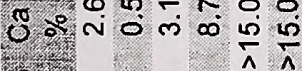

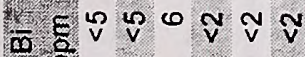

m. $\frac{E}{0}$ i $v i$

है:

क. ก ก

o.

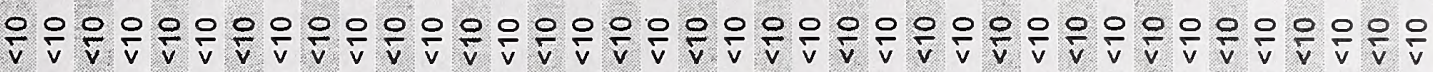

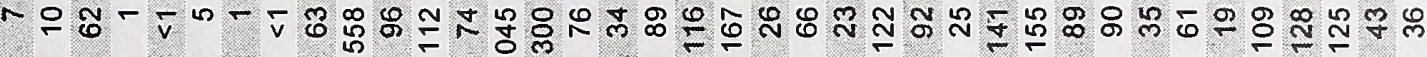

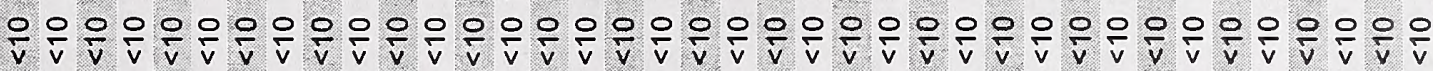

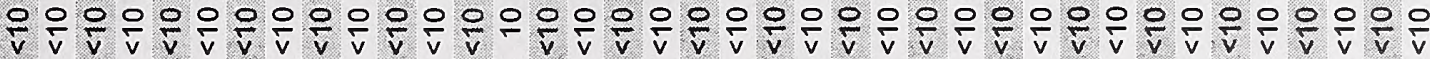

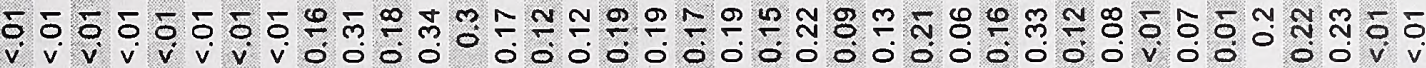

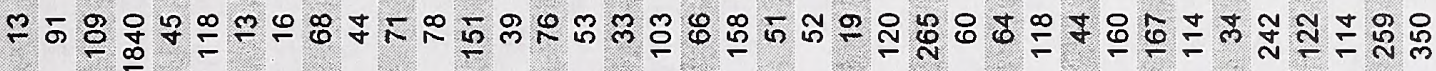

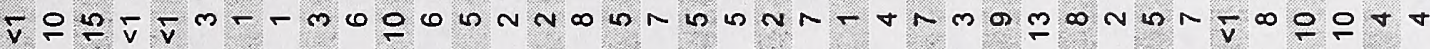

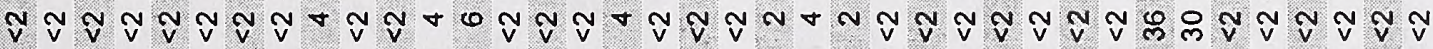

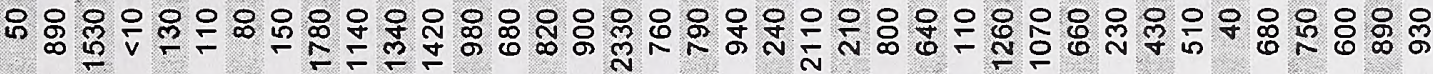

ก 00000000000000000000000000000000000000

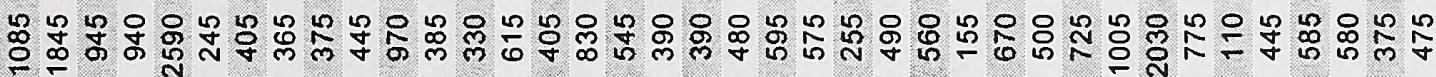

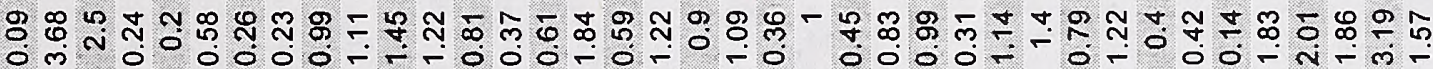

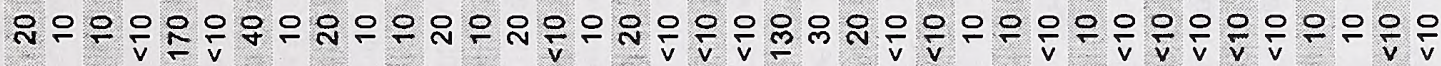

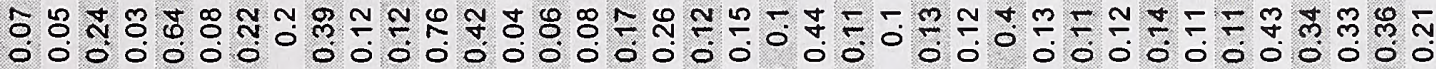

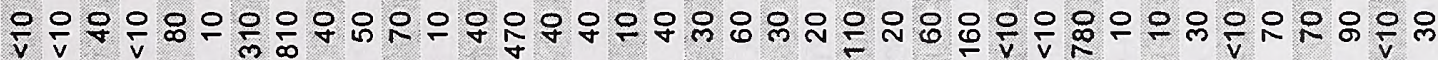

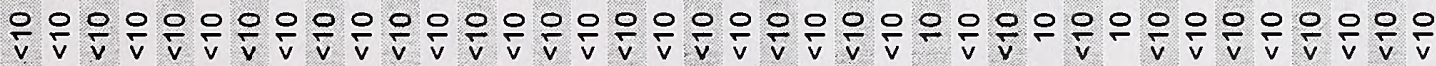

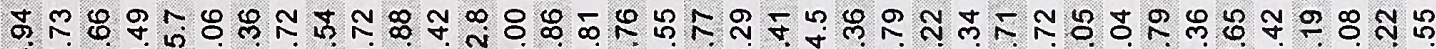

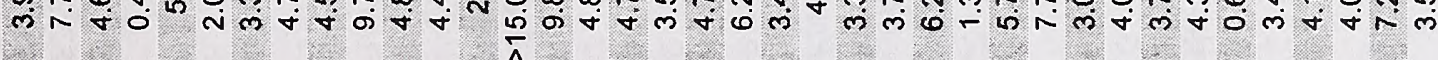

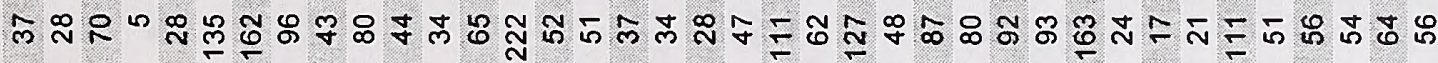

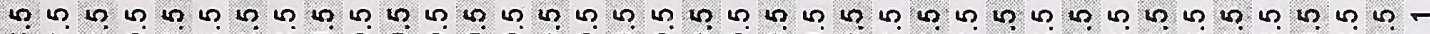
v $v$ v

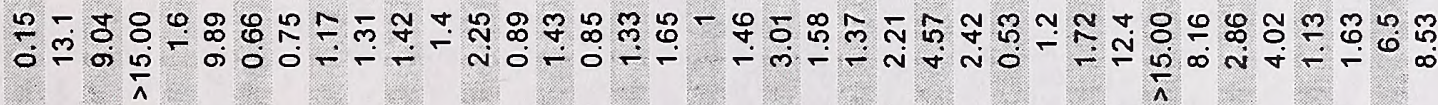
$\mathcal{V} \mathcal{V} \mathcal{V} \mathcal{V} \mathcal{V} \mathcal{V} \mathcal{V} \mathcal{V} \mathcal{V} N \mathcal{N} \mathcal{V} \mathcal{V} \mathcal{V} \mathcal{V} \mathcal{V} \mathcal{V} \mathcal{V} \mathcal{N} \mathcal{V} \sim \mathcal{V} \mathcal{V} \mathcal{V} \mathcal{V} \mathcal{V} \mathcal{V} \mathcal{V} \mathcal{V} \mathcal{V} \mathcal{V} \mathcal{V} \mathcal{V} \mathcal{V} \mathcal{V}$ งทำ

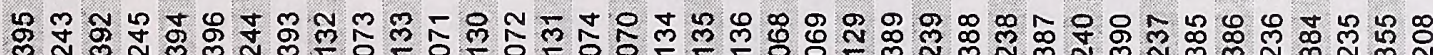

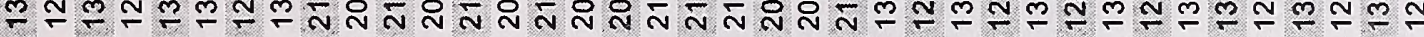

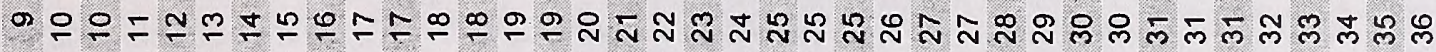




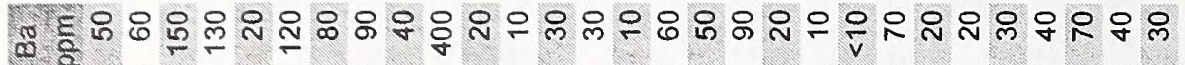
g \&. $\frac{5}{2}$

द B

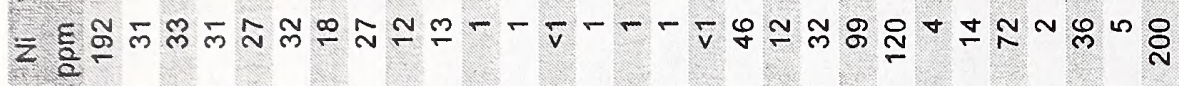

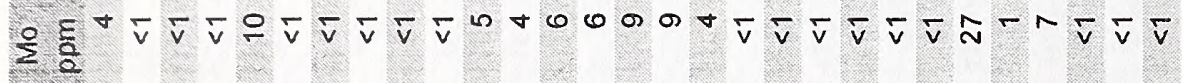

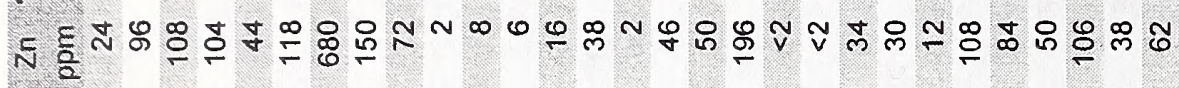

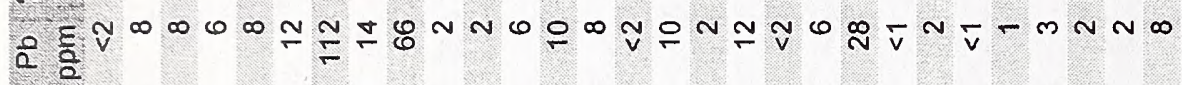
$\therefore$ a

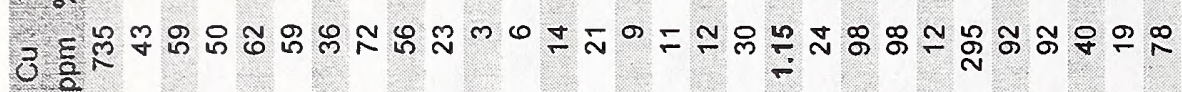

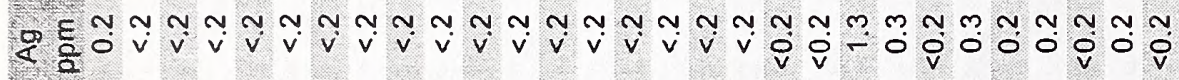
- $\frac{E}{2}$

द⿱

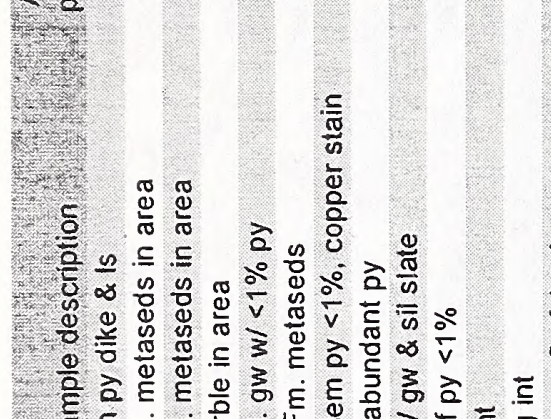

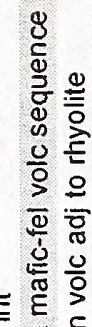

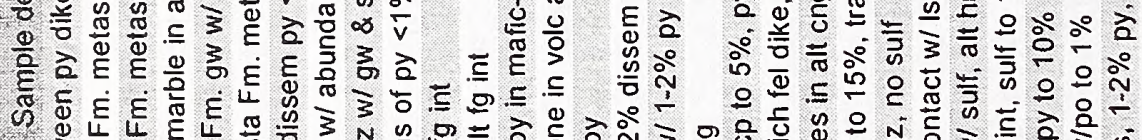

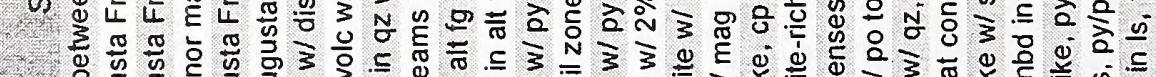

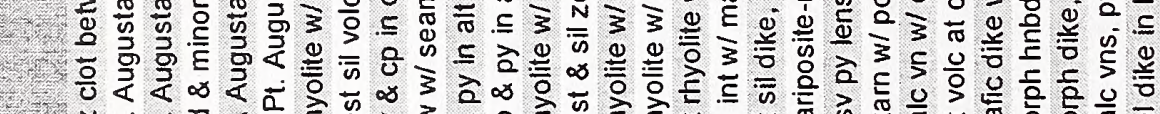

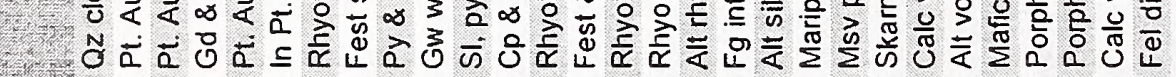
है

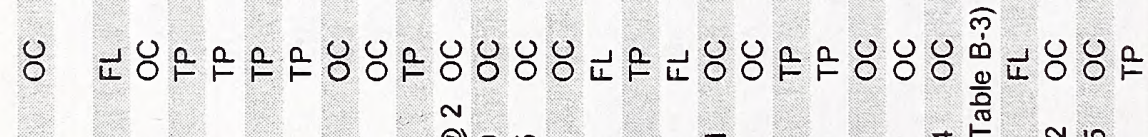

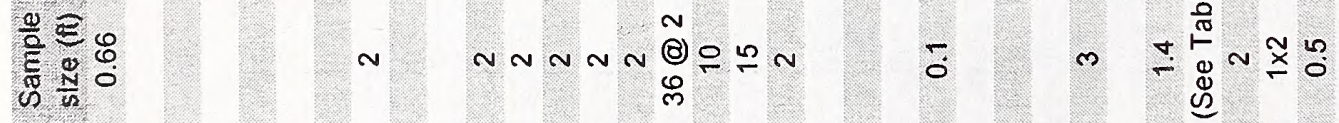
है

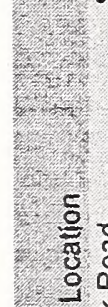

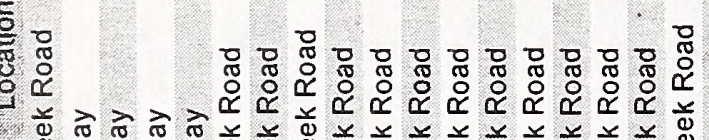

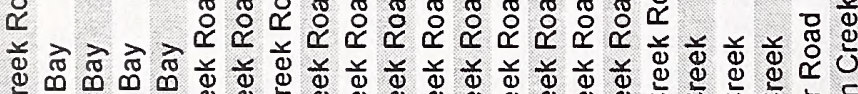
రั

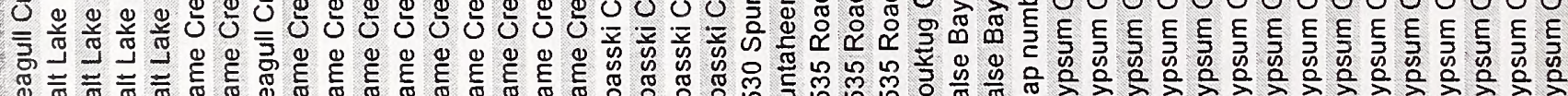

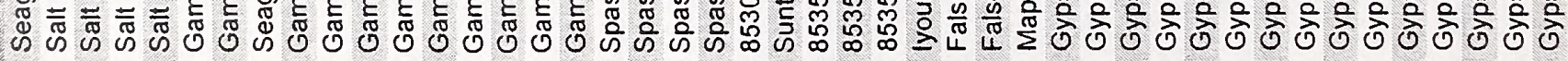
敌

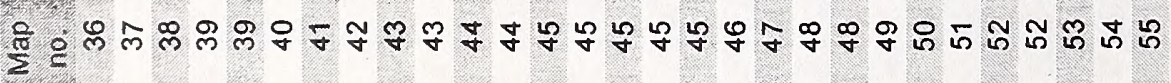

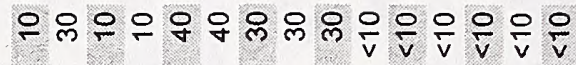

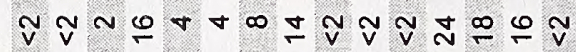

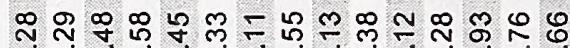

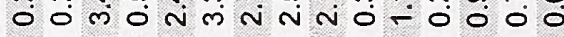
旅

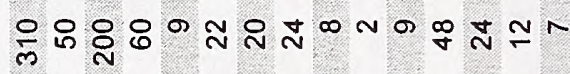
$0 F-n \in m-m \omega-\bar{n} n d$

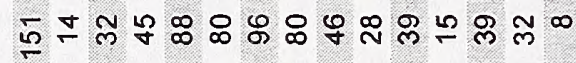

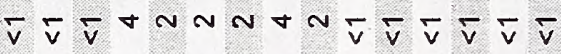

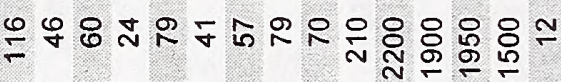

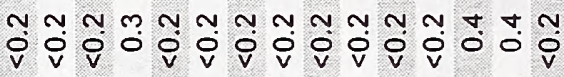

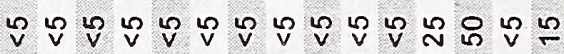

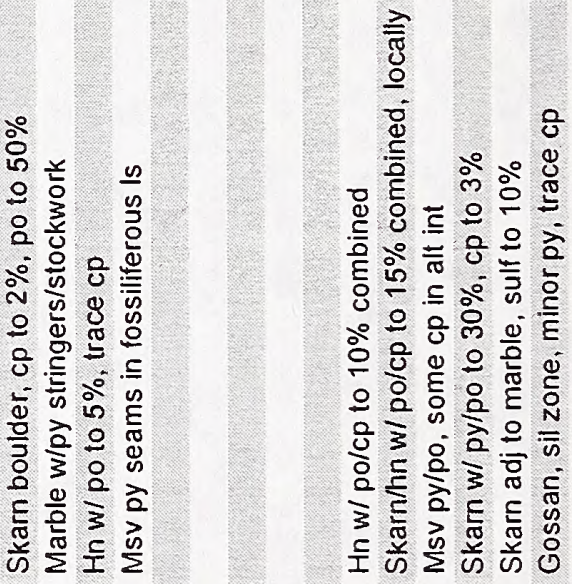

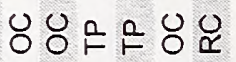

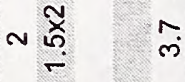

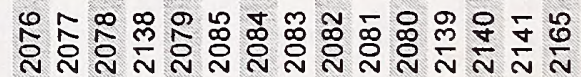

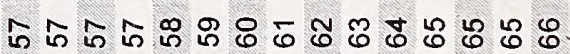




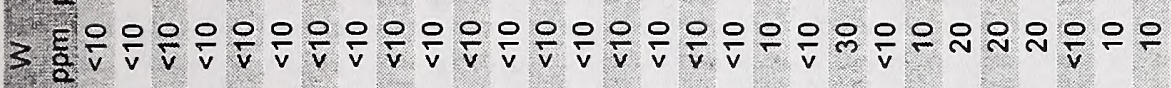

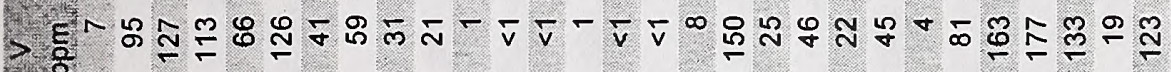

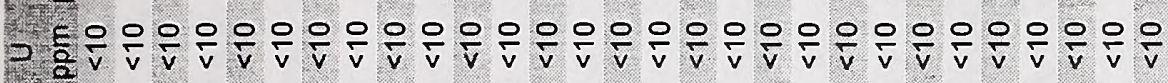

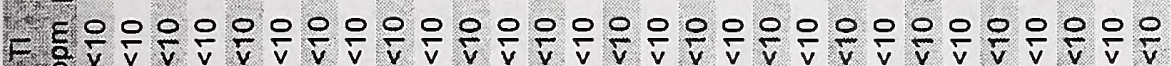
1 F (2) $\frac{\varepsilon}{a}$

त. है

ら 틈 ह $\frac{E}{2}$

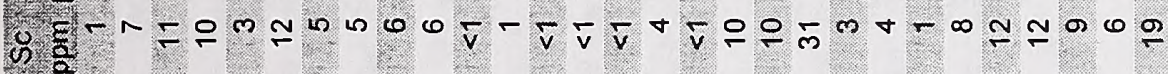
ติ

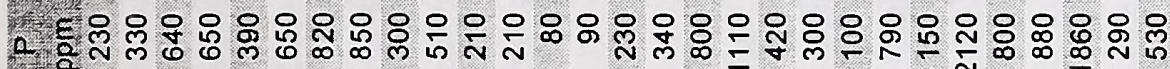
द.

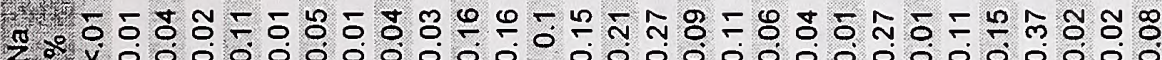

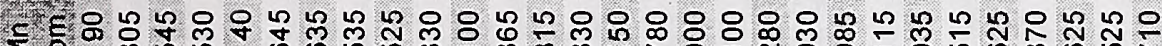

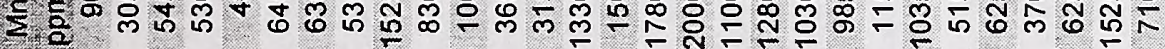

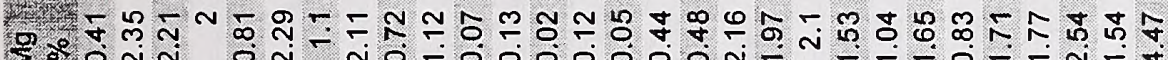

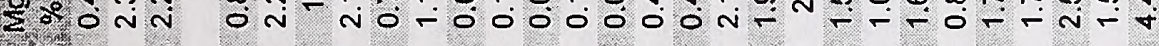

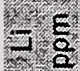

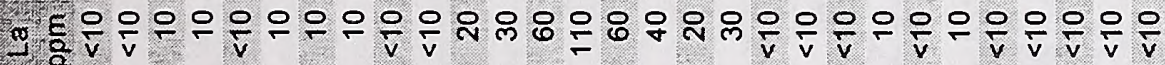

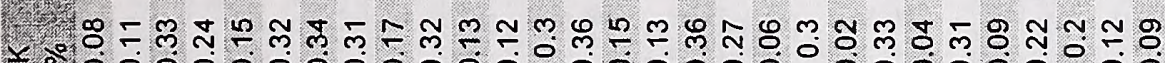
00000000000000000000000000

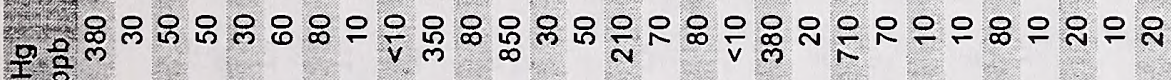

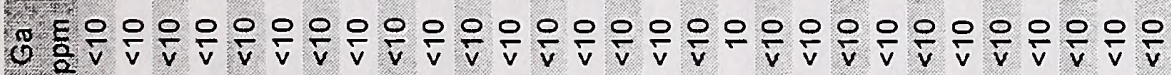
1. 8 于

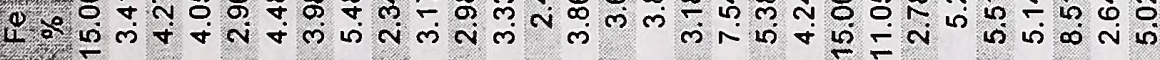

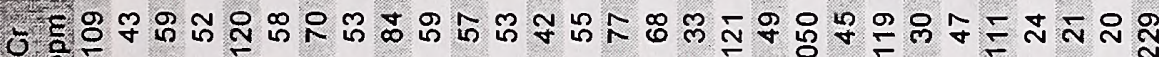

a

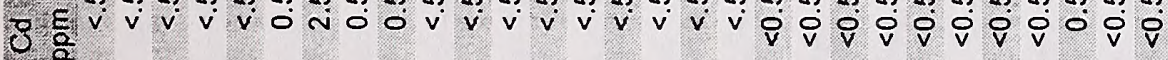

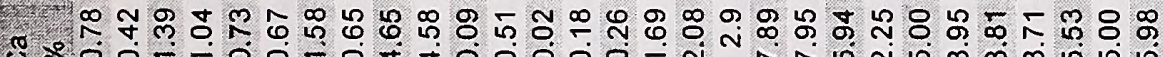

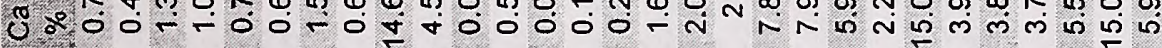

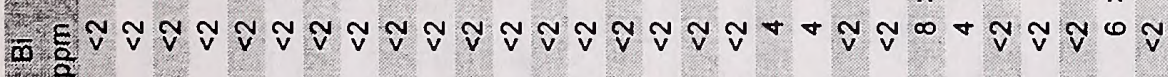
de

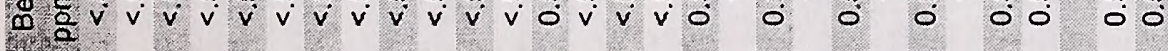

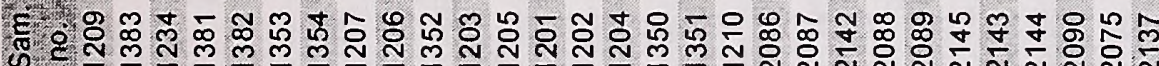
(1)

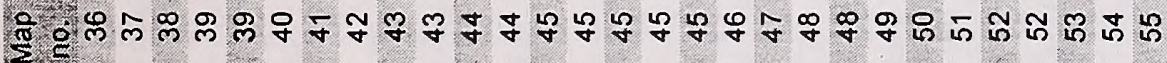

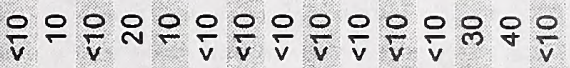

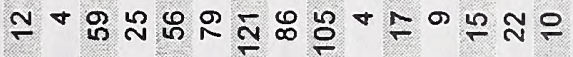

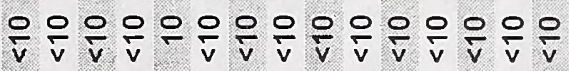

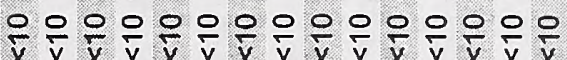

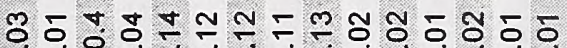
0 i. 0.00000000000

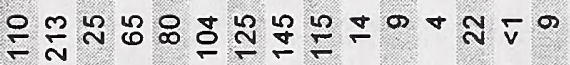

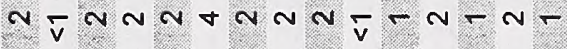

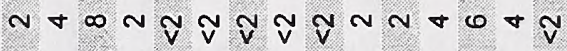

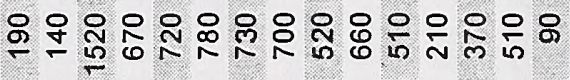

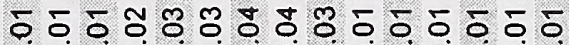
i io 0000000 i i i

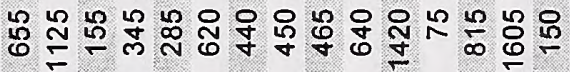

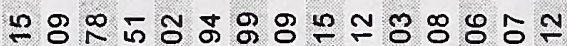

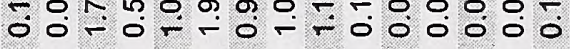

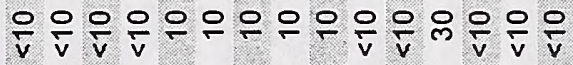
ธธโค i 0.000 .000 .00000

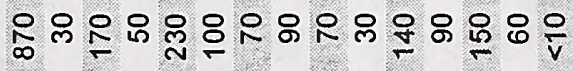

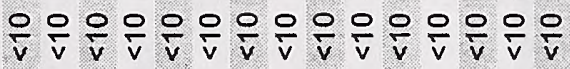
Вกัล

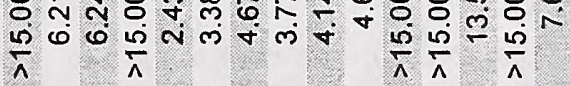

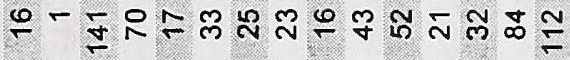

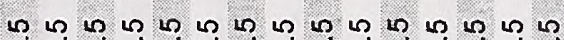

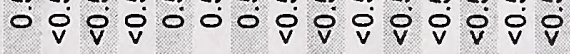

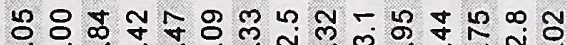

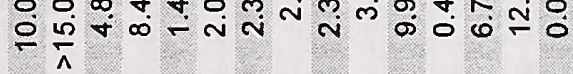

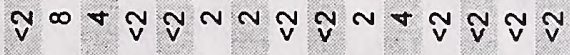
20.

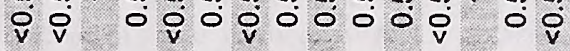

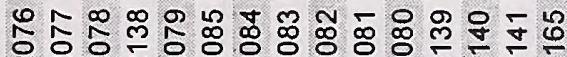

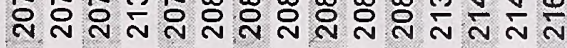
乩的的品星 
๓ ด $\leqslant 2$

ব ๙

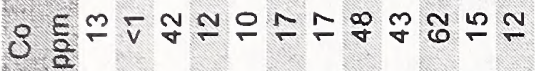

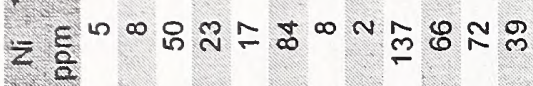
$\frac{\Sigma}{\delta} \frac{E}{0} \bar{v} \bar{v} \underset{0}{0} \bar{v} \bar{v} N \bar{v} \bar{v} \bar{v} \bar{v}-$

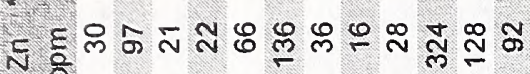
*-

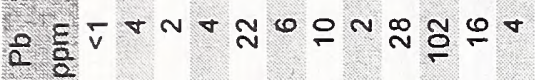
$\div 2$

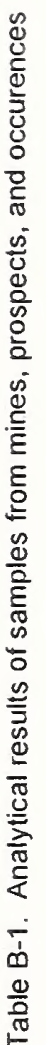

उ

\&. ,

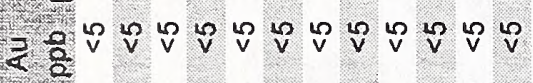

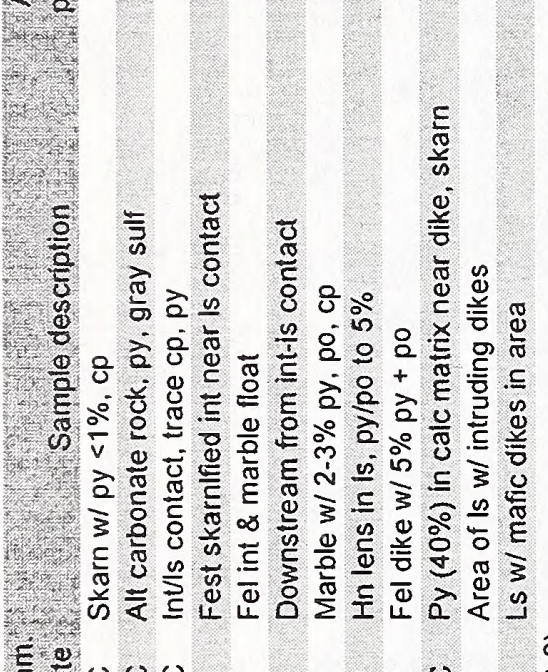

ڤึ u암

$\frac{0}{\frac{0}{2}} \frac{0}{\infty}$ i
के

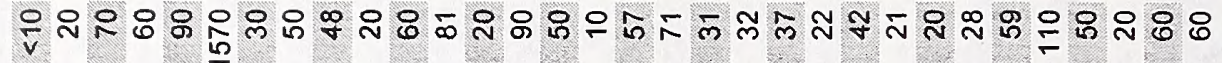

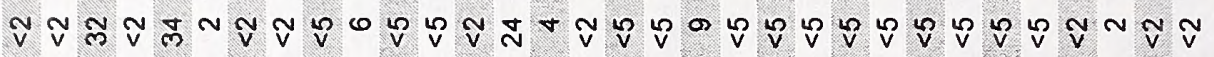

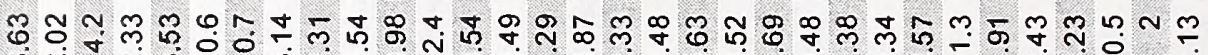
mลำำ

nกั่ $\bar{v}$ 으 เก นี้

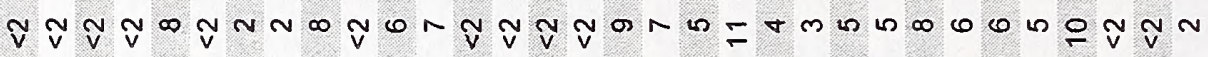
党尓

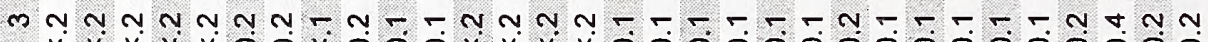

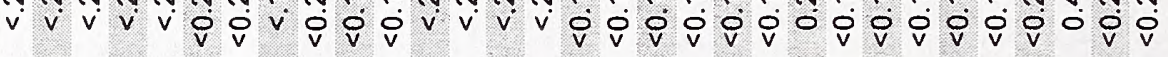

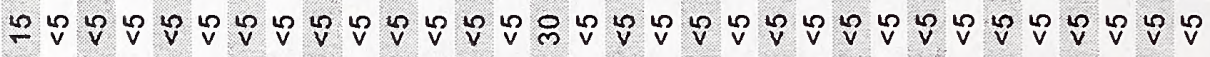

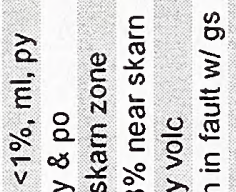

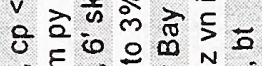

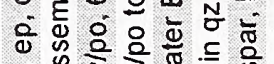

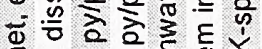

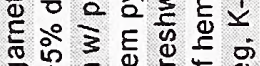
万ิ उ范

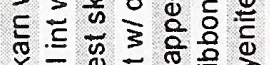
के

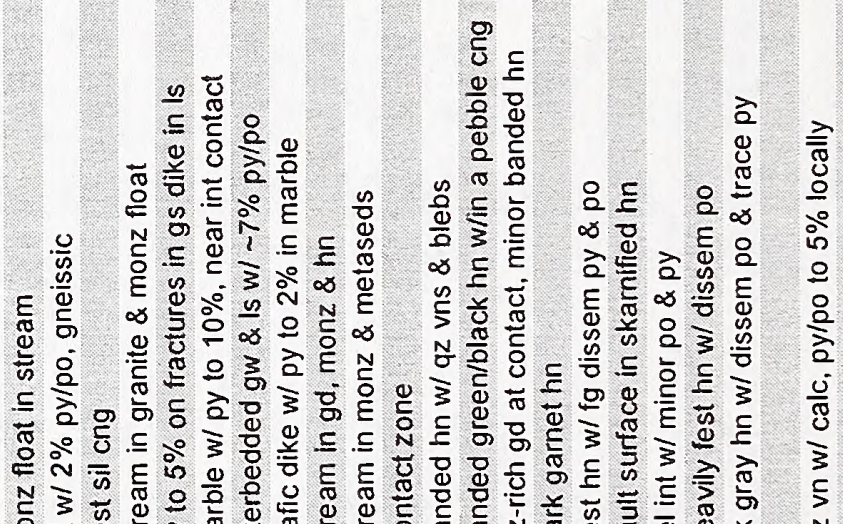

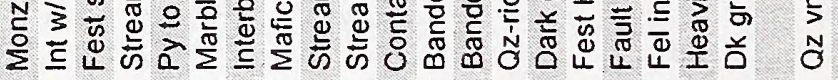
OூOOOOO

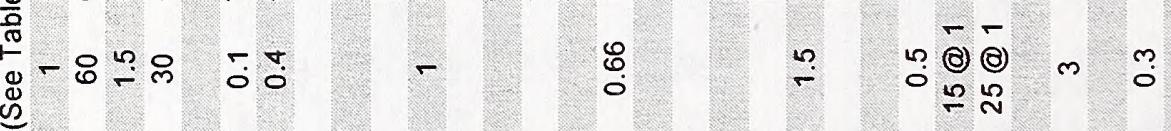

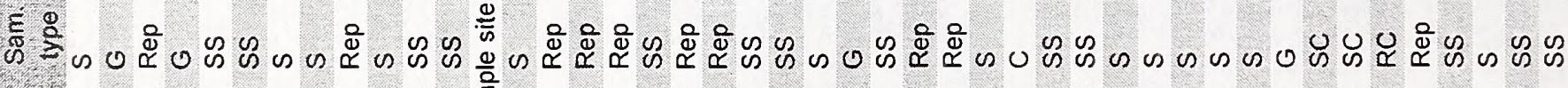

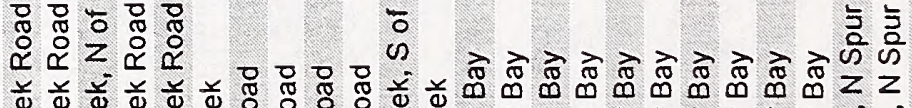

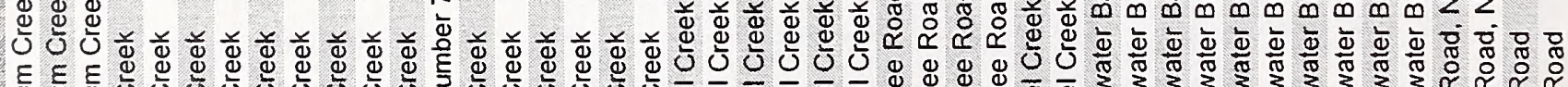
E E

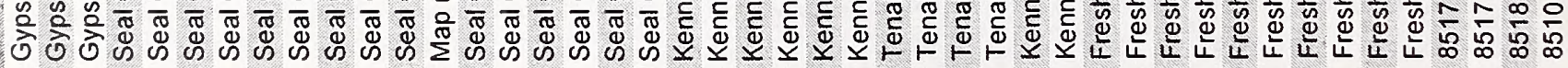
焉 政 


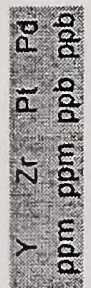

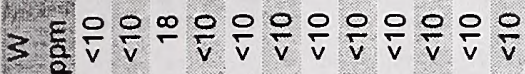
> E⿱艹

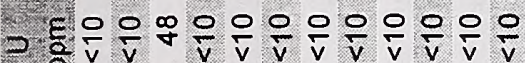
F $E$ 은은은은은은은은은은은은은 F o e. 통

(1)

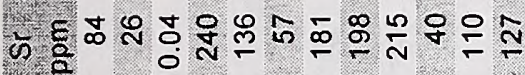
$5 \%$

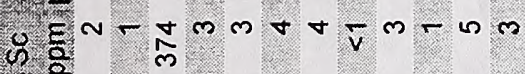

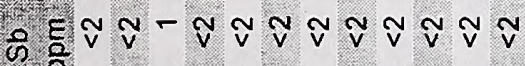

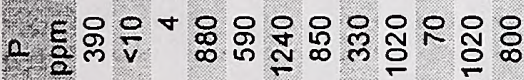
z

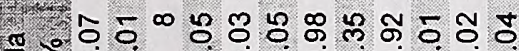

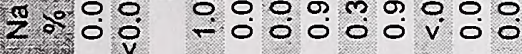

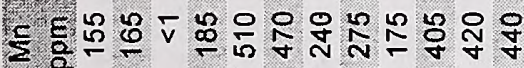

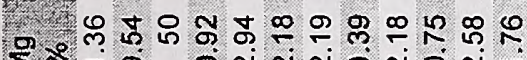

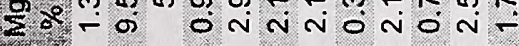
플

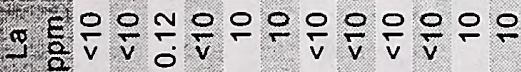
ㄴ.

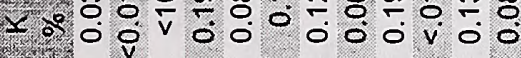

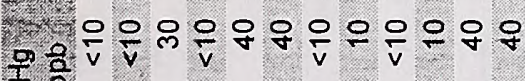

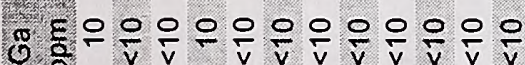

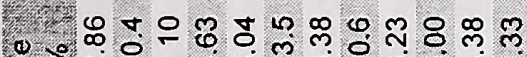

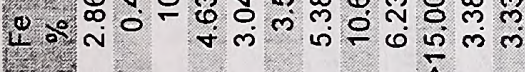

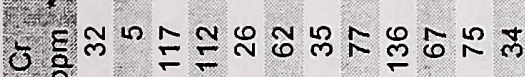

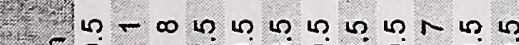
B. है 18. 80.幺

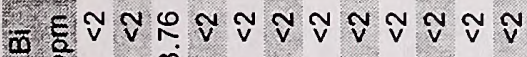

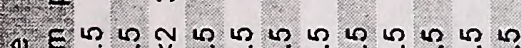

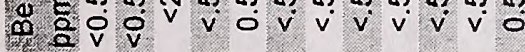

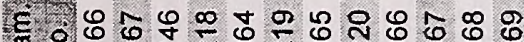
ก.

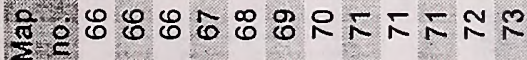

$$
\ln \frac{\pi n}{4} a n
$$$$
n n m m \rightarrow n m \rightarrow m \infty \pi
$$$$
\text { t }
$$

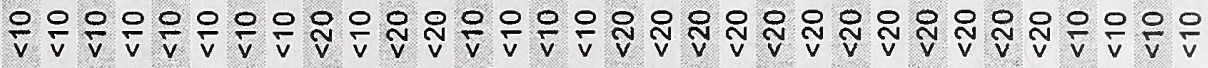

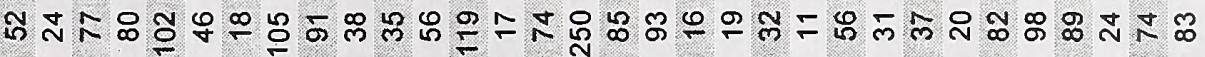
은은은은 은은은은 은 은 은 은 은 윤 운 운

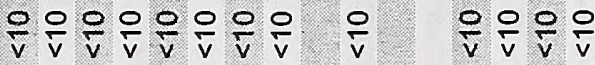
은 은은 은

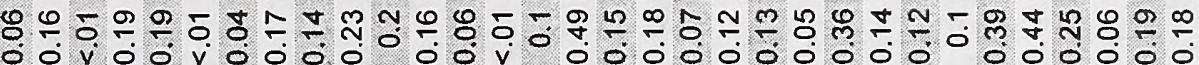

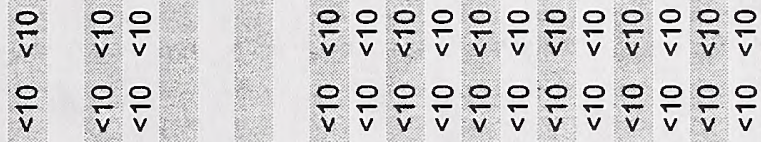

⿰ ใัง

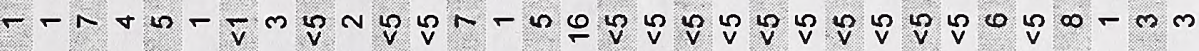

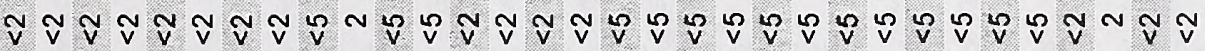

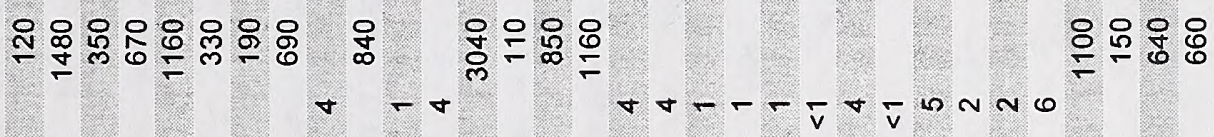

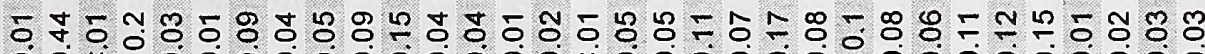
O.

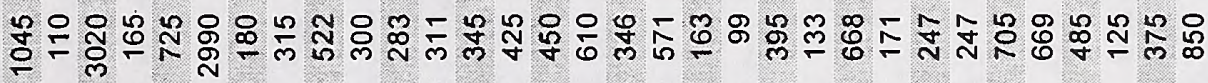

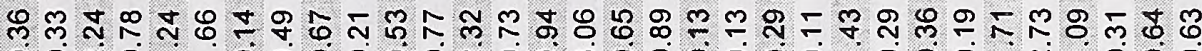

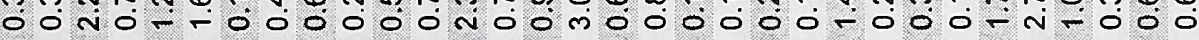

$$
\text { I }
$$

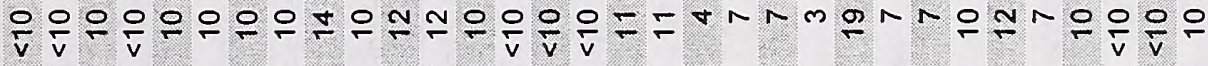

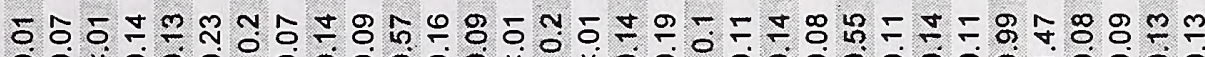
$00 \mathrm{v} 00000000 \mathrm{v} v 000000000-0000$

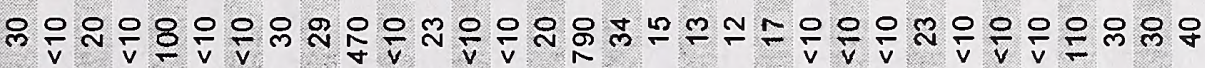

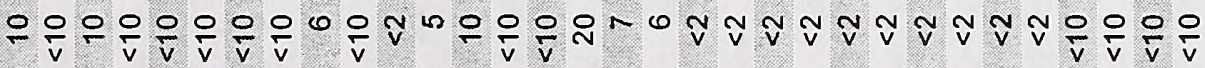

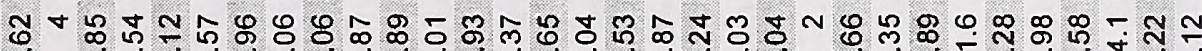
i.

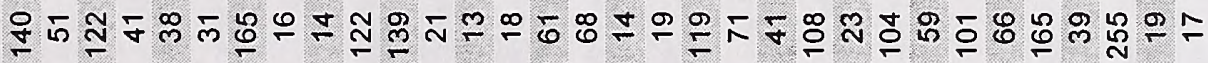

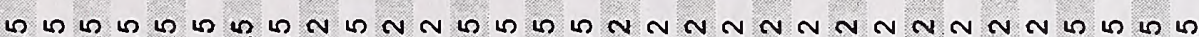

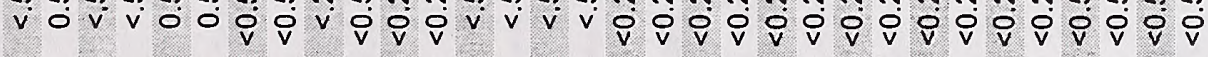

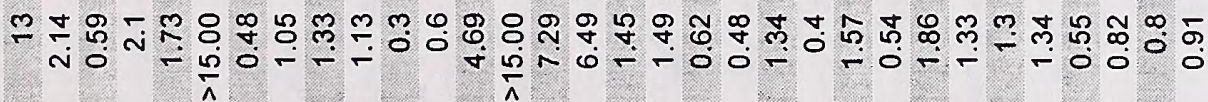

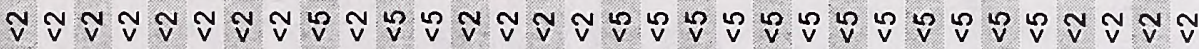
in $\ln$ in $\ln$ in $\ln$ in $\log$ (2)

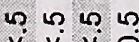
n. 40 in 40

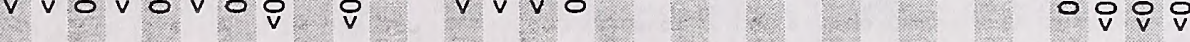

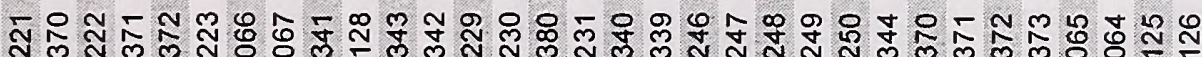
N

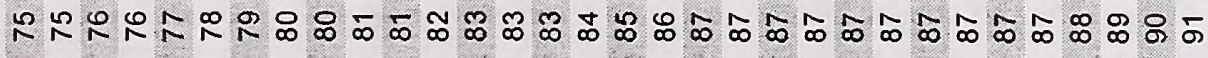




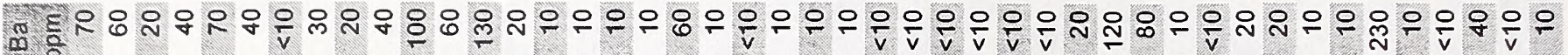

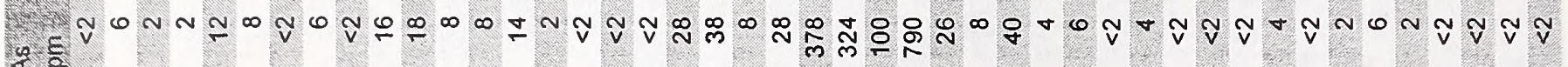
\&응

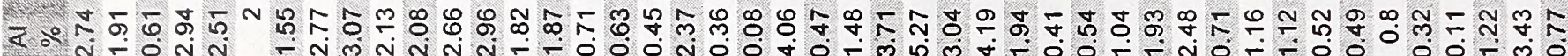

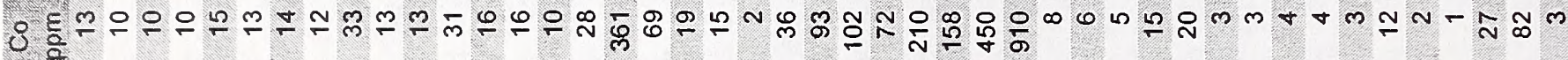
z 옹

ᄃุ่ b $\frac{0}{5}$ - 。

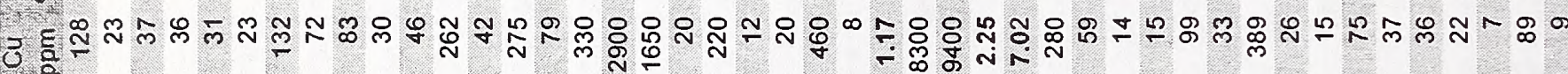
द⿱乛龰융 - ह

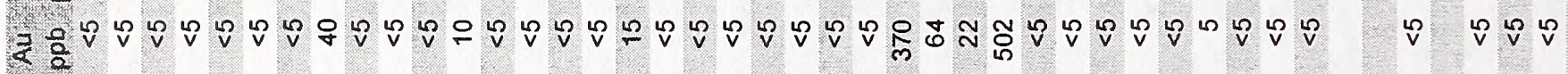

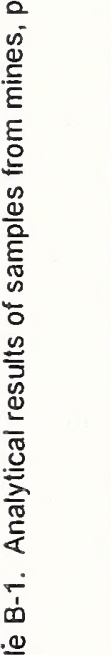

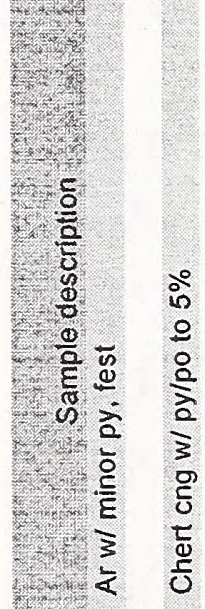

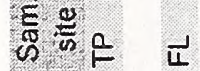

$\sim E$

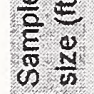

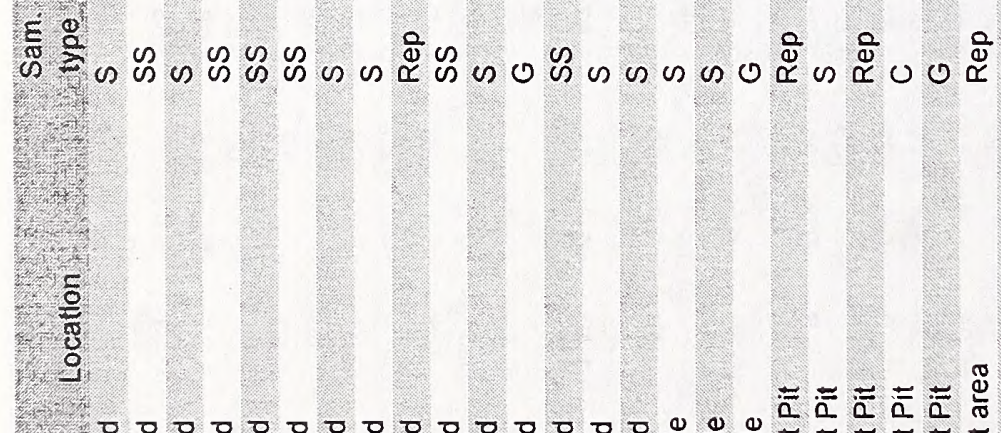

U2.

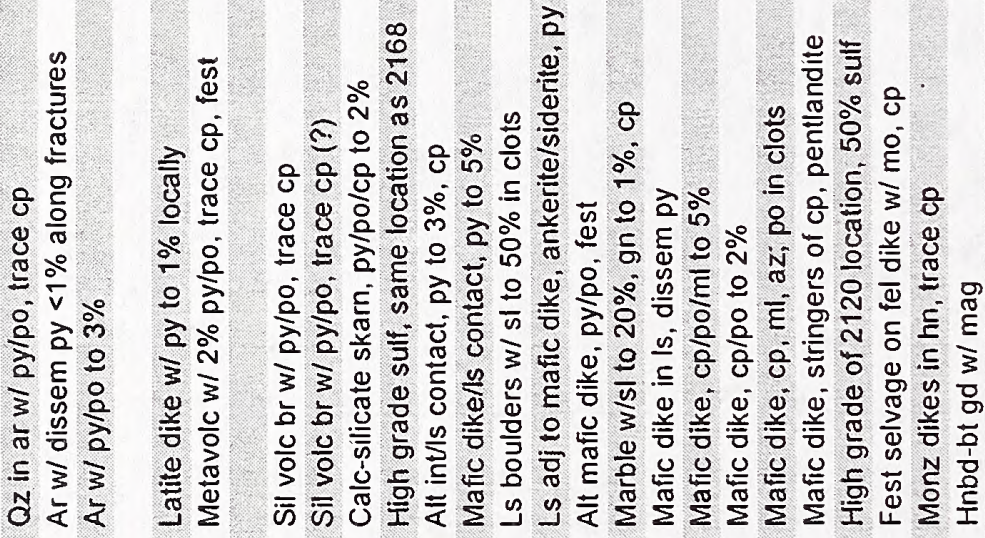
४品

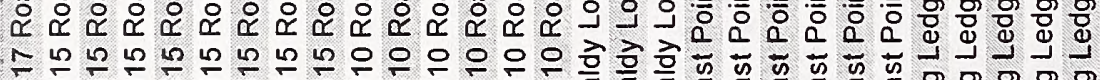

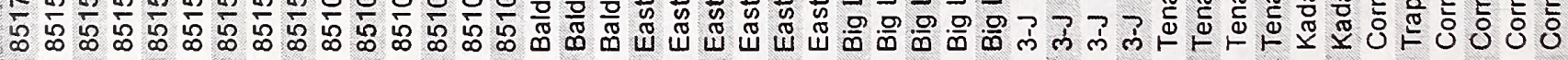

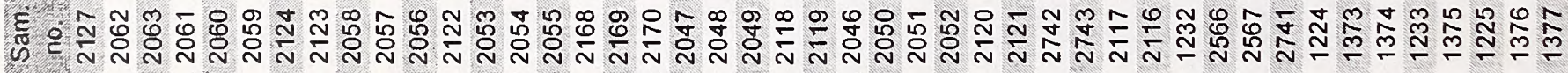

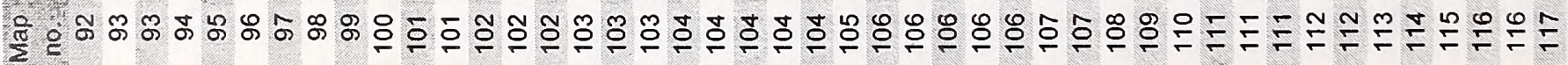




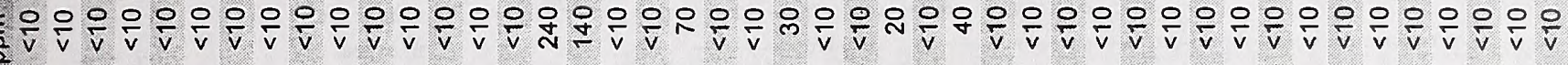
ह

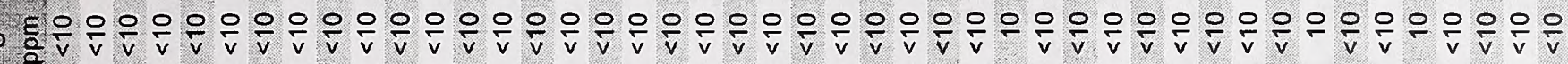

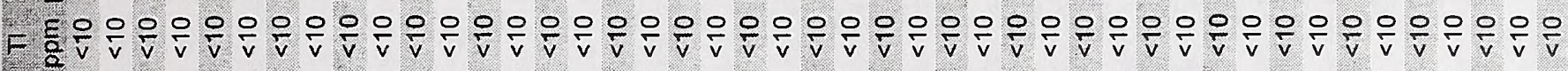
- ำ

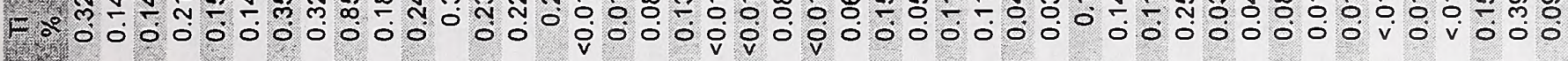

등

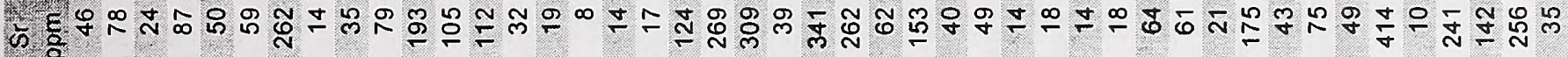
$5 \frac{E}{2}$

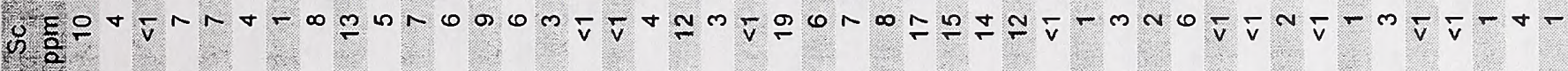

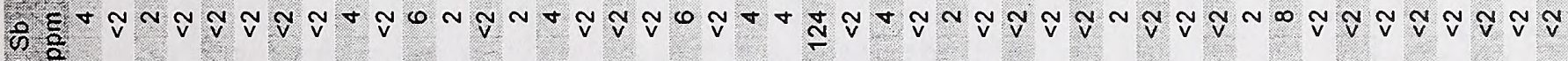

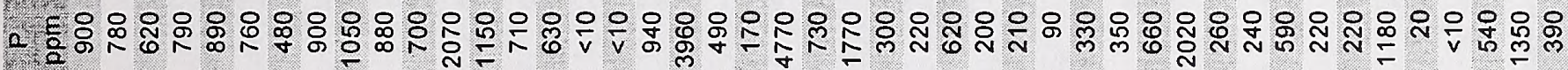
: E

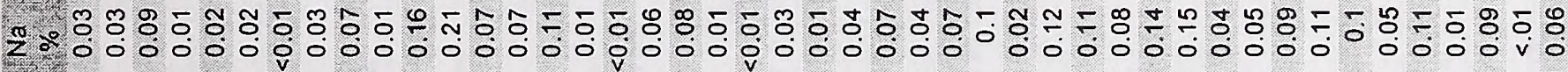

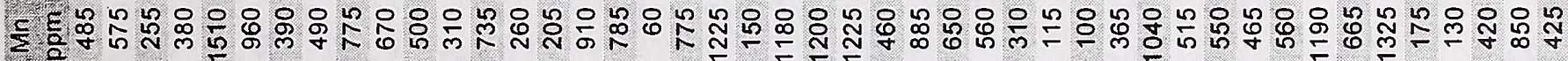

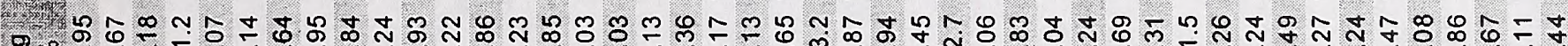
罗。 $\bar{\varepsilon}$

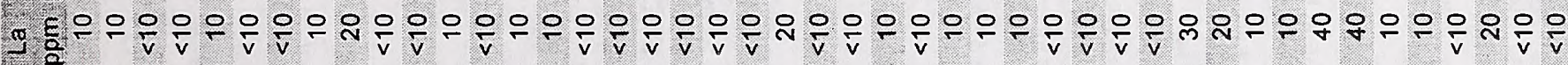

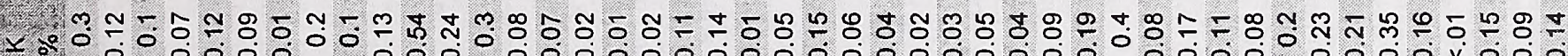

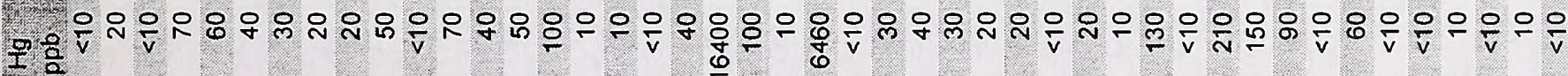

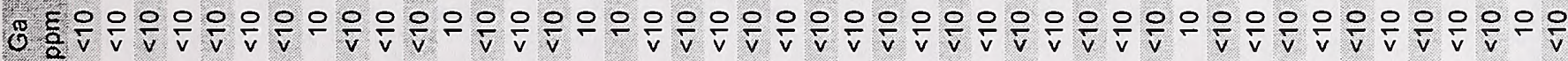

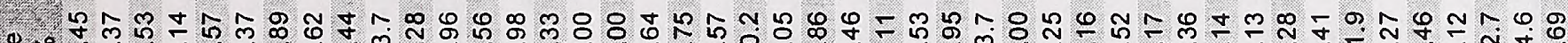

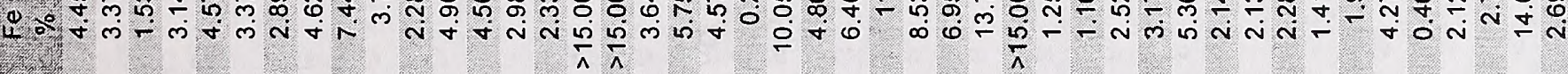

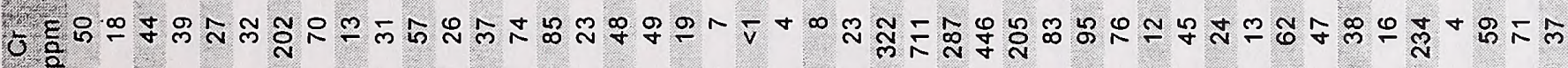

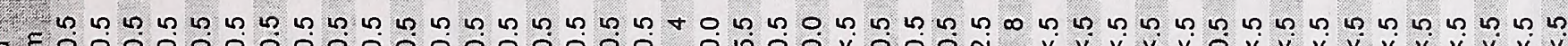
J E⿺辶े

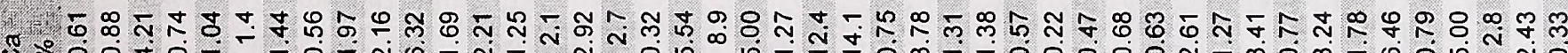

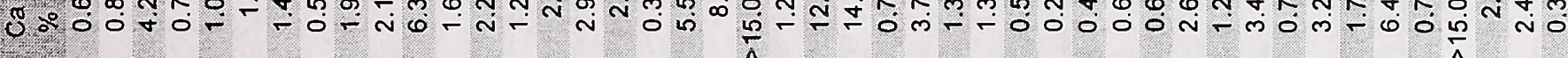

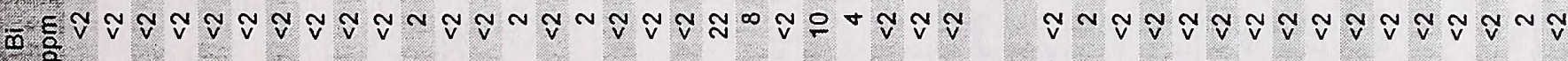

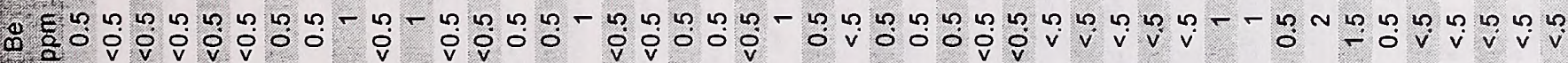
E ஸ.

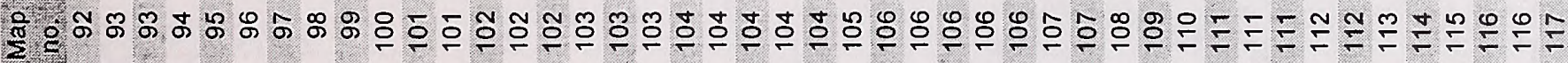




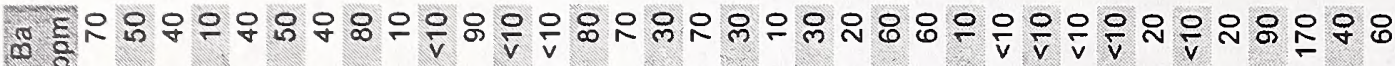
웅유유유 \&

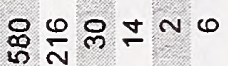

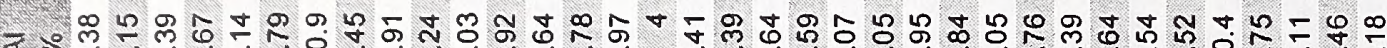

$\bar{ก}$ $0 .+4-\dot{m}$ m n

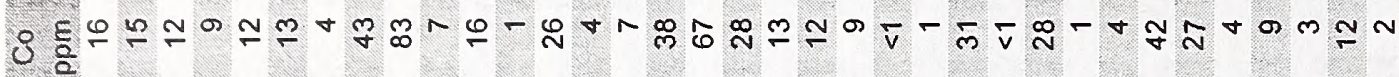
๓กะน z $-n \bar{r} \ln$

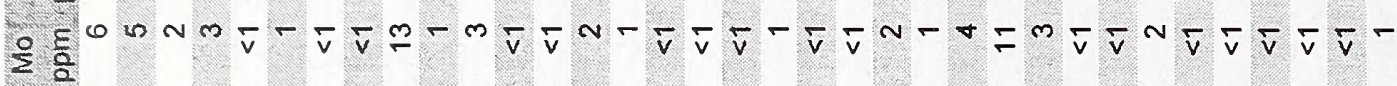
(x)

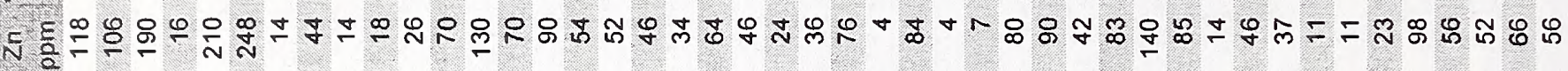

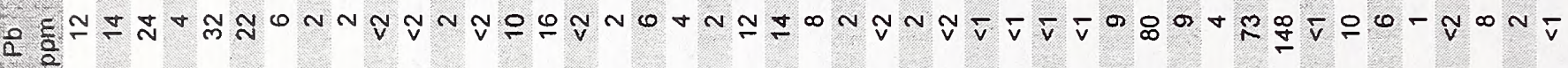
$\therefore \approx$ 了 \& -

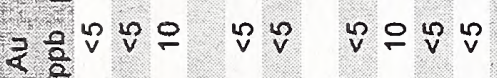

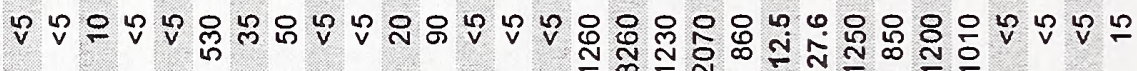

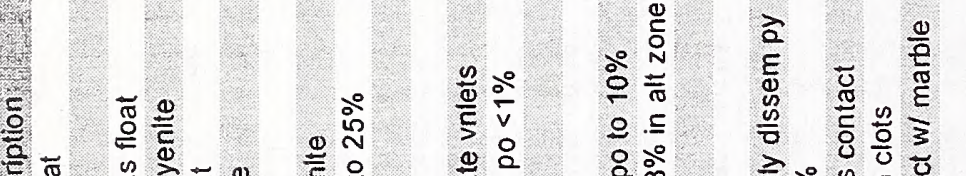

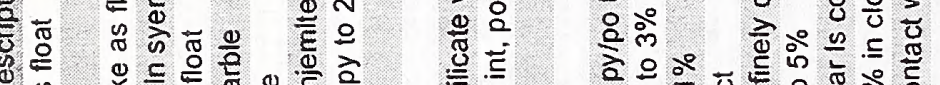

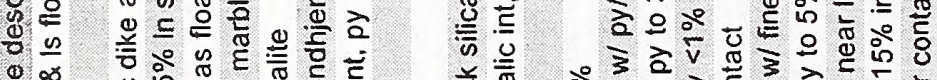

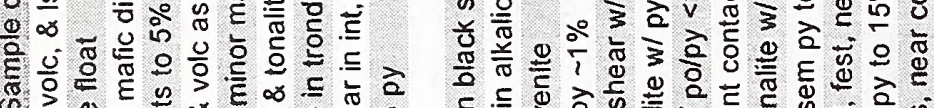

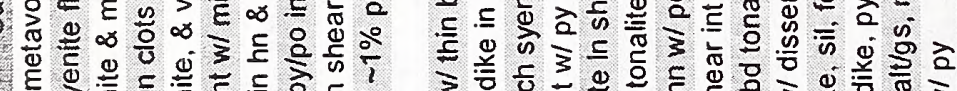

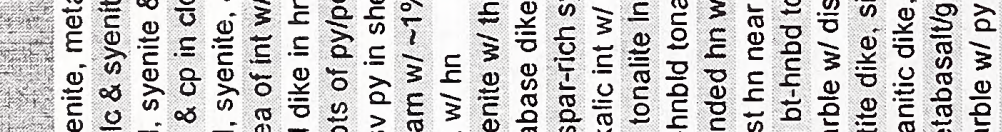
心

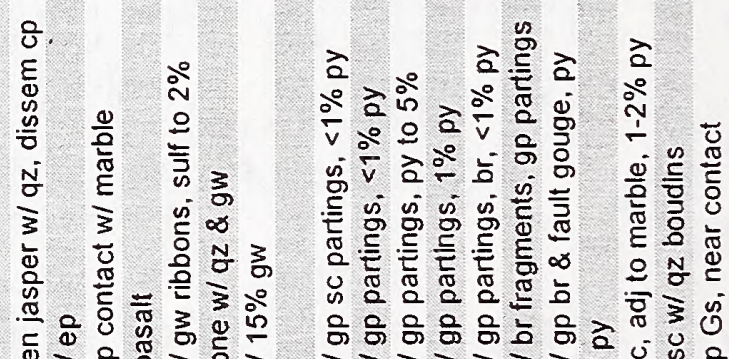

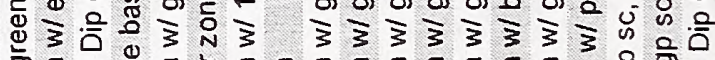

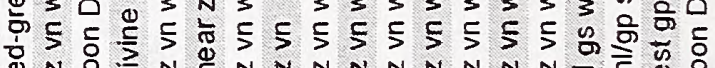

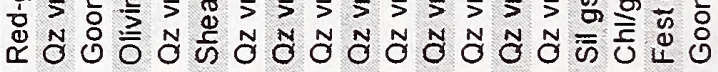

館

\& O

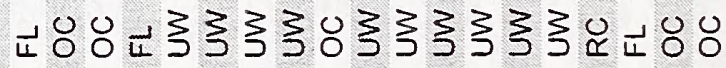

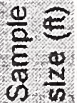

- n $\stackrel{\text { i }}{0}$

ก
พู

N

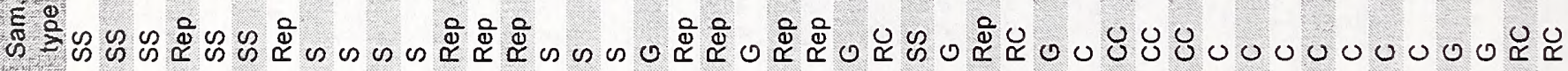

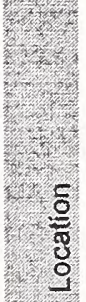

r-t-rt-r-t

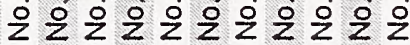

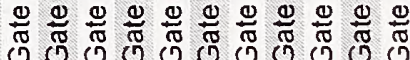

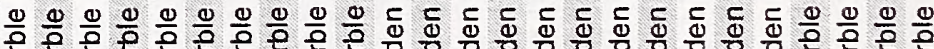

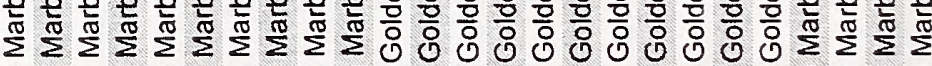

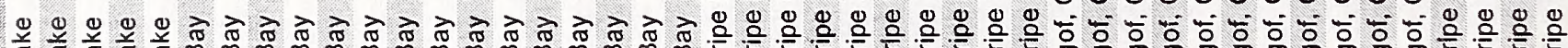
ज త

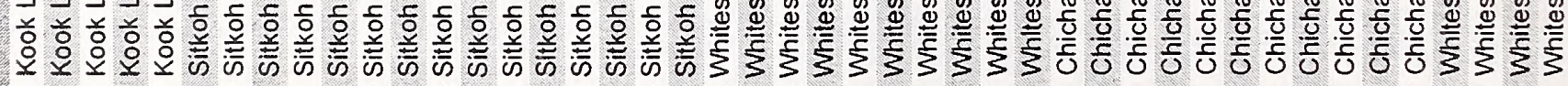
E

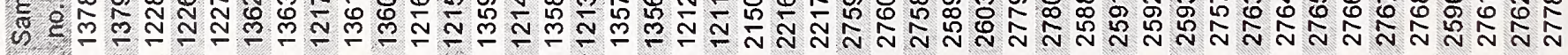
定 


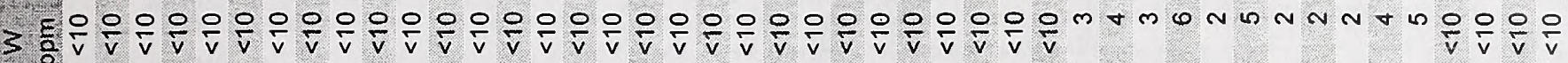

> a

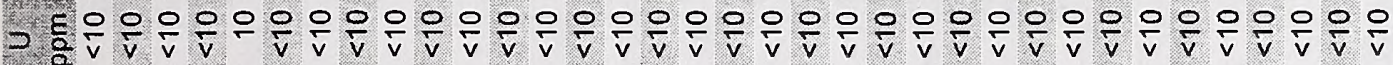
$\frac{0}{\mathrm{v}} \frac{\mathrm{O}}{\mathrm{v}} \mathrm{O} \frac{\mathrm{V}}{\mathrm{v}} \frac{\mathrm{O}}{\mathrm{v}} \mathrm{O} \mathrm{v}$ 은

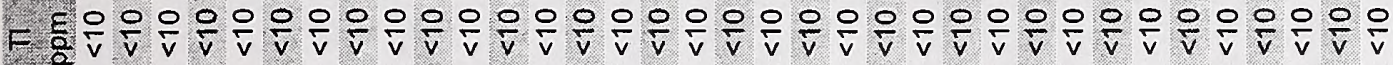
은 은 운 은 운은 -

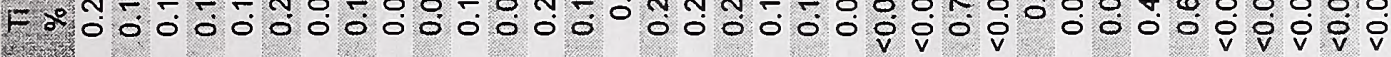

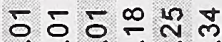
iे

을

त. $\frac{E}{2}$

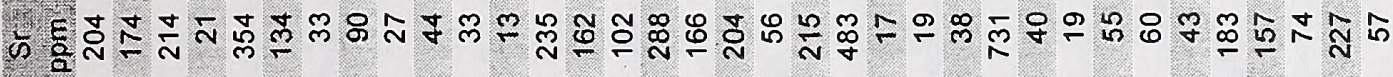

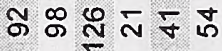

कह ह

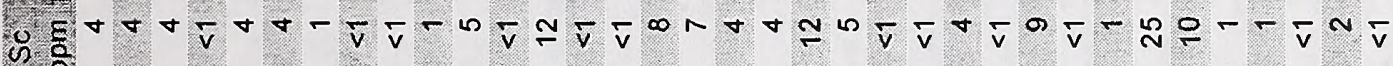

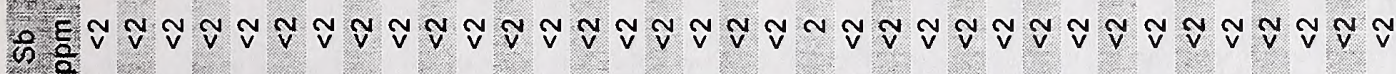

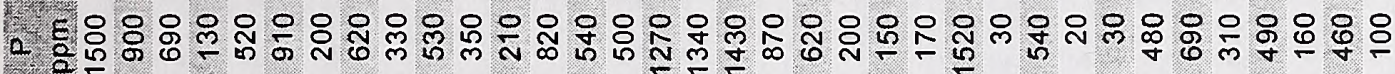
를

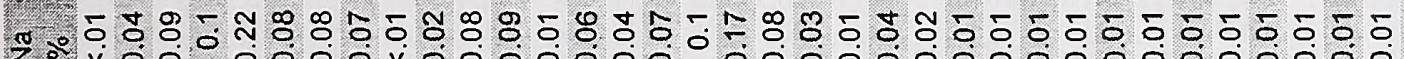

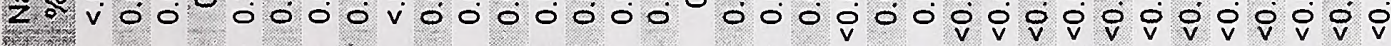

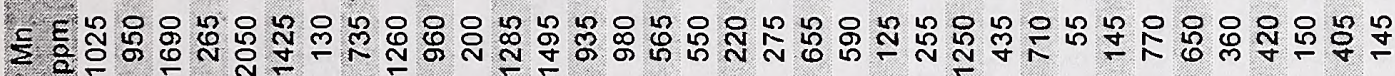

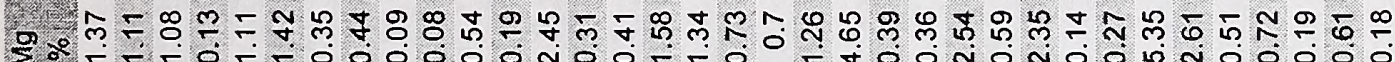
$1=\frac{E}{0}$

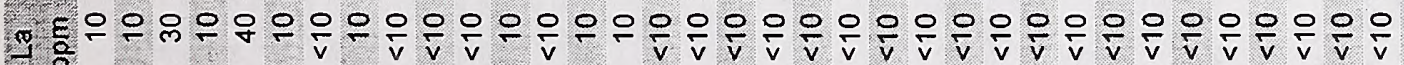

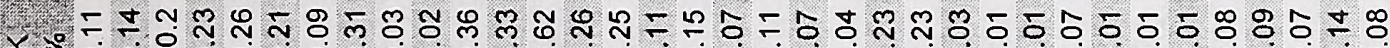

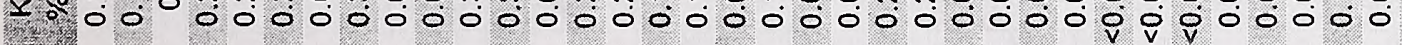

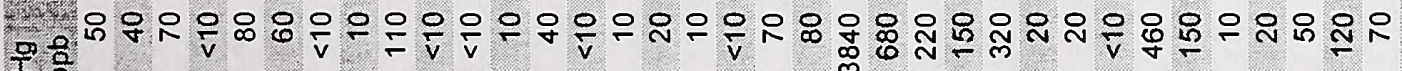

0 L

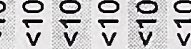

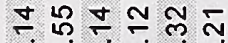
$-\leftarrow$ in लं ले

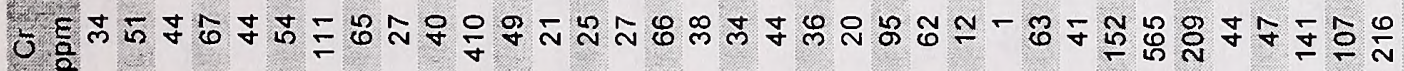

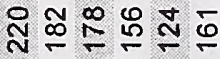

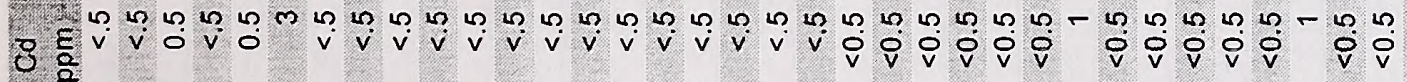
$\ln 20.060$. i i i i i i

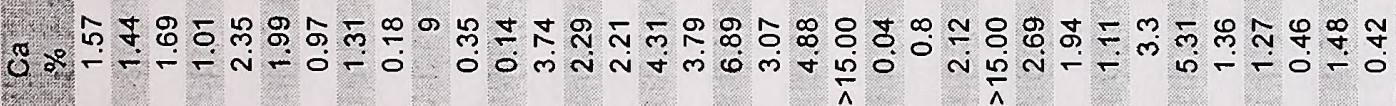
โ กู่

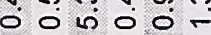

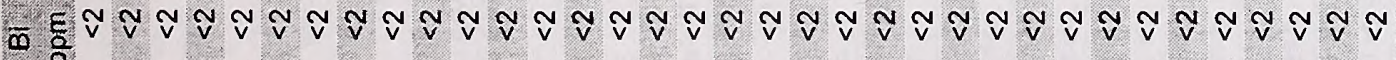
$\tilde{v} \widetilde{v} \mathfrak{v} \widetilde{v}$

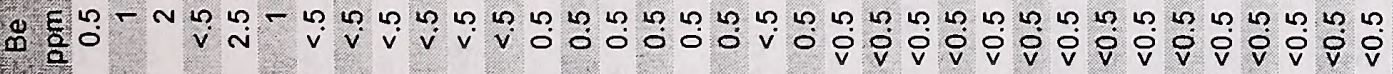
จ E 유ำ 노ำ U 商 
๓

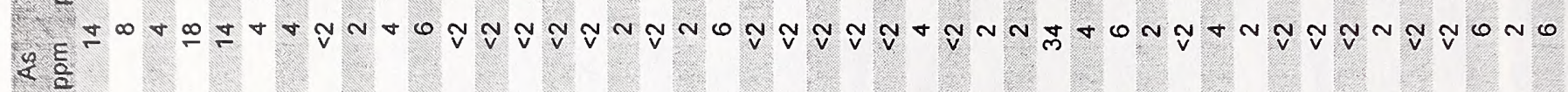

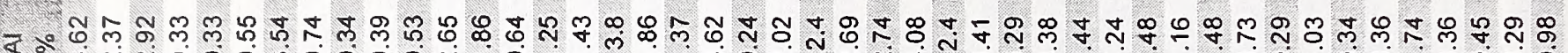

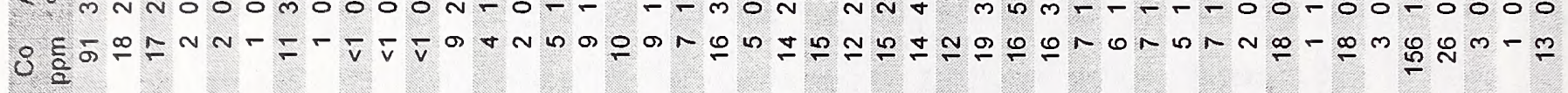
z

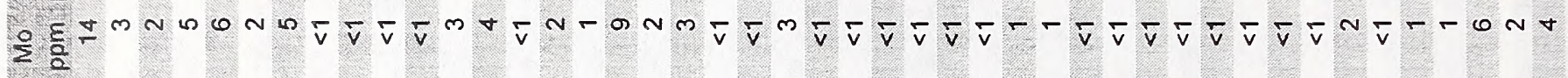

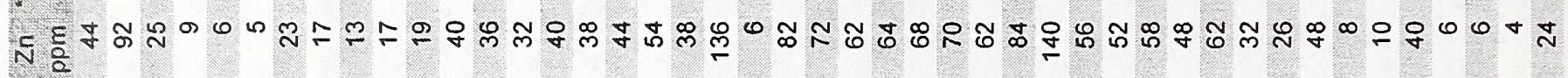

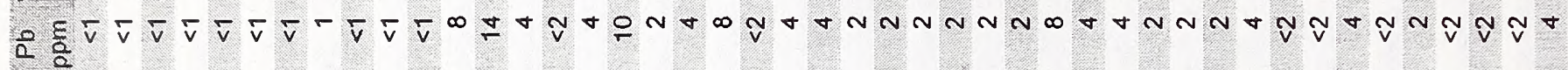
* o.

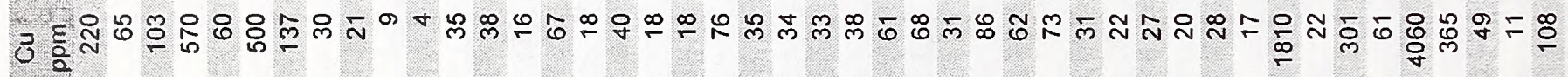
वํํำ

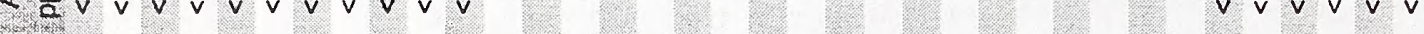
- $\frac{E}{2}$

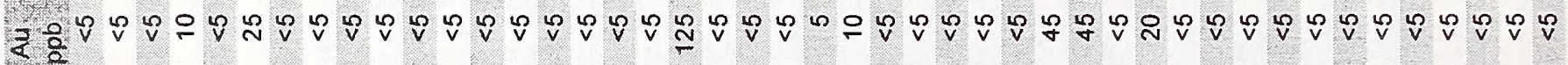

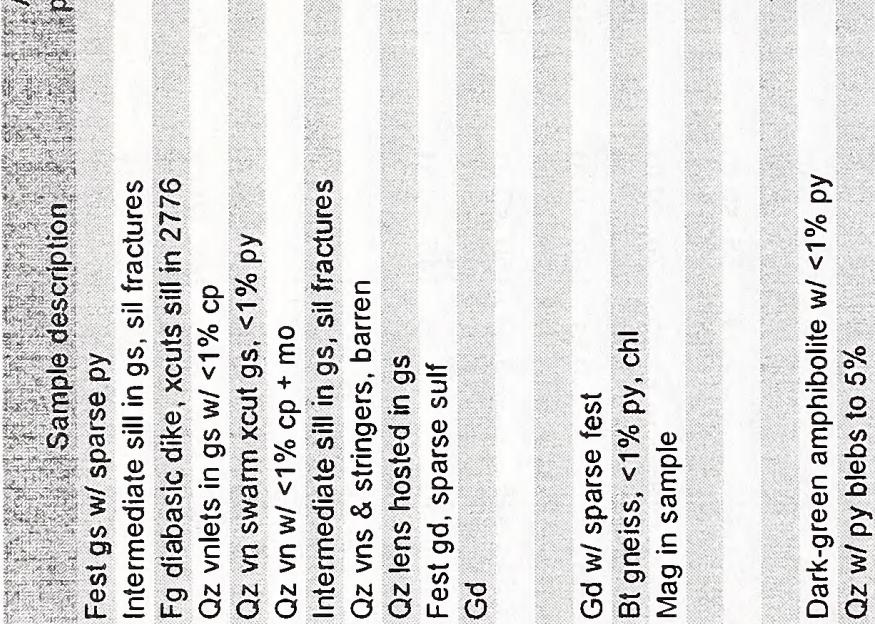

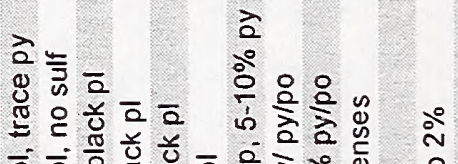

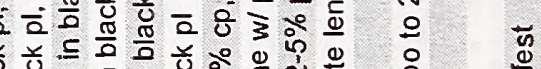

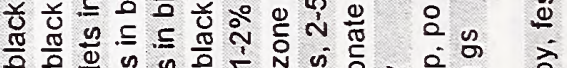

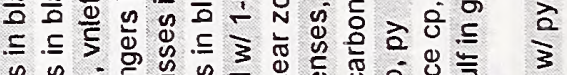

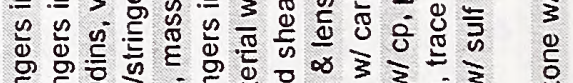

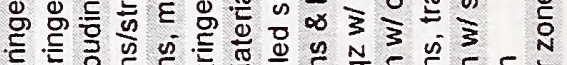

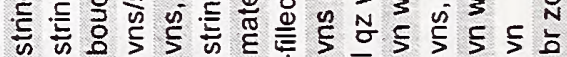
है O O $\overrightarrow{0} \vec{\omega}$

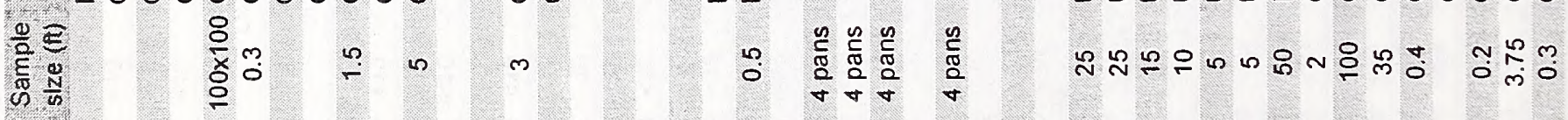

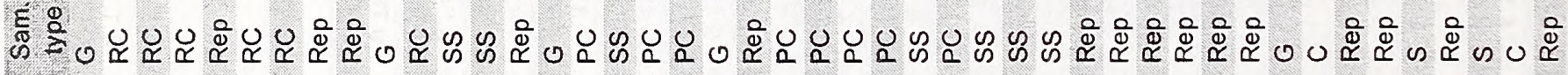

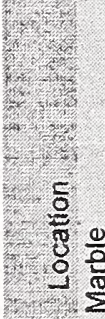

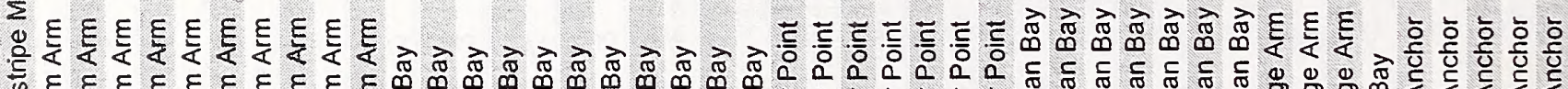

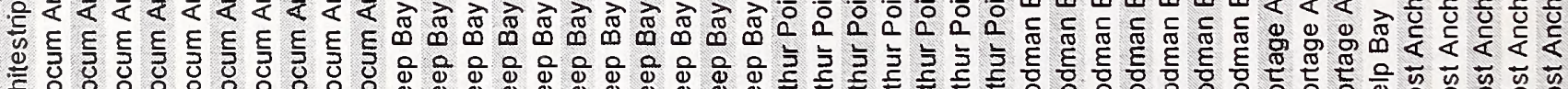

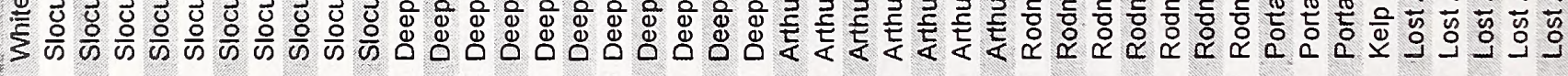

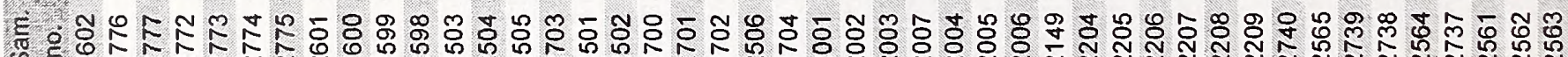
ת

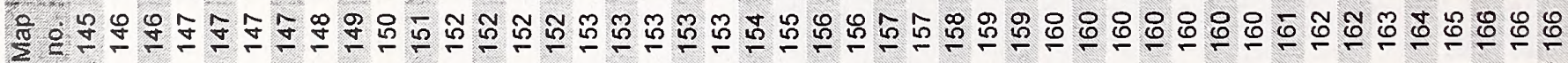




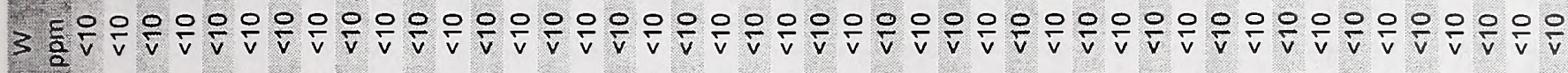

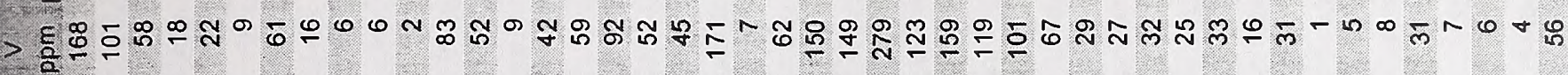

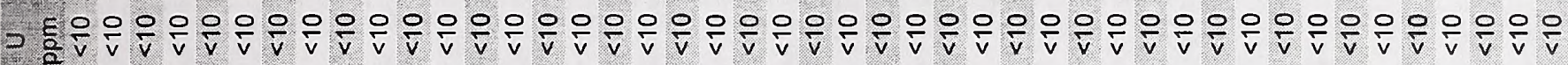

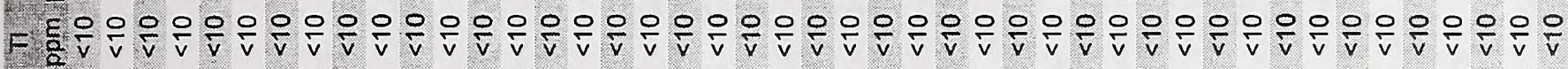
=

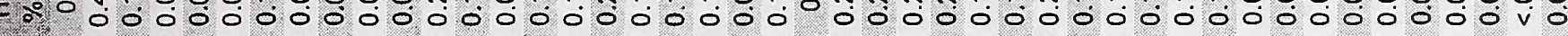

(c) $\frac{E}{\alpha}$

들

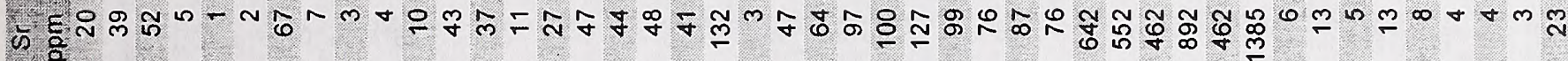

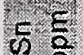

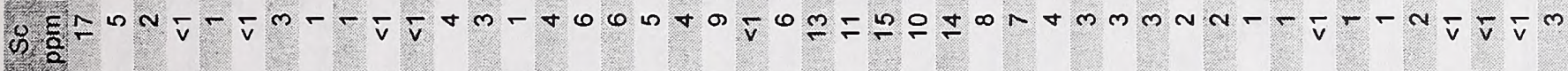
ต.

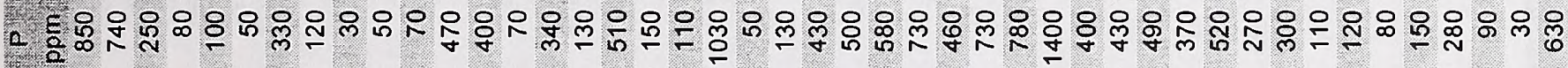
ह ह $\frac{1}{2}$

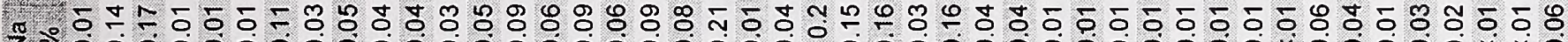

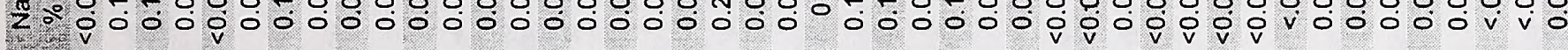

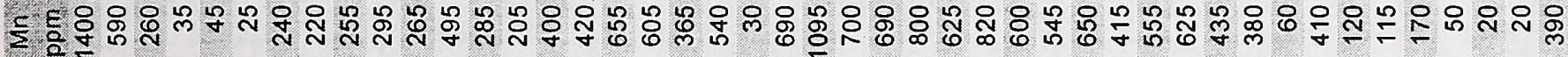

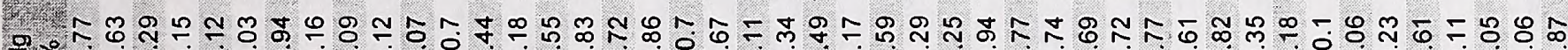

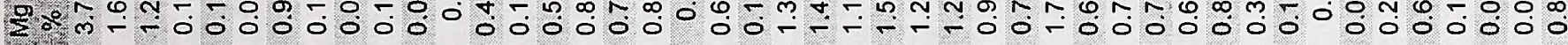
$-\frac{E}{0}$

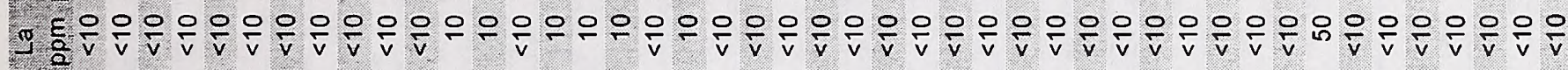
र

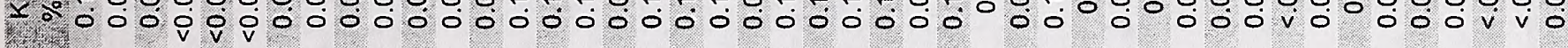

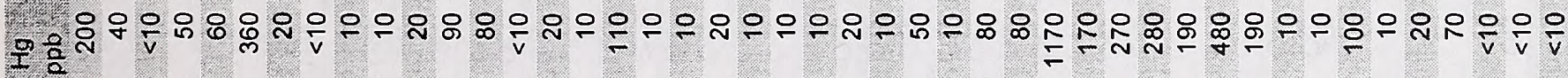

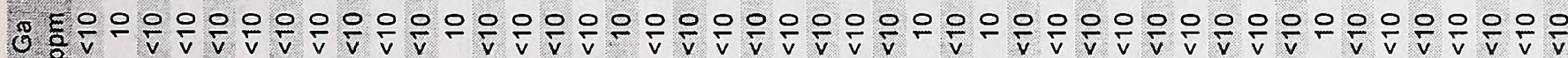

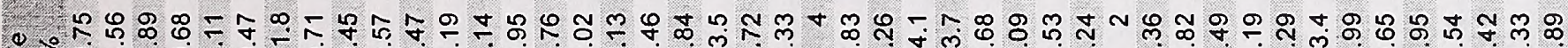

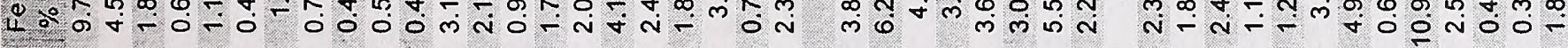

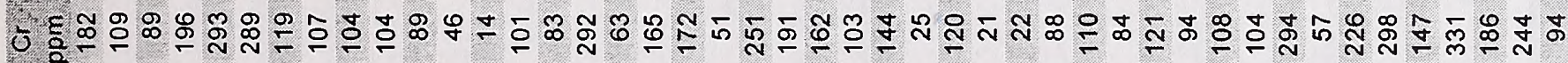

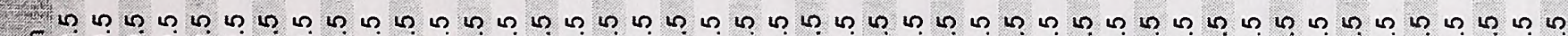
\begin{tabular}{ll}
8 \\
\hline
\end{tabular}

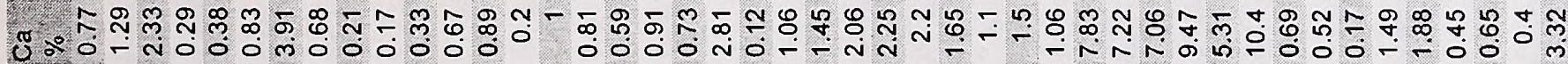

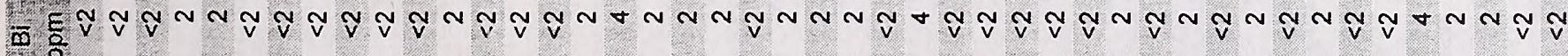
4 En

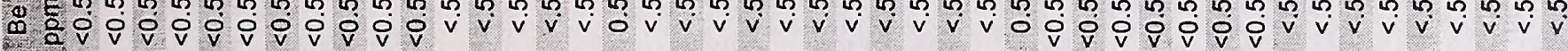

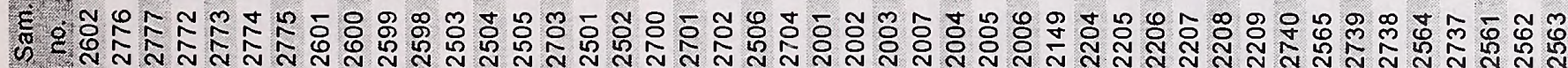

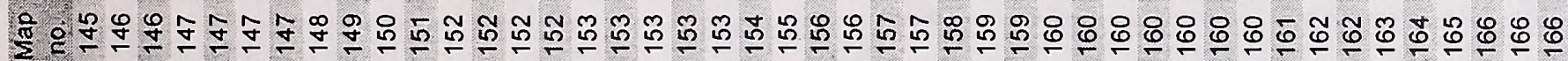


๓ 及 < ฌ ฉ

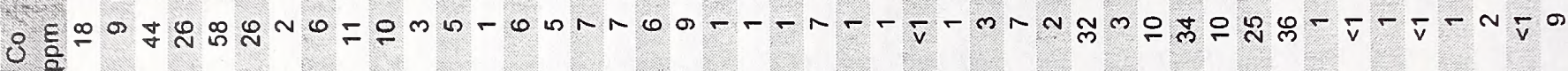
z

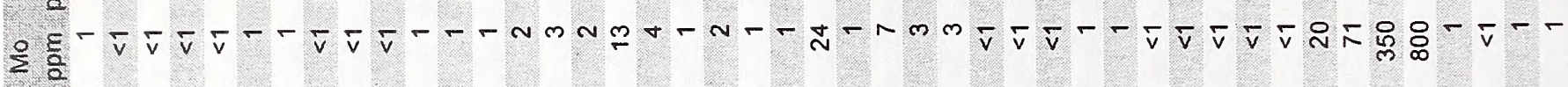

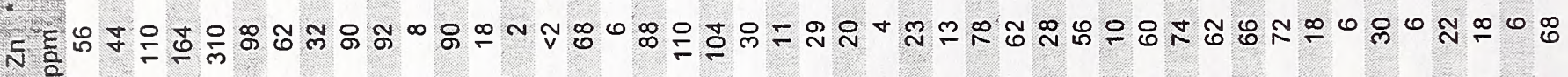

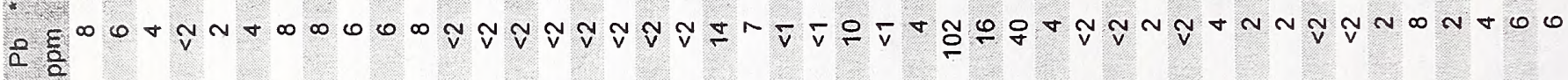
a. $\frac{0}{2}$

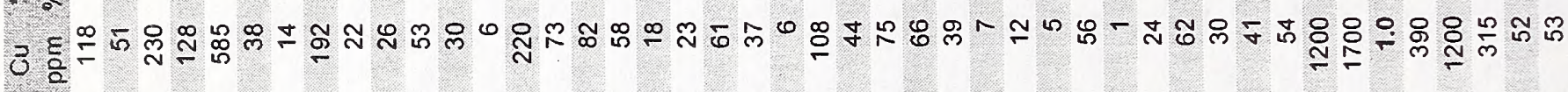

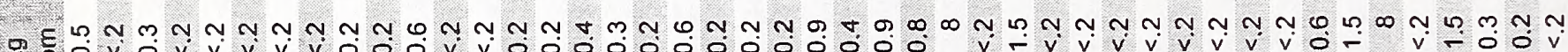

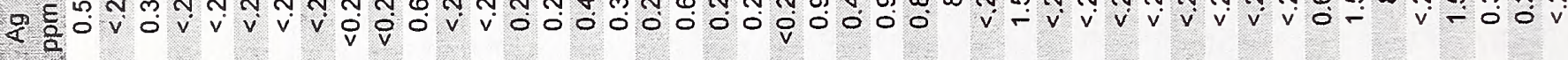
- 8

즌

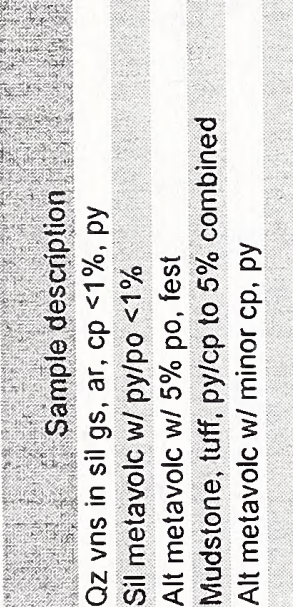
हूँ 产

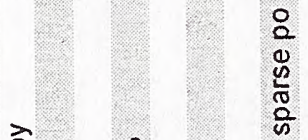

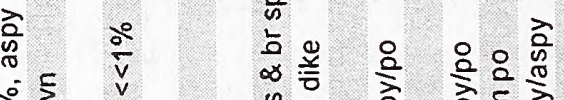
公

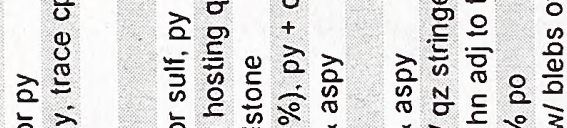

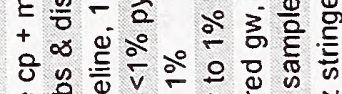

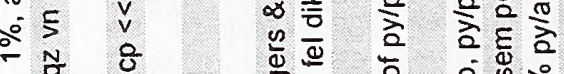

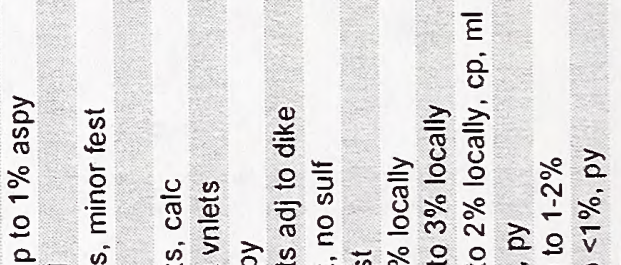
$\pi)^{2}$

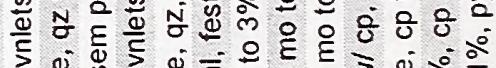

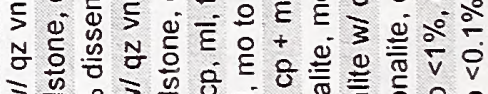

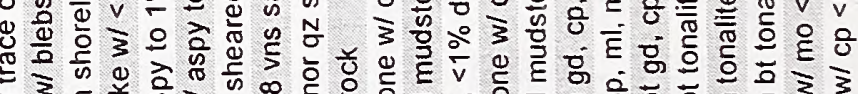

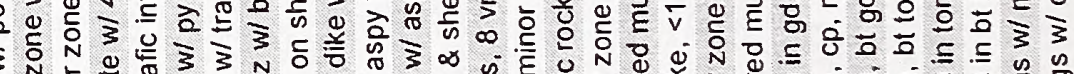

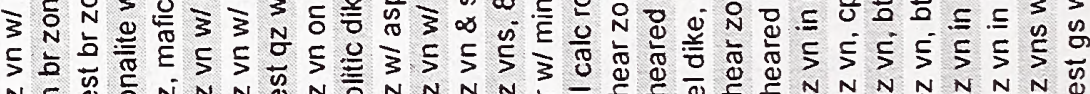

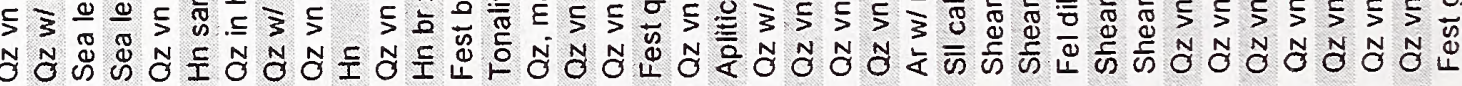
88

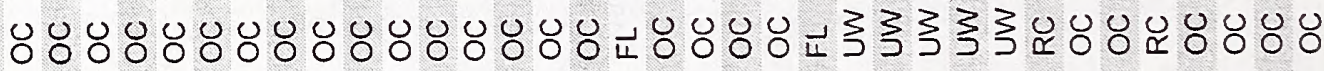

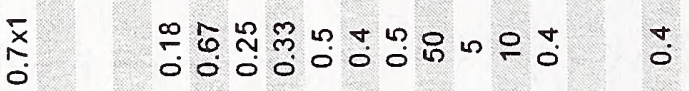

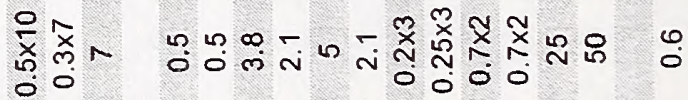

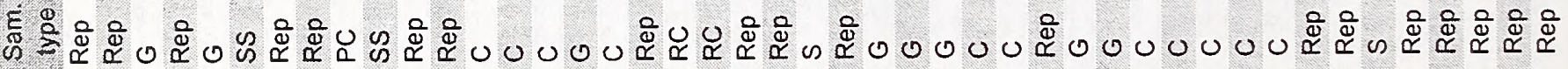

$\frac{1}{4}$

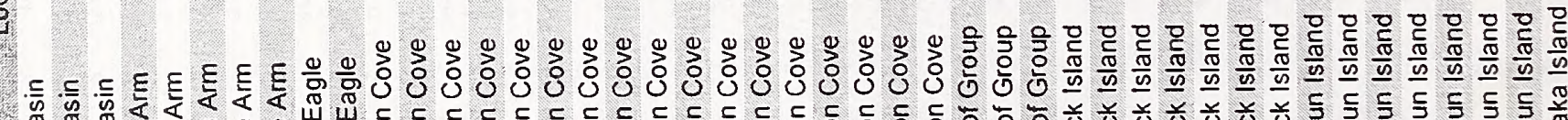

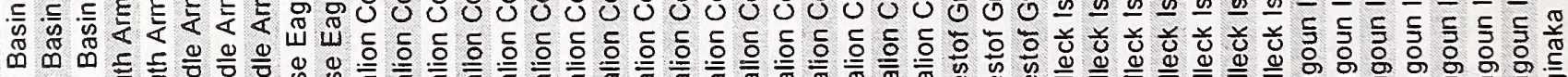

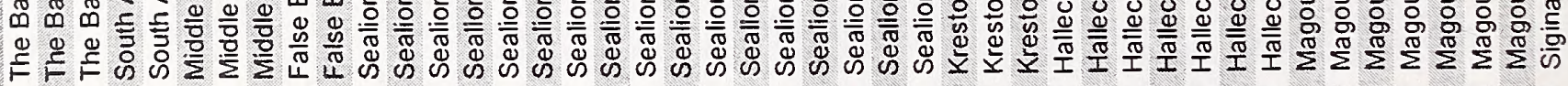
E

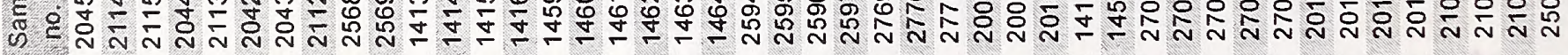

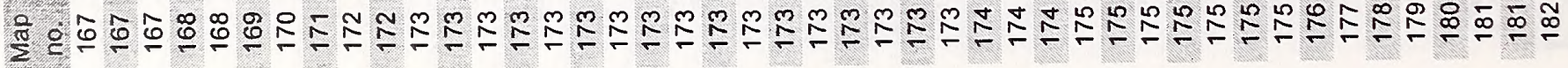




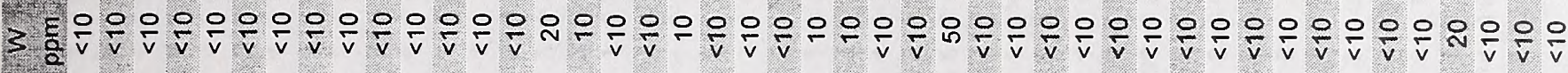
$>$ ㄷำ

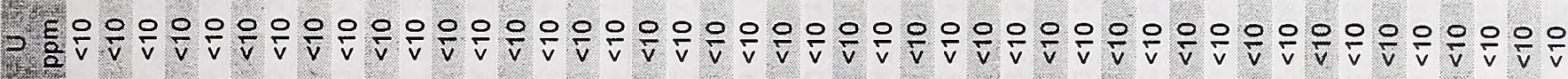

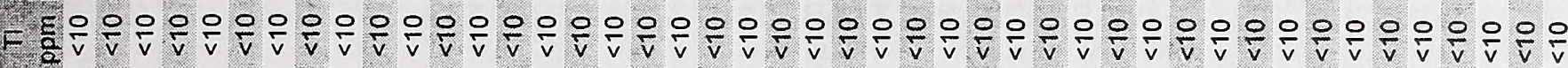
$=$ = $\delta$ б

क. $5 \frac{1}{2} \mathrm{E}$

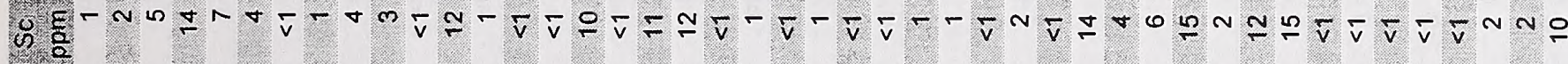

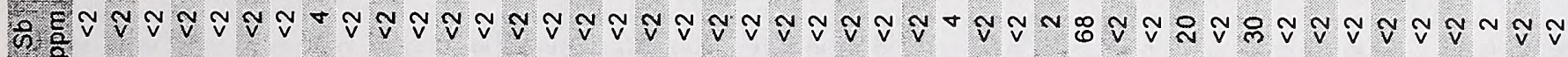

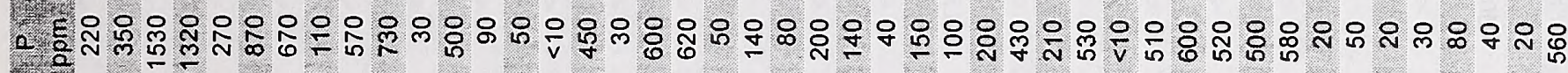

z.

₹

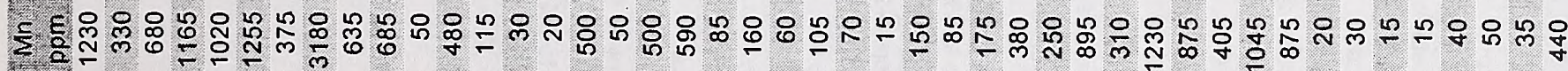

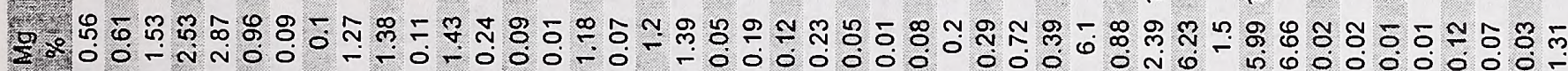
$=\frac{E}{2}$

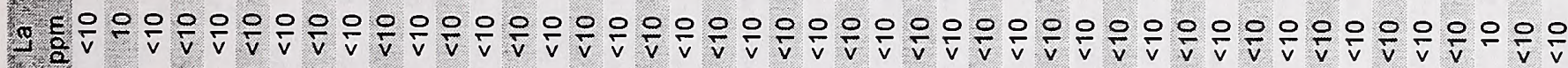

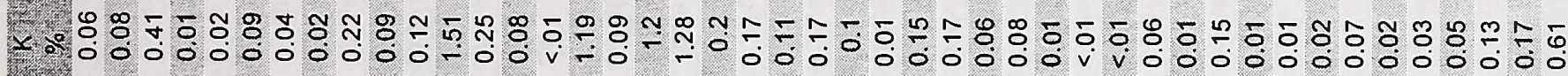

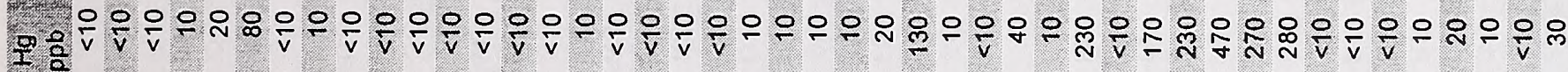

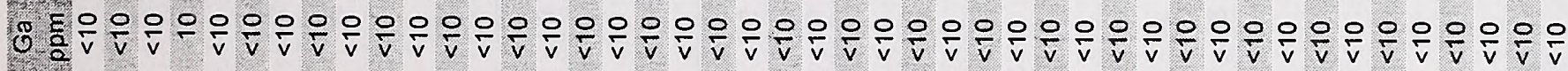

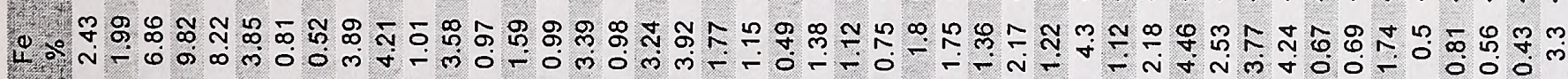

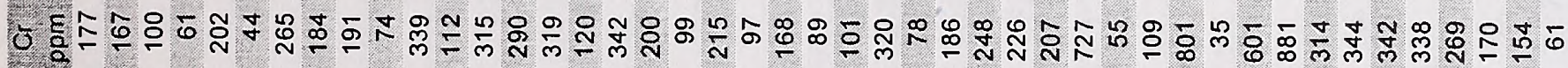

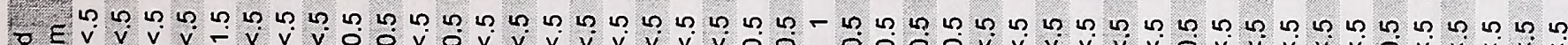

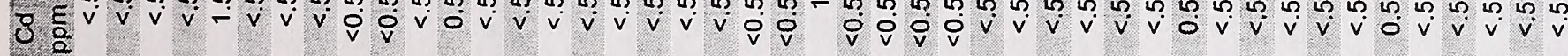

ช

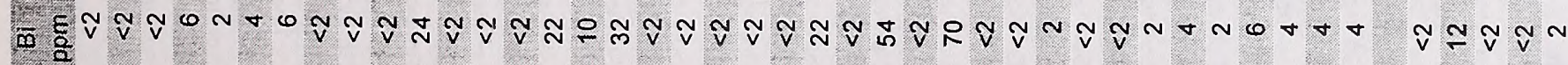

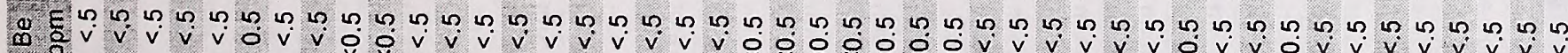

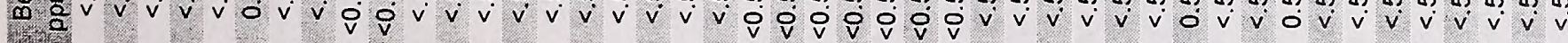
ह i. J 


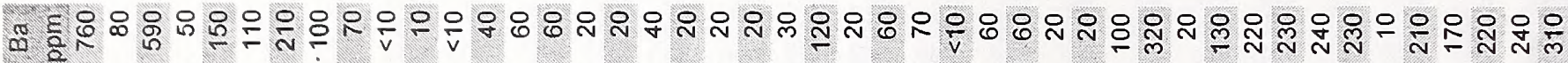
$\& \frac{E}{2}$

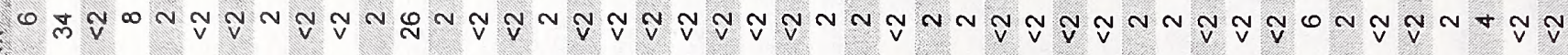

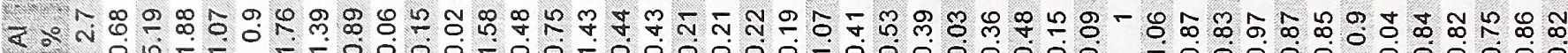

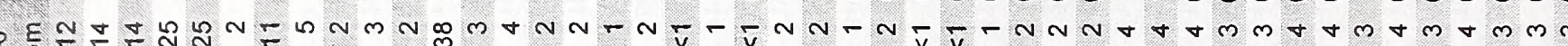
0 을

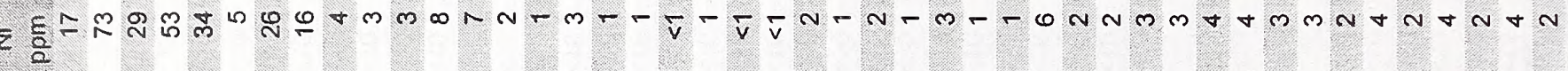

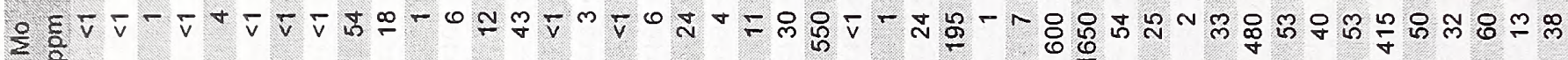

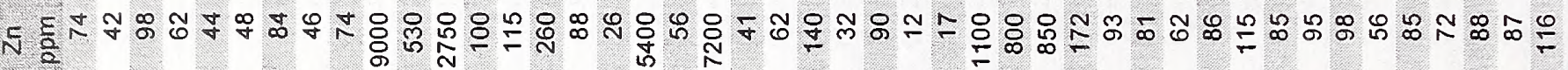
อำ *. ¿0

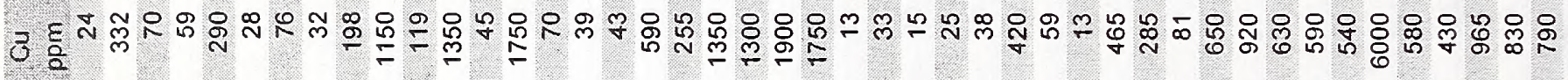

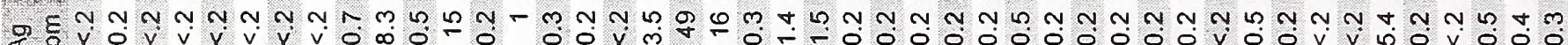

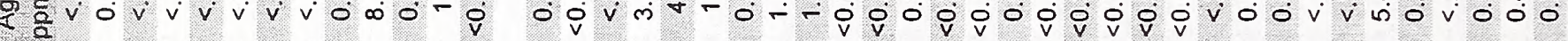
- $\frac{\mathrm{E}}{\mathrm{a}}$

द



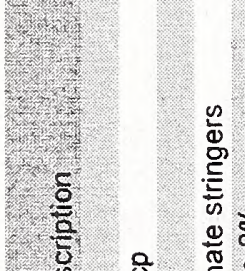

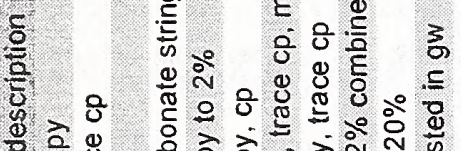

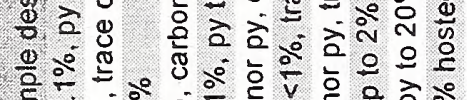

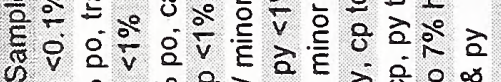

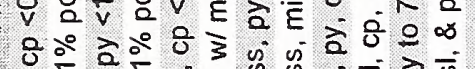

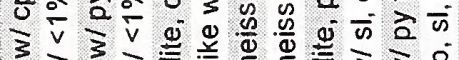

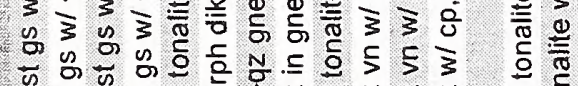
-

हึँ

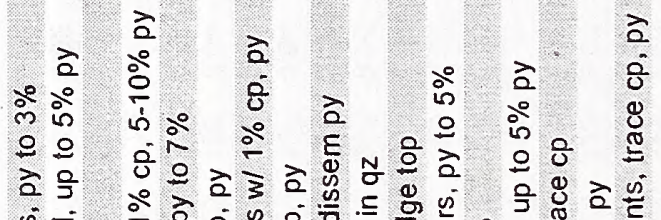

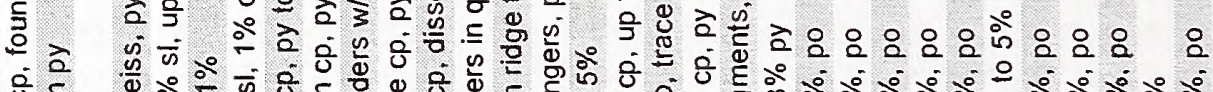

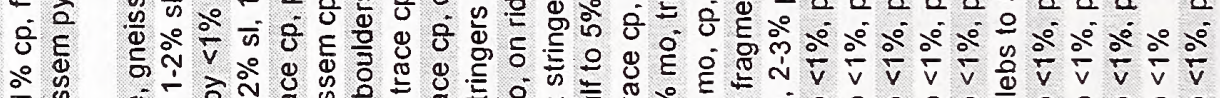
v ब

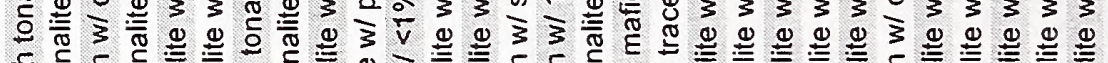

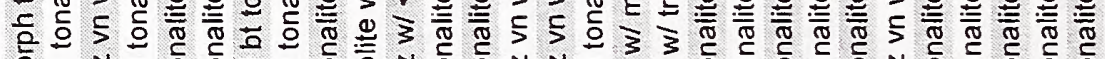
๙

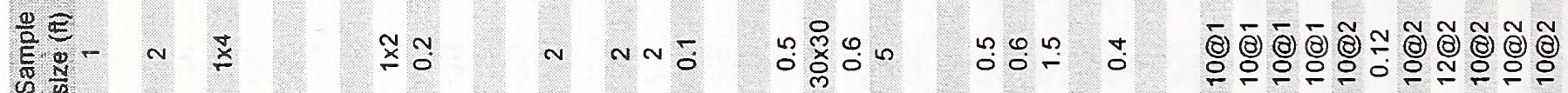

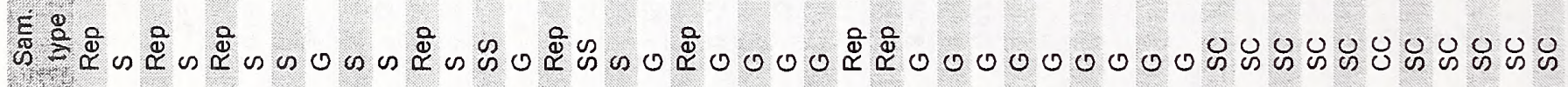

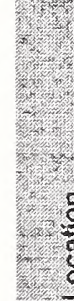

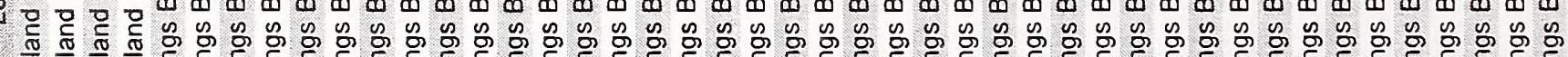

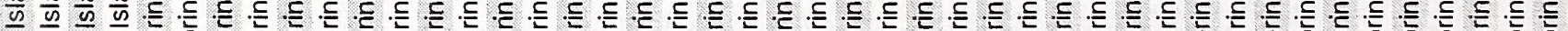

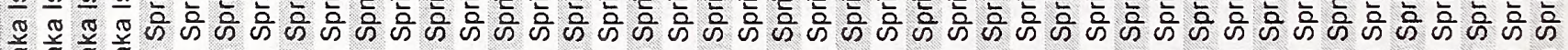
ه

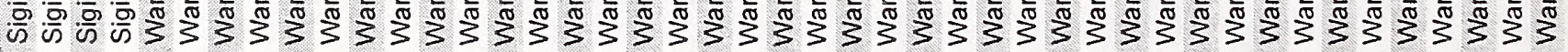

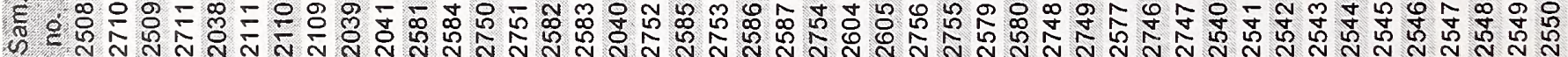

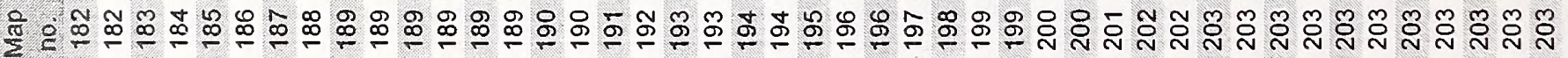




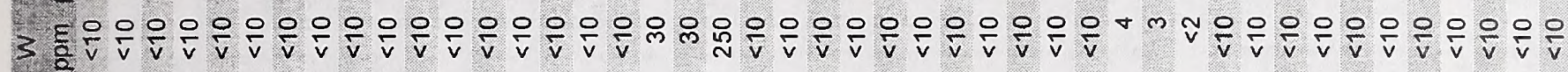

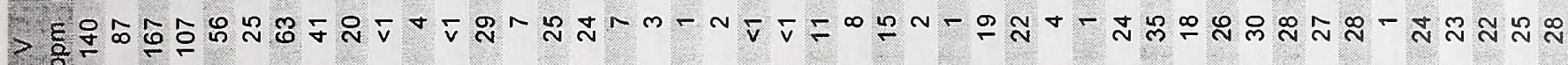

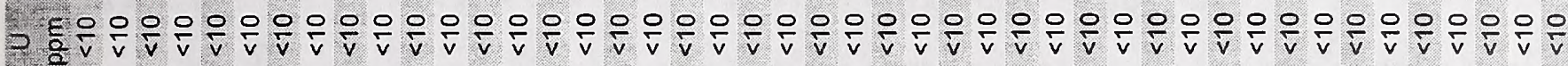

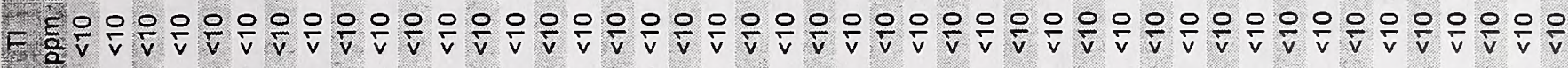
F I. E

6:

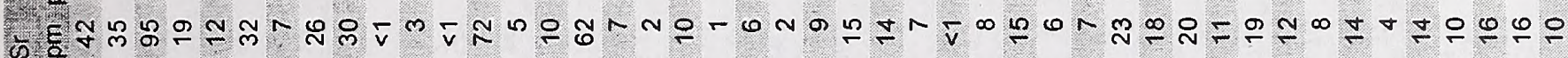
5. $\frac{E}{a}$

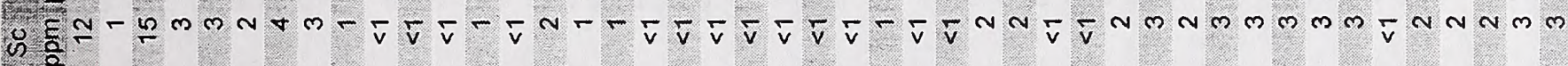

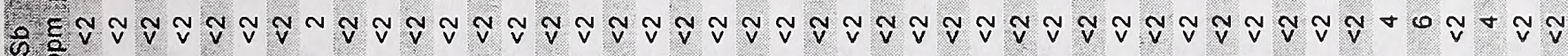

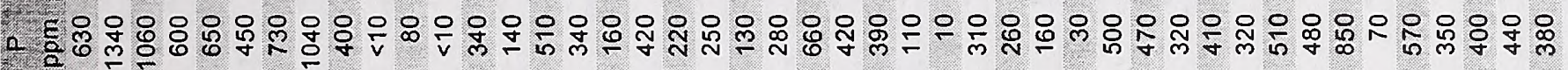
$\frac{1}{2}$ a

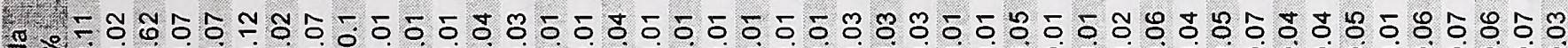

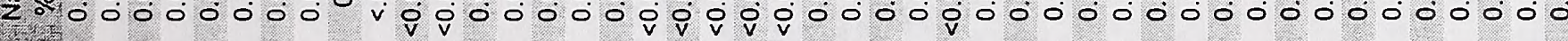

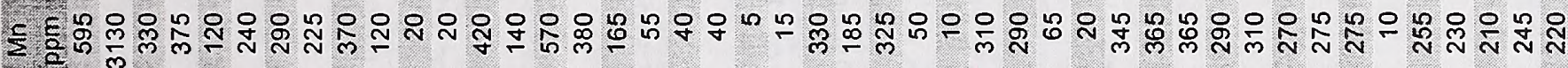

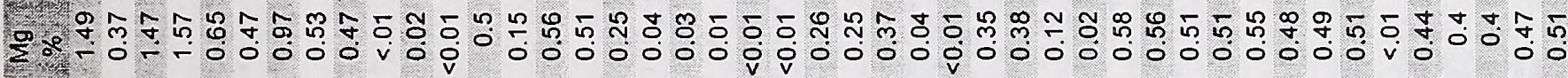

I.

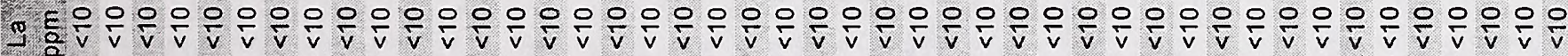
หะ ๘

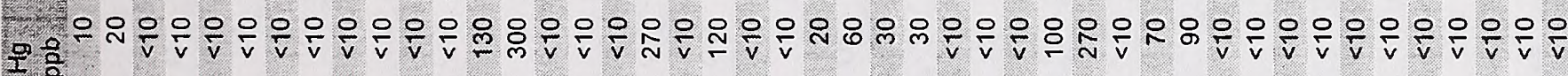

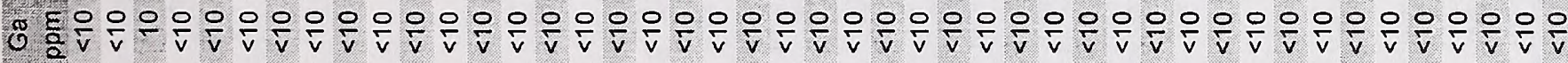

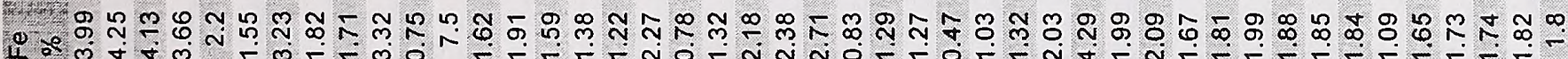

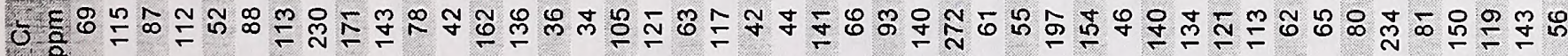

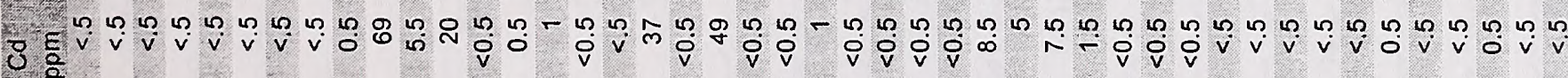
గ艹

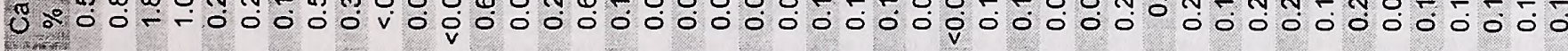

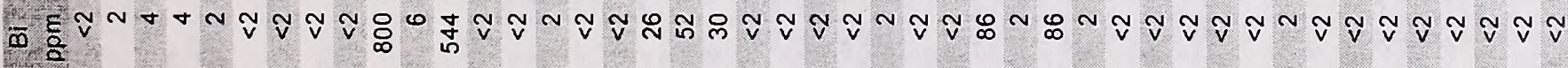
送

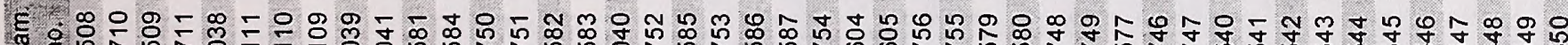

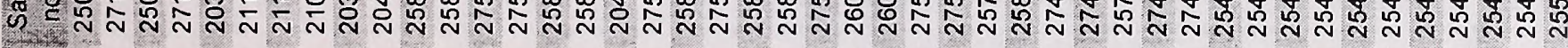

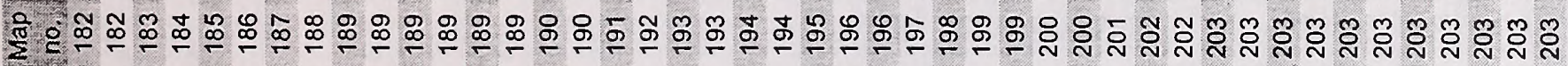




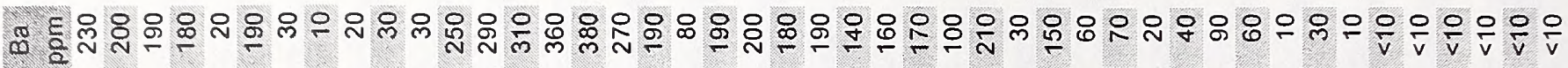
g $<\approx$

く

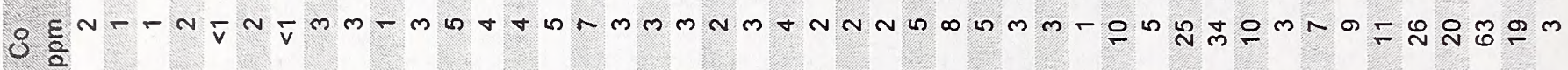

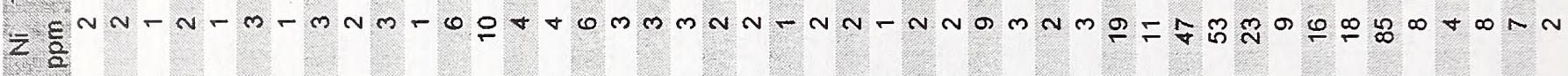
造

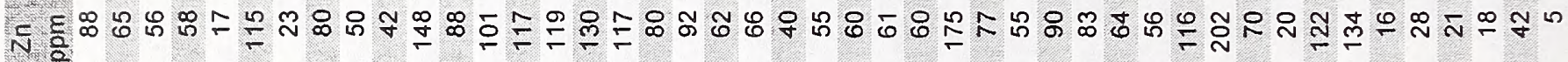

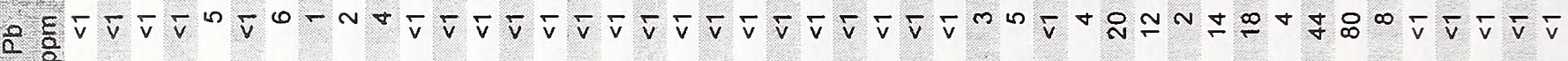
- ஃ

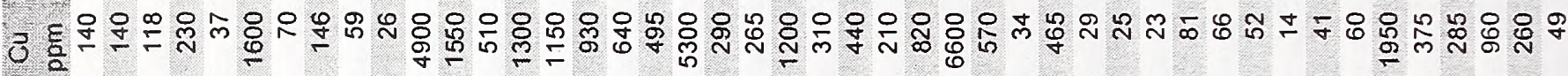

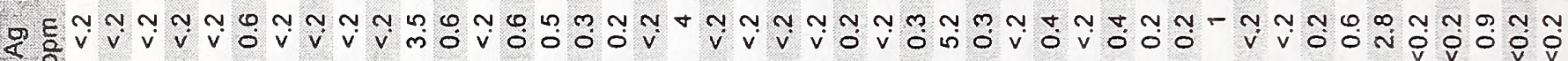
- $\frac{E}{0}$

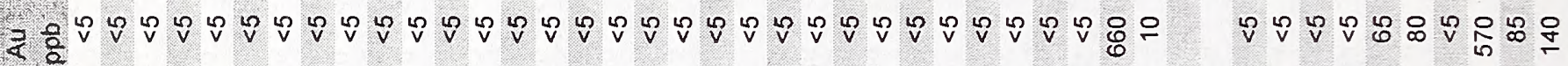

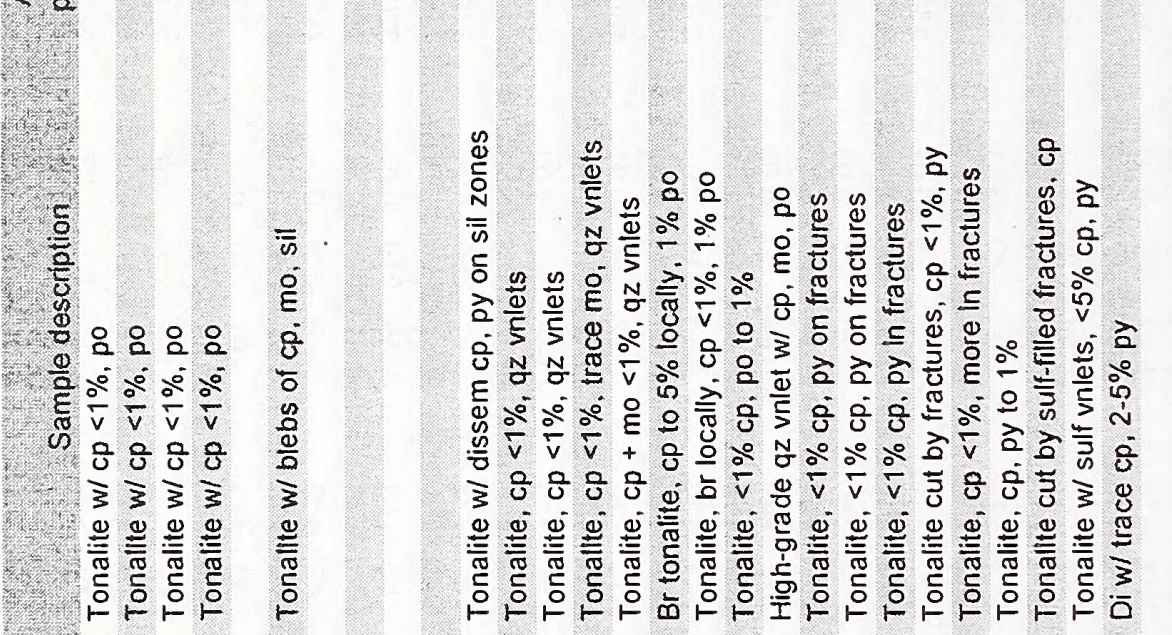

हूँ Ш

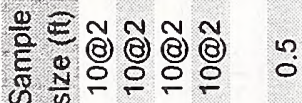

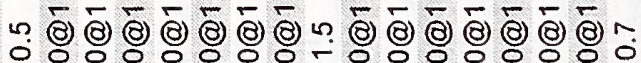

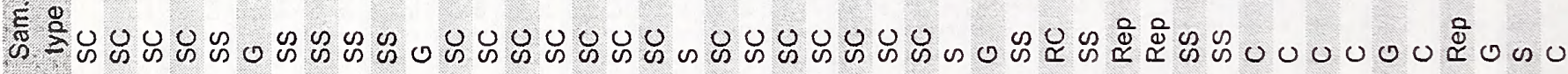

5

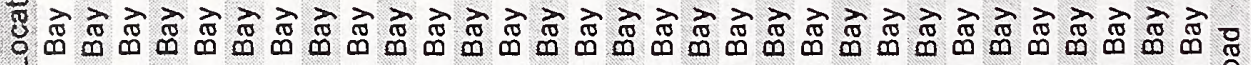

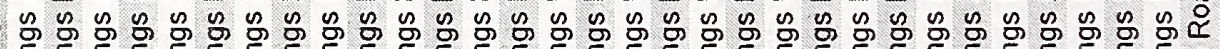

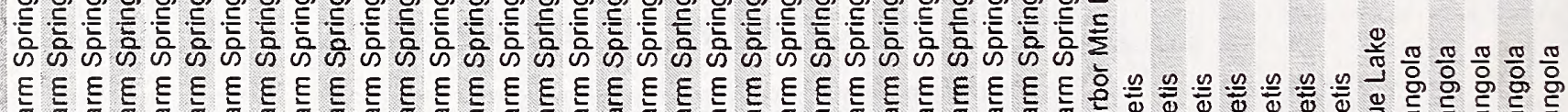

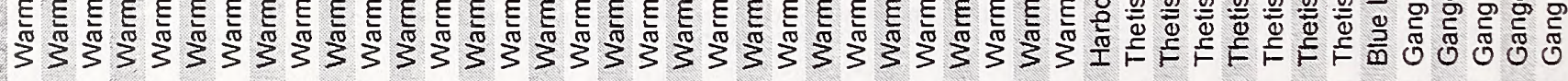

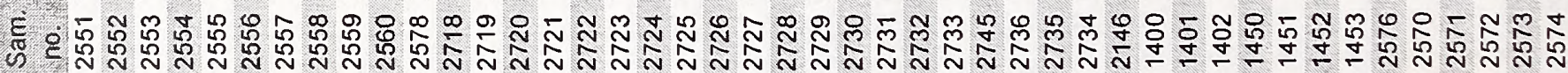

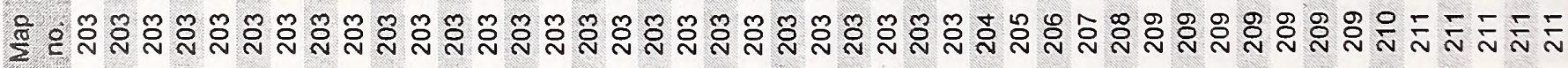


$>$ ह

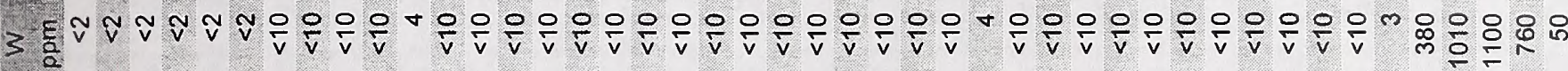

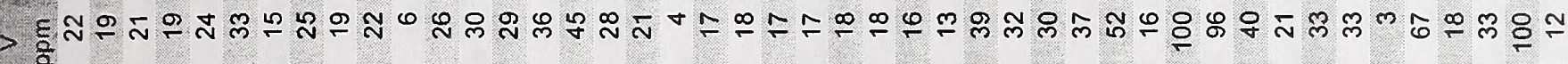

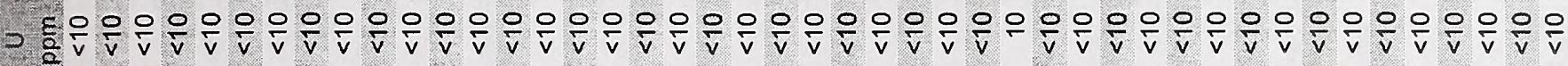

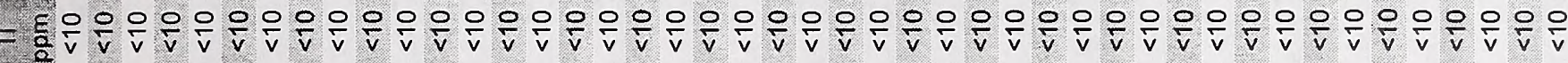

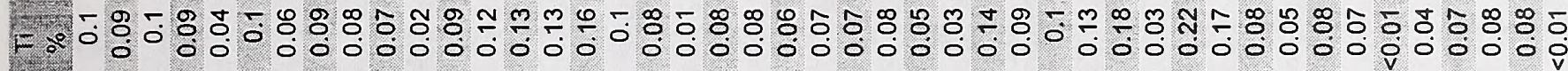

Q $\frac{E}{0}$

ए5

ต $5 \stackrel{5}{\circ}$

i:

Emmmn-m-m-

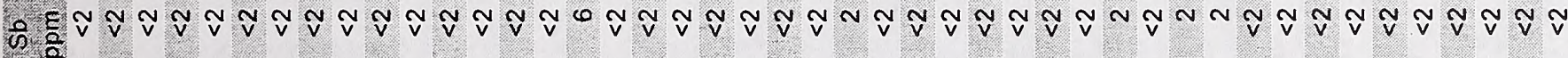

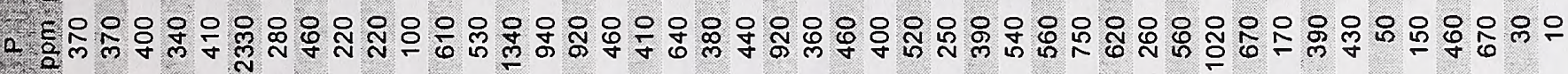
乙

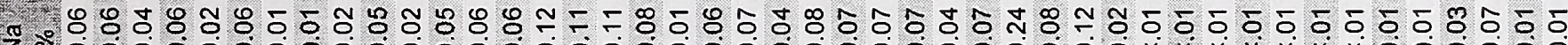

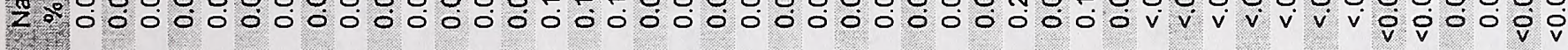

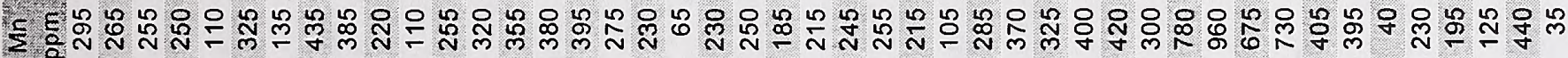

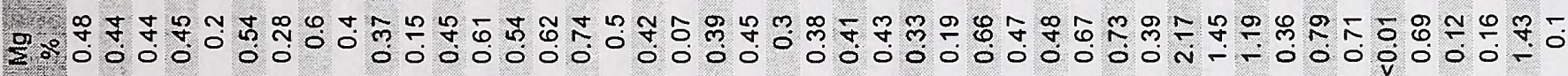
च E

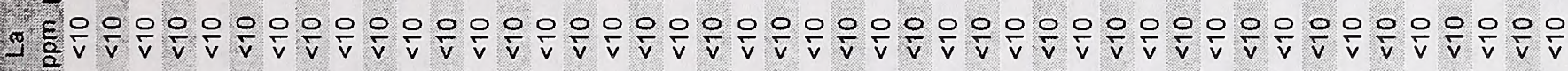

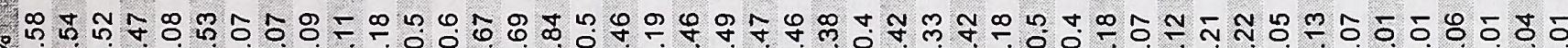

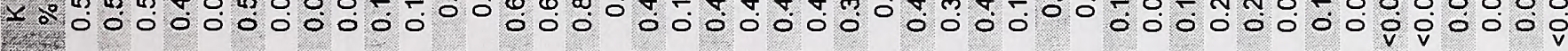

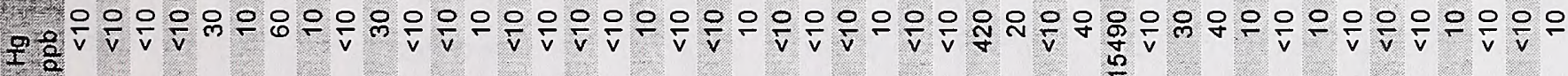

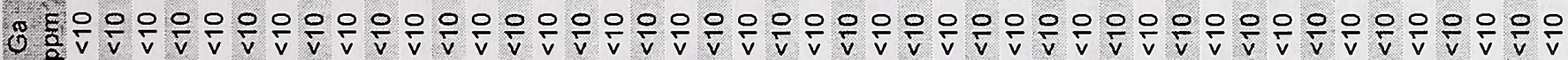

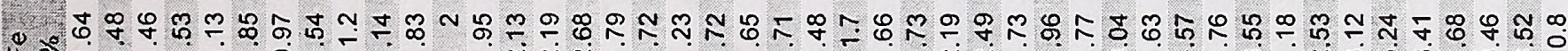

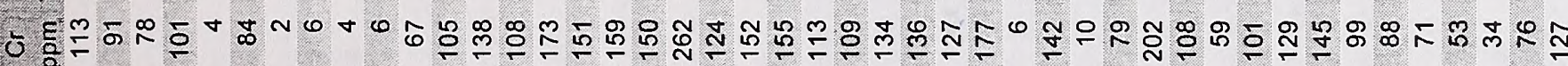

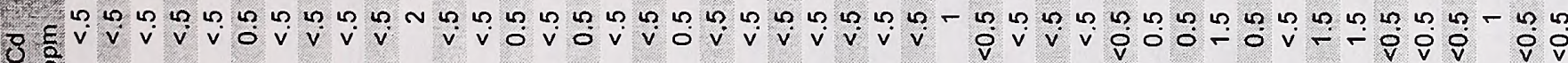
แ

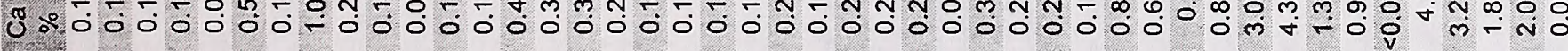
ल :

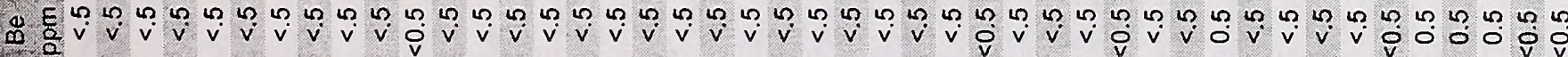

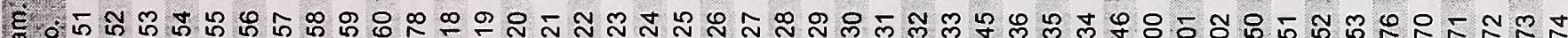

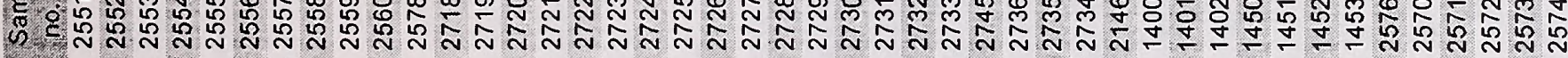

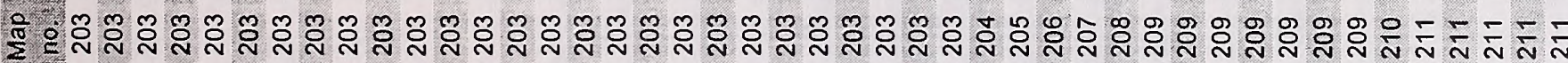


๓

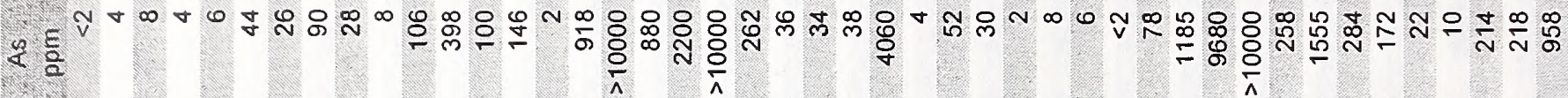
ব ๙

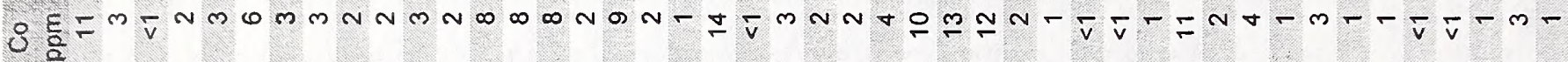

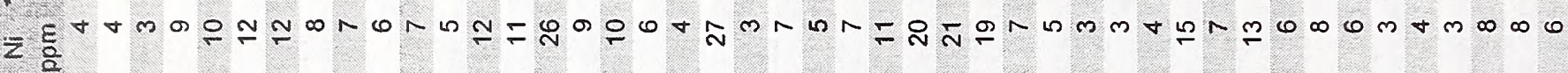
$\sum \sum_{0}^{0} \bar{v} N---\bar{v}-\bar{v} \bar{v} \bar{v} \bar{v} \bar{v} \bar{v}-\bar{v}-\bar{v}--\bar{v} \bar{v} \bar{v} \bar{v} \bar{v} m \omega m-\bar{v} \bar{v} \bar{v} \bar{v}--\bar{v} \bar{v}-\bar{v}-\bar{v}-\bar{v}-$

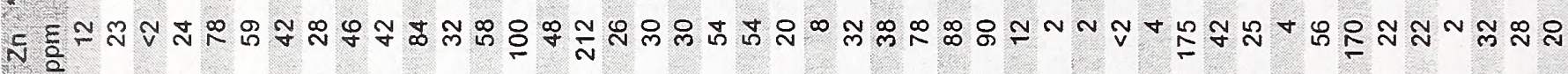

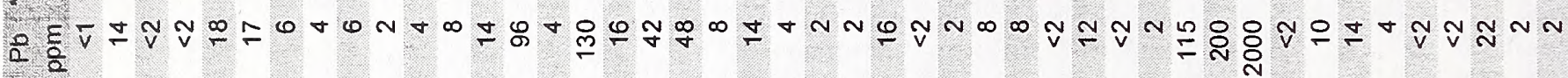
उ g - हू

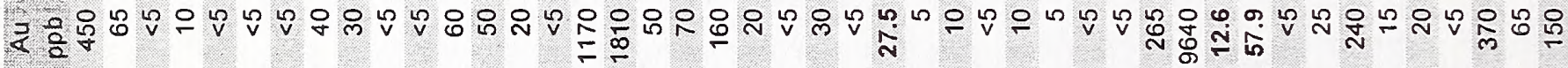

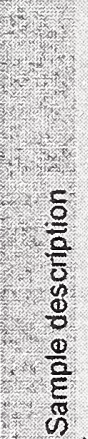

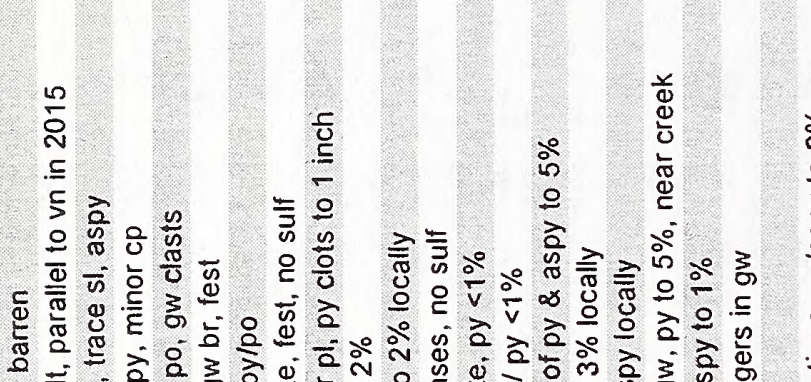

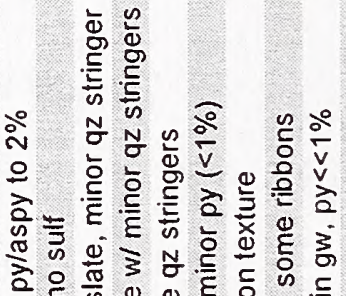

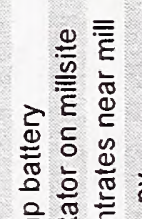

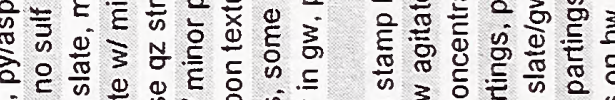

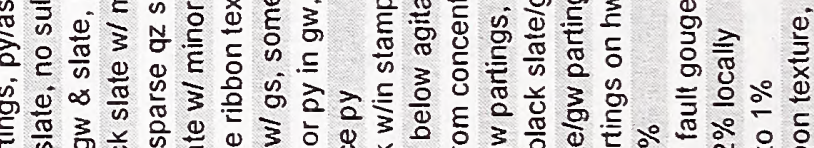

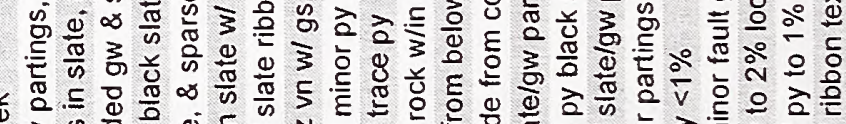

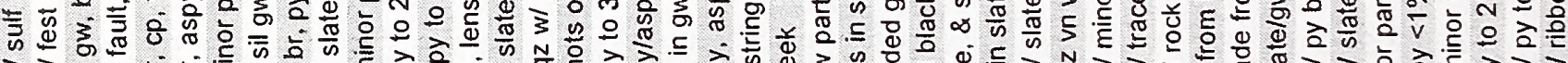

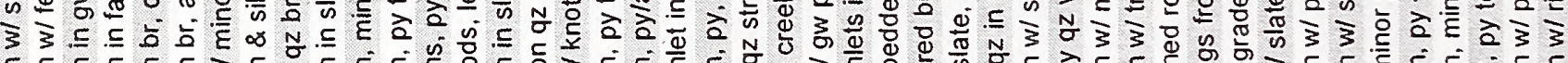

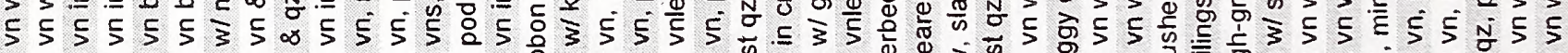
Õ $\sigma^{N}$ O

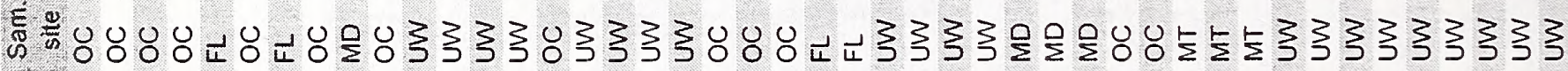

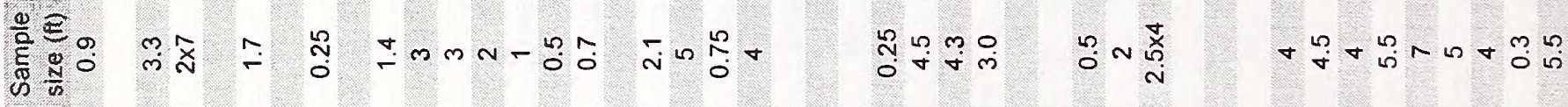
हूँ

\section{동 등 을 을} 은 은 은 응 흔 흔 융 을 은 은 을 을 을

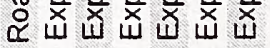

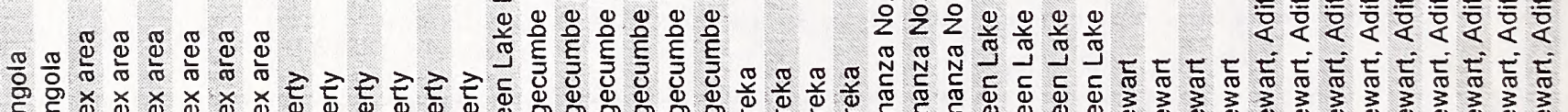

- -

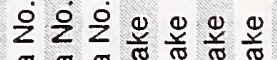

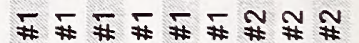

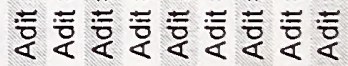

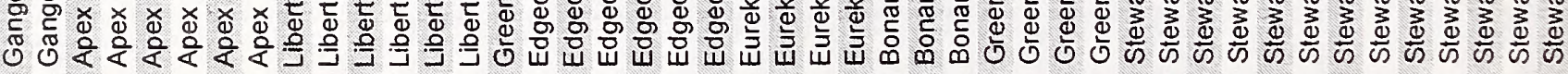

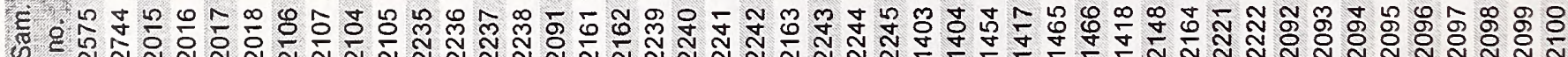
b 는

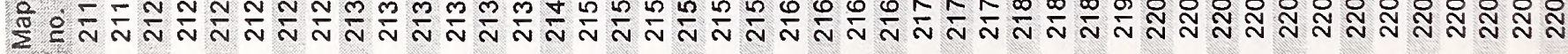




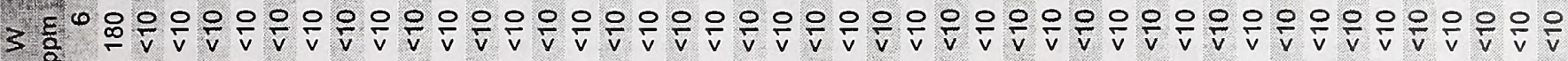
>

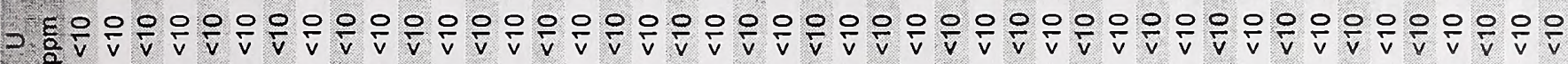

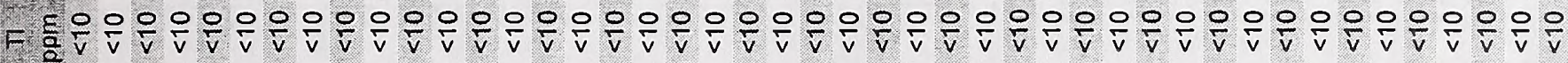

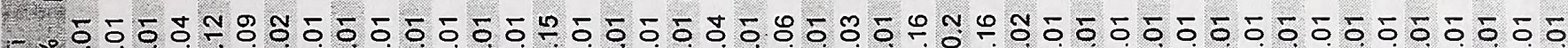

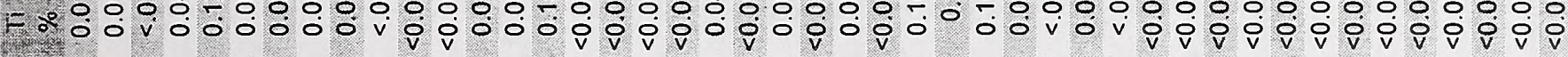

(1) $\varepsilon$

10 ह

ติ

ᄃ

ธ็

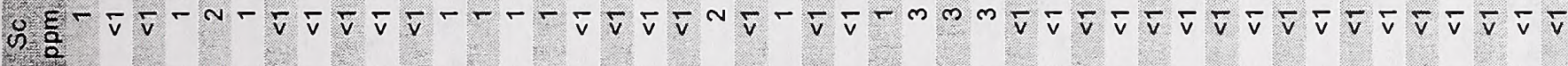

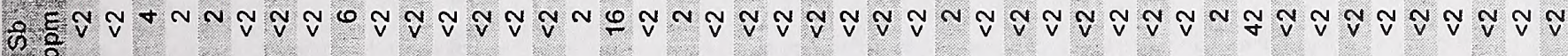

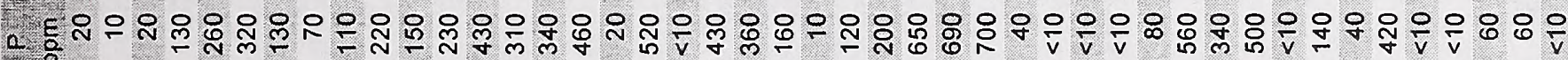

₹ $\frac{E}{2}$

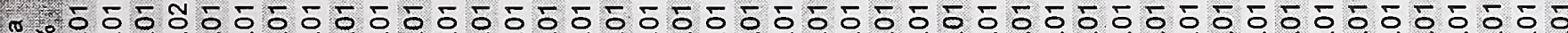

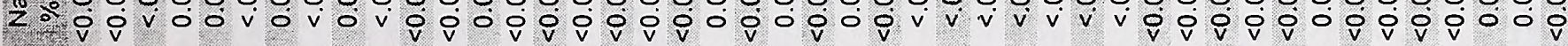

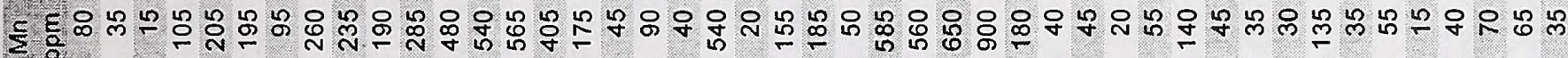

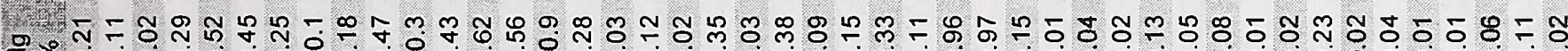

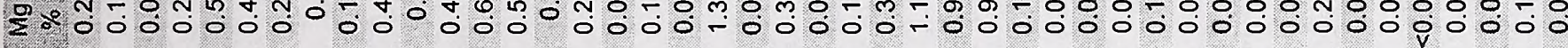

I. $\frac{E}{2}$

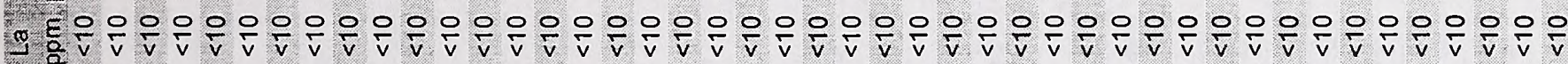

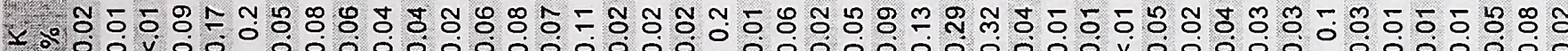
- $0000000000000000000000000000 v 000000000000$

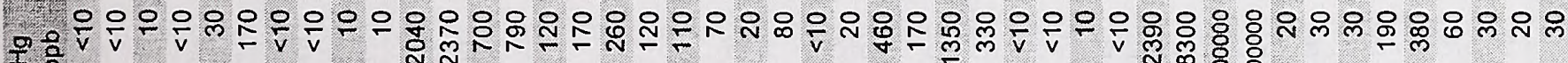

S

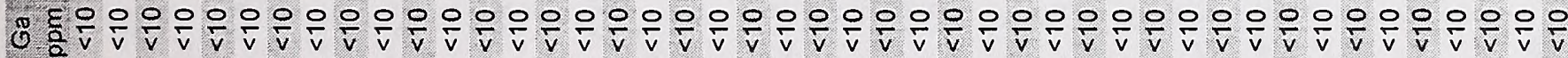

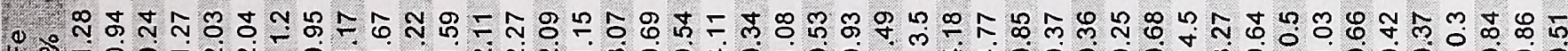

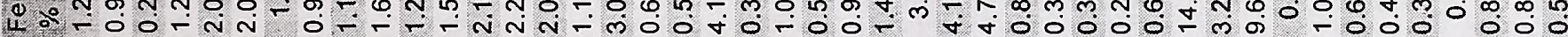

క

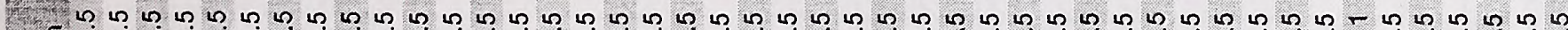
ठ

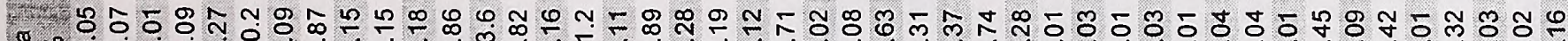

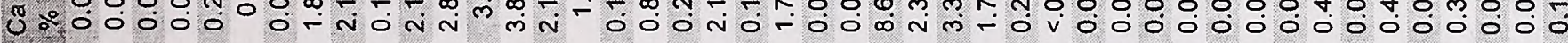

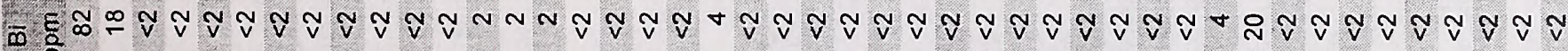

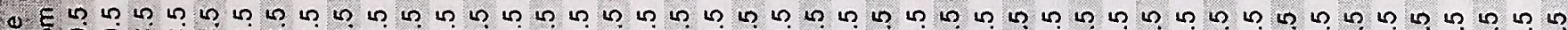

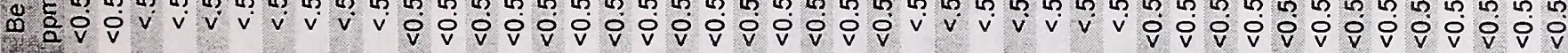
हี่

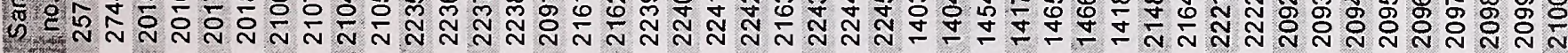

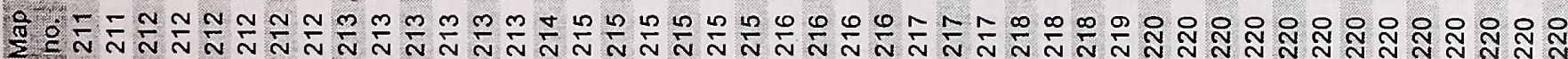


œ < ๔

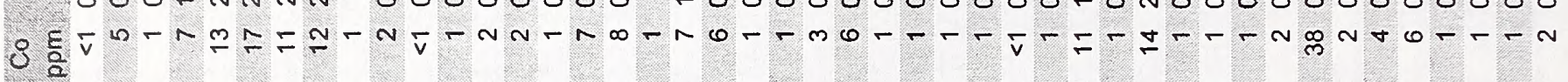

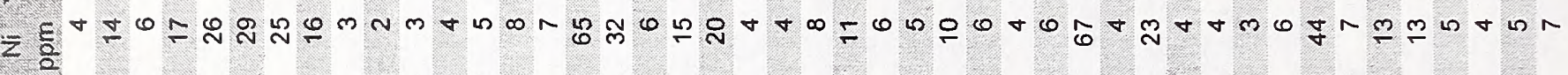

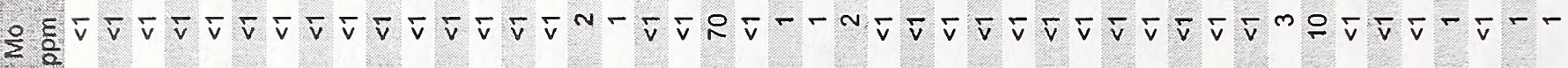

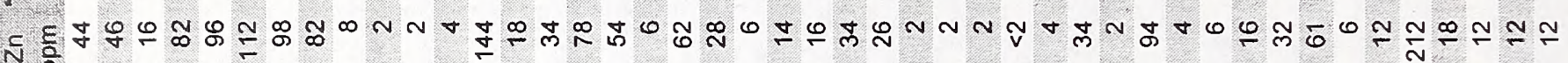

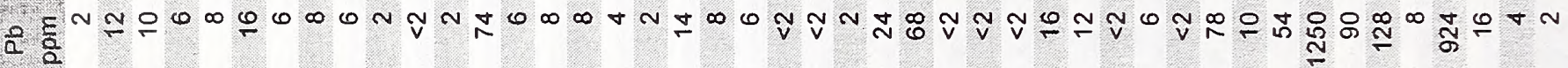
$+2$ उँ $\frac{\varepsilon}{2}$

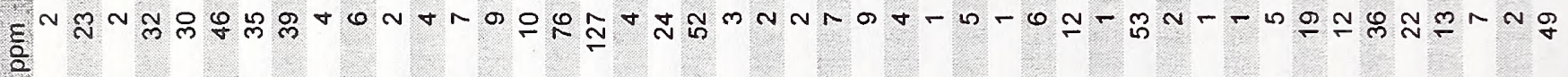


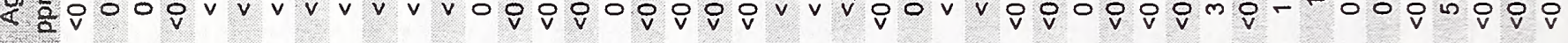
흥

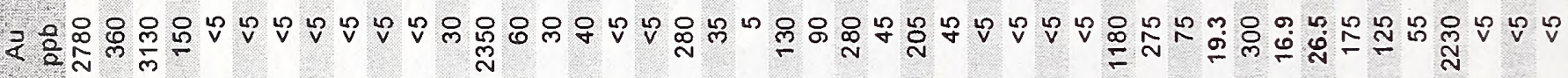<smiles>[CH]1CCCC1</smiles>

$\sin \frac{0}{2}$

ᄃำ $\cong$

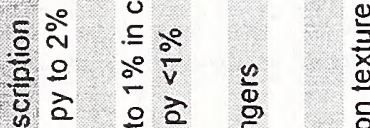

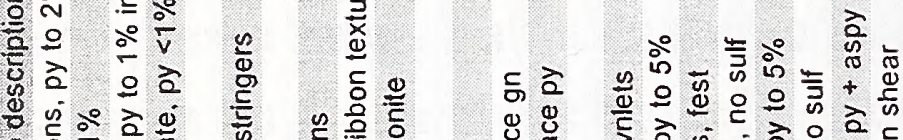

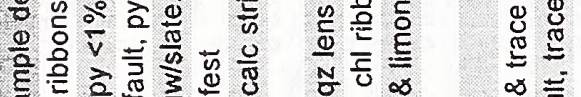

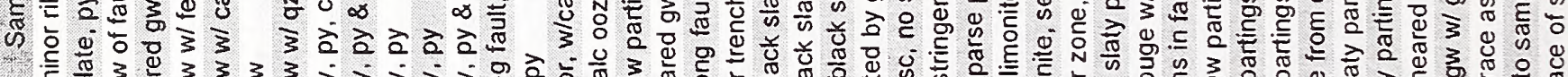

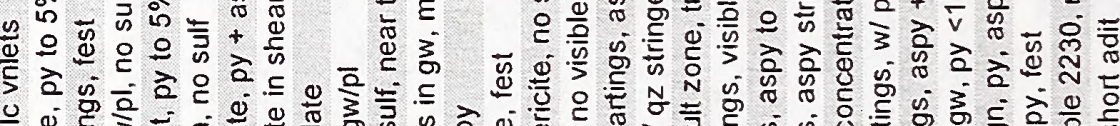
U⿱艹⿻心丨

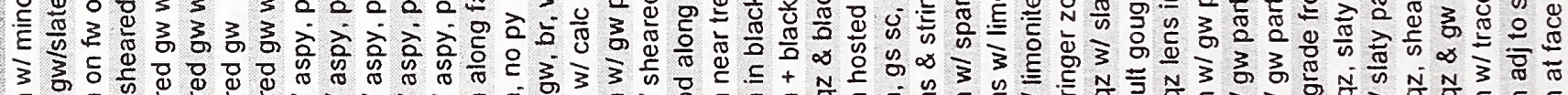

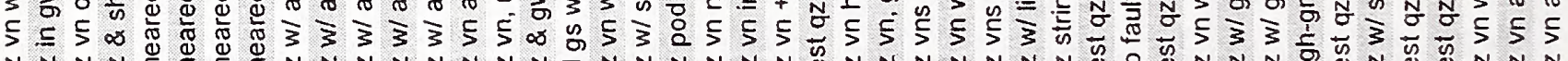
Oै Oٓ Oै Oै

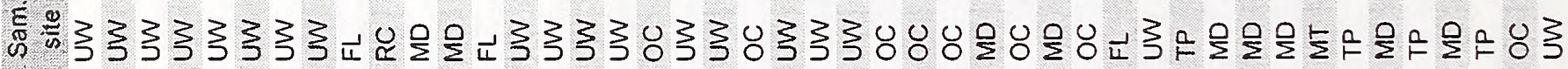

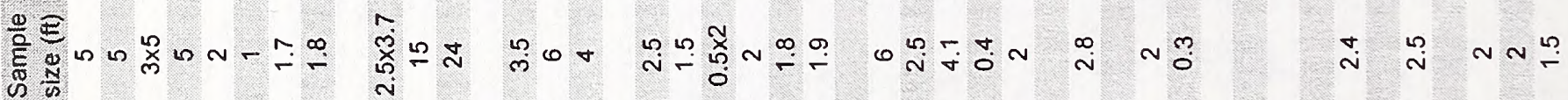

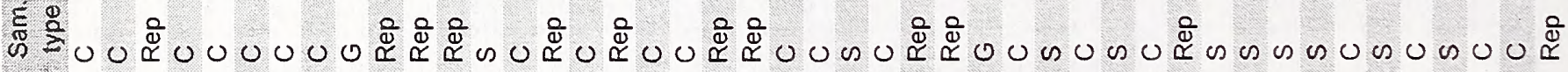

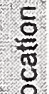
\# $¥ \Re$

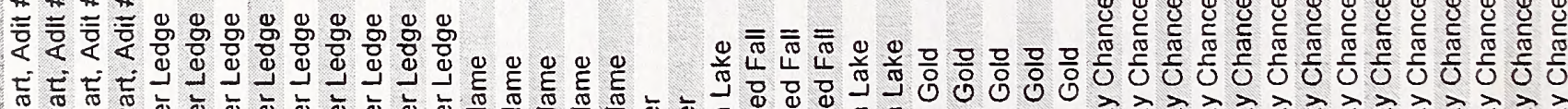

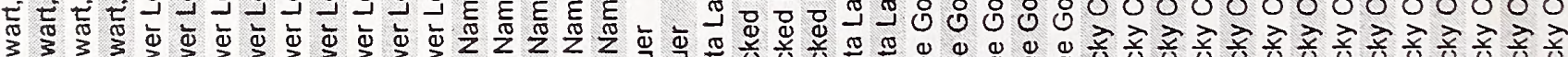

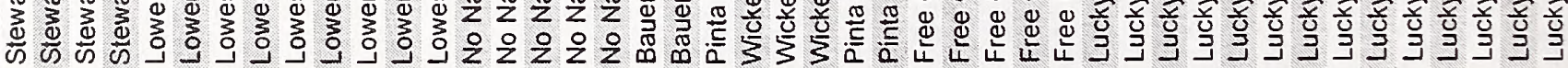
E

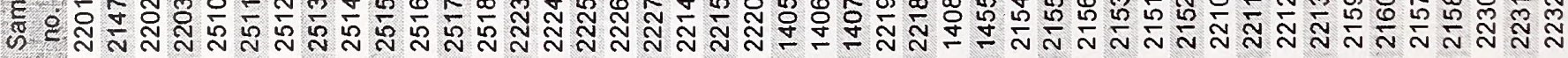

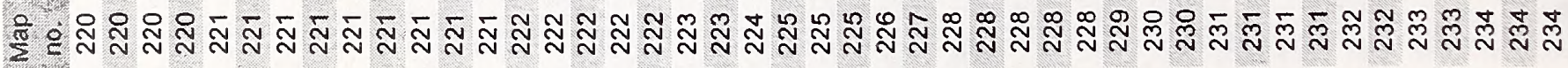




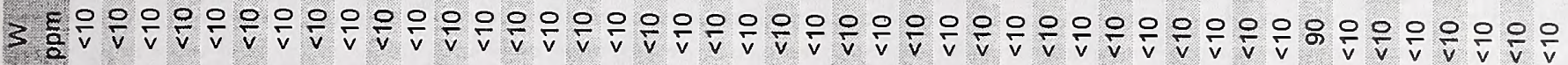
>

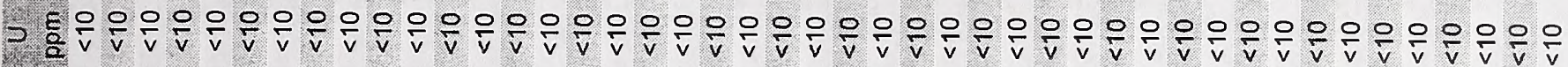

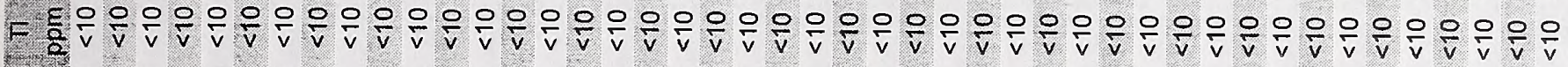

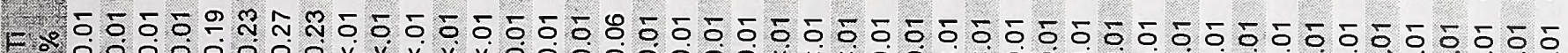

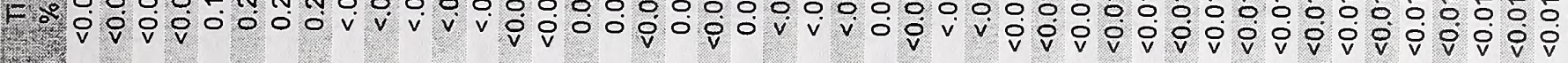
1. $\frac{5}{0}$

๘

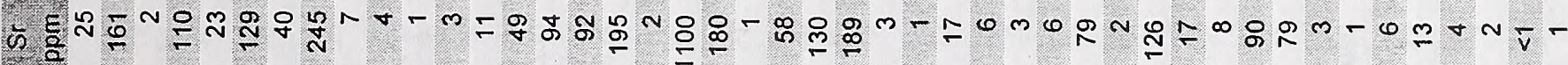
is $\frac{E}{0}$

D. ถ⿻ำ

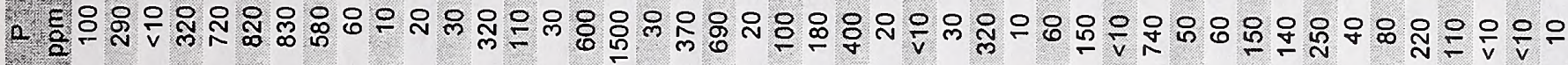
2 :

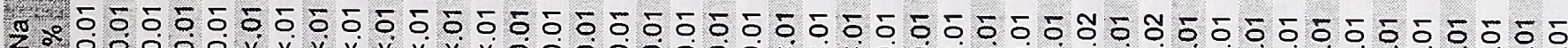

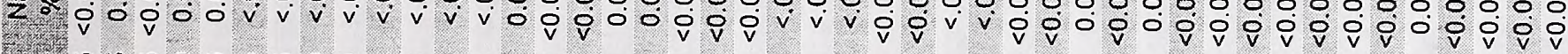

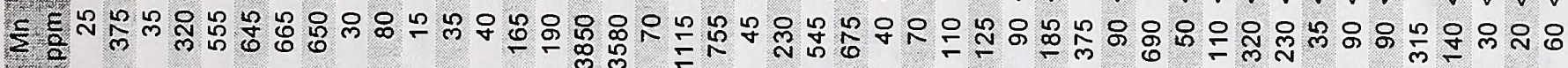

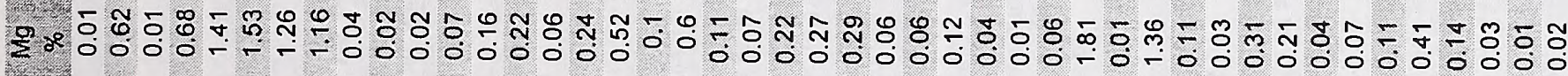
- $E$

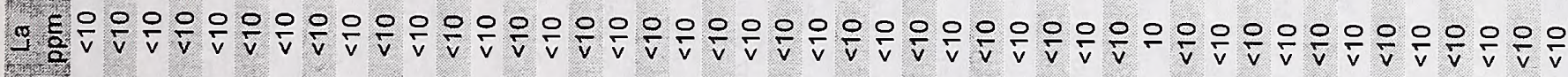

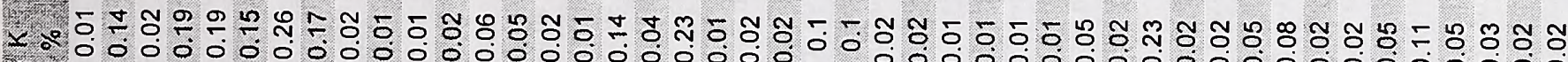

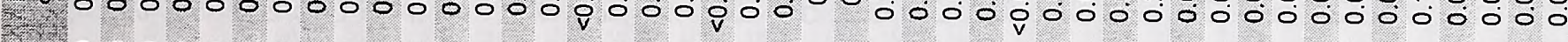

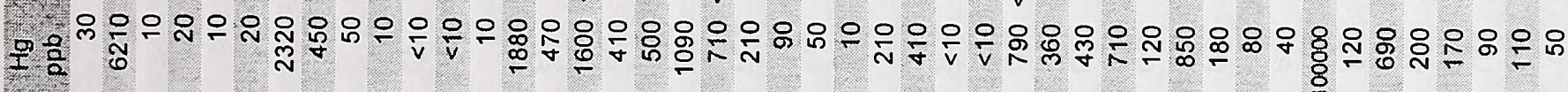

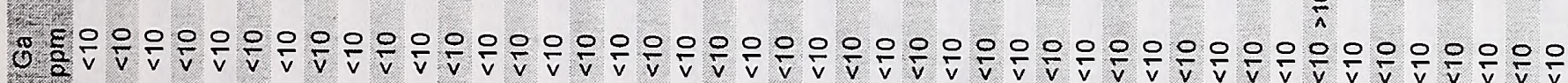
- 눈

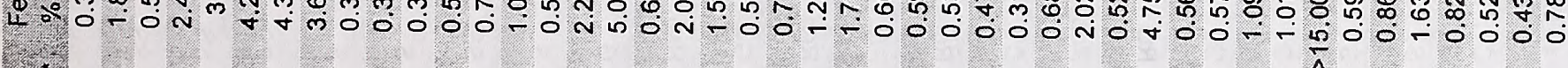

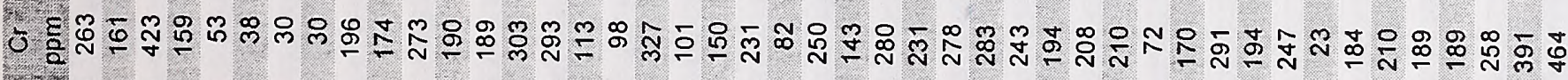

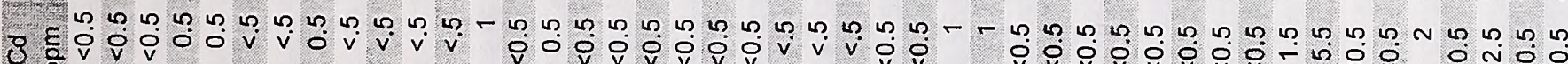

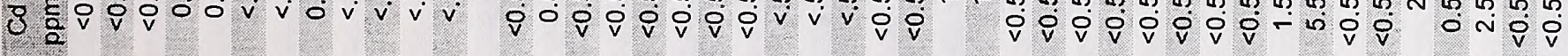

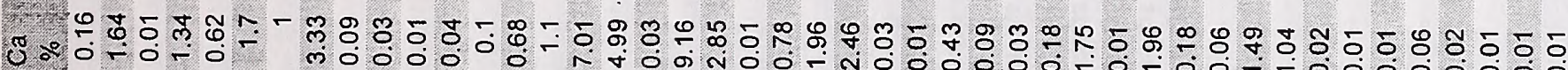
(1)

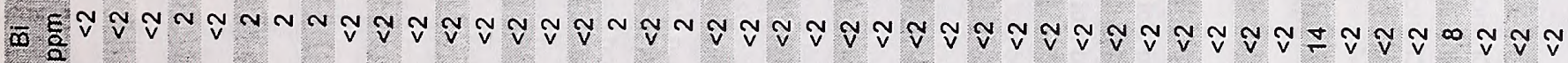
m E⿱

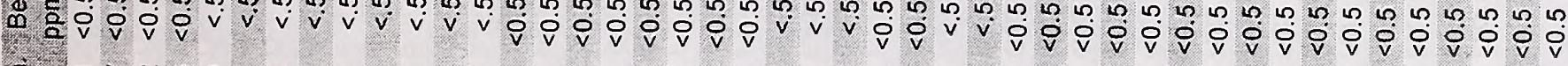

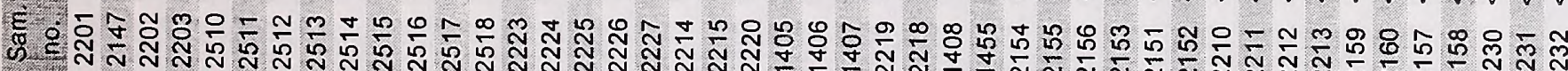
5.

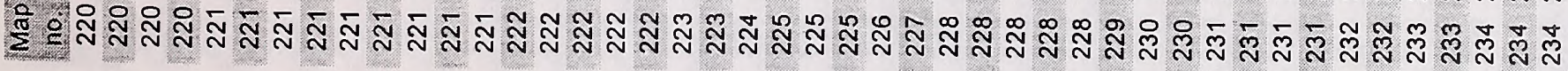




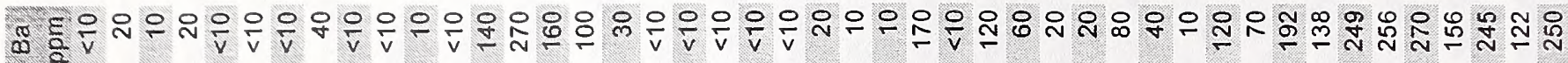
<

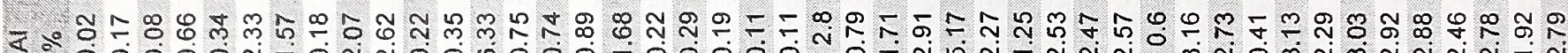
b z

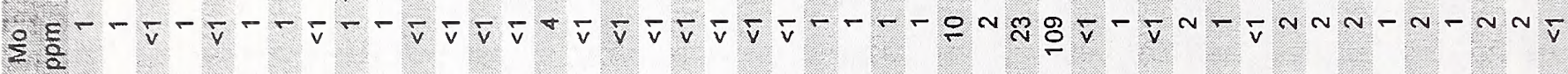

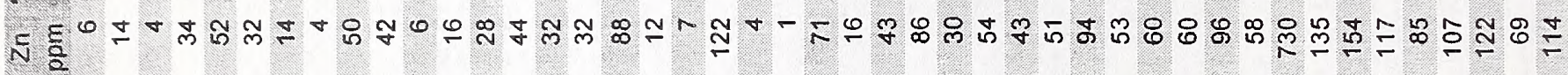
อ. $\therefore$.

उ

g

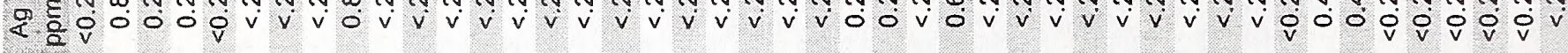
+. $\frac{\varepsilon}{2}$

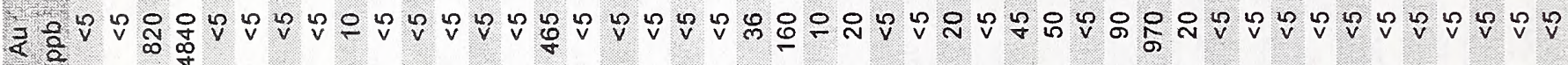

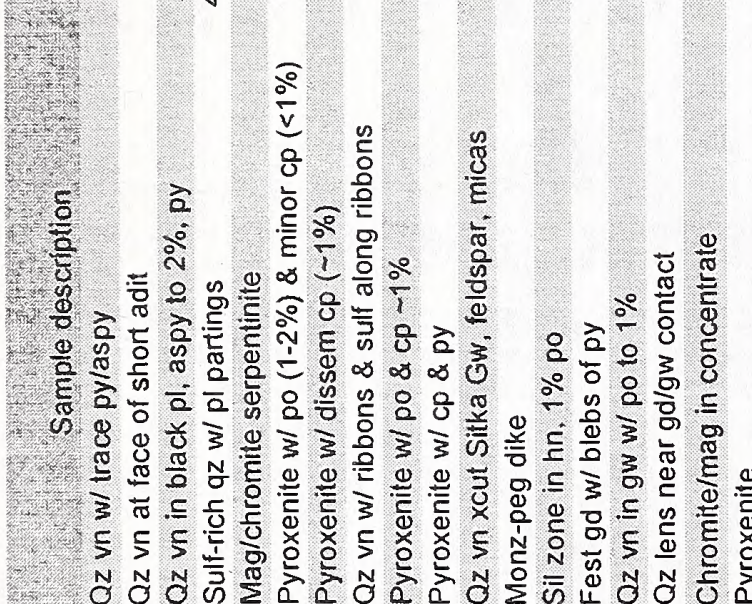

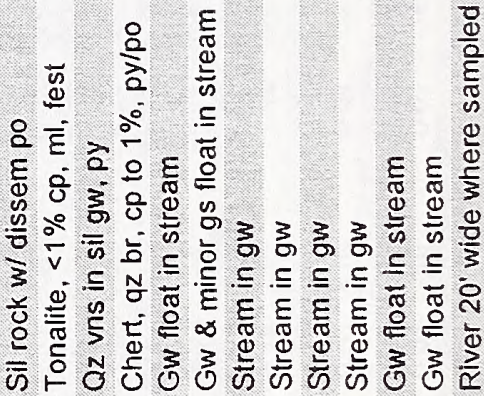

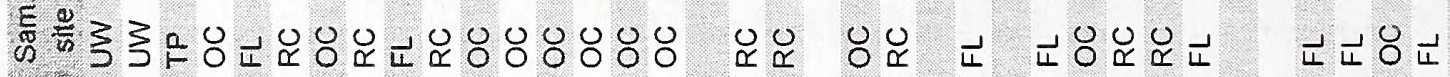

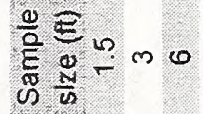

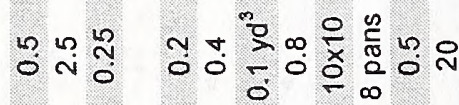
¿ே.
mo:

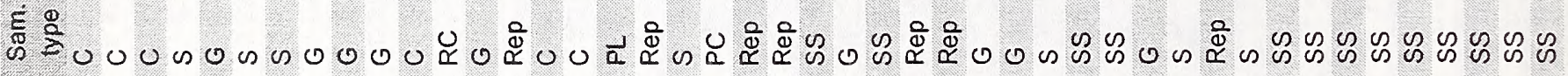

ᄃ 范 $\frac{5}{2} \sum \frac{5}{2}$

\& \& \&

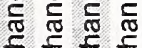

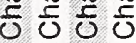

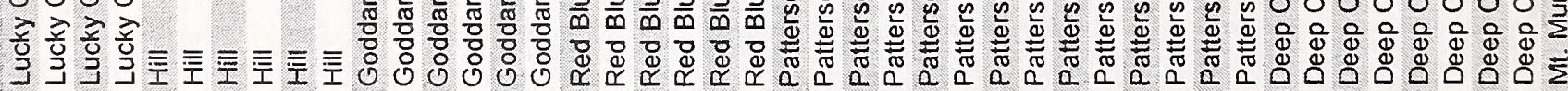
®

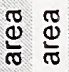

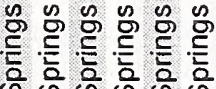

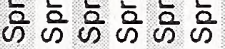




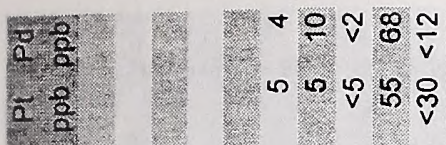

ฌ

8 요 8 위

$\bar{v} \bar{v} \bar{v} \bar{v} \bar{v} \bar{v} \bar{v} \bar{v}$

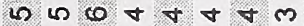

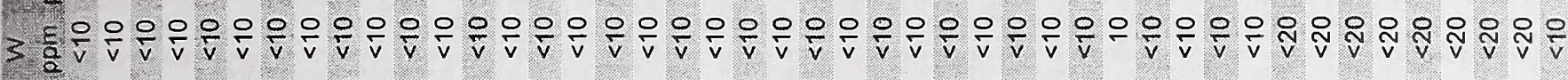

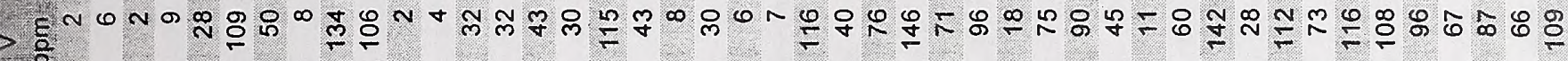

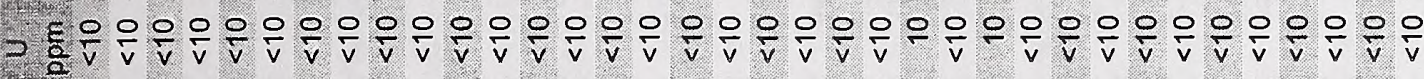

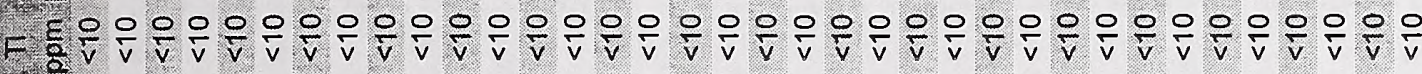

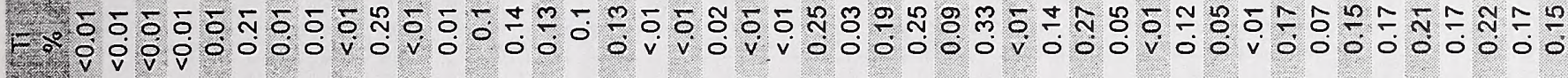
을

r. $\frac{0}{\mathrm{v}} \frac{\mathrm{O}}{\mathrm{v}} \frac{\mathrm{O}}{\mathrm{v}} \frac{\mathrm{O}}{\mathrm{v}} \frac{\mathrm{O}}{\mathrm{v}} \frac{\mathrm{O}}{\mathrm{v}} \frac{\mathrm{O}}{\mathrm{v}} \frac{\mathrm{O}}{\mathrm{v}}$ $\frac{O}{\mathrm{v}} \frac{\mathrm{O}}{\mathrm{v}} \frac{\mathrm{O}}{\mathrm{v}} \frac{\mathrm{O}}{\mathrm{v}} \frac{\mathrm{O}}{\mathrm{v}} \frac{\mathrm{O}}{\mathrm{v}} \frac{\mathrm{O}}{\mathrm{v}} \frac{\mathrm{O}}{\mathrm{v}}$

क.

5.

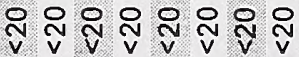

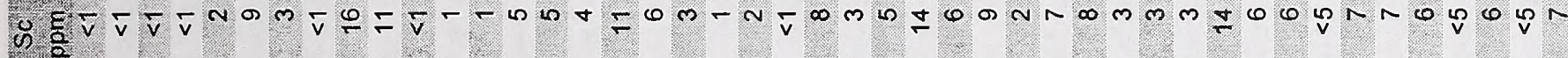

⿸\zh14

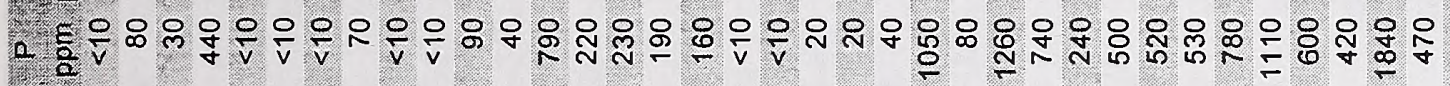

$\mathcal{E} \frac{E}{\alpha}$

ช zo.ji

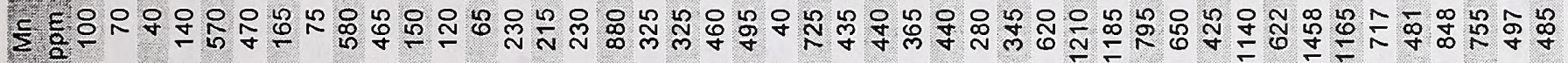

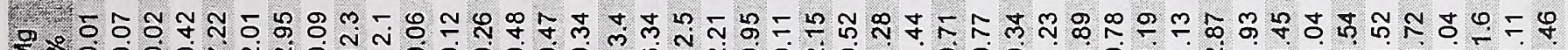

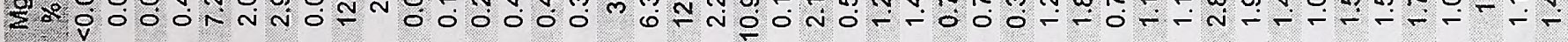

$=\frac{E}{2}$

: ผ

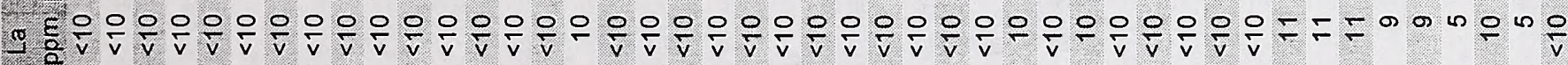
ช.

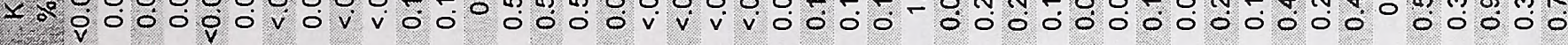

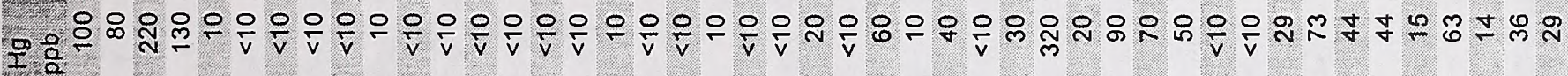

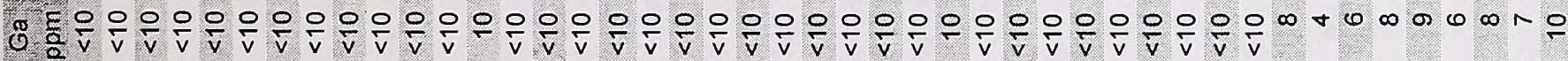

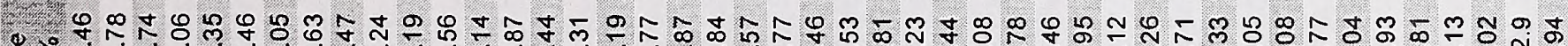

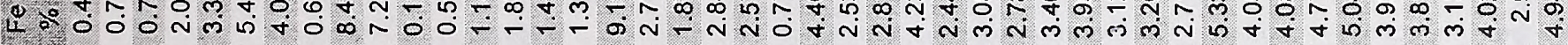

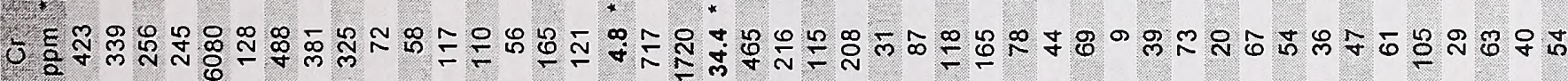

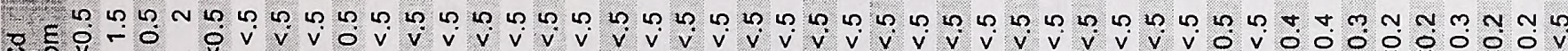
0.0
0.0

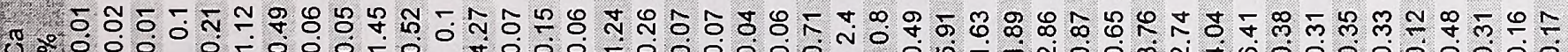
E की

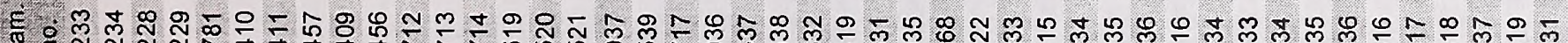

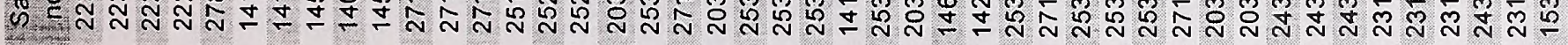
范 


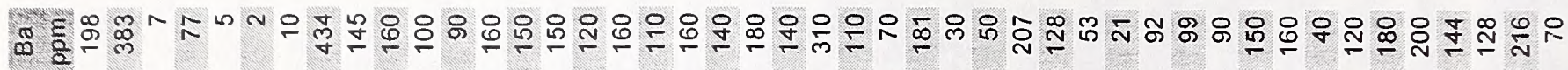

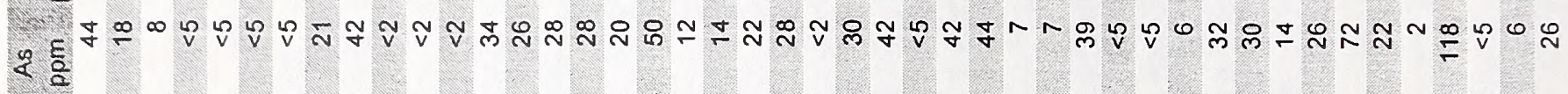

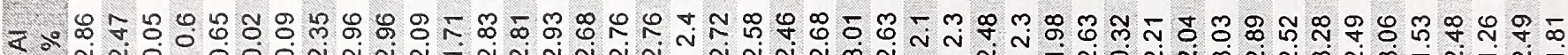
ช

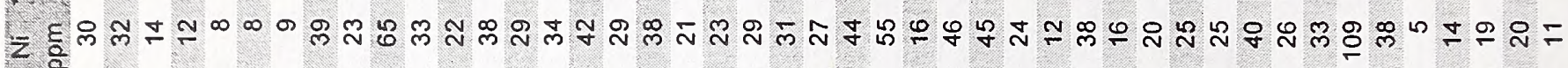

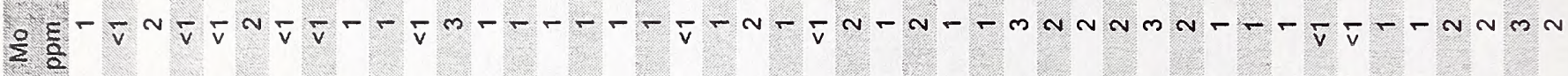

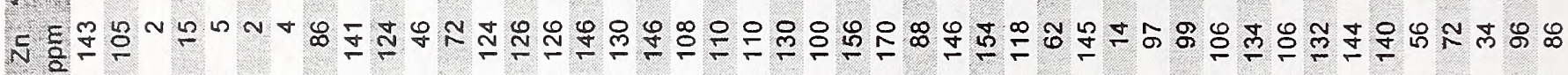

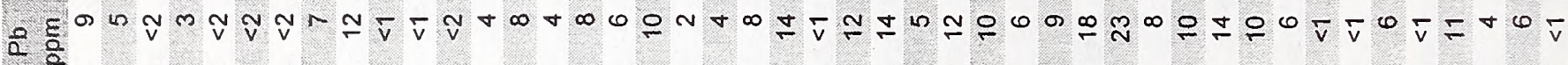
$* \circ$

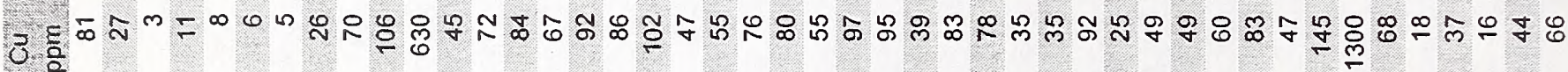
ฉह 1. है

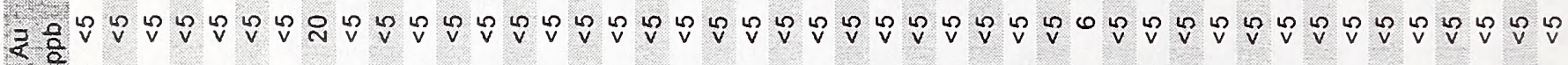
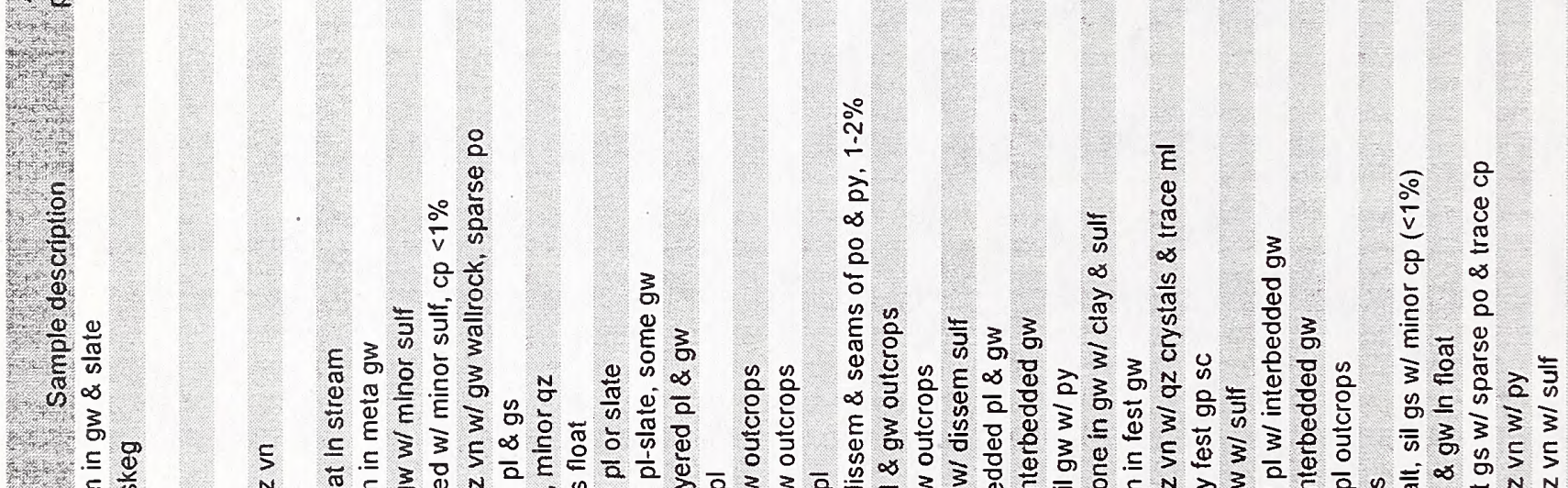

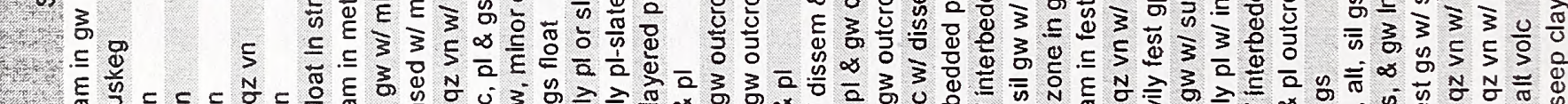
W.

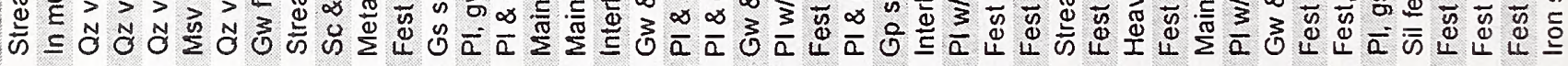
हू

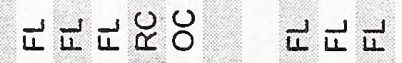 잉ำ ?

u

○०

品

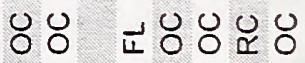

है กี

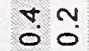

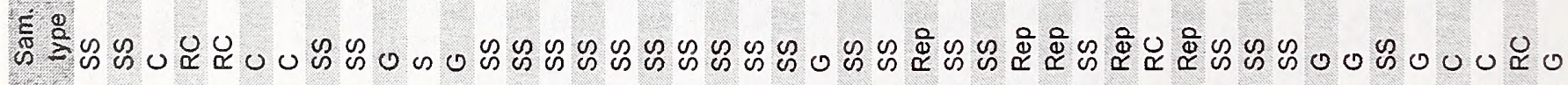

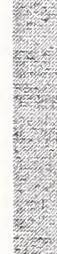

3.

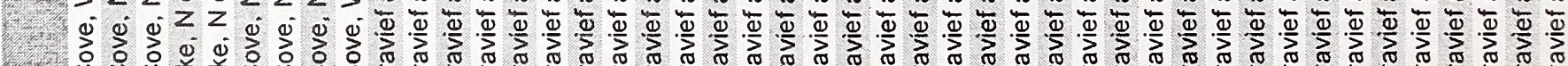

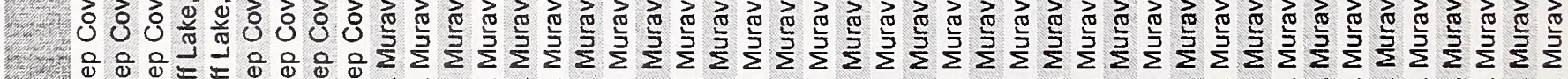

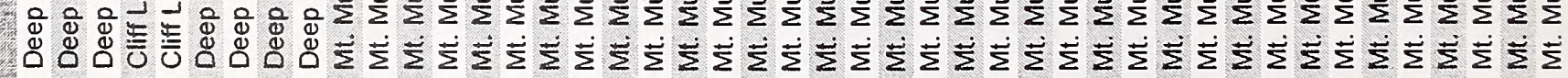

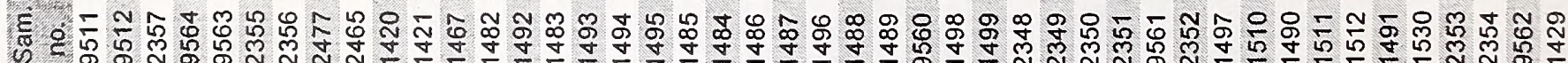
W

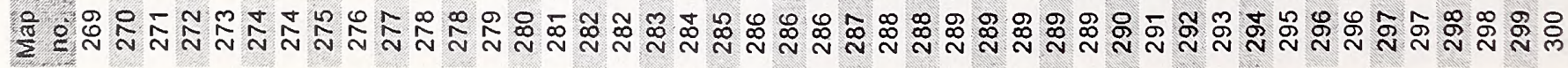




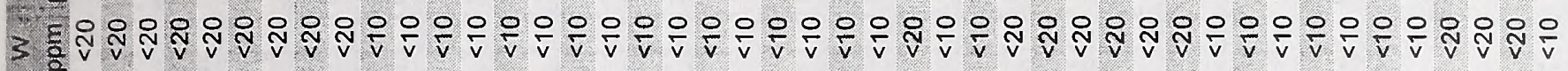
$>$ ร

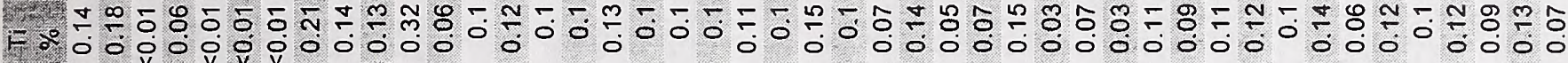

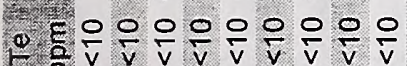

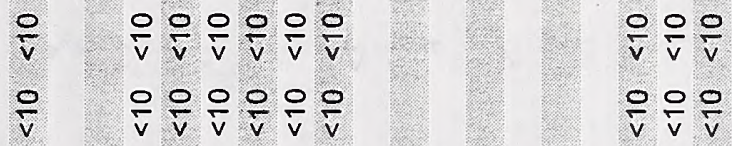

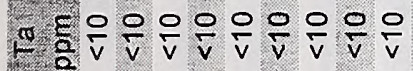

$\frac{0}{\mathrm{~V}} \frac{\mathrm{O}}{\mathrm{v}}$

m

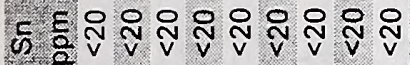

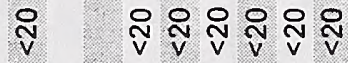

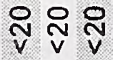

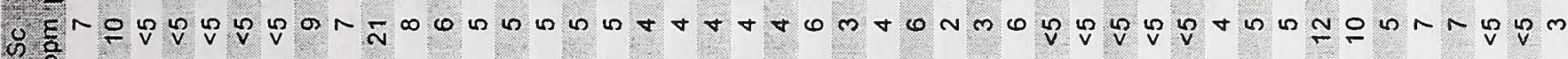

की

a. $\frac{E}{0}$

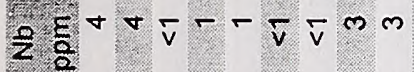

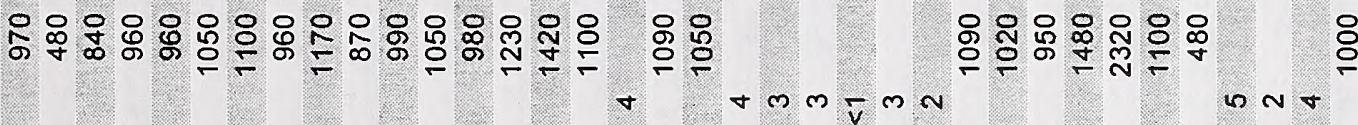

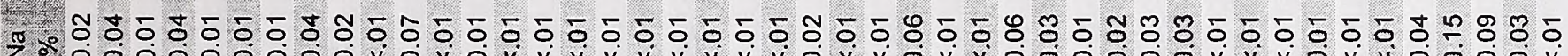

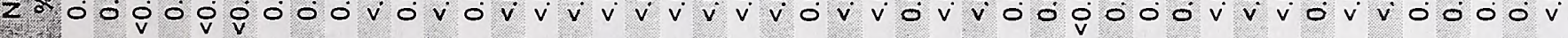

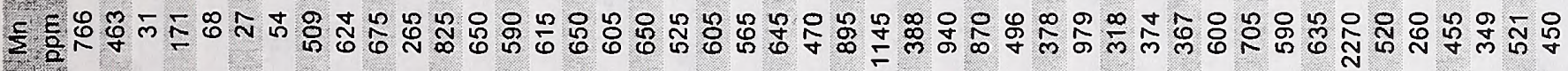

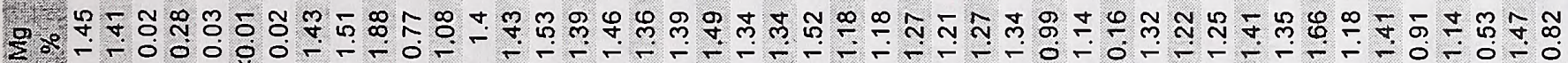
క

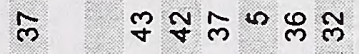

유요

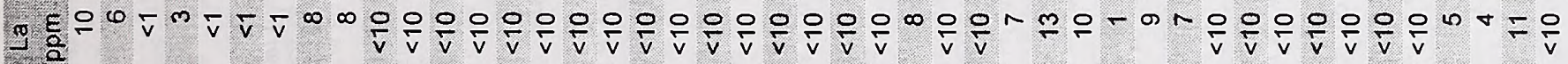

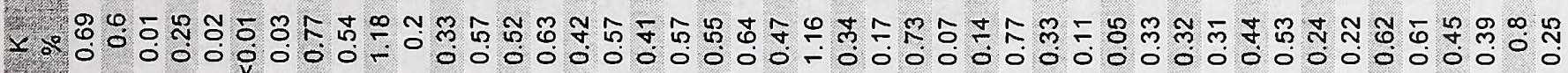

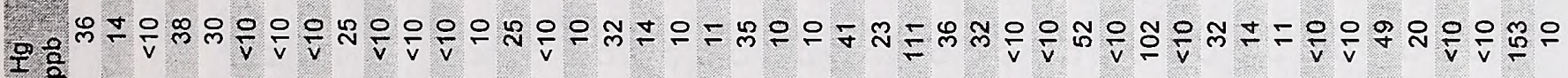

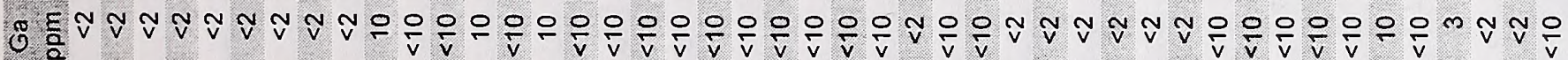

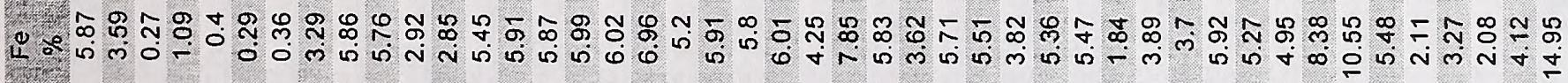

б

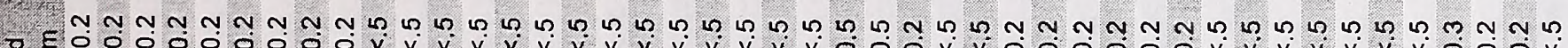

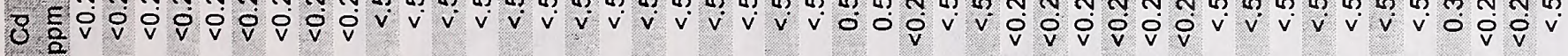

유ำ

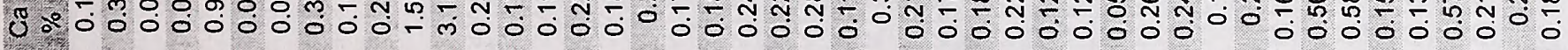

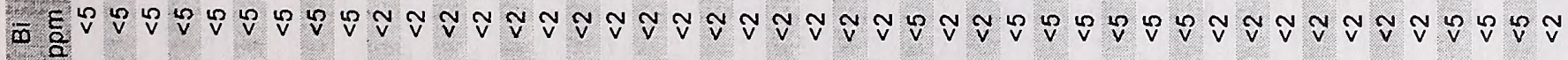
ल. ह :

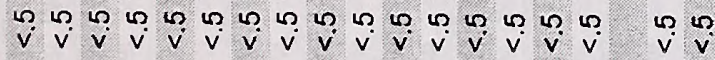

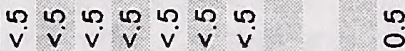

究 范 


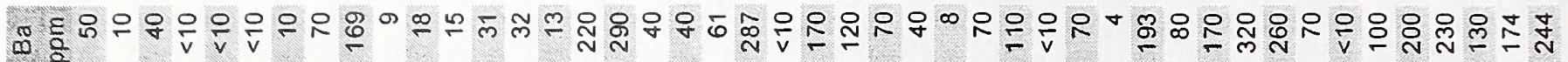
\& $\therefore \approx$

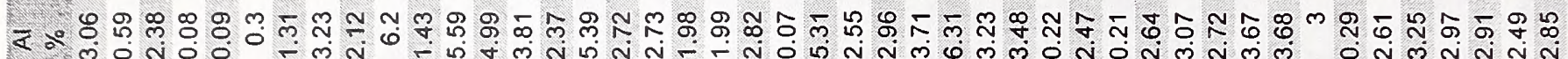

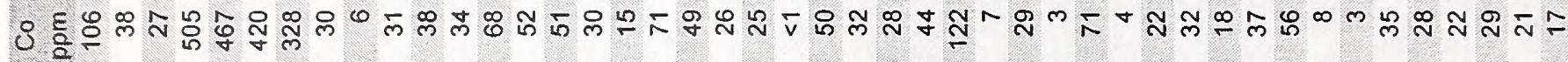
క

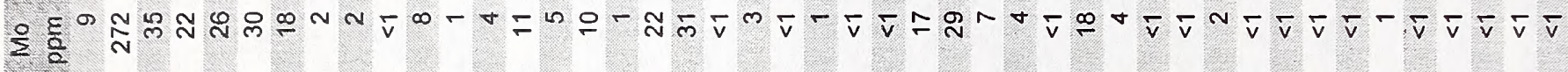

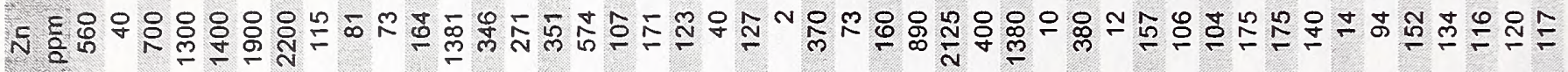

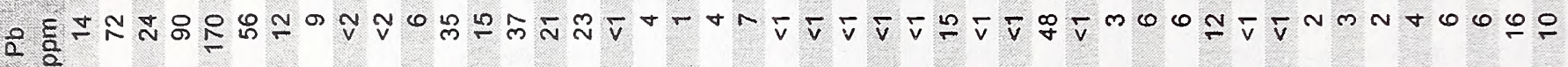
* 20* * * * *

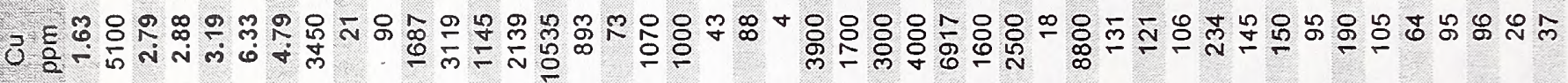
\& * $\frac{\mathrm{E}}{2}$

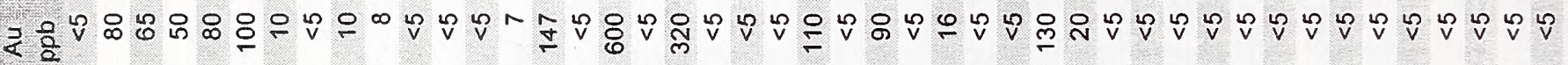

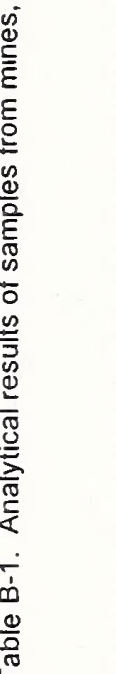

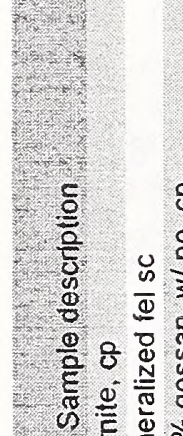

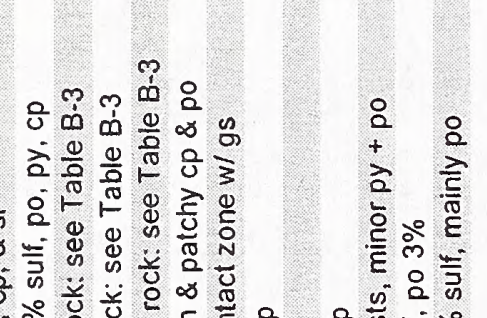

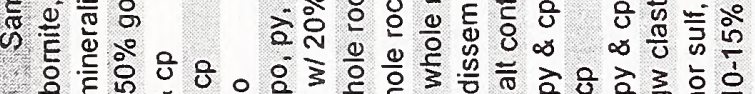

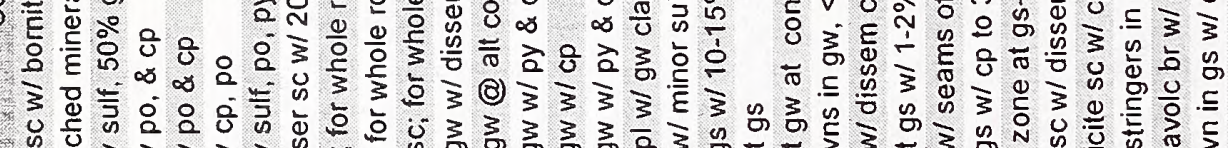

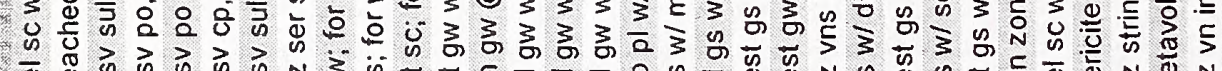

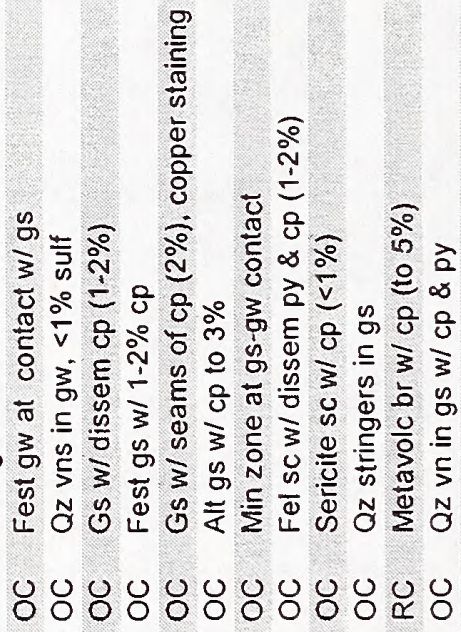

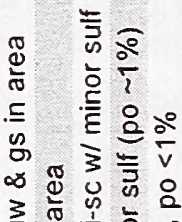

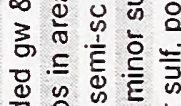

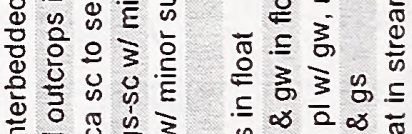

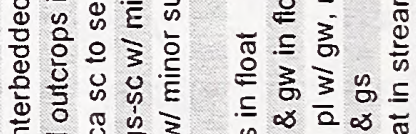

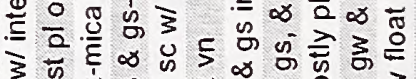

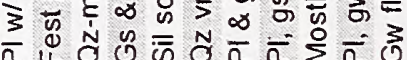

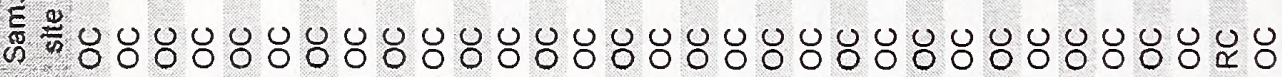
पै山्ये

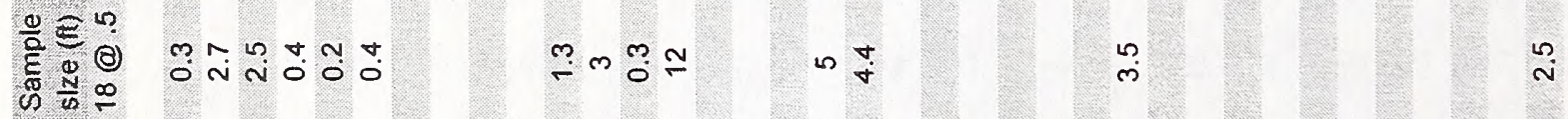
हूं ate

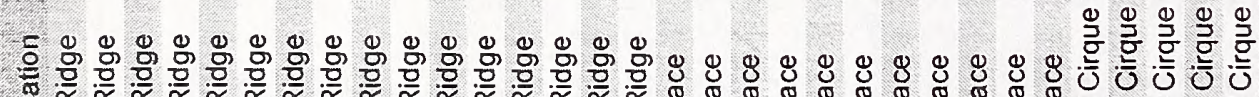

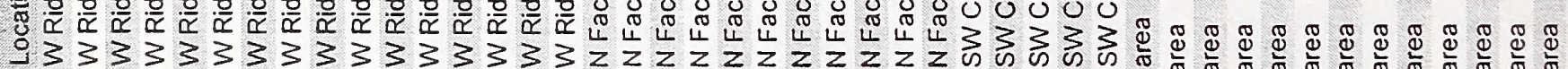

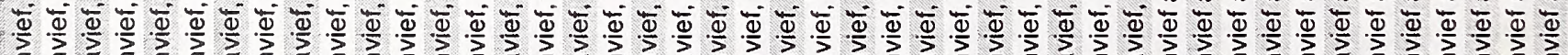

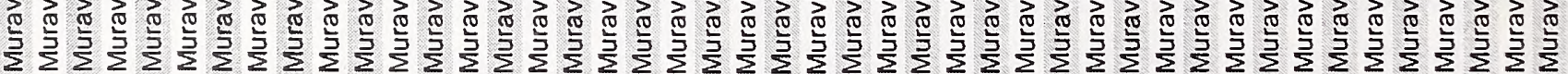

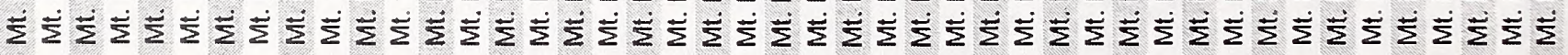

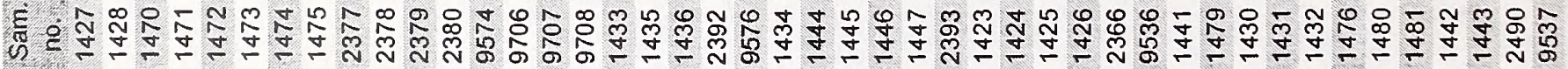

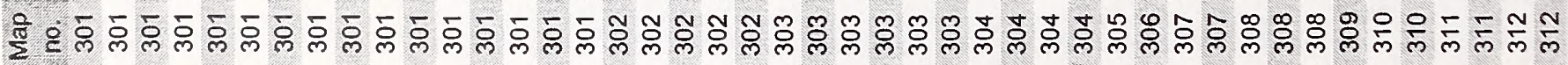


उ > ह 듕듀윰

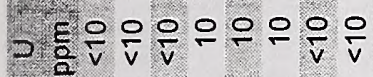

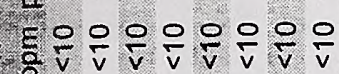

\section{은은은 \\ 운은운 \\ 은 운운 운은 \\ 은 운 은 은 \\ 은운운은은 \\ 은은 운운}

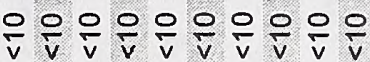

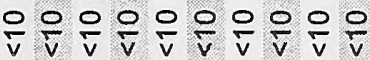

넌 F夫

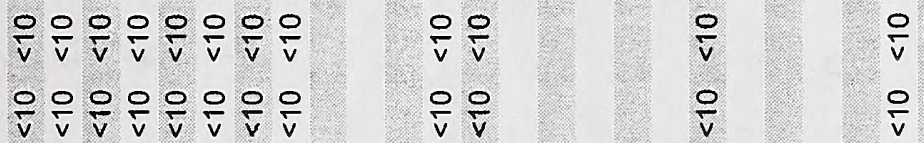

은 운

$\pi \varepsilon_{0}$

$\frac{0}{\mathrm{v}} \div \frac{\mathrm{v}}{\mathrm{v}} \frac{\mathrm{V}}{\mathrm{v}} \frac{\mathrm{V}}{\mathrm{v}} \frac{\mathrm{T}}{\mathrm{v}} \frac{\mathrm{V}}{\mathrm{v}} \frac{\mathrm{V}}{\mathrm{v}} \frac{\mathrm{V}}{\mathrm{v}} \quad \frac{\mathrm{O}}{\mathrm{v}} \frac{\mathrm{O}}{\mathrm{v}}$

$\frac{0}{\mathrm{~V}} \frac{\mathrm{O}}{\mathrm{v}}$

$\frac{0}{\mathrm{~V}} \frac{\mathrm{C}}{\mathrm{V}}$

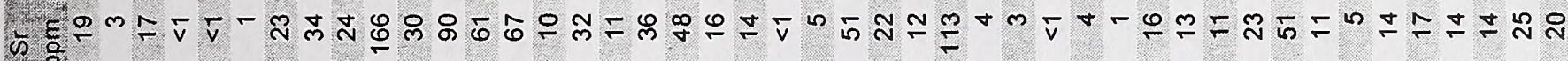

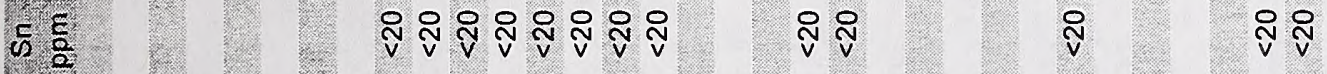

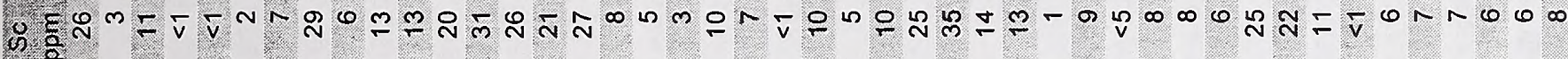
हो

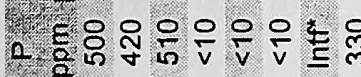

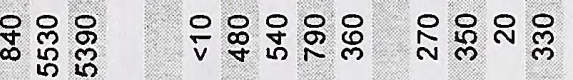

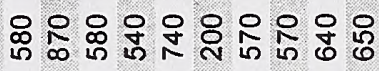

$8 \div$

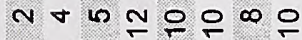

in

$\digamma$

$\bar{v}^{m}$

$\checkmark m$

ช

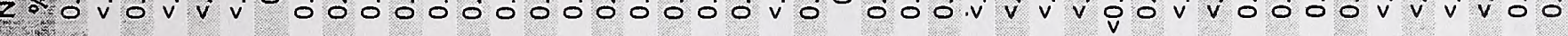

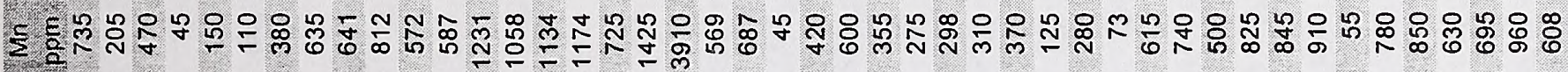

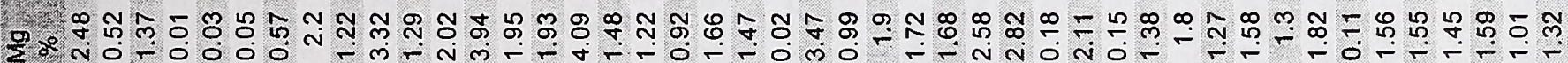
பЕ

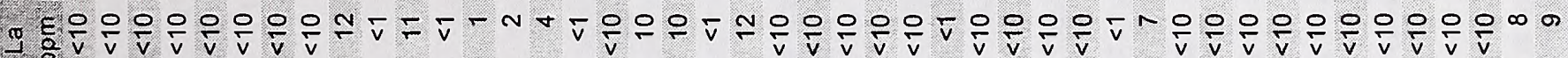

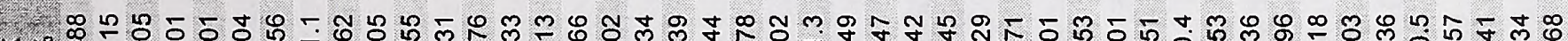

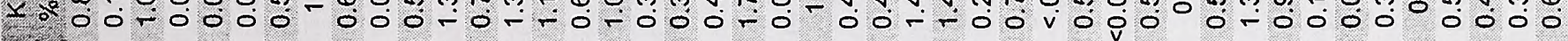

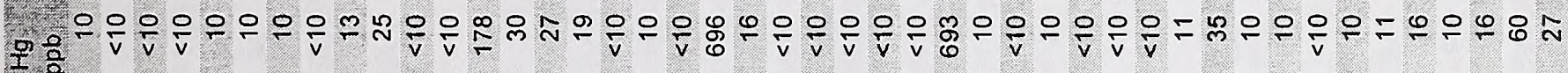

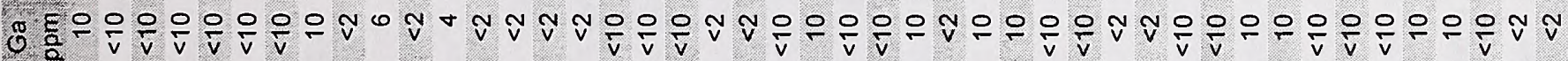

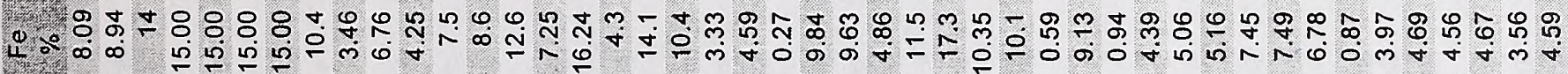

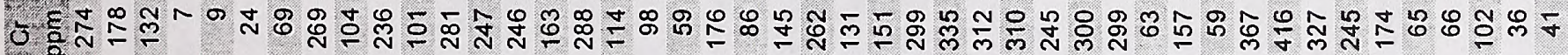

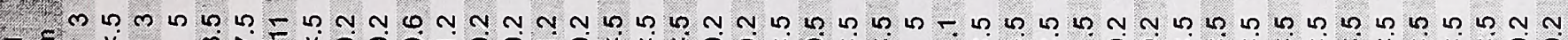

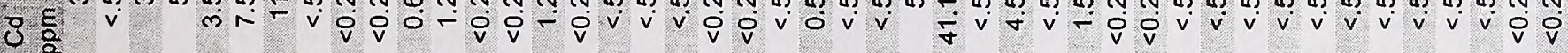

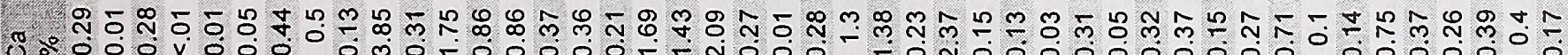

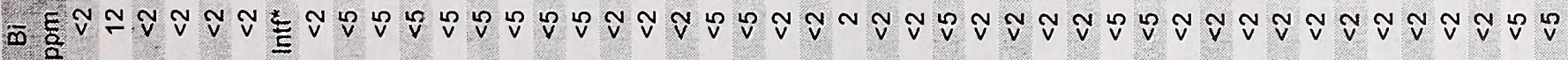

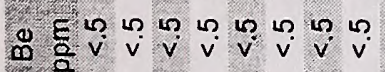

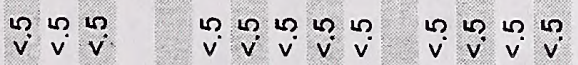

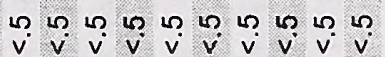

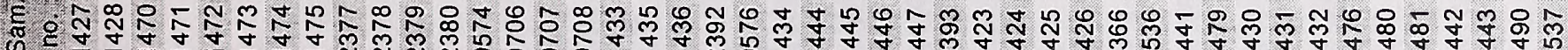

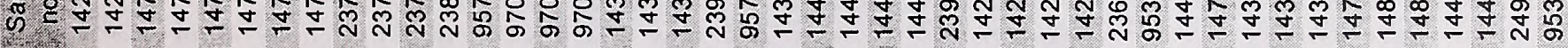
颉 


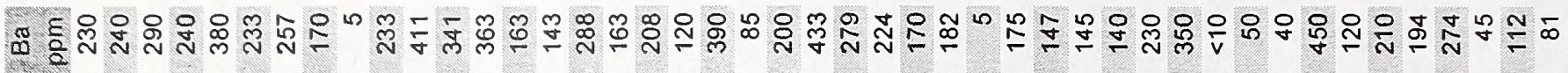

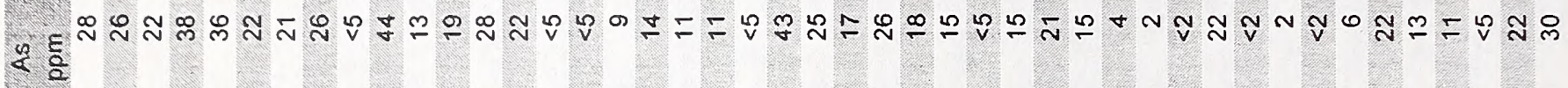

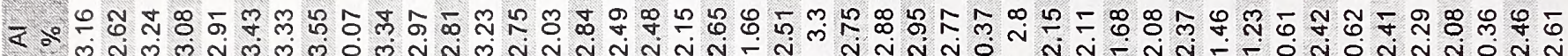

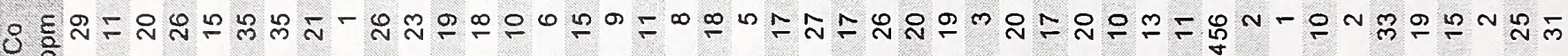

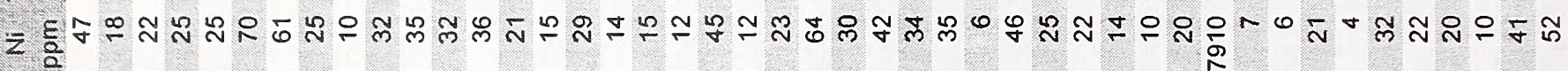

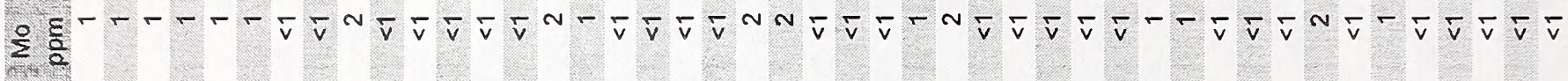

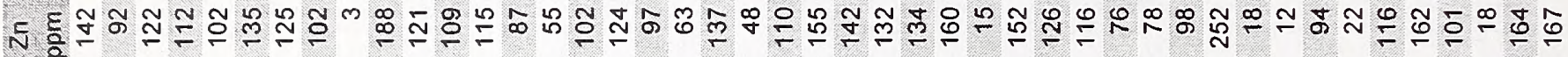

å

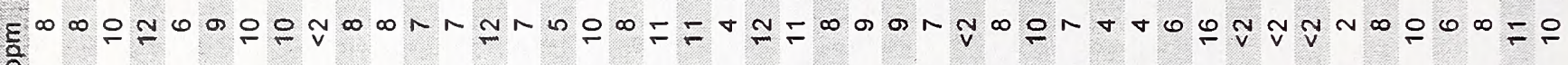
* $\therefore$

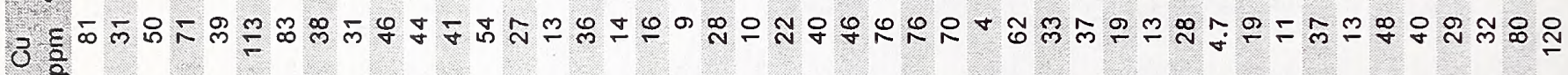
Q * $\frac{5}{2}$

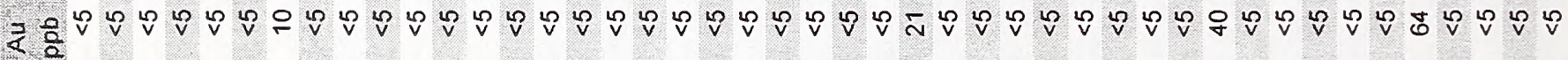

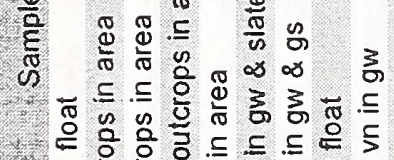

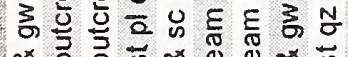

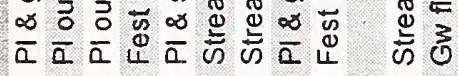
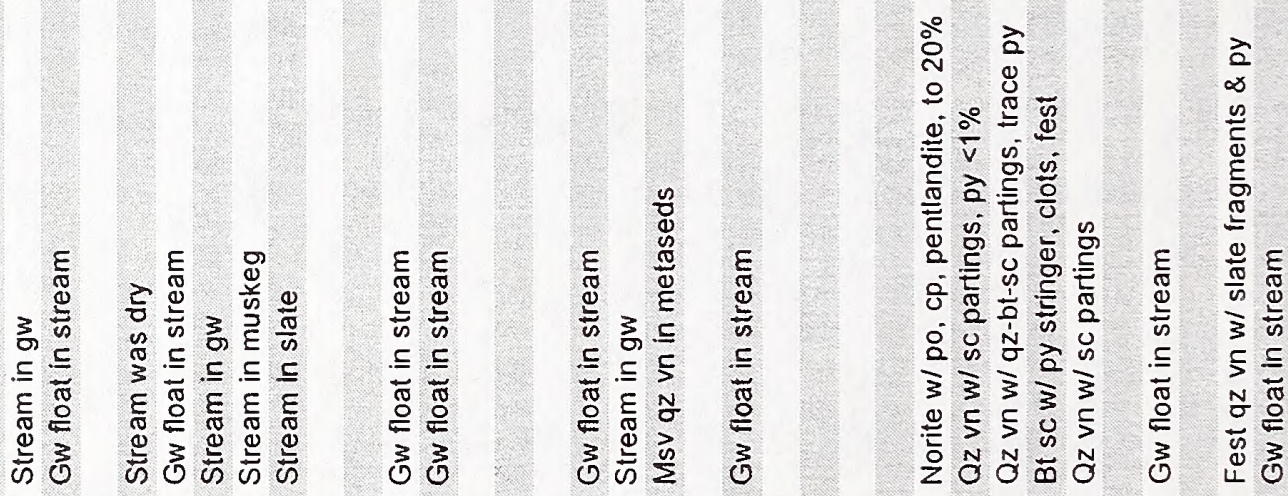

हैं

O

ช

옳요

u.

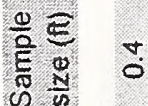

ஸั.

$\stackrel{\dddot{x}}{x}$

$\stackrel{\infty}{0}$

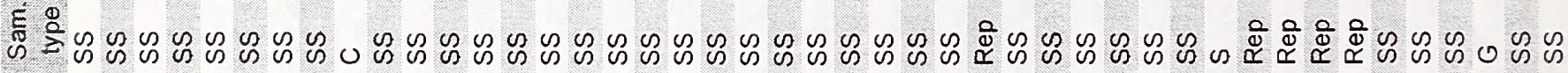

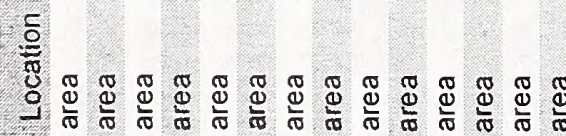
ఖ

ธัธ

¿ర0心

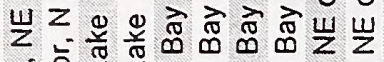

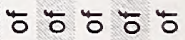
岂岂岩岩

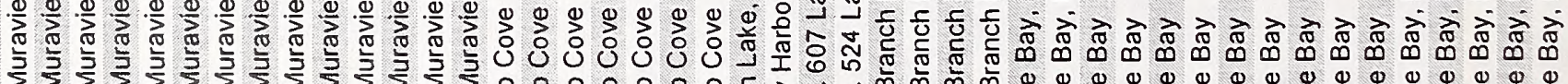

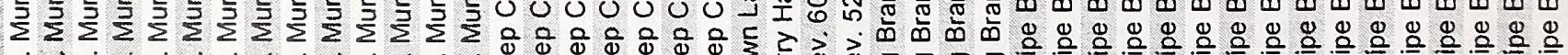

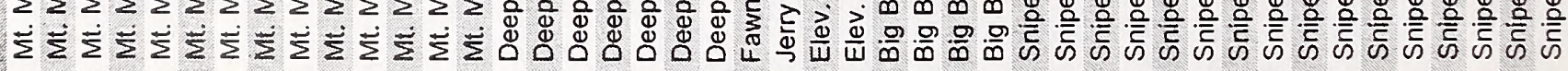
ह ¿

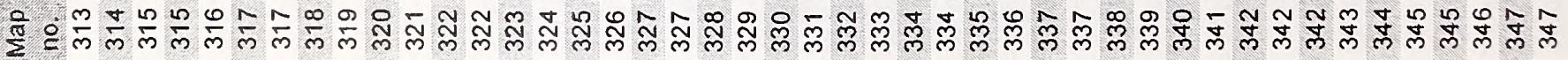


3

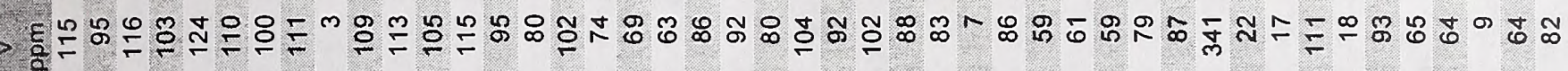

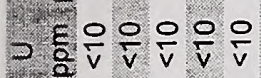

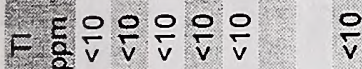

47.

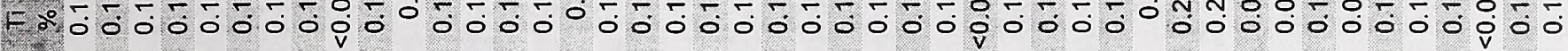

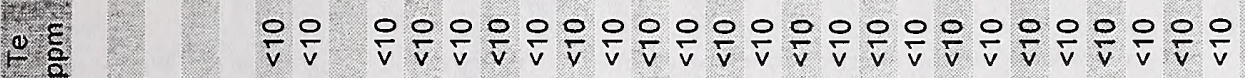
$\frac{0}{\mathrm{v}} \frac{\mathrm{O}}{\mathrm{v}} \stackrel{\mathrm{v}}{\mathrm{v}} \stackrel{\mathrm{v}}{\mathrm{v}} \mathrm{i}$

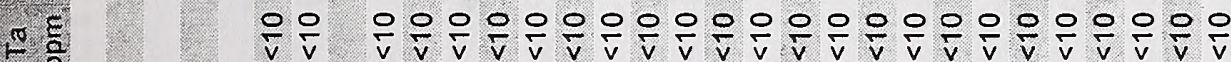
$\frac{O}{v} \div \frac{0}{v} \frac{0}{v} \div \frac{0}{v} \frac{0}{v}$ שூ के 균

lu ER 30

की

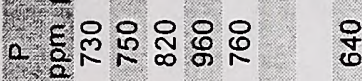

$\frac{1}{2} \frac{E}{0}$

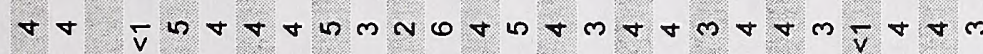

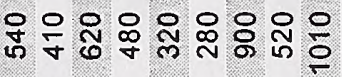
ব

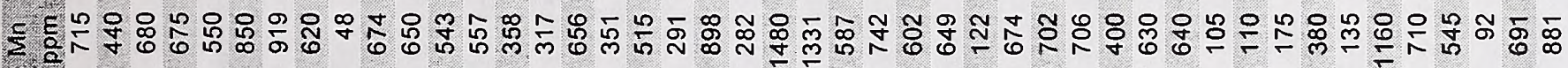

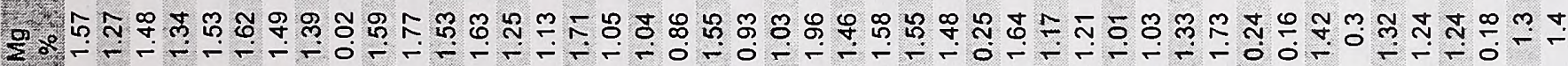

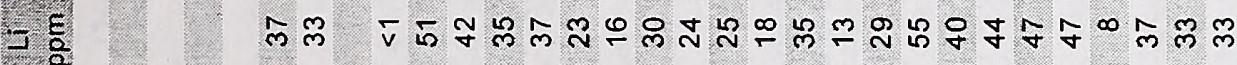
ก

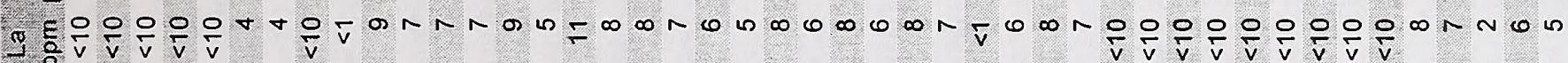

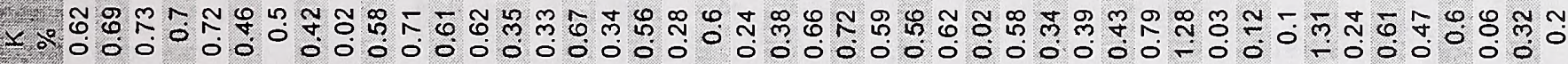

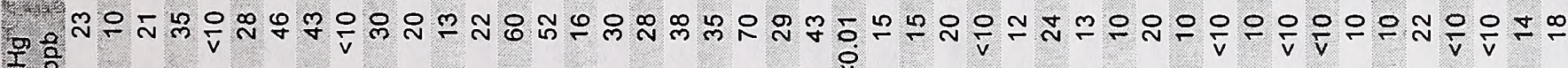

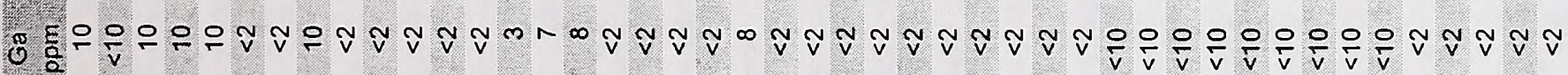

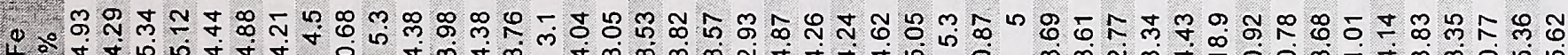

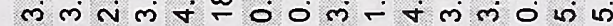

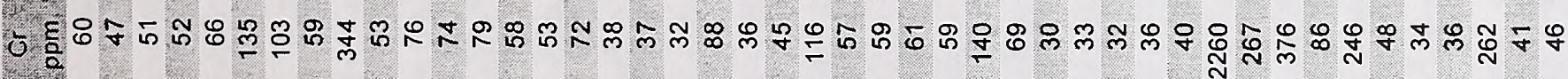

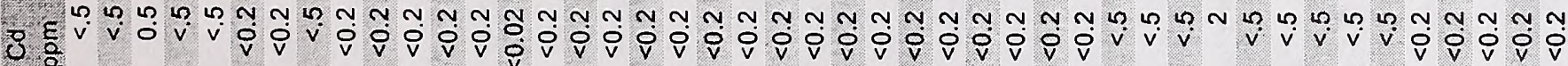

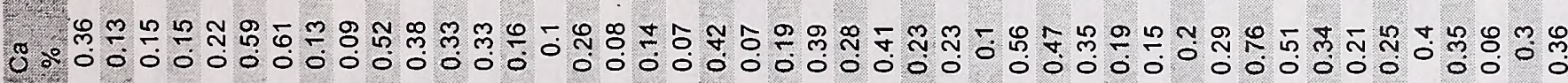

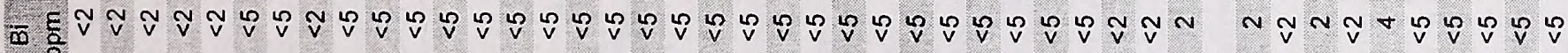

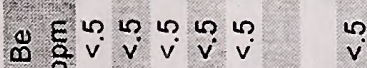

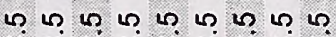
ह่ํำ

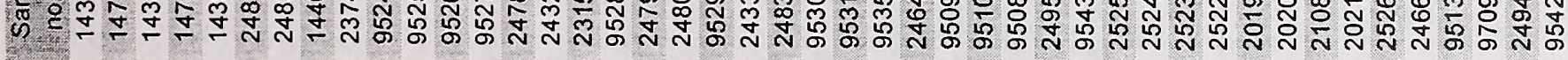
这 


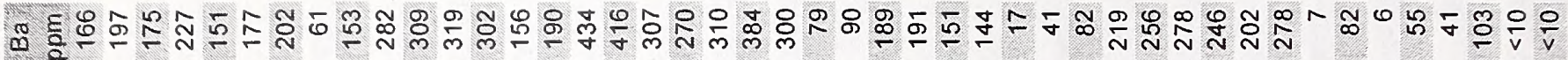
ห

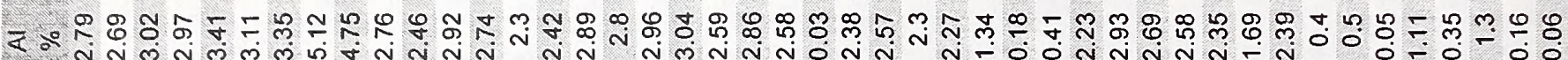

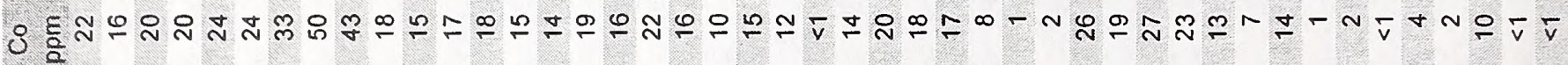
こ ह⿱艹

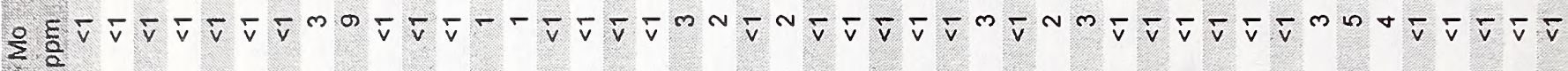

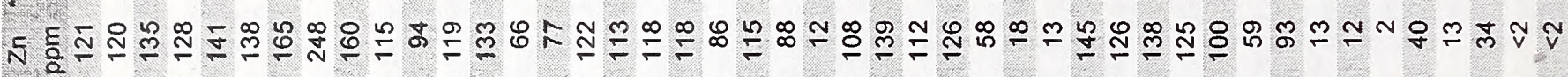

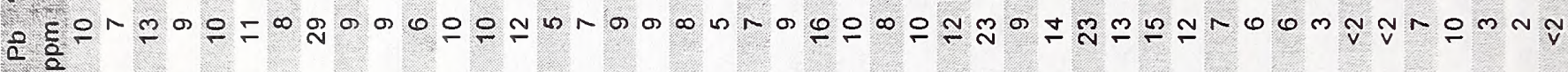
, ¿

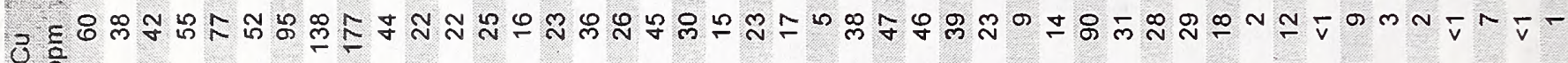

\& 3. $\frac{\xi}{0}$

द⿱

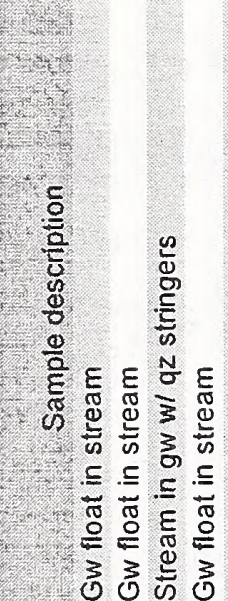

हूँ के
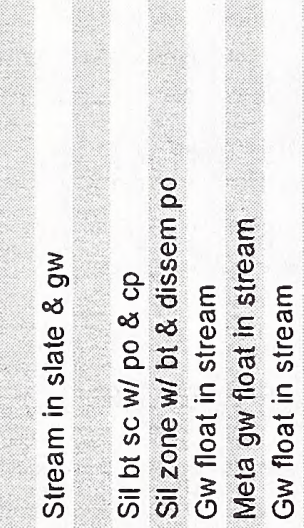

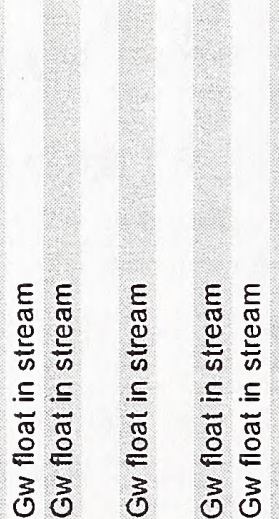

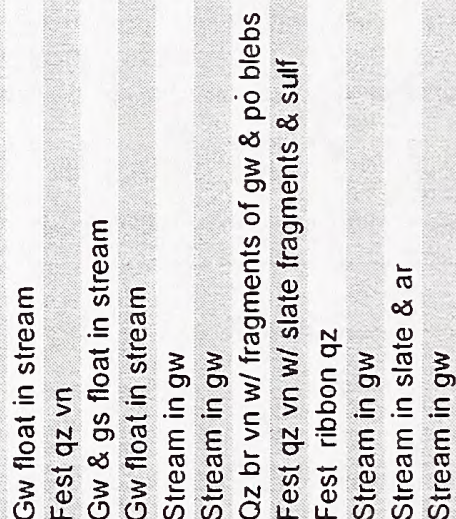

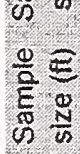

뜨

¿

눈요 웅

பூ๐

80

$\dddot{0}$

$\stackrel{\circ}{\circ}$

\%

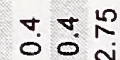

Nm

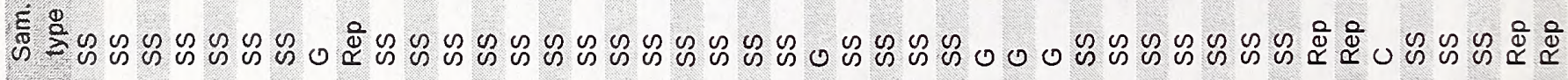

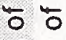

ш

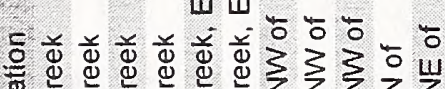

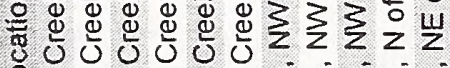

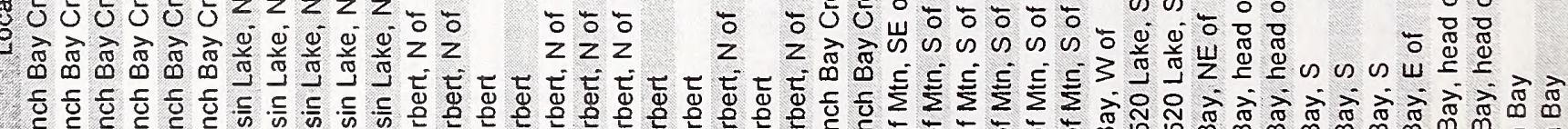

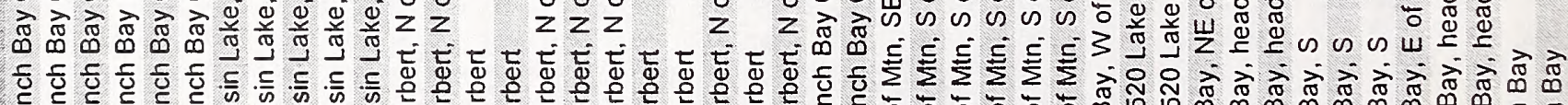

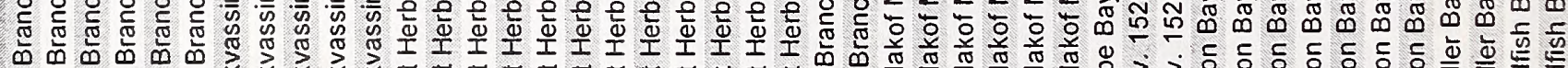

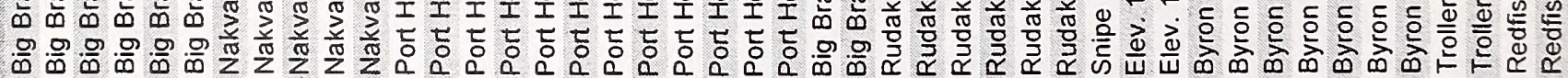

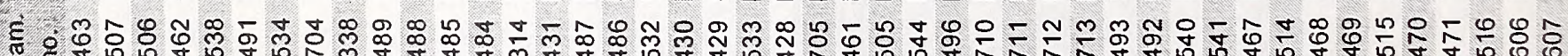

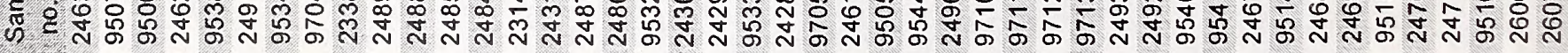
远 
$\bar{a}_{0} \bar{v} \bar{v} \bar{v} \bar{v} \bar{v} \bar{v} \bar{v} \bar{v} m \bar{v} \bar{v} \bar{v} \bar{v} \bar{v} \bar{v} \bar{v} \bar{v} \bar{v} \bar{v} \bar{v} \bar{v} \bar{v} \bar{v} \bar{v} \bar{v} \bar{v} \bar{v} \bar{v} \bar{v} \bar{v} \bar{v} \bar{v} \bar{v} \bar{v} \bar{v} \bar{v} \bar{v} \sim \bar{v} \bar{v} \bar{v} \bar{v} \bar{v}$

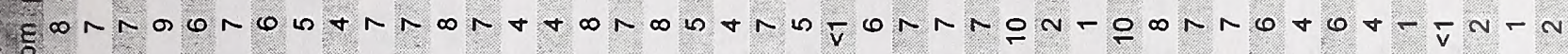

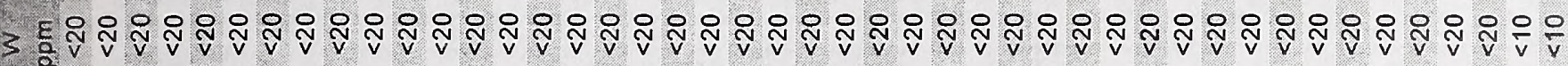

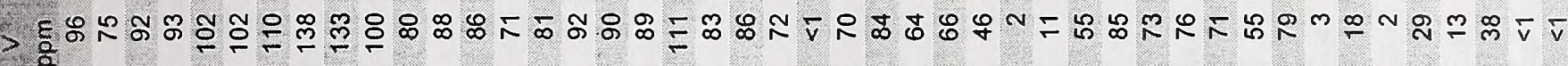

-

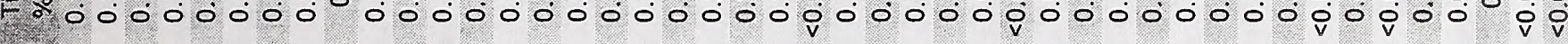

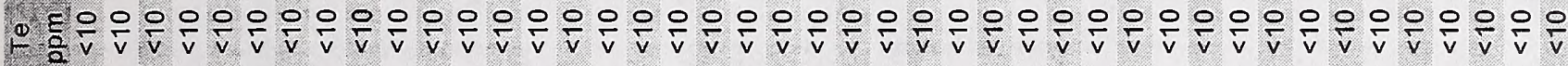

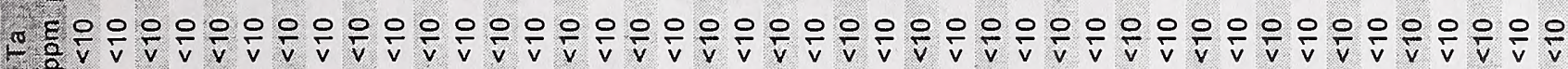

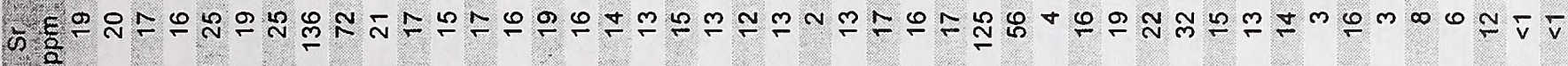
E दु हु० कह ह n. $\frac{2}{2}$

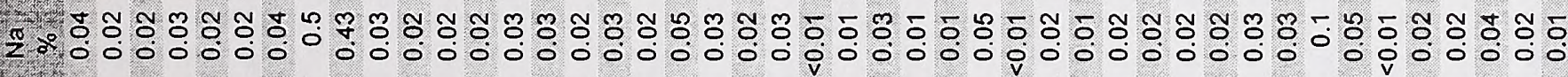
를 만

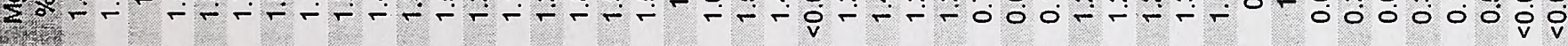

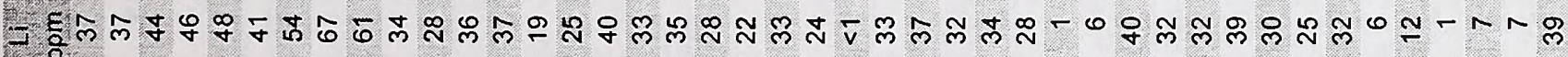
(ए) ह ह र 무유 음 은

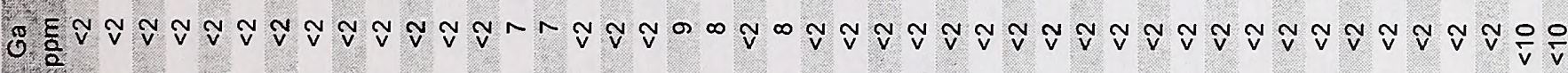

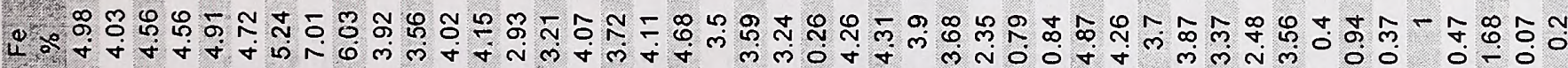

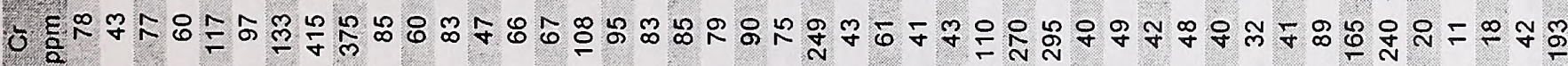
S.

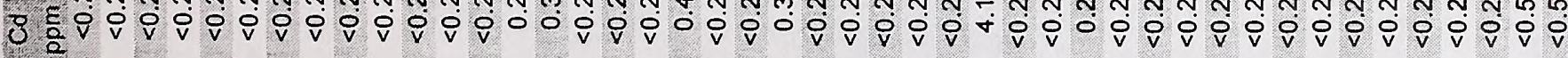
ช্

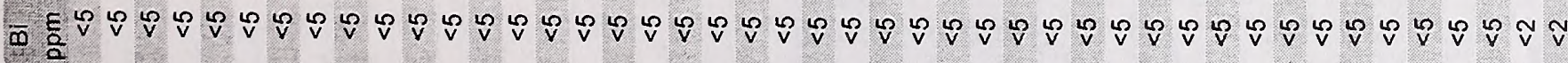
i. $\frac{E}{2}$

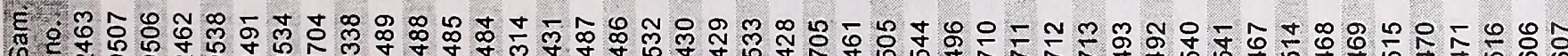

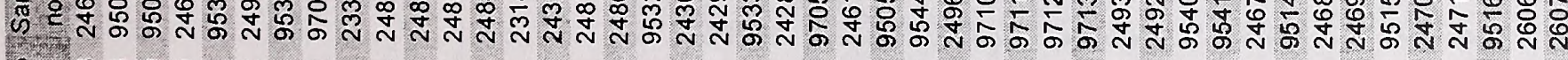

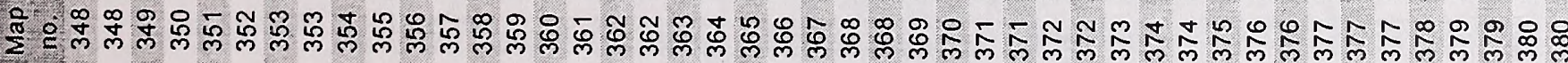




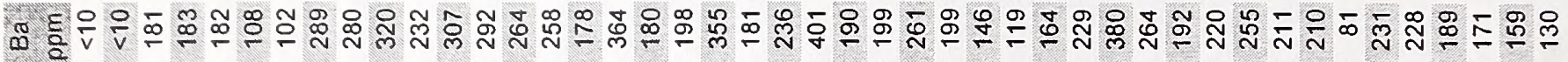
$\& \frac{E}{0}$

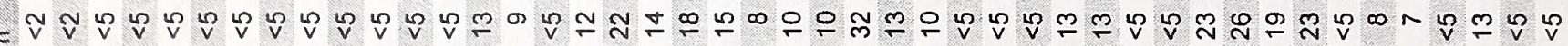

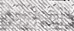

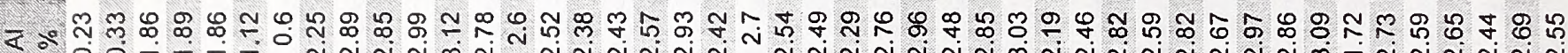

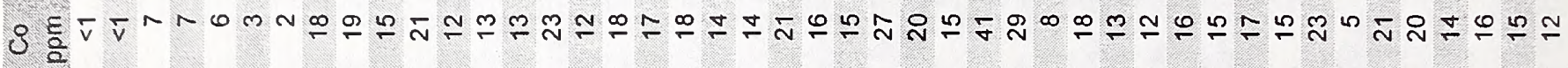

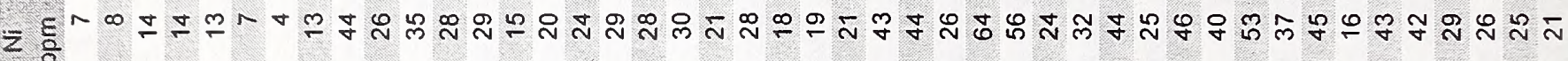

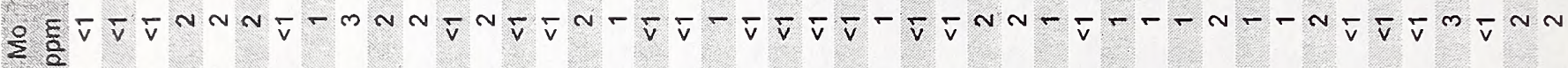

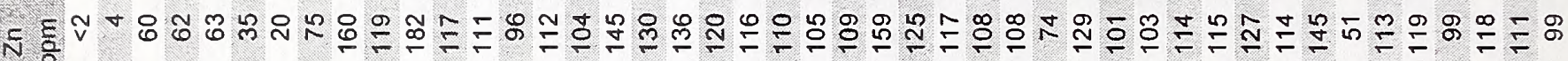

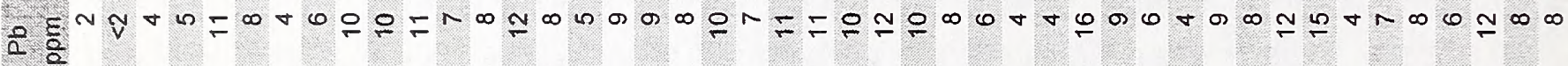
* 2

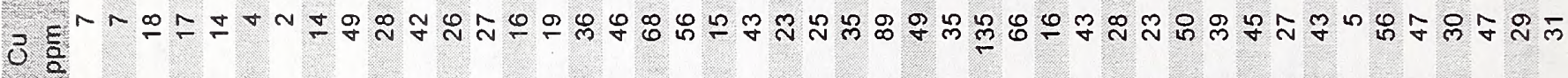

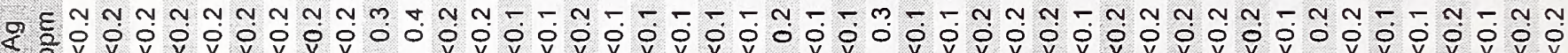
- $\frac{\text { ह }}{0}$

द⿱ (1)

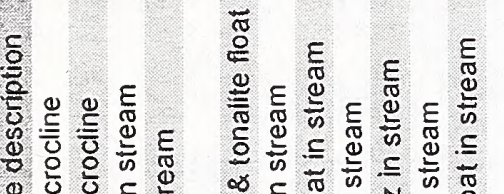

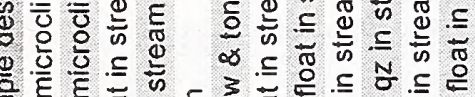

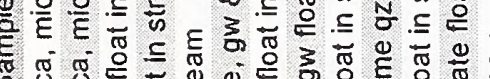
0 命 ह

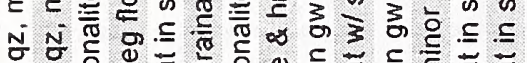
उऐक ळ

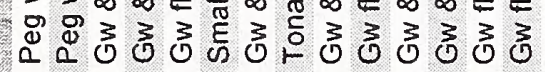

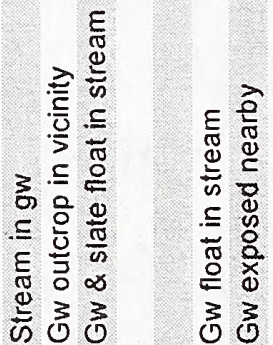

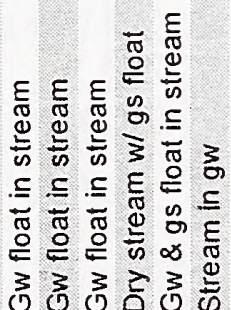

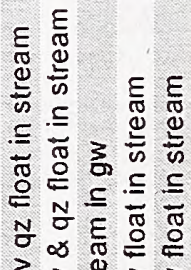

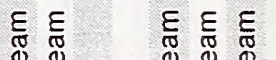

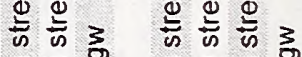

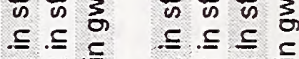
กั 을 䒕

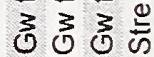
हึँ

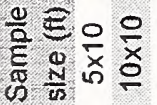

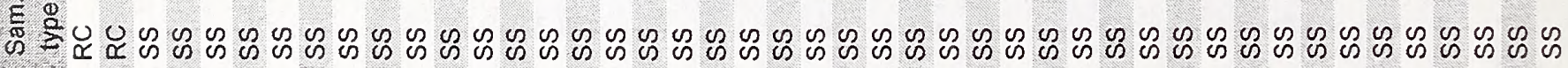
$\frac{5}{3}$

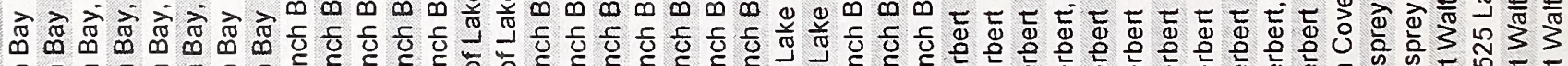

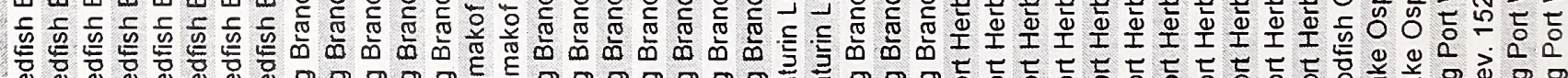

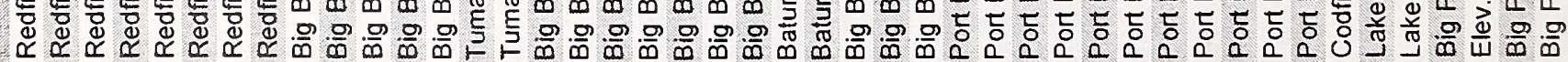
ह่.

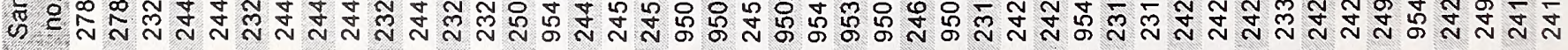

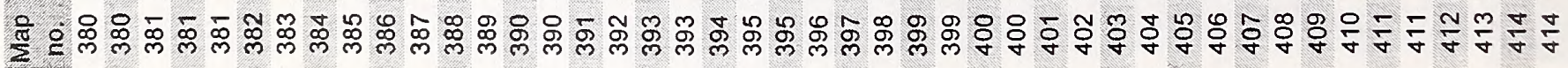


$\bar{v} \bar{v} \bar{v} \bar{v} \bar{v} \bar{v} \bar{v} \bar{v} \bar{v} \bar{v} \bar{v} \bar{v} \bar{v} \bar{v} \bar{v} \bar{v} \bar{v} \bar{v} \bar{v} \bar{v} \bar{v} \bar{v} \bar{v} \bar{v} \bar{v} \bar{v} \bar{v} \bar{v} \bar{v} \bar{v} \bar{v} \bar{v} \bar{v} \bar{v} \bar{v} \bar{v} \bar{v} \bar{v} \bar{v} \bar{v} \bar{v} \bar{v} \bar{v}$ +mnN-m n m

$\zeta$

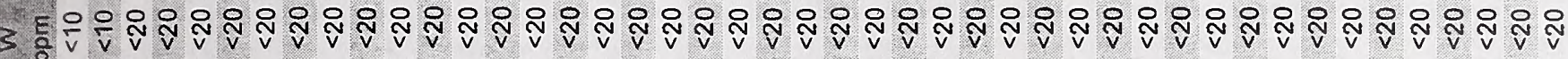

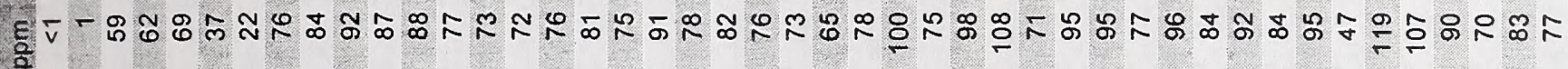

를 $\frac{0}{\mathrm{v}} \frac{\mathrm{O}}{\mathrm{v}}$

F $\frac{E}{2} \frac{0}{\mathrm{~V}} \frac{\mathrm{O}}{\mathrm{v}}$

= V0

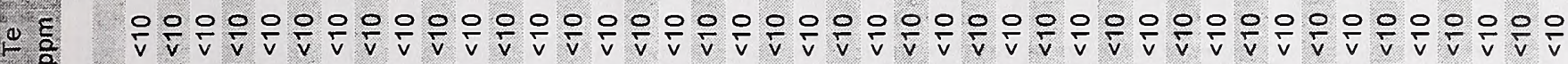

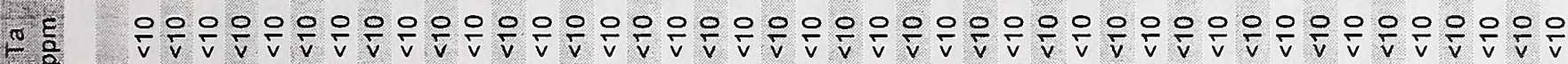
ć E. $\quad$ ह

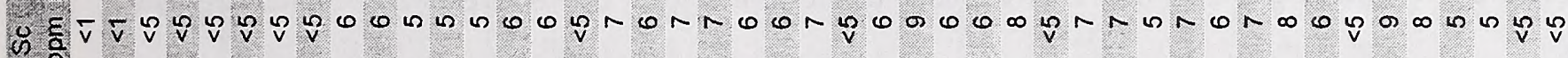
ठ a. 8 \% 8

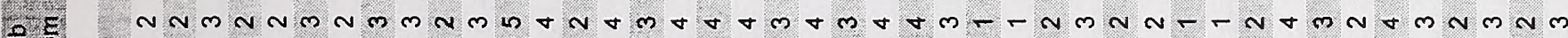

2 \%

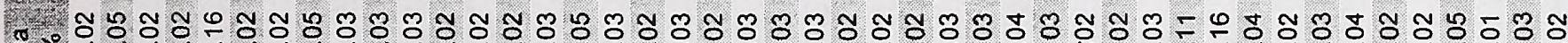

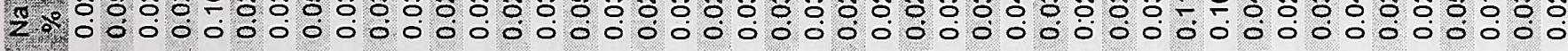

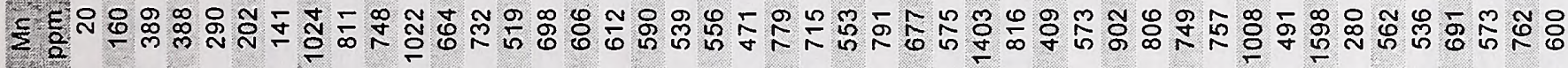

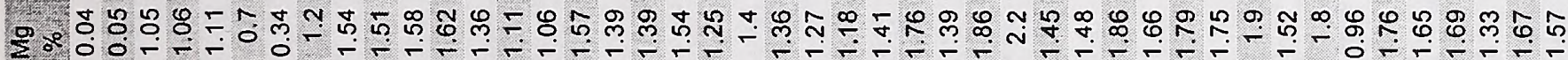

ป

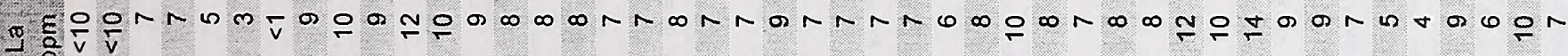

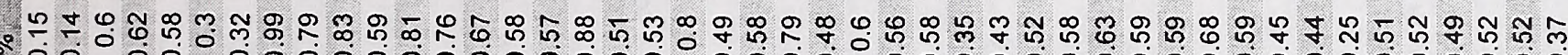
10000000000000000000000000000000000000000000 몬

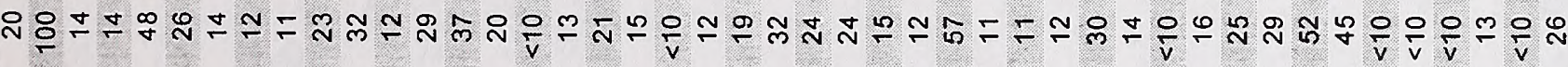

B E 탕ํำ U。

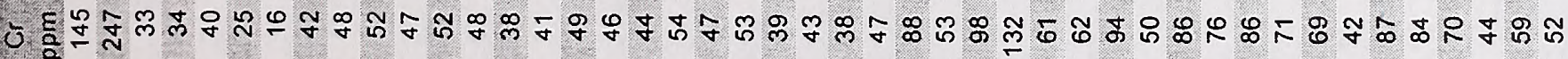
de उ

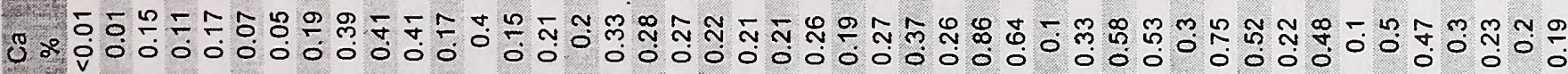
ले EกN

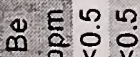

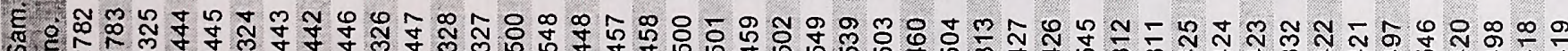

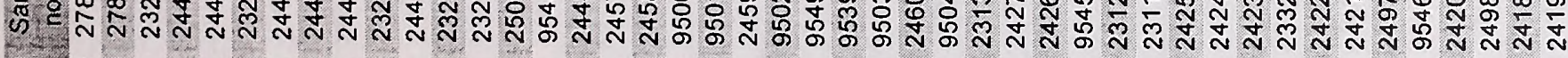

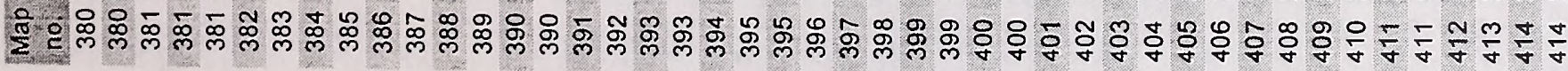




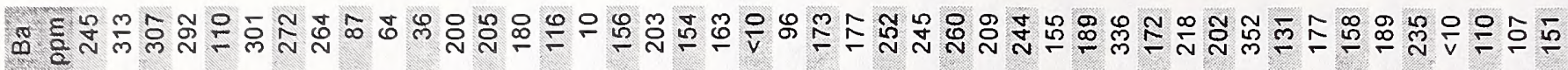
र

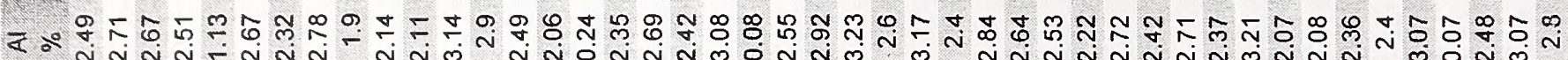

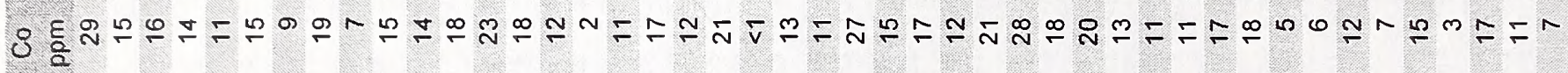

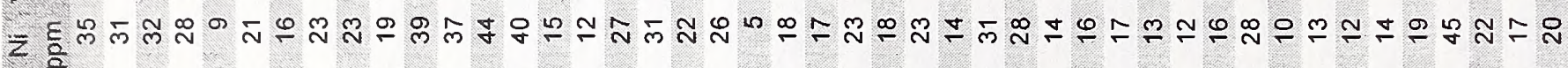

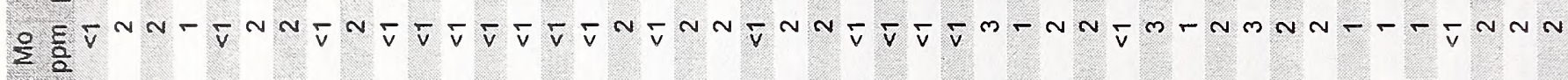

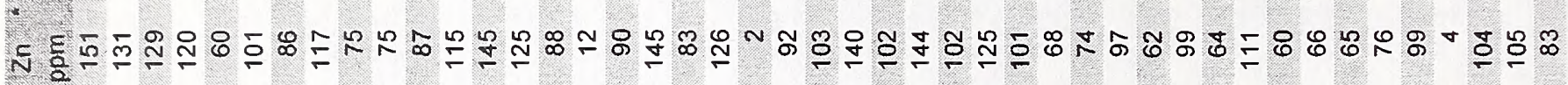

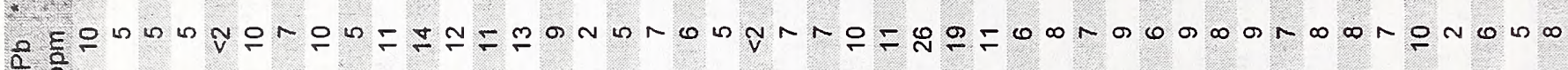
을 * के

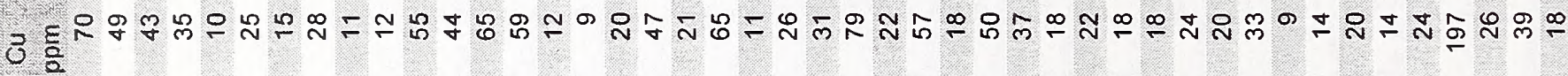

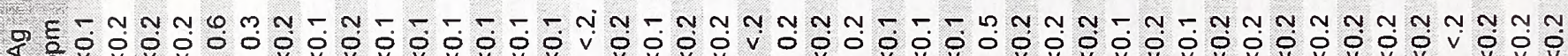
- ह ह

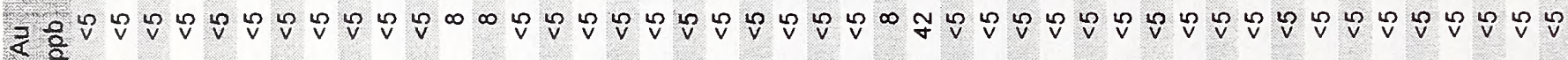
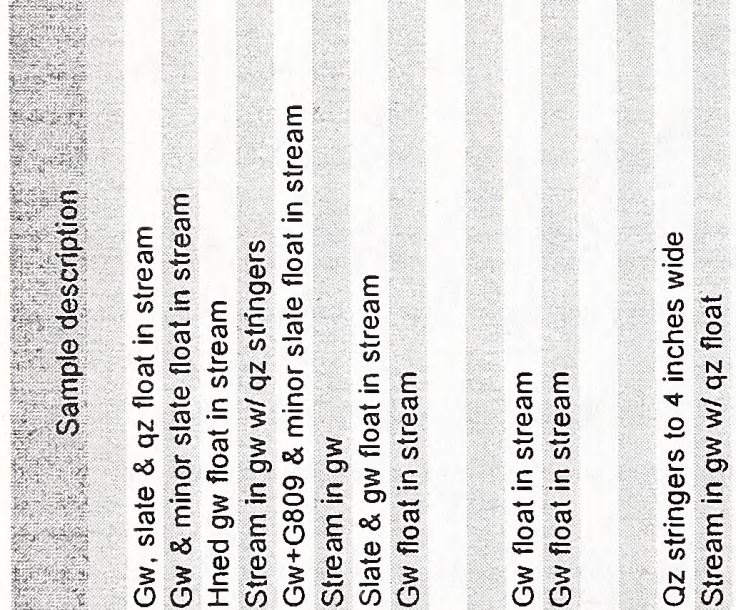

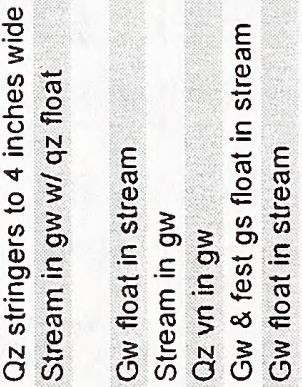

8
8

m

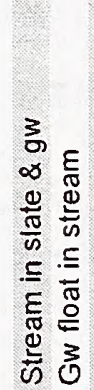

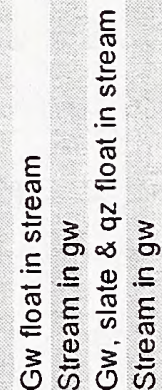

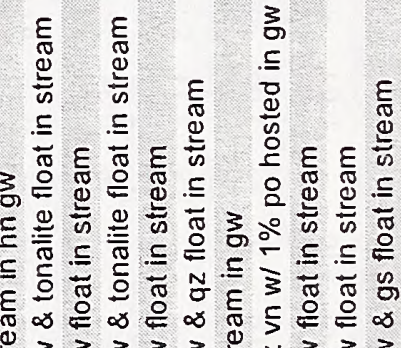

o $\infty=\infty=\infty$

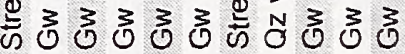

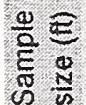

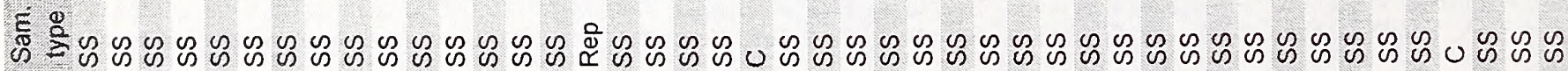

\section{,}

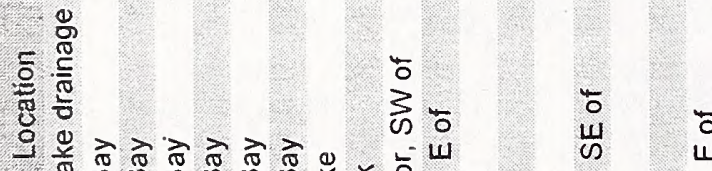

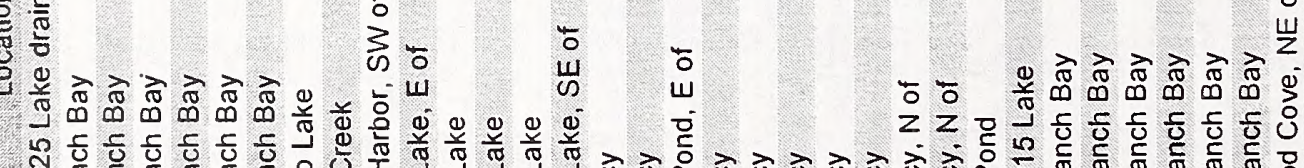

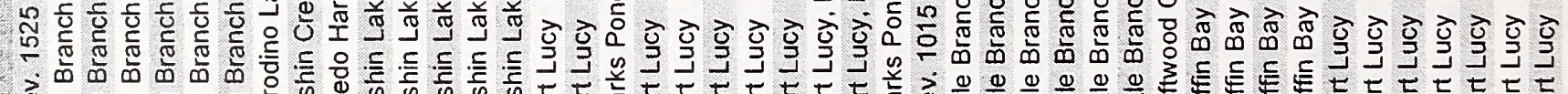

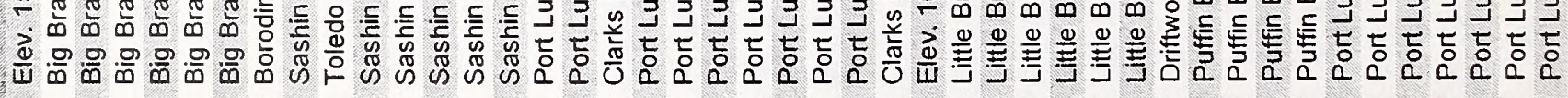

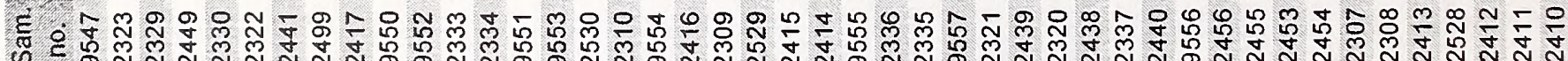

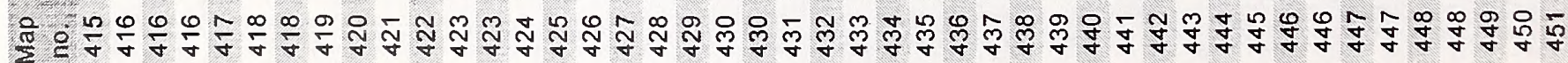




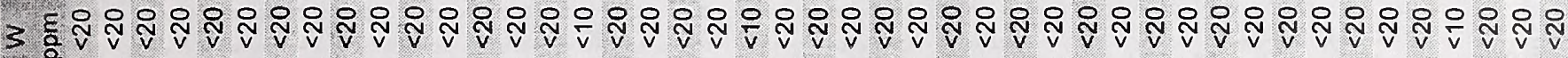

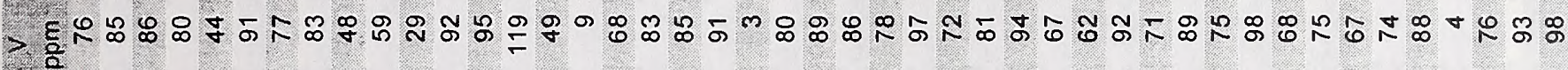

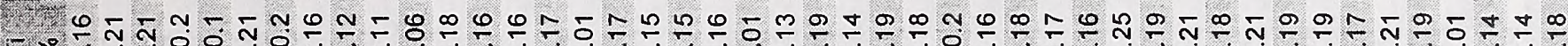

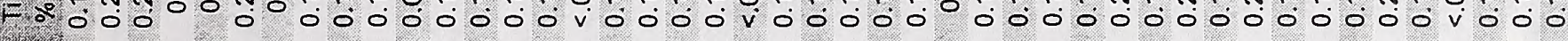

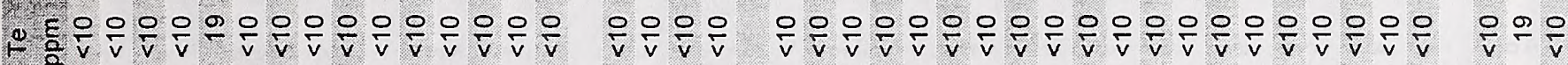

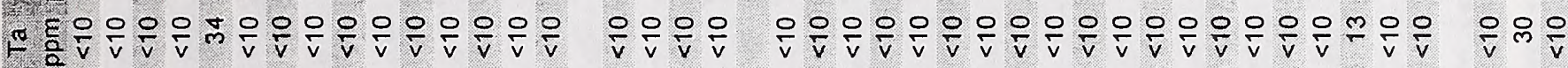
แ E 5 乌ี ह คี ค. $\frac{2}{2}$

SEthn-mmnthmhatmm hmm Z

ת

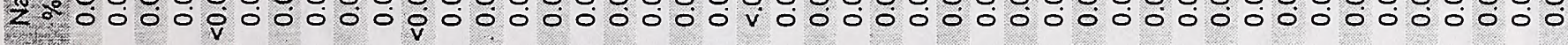

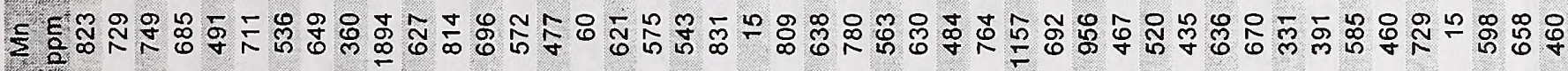

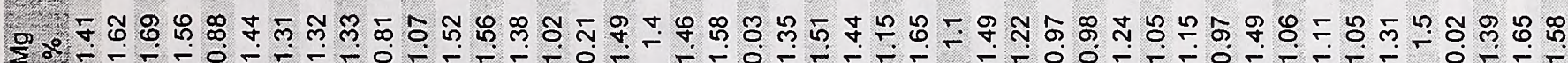
ప

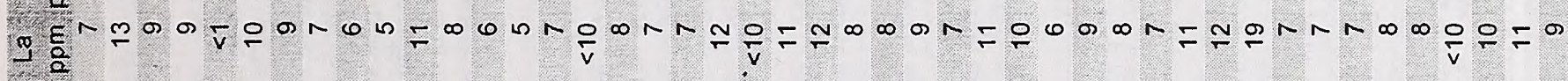

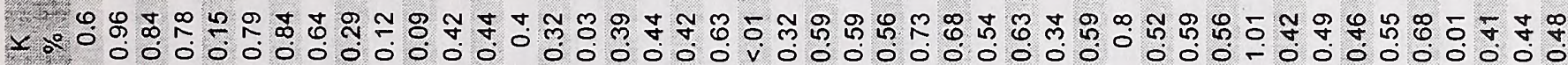

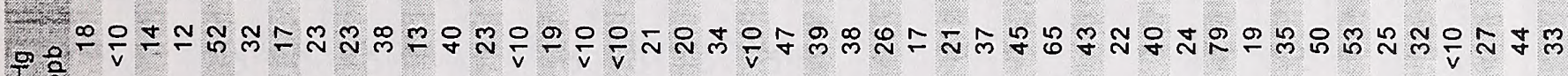
10

ठ एँ.

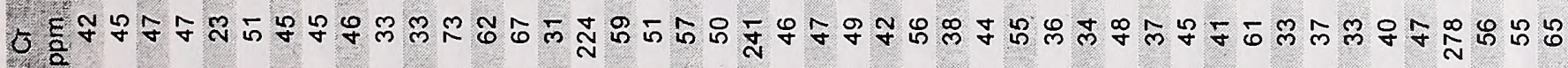
ת

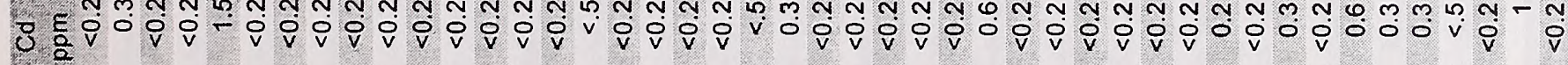

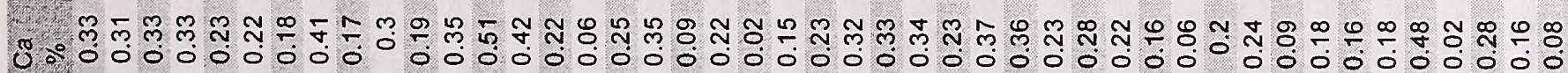

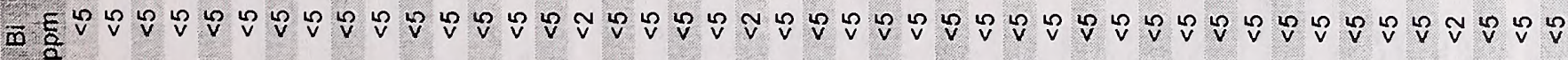
ल $\frac{E}{2}$

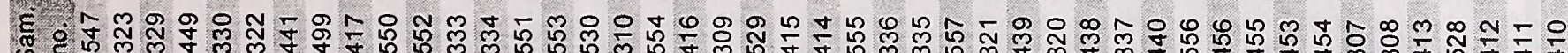
ऊ

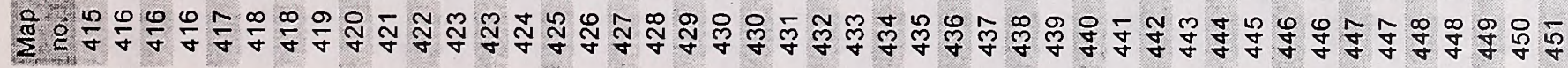




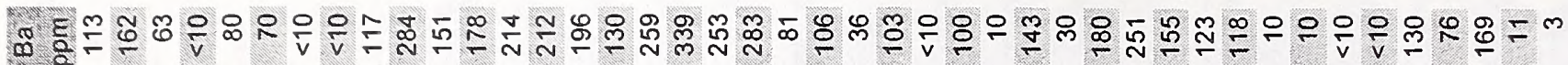
रह

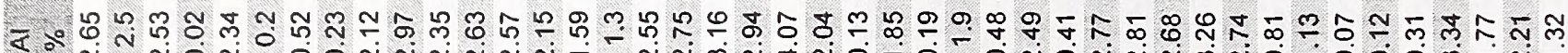
马E⿱ ¿

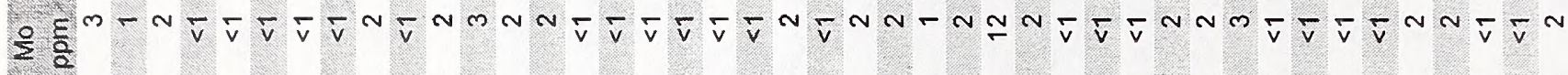

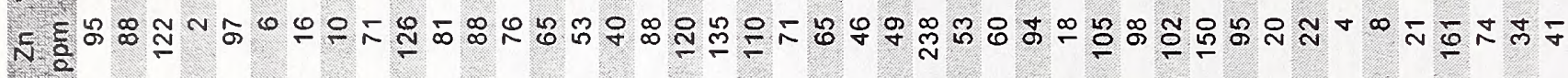

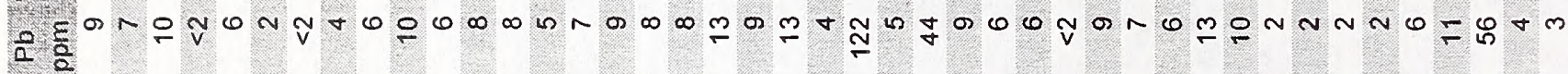
* a

రై

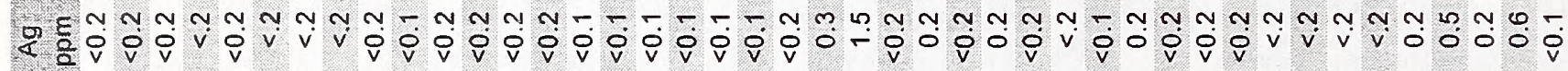
है을

द⿱宀

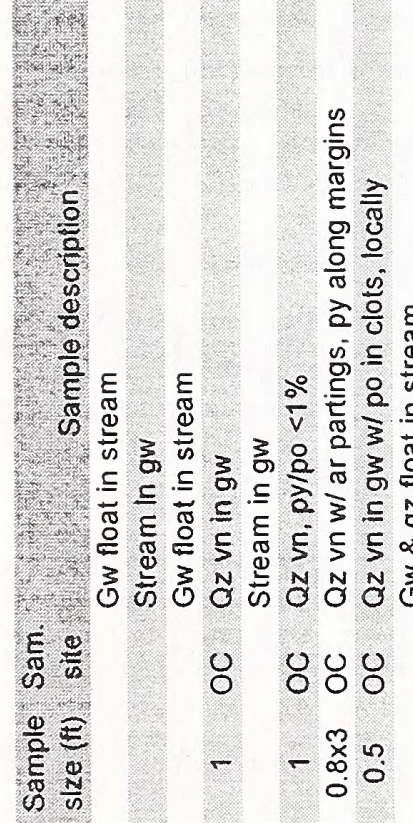

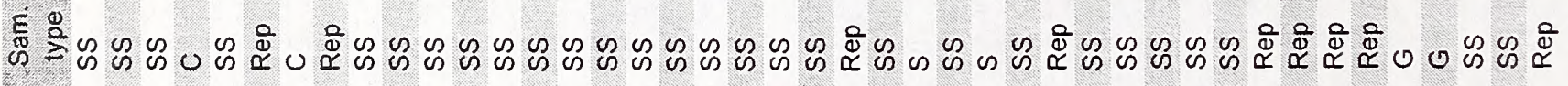

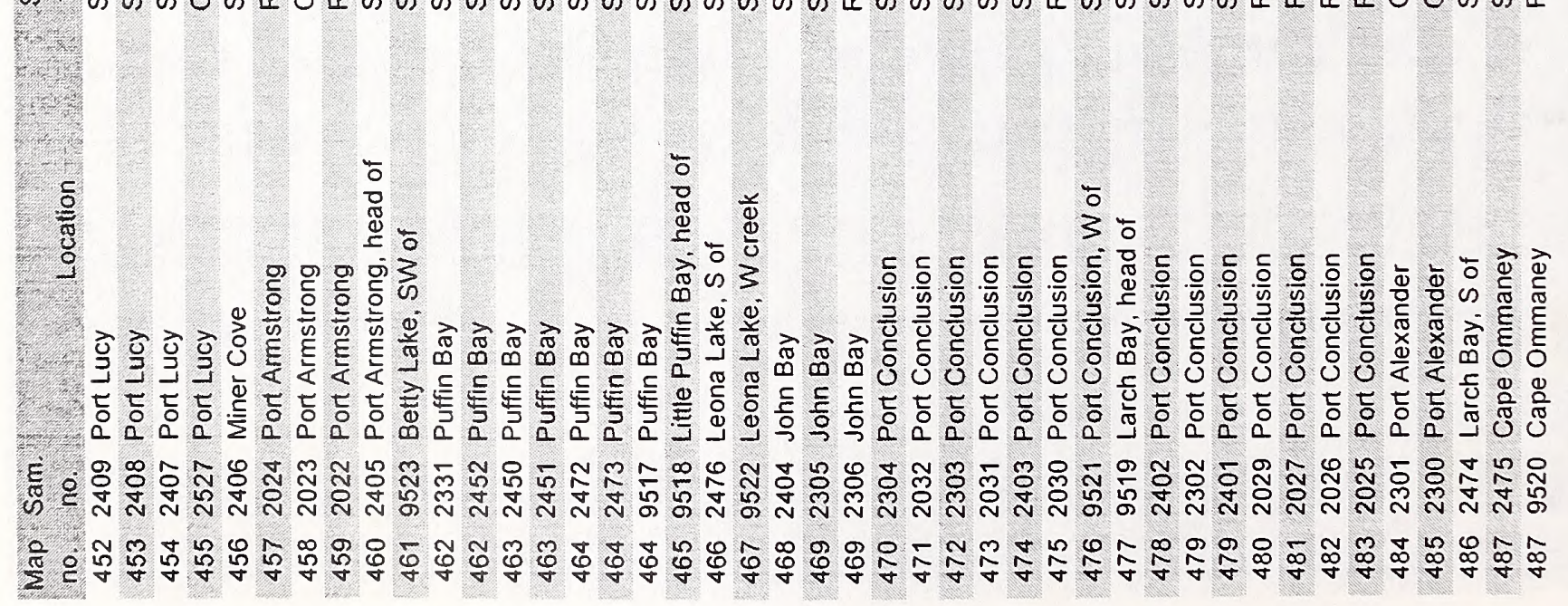




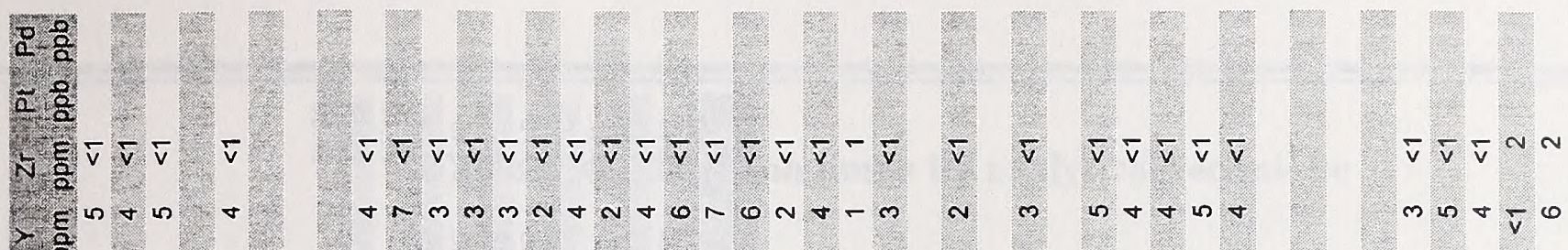
3 命 원 > हூ
$P \frac{E}{2} \quad \frac{O}{v} \quad \frac{O}{v} \frac{O}{v} \frac{i}{v}$
F $\frac{E}{2} \quad \frac{\mathrm{V}}{\mathrm{v}} \quad \frac{\mathrm{V}}{\mathrm{v}} \frac{\mathrm{O}}{\mathrm{v}}$

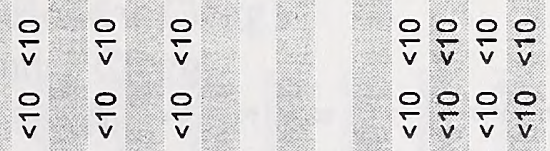

=

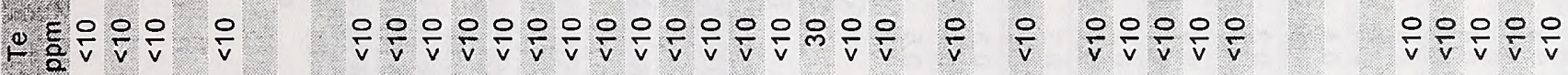

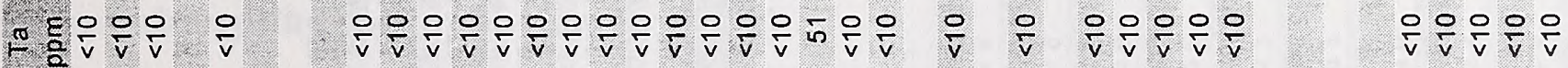
ह हE

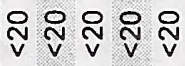
岁 की

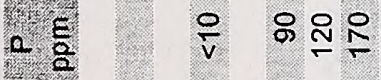
虽 弚
앴융 용

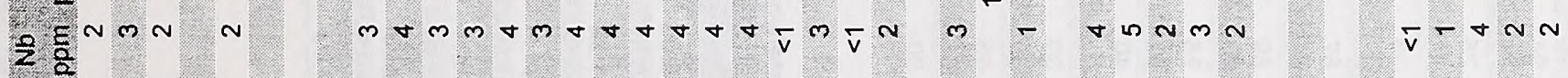

๘ 들 튱 \&

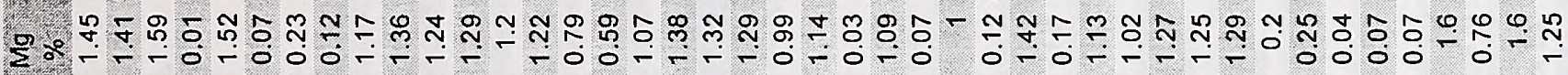
필

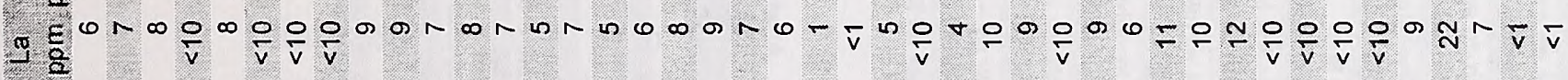

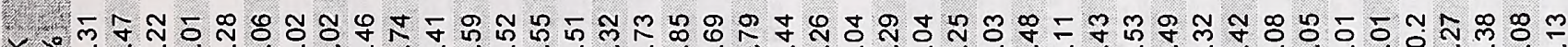
× 무 윰

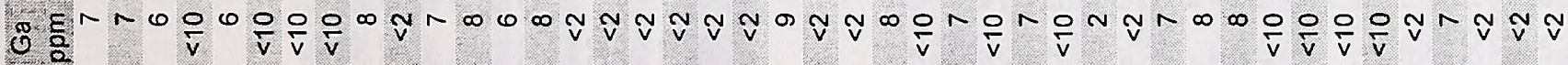
ही

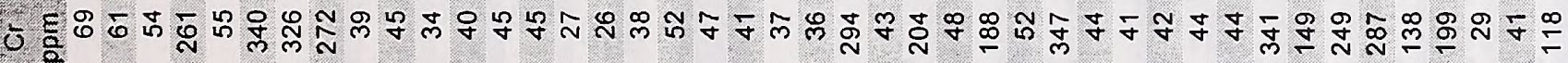
DE

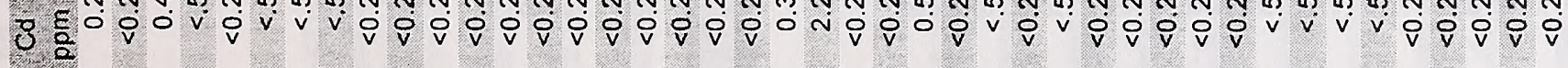

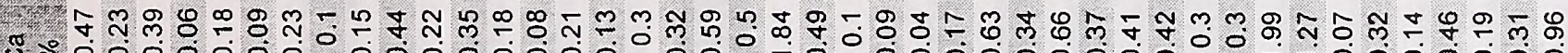

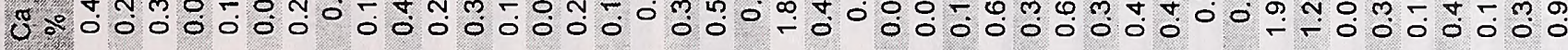
ह
ल
in $\quad$ v

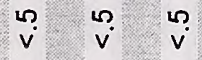

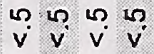

ह

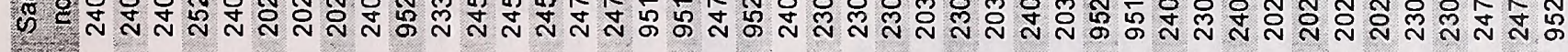

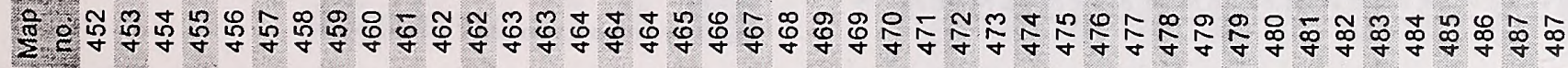




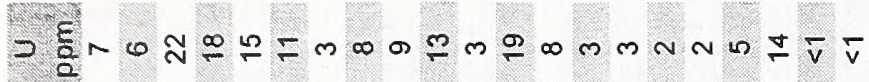

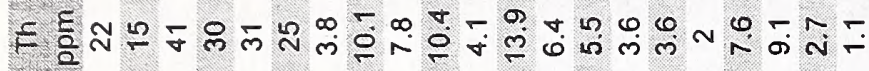

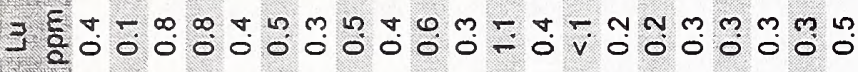

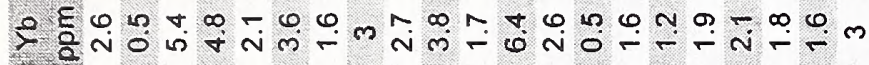

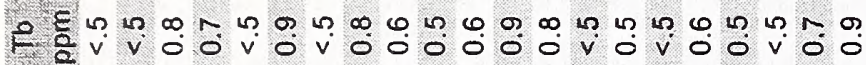
Uี

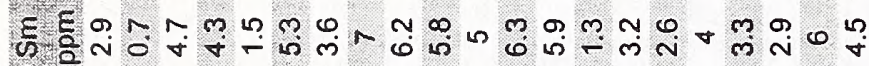
$\frac{0}{2}$

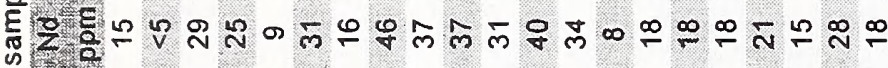
$\underline{\underline{u}}$ 崩 ग.

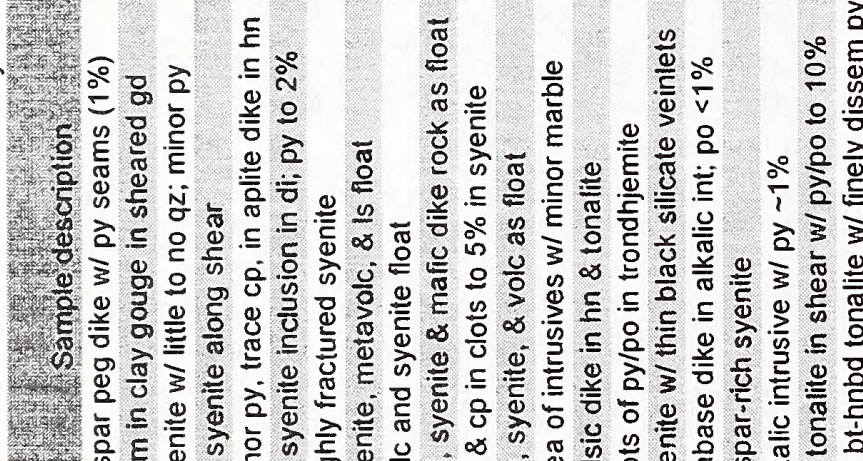

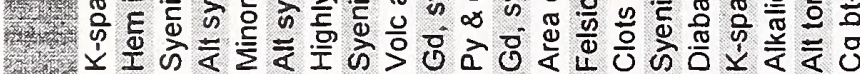
हैa a a a a ou000000 है

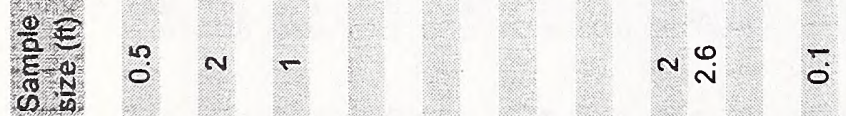

ह. ¿

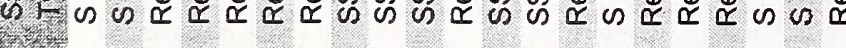
.

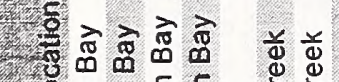

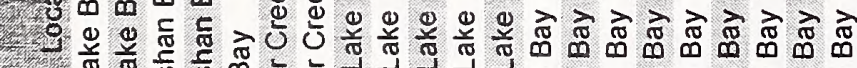

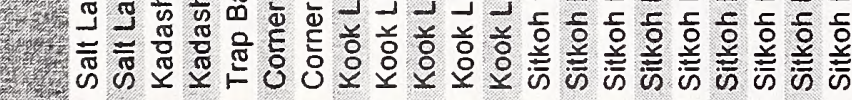

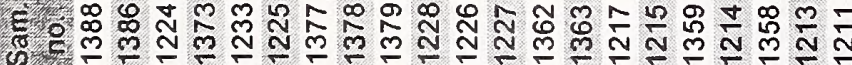
绻

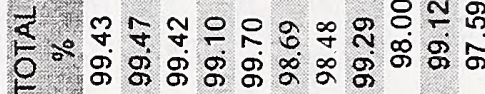

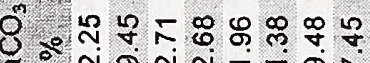

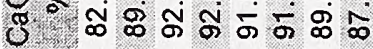

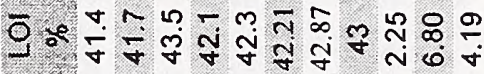

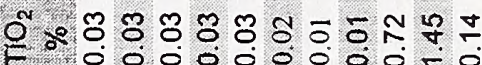

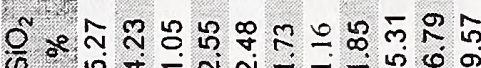

कि

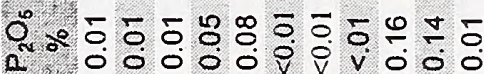
요 z $00000000 \mathrm{v}$ N 0 v

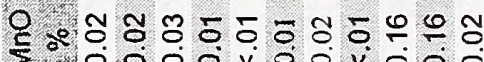
Sㅇำ

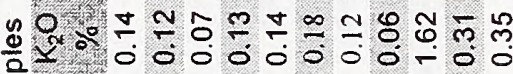
营

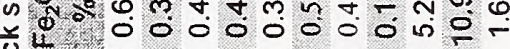
ㅇำ

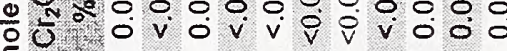
รo.

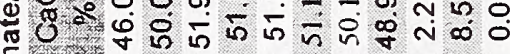
요요

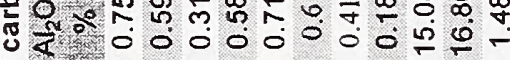

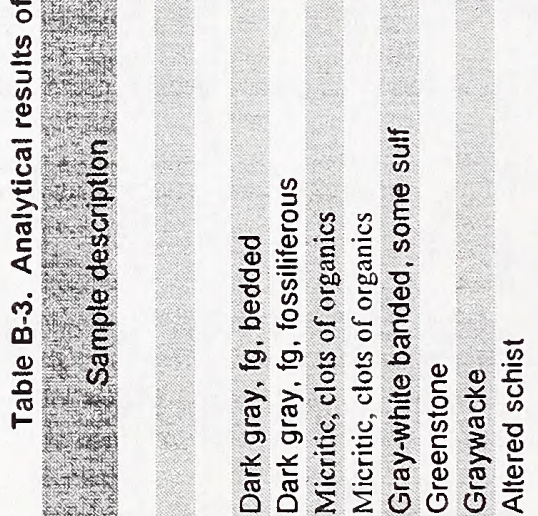

Е

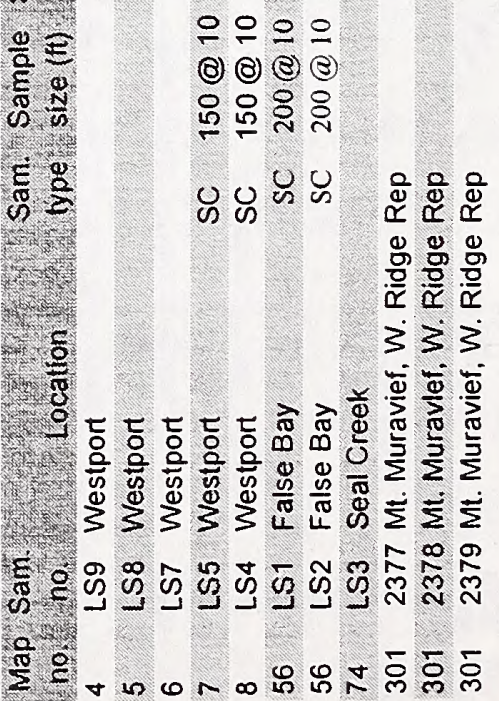


Table B-4. Detection limits by analytical technique

Fire assay

\begin{tabular}{|c|c|c|}
\hline Element & Minimum, ppm & Finish Method \\
\hline $\mathrm{Au}$ & 0.005 & AA (Chemex \& Bondar Clegg) \\
\hline $\mathrm{Au}$ & $0.005 \mathrm{oz} / \mathrm{t}$ & gravimetric (Bondar Clegg) \\
\hline $\mathrm{Au}$ & $0.07 \mathrm{oz} / \mathrm{t}$ & gravimetric (Chemex) \\
\hline $\mathrm{Pd}$ & 0.002 & ICP (Chemex) \\
\hline $\mathrm{Pt}$ & 0.005 & ICP (Chemex) \\
\hline
\end{tabular}

Atomic absorption spectrophotometry (AA)

\begin{tabular}{|c|c|c|c|c|c|}
\hline & Min, ppm & Min, ppm & & Min, \% & Min, \% \\
\hline Element & Chemex & Bondar Clegg & Element & $\underline{\text { Chemex }}$ & Bondar Clegg \\
\hline $\mathrm{Ag}$ & 0.2 & 0.1 & $\mathrm{Cu}$, ore-grade & 0.01 & 0.01 \\
\hline $\mathrm{Cu}$ & 1 & 1 & $\mathrm{~Pb}$, ore-grade & 0.01 & N/A \\
\hline $\mathrm{Pb}$ & 1 & 2 & $\mathrm{Zn}$, ore-grade & 0.01 & N/A \\
\hline $\mathrm{Zn}$ & 1 & 1 & $\mathrm{Ni}$, ore-grade & 0.01 & N/A \\
\hline Mo & 1 & 1 & & tr & \\
\hline Co & 1 & 1 & & 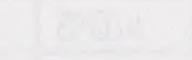 & \\
\hline $\mathrm{Ni}$ & 1 & 1 & & & \\
\hline $\mathrm{Hg}$ & 0.01 & 0.01 & & & \\
\hline
\end{tabular}

Inductively coupled argon plasma atomic emission spectroscopy (ICP)

\begin{tabular}{|c|c|c|c|c|c|}
\hline Element & $\begin{array}{l}\text { Min, ppm } \\
\text { Chemex }\end{array}$ & $\begin{array}{l}\text { Min, ppm } \\
\text { Bondar Clegg }\end{array}$ & Element & $\begin{array}{l}\text { Min, ppm } \\
\text { Chemex }\end{array}$ & $\begin{array}{l}\text { Min, ppm } \\
\text { Bondar Clegg }\end{array}$ \\
\hline $\mathrm{Ag}$ & 0.2 & 0.2 & $\mathrm{Fe}$ & 100 & 100 \\
\hline $\mathrm{Cu}$ & 1 & 1 & $\mathrm{Ga}$ & 10 & 2 \\
\hline $\mathrm{Pb}$ & 2 & 2 & $\mathrm{~K}$ & 100 & 100 \\
\hline $\mathrm{Zn}$ & 2 & 1 & $\mathrm{La}$ & 10 & 1 \\
\hline Mo & 1 & 1 & $\mathrm{Li}$ & N/A & 1 \\
\hline $\mathrm{Ni}$ & 1 & 1 & $\mathrm{Mg}$ & 100 & 100 \\
\hline Co & 1 & 1 & $\mathrm{Mn}$ & 5 & 1 \\
\hline $\mathrm{Al}$ & 100 & 100 & $\mathrm{Na}$ & 100 & 100 \\
\hline As & 2 & 5 & $\mathrm{Nb}$ & N/A & 1 \\
\hline $\mathrm{Ba}$ & 10 & 1 & $\mathrm{P}$ & 10 & N/A \\
\hline $\mathrm{Be}$ & 0.5 & & $\mathrm{Sb}$ & 2 & 5 \\
\hline $\mathrm{Bi}$ & 2 & 5 & $\mathrm{Sc}$ & 1 & 5 \\
\hline $\mathrm{Ca}$ & 100 & 100 & $\mathrm{Sn}$ & $\mathrm{N} / \mathrm{A}$ & 20 \\
\hline $\mathrm{Cd}$ & 0.5 & 0.2 & & & \\
\hline $\mathrm{Cr}$ & 1 & 1 & & & \\
\hline
\end{tabular}


ICP Spectroscopy continued

\begin{tabular}{|c|c|c|c|c|c|}
\hline & Min, ppm & Min,ppm & & Min, ppm & Min,ppm \\
\hline Element & Chemex & Bondar Clegg & $\underline{\text { Element }}$ & Chemex & Bondar Clegg \\
\hline $\mathrm{Sr}$ & 1 & 1 & $\mathrm{U}$ & 10 & N/A \\
\hline $\mathrm{Ta}$ & N/A & 10 & V & 1 & 1 \\
\hline $\mathrm{Te}$ & N/A & 10 & W & 10 & 20 \\
\hline $\mathrm{Ti}$ & 100 & 100 & Y & N/A & 1 \\
\hline $\mathrm{Tl}$ & 10 & N/A & $\mathrm{Zr}$ & N/A & 1 \\
\hline
\end{tabular}

\section{Detection Limits - Neutron activation analysis}

Element $\quad$ Min, ppm

La 1

$\mathrm{Ce} \quad 2$

$\mathrm{Nd} \quad 5$

$\mathrm{Sm} \quad 0.1$

$\mathrm{Eu} \quad 0.5$

$\mathrm{Tb} \quad 0.5$

$\mathrm{Yb} \quad 0.5$

$\mathrm{Lu} \quad 0.1$

Th 0.5

U 1

X-ray fluorescence spectroscopy (XRF)

\begin{tabular}{|c|c|c|}
\hline Element & $\underline{\operatorname{Min}, \%}$ & Max, \% \\
\hline $\mathrm{Al}_{2} \mathrm{O}_{3}$ & 0.01 & 100 \\
\hline $\mathrm{CaO}$ & 0.01 & 100 \\
\hline $\mathrm{Cr}_{2} \mathrm{O}_{3}$ & 0.01 & 100 \\
\hline $\mathrm{Fe}_{2} \mathrm{O}_{3}$ & 0.01 & 100 \\
\hline $\mathrm{K}_{2} \mathrm{O}$ & 0.01 & 100 \\
\hline $\mathrm{MgO}$ & 0.01 & 100 \\
\hline $\mathrm{MnO}$ & 0.01 & 100 \\
\hline $\mathrm{Na}_{2} \mathrm{O}$ & 0.01 & 100 \\
\hline $\mathrm{P}_{2} \mathrm{O}_{5}$ & 0.01 & 100 \\
\hline $\mathrm{SiO}_{2}$ & 0.01 & 100 \\
\hline $\mathrm{TiO}_{2}$ & 0.01 & 100 \\
\hline LOI & 0.01 & 100 \\
\hline
\end{tabular}

Titration

$\frac{\text { Element }}{\mathrm{CaCO}_{3}} \quad \frac{\mathrm{Min}, \%}{0.01} \quad \frac{\text { Max, \% }}{100}$


APPENDix C - AlPhabetical list of Mines, PRospects, AND Mineral OCCURRences

\begin{tabular}{|c|c|c|c|c|c|}
\hline Name & $\begin{array}{c}\text { Prospect } \\
\text { no. } \\
\text { (Plate 1) }\end{array}$ & $\begin{array}{c}\text { Map no. } \\
\text { (Plate 2, } \\
\text { Table B-1) } \\
\end{array}$ & Name & $\begin{array}{c}\text { Prospect } \\
\text { no. } \\
(\text { Plate 1) }\end{array}$ & $\begin{array}{c}\text { Map no. } \\
\text { (Plate 2, } \\
\text { Table B-1) }\end{array}$ \\
\hline Alaska Chichagof & P71 & & Deep Bay & P97 & $152-155$ \\
\hline American Gold Company & P69 & & Discovery on 1st Teer & P56 & \\
\hline Anderson & P83 & & Eagle Group & P58 & \\
\hline Andy & P79 & & East Point Pit & $\mathrm{P} 23$ & 104 \\
\hline Apex & $\mathrm{P} 120$ & 212 & Edgecumbe Exploration & P125 & 215 \\
\hline Apex El Nido & $\mathrm{P} 17$ & & Eldorado & P89 & \\
\hline Baldy Lode & P25 & 103 & Eureka & $\mathrm{P} 126$ & 216 \\
\hline Baney & P67 & & Falcon Arm & $\mathrm{P} 90$ & \\
\hline Baranof Queen & P122 & & Falls & P87 & \\
\hline Basket Bay & $\mathrm{P} 30$ & & $\begin{array}{l}\text { Flat Top Mountain, Upper } \\
\text { Workings }\end{array}$ & P85 & \\
\hline Basoiniuer & P62 & & Flat Top Mountain, Sea Level & $\mathrm{P} 84$ & \\
\hline Bauer & P64 & & Flora & P73 & \\
\hline Bauer & $\mathrm{P} 132$ & 223 & Free Gold & $\mathrm{P} 134$ & 228 \\
\hline Bertha Bay & $\mathrm{P} 41$ & & Freshwater Bay & $\mathrm{P} 22$ & 87 \\
\hline Big Ledge & $\mathrm{P} 24$ & 106 & Gangola & P118 & 211 \\
\hline Black Hawk \& Susie Groups & $\mathrm{P} 104$ & & Goddard Hot Springs & P139 & $239-242$ \\
\hline Bohemia Basin & P11 & & Gold Reef & P127 & \\
\hline Bon Tara Mine & $\mathrm{P} 12$ & & Golden Hand Apex & P51 & \\
\hline Bonanza & $\mathrm{P} 2$ & & Goldwin & $\mathrm{P} 13$ & \\
\hline Boston Claim & $\mathrm{P} 116$ & & Green Lake & P128 & 218 \\
\hline Bullion & P119 & & Gypsum Creek & P19 & $57,63-65$ \\
\hline Cable Claims & P32 & & Haley \& Hanlon & P117 & \\
\hline Calcium Carbonate Time & P55 & & Halleck Island & P109 & 175 \\
\hline Camel Gypsum & $\mathrm{P} 20$ & & Handy & P78 & \\
\hline Cascade & P114 & & Hanlon & $\mathrm{P} 65$ & \\
\hline Chichagof Star & P86 & & Hansen \& Bolshan & P68 & \\
\hline Chichagof Prosperity & $\mathrm{P} 63$ & & Helen Chichagof & P76 & \\
\hline Chichagof & P75 & 141 & Henrietta & P123 & \\
\hline Cobol Mine & P91 & & Hill \& Berkland & $\mathrm{P} 80$ & \\
\hline Columbia Point & $\mathrm{P} 27$ & & Hill & $\mathrm{P} 137$ & $236-238$ \\
\hline Columbine Group & $\mathrm{P} 16$ & & Hill Point & P26 & 107-109 \\
\hline Column Point & P7 & & Hirst-Chichagof & P60 & \\
\hline Congress & P52 & & Hodson & P61 & \\
\hline Cox Brothers & $\mathrm{P} 48$ & & Indian River & P111 & \\
\hline Crow Point & $\mathrm{P} 3$ & & Inian Island & P5 & \\
\hline Cub Mountain & $\mathrm{P} 35$ & & Jumbo & $\mathrm{P} 70$ & \\
\hline
\end{tabular}




\begin{tabular}{|c|c|c|c|c|c|}
\hline Name & $\begin{array}{c}\text { Prospect } \\
\text { no. } \\
\text { (Plate 1) }\end{array}$ & $\begin{array}{c}\text { Map no. } \\
\text { (Plate 2, } \\
\text { Table B-1) }\end{array}$ & Name & $\begin{array}{c}\text { Prospect } \\
\text { no. } \\
\text { (Plate 1) }\end{array}$ & $\begin{array}{l}\text { Map no. } \\
\text { (Plate 2, } \\
\text { Table B-1) }\end{array}$ \\
\hline Kaiser Gypsum & $\mathrm{P} 21$ & & Port Lucy & P144 & 426 \\
\hline Koby & P31 & & Port Conclusion & P145 & $480-483$ \\
\hline Krestof Group & P107 & 174 & Portage Arm & $\mathrm{P} 100$ & $161-162$ \\
\hline Lake Anna & P81 & & Power Line Prospect & P77 & \\
\hline Lake Morris-mt. & $\mathrm{P} 42$ & & Ram & $\mathrm{P} 92$ & \\
\hline Lake Elfendahl & $\mathrm{P} 43$ & & Red Bluff Bay & $\mathrm{P} 138$ & $243-247$ \\
\hline Lemesurier Island Paligorskite & P1 & & Redfish Bay & $\mathrm{P} 143$ & 380 \\
\hline Liberty & P121 & 213 & Redone & P29 & \\
\hline Little Bay & $\mathrm{P} 46$ & & Rodman Bay & $\mathrm{P} 98$ & 160 \\
\hline $\begin{array}{l}\text { Little Blonde \& High Grade } \\
\text { Groups }\end{array}$ & $\mathrm{P} 106$ & & Rossman Vein & $\mathrm{P} 15$ & \\
\hline Lost Anchor & P101 & $164-166$ & Sealion Cove & $\mathrm{P} 105$ & 173 \\
\hline Lower Ledge & P129 & 221 & Senate & P53 & \\
\hline Lucky Chance & $\mathrm{P} 135$ & 231 & Siginaka Island & $\mathrm{P} 110$ & $182-184$ \\
\hline Lucky Chance Mtn. & $\mathrm{P} 136$ & $232-235$ & Silver Bay & $\mathrm{P} 124$ & \\
\hline Magoun Island & P108 & 176-181 & Slim \& Jim & $\mathrm{P} 40$ & \\
\hline Martha-brown Cub & P50 & & Slocum Arm & $\mathrm{P} 95$ & $146-151$ \\
\hline Marvitz & P6 & 1 & Snipe Bay & $\mathrm{P} 142$ & $341-343$ \\
\hline McKallick Lode & P59 & & Snow Slide & P47 & \\
\hline McKallick Placer & P66 & & South Arm & $\mathrm{P} 103$ & 168 \\
\hline McKallick Chichagof Mines & $\mathrm{P} 74$ & & Squid Bay & $\mathrm{P} 10$ & \\
\hline Middle Arm & P99 & $169-171$ & Stag Bay Gold & $\mathrm{P} 36$ & \\
\hline Mine Mountain Area & $\mathrm{P} 33$ & & Stag Bay Copper & $\mathrm{P} 38$ & \\
\hline Mine Mountain Mine & $\mathrm{P} 34$ & & Stag Bay Magnetite & $\mathrm{P} 37$ & \\
\hline Mirror Harbor & $\mathrm{P} 45$ & & Stewart & $\mathrm{P} 130$ & 220 \\
\hline Mt. Baker & $\mathrm{P} 44$ & & Stranger River & P39 & \\
\hline Mt. Muravief & $\mathrm{P} 141$ & $301-305$ & Surge Bay & P9 & \\
\hline Neka Bay & $\mathrm{P} 8$ & & Tenakee Inlet Marble & $\mathrm{P} 28$ & \\
\hline $\begin{array}{l}\text { New Chichagof Mining } \\
\text { Syndicate }\end{array}$ & P49 & & The Basin & $\mathrm{P} 102$ & 167 \\
\hline Next & $\mathrm{P} 96$ & & Thetis & $\mathrm{P} 115$ & 209 \\
\hline Nilsen & $\mathrm{P} 14$ & & Triplet Island & $\mathrm{P} 54$ & \\
\hline No Name & $\mathrm{P} 131$ & 222 & Ushk & P93 & \\
\hline $\mathrm{Ob}$ & $\mathrm{P} 72$ & & Warm Springs Bay & $\mathrm{P} 113$ & $185-207$ \\
\hline Orange Gulch & P94 & & Whitney & $\mathrm{P} 4$ & \\
\hline Pande Basin & $\mathrm{P} 112$ & & Wicked Fall & $\mathrm{P} 133$ & 225 \\
\hline Pat & P88 & & Winther & P57 & \\
\hline Patterson Bay & $\mathrm{P} 140$ & $253-257$ & Woll & $\mathrm{P} 82$ & \\
\hline Phonograph & P18 & & & & \\
\hline
\end{tabular}










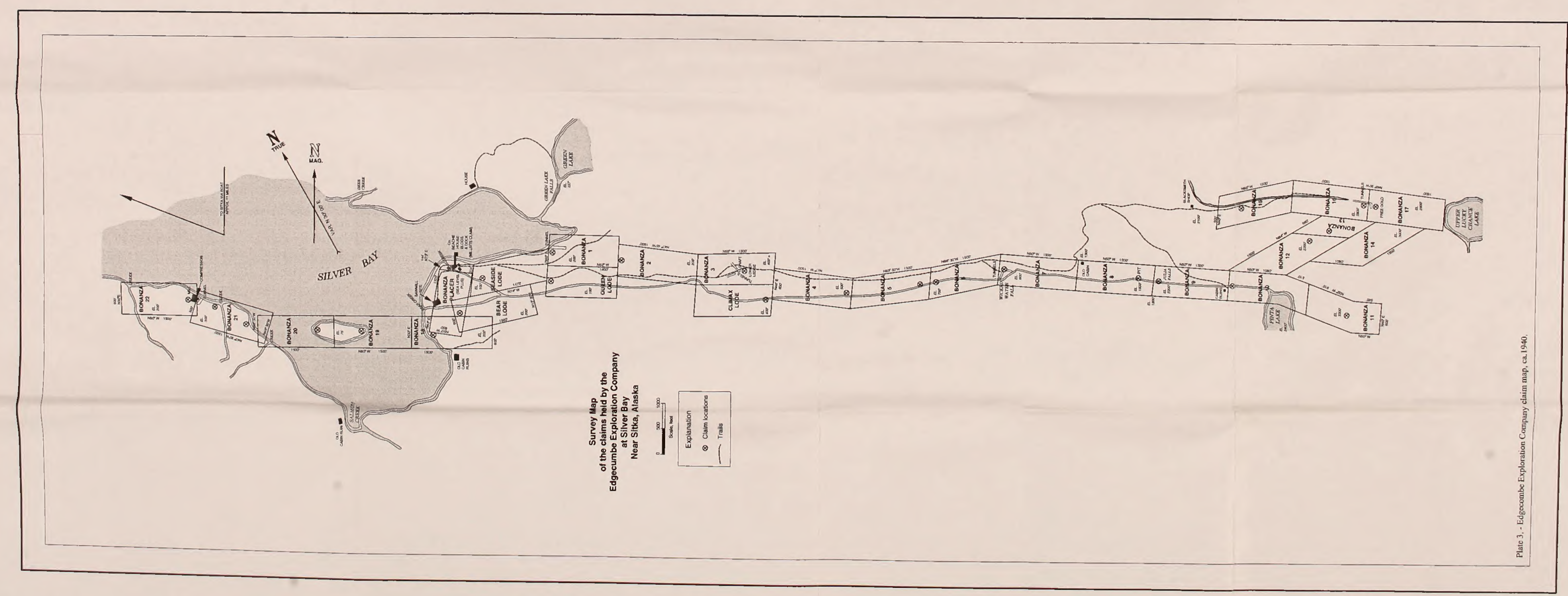






\section{BLM LIRAATY \\ BLDG 50, ST-150A \\ DENVER FED, ST-150A \\ P. BORAL CENTER \\ DENVER, COX 25047 \\ 80225}


